Benedito Coutinho Neto

\title{
AVALIAÇÃO DO REAPROVEITAMENTO DE AREIA DE FUNDIÇÃO COMO AGREGADO EM MISTURAS ASFÁLTICAS DENSAS
}

Tese apresentada à Escola de

Engenharia de São Carlos da Universidade de São Paulo, como parte dos requisitos para a obtenção do Título de Doutor em Engenharia de Transportes.

Orientador: Prof. Dr. Glauco Tulio Pessa Fabbri 
Ficha Catalogáfica preparada pela seção de Tratamento da Informação do serviço de Biblioteca - EESC/USP

c $871 \mathrm{a}$

Coutinho Neto, Benedito

Avaliação do reaproveitamento de areia de fundição Como agregado em misturas asfálticas densas /. Benedito Coutinho Neto. -- São Carlos, 2004.

Tese (Doutorado) -- Escola de Engenharia de São Carlos-Universidade de São Paulo, 2004.

Área: Engenharia de Transportes.

Orientador: Prof. Dr. Glauco Tulio Pessa Fabbri.

1. Reaproveitamento de areia de fundição. 2. Misturas asfálticas. 3. Impacto ambiental. 4. Pavimentação. 5.

Ensaios em pavimentação. 6. Resíduos sólidos. I. Título. 
À minha esposa e aos meus filhos pelo amor, companheirismo, solidariedade e incentivo.

Aos meus pais (in memórian), Joaquim e Adalgiza, por me concederem embasamento de vida, deixando-me apto para prosseguir o meu caminho. 


\section{AGRADECIMENTOS}

A Deus por tudo;

Ao professor Glauco Túlio Pessa Fabbri, pela maneira simples e honesta de orientar e, sobretudo, por confiar a mim esta pesquisa;

À minha esposa, Lêda, e aos meus filhos, Jean Vítor e Tiago, pelo apoio incansável e a compreensão pelos sacrifícios impostos durante esse período;

Ao meu filho Jean Vítor por me ajudar nas ilustrações e por me acompanhar, muitas vezes antes de raiar o dia e em finais de semana, aos laboratórios do STT;

A Escola de Engenharia de São Carlos, à chefia e à Coordenação de Pós-Graduação do Departamento de Transportes, pelo suporte acadêmico oferecido durante o doutorado;

A FIDESA e a UNAMA pelo apoio financeiro e ao Centro de Ciências Exatas e Tecnológica desta Instituição, em especial aos professores Evaristo Clementino Rezende dos Santos e Clementino José dos Santos Filho, pelo incentivo e compreensão; Ao Centro Federal de Educação Tecnológica do Pará (CEFET-PA), em especial ao professor João Ferreira, pelo o apoio concedido;

Aos amigos e funcionários do Departamento de Transportes: Carlos (Toco), Elisabeth (Beth), Heloísa, Magali, Sueli e Vicente, por estarem sempre aptos a contribuírem;

Aos professores do curso de pós-graduação pelos ensinamentos e experiências transmitidos;

Aos funcionários do Laboratório de Estradas da Escola de Engenharia de São Carlos, Antônio Carlos Gigante, João Domingos Pereira Filho e Paulo Toyama, pelo apoio concedido e amizade;

Aos demais professores e funcionários do Departamento de Transportes;

Ao Laboratório de Saneamento da Escola de Engenharia de São Carlos pela realização de análises químicas e dos ensaios de solubilização e Lixiviação. Em especial ao professor Associado Luís Antônio Daniel e aos senhores: Paulo Fragiácomo, Júlio César Trofino, Juliana Gonçalves dos Santos e Maria Aparecida Peres Viudes; 
Ao Laboratório de Recursos Hídricos da Universidade de Ribeirão Preto, em especial a professora M.Sc. Cristina F. Pereira Rosa Paschoalato, pela amizade e apoio a esta pesquisa, realizando os ensaios de massa bruta e grande parte das análises químicas;

Aos senhores: Edivaldo Cardoso, Ercio Santoni do IFSC e Mário Sérgio Schultz do IQSC, pela adequação de alguns componentes do equipamento do ensaio de lixiviação com extrator soxhlet;

Ao engenheiro Mário Rubens Pereira da PAMA - Fundição pelas informações e ao Centro da Indústria de Sertãozinho e Região (CEISE), em especial ao Senhor Gembre;

Ao Senhor Anderson Macieira Bramé pelas informações relativas ao passivo ambiental da areia de fundição em Ibaté /SP (MPLM);

À Filomena Aguiar Mergulhão, minha sogra, e aos meus irmãos, em especial a Lúcia, por todas as contribuições;

Ao amigo João Ferreira Gonçalves, Aeronáutica - Belém/Pará, pela amizade e colaboração;

A todos os amigos do STT, em especial: ao Adalberto Leandro Faxina pelas contribuições, amizade e suporte na impressão, encadernação e distribuição dos exemplares finais da Tese; ao Adson Viana Alecrin por todas as contribuições e amizade; à Ana Furlan e ao Caio Rubens, pelo apoio na moldagem dos corpos-de-prova e a permuta de experiências, e à Jisela Aparecida Santanna Greco pela valiosa contribuição referente à execução dos ensaios de interesse à pavimentação;

À Dra. Sandra Bertollo, à Lílian Pereira Rossi e à Elena Luzia Palloni Gonçalves (Setor de referência da Biblioteca da EESC) por todas as contribuições;

À Sonia Lúcia Costardi, pela amizade e contribuição; Aos colegas do Departamento de Transportes de São Carlos. 
SUMÁRIO

LISTA DE FIGURAS viii

LISTA DE TABELAS Xiii

RESUMO xix

ABSTRACT $\quad x x i$

1. INTRODUÇÃO 1

1.1 Identificação do problema e justificativa 1

1.2 Objetivos 3

1.3 Estrutura da pesquisa 3

2.FUNDICAO 5

2.1. Introdução 5

2.1.1 Método de fabricação de objetos metálicos 6

2.1.1.1 Tratamento mecânico 6

2.1.1.2 Usinagem

2.1.1.3 Metalurgia do pó $\quad 8$

2.1.1.4 Soldagem 8

2.1.1.5 Fundição 8

$\begin{array}{ll}2.2 \text { Etapas do processo de fundição } & 10\end{array}$

2.2.1 Modelação 10

$\begin{array}{ll}\text { 2.2.2 Moldagem } & 11\end{array}$

2.2.2.1 Moldagem em areia verde 12

2.2.2.2 Moldagem em areia seca 13

2.2.2.3 Moldagem em areia-cimento 14

2.2.2.4 Moldagem em areia de macho 14 
2.2.2.5 Moldagem pelo processo $\mathrm{CO}_{2}$

2.2.2.6 Processo em casca (Shell molding)

2.2.2.7 Moldagem pelo processo de cera perdida ou por investimento $\begin{array}{ll}\text { (Investment casting) } & 16\end{array}$

2.2.2.8 Processo em moldes permanentes ou fundição em coquilha 16

2.2.2.9 Processo em moldes semipermanentes 17

2.2.2.10 Processo em fundição por centrifugação 17

$\begin{array}{ll}\text { 2.2.3 Macharia } & 18\end{array}$

$\begin{array}{ll}2.2 .4 \text { Fusão } & 18\end{array}$

$\begin{array}{ll}2.2 .5 \text { Vazamento } & 19\end{array}$

2.2.6 Desmoldagem 20

2.2.7 Limpeza e rebarbação $\quad 20$

2.3 Areia de fundição $\quad 21$

$\begin{array}{ll}\text { 2.3.1 Passivo ambiental de areia de Fundição } & 27\end{array}$

2.3.2 Reutilização da areia de Fundição 32

2.3.3 Reutilização da areia de fundição em pavimentação asfáltica 35

3. MISTURAS ASFÁLTICAS 38

3.1 Cimentos asfálticos de petróleo 41

3.2 Agregados 46

3.3 Projeto de misturas asfálticas 53

$\begin{array}{ll}\text { 3.4 Deformação permanente } & 60\end{array}$

$\begin{array}{ll}3.5 \text { Fadiga } & 64\end{array}$

3.6 Ensaio para avaliação das propriedades mecânicas das misturas 67

3.6.1 Ensaio de fluência por compressão uniaxial estática 67

3.6.1.1 Procedimento para o ensaio de fluência por compressão uniaxial estática 69

3.6.2 Ensaio de resistência à tração por compressão diametral (ensaio de tração indireta) 72

3.6.3 Ensaio do módulo de resiliência por compressão diametral dinâmica $\quad 73$

$\begin{array}{ll}\text { 3.6.4 Ensaio Cantabro } & 78\end{array}$

3.6.5 Ensaio de dano por umidade induzida (AASHTO T 283/99- Metodologia Lottman Modificada) $\quad 80$

3.6.6 Envelhecimento 82 
4. MATERIAIS E MÉTODOS

4.1 Programação experimental $\quad 85$

4.2 Materiais utilizados 86

4.2.1 Agregados 86

4.2.2 Cimento asfáltico $\quad 91$

4.3 Misturas asfálticas 93

4.3.1 Planejamento fatorial 98

4.3.2 Processo de misturação dos materiais para moldagem 103

4.3.3 Ensaios Ambientais 106

4.3.3.1 Ensaio de lixiviação de resíduos sólidos $\quad 107$

4.3.3.2 Ensaio de solubilização de resíduos sólidos $\quad 107$

4.3.3.3 Ensaio de alteração por lixiviação contínua com extrator soxhlet 108

4.3.4 Ensaios de Interesse à Pavimentação 110

$\begin{array}{ll}\text { 4.3.4.1 Ensaios de envelhecimento } & 110\end{array}$

4.3.4.2 Ensaio de dano por umidade induzida 111

4.3.4.3 Ensaio de fluência por compressão uniaxial estática 115

4.3.4.4 Ensaio cantabro 116

4.3.4.5. Ensaio de resistência à tração 117

4.3.4.6 Ensaio do módulo de resiliência 118

$\begin{array}{ll}\text { 4.3.5 Tratamento estatístico dos resultados } & 119\end{array}$

5. APRESENTAÇÃO, ANÁLISE E DISCUSSÃO DOS RESULTADOS 120

5.1 Dosagem Marshall 122

5.2 Cantabro (NLT 325/86) 123

5.3 Dano por Umidade Induzida (AASHTO T 283-99) 128

5.4 Resistência à Tração por Compressão Diametral (DNER-ME 138/94) 132

5.5 Módulo de Resiliência (DNER-ME 133/94) 135

5.6 Fluência por Compressão Uniaxial Estática 143

5.6.1. Fluência por Compressão Uniaxial Estática com tensão de 0,1 MPa 143

5.6.2. Fluência por Compressão Uniaxial Estática com tensão de 0,4 MPa 153

5.6.2.1 Análise e discussão dos resultados do ensaio de Fluência por

Compressão Uniaxial Estática - tensão de 0,4 MPa e prato superior normal (102 mm)

5.6.2.2 Análise e discussão dos resultados do ensaio de Fluência por 
Compressão Uniaxial Estática - tensão de 0,4 MPa e prato superior reduzido $(51 \mathrm{~mm})$

5.6.2.3 Comparação entre resultados do ensaio com o prato superior padrão e os resultados do ensaio com o prato superior reduzido (tensão - 0,4 MPa)

5.7 Ensaios ambientais de classificação de resíduo sólidos

6. CONCLUSÕES E RECOMENDAÇÕES

6.1 Dosagem Marshall 181

6.2 Ensaio Cantabro 181

6.3 Ensaio de Dano por Umidade Induzida 182

6.4 Ensaio de Resistência à Tração por Compressão Diametral 183

6.5 Ensaio de Módulo de Resiliência 183

6.6 Ensaio de Fluência por Compressão Uniaxial Estática 185

6.6.1 Deformação total 185

6.6.2 Módulo de fluência 186

6.6.3 Inclinação do estágio secundário 188

6.7 Ensaios de avaliação do risco ambiental 189

6.8 Conclusão geral (Resumo) 190

REFERÊNCIAS 192

APÊNDICE A 198

APÊNDICE B 207

APÊNDICE C 238 ANEXO A 


\section{LISTA DE FIGURAS}

Figura 2.01. Vazamento do metal no molde 9

Figura 2.02. Molde em areia $\quad 12$

Figura 2.03. Vazamento do metal no molde 19

Figura 2.04. Passivo ambiental 30

Figura 2.05. Poço de monitoramento 30

Figura 3.01. Análise visual do CP submetido ao dano de umidade induzida $\quad 51$

Figura 3.02. Representação de uma partícula de agregado 53

Figura 3.03. Representação das densidades: aparente, real e efetiva; teor de vazios e teor de asfalto efetivo em mistura compactadas no pavimento (adaptada do ASPHALT INSTITUTE, 1995) 59

Figura 3.04. Representação dos volumes em uma amostra de asfalto compactada (adaptada do ASPHALT INSTITUTE, 1995)

Figura 3.05. Estágios da curva de fluência (adaptado de LITTLE et al.,1993) 69

Figura 3.06. Ensaio de fluência por compressão uniaxial estática 70

Figura 3.07. Ensaio de resistência à tração por compressão diametral 73

Figura 3.08. Montagem do ensaio do Módulo de resiliência 76

Figura 3.09. Representação das deformações verticais e horizontais no ensaio de módulo de resiliência $\quad 76$

Figura 3.10. Parte do gráfico do ensaio do Módulo de Resiliência (deformação horizontal versus o tempo) 77

Figura 4.01. Distribuição granulométrica da areia de Fundição e da Areia Virgem 89

Figura 4.02. Faixa C do DNER e distribuição granulométrica dos agregados com 5, 10 e 15\% de Areia de Fundição 91

Figura 4.03. Variação da Viscosidade Saybolt-Furol com a temperatura 93

Figura 4.04. Gráfico dos parâmetros Marshall das misturas asfálticas 97

Figura.4.05. Ensaio de lixiviação contínua com extrator soxhlet 109 
Figura 4.06. Corpos-de-prova durante o período de esfriamento (envelhecimento em longo prazo)

Figura 4.07. Croquis - ensaios de fluência por compressão uniaxial estática

Figura 5.01. Perda de massa versus volume de vazios

Figura 5.02. Perda de massa versus teor de asfalto

Figura 5.03. Resistências à tração dos corpos-de-prova condicionados e não condicionados - ensaios de dano por umidade induzida

Figura 5.04. Relações de resistência à tração dos ensaios de dano por umidade induzida

Figura 5.05. Resistências à tração dos corpos-de-prova não condicionados no ensaio de umidade induzida e dos corpos-de-prova no ensaio de tração indireta (normal)

Figura 5.06. Resistência à tração versus volume de vazios reais médios

Figura 5.07. Resistência à tração versus teor de asfalto

Figura 5.08. Resistência à tração versus condições de envelhecimento - 4\% de vazios

Figura 5.09. Módulo de resiliência das mistura não envelhecidas - média total 136

Figura 5.10. Módulo de resiliência das mistura não envelhecidas - direção $0^{\circ} \quad 136$

Figura 5.11. Módulo de resiliência das mistura não envelhecidas - direção 90 137

Figura 5.12. Módulo de resiliência das mistura versus condições de envelhecimento ( $4 \%$ de vazios)

Figura 5.13. Módulo de resiliência das mistura versus condições de envelhecimento (4\% de vazios)

Figura 5.14. Módulo de resiliência das mistura versus condições de envelhecimento (4\% de vazios)

Figura 5.15. Módulo de resiliência das misturas não envelhecidas versus teor de asfalto - média nas duas direções

Figura 5.16. Relação MR/RT versus volume de vazios reais médios

Figura 5.17. Relação MR/RT versus teor de asfalto

Figura 5.18. Relação MR/RT versus condições de envelhecimento (4\% de vazios)

Figura 5.19. Deformação total versus volume de vazios (EFUE)

Figura 5.20. Recuperação de deformação versus volume de vazios (EFUE) 
Figura 5.21. Deformação total versus condições de envelhecimento (EFUE)

Figura 5.22. Recuperação de deformação versus condições de envelhecimento (EFUE)

Figura 5.23. Inclinação do estágio secundário versus volume de vazios (EFUE)

Figura 5.24. Inclinação do estágio secundário versus condições de envelhecimento (EFUE)

Figura 5.25. Módulo de fluência antes da recuperação versus volume de vazios (EFUE)

Figura 5.26. Módulo de fluência após a recuperação versus volume de vazios (EFUE)

Figura 5.27. Módulo de fluência antes da recuperação versus condições de envelhecimento (EFUE)

Figura 5.28. Módulo de fluência após a recuperação versus condições de envelhecimento (EFUE)

Figura 5.29. Deformação total versus volume de vazios - pratos normal (PN) e reduzido (PR) (EFUE)

Figura 5.30. Recuperação de deformação versus volume de vazios - PN e PR (EFUE)

Figura 5.31. Deformação total versus condições de envelhecimento- PN e PR (EFUE)

Figura 5.32. Recuperação de deformação versus condições de envelhecimento PN e PR (EFUE)

Figura 5.33. Inclinação do estágio secundário versus volume de vazios - PN e PR (EFUE)

Figura 5.34. Inclinação do estágio secundário versus condições de envelhecimento - PN e PR (EFUE)

Figura 5.35. Módulo de fluência antes da recuperação versus volume de vazios PN e PR (EFUE)

Figura 5.36. Módulo de fluência após a recuperação versus volume de vazios PN e PR (EFUE)

Figura 5.37. Módulo de fluência antes da recuperação versus condições de envelhecimento - PN e PR (EFUE)

Figura 5.38. Módulo de fluência, após a recuperação, para as misturas 
condicionadas - Prato Normal e Prato Reduzido

Figura 5.39. Comportamento de parâmetros químicos ao longo do tempo (lixiviação com extrator soxhlet)

Figura 5.40. Comportamento de parâmetros químicos ao longo do tempo (lixiviação com extrator soxhlet)

Figura 5.41. Comportamento de parâmetros químicos ao longo do tempo (lixiviação com extrator soxhlet)

Figura 5.42. Comportamento de parâmetros químicos ao longo do tempo (lixiviação com extrator soxhlet)

Figura 5.43. Comportamento de parâmetros químicos ao longo do tempo (lixiviação com extrator soxhlet)

Figura A.01. Gráficos dos parâmetros Marshall para a mistura com 5\% de Areia de fundição

Figura A.02. Gráficos dos parâmetros Marshall para a mistura com 10\% de Areia de fundição

Figura A.03. Gráficos dos parâmetros Marshall para a mistura com 15\% de Areia de fundição

Figura A.01. Gráficos dos parâmetros Marshall para a mistura com 10\% de Areia Virgem

Figura C.01. Comportamento de parâmetros químicos ao longo do tempo (lixiviação com extrator soxhlet) - Situação I

Figura C.02. Comportamento de parâmetros químicos ao longo do tempo (lixiviação com extrator soxhlet) - Situação I

Figura C.03. Comportamento de parâmetros químicos ao longo do tempo (lixiviação com extrator soxhlet) - Situação I

Figura C.04. Comportamento de parâmetros químicos ao longo do tempo (lixiviação com extrator soxhlet) - Situação I

Figura C.05. Comportamento de parâmetros químicos ao longo do tempo (lixiviação com extrator soxhlet) - Situação I

Figura C.06. Comportamento de parâmetros químicos ao longo do tempo (lixiviação com extrator soxhlet) - Situação II

Figura C.07. Comportamento de parâmetros químicos ao longo do tempo (lixiviação com extrator soxhlet) - Situação II 
Figura C.08. Comportamento de parâmetros químicos ao longo do tempo

$$
\text { (lixiviação com extrator soxhlet) - Situação II }
$$

Figura C.09. Comportamento de parâmetros químicos ao longo do tempo (lixiviação com extrator soxhlet) - Situação II

Figura C.10. Comportamento de parâmetros químicos ao longo do tempo

$$
\text { (lixiviação com extrator soxhlet) - Situação II }
$$

Figura C.11. Comportamento de parâmetros químicos ao longo do tempo (lixiviação com extrator soxhlet) - Situação III

Figura C.12. Comportamento de parâmetros químicos ao longo do tempo (lixiviação com extrator soxhlet) - Situação III

Figura C.13. Comportamento de parâmetros químicos ao longo do tempo (lixiviação com extrator soxhlet) - Situação III

Figura C.14. Comportamento de parâmetros químicos ao longo do tempo

$$
\text { (lixiviação com extrator soxhlet) - Situação III }
$$

Figura C.15. Comportamento de parâmetros químicos ao longo do tempo 


\section{LISTA DE TABELAS}

Tabela 2.01. Contração de solidificação de diferentes metais e ligas não ferrosos

Tabela 2.02. Temperatura de fusão e de vazamento

de alguns metais e ligas não ferrosas

Tabela 2.03. Mudança de fase do quartzo quando aquecido

Tabela 2.04. Densidades e pontos de fusão das principais areias utilizadas como material de moldagem

Tabela 2.05. Comparativo da produção regional de fundidos (toneladas) entre 2002 e 2003

Tabela 2.06. Comparativo da produção de metais fundidos (toneladas) entre 2002 e 2003.

Tabela 3.01. Especificação para o Cimento Asfáltico de Petróleo - Classificação por penetração - Regulamento Técnico 01/92 - REV.02 - DNC

Tabela 3.02. Especificação para o Cimento Asfáltico de Petróleo - Classificação por Viscosidade - Regulamento Técnico 01/92 - REV.02 - DNC

Tabela 3.03. Faixas dos parâmetros Marshall para camadas asfálticas

Tabela 4.01. Granulometria do agregado da Pedreira Sta Isabel da Leão-leão (Laboratório da EESC)

Tabela 4.02. Granulometria do agregado da Pedreira Bandeirantes (Laboratório da EESC)

Tabela 4.03. Granulometria das Areias utilizadas

(Laboratório da EESC)

Tabela 4.04. Granulometria (composição) do Agregado utilizado na pesquisa com $5 \%$ de areia de fundição

Tabela 4.05. Granulometria (composição) do Agregado utilizado na pesquisa com $10 \%$ de areia de fundição

Tabela 4.06. Granulometria (composição) do Agregado utilizado na pesquisa 
com 15\% de areia de fundição

Tabela 4.07. Granulometria (composição) do Agregado utilizado na pesquisa com $10 \%$ de areia virgem

Tabela 4.08. Características físicas dos agregados minerais

Tabela 4.09. Resultados dos Ensaios de caracterização do CAP 20 (Laboratório EESC)

Tabela 4.10. Faixa de temperatura dos componentes da mistura e de Compactação

Tabela 4.11. Composição granulométrica dos corpos-de-prova e densidade média dos grãos de cada composição de agregado

Tabela 4.12. Especificações das misturas asfálticas para a camada de rolamento 96

Tabela 4.13. Características das misturas asfálticas estudadas 98

Tabela 4.14. Identificação dos Fatores e Níveis 98

Tabela 4.15. Condições Experimentais 99

Tabela 4.16. Planejamento experimental para os ensaios de módulo de resiliência, tração indireta e fluência estática 102

Tabela 4.17. Planejamento experimental para o ensaio cantabro 102

Tabela 4.18. Planejamento experimental para o ensaio de dano por umidade induzida 103

Tabela 4.19. Comparativo entre teor de asfalto de projeto e prática 105

Tabela 4.20. Comparativo entre granulometria de projeto e prática 105

Tabela 4.21. Cronograma de coleta do extrato resultante do ensaio de lixiviação contínua com extrator soxhlet 109

Tabela 5.01. Resultados da dosagem Marshall

Tabela 5.02. Resultados do ensaio cantabro - misturas com 5\% de areia de fundição

Tabela 5.03. Resultados do ensaio cantabro - misturas com $10 \%$ de areia de fundição

Tabela 5.04. Resultados do ensaio cantabro - misturas com 15\% de areia de fundição

Tabela 5.05. Resultados do ensaio cantabro - misturas com 10\% de areia virgem

Tabela 5.06. Efeito do envelhecimento na RT (MPa) das misturas analisadas 
Tabela 5.07. Efeito do teor e do tipo de areia na RT (MPa) considerando as condições de envelhecimento

Tabela 5.08. Efeito do envelhecimento no MR (MPa) das misturas analisadas

Tabela 5.09. Efeito do teor e do tipo de areia no MR (MPa) - considerando as condições de envelhecimento

Tabela 5.10. Efeito do teor e do tipo de areia na deformação total $\left(10^{-3}\right)$ considerando as condições de envelhecimento (0,1 MPa)

Tabela 5.11. Efeito do teor e do tipo de areia na deformação total $\left(10^{-3}\right)$ considerando as condições de envelhecimento (0,4 MPa - prato normal)

Tabela 5.12. Resultados Analíticos dos parâmetros que ultrapassaram o limite de norma no ensaio de solubilização em amostra de areia de fundição 168

Tabela 5.13. Resultado Total da análise química do extrato oriundo do corpo-deprova de mistura asfáltica com 15\% de Areia de Fundição, submetido ao ensaio de lixiviação com extrator soxhlet

Tabela 5.14. Resultado da análise química do extrato oriundo da amostra de CAP20, submetida ao ensaio de alteração por lixiviação com extrator soxhlet

Tabela A.01. Resultado da dosagem Marshall para a mistura com 5\% de Areia de Fundição

Tabela A.02. Resultado da dosagem Marshall para a mistura com 10\% de Areia de Fundição

Tabela A.03. Resultado da dosagem Marshall para a mistura com 15\% de Areia de Fundição

Tabela A.04. Resultado da dosagem Marshall para a mistura com 10\% de Areia Virgem

Tabela B.01. Dados dos danos da umidade Induzida para a mistura com 5\% de Areia de Fundição - Volume de vazios 4\%

Tabela B.02. Dados dos danos da umidade Induzida para a mistura com 10\% de Areia de Fundição - Volume de vazios 4\%

Tabela B.03. Dados dos danos da umidade Induzida para a mistura com 15\% de Areia de Fundição - Volume de vazios 4\%

Tabela B.04. Dados dos danos da umidade Induzida para a mistura com 10\% de 
Areia Virgem - Volume de vazios 4\%

Tabela B.05. Dados dos danos da umidade Induzida para a mistura com 10\% de Areia de Fundição - volume de vazios $7 \pm 1 \%$

Tabela B.06. Dados dos danos da umidade Induzida para a mistura com 10\% de Areia Virgem - volume de vazios $7 \pm 1 \%$

Tabela B.07. Dados dos ensaios de resistência à tração para todas as condições experimentais (misturas)

Tabela B.08. Resultados dos ensaios de módulo de resiliência para todas as condições experimentais (misturas)

Tabela B.09. Resultados dos ensaios de módulo de resiliência para todas as misturas não envelhecidas (Média Total)

Tabela B.10. Resultados dos ensaios de módulo de resiliência para todas as misturas condicionadas - 4\% de vazios (Média Total)

Tabela B.11. Resultados da Relação Módulo de Resiliência por Resistência à Tração - misturas não envelhecidas - teor de vazios (Média Total)

Tabela B.12. Resultados da Relação Módulo de Resiliência por Resistência à Tração - misturas não envelhecidas - teor de asfalto (Média Total)

Tabela B.13. Resultados da Relação Módulo de Resiliência por Resistência à Tração - misturas condicionados - 4\% de vazios (Média Total)

Tabela B.14. Resultados dos ensaios de fluência uniaxial para todas as condições experimentais (misturas) no nível de tensão de 0,1 MPa, exceto os dos módulos de fluência

Tabela B.15. Resultados dos ensaios de fluência uniaxial para todas as condições experimentais (misturas) no nível de tensão $0,4 \mathrm{MPa}$, com prato superior de $102 \mathrm{~mm}$, exceto os dos módulos de fluência

Tabela B.16. Resultados dos ensaios de fluência uniaxial para todas as condições experimentais (misturas) no nível de tensão 0,4 MPa, com prato superior de $51 \mathrm{~mm}$, exceto os dos módulos de fluência

Tabela B.17. Resultados dos módulos de fluência uniaxial para todas as condições experimentais (misturas) no nível de tensão de 0,1 MPa

Tabela B.18. Resultados dos módulos de fluência uniaxial para todas as condições experimentais (misturas) no nível de tensão de 0,4 MPa, com prato superior de $102 \mathrm{~mm}$ 
Tabela B.19. Resultados dos módulos de fluência uniaxial para todas a condições experimentais (misturas) no nível de tensão de 0,4 MPa, com prato superior de $51 \mathrm{~mm}$

Tabela C.01. Resultados Analíticos de ensaios de solubilização, lixiviação e massa bruta da areia de fundição utilizada na pesquisa

Tabela C.02. Resultados Analíticos de ensaios de solubilização, lixiviação e massa bruta da areia Virgem utilizada na pesquisa

Tabela C.03. Resultado Analítico dos ensaios de solubilização, lixiviação e massa bruta de uma amostra de massa asfáltica com 10\% de Areia Virgem - massa solta

Tabela C.04. Resultado Analítico dos ensaios de solubilização, lixiviação e massa bruta de uma amostra de massa asfáltica com 15\% de Areia de Fundição - massa solta

Tabela C.05. Resultado da análise química do extrato oriundo do corpo-de-prova de mistura asfáltica com 15\% de Areia de Fundição, submetido ao ensaio de lixiviação com extrator soxhlet (primeiro dia $-1^{\mathrm{a}}$ Coleta)

Tabela C.06. Resultado Parcial da análise química do extrato oriundo do corpode-prova de mistura asfáltica com 15\% de Areia de Fundição, submetido ao ensaio de alteração por lixiviação com extrator soxhlet - (sétimo dia do início do ensaio - $2^{\text {a }}$ Coleta)

Tabela C.07. Resultado Parcial da análise química do extrato oriundo do corpode-prova de mistura asfáltica com 15\% de Areia de Fundição, submetido ao ensaio de alteração por lixiviação com extrator soxhlet - $\left(21^{\circ}\right.$ dia do início do ensaio - $3^{\mathrm{a}}$ Coleta $)$

Tabela C.08. Resultado Parcial da análise química do extrato oriundo do corpode-prova de mistura asfáltica com 15\% de Areia de Fundição, submetido ao ensaio de alteração por lixiviação com extrator soxhlet - $\left(45^{\circ}\right.$ dia do início do ensaio - $4^{\mathrm{a}}$ Coleta $)$

Tabela C.09. Resultado Parcial da análise química do extrato do corpo-de-prova de mistura asfáltica com 15\% de Areia de Fundição, submetido ao ensaio de lixiviação com extrator soxhlet - $\left(90^{\circ}\right.$ dia do início do ensaio $-5^{\mathrm{a}}$ Coleta) 
Tabela C.10. Resultado Total da análise química do extrato do corpo-de-prova de mistura asfáltica com 15\% de Areia de Fundição, submetido ao ensaio de lixiviação com extrator soxhlet - (Resumo)

Tabela C.11. Resultado Total da análise química do extrato do corpo-de-prova de mistura asfáltica com 15\% de Areia de Fundição, submetido ao ensaio de lixiviação com extrator soxhlet - (Resumo, desprezando-se a $4^{\mathrm{a}}$ coleta)

Tabela C.12. Resultado Total da análise química do extrato do corpo-de-prova de mistura asfáltica com 15\% de Areia de Fundição, submetido ao ensaio de lixiviação com extrator soxhlet - (Resumo multiplicado por 0,418)

Tabela C.13. Resultado da análise química do extrato oriundo da amostra de CAP 20, submetida ao ensaio de lixiviação com extrator soxhlet 


\section{RESUMO}

COUTINHO NETO, BENEDITO (2004). Avaliação do reaproveitamento de areia de fundição como agregado em misturas asfálticas densas. 304 p.Tese (Doutorado) - Escola de Engenharia de São Carlos, Universidade de São Paulo, São Carlos, 2004.

A areia de fundição é um resíduo sólido industrial oriundo da etapa de desmoldagem de peças metálicas no processo de produção de fundidos. Esse resíduo, dependendo do processo de fundição utilizado (moldagem a verde, moldagem em casca, moldagem com resina sintética e outros) e do material moldado, pode conter elementos e/ou compostos químicos que podem causar impacto ambiental. As substâncias que podem estar presentes na areia de fundição são provenientes, em parte, do tipo de metal moldado e, em parte, do aglomerante utilizado no processo. O objetivo deste trabalho é apresentar um estudo de alternativa para utilização desse rejeito com a finalidade de contribuir para a minimização do problema, reutilizando-o na composição dos agregados para concreto asfáltico. Para tanto, foram realizados ensaios de classificação de resíduos em amostras de areias virgem e de fundição e em misturas asfálticas, contendo areia vigem e de fundição, não compactadas, para verificar se este resíduo, quando incorporado à massa asfáltica, poluiria o meio ambiente. Realizou-se, também, ensaio de lixiviação com extrator soxhlet em corpo-de-prova de mistura asfáltica com $15 \%$ de areia de fundição para avaliar o comportamento, em termos ambientais, desse material a longo prazo. Para verificar o desempenho, da massa asfáltica contendo esse resíduo, na pavimentação, foram realizados ensaios de dosagem Marshall, dano por umidade induzida, cantabro, resistência à tração, módulo de resiliência e fluência estática. Com base nos resultados obtidos, pôde-se concluir, em linhas gerais, que a reutilização de areia de fundição em pavimentação asfáltica é viável, pois as misturas asfálticas contendo este resíduo apresentaram boas propriedades mecânicas de interesse à pavimentação. Além disso, os ensaios de classificação de resíduos sólidos realizados na massa asfáltica com areia de fundição, cuja classificação original é Classe II - Não Inerte, classificaram a massa asfáltica como resíduo Classe III - Inerte, o que sugere um encapsulamento deste resíduo pela massa asfáltica.

Palavras-chaves: reaproveitamento de areia de fundição; misturas asfálticas; impacto ambiental; pavimentação; ensaios em pavimentação; resíduos sólidos 


\section{ABSTRACT}

COUTINHO NETO, BENEDITO (2004). Evaluation of the reusing of waste foundry sand as an aggregate in dense asphalt. 304 p. Ph.D Thesis - Escola de Engenharia de São Carlos, Universidade de São Paulo, São Carlos, 2004.

Foundry sand is an industrial solid waste resulting from sand casting process in foundry industries. Depending on the type of foundry process (green sand molding, shell sand molding, molding using synthetic resin and others) and of the type cast metal, this waste may contain elements and/or chemical compounds that may cause environmental impact. The substances that may be found in foundry sand proceed partly from the type of the metal and partly from the agglutinant used on the process. The purpose of this research is to present an alternative study for the use of the foundry sand, reusing it in the composition of the aggregate for asphalt concrete and thus to contribute to minimize the environmental impact caused for this waste. To reach this purpose, classification tests of solid wastes were run in virgin sand and foundry sand and asphaltic mixtures not compacted containing both types of sand. This investigation considered the possibility of this waste when incorporated to asphaltic mixture to pollute the environment. Leaching with soxhlet extractor test in specimen of asphaltic mixture with $15 \%$ of foundry sand was also realized to evaluate the performance of this material a long-term period in environmental terms. In order to verify the performance in paving, the mixtures were submitted to Marshall method of mix design and to the tests of resilient modulus, indirect tensile strength, cantabro, resistance of compacted bituminous mixture to moisture-induced damage and static creep. Based on the results, it could be concluded that, in a general way, the reuse of foundry sand in asphaltic paving is viable, once the asphaltic mixtures containing this residue presented good mechanical properties. Besides the classification tests of solid wastes realized in asphaltic mixture containing foundry sand, which original classification as class II - No inert, passed to a classification of asphaltic mixture Class III - Inert, what suggests that the waste was encapsulated in hot mix asphalt.

KEY WORDS: reusing of foundry sand; hot mix asphalt; environment impact; paving; pavement tests; solid wastes. 


\section{INTRODUÇÃO}

\subsection{Identificação do problema e justificativa}

$\mathrm{Na}$ indústria de fundição, a moldagem em areia, apesar de antiga, ainda é o processo mais utilizado. Neste processo, geralmente, a areia silicosa é misturada a um aglomerante (argila, cimento, resina) e água. A moldagem em areia é bastante usada, por ser econômica, por permitir uma produção de qualidade, tanto em metais ferrosos como em não ferrosos e por ser bastante apropriada para a produção em série, pois admite uma perfeita sincronização entre a operação de moldagem e a de fusão do metal. Contudo, a areia, após a utilização na indústria de fundição, torna-se um grave problema ambiental, pois fica contaminada por elementos e compostos químicos, tais como: arsênio, bário, cádmio, chumbo, sódio, mercúrio, cloretos, fluoretos, fenóis e surfactantes.

As indústrias de fundição brasileiras geraram, de janeiro a novembro de 2003, 2.083.581 toneladas de produtos fundidos, sendo a região Sudeste a maior geradora destes produtos, tendo a maior concentração no Estado de São Paulo (ABIFA, 2003). Segundo McIntyre et al. (1992), a cada tonelada de metal produzida, tem-se aproximadamente uma tonelada de resíduo de fundição, conseqüentemente, a quantidade deste resíduo gerada no Brasil em 2003 ultrapassou a dois milhões de toneladas. Com base nesses dados, conclui-se que o passivo ambiental das fundições no País é preocupante.

O reaproveitamento da areia de fundição, seja no reuso, ou na reciclagem (primária e secundária), traz grandes benefícios para o meio ambiente e para as indústrias. Com isto, contribui-se para diminuir a poluição do meio ambiente e a quantidade de recursos naturais utilizados, além de minimizar a problemática das indústrias com o destino final deste resíduo. Os empresários, ao destinarem o resíduo inadequadamente, estão contribuindo, de uma forma irresponsável, com a poluição do meio ambiente, e sujeitos a multas dos órgãos competentes; se adequadamente, que seria a remoção deste material para aterros industriais, não acabam com o problema, pois isto diminui a vida útil destes 
e contribui para aumentar o custo final do produto de fundição. Segundo os empresários do ramo, a remoção dos resíduos para aterros industriais é altamente dispendiosa, visto que há o custo de transporte e o pagamento de altas taxas para utilizá-los.

Assim, universidades e empresas internacionais e nacionais têm se envolvido em pesquisas com a finalidade de buscar um destino mais adequado para esse resíduo. Estas pesquisas estão relacionadas à reutilização da areia fora da atividade de fundição (reciclagem secundária), tais como: na fabricação de blocos de concreto, aterro em rodovias, como parte do agregado fino na massa asfáltica, na composição da pavimentação asfáltica armada e em concreto para aplicação não estrutural.

Destas pesquisas, vale salientar o estudo de Partridge et al. (1999) sobre a reutilização de areia de fundição para a construção de aterro de rodovias em Indiana nos Estados Unidos. Em 1996, o Departamento de Transportes de Indiana, em parceria com a Universidade de Purdue, construiu um aterro rodoviário utilizando areia de fundição de origem ferrosa. Monitoraram, antes, durante e após a construção (de 1994 a 1998) este aterro, por meio de ensaio para verificar o comprometimento do meio ambiente e constataram que o impacto ambiental no local fora negativo. Javed e Lovell (1995), também em Indiana, realizaram um estudo sobre a aplicação de areia de fundição em Engenharia Civil. Estes pesquisadores verificaram o potencial de utilização deste resíduo em aterro e subleito de rodovias, como agregado fino em material de baixa resistência controlada (Flowable fill) e como agregado fino no concreto asfáltico. Concluíram, dentre outras, que as areias de fundição estudadas demonstraram boas propriedades físicas e mecânicas e que as areias de fundição estudadas, provenientes do processo de moldagem a verde de metais ferrosos, têm baixa possibilidade de contaminar o meio ambiente.

A areia de fundição utilizada nesta pesquisa é proveniente de um processo de moldagem denominado cold-box (cura a frio). Neste processo, utilizam-se 98,56\% de areia de quartzo, 1,2\% de resina fenólica alcalina e 0,24\% de catalisador. Portanto, este resíduo (areia de fundição) tem grande probabilidade de conter fenóis, o que foi constatado por meio dos ensaios de classificação de resíduos sólidos (lixiviação, solubilização e massa bruta) realizados em amostra deste material. Os resultados das análises químicas dos parâmetros solubilizados mostraram que os fenóis, fluoretos, cloretos, alumínio e ferro ultrapassaram o valor máximo permitido pela norma (NBR 10004/87). 


\subsection{Objetivos}

Os objetivos desta pesquisa são:

$\checkmark$ testar a hipótese de que o emprego da areia de fundição das indústrias brasileiras na massa asfáltica não contribui para a contaminação do meio ambiente e não diminui a qualidade da massa asfáltica, quando empregando a mesma areia antes de sua utilização na fundição;

$\checkmark$ classificar as areias, segundo as normas ambientais vigentes, tanto a de fundição como a virgem (antes da utilização no processo de fundição), e a mistura asfáltica com incorporação de areia de fundição;

$\checkmark$ avaliar o potencial de poluição da areia de fundição quando incorporada a massa asfáltica;

$\checkmark$ avaliar o desempenho da massa asfáltica contendo areia de fundição, segundo as propriedades de engenharia, no que diz respeito à compatibilidade dessa areia com o aglutinante asfáltico, refletida na adesividade, oxidação do ligante e permanência das propriedades ao longo do tempo.

\subsection{Estrutura da pesquisa}

Esta pesquisa está dividida em seis capítulos, incluindo a introdução (capítulo 1), três apêndices (A, B e C) e um anexo. O capítulo 2 (Fundição) é referente à revisão bibliográfica, abordando, sucintamente, um histórico sobre o descobrimento do metal pela nossa civilização, os métodos de produção de peças metálicas, dando-se ênfase a fundição, visto que esta está diretamente relacionada com o propósito deste trabalho. Dentro do assunto fundição, abordam-se as etapas desse método, os processos de moldagem, os materiais para moldes, o passivo ambiental relativo a esse ramo industrial, a reutilização do resíduo de fundição (areia) de um modo geral e a reutilização da areia de fundição em pavimentação asfáltica.

O capítulo 3, denominado Misturas Asfálticas, também faz parte da revisão bibliográfica e versa sobre os materiais (cimentos asfálticos e agregados) utilizados em misturas asfálticas, projeto de misturas asfálticas, deformação permanente, fadiga, ensaio para avaliação das propriedades mecânicas das misturas (cantabro, dano por umidade induzida, envelhecimento, resistência à tração, módulo de resiliência e fluência por compressão uniaxial estática). 
No capítulo 4, abordam-se a descrição e a caracterização dos materiais utilizados para preparar as misturas asfálticas, bem como máquinas, equipamentos empregados e os métodos usados na realização dos ensaios ambientais (lixiviação, solubilização, massa bruta e lixiviação com extrator soxhlet) e mecânicos supracitados.

No capítulo 5, são apresentados os resultados, as análises realizadas (qualitativa e quantitativa) e as discussões acerca dos resultados, além de abordar sucintamente os procedimentos para investigar (identificar) o efeito dos fatores (volume de vazios, teor de areia e condições de envelhecimento) sobre as respostas (ensaios de interesse à pavimentação). O nível de significância ( $\alpha$ ) adotado para o tratamento estatístico foi 5\% (valores comumente utilizados, 1 e $5 \%$ ).

No capítulo 6, expõem-se as conclusões e sugestões fundamentadas nos resultados, nas análises e nas discussões apresentadas no capítulo 5.

Nos apêndices A, B e C, apresentam-se, respectivamente, resultados e gráficos da dosagem Marshall, dados e resultados dos ensaios mecânicos e resultados analíticos e gráficos (concentrações de parâmetros químicos versus tempo) relativos aos ensaios ambientais.

No anexo A, apresentam-se os laudos, referentes aos ensaios de classificação de resíduos (areia de fundição e areia virgem), segundo a NBR 10004/87, emitidos pela BIOAGRI AMBIENTAL LTDA e os laudos emitidos pelo Laboratório de Recursos Hídricos da UNAERP (Universidade de Ribeirão Preto) em conjunto com o Laboratório de Saneamento da Escola de Engenharia de São Carlos, concernentes à caracterização das massas asfálticas com 15\% de areia de fundição e com 10\% de areia virgem, além dos resultados da análise química do extrato (cinco coletas - idades diferentes) oriundo do ensaio de lixiviação com extrator soxhlet. 


\section{FUNDIÇÃO}

Neste capítulo abordam-se, sucintamente, um histórico sobre o descobrimento do metal pela nossa civilização, os processos de produção de peças metálicas, dando-se ênfase ao processo de fundição, visto que este está relacionado diretamente com o estudo aqui desenvolvido.

\subsection{Introdução}

Aceita-se que o descobrimento do metal pelo homem tenha ocorrido há cerca de 8000 anos, portanto, logo após o período neolítico (idade da pedra polida), que faz parte da época holocena, em que os vestígios culturais do homem pré-histórico se caracterizam pela presença de artefatos de pedra polida (instrumentos de trabalho e de defesa), pelo aparecimento das mais primitivas formas de agricultura, pela domesticação de alguns animais e pela a arte de trabalhar a argila.

Quando o homem aprendeu a dominar o fogo e a confeccionar artefatos de argilas, dispunha de dois elementos essenciais para a fundição de metais: o fogo para produzir calor para fundi-los e o vasilhame para contê-los durante as fases de fusão e vazamento.

De todos os metais, o ouro, confundido com pedra, parece ter sido o primeiro a chamar a atenção do homem primitivo pela sua aparência (pedra amarela), porém descobriu que este não era adequado para a produção de ferramentas e armas, em virtude de sua baixa dureza e alta ductilidade, mas que era de grande serventia para a produção de ornamentos. Após o descobrimento do ouro, o homem conheceu o cobre nativo (idade do cobre) há, aproximadamente, 5000 a.C., começando assim, o mais antigo período da idade do metal. Com o cobre o homem confeccionou utensílios e armas, pois descobriu que ao martelá-lo ele endurecia e que ao juntar pedaços desse metal e ao aquecê-los e martelá-los (forja rudimentar) formariam uma única massa. Desta forma, nasceu o primeiro metal industrial.

Após o cobre, o homem conheceu também a prata nativa, mas utilizavam esses metais (ouro, cobre e prata) da mesma forma que a pedra, a madeira e o osso. Ele considerava estes metais como uma espécie de pedra maleável. 
Em 3000 a.C., os sumérios, que já conheciam o princípio de fundição, descobriram o bronze, quando, acidentalmente, misturavam minério de estanho com minério de cobre, dando origem à idade do bronze. A idade do ferro começou, aproximadamente, em1000 a.C, na Ásia, se estendendo em seguida para a Europa e depois para a África (BARSA, 2003).

\subsubsection{Método de fabricação de objetos metálicos}

Atualmente, a fabricação de peças metálicas e de ligas, é fundamentada no que os nossos ancestrais nos legaram, mas com técnicas bastante desenvolvidas. Esta pode ser realizada, conforme os processos a seguir (BRADASCHIA et al.,1981):

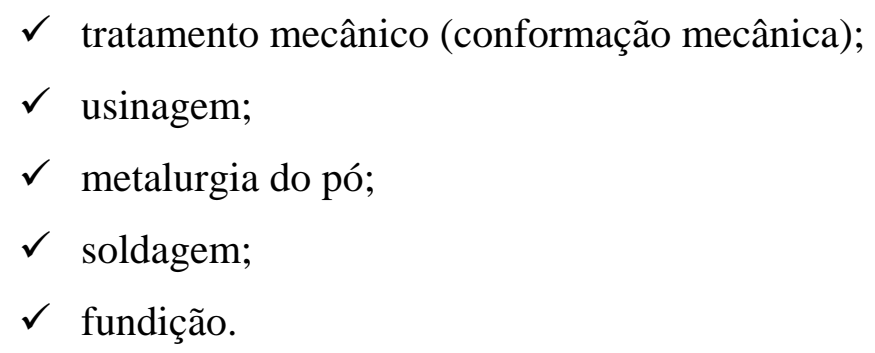

\subsubsection{Tratamento mecânico}

Vem a ser a conformação plástica no estado sólido, por meio de aplicação de esforços mecânicos sobre o metal a ser trabalhado, podendo ser a frio, se realizado a uma temperatura inferior a de recristalização ou a quente, se realizado a uma temperatura superior a de recristalização. Os principais processos de conformação dos metais são, a saber:

$\checkmark$ laminação - modificação da seção transversal de uma barra metálica, pela passagem forçada entre dois cilindros, cuja distância entre eles seja inferior a seção inicial da barra. O deslocamento da barra entre os cilindros se processa devido à ocorrência de forças de atrito que se originam na superfície de contato dos cilindros com a barra que está sendo trabalhada. A laminação é o processo de conformação mais importante;

$\checkmark$ forjamento - consiste no aquecimento de barra laminada, anteriormente, e submetê-la a batidas que darão a forma que o forjador necessita. Neste processo são utilizadas fornalhas, bigornas, marretas, foles, etc;

$\checkmark$ extrusão - o metal (laminado) é forçado a passar através de um orifício, tendo por objetivo alcançar uma forma alongada ou filamentosa; 
$\checkmark$ trefilação - baseia-se na conformação do metal por meio de uma tensão axial demasiada, isto é, por estiramento;

$\checkmark$ estampagem - consiste em submeter uma chapa metálica a uma pressão que marcará figuras, ornatos ou letras, a entalhe ou em relevo, por meio de molde, ou de molde e contramolde combinados.

Segundo Bradaschia et al. (1981), a laminação é o principal método de conformação de metais, não apenas pelo volume de produção, mas também, pelo fato de que os outros métodos de conformação necessitam geralmente ser submetidos antes ao processo de laminação.

\subsubsection{Usinagem}

Processo de dar forma aos metais, ou apenas, o método de acabamento final, que consiste em submeter o metal, a temperatura ambiente, a peças cortantes mais duras que ele mesmo, tendo em vista a forma definitiva, o bom arremate e dimensões dentro de rigorosos padrões de qualidade. Segundo Bradaschia et al. (1981), existem cinco tipos de operação de usinagem, definidas como a seguir:

$\checkmark$ torneamento é o processo mecânico de usinagem destinado a aquisição de superfícies de revolução utilizando uma ou mais ferramentas monocortantes;

$\checkmark$ aplainamento é o processo de usinagem que tem como finalidade a obtenção de superfícies geradas por um movimento retilíneo alternativo da peça ou da ferramenta;

$\checkmark$ furação é o processo mecânico destinado à obtenção de um orifício, geralmente, cilíndrico, por intermédio de brocas em máquinas de furar (furadeiras). Estas máquinas podem ser de eixo vertical ou horizontal. A ferramenta ou a peça gira e, concomitantemente, ou uma, ou a outra se afasta, de acordo com uma trajetória retilínea, coincidente ou paralela ao eixo principal da máquina;

$\checkmark$ fresamento é o processo mecânico de usinagem destinado a aquisição de superfícies quaisquer, por meio de instrumentos multicortantes e para executá-la, o instrumento gira e a peça ou o instrumento multicortante se desloca, de acordo com uma trajetória qualquer;

$\checkmark$ retificação é o processo de usinagem por abrasão destinado à aquisição de superfícies mediante ferramenta abrasiva de revolução. A ferramenta gira e a 
peça ou a ferramenta se afasta segundo uma trajetória predeterminada, podendo a peça girar ou não.

Nos processos de usinagem são utilizadas ferramentas manuais ou máquinas operatrizes, como tornos, plainas, furadeiras, fresadoras, retificadoras, etc.

\subsubsection{Metalurgia do pó}

É o método que trata dos pós metálicos, geralmente associados a pós não metálicos com a finalidade de obter peças que possam ser usadas em ramos como a mecânica e a eletricidade. Neste processo, o metal é reduzido ao estado pulverulento para, em seguida, ser submetido a uma série de operações mecânicas e térmicas até a obtenção de peças com formas, dimensões e propriedades adequadas para o uso a que se destina, isto é, o pó metálico ou de liga são comprimidos em matrizes com a forma da peça a ser produzida.

As partículas comprimidas atingem densidades aparentes elevadas e em seguida são aquecidas ou sinterizadas (colocadas em fornos de atmosfera controlada a temperaturas inferiores às de fusão), podendo, ainda, no caso de algumas ligas, receberem tratamento térmico subseqüente. Os pós podem ser produzidos por processos mecânicos, físicos ou químicos. As grandes vantagens da metalurgia do pó são a garantia de trabalhar com ligas ou metais de alta pureza, o que não é possível utilizando outros métodos, e perdas mínimas no processo de fabricação.

\subsubsection{Soldagem}

Técnica de fabricação de metais que consiste em reunir duas ou mais peças constitutivas, produzidas por fundição, usinagem ou outro método de manufatura de objetos metálicos, para formar uma nova peça, assegurando entre si, a continuidade do material e, conseqüentemente, suas propriedades químicas e mecânicas.

\subsubsection{Fundição}

O outro processo de fabricação de metais muito importante e que faz parte deste estudo, é o de Fundição, que por definição, segundo Kondic (1973), é qualquer processo de fusão e vazamento de metais em moldes, tendo como objetivo a produção de peças com formas e dimensões previamente estabelecidas (Figura 2.01a).

As peças fundidas são obtidas pela solidificação do metal líquido em molde, que possa permanecer em contato com o fogo ou suportar calor elevado, sem alterações significativas 
em suas características (refratário) e que tenha a forma, em negativo, do produto final (Figura 2.01b).

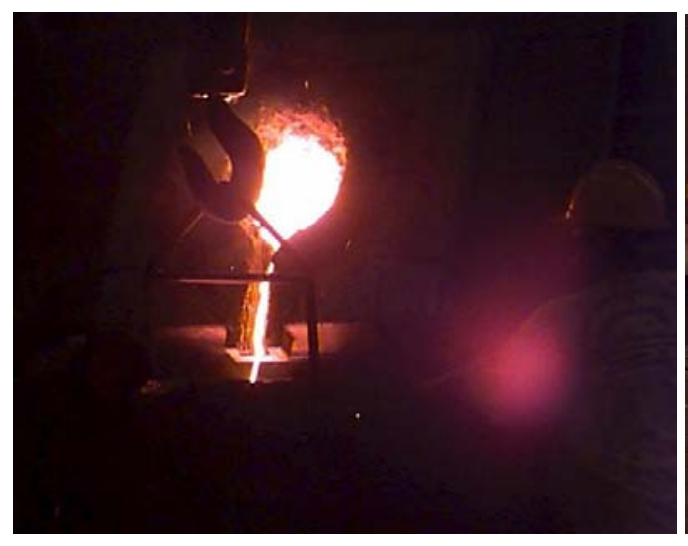

2.01a. Vazamento do metal

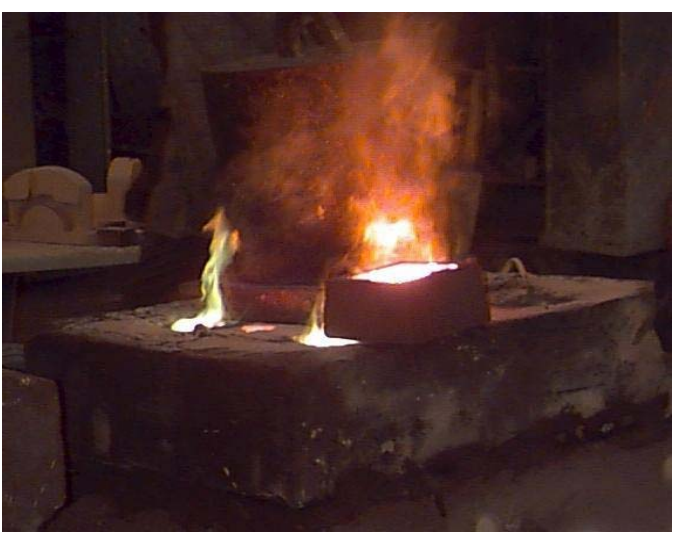

2.01b. Molde após preenchimento

Figura 2.01. Vazamento do metal no molde

Ainda, segundo Kondic (1973), a fundição sendo essencialmente uma atividade humana, a experiência ou a habilidade de "como fazer" peças fundidas podem ser adquiridas por meio de treinamento prático, no entanto, o conhecimento necessário para entender “como são ou podem ser feitas as peças fundidas” é alcançado pelo estudo do processo em termos de conceitos científicos e tecnológicos. O conhecimento prático de fundição pode ser, de um modo geral, resumido em procedimentos empíricos alcançados da prática da arte e a faculdade de compreender os inúmeros problemas, que surgem ao se praticar essa arte, deve, no entanto, ser embasada nos princípios fundamentais da engenharia e da ciência metalúrgica.

Desta forma, pode-se entender que fundição não é apenas uma arte, mas também, tecnologia e ciência aplicada. É arte, porque é transmitida por meio da prática, embora possa ser, em alguns aspectos, entendida e apreendida através de leitura; tecnologia porque, como em qualquer processo de fabricação, visa produzir grandes quantidades com o menor custo e obter requisitos mais precisos quanto às características dos metais fundidos (acabamento, resistência e durabilidade, por exemplo); ciência aplicada, porque os problemas de controle dos metais e ligas nos diversos estágios da fundição necessitam da aplicação de conhecimento da ciência dos metais e de outros materiais (KONDIC, 1973). 


\subsection{Etapas do processo de fundição}

Segundo Siegel et al. (1982), a fundição de uma peça metálica pode ser resumida, em síntese, em modelação, moldagem, macharia, fusão, vazamento, desmoldagem e rebarbação - limpeza.

Todas as etapas de fundição são abordadas considerando o exposto por SIEGEL et al. (1982). Estas são descritas sucintamente no desenvolvimento desse item, exceto a moldagem, por sua grande importância no processo de fundição e para o desenvolvimento desta pesquisa. Sua importância no processo de fundição é devida aos numerosos processos e materiais utilizados para confeccioná-los, bem como a qualidade dos resíduos resultantes da atividade de fundição está diretamente ligada ao processo de moldagem empregado.

\subsubsection{Modelação}

Esta operação engloba os requisitos necessários para a confecção do modelo, que é uma réplica da peça a ser reproduzida, porém com as dimensões acrescidas da contração para ela prevista (Tabela 2.01), devida à solidificação e o resfriamento, pois os metais/ligas, de um modo geral, se contraem ao se solidificarem. A reprodução em metal fundido e a criação do negativo do modelo forçam o projetista a ter em mente as melhores condições para a aquisição de peças facilmente moldáveis e que favoreçam as condições de enchimento para o metal a ser vazado.

Tabela 2.01. Contração de solidificação de diferentes metais e ligas não ferrosos

\begin{tabular}{cc}
\hline \hline Material & Contração (\%) \\
\hline \hline Alumínio & 1,4 \\
Antimônio & 0,0 \\
Bismuto & 1,3 \\
Latão & 1,6 \\
Bronze & 1,5 \\
Cobre & 1,3 \\
Chumbo & 2,6 \\
Magnésio & 1,6 \\
Níquel & 1,6 \\
Prata & 1,0 \\
Estanho & 0,7 \\
Zinco & 2,6 \\
\hline
\end{tabular}

Fonte: Bradaschia et al. (1981) 
Os fatores que mais influenciam no projeto de peças fundidas são a fluidez, a contração, a resistência a quente, as características geométricas e o acabamento superficial. Uma Modelação mal projetada não só onera os custos do processo de fabricação, pois dificulta a execução da peça fundida, mas também influi no acabamento e preço final. Os modelos são, geralmente, confeccionados em madeira, mas também podem ser confeccionados em metal, em plástico ou outro material que seja apropriado para esse fim, tais como cera, poliestireno (isopor) ou resina epóxi.

\subsubsection{Moldagem}

São os requisitos necessários para a confecção do molde, em material refratário moldado, sobre o modelo, que, ao ser extraído, deixa a impressão da peça que será fundida. O acabamento do produto final é caracterizado pelo material utilizado na confecção do molde, portanto o processo de fundição é dependente da natureza do molde (Figura 2.02).

Como supradito, a importância da moldagem no processo de fundição é em virtude dos numerosos processos e materiais empregados para sua execução, bem como a qualidade dos resíduos resultantes da atividade de fundição ser altamente dependente do processo empregado. Desta forma, segundo Siegel et al. (1982), os processos básicos de fundição são caracterizados pela técnica de moldagem e podem ser classificados como a seguir:

$\checkmark$ em areia verde;

$\checkmark$ em areia seca;

$\checkmark$ em areia-cimento;

$\checkmark$ em areia de macho;

$\checkmark$ pelo processo $\mathrm{CO}_{2}$;

$\checkmark$ em casca (Shell molding);

$\checkmark$ pelo processo de cera perdida ou por investimento (Investment casting);

$\checkmark$ em moldes permanentes;

$\checkmark$ em moldes semipermanentes;

$\checkmark$ em fundição por centrifugação.

No processo de $\mathrm{CO}_{2}$, o molde executado em areia verde é submetido ao tratamento com $\mathrm{CO}_{2}$, que provoca a passagem de uma corrente do gás através do molde. O gás reage com o silicato de sódio, produzindo sílica-gel, carbonato de sódio e água, resultando no endurecimento do molde em curto espaço de tempo. No processo em 
casca, com a areia aglomerada com resina polimerizável a quente, executam-se moldes, em forma de cascas finas, desde $5 \mathrm{~mm}$ de espessura. Como pode ser verificada, a maioria dos processos de fundição (moldagem), e até mesmo, os processos $\mathrm{CO}_{2}$ e em casca utilizam a areia.

A moldagem em areia (Figura 2.02) ainda é responsável pela maior tonelagem de produção de peças fundidas. A justificativa para isto, é a abundância desse material na natureza, tornando o processo mais econômico e por permitir produção de peças de qualidade, tanto em metais ferrosos como em não ferrosos. Desta forma, verifica-se a importância da areia para a indústria de fundição.

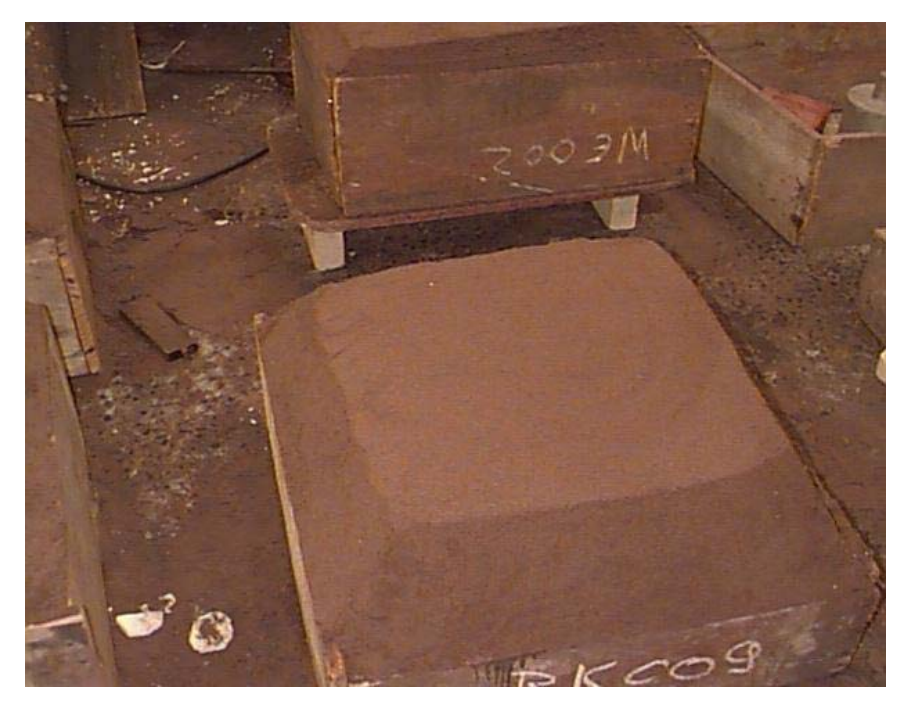

Figura 2.02. Molde em areia

Os processos de fundição abordados a seguir (2.2.2.1 a 2.2.10) são embasados nos conceitos de Kondic (1973), Bradaschia et al. (1981) e Siegel et al. (1982).

\subsubsection{Moldagem em areia verde}

É realizada com uma mistura composta, basicamente, de areia silicosa, argila (8 a 15\%) e água (5 a 10\%). Com base no desenho, fabrica-se um modelo, em torno do qual, compacta-se a mistura plástica de areia, utilizando-se caixas de moldagem para suportar as faces laterais do molde (Figura 2.02). Após esta fase, retira-se o modelo e colocam-se os machos, se necessários, fecham-se as partes do molde ${ }^{1}$, deixando-o apto a receber o

\footnotetext{
${ }^{1}$ É composto, geralmente, de duas partes (metades) superior e inferior (tampa e fundo), mas pode ser projetado em mais partes.
} 
metal vazado imediatamente. O processo é denominado de areia verde, pelo fato de não necessitar de secagem.

A areia de moldagem pode ser natural, quando encontrada na natureza com as propriedades requeridas, ou sintética, quando misturada tomando-se por base areias lavadas e argilas selecionadas, ou ainda, semi-sintética, obtida com areia natural, em que se adicionam elementos para retificar as suas propriedades de origem. A areia natural é encontrada em depósitos naturais de arenitos de cimento argiloso ou de alteração de rochas feldspáticas, caracterizados pelos grãos silicosos encontrarem-se envolvidos em pastas argilosas, podendo desta forma, apenas com a adição adequada de água, serem utilizados diretamente na moldagem.

Seja qual for o tipo de areia utilizado, esse processo de moldagem, como executado geralmente, está sujeito a uma série de limitações quanto as suas propriedades. Estas tendem a limitar a sua aplicação a produção de peças pequenas ou médias. Por sua vez, essas propriedades favorecem a produção de peças complicadas, pois facilitam a desmoldagem e limpeza, além de reduzirem o risco de ruptura a quente durante a solidificação. Peças grandes também podem ser fabricadas, contudo, dependendo das especificações, outros processos são mais vantajosos ou mais indicados para esta finalidade.

\subsubsection{Moldagem em areia seca}

O procedimento para a execução dos moldes, de um modo geral é similar a moldagem em areia verde, diferenciando na parte final, pois os moldes são submetidos à secagem em estufa numa faixa de temperatura de 150 a $300^{\circ} \mathrm{C}$. Moldes que não podem ser levados à estufa, por qualquer que seja a limitação, podem ser secos por meio de secadores apropriados para este fim.

As areias sintéticas ou semi-sintéticas são as mais recomendadas, pois se indica a adição de aglomerantes orgânicos, a fim de se alcançar as resistências necessárias, sem comprometimento demasiado da colapsibilidade do molde. Geralmente, as superfícies dos moldes são pintadas para protegê-las, o que também contribui para o bom acabamento do produto. Desta forma, este processo apresenta maior resistência à erosão provocada pelo metal líquido, maior estabilidade dimensional e maior resistência à pressão estática do metal líquido. 
Para a fundição de peças pesadas e com grandes seções de parede, em quaisquer metais (ferrosos ou não ferrosos), com especificações rigorosas de acabamento e de tolerância dimensionais, é o processo mais usual, pelos motivos supracitados.

Por necessitar de secagem, areia sintética ou semi-sintética, aglomerantes orgânicos (óleo e resina, por exemplo), tinta para proteger o molde e etapas que envolvem maior mão-de-obra, verifica-se que tem custo mais elevado do que o processo em areia verde.

\subsubsection{Moldagem em areia-cimento}

Os moldes são executados com uma mistura de areia silicosa, devidamente especificada, cimento portland (cerca de 10\%) e água (5\%). Muito parecido com o processo em areia seca, com a diferença de se usar cimento portland em vez de aglomerantes orgânicos e com a vantagem de dispensar calor e equipamento para a secagem do molde. Tem a inconveniência de impossibilitar a recuperação da mistura, o que acarreta um aumento de custo de produção e colapsibilidade deficiente, o que dificulta a desmoldagem, além de gerar mais resíduo. Essas limitações tornam esse processo menos usual do que os demais.

\subsubsection{Moldagem em areia de macho}

Moldagem com mistura de areia, óleo secativo (óleo de linhaça, óleo de macho), bentonita, com adição de elementos orgânicos, que dependem do metal/liga a ser fundido e porte da peça. A sua boa fluxibilidade permite a conformação de modelos complicados. Os moldes devem ser secos numa temperatura na faixa de 150 a $250^{\circ} \mathrm{C}$.

Processo precursor dos métodos de fundição de peças de precisão, bastante utilizado para moldar peças de geometria complicada, difíceis de serem moldadas em areia comum. Em virtude da rigidez adquirida pelo molde, após secagem, permite a produção de peças com boa precisão dimensional e acabamento muito bom, pois os moldes são pintados, dependendo do acabamento superficial desejado.

\subsubsection{Moldagem pelo processo $\mathrm{CO}_{2}$}

Este processo, desenvolvido na Europa, tem uma boa aceitação na confecção de moldes e machos em várias aplicações, para tanto é utilizada uma mistura de areia lavada e de ligante inorgânico, a base de silicato de sódio no teor variando de 3 a 5\%. Após compactar o molde ou encher a caixa de macho, estes são submetidos a passagem do gás $\mathrm{CO}_{2}$ por um curto período de tempo (0,5 a $\left.1 \mathrm{~min}\right)$. A reação do silicato de sódio 
com o $\mathrm{CO}_{2}$ produz sílica-gel, carbonato de sódio e água (expressão 2.01), provocando o endurecimento em curto espaço de tempo. Após este período, o molde ou o macho fica suficientemente resistente, podendo ser realizada a montagem do molde e em seguida o vazamento.

A alta resistência alcançada (molde) nesse processo, habilita-o a substituir o processo em areia seca ou areia-cimento.

$$
\mathrm{Na}_{2} \mathrm{SiO}_{3}+\mathrm{H}_{2} \mathrm{O}+\mathrm{CO}_{2} \rightarrow \mathrm{Na}_{2} \mathrm{CO}_{3}+\mathrm{SiO}_{2}+\mathrm{H}_{2} \mathrm{O}
$$

\subsubsection{Processo em casca (Shell molding)}

É um processo recente, foi desenvolvido na Alemanha durante a segunda guerra (1943) e denominado de processo Croning ${ }^{2}$ ou C. Nos Estados Unidos é conhecido como Shell molding. Neste processo, uma mistura de areia aglomerada com ligante orgânico sintético (resina polimerizável a quente), em forma pulverulenta, é distribuída sobre o modelo/caixa de macho, pré-aquecidos, numa temperatura variando de 150 a $350^{\circ} \mathrm{C}$. A resina, ao entrar em contato com o modelo ou com a caixa de macho, forma uma casca delgada, em razão do início de polimerização da resina. A espessura da casca formada está sujeita a parâmetros, como: tempo de contato, temperatura de pré-aquecimento e natureza da mistura, porém a espessura desejada, para resistir aos esforços causados pelo vazamento e outros, depende do tamanho e peso do produto final e varia de 5 a 10 mm. Após esta fase, a casca, parcialmente curada, extraída ou no próprio modelo, é colocada em estufa, numa faixa de temperatura de 280 a $350^{\circ} \mathrm{C}$, para completar a cura.

O molde, geralmente constituído de duas partes (cascas), tampa e fundo, é montado com os machos (se existirem) e devidamente fechado e então, está pronto para receber o metal vazado. Este processo é vantajoso na fabricação de peças pequenas, mas não é tão atraente no caso de peças de médio e pequeno porte, visto que o modelo utilizado neste processo tem custo muito alto, pois deve ser fabricado com o acabamento e dimensões desejadas na peça a ser fundida. Além do custo do modelo, deve ser considerado também o custo elevado da resina polimerizável a quente, utilizada na proporção de 3 a $10 \%$.

De qualquer forma, é sempre bom verificar a relação custo/benefício para avaliar qual o processo é mais viável para a execução de um determinado projeto, observando

\footnotetext{
${ }^{2}$ Conhecido por esse nome em virtude de seu inventor se chamar Johannes Croning.
} 
que as peças fundidas, utilizando essa técnica, dispensam totalmente ou parcialmente a usinagem, o que implica em redução de custo.

\subsubsection{Moldagem pelo processo de cera perdida ou por investimento (Investment casting)}

Menos antigo que a técnica de moldagem em areia, mas com cerca de 4000 anos. A mais antiga peça fundida utilizando essa técnica é de, aproximadamente, 1766 a 1122 a.C., originária da China governada pela dinastia Shang. Trata-se de uma caixa em bronze com delicadas filigranas ${ }^{3}$.

Essa técnica consiste no envolvimento completo de um modelo com o material de moldagem (investimento) e removê-lo sem danificar o molde. Assim, a única forma de remover totalmente o modelo sem danificar o molde, conforme método original, é destruindo-o. Desta forma, o modelo pode ser usado apenas uma vez, o que torna o processo inviável para produção em larga escala. Após o investimento do modelo, este é colocado em estufa numa temperatura que o material do modelo seja fundido, ficando apenas o molde. Para garantir a queima final do material do modelo e eliminar totalmente a umidade, o molde é submetido a uma temperatura mais elevada, na faixa de 650 a $1000^{\circ} \mathrm{C}$. Finalizada esta fase, o molde está pronto para receber o metal vazado.

Técnica muito utilizada na produção de peças artísticas, para a qual, foi exclusiva, durante vários anos, sendo bastante utilizada, atualmente, para peças que requerem alta precisão, com geometrias especiais ou em ligas especiais.

A cera é o material mais antigo utilizado para confeccionar o modelo, por isso é denominado de cera “perdida”, mas pode ser feito, também, em materiais, como: mercúrio congelado, poliestireno e plástico (termoplásticos). Para confeccionar o molde, usam-se materiais refratários, tais como: gesso, pó de sílica, pó de zircônia e pó de chamota ${ }^{4}$.

\subsubsection{Processo em moldes permanentes ou fundição em coquilha}

Como se pode concluir pela própria denominação, este processo consiste em utilizar o molde, inúmeras vezes, na confecção de uma mesma peça. É uma técnica, provavelmente, mais antiga do que a moldagem em areia, visto que, achados

\footnotetext{
${ }^{3}$ Arte em metal, formada de fios, delicadamente entrelaçados e soldados.

${ }^{4}$ Mistura de alumina e sílica, aquecida a alta temperatura, e que é adicionada, depois de arrefecida, à massa de argila cerâmica que irá ser submetida à ação do calor para constituir material refratário (FERREIRA, 1999).
} 
arqueológicos indicam a sua existência há, aproximadamente, 5000 anos. Esses achados, tratam-se de moldes abertos, esculpidos em rochas (arenito, micaxisto, calcário) ou em argilas endurecidas pelo sol para a confecção de adornos, armas e/ou ferramentas, como por exemplo, punhais, machados, pontas de lanças e talhadeiras. Essa técnica foi empregada, inicialmente, em moldes abertos e depois foi aprimorada e também utilizada em moldes fechados. Os materiais usados nesta época para a fabricação desses utensílios eram os metais não ferrosos (ouro, prata, cobre e mais tarde, o bronze).

Atualmente, o material usado na confecção dos moldes, é quase que exclusivamente metálico, sendo utilizado para esta finalidade, o aço, o ferro fundido e o bronze. Esses moldes têm acabamento final por usinagem.

O aprimoramento da coquilha (molde permanente) depende do acabamento e da tolerância dimensional que se deseja do produto final. A sua vida útil depende de fatores, como: material usado para confeccioná-la, material vazado e temperatura de vazamento.

\subsubsection{Processo em moldes semipermanentes}

Essa técnica consiste na utilização do molde mais de uma vez. O molde é confeccionado em materiais refratários menos duráveis do que os utilizados para o processo permanente, podendo ser: gesso, vidro, borracha, cerâmica refratária cozida e grafita. Moldes de borracha são usados para fabricar pequenas peças metálicas, de ponto de fusão muito baixo, como o chumbo e ligas de estanho.

\subsubsection{Processo em fundição por centrifugação}

Esse processo consiste na solidificação do material vazado sob pressões resultantes de força centrífuga. Os moldes são submetidos a rápido movimento de rotação enquanto o metal é vazado, sendo que o eixo rotacional deve coincidir com o eixo de simetria da peça a ser fundida. Esta deve ter paredes relativamente finas em relação ao diâmetro, para permitir a distribuição uniforme das pressões em toda a seção.

Essa técnica pode ser aplicada em moldes (processo de moldagem): permanentes, semipermanentes, de areia, em casca e de cera perdida. Suas principais vantagens são: melhor enchimento do molde em virtude da força centrífuga, melhoria das propriedades dos metais por centrifugação e boa tolerância dimensional. 


\subsubsection{Macharia}

É a etapa de confecção dos machos, que correspondem aos ocos e às reentrâncias das peças fundidas. Desta forma, os machos são peças sólidas, executadas em mistura de moldagem compatível com o metal a ser vazado e com o tamanho da peça fundida. $\mathrm{O}$ molde do macho é a caixa de macho, em cuja cavidade é socada a mistura de moldagem, com características próprias para este fim. As caixas de macho devem apresentar as qualidades, a seguir:

$\checkmark$ exatidão de formas e dimensões;

$\checkmark$ permanência de formas e dimensões com o passar do tempo;

$\checkmark$ facilidade de extração;

$\checkmark$ superfície em bom estado.

Os machos são colocados no molde antes deste ser fechado para receber o metal fundido e são retirados, após o vazamento. Devem ter alta resistência inicial para suportarem a pressão, seguida de colapsibilidade para permitir contração livre das peças solidificadas.

\subsubsection{Fusão}

É a etapa na qual uma determinada quantidade de material metálico, constituída por pedaços sólidos de metais ou ligas, com formatos geométricos e purezas químicas diversos (carga), é derretida num forno revestido de material refratário em uma temperatura compatível com o material a ser fundido.

O material fundido, com um determinado grau de superaquecimento é transferido a uma panela e em seguida colocado nos moldes na temperatura de vazamento, ou se houver conveniência, o vazamento pode ser realizado diretamente do forno.

A temperatura de vazamento é determinada a partir do ponto de fusão (varia de 200 a $1600^{\circ} \mathrm{C}$ ) de cada metal ou liga que será trabalhado. Antes do vazamento, deve ser verificado se o material fundido está dentro dos padrões especificados (controle de qualidade), isto é, o metal apresentando os limites desejados, no que diz respeito à pureza e a temperatura (100 a $300^{\circ} \mathrm{C}$ acima de sua temperatura de início de solidificação) e as ligas, os teores de cada elemento que as compõem, a temperatura dentro de uma faixa de aceitação e as impurezas abaixo dos limites especificados. 


\subsubsection{Vazamento}

Preenchimento do molde com o metal fundido. O vazamento deve ser realizado cuidadosamente. Se o fundido for despejado de uma grande altura no molde, uma quantidade maior de oxigênio será absorvida pelo metal líquido formando uma camada oxidada que o penetrará, além de poder ocasionar turbulências dentro do molde, causando defeitos na superfície do mesmo e por conseqüência na superfície da peça. Quanto menor a distância do utensílio com o material fundido ao canal de entrada (menor altura de queda possível) melhor a técnica de vazamento, pois diminui a distância de queda do metal através do ar (Figura 2.03). Essa fase exige um controle rigoroso de temperatura, estando essa numa faixa pré-fixada, como supracitada, entre 100 a $300^{\circ} \mathrm{C}$ acima da temperatura de início de solidificação do metal/liga.

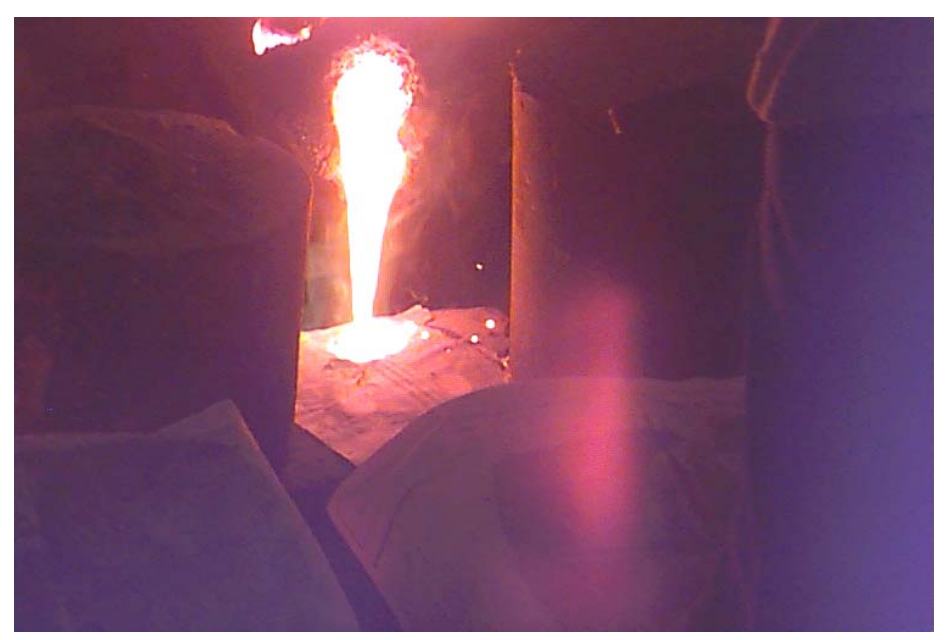

Figura 2.03. Vazamento do metal no molde

A temperatura de vazamento (Tabela 2.02) depende da natureza do material, do tipo de peça e do método de vazamento empregado. Peças pequenas requerem temperatura mais elevada, visto que é necessário considerar a perda de temperatura ocorrida entre a retirada do metal do forno e o vazamento no último molde. Esse superaquecimento não pode ser muito grande, pois quanto mais alta a temperatura, maior a quantidade de gases dissolvidos, aumentando a possibilidade de porosidade no produto final. Temperaturas mais baixas ocasionam o defeito mais comum com o vazamento a frio, que é o não enchimento completo da cavidade do molde, isto é, a formação de descontinuidade nas peças. 


\subsubsection{Desmoldagem}

Após o vazamento, o metal solidifica-se e é deixado resfriar-se, até atingir uma temperatura que seja possível manipulá-lo convenientemente. Após o resfriamento, a peça é retirada do molde, manualmente ou mecanicamente e está pronta para ser efetuada a etapa final do processo de fundição, que é a limpeza e acabamento. O período de resfriamento depende do metal e dos tipos de peça e molde.

\subsubsection{Limpeza e rebarbação}

A limpeza e corte de canais e rebarbas (saliência, quase sempre irregular, que apresenta uma peça fundida, por haver o metal entrado nas juntas do molde) é de suma importância , pois, após a desmoldagem são necessárias algumas operações para que as peças estejam prontas para uso ou para usinagem e montagem. Segundo Siegel et al. (1982), a seqüência destas operações, é a seguinte:
$\checkmark$ limpeza grosseira - remoção de canais e alimentadores ${ }^{5}$;
$\checkmark$ limpeza das superfícies internas e externas do fundido;
$\checkmark$ remoção de rebarba e arame nos locais de canais e alimentadores;
$\checkmark$ acabamento final de superfícies;
$\checkmark$ inspeção.

Tabela 2.02. Temperatura de fusão e de vazamento de alguns metais e ligas não ferrosas

\begin{tabular}{ccc}
\hline \hline Metais/Ligas & Temp. de Fusão $\left({ }^{\mathbf{0}} \mathbf{C}\right)$ & Temp. de Vazamento $\left({ }^{\mathbf{0}} \mathbf{C}\right)$ \\
\hline \hline Cobre & 1083 & $1120-1200$ \\
Cobre-alumínio & $1040-1050$ & $980-1150$ \\
Bronze & $825-1000$ & $975-1100$ \\
Bronze ao chumbo & $854-1010$ & 950 a 1100 \\
Latão & 850 & $875-925$ \\
Alpaca & 1100 & $1200-1300$ \\
Monel & $1180-1230$ & $1200-1300$ \\
Ligas de zinco & 380 & $425-450$ \\
Magnésio & 650 & 760 a 810 \\
Ligas de alumínio & 660 & $660-680$ \\
\hline \hline
\end{tabular}

Fonte: Bradaschia et al. (1981)

\footnotetext{
${ }^{5}$ Também denominados de massalotes ou montantes, em inglês, riser e feed head - reservatório com metal líquido, cujo objetivo é alimentar as contrações que ocorrem durante a passagem do metal do estado líquido para o sólido

${ }^{6}$ É a liga mais comum pertencente ao grupo níquel/cobre, contendo 30\% de cobre, 60\% de níquel e quantidades variáveis de outros elementos, como silício, manganês, ferro e carbono. Muito resistente à tração e aos agentes químicos.
} 


\subsection{Areia de fundição}

Como dito anteriormente, a moldagem em areia, ainda, responde pela maior quantidade de produtos fundidos. A importância desse material nas indústrias de fundição mundial é muito grande, principalmente, pelo custo, relativamente baixo, considerando os outros métodos. Se a moldagem for em areia verde, este custo cai mais ainda, visto que, este método utiliza areia natural e não requer secagem do molde, dispensando, portanto, o gasto com a energia e mão-de-obra necessárias para esta fase.

Segundo Mariotto (2000), estima-se que mais de $80 \%$ dos produtos fundidos sejam fabricados utilizando moldes confeccionados com areia aglomerada, sendo que o ligante mais usual é argila (moldagem em areia verde). Os processos, que utilizam argila, são empregados, geralmente, para confeccionar os moldes que dão forma às superfícies externas do produto fundido, sendo que, para confeccionar os machos, que conformam as superfícies internas das peças, utilizam-se areias aglomeradas com resinas sintéticas que, geralmente, são de origem fenólica.

No Brasil, anualmente, são utilizadas, aproximadamente, 2 milhões de toneladas deste material, com características próprias para este fim. Dentro do processo de fundição é denominado de agregado base ou simplesmente base.

A areia (base) deve estar dentro de uma determinada faixa granulométrica que depende, principalmente, do acabamento superficial do produto fundido, caracterizado pelo processo de moldagem usado. Moldes com superfícies lisas produzem peças com superfícies com a mesma característica. Este tipo de molde é requerido, principalmente, nos processos de moldagem de investimento e em casca. Desta forma, para confeccioná-los, há necessidade de agregado muito fino na mistura de moldagem, ou se isso não for possível, pelo menos parte deste agregado, a camada que ficará em contato com a superfície da peça a ser fundida, deve ter $100 \%$ do material passando na peneira $n^{0} .50(0,297 \mathrm{~mm})$ e retido na peneira $\mathrm{n}^{0}$. 200 (0,075mm) (KONDIC, 1973). De um modo geral, a areia utilizada nos diversos processos de fundição apresentam tamanho entre 0,075 e $1 \mathrm{~mm}$, tendo cerca de 85 a 95\% de material passando na peneira $n^{0} .30(0,59 \mathrm{~mm})$ e retido na $\mathrm{n}^{0} .100(0,149 \mathrm{~mm}) . \mathrm{A}$ areia utilizada nesta pesquisa apresenta, aproximadamente, $90 \%$ de material passando na 30 e retido na 100 .

Além das características acima mencionadas, há outras que são de suma importância no agregado base/mistura de moldagem. Destas, de um modo geral, destacam-se (KONDIC, 1973; BRADASCHIA et al., 1981; SIEGEL et al., 1982): 
$\checkmark$ escoabilidade - habilidade de o material fluir (escorrer) facilmente e preencher as cavidades e reentrâncias do modelo, de forma a permitir a perfeita reprodução do mesmo e acabamento superficial, conforme projeto;

$\checkmark$ comportamento refratário (refratariedade) - resistência a altas temperaturas sem haver alteração significativa na sua forma, isto é, a capacidade da areia não se liquefazer quando em contato com o metal/liga vazado;

$\checkmark$ resistência mecânica - habilidade dos grãos de se unirem mutuamente, apresentando o molde, resistência o bastante para não entrar em colapso quando manuseado, transportado ou a ser submetido a qualquer tipo de esforço exercido pela presença do metal;

$\checkmark$ permeabilidade - capacidade de o material permitir a passagem de gases, presentes ou gerados em seu interior por ocasião do vazamento do metal, através dele. Alta permeabilidade é característica de grande importância nas areias utilizadas na confecção de machos, visto que, as elevadas temperaturas e composição destas areias produzem grande quantidade de gases, sendo que estes não devem atravessar a peça em estado líquido. A baixa permeabilidade provoca o aparecimento de bolhas que são produzidas pelos gases gerados do contato da areia com o metal quente, e responsáveis por alguns defeitos no produto fundido;

$\checkmark$ desmoldabilidade - capacidade de o material permitir, facilmente, a retirada do produto solidificado do interior do molde, sem lhe imprimir dano algum e deixando a superfície isenta de restos de moldagem;

$\checkmark$ estabilidade térmica dimensional - deve permitir variações dimensionais (expansões e contrações) mínimas possíveis (limitadas pela especificação da peça), em virtude de mudança de temperatura. Variações significativas são responsáveis por defeitos muito freqüentes em peças fundidas, como: crostas, descascamento, etc;

$\checkmark$ colapsibilidade x resistência a quente - o material deve conferir ao molde a capacidade de ceder sob esforços a que é submetido, quando a peça se contrai ao se solidificar. Se o molde oferecer resistência à contração da peça, esta poderá sofrer a formação de trincas a quente ou, até mesmo, a ruptura. Contudo as paredes do molde não devem ceder quando submetidos aos esforços provocados pelo metal fundido ao encher o molde; 
$\checkmark$ difusividade térmica - permite o estudo das transferências de calor nos moldes, que não acontecem no regime permanente, e sim em regime transiente, pois a temperatura em cada ponto do molde varia constantemente;

$\checkmark$ teor de umidade - o material deve apresentar baixa umidade, pois umidade excessiva pode dar origem a bolhas de vapor quando a areia entrar em contato com o metal/liga fundido.

As areias de fundição são essencialmente produtos de quartzo, originários da decomposição mecânica pela ação atmosférica, tendo as suas propriedades influenciadas pelo tipo de rocha que as originaram, pela forma de processamento da decomposição, pelo transporte e pelas transformações ocorridas, após sedimentação (BERNDT, 1989).

O quartzo (sílica) é bastante utilizado por razões econômicas, pois ocorre na natureza com granulometria variada e em abundância no mundo inteiro, mas na faixa de temperatura de 560 a $580^{\circ} \mathrm{C}$ (Tabela 2.03) sofre uma transformação alotrópica (apresenta diferentes propriedades físicas) irreversível acompanhada de expansão volumétrica. Contudo, essa inconveniência, nos casos em que ela pode produzir defeitos na peça fundida, geralmente, é compensada por uma seleção mais cuidadosa do tamanho dos grãos e da distribuição granulométrica e por adições especiais, à areia, de aditivos orgânicos (KONDIC, 1973). A função dos aditivos é aumentar a plasticidade a quente da face do molde, deixando-a livre de trincamento.

Tabela 2.03. Mudança de fase do quartzo quando aquecido

\begin{tabular}{ccc}
\hline \hline Temperatura de aquecimento $\left({ }^{\mathbf{O}} \mathbf{C}\right)$ & Produto & Expansão (\%) - aproximada \\
\hline \hline até 200 & quartzo & - \\
até 575 & quartzo & 1,4 \\
até 870 & tridimita & 1,6 \\
até 1470 & cristobalita & 1,4 \\
\hline \hline
\end{tabular}

Fonte: Strauss (1970)

Além das areias de quartzo, também podem ser utilizadas areias de zirconita, de cromita e de olivina.

As areias de zircônio são formadas, quase que basicamente, por silicato de Zircônio puro $\left(\mathrm{ZrO}_{2} \mathrm{~S}_{\mathrm{i}} \mathrm{O}_{4}\right)$ e encontrado nesta forma, em países, como: Austrália, Estados Unidos, Índia e Brasil. Estas areias apresentam grandes vantagens, como: alto ponto de fusão, alta condutividade e baixa expansão (1/3 da expansão da areia de quartzo), porém tem a 
desvantagem de ser, economicamente, inviável para uso habitual, principalmente em países onde não é encontrada, naturalmente, com as características necessárias para utilização imediata.

As areias de cromita $\left(\mathrm{FeOCr}_{2} \mathrm{O}_{3}\right)$ são obtidas por meio da britagem de pedras de cromita e ferro, podendo ter composição bastante variada e são encontradas, principalmente, no Brasil, Índia, África, Rússia e Finlândia. Segundo Strauss (1970), as areias de cromita foram desenvolvidas para substituir as areias de zircônio, principalmente, em virtude do alto preço desta.

As areias de olivina $\left(\mathrm{Mg}_{2} \mathrm{~S}_{\mathrm{i}} \mathrm{O}_{4}+\mathrm{Fe}_{2} \mathrm{~S}_{\mathrm{i}} \mathrm{O}_{4}\right)^{7}$ apresentam densidade e pontos de fusão mais elevados do que as de quartzo (Tabela 2.04). As principais jazidas de olivina encontram-se nos países escandinavos: Suécia, Noruega, Islândia e Dinamarca.

A zirconita, por apresentar ponto de fusão bem mais elevado (Tabela 2.4), é particularmente indicada para a fusão de materiais ou de peças que demandem elevadas solicitações térmicas, enquanto a olivina é raramente usada em materiais de moldagem ligados por resina sintética (BERNDT, 1989).

Verificando a Tabela 2.04 (densidade), observa-se o aspecto econômico, em relação ao peso de areia necessário para preencher o mesmo volume de um molde. Comparando-se um molde preenchido com areia de quartzo, necessita-se de uma quantidade (em peso) de 30\% a mais de olivina, $64 \%$ a mais de zirconita e de $75 \%$ a mais de cromita.

É conveniente que, estas areias, não apresentem em suas composições, minerais que exibam baixo ponto de fusão, pois estes se fundem ao vazamento do metal, comprometendo as características desejadas do produto acabado. Estes minerais, pelo exposto, são considerados como impurezas e destes podem ser citados: a ilmenita, a hematita, o feldspato e a calcinita.

Tabela 2.04. Densidades e pontos de fusão das principais areias utilizadas como material de moldagem

\begin{tabular}{|c|c|c|c|}
\hline Areia & $\begin{array}{c}\text { Densidade } \\
\text { Aparente }\left(\mathrm{g} / \mathrm{cm}^{3}\right)\end{array}$ & $\begin{array}{c}\text { Densidade real } \\
\left(\mathrm{g} / \mathrm{cm}^{3}\right)\end{array}$ & $\begin{array}{c}\text { Ponto de fusão } \\
\left({ }^{\circ} \mathrm{C}\right)\end{array}$ \\
\hline quartzo & $\overline{~ 1,7}$ & 2,20 a 2,65 & 1650 a 1750 \\
\hline cromita & 2,7 a 2,9 & 4,5 a 4,8 & 2180 \\
\hline olivina & 2,1 a 2.3 & 3,25 a 3,4 & 1300 a 1800 \\
\hline zirconita & 3,0 a 3,1 & 3,9 a 4,8 & 2200 a 2420 \\
\hline
\end{tabular}

\footnotetext{
${ }^{7}$ Silicato de magnésio e silicato de ferro
} 
Além do material base, as misturas de moldagem (ver item 2.2.2) são compostas também, dependendo do processo de moldagem, de aglomerantes (orgânicos ou inorgânicos), água e aditivos. Os aglomerantes orgânicos podem ser: óleos secativos ou semi-secativos (óleos de linhaça, mamona, oiticica), farinhas de cereais (dextrina, mogul, breu) e produtos sintéticos (resinas furânicas e fenólicas, por exemplo). Os ligantes inorgânicos principais, são: argila, cimento portland e o silicato de sódio.

Dos ligantes inorgânicos utilizados, o mais usual é a argila, que deve ter um alto poder aglomerante, conferindo à mistura consistência e plasticidade. O poder aglomerante das argilas é originado no fenômeno de coesão, isto é, na atração recíproca das partículas de argila umedecida e na sua adesão à superfície do material granular. O termo “argila” referese ao grupo de argilo-minerais, no qual o principal componente é o silicato de alumínio hidratado. Estes variam quanto à sua estrutura cristalina, constituição física e composição química, existindo, desta forma, diversos tipos, dentre estes os mais utilizados são:

$\checkmark$ caulinita - inclui as argilas refratárias de baixa plasticidade, portanto pouco usada como aglomerante nas misturas de areia de moldagem, mas muito utilizada como material refratário nas indústrias de fundição;

$\checkmark$ ilitas (micácea) - consistem de argilas refratárias com média plasticidade. Exibem grau de plasticidade entre o da caulinita e o da bentonita. São adicionadas à mistura para acrescentar resistência a ligação a verde e resistência a seco;

$\checkmark$ bentonitas - é uma argila que tem como principal mineral constituinte a montmorillonita. Esta argila tem grande capacidade de expansão (inchamento) e absorção de umidade, o que a faz de grande serventia como ligante nas areias de fundição, apresentando plasticidade mesmo em uma ampla faixa de teor de umidade. Por apresentar alta poder aglomerante, as misturas necessitam de um pequeno teor desta argila e de água para adquirir a resistência necessária para o vazamento do metal. As bentonitas sódicas são mais plásticas do que as bentonitas cálcicas, mas ambas apresentam valores altos de resistência na areia a verde.

Do ponto de vista do preparo de misturas de moldagem, as propriedades mais importantes das argilas são sua estrutura lamelar fina e sua capacidade de adsorver íons metálicos (capacidade de troca de cátion) e água. A água adsorvida faz com que as partículas de argila se unam e, por meio da água, as mesmas aderem à superfície do mineral base (KONDIC, 1973). 
Segundo Nogami e Villibor (1995), os argilo-minerais distinguem-se por possuir uma série de propriedades peculiares, tais como:

$\checkmark$ grande superfície específica, como conseqüência de suas dimensões muita pequenas (de micrômetro a nanômetro) e de sua forma lamelar e/ou alongada;

$\checkmark$ cargas elétricas, predominantemente, aniônicas, que lhes proporcionam capacidade de troca catiônica, quando em suspensão aquosa e, também, regulam o grau de acidez do solo;

$\checkmark$ tornam-se plásticos, quando convenientemente umedecidos e quando secos, nessa condição, obtêm resistência considerável;

$\checkmark$ apresentam grandes variações volumétricas, tanto por perda, como por aumento de umidade;

$\checkmark$ quando em suspensão aquosa, apresentam floculação (agregação de grãos) e dispersão, cujo grau depende muito da concentração e natureza das substâncias químicas em solução.

De uma forma geral, as propriedades supracitadas acentuam-se na seguinte ordem: grupo da caulinita, grupo da ilita e grupo da montmorillonita (bentonita). Muitas destas propriedades, em maior intensidade, são prejudiciais às obras civis, portanto, a presença de minerais com quantidades elevadas de montmorillonita é, freqüentemente, temida (NOGAMI e VILLIBOR, 1995). Contudo, essas propriedades são essenciais nos aglomerantes para fins de moldagem em fundição, pois o teor de argila deve ser o mínimo possível para manter a elevada permeabilidade da mistura e conceder uma resiliência adequada.

Dos argilo-minerais, o mais utilizado nas indústrias de fundição é a bentonita, por apresentar características mais favoráveis para esta finalidade, sendo os países americanos beneficiados, no que diz respeito à utilização deste material, pois as melhores jazidas estão localizadas nas Américas (STRAUSS, 1970).

Dos aglomerantes orgânicos, os mais usuais, atualmente, são as resinas sintéticas ${ }^{8}$, visto que estas produzem estruturas (moldes e machos) com uma cadeia entrelaçada bem forte e chega a um estado rígido e quebradiço com alta resistência mecânica. Os produtos confeccionados com resina sintética apresentam estado não fundível e indissolúvel, permitindo desta forma, transporte para estocagem e vazamento (BERNDT, 1989).

\footnotetext{
“"Produto obtido pela condensação e polimerização de duas ou mais substâncias, com aspecto resinoso e propriedades mecânicas que possibilitam ampla gama de aplicações” (FERREIRA, 1999).
} 
Os aglutinantes utilizados para composição dos machos devem conferir à mistura de moldagem, propriedades, tais como: alta resistência, fácil escoamento, dureza superficial, gerar o mínimo de gases possível e colapsibilidade.

As resinas sintéticas, por vários fatores, dentre eles o alto custo, são usadas, principalmente para confeccionar machos, visto que estes requerem misturas mais resistentes, sendo que, para esta finalidade, são utilizadas, freqüentemente, resinas fenólicas. Há outros tipos de resinas que também podem ser usadas, como: uréia-formaldeído, furânicas e poliuretânicas. Algumas são termoestáveis (termofixas ou termorrígidas), isto é, curam pelo aquecimento, mas após endurecimento, não amolecem sob a ação de mais calor, portanto, após a cura não pode mais ser remodelada ou trabalhada; outras termoplásticas, que endurecem, quando resfriadas e amolecem ao serem aquecidas e mesmo após a cura, podem ser reconformadas.

A resina fenólica é o mais antigo dos plásticos sintéticos, descoberta em 1907 por Leo Hendrik Backeland. É obtida pela condensação de fenóis com aldeído fórmico (formaldeído) e é conhecida, popularmente, como baquelita. Dentre as resinas, também, são as mais utilizadas, em virtude de apresentarem preços mais acessíveis.

A resina uréia-formaldeído (termoestável) é preparada pela reação da uréia com o aldeído fórmico, sendo que, para desencadear a reação de cura, adiciona-se mais uma quantidade de uréia e um catalisador (BLASS, 1985).

A resina poliuretânica (termoestável e termoplástica) é obtida pela reação de diisocianatos com diálcoois, para produzir cerdas, ou com resinas poliéster, para espuma.

A quantidade de aglutinante (resina sintética) na mistura de moldagem deve ser o mínimo possível, em virtude do seu alto custo e por questões técnicas, visto que quantidade desnecessária pode comprometer a qualidade do produto final, ocasionando o aparecimento de bolhas provocadas pelos gases desprendidos durante o vazamento do metal. Normalmente, o teor de aglutinante é da ordem de 1 a 5\% (em peso) na mistura de areia.

\subsubsection{Passivo ambiental de areia de Fundição}

Segundo Mariotto (2000), se não fossem as areias de macho, muitas areias de descartes de fundição poderiam ser classificadas como resíduo "inerte" (classe III), segundo a NBR 10004. Contudo, a presença desta areia no descarte, com teores de algumas substâncias nocivas ao meio ambiente, acima do permitido pela norma, faz com que a maioria dessas areias sejam classificadas como resíduos “não inertes” (classe II) e algumas, dependendo 
das substâncias e/ou teores, como resíduos perigosos (classe I). Nas areias de descarte de fundição, há também substâncias incorporadas, resultantes dos constituintes das ligas fundidas, mas que, raramente, ultrapassam os limites permitidos pela norma, sendo exceções, as areias descartadas por fundições de bronze ou de ferros fundidos brancos de alto cromo.

As indústrias de fundição brasileiras geram em torno de 2 milhões de toneladas ao ano de produtos fundidos, sendo a região Sudeste a maior geradora destes produtos, tendo a maior concentração no Estado de São Paulo (Tabela 2.05). A produção de fundidos no período de janeiro a novembro de 2003, neste Estado, foi de 723.001 t e a produção do país no mesmo período foi de 2.083.581 t (ABIFA, 2003). Segundo McIntyre et al. (1992), a cada tonelada de metal produzida, tem-se, aproximadamente, uma tonelada de resíduo de fundição, portanto, a quantidade deste resíduo industrial gerada no país, no ano de 2003, ultrapassou a 2 milhões de toneladas (Tabela 2.05). Desse total, 92,20\% é correspondente a produção de fundidos de ferro e aço, sendo 86,75\% de ferro (Tabela 2.06). Com base nesses dados, conclui-se que o passivo ambiental das fundições no país, principalmente no Estado de São Paulo é bastante preocupante. Vale salientar que parte deste resíduo é recuperada pela empresa e reutilizada no processo e o restante é descartado.

No Estado de São Paulo há vários passivos ambientais oriundos da disposição de resíduos sólidos das indústrias de fundição aqui localizadas. Este passivo é em virtude da grande concentração destas empresas no Estado.

Tabela 2.05. Comparativo da produção regional de fundidos (toneladas) entre 2002 e 2003

\begin{tabular}{ccccccccc}
\hline \hline Região & $\begin{array}{c}\text { Nov/03 } \\
\text { (A) }\end{array}$ & $\begin{array}{c}\text { Out/03 } \\
(\mathbf{B})\end{array}$ & $\begin{array}{c}\text { Nov/02 } \\
(\mathbf{C})\end{array}$ & $\begin{array}{c}\text { A/B } \\
\mathbf{( \% )}\end{array}$ & $\begin{array}{c}\text { A/C } \\
\mathbf{( \% )}\end{array}$ & $\begin{array}{c}\text { Jan-nov/03 } \\
\mathbf{( D )}\end{array}$ & $\begin{array}{c}\text { Jan-nov/02 } \\
(\mathbf{E})\end{array}$ & $\begin{array}{c}\text { D/E } \\
\mathbf{( \% )}\end{array}$ \\
\hline \hline Centro/MG & 58079 & 61521 & 52141 & 94,40 & 111,39 & 565043 & 540217 & 104,60 \\
Norte/NE & 3785 & 4075 & 3828 & 92,88 & 98,88 & 43710 & 42029 & 104,00 \\
R. de Janeiro & 13754 & 14492 & 10965 & 94,90 & 125,44 & 135034 & 116607 & 115,80 \\
São Paulo & 67772 & 68334 & 61715 & 99,18 & 109,81 & $\mathbf{7 2 3 0 0 1}$ & 623886 & 115,89 \\
Sul & 58241 & 63910 & 46057 & 91,13 & 126,45 & 616793 & 513903 & 120,02 \\
Total & 201631 & 212332 & 174706 & 94,96 & 115,41 & $\mathbf{2 0 8 3 5 8 1}$ & 1836642 & 113,44 \\
\hline \hline
\end{tabular}

Fonte: Associação Brasileira de Fundição - ABIFA (2003) 
Tabela 2.06. Comparativo da produção de metais fundidos (toneladas) entre $2002 \mathrm{e}$ 2003

\begin{tabular}{ccccccccc}
\hline \hline $\begin{array}{c}\text { Período/ } \\
\text { Metal }\end{array}$ & $\begin{array}{c}\text { Nov/03 } \\
\text { (A) }\end{array}$ & $\begin{array}{c}\text { Out/03 } \\
\text { (B) }\end{array}$ & $\begin{array}{c}\text { Nov/02 } \\
\text { (C) }\end{array}$ & $\begin{array}{c}\text { A/B } \\
\mathbf{( \% )}\end{array}$ & $\begin{array}{c}\text { A/C } \\
(\mathbf{\%})\end{array}$ & $\begin{array}{c}\text { Jan-Nov/03 } \\
\text { (D) }\end{array}$ & $\begin{array}{c}\text { Jan-Nov/02 } \\
\text { (E) }\end{array}$ & $\begin{array}{c}\text { D/E } \\
\text { (\%) }\end{array}$ \\
\hline \hline Ferro (Total) & 175047 & 184663 & 154208 & 94,80 & 113,51 & 1807439 & 1619797 & 111,54 \\
Aço (Total) & 11438 & 7425 & 7829 & 154,05 & 146,10 & 113654 & 80907 & 140,47 \\
Não Ferrosos & 15146 & 15918 & 13073 & 95,15 & 115,86 & 162488 & 135938 & 119,53 \\
Cobre & 1263 & 1345 & 1339 & 93,90 & 94,32 & 14710 & 12445 & 118,20 \\
Zinco & 439 & 440 & 652 & 99,78 & 67,33 & 5620 & 7082 & 79,36 \\
Alumínio & 13056 & 13743 & 10885 & 95,00 & 119,94 & 137986 & 112533 & 122,62 \\
Magnésio & 388 & 390 & 197 & 99,49 & 196,95 & 4172 & 3878 & 107,58 \\
Total (Geral) & 201631 & 212332 & 174706 & 94,96 & 115,41 & 2083581 & 1836642 & 113,44 \\
\hline \hline
\end{tabular}

Fonte: Associação Brasileira de Fundição - ABIFA (2003)

Segundo Mariotto (2000), estima-se que o parque industrial brasileiro de fundição tenha cerca de 1000 empresas, sendo 80\% de pequeno porte (menos de 100 empregados) e o Estado de São Paulo concentra 60\% do total dessas. Em 2003, as empresas paulistas foram responsáveis por, aproximadamente, 35\% da produção (em peso) nacional de fundidos, como pode ser verificado na Tabela 2.05.

Com base nesses dados, procurou-se, nos arredores de São Carlos, passivos ambientais referentes a essa categoria de empresa e destes comentar-se-á sucintamente, a seguir, o aterro de resíduos sólidos de uma empresa de fundição de componentes de motores de trator.

Em Ibaté/SP (a $12 \mathrm{~km}$ de São Carlos) funcionou durante muitos anos (até 1990) uma empresa de fundição e montagem de motores, a MPL - Motores S.A, situada à Rodovia Washington Luiz, km 249 (SP-310). O interesse por essa empresa foi, basicamente, em virtude de querer conhecer mais sobre o assunto, visto que a empresa havia falido e, portanto, foi possível verificar mais, confortavelmente (ausência das altas temperaturas e acesso livre a todas as dependências da fábrica), como funcionava. Desta forma, verificaram-se os tipos de fornos, cadinhos, sistema de transportes da matéria-prima e/ou peças prontas, modelos e outros equipamentos utilizados com essa finalidade.

Esta fábrica acumulou durante o período de funcionamento, dentro do pátio da empresa, um passivo ambiental em torno de 240.000 toneladas (Figura 2.04), correspondente ao descarte de produção de peças metálicas ferrosas e não ferrosas. 


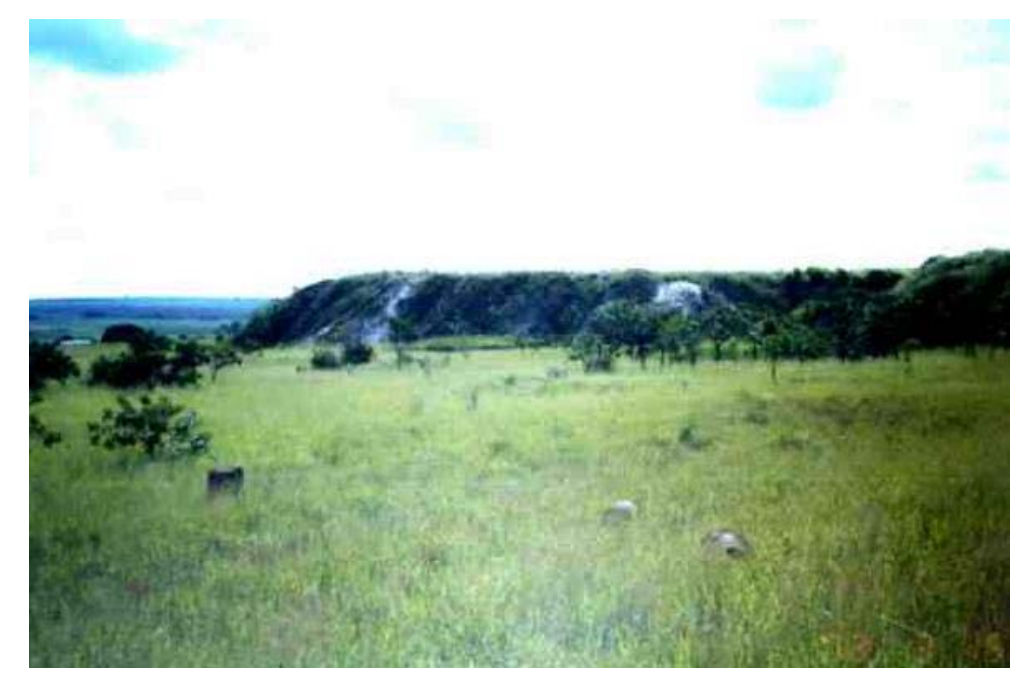

Figura 2.04. Passivo ambiental da MPL - Motores S.A

Em visita ao local, acompanhado de um ex-funcionário da empresa MPL - Motores S.A, foi verificada a existência de três poços de monitoração do lençol freático (Figura 2.05), pois foi realizado um estudo (informação verbal) ${ }^{9}$ para verificar o seu comprometimento por metais pesados e/ou fenóis . Próximo da área, também, existem mananciais, como o Córrego Bela Vista e o Ribeirão São José das Correntes. Todas estas informações foram, posteriormente, ratificadas por meio do Parecer Técnico emitido por Schalch et al. (2000). Estes poços têm profundidade revestida, em média, de $16 \mathrm{~m}$.

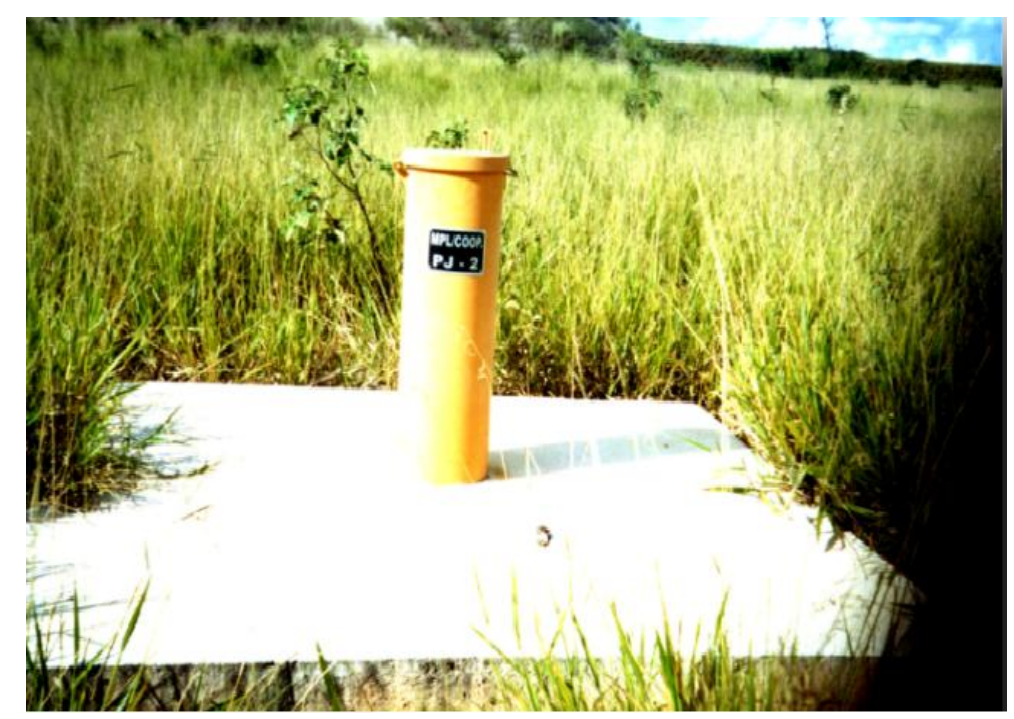

Figura 2.05. Poço de monitoração do lençol subterrâneo do pátio da MPL - Motores S.A

\footnotetext{
${ }^{9}$ Informações fornecidas por um ex-funcionário da MPL - Motores S.A, Anderson Macieira Bramé, em março de 2003.
} 
Para se conhecer melhor a qualidade do resíduo industrial do aterro a céu aberto no pátio da empresa, comentar-se-ão os processos de moldagem empregados, visto que estes são os principais caracterizadores do tipo de resíduo gerado.

Os processos de moldagem empregados pela empresa, consistiam, basicamente, de: moldagem em areia verde, processo $\mathrm{CO}_{2}$ (Silicato de Sódio), moldagem em areia de macho (macho estufado) e processo de cura a frio. Os teores de areia utilizados nestes processos de moldagem foram de: 79 a 87\% para moldagem em areia verde, 96,8\% para moldagem no processo $\mathrm{CO}_{2}$ (Silicato de Sódio), 93\% para moldagem em areia de macho e 97,6 a 98,8\% para moldagem no processo de cura a frio (Fluxograma da Fundição: 26/05/87 - MPL Motores S.A).

Na moldagem em areia verde, o aglutinante utilizado era a bentonita (7 a 10\%) com adição de Carvão Cardife (3 a 6\%) e água (3 a 5\%); no processo $\mathrm{CO}_{2}$, era usado o silicato de sódio no teor de 2,4\%, 0,8\% de dextil-60 ou katsil-F e gás carbono 3 kg/100 kg; no processo de macho estufado, com os aglutinantes, dextrina (3\%) e óleo de macho (3\%) e $1 \%$ de água e no processo de cura a frio, eram utilizadas resinas fenólicas no teor de 1 a 1,5\%. (Fluxograma da Fundição: 26/05/87 - MPL - Motores S.A; SCHALCH et al. 2000).

Desta forma, pode-se verificar que o passivo ambiental desta empresa poderia ser classificado como resíduos perigosos (classe I), se o extrato proveniente da lixiviação de resíduos (NBR 10005/87) contivesse qualquer um dos parâmetros lixiviados em concentração superior ao limite da norma 10004/87. Poderia resultar nesta classificação (resíduos perigosos) por ter resíduos provenientes do processo de moldagem de peças não ferrosas. Classificado como resíduo não inerte (classe II), se apenas um dos parâmetros solubilizados ultrapassassem o limite da norma, e como resíduo inerte (classe III), se nenhum parâmetro ultrapassasse o limite máximo permitido (NBR 10004/87).

Uma outra área em estudo, da qual foram retiradas as areias (virgem e de fundição) utilizadas nesta pesquisa, foi a região de Sertãozinho/SP. O passivo ambiental anual desta região está em torno de 26.400 toneladas. O descarte da empresa Pama Mecânica e Fundição Ltda, situada à rua Albino Russi, 269 - Parque Industrial -Sertãozinho/SP, de onde foi coletada a areia de fundição, é em média 200 t/mês, correspondente a 30\% da areia utilizada na fabricação do moldes e machos, sendo e 70\% reutilizado na fabricação de novas peças (Informação verbal) ${ }^{10}$.

\footnotetext{
${ }^{10}$ Informações fornecidas pelo Gerente de Fundição, Mário Rubens Pereira, em Fevereiro de 2004.
} 
O processo de moldagem usado é o de cura a frio (cold-box), que utiliza 98,56\% de areia de quartzo, 1,2\% de resina fenólica alcalina e 0,24\% de catalisador (20\% do teor de resina), sendo 100\% manual. Desta forma, verifica neste produto (areia de fundição) a ausência da bentonita, visto que a empresa não utiliza o processo de moldagem em areia verde, cujo aglutinante, geralmente, é uma argila do grupo das montmorillonitas (pode conter cátions de sódio, potássio, cálcio ou magnésio). Vale salientar, que a empresa funde metais ferrosos e não ferrosos. À época da coleta do descarte para a pesquisa, estavam sendo moldadas, também, peças de bronze (componentes de usina de cana-de-açúcar), portanto esse descarte tem resíduos não ferrosos (Informação verbal) ${ }^{10}$.

\subsubsection{Reutilização da areia de Fundição}

O reaproveitamento da areia de fundição se faz necessário para que se evite a disposição inadequada desses resíduos e também porque essa atividade é grande consumidora de insumos naturais (areia, argila, por exemplo). Desta forma estar-se-á minimizando o uso destes recursos e contribuindo para a diminuição da poluição do meio ambiente.

As indústrias de fundição dão uma grande contribuição para a sociedade, visto que utilizam também todo o tipo de sucata metálica como matéria-prima, transformando-a em peças novas e desta forma, evitando um maior desgaste das riquezas naturais do planeta e disposição inadequada destas.

A reutilização pode ser realizada dentro do próprio processo (reciclagem primária) ou externamente (reciclagem secundária), quando o resíduo serve como matéria-prima em outra atividade que não seja a de fundição. Na Figura 2.06 é apresentado um diagrama de blocos do gerenciamento de práticas correntes para resíduos industriais, segundo Bishop ${ }^{11}$ (2000 apud SCHALCH et al., 2002, p.3), adaptado para a indústria de fundição.

No reaproveitamento interno, dependendo do processo de moldagem utilizado, há a necessidade de recuperar a areia, deixando-a livre de quaisquer substâncias que venham prejudicar a sua utilização na confecção de novos moldes. Esta regeneração nem sempre é eficiente e/ou econômica, pois dependendo do aglutinante utilizado na moldagem, torna-se muito caro recuperá-la ou então, as suas características podem ser alteradas. Ou ainda, em virtude de várias vezes passar pelo processo de recuperação perde as características necessárias para a mistura de moldagem, sendo necessário descartá-la em grande parte, ou

\footnotetext{
11 BISHOP, P.L. (2000). Pollution Prevention: Fundamentals and practice. Singapore: McGraw-Hill companies Inc apud SCHALCH, V. et al. (2002). Prevenção da poluição, análise de ciclo de vida, redução, reutilização e reciclagem de resíduos sólidos. Apostila. Departamento de Hidráulica e Saneamento. Escola de Engenharia de São Carlos. São Carlos.
} 
totalmente. De qualquer forma, as técnicas usuais tendem a agredir a composição do agregado base. Estas características podem estar relacionadas com a distribuição granulométrica, forma e superfície dos grãos, teor de finos e pH (BRADASCHIA et al.,1981; SIEGEL et al., 1982).

Para a regeneração de areia de fundição, utilizam-se, basicamente, duas técnicas, a saber:

$\checkmark$ regeneração mecânica;

$\checkmark$ regeneração térmica.

No processo de regeneração mecânica, a matéria estranha na superfície dos grãos de areia é removida por meio de impacto e/ou fricção de grãos contra grãos, ou ainda, de grãos contra componentes do equipamento. Esta remoção pode ser por atrição a seco ou úmida.

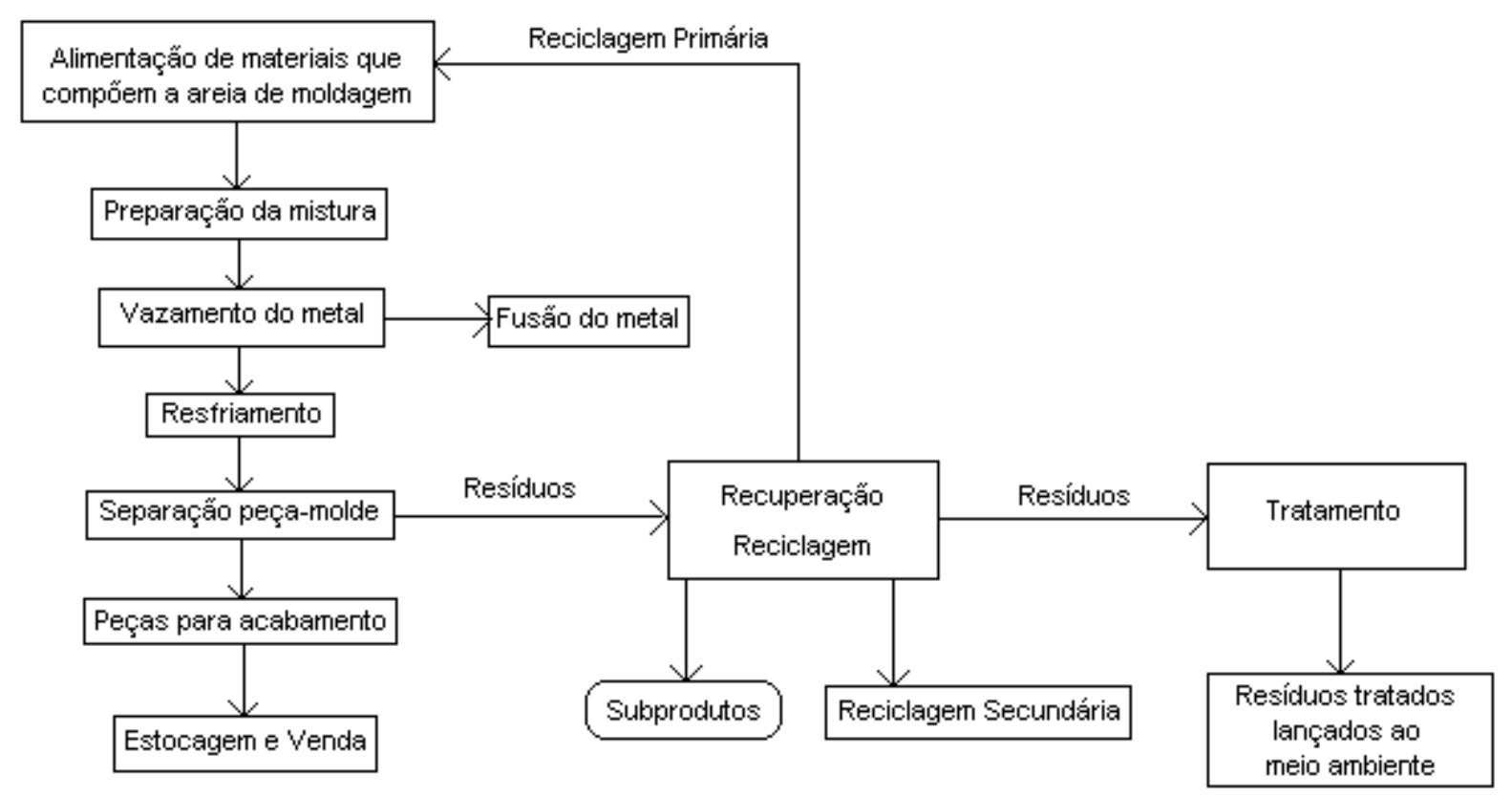

Figura 2.06. Prática corrente de gerenciamento de resíduos industriais, adaptada para um processo usual de fundição - Fonte: Matos (1997); Bishop (2000) - modificados

Segundo Mariotto (2000), a atrição a seco é recomendada quando o material a ser removido é duro e frágil, mas a obtenção de altas taxas de remoção requer atrição intensa, o que pode fraturar os grãos, tornando o processo ineficiente. A remoção por atrição úmida consiste na suspensão da areia a ser tratada em água, sendo, particularmente recomendada, quando o material a ser removido é oriundo de substâncias hidrófilas, como a bentonita na moldagem de areia a verde ou solúveis em água, como o silicato de sódio no processo $\mathrm{CO}_{2}$. Este processo tem alta eficiência, muito utilizado no passado, mas atualmente é desanimador pelo custo elevado de operação. 
O processo de regeneração térmica consiste, basicamente, no aquecimento da areia a uma temperatura suficiente para queimar completamente todo o material estranho, removendo-o da superfície dos grãos de areia. Este tratamento é recomendado, principalmente, para a remoção de material de origem orgânica da superfície dos grãos de areia. Desta forma, é indicado, geralmente, para a recuperação de areia aglomerada com aglutinantes, tais como: resinas sintéticas, óleo e melaço, mas pode ser empregado, também, como um pré-tratamento para facilitar a remoção por atrição a seco. Na recuperação de areias de boa qualidade é bastante eficiente, visto que o fraturamento de grãos por choque térmico é muito reduzido. Os fornos, empregados para realizar esse tratamento, trabalham numa faixa de temperatura de 500 a $700^{\circ} \mathrm{C}$ (SIEGEL et al., 1982; MARIOTTO, 2000).

Para o possível reaproveitamento externo (reciclagem secundário), o resíduo de areia de fundição deve passar primeiro por um pré-tratamento, que seria a retirada dos restos metálicos e/ou torrões existentes ou desagregação destes, bem como a remoção de qualquer material, oriundo do processo de fundição, que comprometa o seu reaproveitamento em outra atividade. De qualquer forma, é necessário fazer um estudo ambiental para a verificação do comprometimento ou não do meio ambiente, quando incorporá-lo neste novo processo. O uso rotineiro de tais resíduos deve ser reavaliado temporariamente e/ou sempre que mudar de fundição, pois, dependendo do metal/liga moldado e do processo de moldagem empregado, a composição do resíduo pode ser alterada, tendo maior ou menor teor de substâncias contaminantes e esta alteração pode influenciar a classificação do resíduo, de acordo com a NBR 10004/87.

A possibilidade da reciclagem secundária do resíduo de fundição está relacionada, principalmente, com a construção civil. Neste sentido, várias instituições de pesquisas brasileiras e mundiais têm se empenhado em projetos, que possam possibilitar a reutilização de areia de fundição, descartada, tais como:

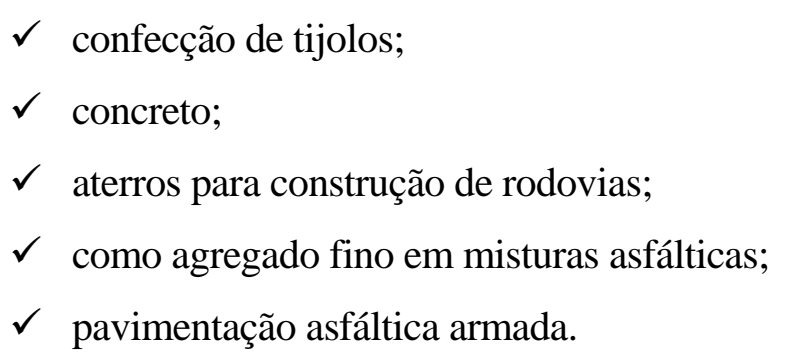

McIntyre et al. (1992) substituíram, parcialmente, o agregado fino da composição do concreto, para confeccionar corpos-de-prova cilíndricos (15\%) e prismáticos (15, 30 e $45 \%$ ), por areia de fundição oriunda do processo de moldagem a verde e compararam com 
os produzidos com o concreto de controle (100\% de agregado fino natural). Concluíram que:

$\checkmark$ a resistência do concreto à compressão cresce com o tempo de cura, mas não tão rapidamente como o que acontece com a mistura de controle;

$\checkmark$ a resistência decresce quanto maior a quantidade de areia de fundição, para os corpos-de-prova prismáticos;

$\checkmark$ as resistências são, em geral, mais baixas do que as da mistura de controle para os prismáticos e para os cilíndricos acontece o inverso.

Com o intuito de reaproveitar a areia de fundição na confecção de tijolos (em vez do barro, areia e cimento), cita-se uma pesquisa realizada por Bonin e Rossini (1994) no Centro Superior de Educação Tecnológica da Unicamp em Limeira/SP. Estes pesquisadores identificaram uma alternativa para a reutilização da areia de fundição de uma determinada empresa da região. Nessa pesquisa, foram realizados todos os ensaios ambientais exigidos e foi concluído que os tijolos desenvolvidos apresentaram valores menores de substâncias contaminantes do que os já existentes no mercado, originando a denominação "ecossocial". Foi constatada, também, a viabilidade de se produzir em larga escala, blocos, postes, guias, sarjetas, bloquetes e outros artefatos de concreto.

\subsubsection{Reutilização da areia de fundição em pavimentação asfáltica}

A atividade de pavimentação de vias é consumidora de forma intensa (grandes volumes de materiais) dos insumos naturais em qualquer uma de suas camadas. Ao se analisar o revestimento, se rígido, verifica-se em sua composição, agregado graúdo, agregado miúdo, cimento, água e aditivos; se flexível, composto, basicamente, de agregado grosso, agregado fino, fíler e asfalto. Desta forma, verifica-se que ambos são constituídos de elementos extraídos da natureza e não são bens renováveis. Nas camadas inferiores: base, sub-base, reforço do subleito, seja qual for o tipo de pavimentação, a matéria-prima continua sendo esses mesmos insumos. Desta forma, visando devastar menos a natureza e preservar mais o meio ambiente (dando um destino adequado para os resíduos), tem-se pesquisado a possibilidade de reutilização de resíduos sólidos (industriais, domésticos, urbanos) de várias procedências, como: resíduos de celulose, fosfogesso, borrachas de pneus, escória de aciaria e, nesta pesquisa, abordar-se-á a possibilidade de se empregar a areia de fundição na construção de vias (revestimento flexível).

Javed e Lovell (1995), em Indiana nos Estados Unidos, realizaram um estudo sobre a aplicação de areia de fundição em Engenharia Civil. Estes pesquisadores verificaram o 
potencial de utilização deste resíduo em aterro e subleito de rodovias, como agregado fino em material de baixa resistência controlada (Flowable fill) e como agregado fino no concreto asfáltico. Concluíram, dentre outras, que as areias de fundição estudadas demonstraram boas propriedades físicas e mecânicas e que aquelas (areias de fundição), provenientes do processo de moldagem a verde de metais ferrosos, têm baixa possibilidade de contaminar o meio ambiente.

Partridge et al. (1999) pesquisaram sobre a reutilização de areia de fundição para a construção de aterro de rodovias em Indiana nos Estados Unidos. Em 1996 o Departamento de Transportes de Indiana, em parceria com a Universidade de Purdue, construiu um aterro utilizando areia de fundição de origem ferrosa. Monitoraram, antes, durante e após a construção (de 1994 a 1998) este aterro por meio de ensaio para verificar o comprometimento do meio ambiente e constataram que não houve impacto ambiental no local. O desempenho geotécnico da seção construída com areia de fundição foi similar ao da seção construída com areia natural, com pequenas deformações internas e um alto padrão de resistência à penetração.

Delage et al. (2001) realizaram uma pesquisa na Universidade de Wisconsin sobre a possibilidade do emprego de areia de fundição em misturas asfálticas a quente. Com esta finalidade estudaram amostras de areia de cinco origens diferentes, sendo três de Wisconsin, uma da Pennsylvania e uma de Michigan. O objetivo da pesquisa era verificar se as areias de fundição, em estudo, exibiam propriedades aceitáveis quando usadas na composição de misturas asfálticas. Esses pesquisadores concluíram, dentre outras, que:

$\checkmark$ algumas areias parecem melhorar a resistência à trilha de roda, enquanto outras não, contudo todas parecem contribuir positivamente para a resistência das misturas aos danos da fadiga sob deformação controlada;

$\checkmark$ o emprego de areia de fundição pode causar efeito positivo no desempenho das misturas, mas deve haver beneficiamento e controle de qualidade desse resíduo para conduzir a um produto que possa substituir os agregados virgens da mistura, bem como agregar valores ao seu desempenho;

$\checkmark$ em virtude dos resultados positivos, recomendam que mais pesquisas sejam conduzidas no sentido de definir as características e/ou técnicas de beneficiamento das areias para melhorar o desempenho das misturas asfálticas, ao utilizá-las na composição do agregado para estas misturas.

Bina et al. (2003) realizaram uma pesquisa sobre a utilização de areia de fundição descartada na pavimentação asfáltica armada. Segundo Bina et al. (2003), a pavimentação 
asfáltica armada é uma tecnologia relativamente nova e seria a melhor opção para a utilização de areia de fundição de descarte. Esta tecnologia consiste na colocação de uma camada composta de tela de aço e lama asfáltica (1 a 1,5 cm de espessura) entre duas camadas de CBUQ, sendo a camada inferior com espessura de 5 a $12 \mathrm{~cm}$ e a superior, de 5 a $7 \mathrm{~cm}$. Segundo esses autores, as vantagens do sistema de pavimentação armada sobre a convencional são:

$\checkmark$ maior desempenho e durabilidade, quanto à perda de capacidade de suporte das camadas inferiores, pois possibilita maior distribuição das tensões provocadas pelo carregamento em virtude do aumento da área colaborante;

$\checkmark$ menor incidência de fissuras que possam favorecer a penetração das águas superficiais nas camadas inferiores;

$\checkmark$ facilidade de instalação e controle, quando confrontado com sistema alternativo de remoção e reconstrução de toda a pavimentação - restauração da pavimentação;

$\checkmark$ custos totalmente conciliáveis com os demais sistemas de reforço e restauração de pavimentação.

Para viabilizar a pesquisa de Bina et al. (2003) foi executado um trecho experimental (restauração) na pista expressa da avenida Coronel Alfredo Fláquer (Perimetral), no município de Santo André/SP, sendo instalados poços para monitoramento das águas provenientes das chuvas e lavagens da camada em estudo. Foram realizados ensaios ambientais, tanto na areia de fundição de descarte, como nos corpos-de-prova de misturas asfálticas preparadas com areia comum (natural) e com areia de fundição de descarte e nos extratos coletados nos poços de monitoramento. No resíduo (areia de fundição de descarte), os parâmetros manganês, ferro e alumínio (ensaio de solubilização - NBR 10004/87) apresentaram limites superiores aos permitidos pela norma; nas amostras de massa asfáltica com areia natural e com areia de fundição, os resultados para todos os parâmetros, nos ensaios de lixiviação, solubilização e massa bruta, foram inferiores ao limite da norma e para as amostras (extrato) coletadas nos poços de monitoramento, os resultados, também, foram inferiores aos limites das normas vigentes.

Estes autores (BINA et al., 2003) concluíram que o emprego de areia de fundição de descarte para a pavimentação asfáltica armada é ambientalmente viável e que esta utilização parece ser mais segura, ambientalmente, do que o risco de descarte não controlado ou do risco de acidentes com aterros industriais aprovados. 


\section{MATERIAIS E MÉTODOS}

Neste capítulo, abordam-se a descrição e a caracterização dos materiais utilizados para preparar as misturas asfálticas, bem como, máquinas, equipamentos empregados e os métodos usados na realização dos ensaios. Para avaliar as propriedades mecânicas das misturas, foram efetuados ensaios como: dosagem pelo método Marshall; moldagem de corpos-de-prova nos teores específicos de vazios (3, 4 e 5\%); envelhecimento (curto e/ou longo prazo); cantabro; umidade induzida; resistência à tração por compressão diametral; módulo de resiliência por tração indireta, com carregamento repetitivo; fluência por compressão uniaxial estática, em dois níveis de tensão (0,1 e 0,4 MPa), sendo que na tensão de 0,4 MPa, este ensaio foi executado com prato superior de carregamento normal (diâmetro do corpo-de-prova) e reduzido (diâmetro de 51 mm).

Para o estudo ambiental, foram executados ensaios de lixiviação, solubilização e massa bruta, nas misturas asfálticas soltas contendo 10\% de areia virgem (areia antes da utilização no processo de fundição) e 15\% de areia de fundição. Para este estudo, além dos ensaios anteriores, também foi realizado o ensaio de lixiviação com extrator soxhlet em amostra de cimento asfáltico e no corpo-de-prova compactado (5\% de vazios), proveniente de misturas asfálticas com 15\% de areia de fundição. Este ensaio foi realizado no CAP 20 com a finalidade de qualificar os materiais (elementos e substâncias químicas) que poderiam ser encontrados no cimento asfáltico, considerando os mesmos parâmetros pesquisados na areia de fundição, e no corpo-de-prova compactado, com o objetivo de avaliar o comportamento desta mistura a longo prazo, considerando as substâncias contaminantes que podem ser liberadas pelo pavimento (massa asfáltica, contendo resíduo industrial).

Para planejar e conduzir a parte experimental deste estudo, utilizou-se o planejamento fatorial. Este tipo de experimento é realizado com o objetivo de investigar a influência dos diversos fatores (variáveis independentes) sobre o parâmetro estudado (variável dependente, como por exemplo, o módulo de resiliência), verificando qual(is) variável(is) tem maior influência sobre a resposta. O fator é a variável que está sendo 
estudada para determinar o seu efeito sobre a resposta (variável dependente), podendo ser qualitativa, como por exemplo, as condições de envelhecimento (sem envelhecimento e com envelhecimento em curto e longo prazo) ou quantitativo, como o teor de areia de fundição.

\subsection{Programação experimental}

Para a realização dos ensaios de laboratório propostos nesta pesquisa foram realizadas as seguintes etapas:

1. escolha e coleta dos agregados minerais;

2. caracterização dos agregados minerais, por meio dos ensaios de abrasão Los Angeles (DNER ME-035/98), análise granulométrica (DNER-ME 083/98), densidade real das partículas, tanto do agregado graúdo (DNER-ME 081/98), quanto do agregado miúdo (DNER-ME 084/95);

3. caracterização dos cimentos asfálticos por meio dos seguintes ensaios: viscosidade Saybolt-Furol nas temperaturas de 135, 155 e $175{ }^{\circ} \mathrm{C}$ (DNER-ME 004/94), viscosidade absoluta a $60{ }^{\circ} \mathrm{C}$ (ABNT-NB 5847/01), ponto de fulgor (DNER-ME 148/94), ponto de amolecimento (ABNT-NBR 6560/00), penetração, 25ㄷ, 100 g, 5 s (0,1mm) (DNER-ME 193/96), densidade (DNERME 193/96) e índice de susceptibilidade térmica - IST;

4. escolha da faixa granulométrica para enquadramento do material granular e posterior separação dos percentuais necessários, nas respectivas peneiras da especificação, para a montagem dos corpos-de-prova das misturas;

5. execução das dosagens Marshall para a determinação dos teores de asfalto, respectivamente, para os teores de vazios de 3, 4 e 5\% nas misturas estudadas. Cada uma delas é identificada pelo teor de areia de fundição ou areia virgem nelas contido, como a seguir:

5\%AF - mistura com areia de fundição no teor de 5\% de peso em relação ao agregado total;

$\checkmark 10 \%$ AF - mistura com areia de fundição no teor de $10 \%$ de peso em relação ao agregado total;

$\checkmark$ 15\%AF - mistura com areia de fundição no teor de $15 \%$ de peso em relação ao agregado total;

$10 \% \mathrm{AV}$ - mistura com areia virgem no teor de $10 \%$ de peso em relação ao agregado total. 
6. moldagem dos corpos-de-prova de cada mistura, nos seus respectivos teores de vazios;

7. realização dos ensaios de caracterização mecânica das misturas;

8. coleta de amostras (NBR 10007/87) e realização dos ensaios ambientais.

\subsection{Materiais utilizados}

Os materiais necessários para a realização dos ensaios propostos para esta pesquisa foram: agregados minerais (brita, pedrisco, pó-de-pedra e areia virgem), incluindo areia de fundição e o Cimento Asfáltico de Petróleo - CAP 20.

Os materiais utilizados nesta pesquisa têm as seguintes origens:

$\checkmark$ a brita (pedra 5/8") e o pedrisco foram coletados na pedreira Leão-leão em Santa Isabel na região de Ribeirão Preto/SP;

$\checkmark$ as areias de fundição e virgem foram coletadas na empresa Pama Mecânica e Fundição Ltda, localizada em Sertãozinho/SP. Estas areias são quartzosas, oriundas da jazida Elias Jorge, sendo a areia de fundição resultante do resíduo do processo de moldagem com resina fenólica e materiais ferrosos e nãoferrosos;

$\checkmark$ o pó-de-pedra foi coletado na pedreira Bandeirantes, localizada na região de São Carlos;

$\checkmark$ o Cimento Asfáltico de Petróleo - CAP 20 foi fornecido pela Usina de asfalto da empresa Leão-leão, em Santa Isabel na região de Ribeirão Preto/SP.

\subsubsection{Agregados}

Tentou-se inicialmente utilizar todos os agregados da pedreira Leão-leão, exceto as areias (fundição ou virgem), contudo o teor de fíler contido no pedrisco e no pó-de-pedra, da referida pedreira, não permitiu atingir uma composição granulométrica satisfatória para a faixa “C” de Rolamento do DNER (ES 313/97). Desta forma, realizou-se um estudo para compor a faixa desejada, utilizando-se os agregados das pedreiras Leão-leão (Tabela 4.01), Bandeirantes (Tabela 4.02) e da empresa Pama Mecânica e Fundição Ltda (Tabela 4.03) e concluiu-se que a alternativa aparentemente mais viável era a composição com a pedra 5/8" e pedrisco da pedreira Leão-leão e o pó-de-pedra da Bandeirantes. As composições granulométricas destes agregados para os teores 5, 10 e 15\% de areia de fundição estão apresentadas, respectivamente, nas Tabelas 4.04, 4.05, e 4.06 e a distribuição granulométrica está representada na Figura 02. É conveniente ressaltar, que a composição 
de agregados foi realizada por tentativa, utilizando-se o programa aplicativo (planilha de cálculo) EXCEL (Microsoft Office 2000). As características físicas dos agregados empregados nesta pesquisa podem ser visualizadas na Tabela 4.08 .

As pedreiras supracitadas fornecem agregados britados de rochas basálticas, que são materiais que apresentam características satisfatórias para a composição de misturas asfálticas.

Tabela 4.01. Granulometria do agregado da Pedreira Sta Isabel da Leão-leão

(Laboratório da EESC)

\begin{tabular}{ccccccc}
\hline \hline $\begin{array}{c}\text { Peneiras } \\
(\mathbf{m m})\end{array}$ & $\begin{array}{c}\text { Pedra 3/4" } \\
\text { \% passando }\end{array}$ & $\begin{array}{c}\text { Pedra 5/8" } \\
\text { \% } \\
\text { passando }\end{array}$ & $\begin{array}{c}\text { Pedrisco } \\
\text { \% } \\
\text { passando }\end{array}$ & $\begin{array}{c}\text { Pó-de-Pedra } \\
\text { (Leão-Leão) } \\
\text { \% passando }\end{array}$ & $\begin{array}{c}\text { Pó-de-Pedra } \\
\text { (Serrana) } \\
\text { \% passando }\end{array}$ & $\begin{array}{c}\text { Calcário } \\
\text { \% passando }\end{array}$ \\
\hline \hline 22 & 100 & 100 & 100 & 100 & 100 & 100 \\
19,1 & 99 & 100 & 100 & 100 & 100 & 100 \\
12,7 & 14 & 95 & 100 & 100 & 100 & 100 \\
9,52 & 2 & 65 & 100 & 100 & 100 & 100 \\
4,76 & 0 & 8 & 74 & 100 & 100 & 100 \\
2,00 & - & $1(1,07)$ & 29 & 93 & 63 & 100 \\
0,42 & - & $1(0,75)$ & 11,5 & 33 & 20 & 98 \\
0,18 & - & $1(0,65)$ & 7,5 & 17 & 14 & 93 \\
0,074 & - & 0 & 5 & 9 & 9 & 76 \\
\hline \hline
\end{tabular}

Tabela 4.02. Granulometria do agregado da Pedreira Bandeirantes (Laboratório da EESC)

\begin{tabular}{ccccc}
\hline \hline Peneiras (mm) & $\begin{array}{c}\text { Pedra 1 (grossa) } \\
\text { \% passando }\end{array}$ & $\begin{array}{c}\text { Pedra 1 (fina) } \\
\text { \% passando }\end{array}$ & $\begin{array}{c}\text { Pedrisco } \\
\text { \% passando }\end{array}$ & $\begin{array}{c}\text { Pó-de-Pedra } \\
\text { \% passando }\end{array}$ \\
\hline \hline 22 & 100 & 100 & 100 & 100 \\
19,1 & 99 & 100 & 100 & 100 \\
12,7 & 2 & 43 & 100 & 100 \\
9,52 & 0 & 6 & 99,5 & 100 \\
4,76 & - & 0 & 17 & 100 \\
2,00 & - & - & 0 & 80 \\
0,42 & - & - & - & 40 \\
0,18 & - & - & - & 26 \\
0,074 & - & - & - & 15 \\
\hline \hline
\end{tabular}

Verificando-se a Tabela 4.03 e a Figura 4.01, observa-se que as areias, Virgem e de Fundição, têm praticamente a mesma distribuição granulométrica, o que era esperado, visto que a areia de fundição é a areia virgem, após o processo de moldagem dos metais. Para efeito de pesquisa, considerou-se como granulometria das duas areias, a da areia de fundição (Tabelas 4.04, 4.05, 4.06 e 4.07). 
No ensaio de granulometria, considerando as peneiras 30, 40, 50, 80, 100 e 200, verificou-se que, para a areia virgem, cerca de $92,10 \%$ do material passa na peneira 30 (0,59 mm) e é retido na peneira $80(0,18 \mathrm{~mm}), 1,40 \%$ passa na peneira $100(0,15 \mathrm{~mm})$ e apenas, 0,14\% passa na peneira $200(75 \mu \mathrm{m})$. Para a areia de fundição, como dito anteriormente, os valores são praticamente iguais, sendo, cerca de 91,60\% do material passando na peneira 30 e retido na peneira 80, 1,40\% na peneira 100 e apenas, 0,24\% passando na peneira 200.

Tabela 4.03. Granulometria das Areias utilizadas (Laboratório da EESC)

\begin{tabular}{ccc}
\hline \hline $\begin{array}{c}\text { Peneiras } \\
(\mathbf{m m})\end{array}$ & $\begin{array}{c}\text { Areia Virgem (Elias Jorge - Pama) } \\
\text { \% passando }\end{array}$ & $\begin{array}{c}\text { Areia de Fundição (Pama)) } \\
\text { \% passando }\end{array}$ \\
\hline \hline 22 & 100 & 100 \\
19,1 & 100 & 100 \\
12,7 & 100 & 100 \\
9,52 & 100 & 100 \\
4,76 & 100 & 100 \\
2,00 & 100 & 100 \\
0,42 & 80 & 82 \\
0,18 & 7 & 7,50 \\
0,074 & 0 & 0 \\
\hline \hline
\end{tabular}

Tabela 4.04. Granulometria (composição) do Agregado utilizado na pesquisa com 5\% de areia de fundição

\begin{tabular}{|c|c|c|c|c|c|c|c|c|c|c|}
\hline \multirow{3}{*}{$\begin{array}{c}\begin{array}{c}\text { Peneiras } \\
\text { mm }\end{array} \\
19,1\end{array}$} & \multirow{2}{*}{\multicolumn{2}{|c|}{$\begin{array}{c}\text { Pedra 5/8" } \\
\text { \% passando } \\
40 \%\end{array}$}} & \multirow{2}{*}{\multicolumn{2}{|c|}{$\begin{array}{c}\text { Pedrisco } \\
\% \text { passando } \\
15 \%\end{array}$}} & \multirow{2}{*}{\multicolumn{2}{|c|}{$\begin{array}{c}\text { Pó-de-Pedra } \\
\text { \% passando } \\
40 \%\end{array}$}} & \multirow{2}{*}{\multicolumn{2}{|c|}{$\begin{array}{c}\begin{array}{c}\text { A. de Fundição } \\
\% \text { passando }\end{array} \\
5 \%\end{array}$}} & \multirow{3}{*}{$\begin{array}{c}\begin{array}{c}\text { Soma } \\
(\%)\end{array} \\
100\end{array}$} & \multirow{3}{*}{$\begin{array}{c}\text { Faixa C } \\
\text { DNER } \\
(\%) \\
100\end{array}$} \\
\hline & & & & & & & & & & \\
\hline & $\begin{array}{c}100 \\
\end{array}$ & 440 & 100 & 15 & $\begin{array}{c}100 \\
\end{array}$ & 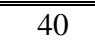 & 100 & $\overline{c 5}$ & & \\
\hline 12,7 & 95 & 38 & 100 & 15 & 100 & 40 & 100 & 5 & 98 & $85-100$ \\
\hline 9,5 & 65 & 26 & 100 & 15 & 100 & 40 & 100 & 5 & 86 & $75-100$ \\
\hline 4,8 & 8 & 3,2 & 74 & 11,1 & 100 & 40 & 100 & 5 & 59,30 & $50-85$ \\
\hline 2,0 & 1 & 0 & 29 & 4,35 & 80 & 32 & 100 & 5 & 41,35 & $30-75$ \\
\hline 0,42 & 1 & 0 & 11,5 & 1,73 & 40 & 16 & 82 & 4,1 & 21,83 & $15-40$ \\
\hline 0,18 & 1 & 0 & 7,5 & 1,13 & 26 & 10,40 & 7,50 & 0,38 & 11,90 & $8-30$ \\
\hline 0,074 & 0 & 0 & 5 & 0,75 & 15 & 6 & 0 & 0 & 6,75 & $5-10$ \\
\hline
\end{tabular}


Tabela 4.05. Granulometria (composição) do Agregado utilizado na pesquisa com $10 \%$ de areia de fundição

\begin{tabular}{|c|c|c|c|c|c|c|c|c|c|c|}
\hline \multirow{3}{*}{$\begin{array}{c}\begin{array}{c}\text { Peneiras } \\
\text { mm }\end{array} \\
19,1\end{array}$} & \multirow{2}{*}{\multicolumn{2}{|c|}{$\begin{array}{c}\begin{array}{c}\text { Pedra } 5 / 8 " \\
\% \text { passando }\end{array} \\
30 \%\end{array}$}} & \multirow{2}{*}{\multicolumn{2}{|c|}{$\begin{array}{c}\begin{array}{c}\text { Pedrisco } \\
\% \text { passando }\end{array} \\
17,5 \%\end{array}$}} & \multirow{2}{*}{\multicolumn{2}{|c|}{$\begin{array}{c}\begin{array}{c}\text { Pó-de-Pedra } \\
\text { \% passando }\end{array} \\
42,5 \%\end{array}$}} & \multirow{2}{*}{\multicolumn{2}{|c|}{$\begin{array}{c}\begin{array}{c}\text { A. de Fundição } \\
\% \text { passando }\end{array} \\
10 \%\end{array}$}} & \multirow{3}{*}{$\begin{array}{r}\begin{array}{c}\text { Soma } \\
(\%)\end{array} \\
100\end{array}$} & \multirow{3}{*}{$\begin{array}{c}\text { Faixa C } \\
\text { DNER } \\
(\%)\end{array}$} \\
\hline & & & & & & & & & & \\
\hline & 100 & 30 & 100 & 17,5 & 100 & 42,5 & 100 & 10 & & \\
\hline 12,7 & 95 & 28,5 & 100 & 17,5 & 100 & 42,5 & 100 & 10 & 98,50 & $85-100$ \\
\hline 9,5 & 65 & 19,5 & 100 & 17,5 & 100 & 42,5 & 100 & 10 & 89,50 & $75-100$ \\
\hline 4,8 & 8 & 2,4 & 74 & 12,95 & 100 & 42,5 & 100 & 10 & 67,85 & $50-85$ \\
\hline 2,0 & 1 & 0 & 29 & 5,08 & 80 & 34 & 100 & 10 & 49,08 & $30-75$ \\
\hline 0,42 & 1 & 0 & 11,5 & 2,01 & 40 & 17 & 82 & 8,2 & 27,21 & $15-40$ \\
\hline 0,18 & 1 & 0 & 7,5 & 1,31 & 26 & 11,05 & 7,50 & 0,75 & 13,11 & 8-30 \\
\hline 0,074 & 0 & 0 & 5 & 0,88 & 15 & 6,38 & 0 & 0 & 7,25 & $5-10$ \\
\hline
\end{tabular}

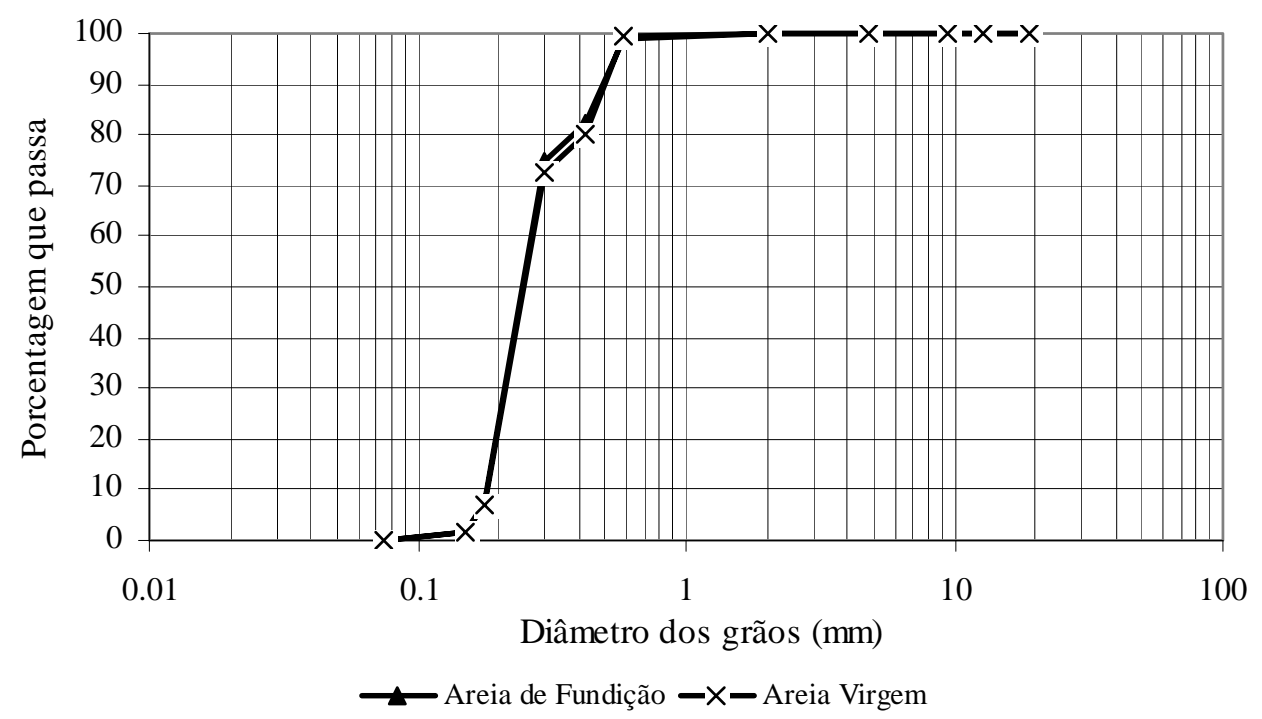

Figura 4.01. Distribuição granulométrica das areias de Fundição e Virgem

Tabela 4.06. Granulometria (composição) do Agregado utilizado na pesquisa com 15\% de areia de fundição

\begin{tabular}{|c|c|c|c|c|c|c|c|c|c|c|}
\hline \multirow{3}{*}{$\begin{array}{c}\text { Peneiras } \\
\text { mm } \\
19,1\end{array}$} & \multirow{2}{*}{\multicolumn{2}{|c|}{$\begin{array}{c}\begin{array}{c}\text { Pedra } 5 / 8^{\prime \prime} \\
\% \text { passando }\end{array} \\
20 \%\end{array}$}} & \multirow{2}{*}{\multicolumn{2}{|c|}{$\begin{array}{c}\begin{array}{c}\text { Pedrisco } \\
\text { \% passando }\end{array} \\
20 \% \\
\end{array}$}} & \multirow{2}{*}{\multicolumn{2}{|c|}{$\begin{array}{c}\text { Pó-de-Pedra } \\
\text { \% passando } \\
45 \%\end{array}$}} & \multirow{2}{*}{\multicolumn{2}{|c|}{$\begin{array}{c}\begin{array}{c}\text { A. de Fundição } \\
\text { \% passando }\end{array} \\
15 \%\end{array}$}} & \multirow{3}{*}{$\begin{array}{c}\text { Soma } \\
(\%) \\
100\end{array}$} & \multirow{3}{*}{$\begin{array}{c}\text { Faixa C } \\
\text { DNER } \\
(\%) \\
100\end{array}$} \\
\hline & & & & & & & & & & \\
\hline & 100 & 20 & 100 & 20 & $\begin{array}{l}100 \\
\end{array}$ & 45 & 100 & 15 & & \\
\hline 12,7 & 95 & 19 & 100 & 20 & 100 & 45 & 100 & 15 & 99 & $85-100$ \\
\hline 9,5 & 65 & 13 & 100 & 20 & 100 & 45 & 100 & 15 & 93 & $75-100$ \\
\hline 4,8 & 8 & 1,6 & 74 & 14,8 & 100 & 45 & 100 & 15 & 76,40 & $50-85$ \\
\hline 2,0 & 1 & 0 & 29 & 5,8 & 80 & 36 & 100 & 15 & 56,8 & $30-75$ \\
\hline 0,42 & 1 & 0 & 11,5 & 2,3 & 40 & 18 & 82 & 12,3 & 32,6 & $15-40$ \\
\hline 0,18 & 1 & 0 & 7,5 & 1,5 & 26 & 11,7 & 7,50 & 1,13 & 14,33 & 8-30 \\
\hline 0,074 & 0 & 0 & 5 & 1 & 15 & 6,75 & 0 & 0 & 7,75 & $5-10$ \\
\hline
\end{tabular}


Tabela 4.07. Granulometria (composição) do Agregado utilizado na pesquisa com $10 \%$ de areia virgem

\begin{tabular}{|c|c|c|c|c|c|c|c|c|c|c|}
\hline \multirow[t]{2}{*}{$\begin{array}{c}\text { Peneiras } \\
\text { mm }\end{array}$} & \multicolumn{2}{|c|}{$\begin{array}{l}\text { Pedra 5/8" } \\
\% \text { passando }\end{array}$} & \multicolumn{2}{|c|}{$\begin{array}{c}\text { Pedrisco } \\
\text { \% passando }\end{array}$} & \multicolumn{2}{|c|}{$\begin{array}{l}\text { Pó-de-Pedra } \\
\text { \% passando }\end{array}$} & \multicolumn{2}{|c|}{$\begin{array}{c}\text { Areia } \\
\text { Virgem } \\
\text { \% passando }\end{array}$} & \multirow[t]{2}{*}{$\begin{array}{l}\text { Soma } \\
(\%)\end{array}$} & \multirow[t]{2}{*}{$\begin{array}{c}\text { Faixa C } \\
\text { DNER (\%) }\end{array}$} \\
\hline & \multicolumn{2}{|c|}{$30 \%$} & \multicolumn{2}{|c|}{$\overline{17,5 \%}$} & \multicolumn{2}{|c|}{$\bar{~} 42,5 \%$} & \multicolumn{2}{|c|}{$\overline{110 \%}$} & & \\
\hline 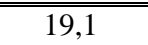 & $\begin{array}{c}100 \\
\end{array}$ & 30 & $\begin{array}{ll}100 \\
\end{array}$ & \begin{tabular}{l|l|}
17,5 \\
\end{tabular} & \begin{tabular}{c|c|}
100 \\
\end{tabular} & 42,5 & $\begin{array}{c}100 \\
\end{array}$ & \begin{tabular}{c|c|}
10 \\
\end{tabular} & $\begin{array}{ll}100 \\
\end{array}$ & $\begin{array}{ll}100 \\
\end{array}$ \\
\hline 12,7 & 95 & 28,5 & 100 & 17,5 & 100 & 42,5 & 100 & 10 & 98,50 & $85-100$ \\
\hline 9,5 & 65 & 19,5 & 100 & 17,5 & 100 & 42,5 & 100 & 10 & 89,50 & $75-100$ \\
\hline 4,8 & 8 & 2,4 & 74 & 12,95 & 100 & 42,5 & 100 & 10 & 67,85 & $50-85$ \\
\hline 2,0 & 1 & 0 & 29 & 5,08 & 80 & 34 & 100 & 10 & 49,08 & $30-75$ \\
\hline 0,42 & 1 & 0 & 11,5 & 2,01 & 40 & 17 & 82 & 8,2 & 27,21 & $15-40$ \\
\hline 0,18 & 1 & 0 & 7,5 & 1,31 & 26 & 11,05 & 7,50 & 0,75 & 13,11 & $8-30$ \\
\hline 0,074 & 0 & 0 & 5 & 0,88 & 15 & 6,38 & 0 & 0 & 7,25 & 5-10 \\
\hline
\end{tabular}

Verificando-se os resultados dos ensaios de caracterização do agregado (Tabela 4.08), constata-se que, considerando a resistência ao desgaste por abrasão Los Angeles, o material é de excelente qualidade, contudo, em relação a adesividade, tanto o agregado miúdo quanto o graúdo apresentam adesividade não satisfatória (má para o miúdo e insatisfatória para o graúdo). No entanto, com base em trabalhos realizados nessa instituição com materiais oriundos dessa pedreira (Leão-leão) e outros fatores referentes a este estudo, resolveu-se que o agregado se mostra apropriado para o uso nas misturas aqui pesquisadas. Além disso, a adesividade das misturas asfálticas será avaliada com o método AASHTO T-283/99 (metodologia Lottman modificado), considerado por Hicks (1991), de alta severidade na avaliação dessa propriedade. A opção por esse método, foi, principalmente, pelo uso da areia de fundição incorporada a mistura. Esta areia é de natureza sílica (hidrófila) e pode possuir em sua superfície uma fina camada de resina e pó, resultante da alta temperatura que fica submetida no processo de moldagem, e, dependendo da natureza do produto fundido, resíduos de metais ferrosos ou não ferrosos, que podem dificultar ou favorecer a adesividade do filme asfáltico à areia.

O fíler originado do pó-de-pedra basáltico foi escolhido por ser o mais utilizado na região e também por ser mais desfavorável, considerando a adesividade asfalto/agregado. Pelos motivos expostos no parágrafo anterior, existe uma preocupação na adesividade da areia de fundição com o asfalto. Se a opção fosse por fíler de natureza calcária, por exemplo, diminuiria a susceptibilidade da mistura a este fenômeno, visto 
que esse material agiria como um agente melhorador de adesividade. Com esta opção, tentou-se ser o mais severo possível no que se refere a esta propriedade.

Tabela 4.08. Características físicas dos agregados minerais

\begin{tabular}{|c|c|c|c|c|c|c|}
\hline \multirow[b]{2}{*}{ Ensaios } & \multirow[b]{2}{*}{ Métodos } & \multicolumn{5}{|c|}{ "Agregado Mineral } \\
\hline & & Graúdo & Miúdo & $\begin{array}{c}\text { Areia de } \\
\text { Fundição }\end{array}$ & Areia Virgem & Fíler \\
\hline Densidade Real & $\begin{array}{l}\text { DNER-ME 081/98 } \\
\text { e } 084 / 95\end{array}$ & 2,915 & 2,908 & 2,651 & 2,647 & 2,872 \\
\hline $\begin{array}{c}\text { Abrasão Los } \\
\text { Angeles }\end{array}$ & DNER-ME 035/98 & $15 \%(<40 \%)$ & - & - & - & - \\
\hline Adesividade & $\begin{array}{c}\text { DNER-ME 078/94 } \\
\text { e } 079 / 94\end{array}$ & Insatisfatória & Má & - & - & - \\
\hline
\end{tabular}

\section{Distribuição em relação à Faixa "C" do DNER}

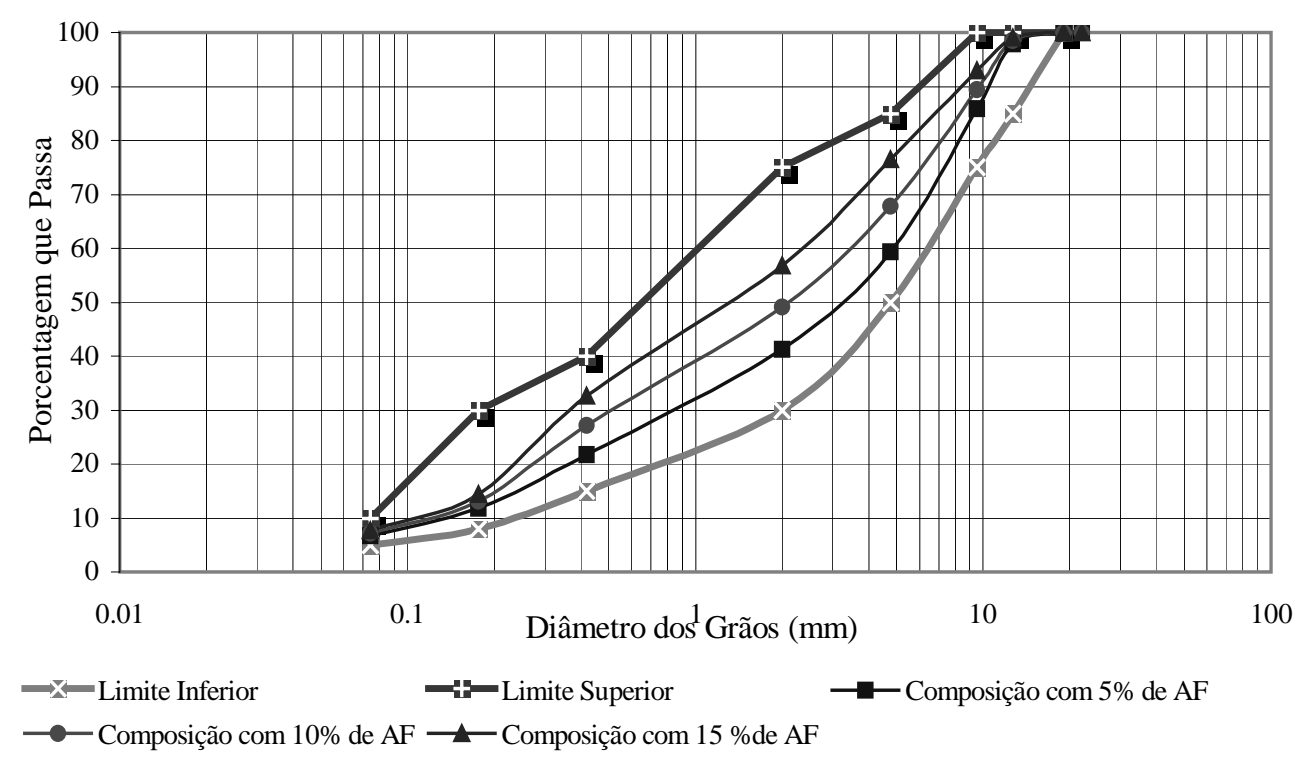

Figura 4.02. Faixa C do DNER e distribuição granulométrica dos agregados com 5, 10 e 15\% de Areia de Fundição

\subsubsection{Cimento asfáltico}

O cimento asfáltico de petróleo escolhido foi o CAP 20, por ser indicado para todas as misturas a quente (pré-misturado, areia-asfalto e concreto asfáltico usinado) e por ser o mais utilizado e o mais apropriado para a região. 
Este material foi fornecido pela Usina de asfalto da empresa Leão-leão em Santa Isabel na região de Ribeirão Preto/SP, produzido na refinaria de São José dos Campos/SP (Revap).

Todos os parâmetros (Tabela 4.09) estão dentro dos limites especificados (Tabela 3.02 Especificação para o Cimento Asfáltico de Petróleo - Classificação por Viscosidade Regulamento Técnico 01/92 - REV.02 - DNC), exceto a penetração que deveria ser no mínimo 50 décimos de milímetro (5 mm), mas o resultado encontrado foi de 48 (4,8 mm). Segundo Pinto (1991), um acréscimo na viscosidade, associado a um decréscimo na penetração geralmente indicia um processo de envelhecimento do cimento asfáltico, com uma diminuição nas suas características aglutinantes. Contudo, não se verificou nenhum aumento na viscosidade absoluta a $60^{\circ} \mathrm{C}$ (Tabela 4.09), que está dentro do especificado, que é de 2.000 a 3.500 .

Tabela 4.09. Resultados dos Ensaios de caracterização do CAP 20 (Laboratório EESC)

\begin{tabular}{|c|c|c|c|}
\hline \multicolumn{2}{|l|}{ Ensaios } & \multirow[t]{2}{*}{ Métodos } & \multirow{2}{*}{$\begin{array}{c}\text { Resultados } \\
160\end{array}$} \\
\hline & $135^{\circ} \mathrm{C}$ & & \\
\hline \multirow[t]{2}{*}{ Viscosidade Saybolt-Furol (sSF) } & $155^{\circ} \mathrm{C}$ & DNER ME - 004/94 (ABNT MB - 517/71) & 50 \\
\hline & $175^{\circ} \mathrm{C}$ & & 26 \\
\hline \multicolumn{2}{|c|}{ Viscosidade Absoluta a $60^{\circ} \mathrm{C}$ (Poises) } & ABNT NBR 5847/01 & 2.975 \\
\hline \multicolumn{2}{|c|}{ Penetração, $25^{\circ} \mathrm{C}, 100$ g, 5s (0,1mm) } & DNER ME - 003/99 & 48 \\
\hline \multicolumn{2}{|l|}{ Ponto de Amolecimento $\left({ }^{\circ} \mathrm{C}\right)$} & ABNT NBR 6560/00 & 52 \\
\hline \multicolumn{2}{|l|}{ Ponto de Fulgor $\left({ }^{\circ} \mathrm{C}\right)$} & DNER ME-148/94 (ABNT NBR-11341/00) & 280 \\
\hline \multicolumn{2}{|l|}{ Densidade } & DNER ME - 193/96 & 1,018 \\
\hline \multicolumn{2}{|c|}{ Índice de Susceptibilidade Térmica, IST } & - & $-0,80$ \\
\hline
\end{tabular}

Com a finalidade de se obter as temperaturas do ligante, de compactação e do agregado, traçou-se o gráfico (Figura 4.03) da viscosidade Saybolt-Furol (sSF) versus temperatura $\left({ }^{\circ} \mathrm{C}\right)$. Segundo o DNER-ME 043/95, a temperatura em que o cimento asfáltico deve ser aquecido é aquela na qual ele apresenta uma viscosidade de 75 a 95 sSF $(85 \pm 10)$ e a temperatura de compactação da mistura é aquela na qual o cimento asfáltico apresenta uma viscosidade de 125 a 155 sSF (140 \pm 15$)$. O agregado deve ser aquecido à temperatura de, aproximadamente, 10 a $15^{\circ} \mathrm{C}$ acima da temperatura de aquecimento do cimento asfáltico, não devendo ultrapassar a $177^{\circ} \mathrm{C}$ (item 5.2 .5 do DNER-ME 043/95). 


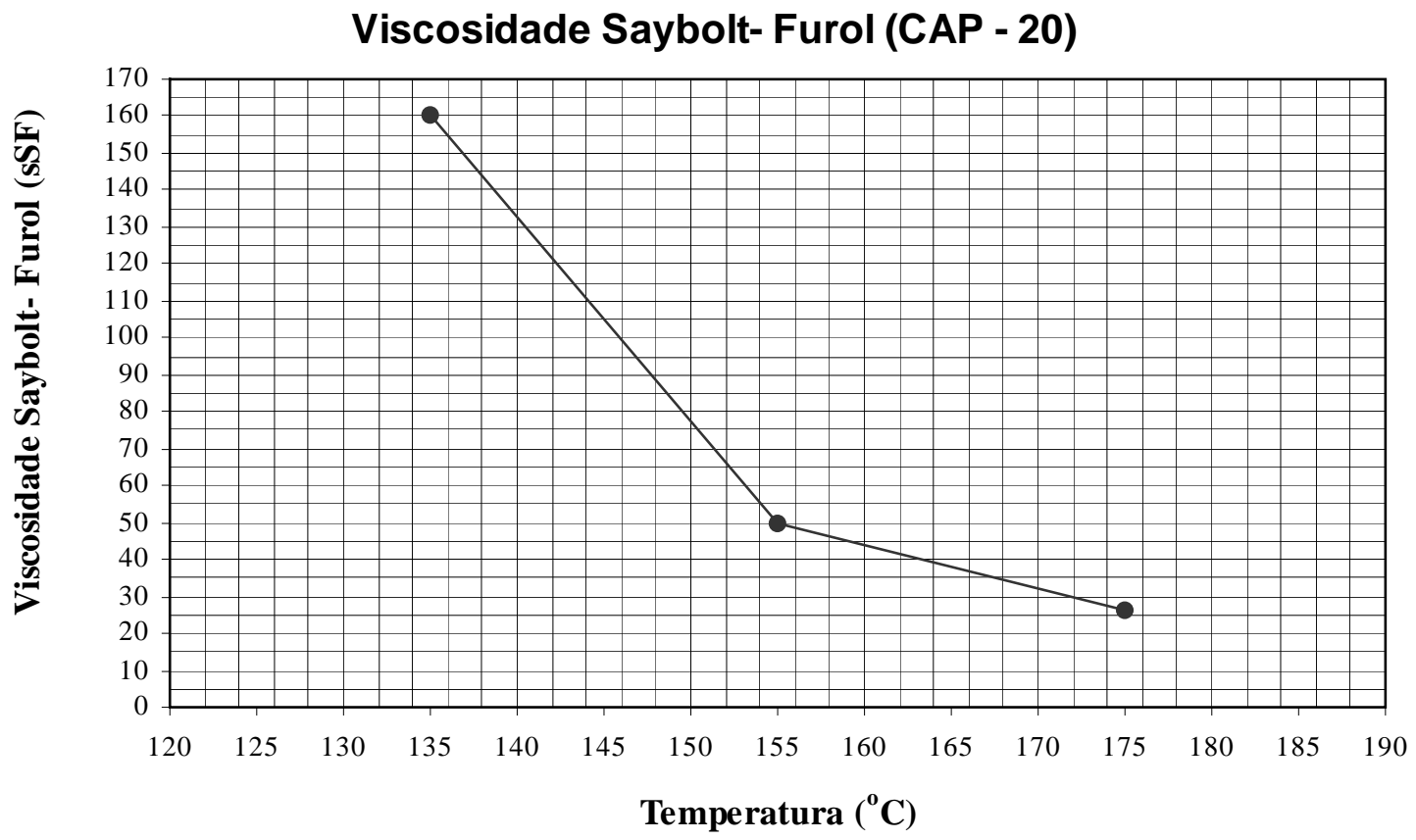

Figura 4.03. Variação da Viscosidade Saybolt-Furol com a temperatura

Pela Tabela 4.10 (obtida do gráfico da figura 4.03), verifica-se que a temperatura média de aquecimento do ligante é de $149^{\circ} \mathrm{C}$, a temperatura média de aquecimento dos agregados é de $164^{\circ} \mathrm{C}$, considerando $15^{\circ} \mathrm{C}$ acima da temperatura do ligante, conforme o DNER-ME 043/95 e a temperatura média de compactação é de $138,5^{\circ} \mathrm{C}$.

Tabela 4.10. Faixa de temperatura dos componentes da mistura e de Compactação

\begin{tabular}{cc}
\hline \hline Parâmetros & Faixa de Temperatura $\left({ }^{\mathbf{0}} \mathbf{C}\right)$ \\
\hline \hline Cimento asfáltico & 147 a 151 \\
Agregados & 162 a 166 \\
Compactação & 136 a 141 \\
\hline \hline
\end{tabular}

\subsection{Misturas asfálticas}

As misturas asfálticas foram dosadas e compactadas pelo método Marshall (DNER-ME 043/95), sendo a estimativa inicial do teor ótimo de cimento asfáltico realizada, tomando-se como base o método da superfície específica (DURIEZ e ARRAMBIDE, 1962), utilizando a expressão 4.02, cujos três últimos termos são oriundos da equação proposta por estes pesquisadores. O valor $135\left(\mathrm{~m}^{2} / \mathrm{kg}\right)$ da expressão é uma média das superfícies específicas de 10 fíleres, considerando partículas com diâmetro menores que 
$80 \mu \mathrm{m}$ (Nouveau Traité de Materiaux de Construción. p. 277 - vol.1). Para calcular a superfície especifica de uma fração de agregado, passando em uma peneira e retida na subseqüente, pode-se fazer uso da expressão 4.01.

$$
\begin{aligned}
& S i=\frac{12}{(D+d) \times \delta}, \text { considerando } \delta=2,65 \mathrm{~g} / \mathrm{cm}^{3} \text { (material quartzoso), tem-se: } \\
& S i=\frac{4,53}{(D+d)}
\end{aligned}
$$

onde:

$\mathrm{Si}$ - superfície específica para uma determinada fração de agregado $\left(\mathrm{m}^{2} / \mathrm{kg}\right)$;

$D$ - diâmetro da peneira que passa o agregado (mm);

$d$ - diâmetro da peneira que retém o agregado (mm).

$$
S=\frac{0,14 a+0,20 b+0,32 c+2,30 d+12 e+135 f}{100}
$$

onde:

$S$ - superfície específica para a combinação de agregado $\left(\mathrm{m}^{2} / \mathrm{kg}\right)$;

$a$-material passado na peneira $19,1 \mathrm{~mm}$ e retido na $12,7 \mathrm{~mm}(\%)$;

$b$-material passado na peneira $12,7 \mathrm{~mm}$ e retido na 9,5 $\mathrm{mm}$ (\%);

$c$-material passado na peneira 9,5 mm e retido na 4,8 $\mathrm{mm}(\%)$;

$d$-material passado na peneira 4,8 mm e retido na 0,297 mm (\%);

$e$-material passado na peneira $0,297 \mathrm{~mm}$ e retido na $0,074 \mathrm{~mm}(\%)$;

$f$-material passado na peneira 0,074 $\mathrm{mm}(\%)$.

A montagem dos corpos-de-prova (composição granulométrica), considerando o peso de 1200 gf de agregado, para as dosagens das misturas pesquisadas, pode ser visualizada na Tabela 4.11, bem como a densidade real da composição de agregados para essas misturas. Cada material granular foi homogeneizado, quarteado e retirada a amostra para o ensaio de granulometria e peso específico. Para a dosagem, esses materiais foram secos em estufa a $105^{\circ} \mathrm{C}$, homogeneizados, pesados, em suas respectivas frações para a composição de um corpo-de-prova, sendo posteriormente remisturados e acondicionados em sacos plásticos, devidamente identificados.

O cimento asfáltico foi acondicionado em recipientes de alumínio (com etiquetas de identificação), com dois litros de capacidade, aproximadamente, dois quilogramas- 
força, sendo colocado neste, o material necessário para a dosagem, acrescido de 150 gf, prevendo, desta forma, a possibilidade de faltar material.

Antes do procedimento de dosagem, os componentes das misturas foram deixados em estufa, com temperatura monitorada por multímetros, para garantir a temperatura específica de misturação.

Tabela 4.11. Composição granulométrica dos corpos-de-prova e densidade média dos grãos de cada composição de agregado

\begin{tabular}{ccccc}
\hline \hline Parâmetros & 5\%AF & Misturas \\
& 480 & 10\% & 15\%AF & 10\%AV \\
\hline \hline Pedra 5/8" (gf) & 180 & 210 & 240 & 360 \\
Pedrisco (gf) & 480 & 510 & 540 & 210 \\
Pó-de-pedra (gf) & 60 & 120 & 180 & 510 \\
Areia de Fundição (gf) & 0 & 0 & 0 & 0 \\
Areia Virgem (gf) & 2,882 & 2,866 & 2,852 & 2,866 \\
Densidade Média dos Grãos & & & & \\
\hline \hline
\end{tabular}

Para a dosagem, foram moldados 60 corpos-de-prova, sendo 15 (três por teor de asfalto) para cada mistura. Os procedimentos para a preparação dos corpos-de-prova utilizados na dosagem, bem como a determinação da estabilidade e da fluência Marshall, foram os preconizados pelo DNER-ME 043/95.

Para a obtenção da densidade aparente, todos os corpos-de-prova, independentemente do teor de vazios esperado, foram parafinados para posteriormente serem pesados imersos em água. Todos os procedimentos para a determinação da densidade aparente foram realizados de acordo com o DNER-ME 117/94. A densidade aparente pode ser calculada pela expressão 4.03 .

$$
D_{a p}=\frac{P_{a r}}{P_{p}-P_{p i}-\frac{\left(P_{p}-P_{a r}\right)}{D_{p a r}}}
$$

onde:

$D_{a p \text { - densidade aparente do corpo-de-prova; }}$

$P_{a r-}$ peso do corpo-de-prova ao ar (gf);

$P_{p \text { - }}$ peso do corpo-de-prova envolvido com parafina (gf);

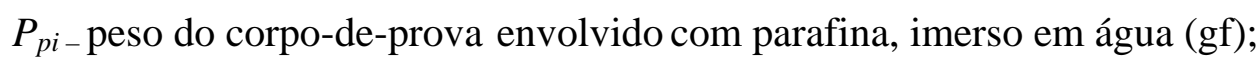




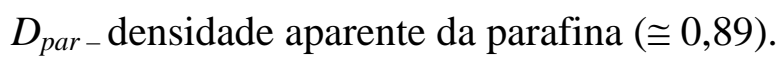

Para a determinação dos parâmetros necessários para traçar os gráficos referentes ao ensaio Marshall, densidade teórica máxima $\left(D_{t}\right)$, volume de vazios $(\mathrm{Vv})$, densidade real média do agregado mineral (Drm), vazios do agregado mineral (VAM), teor de vazios preenchidos por cimento asfáltico (Vb) e relação betume/vazios (RBV), utilizaram-se as expressões preconizadas pela NBR 12891/93.

As especificações do DNER para o teor ótimo de asfalto para a camada de rolamento estão na Tabela 4.12 .

Os gráficos referentes às dosagens das misturas pelo método Marshall estão representados na Figura 4.04. O teor de ligante para cada mistura foi obtido por meio destes gráficos para os teores de vazios de 3, 4 e 5\%, bem como os outros parâmetros Marshall (densidade aparente, estabilidade, fluência, relação betume/vazios e vazio do agregado mineral). Esse parâmetro, os referentes ao ensaio Marshall e outras características (porcentagem de agregado graúdo, miúdo e fíler) dessas misturas podem ser visualizados na Tabela 4.13. Todos os parâmetros Marshall, exceto a relação betume/vazios para o teor de vazios de 5\% para todas as misturas (menores que 75\%), estão dentro da faixa especificada pelo DNER -ME 313/97. O valor mínimo dos vazios do agregado mineral para a faixa “C” do DNER é de, aproximadamente, $12 \%$.

Tabela 4.12. Especificações das misturas asfálticas para a camada de rolamento

\begin{tabular}{cc}
\hline \hline Discriminação & Camada de Rolamento \\
\hline \hline Porcentagem de vazios & 3 a 5 \\
Relação Betume/Vazios (\%) & 75 a 82 \\
Estabilidade, mínima (kgf) & 350 (75 golpes) \\
& 250 (50 golpes) \\
Fluência (mm) & 2 a 4,5
\end{tabular}

Fonte: DNER-ES 313/97 

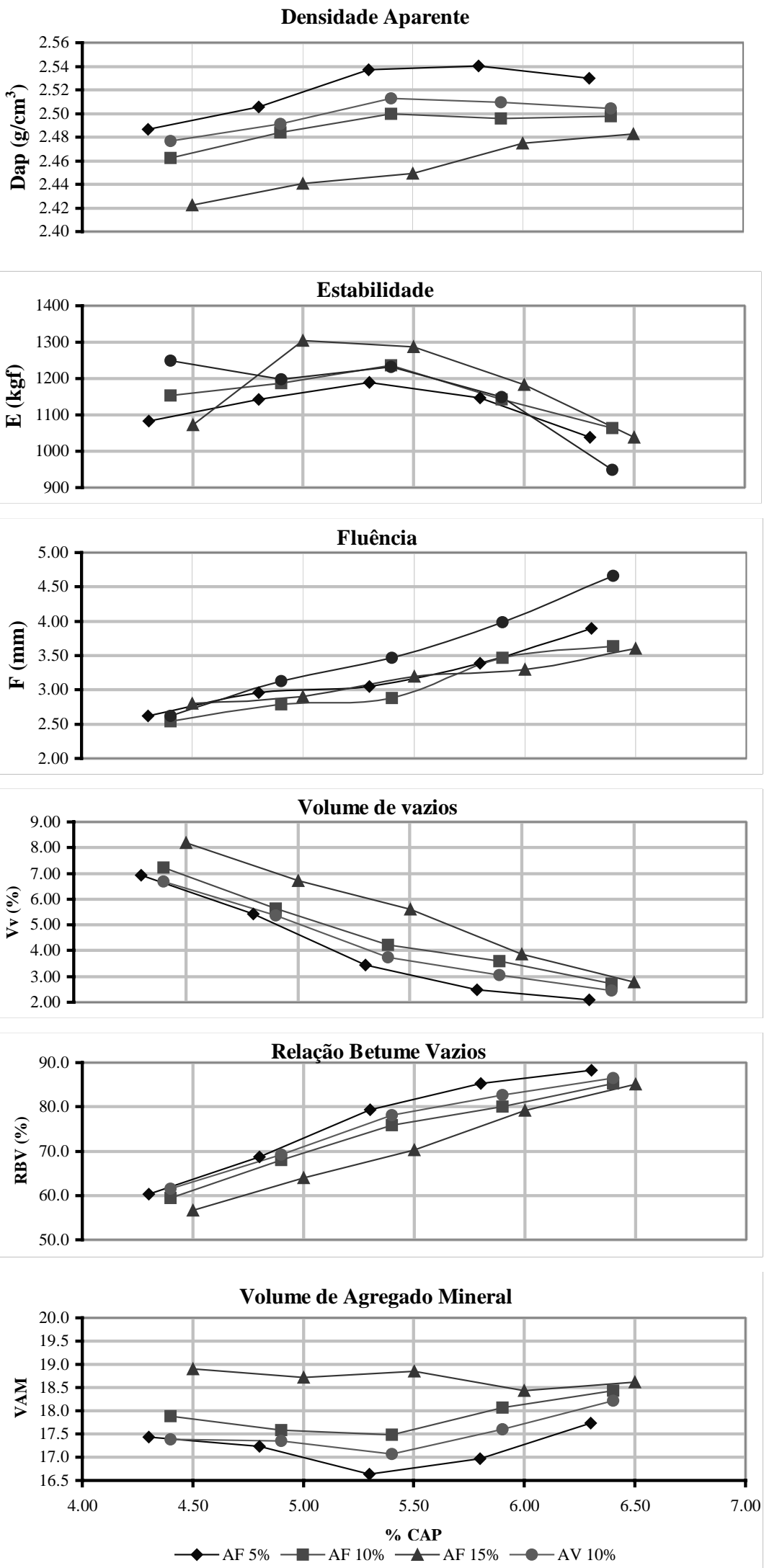

Figura 4.04. Gráfico dos parâmetros Marshall das misturas asfálticas 
Tabela 4.13. Características das misturas asfálticas estudadas

\begin{tabular}{|c|c|c|c|c|c|c|c|c|c|c|c|c|}
\hline \multirow{4}{*}{ Parâmetros } & \multicolumn{12}{|c|}{ Misturas } \\
\hline & \multicolumn{3}{|c|}{$5 \%$ AF } & \multicolumn{3}{|c|}{$10 \%$ AF } & \multicolumn{3}{|c|}{$15 \% A F$} & \multicolumn{3}{|c|}{$10 \% A V$} \\
\hline & \multicolumn{3}{|c|}{ Teor de Vazios } & \multicolumn{3}{|c|}{ Teor de Vazios } & \multicolumn{3}{|c|}{ Teor de Vazios } & \multicolumn{3}{|c|}{ Teor de Vazios } \\
\hline & $3 \%$ & $4 \%$ & $5 \%$ & $3 \%$ & $4 \%$ & $5 \%$ & $3 \%$ & $4 \%$ & $5 \%$ & $3 \%$ & $4 \%$ & $5 \%$ \\
\hline $\begin{array}{l}\text { Agregado } \\
\text { Graúdo (\%) }\end{array}$ & & \multicolumn{2}{|l|}{58,65} & \multicolumn{3}{|c|}{50,92} & \multicolumn{3}{|c|}{43,20} & \multicolumn{3}{|c|}{50,92} \\
\hline $\begin{array}{l}\text { Agregado } \\
\text { Miúdo (\%) }\end{array}$ & & \multicolumn{2}{|l|}{34,60} & \multicolumn{3}{|c|}{41,83} & \multicolumn{3}{|c|}{49,05} & \multicolumn{3}{|c|}{41,83} \\
\hline Fíler (\%) & \multicolumn{3}{|c|}{6,75} & \multicolumn{3}{|c|}{7,25} & \multicolumn{3}{|c|}{7,75} & \multicolumn{3}{|c|}{7,25} \\
\hline $\begin{array}{c}\text { Teor de } \\
\text { Asfalto (\%) }\end{array}$ & 5,50 & 5,20 & 4,90 & 6,00 & 5,50 & 5,10 & 6,50 & 6,00 & 5,80 & 5,85 & 5,30 & 5,00 \\
\hline $\mathrm{D}_{\mathrm{ap}}$ & 2,540 & 2,526 & 2,513 & 2,506 & 2,502 & 2,492 & 2,483 & 2,476 & 2,453 & 2,513 & 2,509 & 2,497 \\
\hline E (kgf) & 1.190 & 1.180 & 1.130 & 1.152 & 1.265 & 1.225 & 1.060 & 1.210 & 1.240 & 1.190 & 1.270 & 1.233 \\
\hline $\mathrm{F}(\mathrm{mm})$ & 3,20 & 3,05 & 2,95 & 3,55 & 2,90 & 2,60 & 3,55 & 3,30 & 3,25 & 4,00 & 3,40 & 3,20 \\
\hline RBV (\%) & 82 & 76 & 71 & 83 & 77 & 71 & 84 & 78 & 74 & 83 & 77 & 71 \\
\hline VAM (\%) & 16,73 & 16,94 & 17,09 & 17,71 & 17,51 & 17,47 & 18,85 & 18,59 & 19,07 & 17,42 & 17,07 & 17,25 \\
\hline
\end{tabular}

\subsubsection{Planejamento fatorial}

Todas as misturas foram estudadas, levando em consideração os fatores especificados na Tabela 4.14. O experimento fatorial completo foi realizado, somente, para o teor de $4 \%$ de vazios $(4 \times 1 \times 4=16)$, contudo, para os outros teores: 3 e 5\%, o fator envelhecimento foi realizado, apenas, no nível um - mistura virgem(4x2x1 = 8), totalizando, assim, 24 condições experimentais. A identificação das combinações experimentais está listada na Tabela 4.15.

Tabela 4.14. Identificação dos Fatores e Níveis

\begin{tabular}{|c|c|c|c|c|}
\hline \multirow[b]{3}{*}{ Fatores } & \multirow{2}{*}{\multicolumn{4}{|c|}{ Níveis }} \\
\hline & & & & \\
\hline & 1 & 2 & 3 & 4 \\
\hline Agregado & $5 \%$ AF (C) & 10\%AF (D) & AF 15\% (Q) & 10\%AV (T) \\
\hline Porcentagem de vazios & $3 \%(3)$ & $4 \%(4)$ & $5 \%(5)$ & - \\
\hline Envelhecimento & Virgem (S) & C.P* $(\mathrm{P})^{1}$ & $\mathrm{~L} . \mathrm{P} * *(\mathrm{~L})^{2}$ & C.L.P*** $(\mathrm{PL})^{1-2}$ \\
\hline $\begin{array}{ll} & \text { - Curto Prazo } \\
* * & \text { - Longo Prazo } \\
* * * & \text { - Curto e Longo Prazos }\end{array}$ & & $\begin{array}{l}\text { 1- } 4 \text { horas } \\
\text { 2- } 5 \text { dias }(\end{array}$ & $\begin{array}{l}5 \text { minutos a } 135 \pm 3^{\circ} \\
20 \text { horas) } \pm 30 \text { minuto }\end{array}$ & $\mathrm{S}$ a $85 \pm 3^{\circ} \mathrm{C}$ \\
\hline
\end{tabular}


Tabela 4.15. Condições Experimentais

\begin{tabular}{cc}
\hline \hline Número & Condição experimental \\
\hline \hline 1 & C3S \\
2 & C4S \\
3 & C5S \\
4 & D3S \\
5 & D4S \\
6 & D5S \\
7 & Q3S \\
8 & Q4S \\
9 & Q5S \\
10 & T3S \\
11 & T4S \\
12 & T5S \\
13 & C4P \\
14 & C4L \\
15 & C4PL \\
16 & D4P \\
17 & D4L \\
18 & D4PL \\
19 & Q4P \\
20 & Q4L \\
21 & Q4PL \\
22 & T4P \\
23 & T4L \\
24 & T4PL \\
\hline \hline
\end{tabular}

Para garantir a aleatoriedade da ordem de execução do experimento no procedimento de moldagem, procedeu-se o sorteio das diversas condições experimentais e obteve-se:

1. D5S - Areia de Fundição no teor de 10\%, com 5\% de vazios e sem envelhecimento;

2. C4P - Areia de Fundição no teor de 5\%, com 4\% de vazios, com envelhecimento em curto prazo e C4PL - Areia de Fundição no teor de 5\%, com 4\% de vazios, com envelhecimentos em curto e em longo prazos;

3. T4P - Areia Virgem no teor de $10 \%$, com $4 \%$ de vazios, com envelhecimento em curto prazo e T4PL - Areia Virgem no teor de $10 \%$, com $4 \%$ de vazios, com envelhecimentos em curto e em longo prazos;

4. D4S - Areia de Fundição no teor de 10\%, com $4 \%$ de vazios, sem envelhecimento e D4L - Areia de Fundição no teor de 10\%, com 4\% de vazios, com envelhecimento em longo prazo;

5. Q4P - Areia de Fundição no teor de 15\%, com 4\% de vazios, com envelhecimento em curto prazo e Q4PL - Areia de Fundição no teor de 15\%, com 4\% de vazios, com envelhecimentos em curto e em longo prazos; 
6. Q5S - Areia de Fundição no teor de 15\%, com 5\% de vazios, sem envelhecimento;

7. C5S - Areia de Fundição no teor de 5\%, com 5\% de vazios, sem envelhecimento;

8. D3S - Areia de Fundição no teor de 10\%, com 3\% de vazios, sem envelhecimento;

9. T5S - Areia Virgem no teor de $10 \%$, com 5\% de vazios, sem envelhecimento;

10. T3S - Areia Virgem no teor de 10\%, com 3\% de vazios, sem envelhecimento;

11. D4P - Areia de Fundição no teor de 10\%, com 4\% de vazios, com envelhecimento em curto prazo e D4PL - Areia de Fundição no teor de 10\%, com 4\% de vazios, com envelhecimentos em curto e em longo prazos;

12. C3S - Areia de Fundição no teor de 5\%, com 3\% de vazios, sem envelhecimento;

13. C4S - Areia de Fundição no teor de 5\%, com 4\% de vazios, sem envelhecimento e C4L - Areia de Fundição no teor de 5\%, com 4\% de vazios, com envelhecimento em longo prazo;

14. T4S - Areia Virgem no teor de $10 \%$, com $4 \%$ de vazios, sem envelhecimento e T4L - Areia Virgem no teor de 10\%, com 4\% de vazios, com envelhecimento em longo prazo;

15. Q4S - Areia de Fundição no teor de 15\%, com 4\% de vazios, sem envelhecimento e Q4L - Areia de Fundição no teor de 10\%, com 4\% de vazios, com envelhecimento em longo prazo.

16. Q3S - Areia de Fundição no teor de 15\%, com 3\% de vazios, sem envelhecimento.

A mistura tomada como referência para a avaliação do desempenho da massa asfáltica com areia de fundição foi a mistura com areia virgem (10\%AV) nos teores de vazios de 3 , 4 e $5 \%$.

Para avaliar o desempenho da massa asfáltica, além dos ensaios de dosagem MARSHALL (DNER-ME 043/95), foram realizados os seguintes ensaios:

$\checkmark$ envelhecimento (AASHTO PP2-00);

umidade induzida (AASHTO T 283-99 - ensaio modificado de Lottman); 


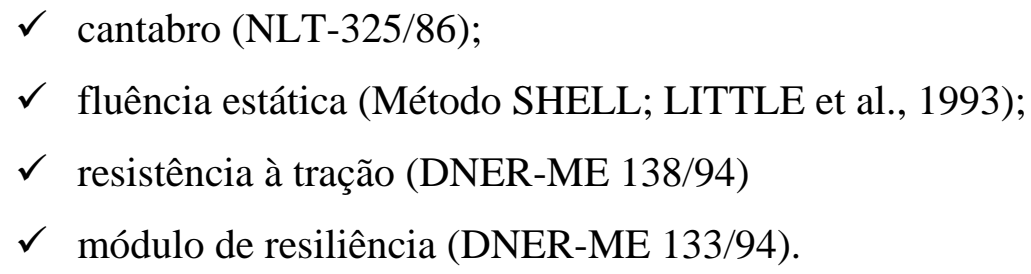

O ensaio cantabro foi realizado nas misturas sem envelhecimento em todos os teores de vazios, portanto, em 12 condições experimentais (C3S, C4S, C5S, D3S, D4S, D5S, Q3S, Q4S, Q5S, T3S, T4S e T5S).

O ensaio de Dano por Umidade Induzida (AASHTO T 283/99) foi realizado nos volumes de vazios, 4\%, (Vv esperado no campo) para todas as misturas, e 7\%, apenas, para as misturas 10\%AF e 10\%AV. Para este ensaio, não foram realizadas as condições de envelhecimento (curto prazo, longo prazo e em curto e em longo prazo), pois a cura a $60^{\circ} \mathrm{C}$ por 16 horas simula o envelhecimento em curto prazo (Colorado Procedure L 5109) e este método prediz a susceptibilidade ao descolamento em longo prazo. Desta forma, esse ensaio foi realizado apenas em quatro condições experimentais (C4S, D4S, Q4S e T4S).

O fator envelhecimento completo foi realizado no volume de vazios $4 \%$ nas quatro misturas, a saber: com 5\% de areia de fundição (AF) - C4S,C4P, C4L e C4PL; com 10\% de AF - D4S, D4P, D4L e D4PL; com 15\% de AF - Q4S, Q4P, Q4L e Q4PL e com 10\% de areia virgem - T4S, T4P, T4L e T4PL. Os outros ensaios (Módulo de resiliência, Fluência estática e tração indireta) foram realizados em todas as condições experimentais. Desta forma, têm-se, a seguir, os ensaios com os respectivos números de corpos-de-prova (CPs):

1. cantabro - 04 CPs $\times 12=48$ CPs;

2. dano por umidade induzida - 06 CPs x $4+08$ CPs x $2=40$ CPs;

3. módulo de resiliência - 02 CPs x $24=48$ CPs;

4. fluência estática - 02 CPs x $24=48$ CPs;

5. tração indireta -02 CPs x $24=48$ CPs.

Para os ensaios de módulo de resiliência e de fluência estática, foram utilizados dois corpos-de-prova por condição experimental. Para justificar esta decisão, no caso do ensaio de módulo de resiliência, optou-se por dois corpos-de-prova em virtude deste ensaio ter sido realizado em duas direções: $0^{\circ}$ e $90^{\circ}$. Desta forma, dispôs-se de quatro módulos para uma mesma condição experimental, que, estatisticamente, parece ser uma decisão satisfatória, visto que, é possível calcular o desvio entre leituras. Para o ensaio 
de fluência estática, fizeram-se duas leituras por cada amostra ensaiada, dispondo, portanto, de quatro resultados para cada condição estudada, sendo, desta forma, justificado estatisticamente.

Para o ensaio cantabro foram utilizados quatro CPs, como preconizado na norma espanhola (NLT-325/86) e para o ensaio Dano por Umidade Induzida, seis CPs no Vv 4\% e oito CPs, no Vv 7\% (AASHTO T 283/99).

Para a realização dos ensaios supracitados foram necessários 232 corpos-de-prova; para a dosagem Marshall, $60 \mathrm{CPs}$, totalizando, assim, 292 corpos-de-prova para a execução desta pesquisa.

Os ensaios de módulo de resiliência (MR), tração indireta (TI) e fluência estática (FE) foram realizados, conforme o planejamento da Tabela 4.16. Contudo, os ensaios Cantabro e Dano por Umidade Induzida (DPUI) foram efetuados, respectivamente, conforme as tabelas 4.17 e 4.18 .

Tabela 4.16. Planejamento experimental para os ensaios de módulo de resiliência, tração indireta e fluência estática

\begin{tabular}{|c|c|c|c|c|c|c|c|c|c|c|}
\hline \multirow{2}{*}{$\begin{array}{c}\text { MR, TI } \\
\text { FE }\end{array}$} & \multicolumn{10}{|c|}{ Volume de vazios (Vv) } \\
\hline & \multicolumn{3}{|c|}{$3 \%$} & \multicolumn{4}{|c|}{$4 \%$} & \multicolumn{3}{|c|}{$5 \%$} \\
\hline \multirow{2}{*}{ Agregado } & \multicolumn{3}{|c|}{ Envelhecimento } & \multicolumn{4}{|c|}{ Envelhecimento } & \multicolumn{3}{|c|}{ Envelhecimento } \\
\hline & S.E $E^{1}$ & E.C.P $P^{2}$ & E.L.P. $P^{3}$ & S.E ${ }^{1}$ & E.C.P ${ }^{2}$ & E.L.P. $P^{3}$ & E.C.L.P ${ }^{4}$ & S.E $E^{1}$ & E.C.P $P^{2}$ & E.L.P $P^{3}$ \\
\hline $5 \% \mathrm{AF}$ & $\mathrm{R}$ & NR & NR & $\mathrm{R}$ & $\mathrm{R}$ & $\mathrm{R}$ & $\mathrm{R}$ & $\mathrm{R}$ & NR & NR \\
\hline $10 \% \mathrm{AF}$ & $\mathrm{R}$ & NR & NR & $\mathrm{R}$ & $\mathrm{R}$ & $\mathrm{R}$ & $\mathrm{R}$ & $\mathrm{R}$ & NR & NR \\
\hline $15 \% \mathrm{AF}$ & $\mathrm{R}$ & NR & NR & $\mathrm{R}$ & $\mathrm{R}$ & $\mathrm{R}$ & $\mathrm{R}$ & $\mathrm{R}$ & NR & NR \\
\hline $10 \% \mathrm{AV}$ & $\mathrm{R}$ & NR & NR & $\mathrm{R}$ & $\mathrm{R}$ & $\mathrm{R}$ & $\mathrm{R}$ & $\mathrm{R}$ & NR & NR \\
\hline em env & ecimen & & & & & нест & . & & & \\
\hline 2 - Envelhe & ento er & urto Prazo & & & $\mathrm{R}$ & atamento & alizado & & & \\
\hline 3 - Envelhe & ento er & ongo Praz & & & & tratamen & não realizado & & & \\
\hline
\end{tabular}

Tabela 4.17. Planejamento experimental para o ensaio cantabro

\begin{tabular}{|c|c|c|c|c|c|c|c|c|c|c|}
\hline \multirow{2}{*}{ Cantabro } & \multicolumn{10}{|c|}{ Teor de vazios (Vv) } \\
\hline & \multicolumn{3}{|c|}{$3 \%$} & \multicolumn{4}{|c|}{$4 \%$} & \multicolumn{3}{|c|}{$5 \%$} \\
\hline \multirow{2}{*}{ Agregado } & \multicolumn{3}{|c|}{ Envelhecimento } & \multicolumn{4}{|c|}{ Envelhecimento } & \multicolumn{3}{|c|}{ Envelhecimento } \\
\hline & S.E $E^{1}$ & E.C.P ${ }^{2}$ & E.L.P $P^{3}$ & S.E $E^{1}$ & E.C.P ${ }^{2}$ & E.L.P $P^{3}$ & E.C.L.P ${ }^{4}$ & S.E $E^{1}$ & E.C.P ${ }^{2}$ & E.L.P ${ }^{3}$ \\
\hline $5 \% \mathrm{AF}$ & $\mathrm{R}$ & NR & NR & $\mathrm{R}$ & NR & NR & NR & $\mathrm{R}$ & NR & NR \\
\hline $10 \% \mathrm{AF}$ & $\mathrm{R}$ & NR & NR & $\mathrm{R}$ & NR & NR & NR & $\mathrm{R}$ & NR & NR \\
\hline $15 \% \mathrm{AF}$ & $\mathrm{R}$ & NR & NR & $\mathrm{R}$ & NR & NR & NR & $\mathrm{R}$ & NR & NR \\
\hline $10 \% \mathrm{AV}$ & $\mathrm{R}$ & NR & NR & $\mathrm{R}$ & NR & NR & NR & $\mathrm{R}$ & NR & NR \\
\hline
\end{tabular}


Tabela 4.18. Planejamento experimental para o ensaio de Dano por Umidade Induzida

\begin{tabular}{|c|c|c|c|c|c|c|c|c|c|c|}
\hline \multirow{2}{*}{ DPUI } & \multicolumn{10}{|c|}{ Volume de vazios (Vv) } \\
\hline & \multicolumn{3}{|c|}{$3 \%$ e $5 \%$} & \multicolumn{4}{|c|}{$4 \%$} & \multicolumn{3}{|c|}{$7 \%$} \\
\hline \multirow{2}{*}{ Agregado } & \multicolumn{3}{|c|}{ Envelhecimento } & \multicolumn{4}{|c|}{ Envelhecimento } & \multicolumn{3}{|c|}{ Envelhecimento } \\
\hline & S.E $E^{1}$ & E.C.P ${ }^{2}$ & E.L.P $P^{3}$ & S.E $E^{1}$ & E.C.P ${ }^{2}$ & E.L.P ${ }^{3}$ & E.C.L.P $P^{4}$ & S.E $E^{1}$ & E.C.P ${ }^{2}$ & E.L.P $P^{3}$ \\
\hline $5 \% \mathrm{AF}$ & NR & NR & NR & $\mathrm{R}$ & NR & NR & NR & NR & NR & NR \\
\hline $10 \% \mathrm{AF}$ & NR & NR & NR & $\mathrm{R}$ & NR & NR & NR & $\mathrm{R}$ & NR & NR \\
\hline $15 \% \mathrm{AF}$ & NR & NR & NR & $\mathrm{R}$ & NR & NR & NR & NR & NR & NR \\
\hline $10 \% \mathrm{AV}$ & NR & NR & NR & $\mathrm{R}$ & NR & NR & NR & $\mathrm{R}$ & NR & NR \\
\hline 1 -Sem envelhe & mento & & & \multicolumn{7}{|c|}{4 4- Envelhecimento em curto e em longo prazos } \\
\hline 2 - Envelhecime & $\mathrm{em} \mathrm{Cu}$ & rto Prazo & & \multicolumn{7}{|c|}{$\mathrm{R}$ - tratamento realizado } \\
\hline 3 -Envelhecime & o em Lo & ngo Prazo & & \multicolumn{7}{|c|}{ NR - tratamento não realizado } \\
\hline
\end{tabular}

\subsubsection{Processo de misturação dos materiais para moldagem}

No processo de moldagem dos corpos-de-prova (232 CPs) para os ensaios desse experimento, utilizou-se uma betoneira para executar o processo de misturação. Devido a isto, procurou-se planejar a moldagem, de forma que em cada betonada (quantidade de concreto asfáltico misturado de uma só vez na betoneira) fosse colocado material para no mínimo 18 corpos-de-prova (23 kgf). Esta quantidade fez-se necessário para evitar que o material retido nas palhetas e paredes da betoneira, principalmente o mástique (asfalto e fíler) interferisse na composição da mistura. Desta forma, todos os agregados necessários para uma betonada foram devidamente secos, pesados, acondicionados em sacos plásticos e identificados. O cimento asfáltico também foi pesado, acondicionado em recipiente de alumínio, devidamente tampado e identificado, tendo-se o cuidado de acrescentar $300 \mathrm{~g}$, prevendo a possibilidade de perda, seja por aderência nas paredes do recipiente ou por outro motivo.

Todos os componentes foram acondicionados em estufa na temperatura de mistura: o cimento asfáltico na faixa de temperatura de 147 a $151^{\circ} \mathrm{C}$ e os agregados na faixa de 162 a $166^{\circ} \mathrm{C}$. Os agregados permaneceram nesta temperatura $\left(164^{\circ} \mathrm{C}\right)$, por pelo menos 16 horas e o cimento asfáltico na temperatura média de $149^{\circ} \mathrm{C}$, por um período máximo de duas horas. Durante o período de permanência em estufa (aquecimento), o recipiente, contendo o cimento asfáltico, ficou tampado, para minimizar o processo de envelhecimento (evaporação de componentes voláteis). 
Em todas as 18 betonadas, o equipamento era devidamente limpo, colocado para funcionar e posteriormente o maçarico era ligado. Para a limpeza, era necessário que a betoneira fosse aquecida, assim, todo o excesso de material que, por ventura, tivesse ficado na betoneira, resultante da betonada anterior, era retirado.

A caçamba da betoneira em movimento facilita a uniformização da temperatura no seu interior. Antes da colocação do agregado mineral no equipamento, este era aquecido até alcançar uma temperatura em torno de $200^{\circ} \mathrm{C}$, o que demorava aproximadamente 75 minutos. Após este período, desligava-se o equipamento, diminuía-se a chama do maçarico e colocavam-se os agregados dentro da betoneira. Antes de acionar novamente o equipamento, o recipiente da betoneira era tampado, para evitar perda de finos e de temperatura. O agregado era misturado (homogeneizado) por aproximadamente um minuto, o equipamento era desligado e verificado se os agregados estavam na temperatura de mistura. Se estivesse na temperatura, o maçarico era desligado, abria-se uma cavidade na composição de agregado, adicionava-se o cimento asfáltico e ligava-se novamente o equipamento para homogeneizar a mistura, por um período de aproximadamente dois minutos. A mistura era despejada em uma bandeja, pesada em porções de \pm 1.260 g (material para confeccionar um corpo-de-prova), colocadas em recipiente de alumínio e acondicionados em estufa, regulada na faixa de temperatura de compactação (136 a $141^{\circ} \mathrm{C}$ ), onde permanecia por aproximadamente uma hora, para uniformizar a temperatura na massa asfáltica. Após este período, iniciava-se o processo de compactação, conforme o DNER-ME 043/95. Ao total foram moldados 364 corposde-prova utilizando este processo de misturação. Alguns destes foram considerados como reserva, visto que o volume de vazios estava fora do esperado. Outros foram utilizados para a avaliação ambiental, no caso foram desmontados para serem realizados os ensaios de solubilização, lixiviação e massa bruta, considerando a massa solta.

Foram tomadas algumas precauções para que as misturas não sofressem perda muito grande de temperatura, tais como: a bandeja, contendo a massa asfáltica recémmisturada, era colocada em cima de uma outra aquecida a uma temperatura de aproximadamente $160^{\circ} \mathrm{C}$; a pesagem era feita rapidamente e a cada quatro pesagens, os recipientes eram acondicionados em estufa, evitando, assim, a sua abertura freqüente, se fossem acondicionados um a um, ou a perda de temperatura acentuada, em virtude do acondicionamento de todos os recipientes, após o término do processo de pesagem; o tempo total do processo de pesagem não ultrapassava ao período de 10 minutos, mesmo quando a betonada era para 26 corpos-de-prova; todas as aberturas (portas e janelas) da 
sala eram fechadas para evitar a troca de temperatura, bem como a entrada de vento; na compactação, as primeiras massas asfálticas (recipientes) colocadas na estufa eram também as primeiras a serem compactadas.

Com o intuito de verificar se os componentes (agregado e asfalto) das misturas executadas com este equipamento estavam, conforme projetados, extraiu-se o asfalto de três corpos-de-prova de betonadas diferentes, porém, de um mesmo tipo de mistura, considerando a granulometria, (15\% de areia de fundição) e posteriormente, após secagem do material em estufa fez-se a granulometria do agregado de cada um. Os resultados de teor de asfalto e granulometria podem ser verificados, respectivamente, nas Tabelas 4.19 e 4.20. As tolerâncias fixas de projeto estão de acordo com o DNERES 313/97.

Perante os resultados obtidos (Tabelas 4.19 e 4.20), parece que, tanto o teor de asfalto quanto a granulometria, mostraram-se satisfatórios. Desta forma, tentou-se buscar embasamento para justificar o uso deste processo de misturação. Vale salientar que Coelho (1996) e Greco (2004) também empregaram este equipamento para a misturação do material utilizado para moldar os corpos-de-prova de suas pesquisas.

Tabela 4.19. Comparativo entre teor de asfalto de projeto e prática

\begin{tabular}{|c|c|c|c|c|}
\hline \multirow{2}{*}{ Teor de asfalto (\%) } & \multicolumn{3}{|c|}{ "Mistura/Identificação do Corpo-de-prova } & \multirow{2}{*}{$\begin{array}{c}\text { Tolerâncias } \\
\text { fixas de projeto }\end{array}$} \\
\hline & Q5S/12 & "Q4P-Q4PL /7 & "Q4P-Q4PL/16 & \\
\hline Projeto & "5,80\% & 6,60\% (1 ${ }^{\mathrm{a}}$ Repetição) & 6,00\% (Definitiva) & \\
\hline Prática & $5,76 \%$ & $6,44 \%$ & $6,07 \%$ & $\pm 0,3 \%$ \\
\hline
\end{tabular}

Tabela 4.20. Comparativo entre granulometria de projeto e prática

\begin{tabular}{|c|c|c|c|c|c|}
\hline \multirow{4}{*}{$\begin{array}{c}\text { Peneiras } \\
\text { mm }\end{array}$} & \multicolumn{4}{|c|}{ Mistura/Identificação do Corpo-de-prova } & \multirow{4}{*}{$\begin{array}{c}\text { Tolerâncias } \\
\text { fixas de } \\
\text { projeto }\end{array}$} \\
\hline & Q (15\%AF) & Q5S/12 & Q4P-Q4PL /7 & Q4P-Q4PL/16 & \\
\hline & Projeto & Prática & Prática & Prática & \\
\hline & \% passando & \% passando & \% passando & \% passando & \\
\hline 19,1 & 100 & 100 & 100 & 100 & $\pm 7 \%$ \\
\hline 12,7 & 99 & 99,29 & 97,77 & 98,75 & $\pm 7 \%$ \\
\hline 9,5 & 93 & 89,21 & 88,25 & 89,71 & $\pm 7 \%$ \\
\hline 4,8 & 76,40 & 73,98 & 73,24 & 75,01 & $\pm 5 \%$ \\
\hline 2,0 & 56,8 & 53,50 & 54,44 & 56,60 & $\pm 5 \%$ \\
\hline 0,42 & 32,6 & 31,52 & 33,05 & 34,70 & $\pm 5 \%$ \\
\hline 0,18 & 14,33 & 14,21 & 15,94 & 16,21 & $\pm 2 \%$ \\
\hline 0,074 & 7,75 & 7,38 & 8,80 & 8,70 & $\pm 2 \%$ \\
\hline
\end{tabular}


Para verificar se os teores de vazios dos corpos-de-prova estavam, conforme planejados (3,4 e 5\%), procedeu-se à monitoração das propriedades volumétricas destes. Desta forma, todos os corpos-de-prova foram pesados ao ar e imersos e determinadas as densidades aparentes, as densidades teóricas máximas (expressão 4.04) e, conseqüentemente, os teores de vazios (expressão 4.05). Estes foram, também, cubicados, sendo para isto, realizadas quatro medidas de altura e duas de diâmetro.

Para a obtenção da densidade aparente, todos os corpos-de-prova foram pesados imersos em água sem parafinagem, visto que os teores de vazios esperados eram menores do que 7\%. Todos os procedimentos para a determinação da densidade aparente foram realizados de acordo com o DNER-ME 117/94.

\subsubsection{Ensaios Ambientais}

Para alcançar os objetivos propostos, foram necessárias algumas precauções para verificar se a areia de fundição (resíduo industrial) incorporada à massa asfáltica contaminaria ou não o meio ambiente e com isto traria risco potencial à saúde. Para tanto, foram realizados os ensaios, a saber:

\footnotetext{
$\checkmark$ lixiviação de resíduos (ABNT-NBR 10005/87);

$\checkmark$ solubilização de resíduos (ABNT- NBR 10006/87);

$\checkmark$ massa bruta (ABNT-NBR 10004/87);

$\checkmark$ alteração por lixiviação contínua com extrator soxhlet.
}

Segundo a ABNT-NBR 10004/87, os resíduos são classificados em:

$\checkmark$ resíduos classe I - perigosos: aqueles que apresentam periculosidade, em função de suas propriedades físicas, químicas ou infecto-contagiosas, podem exibir risco à saúde pública e/ou riscos ao meio ambiente (resíduo manuseado ou destinado de forma inadequada). Além da periculosidade, podem apresentar uma das seguintes características: inflamabilidade, corrosividade, reatividade, toxicidade e patogenicidade

$\checkmark$ resíduos classe II - não inertes: aqueles que não se enquadram nas classificações de resíduo classe I (perigosos) ou de resíduo classe III (inertes), podendo ter propriedades, como: combustibilidade, biodegradabilidade ou solubilidade em água; 
resíduos classe III - inertes: quaisquer resíduos, que, quando amostrado de forma adequada e submetidos a um contato estático ou dinâmico com a água destilada ou deionizada, à temperatura ambiente, segundo ensaio de solubilização (NBR 10006/87), não apresentarem nenhum de seus constituintes solubilizados em concentrações superiores aos padrões de potabilidade de água, excetuando-se os padrões de aspecto, cor, turbidez e sabor.

\subsubsection{Ensaio de lixiviação de resíduos}

O ensaio de lixiviação de resíduos foi executado com o objetivo de separar substâncias contaminantes (fenóis, metais pesados e outras) ou não, do meio ambiente, contidas na areia de fundição por meio de lavagem ou percolação e desta forma, classificar esse resíduo, conforme o seu potencial contaminante (ABNT-NBR 10004/87). Este ensaio foi realizado de acordo com os procedimentos descritos na NBR 10005/87, sendo os valores máximos permitidos, os que fazem parte do ANEXO G, Listagem $n^{0} 7$ (Concentração - limite máximo no extrato obtido no teste de lixiviação) da NBR 10004/87.

\subsubsection{Ensaio de solubilização de resíduos}

O ensaio de solubilização (NBR 10006/87) de resíduos foi realizado com o intuito de diferenciar os resíduos da classe II (não-inertes), que é o caso da areia de fundição utilizada neste estudo, dos resíduos da classe III (inertes), sendo aplicado somente para resíduo no estado físico sólido. Os valores máximos permitidos (Limites máximos no extrato - mg/L), são os que constam na NBR 10004/87 (ANEXO H, Listagem nº 8, Padrões para o teste de solubilização).

Os ensaios classificatórios de resíduos, lixiviação, solubilização e massa bruta, foram realizados em amostra de: areia de fundição (resíduo de fundição); areia virgem (areia antes da utilização no processo de fundição); massa asfáltica contendo $10 \%$ de areia virgem e massa asfáltica contendo 15\% de areia de fundição (soltas).

Os ensaios de lixiviação e solubilização foram realizados no Laboratório de Saneamento do Departamento de Hidráulica e Saneamento da Escola de Engenharia de São Carlos, USP (EESC/USP), segundo, respectivamente, a NBR 10005/87 e a NBR 10006/87. A análise química do material lixiviado, solubilizado e do extrato oriundo do ensaio de lixiviação alterada foi realizada, parte (cianeto, fenol, fluoreto, nitrato, 
cloreto, dureza total, sulfato e sódio) no Laboratório de Saneamento da EESC e parte (metais e surfactantes) no Laboratório de Recursos Hídricos da UNAERP/SP (Universidade da Associação de Ensino de Ribeirão Preto, São Paulo). A análise dos parâmetros, referentes à massa bruta (ANEXO I Listagem $n^{0} 9$ - Concentrações máximas de poluentes na massa bruta de resíduo, que são utilizadas pelo Ministério do Meio Ambiente, França, para a classificação de resíduos), foi inteiramente realizada pelo Laboratório de Recursos Hídricos da UNAERP/SP.

\subsubsection{Ensaio de lixiviação com extrator soxhlet}

Este ensaio foi executado em amostras da massa asfáltica com incorporação de areia de fundição para verificar se este resíduo encapsulado liberaria substâncias perigosas, em concentrações tais, que viessem a comprometer o meio ambiente. Este ensaio foi realizado com o objetivo de avaliar o comportamento, em termos ambientais, desse material na pavimentação de vias em longo prazo, quando submetido à ação de agentes de alterações naturais por meio de solicitações físicas e físico-químicas.

O ensaio foi realizado em corpo-de-prova cilíndrico compactado (diâmetro de 101,8 mm, altura de 63,48 mm e peso de 1255,5 gf) de mistura asfáltica com 15\% de areia de fundição ( $\cong 190$ gf) e com um teor de vazios de, aproximadamente, $5 \%$.

Este ensaio ocasiona uma lixiviação contínua (durante o ciclo, considerado neste estudo de 12 horas), em virtude da água percolar a amostra a uma temperatura em torno de $60^{\circ} \mathrm{C}$, possibilitando, desta forma, o arrastamento de substâncias contidas na mesma (mistura asfáltica compactada - Marshall) para a solução. A água ferve, o vapor passa pelo material asfáltico, entra em contato com o condensador vítreo, quando se liquefaz e desce, percolando o corpo-de-prova. Os ensaios de alteração, geralmente, impõem condições mais severas do que as que ocorrem no meio ambiente, como o que acontece, por exemplo, em relação à temperatura e umidade neste ensaio.

Nesta pesquisa, a duração deste ensaio foi de três meses (90 dias) em sistema intermitente, sendo percolado pela água por, aproximadamente, 12 horas, quando era desligado, permanecendo nesta condição por igual período.

O equipamento para este ensaio é constituído de uma placa aquecedora elétrica, um recipiente cilíndrico de vidro, com capacidade, em torno, de 7,0 litros $\left(7.000 \mathrm{~cm}^{3}\right)$, um suporte (17 cm de altura) e um condensador de vidro (Figura 4.05). A opção pelo vidro, para confeccionar o condensador e o suporte para o corpo-de-prova, foi para que não 
houvesse a presença de materiais que pudessem interferir nos resultados de análise química realizada nas amostras de solução coletadas deste ensaio.

A quantidade de água destilada utilizada para cada coleta foi de 2,1 litros, sendo este o material necessário para cada análise química, visto que esta foi realizada em dois laboratórios, como explicado anteriormente. O cronograma de coleta pode ser verificado na Tabela 4.21.

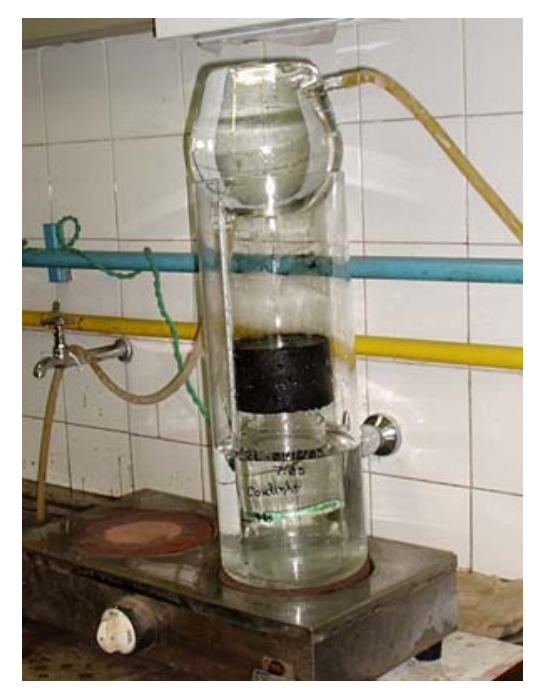

Figura 4.05. Ensaio de lixiviação com extrator soxhlet

Tabela 4.21. Cronograma de coleta do extrato resultante do ensaio de lixiviação com extrator soxhlet.

\begin{tabular}{ccc}
\hline \hline Coletas & Tempo de lixiviação (h) & Duração do ensaio (d) \\
\hline \hline primeira & 12 & 1 \\
segunda & 84 & 7 \\
terceira & 252 & 21 \\
quarta & 540 & 45 \\
quinta & 1080 & 90 \\
\hline \hline
\end{tabular}

O material coletado foi submetido à análise química para quantificar as substâncias presentes e desta forma avaliar se as concentrações estavam dentro dos padrões de potabilidade de água, conforme a listagem $n^{0} 8$ da norma ABNT-NBR 10004/87 (anexo H desta norma). 


\subsubsection{Ensaios de Interesse à Pavimentação}

Além dos ensaios citados anteriormente e dos ensaios de dosagem MARSHALL (DNER-ME 043/95), foram realizados os seguintes ensaios para verificar a qualidade do concreto asfáltico obtido com este resíduo:

$\checkmark$ envelhecimento (AASHTO PP2-00);

$\checkmark$ umidade induzida (AASHTO T 283/99 - ensaio modificado de Lottman);

$\checkmark$ cantabro (NLT-325/86);

$\checkmark$ fluência estática (DE HILSTER e VAN DE LOO, 1977; LITTLE et al., 1993);

$\checkmark$ resistência à tração (DNER-ME 138/94);

$\checkmark$ módulo de resiliência (DNER-ME 133/94).

\subsubsection{Ensaios de envelhecimento}

O ensaio de envelhecimento foi realizado a curto e a longo prazos para simular, respectivamente, o envelhecimento da mistura na fase de pré-compactação (usina, transporte e lançamento) no processo de construção e o envelhecimento que ocorre ao longo da vida em serviço (7 a 10 anos) do pavimento. Para simular o envelhecimento a curto prazo, a mistura foi condicionada em uma estufa $\left(135 \pm 3{ }^{\circ} \mathrm{C}\right)$ com ventilação por um período de 4 horas \pm 5 minutos e a longo prazo, os corpos-de-prova foram colocados em estufa com ventilação $\left(85 \pm 3{ }^{\circ} \mathrm{C}\right)$ por um período de 120 horas (5 dias) \pm 30 minutos.

Os procedimentos para o envelhecimento a curto prazo (AASHTO PP2-00), em linhas gerais, são:

$\checkmark$ colocar a mistura em uma bandeja e espalhá-la em camada uniforme, com espessura de 25 a $50 \mathrm{~mm}$;

$\checkmark$ condicionar a mistura, devidamente espalhada, em uma estufa ventilada, a uma temperatura de $135 \pm 3^{\circ} \mathrm{C}$, por um período de 4 horas \pm 5 minutos;

$\checkmark$ mexê-la a cada $60 \pm 5$ minutos, para garantir o acondicionamento uniforme;

$\checkmark$ retirar a mistura da estufa, após o período de acondicionamento. A mistura, envelhecida em curto prazo, está pronta para ser condicionada na temperatura de compactação e ser compactada, posteriormente.

Os procedimentos para o envelhecimento a longo prazo (AASHTO PP2-00) são:

$\checkmark$ compactar os corpos-de-prova, conforme o método especificado; 
$\checkmark$ após compactação, deixar os corpos-de-prova em temperatura ambiente por um período de $16 \pm 1$ h. Extraí-los do molde, após um período de duas a três horas do término da compactação. O esfriamento dos corpos-de-prova, geralmente, é programado para a noite, contudo pode ser adiantado, com a colocação de um ventilador em frente ao corpo-de-prova;

$\checkmark$ para simular o envelhecimento a curto prazo, condicionar os corpos-deprova em estufa ventilada, a uma temperatura de $85 \pm 3^{\circ} \mathrm{C}$, por um período de $120 \pm 0,5 \mathrm{~h}$;

$\checkmark$ após este período, desligar a estufa, abrir as portas para permitir o esfriamento dos corpos-de-prova em temperatura ambiente (Figura 4.06), por um período de, aproximadamente, 16 horas. Não tocar ou remover as amostras durante este período;

$\checkmark$ após o esfriamento, em temperatura ambiente, remover os corpos-de-prova da estufa. Os corpos-de-prova estão prontos para serem ensaiados.

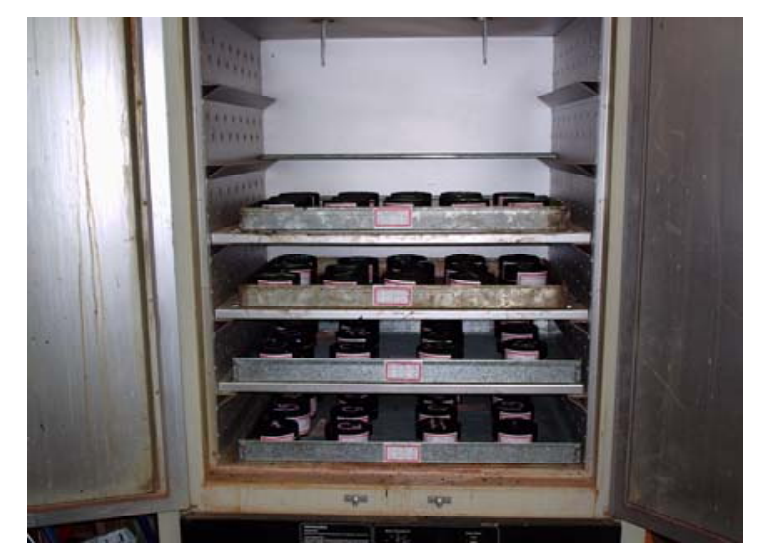

Figura 4.06. Estufa com corpos-de-prova durante o período de esfriamento (envelhecimento a longo prazo)

\subsubsection{Ensaio de Dano por Umidade Induzida}

O ensaio de Dano por Umidade Induzida foi executado para predizer em longo prazo (quatro a 12 anos, segundo AASHTO T 283/99) a susceptibilidade da mistura ao descolamento (stripping) da película asfáltica do agregado e avaliar a necessidade de usar um aditivo antistripping (dope). A areia de fundição utilizada nesta pesquisa é de natureza sílica (hidrófila) e possui em sua superfície uma fina camada de carvão queimado, argila, resina, pó e, dependendo da natureza do produto fundido, resíduos de metais ferrosos ou não ferrosos, que podem dificultar a adesividade do filme asfáltico à 
areia, resultando em perda de agregado fino (a areia) e, em conseqüência, na deterioração acelerada do pavimento.

Os corpos-de-prova cilíndricos para esse ensaio podem ser preparados em laboratório ou serem extraídos da pista e devem ter diâmetro de 101,6 mm (4") e altura de 63,5 mm (2,5") ou 150 mm de diâmetro (6") e altura de 95 mm (3,75") com teor de vazios de $7 \pm 1 \%$ ou o teor esperado no campo (item 6.5 da AASHTO T 283/99). Para este estudo os corpos-de-prova ensaiados foram de quatro polegadas de diâmetro (aproximadamente $101,6 \mathrm{~mm})$ e duas e meia polegadas de altura $(63,5 \mathrm{~mm}$, aproximadamente).

Este ensaio foi realizado nos volumes de vazios, 4\% para todas as misturas, e 7\% (7 $\pm 1 \%$ ), somente, para as misturas $10 \% \mathrm{AF}$ e $10 \% \mathrm{AV}$. Para alcançar o volume de vazios desejado (7 $\pm 1 \%$ ), os corpos-de-prova foram compactados com 25 golpes por face, no caso das misturas com 10\% de areia virgem (10\%AV) e com 23 golpes por face para as misturas com $10 \%$ de areia de fundição (10\%AF).

Os procedimentos para este ensaio, em linhas gerais, são:

1. após o processo de misturação, deixa-se o material em temperatura ambiente por 2 horas \pm 30 minutos (em recipientes apropriados). Após esta fase, coloca-se este, em uma estufa a $60^{\circ} \mathrm{C}$, por 16 horas (cura);

2. após a cura, coloca-se a mistura em uma estufa na temperatura de compactação $\left(135^{\circ} \mathrm{C}\right)$ por 2 horas. A mistura deve ser compactada para um percentual de vazios específico;

3. moldam-se, pelo menos, seis corpos-de-prova (CPs) para cada ensaio, um grupo, formado por três CPs, deve ser submetido ao ensaio de resistência à tração sem condicionamento e o outro grupo deve ser ensaiado, após a saturação parcial e condicionamento Dano por Umidade Induzida, com um ciclo de congelamento e degelo;

4. após a extração, deixam-se os corpos-de-prova em temperatura ambiente por 24 horas;

5. determinam-se as propriedades volumétricas dos corpos-de-prova;

6. separam-se as amostras em dois grupos de pelo menos três corpos-de-prova, de tal forma, que as médias de \% de vazios dos dois grupos sejam, aproximadamente, iguais; 
7. deixa-se o grupo a ser ensaiado sem condicionamento (grupo 1), em temperatura ambiente. Contudo, antes do ensaio de resistência à tração ( $\sigma_{R 1}-$ expressão 4.04), os corpos-de-prova devem ser colocados em sacos plásticos impermeáveis e submetidos a um banho de água na temperatura de $25^{\circ} \mathrm{C}$, por pelo menos duas horas e determina-se o valor de $\mathrm{RT}_{1}$, que é a média aritmética dos três valores de $\sigma_{\mathrm{R} 1}$;

8. saturam-se as amostras do grupo a ser condicionado (grupo 2), com grau de saturação ( $S^{\prime}$ ), expressão 4.05, na faixa de 55 a 80\% (pressão a vácuo de10 a 26 pol de Hg, em um dessecador com água destilada, por um período 5 a 10 minutos), corpos-de-prova com saturação acima de 80\% devem ser eliminados;

$$
R T_{1}=\frac{2000 P}{\pi \mathrm{t} D}
$$

onde:

$R T_{1}$ - resistência à tração $(\mathrm{KPa})$ dos $\mathrm{CPs}$ sem condicionamento;

$P$ - carga de ruptura $(\mathrm{N})$;

$t$ - altura do corpo-de-prova (mm);

$D$ - diâmetro do corpo-de-prova (mm).

$$
S^{\prime}=\frac{100 \times\left(B^{\prime}-B\right)}{I}
$$

onde:

$S^{\prime}$ - grau de saturação (\%);

$B^{\prime}$ - massa saturada do corpo-de-prova em gramas, este com a superfície enxuta, após a saturação parcial a vácuo;

$B$ - massa do corpo-de-prova em gramas, antes da saturação parcial a vácuo;

$I$ - volume de vazios em $\mathrm{cm}^{3}$.

9. envolvem-se os corpos-de-prova, isoladamente e firmemente, em filme plástico, acondicionando cada um, em saco plástico, contendo $10 \mathrm{ml}$ de água destilada;

10. vedam-se os sacos plásticos e coloca-os num freezer a uma temperatura de $-18 \pm 3^{\circ} \mathrm{C}$, por pelo menos 16 horas; 
11. após este período, remover os corpos-de-prova do freezer e imergi-los, imediatamente, em banho de água destilada, a $60 \pm 1^{\circ} \mathrm{C}$, por $24 \pm 1$ hora. Retiram-se, logo que possível, os corpos-de-prova dos sacos e removem-se os filmes plásticos;

12. colocam-se, cuidadosamente, os corpos-de-prova em outro banho a $25 \pm$ $0,5^{\circ} \mathrm{C}$ por 1 hora. Pode ser necessário adicionar gelo para que a temperatura não ultrapasse a $25^{\circ} \mathrm{C}$, sendo que o tempo necessário para que a água atinja $25^{\circ} \mathrm{C}$, igual ou inferior a 15 minutos. Removem-se os corpos-de-prova do banho e determinam-se as espessuras (t');

13. acondicionam-se os corpos-de-prova em outro banho a $25 \pm 0,5^{\circ} \mathrm{C}$ por pelo menos 2 horas;

14. rompem-se os corpos-de-prova e determina-se $\mathrm{RT}_{2}$, que é a média dos três $\sigma_{\mathrm{R} 2}$ (expressão 4.06);

15. exprime-se a resistência ou índice numérico das misturas asfálticas ao efeito prejudicial da água (RRT), como a relação da resistência à tração depois do condicionamento $\left(\mathrm{RT}_{2}\right)$ pela resistência à tração antes do condicionamento $\left(\mathrm{RT}_{1}\right)$;

$$
R T_{2}=\frac{2000 P}{\pi t^{\prime} D}
$$

onde:

$R T_{2}$ - resistência à tração $(\mathrm{KPa})$, dos CPs condicionados;

$P$ - carga de ruptura (N);

$t^{\prime}$ - altura do corpo-de-prova, após o primeiro condicionamento a $25^{\circ} \mathrm{C}(\mathrm{mm})$;

$D$ - diâmetro do corpo-de-prova (mm).

O ensaio de tração foi realizado na prensa VERSATESTER 30M, com ajuste de velocidade automático.

Misturas que apresentem Relação de Resistência à Tração igual ou superior a 70\% são consideradas, quanto à deterioração por umidade, de boa qualidade (HICKS, 1991). 


\subsubsection{Ensaio de fluência por compressão uniaxial estática}

O ensaio de fluência uniaxial estática foi realizado com o intuito de verificar a susceptibilidade da massa asfáltica em resistir ao acúmulo de deformação permanente (afundamento de trilha de roda).

Este ensaio foi realizado na temperatura de $40^{\circ} \mathrm{C}$, temperatura média aproximada da camada asfáltica no verão, e com níveis de tensão de 0,1 e 0,4 MPa (DE HILSTER E VAN DE LOO, 1977 e LITTLE et al., 1993, respectivamente). Os ensaios com tensão de 0,4 MPa foram executados com o prato superior de carregamento em tamanho padrão (habitual), de aproximadamente $102 \mathrm{~mm}$ de diâmetro (Figura 4.07a), e em tamanho reduzido (ULMGREN, 1996; 1997), de 51 mm de diâmetro (Figura 4.07b).
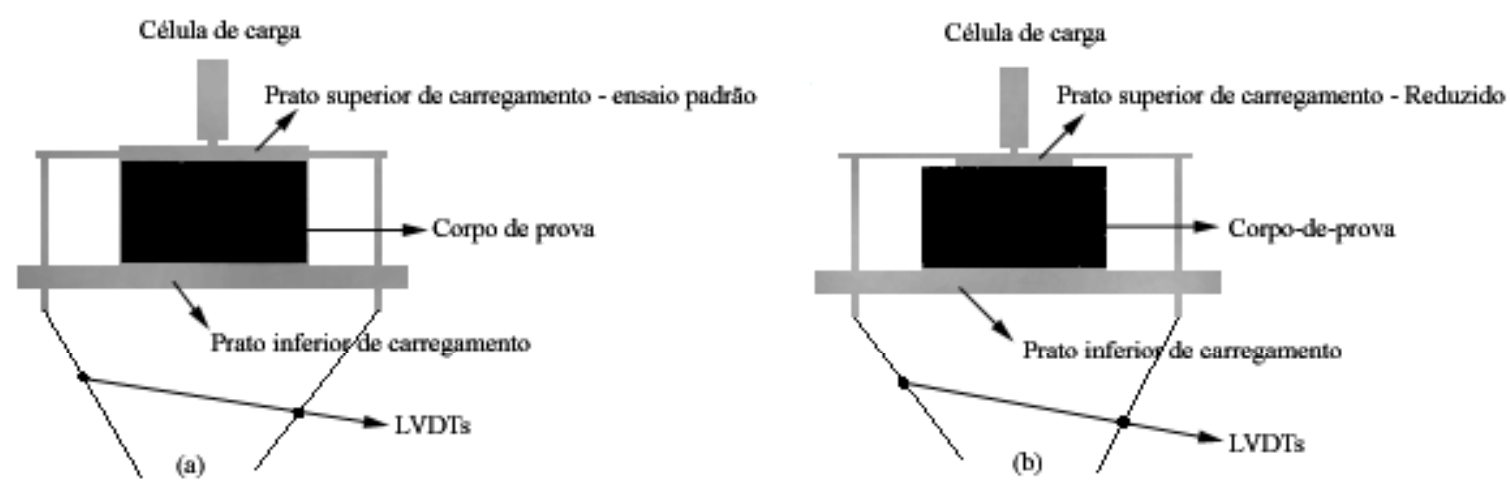

Figura 4.07. Croquis - ensaios de fluência por compressão uniaxial estática

É um ensaio com carga de compressão uniaxial, podendo ser realizado em equipamento pouco sofisticado, como em prensa de adensamento de solos ou equipamento mais sofisticado, como em prensa com sistema pneumático de aplicação de carga.

Os ensaios estáticos têm por objetivo a simulação do efeito de cargas com aplicação de grande duração ou estática sobre o pavimento, como, por exemplo, veículos estacionados sobre este, ou ainda, simular a quantidade de repetições de carga durante o período de ensaio (carregado), sem considerar o tempo de descarregamento. Nesta pesquisa o tempo de aplicação de carga foi de 3600 segundos e 900 segundos de recuperação (descarregamento).

O equipamento utilizado foi uma prensa com sistema pneumático de aplicação de carga, sendo as deformações medidas por dois LVDTs e a aquisição de dados 
realizada por um programa aplicativo em Labview. Inicialmente, são preenchidos os dados referentes ao corpo-de-prova (altura, diâmetro ou área) a ser ensaiado, bem como as constantes da carga e dos dois LVDTs e a identificação do arquivo, onde os dados de entrada e saída devem ser armazenados. Os procedimentos para a realização deste ensaio estão descritos no item 3.6.1.1 do capítulo 3 (página 69).

\subsubsection{Ensaio cantabro}

O ensaio cantabro tem por finalidade a determinação da perda por desgaste de misturas betuminosas empregando o equipamento de abrasão Los Angeles. Este ensaio consiste, basicamente, em introduzir o corpo-de-prova na máquina de abrasão Los Angeles, sem nenhuma carga abrasiva e submetê-lo a 300 revoluções, no caso de concreto asfáltico usinado a quente. Esse ensaio permite, também, avaliar indiretamente a coesão, assim como a resistência à desagregação da mistura, perante a sucção e os efeitos abrasivos originados pelo tráfego.

Os procedimentos para o ensaio são (NLT-325/86):

1. condicionamento do corpo-de-prova na temperatura de $25 \pm 1^{\circ} \mathrm{C}$, por pelo menos seis horas;

2. pesagem do corpo-de-prova, com precisão de $0,1 \mathrm{~g}\left(P_{2}\right)$;

3. submissão do corpo-de-prova ao número de revoluções específico para o tipo de mistura;

4. retirada do corpo-de-prova da máquina de abrasão e pesá-lo novamente, com precisão de $0,1 \mathrm{~g}\left(P_{2}\right)$

5. determinação da massa perdida (perda por desgaste) para o teor de ligante, que é média das massas perdidas dos corpos-de-prova ensaiados, individualmente (expressão 4.07).

$$
P=\frac{\left(P_{1}-P_{2}\right) \times 100}{P_{1}}
$$

onde:

$P$ - porcentagem de massa perdida (\%);

$P_{1}$ - massa inicial (g);

$\mathrm{P}_{2}$ - massa inicial (g).

Os resultados devem ser acompanhados do tempo em que o corpo-de-prova ficou condicionado na temperatura do ensaio. 
Os valores individuais não devem divergir de $\pm 20 \%$ do valor médio (DNER-ME 383/99 - Desgaste por abrasão de misturas betuminosas com asfalto polímero - ensaio Cantabro). Esta perda é de no máximo 25\%, conforme estabelecido pelo DNER ES 386/99 (Pré-misturado a quente com asfalto polímero - camada porosa de atrito).

\subsubsection{Ensaio de resistência à tração}

O ensaio de resistência à tração indireta (compressão diametral) foi realizado até a ruptura do corpo-de-prova a compressão diametral. Este ensaio (DNER-ME 138/94) consiste na aplicação de uma carga progressiva em corpo-de-prova (CP) cilíndrico. Este CP pode ser obtido diretamente do campo ou fabricado em laboratório, com altura entre $3,50 \mathrm{~cm}$ a $6,50 \mathrm{~cm}$ e diâmetro de $10 \pm 0,2 \mathrm{~cm}$. O ensaio é executado com uma velocidade de deformação de 0,8 $\pm 0,1 \mathrm{~mm} / \mathrm{s}$ (42 a $54 \mathrm{~mm} / \mathrm{min}$ ), até que se dê a ruptura, por separação das duas metades do corpo-de-prova, segundo o plano diametral vertical. Com a carga de ruptura, pode-se calcular a resistência à tração pela expressão 4.16.

Esse ensaio foi realizado a uma temperatura em torno de $25^{\circ} \mathrm{C}$ em uma prensa VERSATESTER 30M. Os corpos-de-prova para esse ensaio foram acondicionados em sala climatizada nessa temperatura por 18 horas. Imediatamente, após a ruptura, foi verificada a temperatura interna de cada corpo-de-prova, obtendo uma média de $24,87^{\circ} \mathrm{C}$, sendo o valor máximo de $25,80^{\circ} \mathrm{C}$ e o mínimo de $23,20^{\circ} \mathrm{C}$.

Os procedimentos para a determinação da resistência à tração de corpos-de-prova cilíndricos de misturas asfáltica, segundo o DNER-ME 138/94, são os seguintes:

1. medição da altura $(H)$ do corpo-de-prova, em quatro posições diametralmente opostas, com paquímetro, sendo que a altura a adotar, o valor da média aritmética dessas leituras;

2. medição do diâmetro $(D)$ do corpo-de-prova, em três posições paralelas, com paquímetro, sendo o valor da média aritmética dessas leituras, o diâmetro a adotar;

3. coloca-se o corpo-de-prova em estufa ou sistemas de refrigeração, por um período de duas horas, de maneira a se obter a temperatura especificada para o ensaio, $25^{\circ} \mathrm{C}, 30^{\circ} \mathrm{C}, 40^{\circ} \mathrm{C}$ ou $60^{\circ} \mathrm{C}$;

4. ajustam-se os pratos da prensa, até que seja obtida uma leve compressão, capaz de manter o corpo-de-prova na posição adequada; 
5. aplica-se, progressivamente, a carga, com uma velocidade de deformação de $0,8 \pm 0,1 \mathrm{~mm} / \mathrm{s}$ (42 a $54 \mathrm{~mm} / \mathrm{min}$ ), até que se alcance a ruptura, por separação das duas metades do corpo-de-prova, segundo o plano diametral vertical. Anota-se o valor da carga de ruptura (F);

6. com a carga de ruptura, calcula-se a resistência à tração do corpo-de-prova $(R T)$, rompido por compressão diametral.

A carga de ruptura obtida neste ensaio serve como parâmetro para o ensaio do módulo de resiliência. Este ensaio sob tensão controlada, deve ser realizado em nível de tensão menor ou igual a 30\% da resistência à tração (DNER-ME 133/94).

Este parâmetro norteou a carga que foi utilizada no ensaio de módulo de resiliência, como pode ser visto a seguir.

\subsubsection{Ensaio do módulo de resiliência}

O ensaio de módulo de resiliência (DNER-ME 133/94) consiste, na fase de condicionamento, em aplicar 200 vezes uma carga vertical repetida diametralmente ao corpo-de-prova, de modo a se obter uma tensão menor ou igual a 30\% da resistência à tração obtida no ensaio de resistência à tração indireta (compressão diametral estática). É recomendada a aplicação da menor carga capaz de fornecer um registro dimensível no oscilógrafo, com freqüência de aplicação de 60 ciclos por minuto e duração 0,10 segundo (0,9 segundo de recuperação). O Método do DNER recomenda a utilização de corpos-de-prova obtidos diretamente do campo, por extração, mediante sonda rotativa, ou fabricado em laboratório (Marshall), de forma cilíndrica, com altura entre 3,50 cm (retirado da pista, por exemplo) a 6,50 cm (Marshall) e diâmetro de $10 \pm 0,2 \mathrm{~cm}$. O módulo de resiliência (MR) de misturas betuminosas é a relação entre a tensão de tração $\left(\sigma_{t}\right)$, aplicada repetidamente no plano diametral vertical de um corpo-de-prova cilíndrico e a deformação específica resiliente $\left(\varepsilon_{t}\right)$, que corresponde à tensão aplicada, em uma determinada temperatura.

O módulo de resiliência tem sido utilizado para o dimensionamento racional de pavimentos e para verificar a sua capacidade estrutural em suportar o grande número de repetições de carga, geralmente entre $10^{4}$ e $10^{8}$ (susceptibilidade da massa asfáltica à fadiga). 
Nesta pesquisa, o ensaio foi efetuado em corpos-de-prova Marshall, com quatro polegadas de diâmetro e duas e meia polegadas de altura na temperatura de $25^{\circ} \mathrm{C}$. Este ensaio foi realizado em duas direções: 0 e $90^{\circ}$, sendo, portanto, executados 96 ensaios (48 corpos-de-prova). Os corpos-de-prova permaneceram em sala climatizada, com temperatura controlada (em torno de $25^{\circ} \mathrm{C}$ ), ao longo de todo o ensaio e por pelos menos 12 horas antes de seu início. A temperatura média de realização dos ensaios foi de $25,08^{\circ} \mathrm{C}$, sendo o maior valor observado igual a $25,40^{\circ} \mathrm{C}$ e o menor igual a $24,60^{\circ} \mathrm{C}$. Em relação à carga aplicada, obteve-se uma porcentagem média de 18,14\% da carga de ruptura no ensaio de resistência à tração, sendo o maior valor de 23,75\% e o menor de $12,28 \%$. Como os ensaios foram baseados no DNER-ME 133/94, as cargas estão dentro do valor estabelecido por esta norma (menor ou igual a 30\%).

Para a execução do ensaio de módulo de resiliência foi utilizada uma prensa com sistema pneumático de aplicação de carga. Um programa computacional, desenvolvido em Labview ${ }^{\circledR}$, controlou a aquisição dos deslocamentos (por LVDTs) e das cargas, a aplicação e a retirada da carga, assim como o armazenamento de dados. Antes de iniciar o ensaio, são preenchidos os dados referentes ao corpo-de-prova (diâmetro e altura) a ser ensaiado, bem como as constantes da carga e do extensômetro, e a identificação do arquivo, onde os dados de entrada e saída devem ser armazenados.

Os procedimentos empregados, para esse ensaio, estão descritos no item 3.6.3 do capítulo 3 (página 73).

\subsubsection{Tratamento estatístico dos resultados}

Com objetivo de tratar estatisticamente os resultados dos ensaios de interesse à pavimentação, foram realizados procedimentos para identificar valores que apresentam uma variabilidade diferente das demais e para verificar o efeito (interferência) dos fatores (varáveis independentes - volume de vazios, teor de areia e condições de envelhecimento) sobre as respostas (variáveis dependentes - parâmetros dos ensaios abordados). Estes procedimentos estão descritos no início do capítulo 5 (página 120), sendo para tanto, utilizado o aplicativo EXCEL (Microsoft® Office 2000). 


\section{MISTURAS ASFÁLTICAS}

Segundo o DNER-ES 313/97, concreto betuminoso, nesta pesquisa denominado de mistura asfáltica, é uma mistura produzida a quente, em usina apropriada, com características específicas, sendo constituído de agregado mineral graduado, fíler e ligante betuminoso, lançado e comprimido a quente.

Como qualquer obra em engenharia, as rodoviárias devem apresentar durabilidade, resistência, estética e economia. Estas propriedades estão relacionadas diretamente com os materiais que serão empregados para a sua execução. No caso da pavimentação, mais precisamente, o revestimento flexível é executado com misturas asfálticas e estas devem apresentar características que possam assegurar uma camada asfáltica resistente e durável, a um custo, economicamente, viável. Para tanto, é necessário que os seus componentes sejam materiais que possam garantir um produto final com estas propriedades. Desta forma, segundo o ASPHALT INSTITUTE (1995), o objetivo do projeto das misturas asfálticas para pavimentação é determinar, dentro dos limites das especificações de projeto, a um custo efetivo, a combinação e graduação de agregados minerais e cimento asfáltico que produza uma mistura que apresente as características, a saber:

$\checkmark$ asfalto suficiente para formar uma espessura adequada de película de cimento asfáltico em torno do agregado, assegurando a durabilidade do pavimento;

$\checkmark$ estabilidade necessária para satisfazer as exigências do tráfego, sem distorção ou deslocamentos;

$\checkmark$ vazios suficientes na mistura compactada para permitir uma compactação adicional sob o carregamento do tráfego e uma leve expansão do asfalto em virtude do acréscimo de temperatura, sem, no entanto, apresentar exsudação, escoamento e perda de estabilidade;

$\checkmark$ um teor máximo de vazios que possa impedir a permeabilidade prejudicial do ar (envelhecimento) e da umidade (descolamento do asfalto da superfície do agregado) no interior da mistura; 
trabalhabilidade suficiente para permitir um lançamento eficiente da mistura, sem sacrificar a sua estabilidade e desempenho;

$\checkmark$ superfície com textura e rugosidade que possam fornecer à capa resistência suficiente à derrapagem em condições climáticas desfavoráveis. Assim, são necessários agregados que possibilitem essa característica superficial.

Contudo, não é tarefa fácil obter uma única mistura que possa apresentar todas estas características. Desta forma, procura-se um teor de asfalto (mistura final) que resulte um pavimento, apresentando equilíbrio entre durabilidade, impermeabilidade, resistência, estabilidade, rigidez, flexibilidade, trabalhabilidade, resistência à derrapagem e à fadiga. Como dito anteriormente, não se conseguirá maximizar todas estas propriedades com um único teor de asfalto, em vez disto, seleciona-se um teor (teor ótimo) que possa otimizar as propriedades mais importantes para uma condição específica.

Durabilidade é a propriedade da mistura asfáltica de resistir ao intemperismo e a solicitação do tráfego sem alterar as suas qualidades iniciais, isto é, resistir à perda de integridade por ação do tráfego e do intemperismo.

Impermeabilidade é a propriedade da mistura de impedir a penetração de ar e/ou umidade que venha a comprometer a durabilidade do pavimento. A penetração do ar favorecerá o envelhecimento da mistura por oxidação, enquanto a umidade em excesso deixará o agregado mais susceptível ao descolamento do asfalto de sua superfície (stripping).

Resistência é a propriedade do pavimento de resistir a qualquer esforço solicitante interno (tensões) e/ou externo (carga do tráfego) sem o comprometimento de sua estrutura, isto é, sem o aparecimento de fissuras e/ou deslocamentos que coloque em risco o aspecto estrutural e/ou funcional do pavimento.

Estabilidade é a propriedade da mistura de subsistir às deformações permanentes provocadas pela ação de carregamento estático (longa duração) e/ou repetido (curta duração), sendo composta de três parcelas: a primeira corresponde à resistência coesiva do cimento asfáltico; a segunda referente à resistência viscosa do cimento asfáltico e a terceira a resistência do atrito intergranular dos agregados. Tem-se feito uso da estabilidade medida por meio do ensaio Marshall, porém, este parâmetro parece não refletir o que acontece na prática.

Rigidez é a propriedade da mistura de resistir à solicitação do carregamento do tráfego sem apresentar deslocamento excessivo que possa comprometer o aspecto 
funcional do pavimento. Baixas temperaturas favorecem a rigidez, mas tornam a mistura mais frágil.

Flexibilidade é a propriedade da mistura de subsistir à flexão sob a ação de carga dinâmica, sem a ocorrência de fissuras e de se adequar às deformações permanentes das camadas inferiores. A resistência à fadiga está relacionada à flexibilidade, sendo esta dependente de fatores como quantidade e qualidade do cimento asfáltico, bem como da temperatura do pavimento. A flexibilidade é diretamente proporcional à temperatura. Baixas temperaturas deixam a mistura mais quebradiça e mais rígida, portanto menos flexível.

A medida de resistência à fadiga costuma ser determinada por meio de ensaios de carga repetida, como os ensaios de flexão alternada e compressão diametral. Nesta pesquisa é empregado o ensaio de módulo de resiliência por compressão diametral para se avaliar indiretamente a resistência à fadiga.

A resistência à derrapagem é a propriedade das misturas de proporcionar uma superfície de pavimento capaz de oferecer resistência ao deslizamento dos pneus, aumentando a aderência do sistema pneu/pavimento. Esta propriedade é de grande importância para a segurança do usuário, visto que em dias chuvosos e a altas velocidades esta resistência diminui, podendo ocorrer o fenômeno de hidroplanagem.

Fatores que corroboram a resistência à derrapagem estão relacionados às características do agregado empregado na mistura, como: tamanho (graúdo), textura (rugosa), forma (angular) e resistência ao desgaste e teor de cimento asfáltico, em quantidade tal, que não provoque exsudação, isto é, os agregados, com essas características, proporcionam uma superfície de pavimento mais rugosa, aumentando a aderência e o excesso de cimento asfáltico, uma superfície mais lisa, diminuindo o atrito e favorecendo a derrapagem, principalmente, em temperaturas elevadas.

Trabalhabilidade é a propriedade da mistura de ser facilmente preparada, lançada e compactada. Os problemas de trabalhabilidade são, freqüentemente, descobertos durante a execução do pavimento, pois não existe nenhum método para avaliá-la, em laboratório, durante a fase de projeto da mistura.

Após várias pesquisas, chegou-se a um parâmetro que melhor reflete todas estas propriedades, o teor de vazios que, usualmente, deve estar numa faixa de 3 a $5 \%$, sendo $4 \%$, geralmente, considerado o melhor valor inicial para um projeto que equilibre essas propriedades (ASPHALT INSTITUTE, 1995). Por meio do teor de vazios especificado, chega-se ao teor ótimo de ligante. Contudo, necessita-se saber qual a composição de 
agregado (grosso, fino e fíler) que melhor reflete as propriedades para uma condição específica.

Como visto anteriormente, necessita-se estudar os componentes das misturas asfálticas para se chegar à mistura satisfatória. Estas são compostas de agregados graúdos e miúdos, material de enchimento, cimento asfáltico e, algumas vezes, de algum modificador, como: borracha de pneus, polímeros ou alguma substância que possa conferir-lhe uma propriedade desejada, como, por exemplo, melhorar a adesividade do agregado.

A seleção desses materiais, no caso do asfalto, depende do clima local, e no caso do agregado, do tipo de material disponível na região e se houver necessidade de modificador, este estará sujeito à(s) propriedade(s) que se deseja melhorar.

\subsection{Cimentos asfáticos de petróleo}

O betume é utilizado desde a idade antiga, seja como material impermeabilizante (aquedutos em Roma), como aglutinante de tijolos (na Mesopotâmia) ou como arma, em forma de grandes bolas que eram incendiadas e arremessadas contra o inimigo (Grécia). Como material para pavimentação de ruas e pátios, sua aplicação iniciou-se em 1802 com os franceses, seguidos pelos americanos (1838) e pelos ingleses (1869). Estas aplicações foram realizadas empregando asfaltos naturais provenientes de jazidas.

Os materiais betuminosos podem ser obtidos de materiais, como, asfaltos e alcatrões.

Os alcatrões são obtidos do coque (carvão mineral) por destilação seca a altas temperaturas. Estes são substâncias líquidas viscosas de cor que varia do castanho-escuro ao preto com reflexo esverdeado. O alcatrão não é mais utilizado para fins de pavimentação no Brasil, Europa e Estados Unidos, em virtude das altas concentrações de gases prejudiciais, emitidos durante a sua aplicação (LEITE, 1999).

Os asfaltos ocorrem na natureza ou são produzidos por meio da destilação de petróleo de alta densidade. Os asfaltos podem ser encontrados naturalmente, em forma de bolsões, resultantes da evaporação das frações mais voláteis do petróleo afloradas à superfície em épocas longínquas. Estes asfaltos diferenciam do obtido pela destilação de petróleo, em virtude de apresentar em sua composição agregados minerais e mistura de rochas arenosas ou calcárias. Exemplificam-se sempre, por suas importâncias, os asfaltos de Trinidad e do Lago Bermúdez, mas também há a asfaltita ${ }^{9}$, encontrada na Argentina e nos Estados Unidos.

\footnotetext{
9 "Designação comum aos hidrocarbonetos sólidos com pontos de fusão acima de $110^{\circ} \mathrm{C}$ e peso específico menor que 1,20, solúveis entre 0 e $60 \%$ no sulfeto de carbono.” (FERREIRA, 1999).
} 
O lago Pitch, localizado no sul de Trinidad, é a maior reserva de asfalto natural do mundo, com cerca de $460.000 \mathrm{~m}^{2}$ de superfície e com, aproximadamente, $30 \mathrm{~m}$ de profundidade. $\mathrm{O}$ asfalto forma uma crosta dura na superfície do lago, sendo extraído em pedaços (BARSA, 2003).

A jazida de Bermúdez localiza-se na Venezuela, próximo do lago de Trinidad, com extensão superficial maior do que a do lago Pitch, porém com profundidade menor (BARSA, 2003). Como os asfaltos naturais estão sempre associados a impurezas minerais, como areia e calcário, e são sempre encontrados em forma muito dura, é necessário purificá-los e amolecê-los com óleos de petróleo para torná-los aptos aos serviços de pavimentação.

Esses materiais de composição betuminosa dão origem a outros para várias aplicações, como: impermeabilização, materiais elétricos, fabricação de tintas e vernizes, revestimentos de paredes e tetos.

Segundo Senço (1997), asfaltos são materiais aglutinantes de consistência variável, apresentando cor pardo-escura ou negra e cujo componente predominante é o betume, podendo ocorrer na natureza em jazidas ou ser produzido pelo refinamento do petróleo.

A maior parte do asfalto empregado na pavimentação de rodovias é procedente do refino do petróleo, visto que este permite o controle da viscosidade e da densidade do cimento asfáltico com esta finalidade. Desta forma, possibilita a fabricação de um produto mais adequado para uma determinada região e/ou fim.

A obtenção de asfalto por meio da destilação de petróleo foi iniciada nos Estados Unidos, em 1902, sendo utilizada em serviço de pavimentação em 1909. No Brasil, a produção de asfalto começou em 1944, na refinaria Ipiranga, com petróleo importado, geralmente, da Venezuela. Antes disso, os serviços de Pavimentação eram realizados com asfalto importado de Trinidad, armazenados em tambores de 200 litros (SENÇO, 1997).

Segundo Senço (1997), a destilação do petróleo pode ser efetuada pelos processos, a saber:

$\checkmark$ destilação seca - alguns constituintes de alto ponto de ebulição são decompostos e se fragmentam, originando uma grande gama de elemento de baixo ponto de ebulição. Esse processo é empregado quando a meta é produzir o máximo de gasolina e combustível;

$\checkmark$ destilação a vapor ou destilação fracionada - consiste em injetar vapor seco no destilador, o que origina a vaporização dos constituintes voláteis, diminuindo a decomposição do destilado e do resíduo. Ao se usar este processo em petróleos 
asfálticos, a carga é destilada até que o resíduo obtenha a consistência adequada, o que exige um monitoramento da destilação. Conforme o prosseguimento da destilação, obtém-se um resíduo de ponto de fusão cada vez mais alto, ou seja, de maior consistência;

$\checkmark$ destilação a vácuo - se processa a pressões mais baixas do que a pressão atmosférica e tem o intuito, empregando temperaturas mais baixas, de adquirir as mesmas quantidades de voláteis que os demais processos. Para os petróleos com alto rendimento de asfalto, esta destilação é suficiente, mas para os petróleos que apresentam baixo rendimento de asfalto, a destilação deve ser realizada em dois estágios: primeiro a pressão atmosférica e em seguida a vácuo.

Segundo Leite (1999), cimento asfáltico de petróleo (CAP) é um líquido muito viscoso, semi-sólido ou sólido à temperatura ambiente, que se transforma em líquido, quando aquecido e volta ao estado original, após resfriamento (comportamento termoplástico).

Os cimentos asfálticos de petróleo (CAP) no Brasil podem ser classificados por meio da penetração e pela viscosidade .

Os cimentos asfálticos classificados por penetração são os oriundos de petróleos venezuelanos e são, exclusivamente, os da Refinaria Landulfo Alves Mataripe (RLAM) e da Fábrica de Lubrificantes do Nordeste (LUBNOR). Esta classificação é baseada na penetração a $25^{\circ} \mathrm{C}$ e divide-se em quatro tipos, a saber: CAP 30/45, CAP 50/60, CAP 85/100 e CAP 150/200. A Tabela 3.01 mostra as especificações para os cimentos asfálticos de petróleo com base na classificação por penetração.

Tabela 3.01. Especificação para o Cimento Asfáltico de Petróleo - Classificação por penetração - Regulamento Técnico 01/92 - REV.02 - DNC

\begin{tabular}{|c|c|c|c|c|c|c|}
\hline \multirow{3}{*}{ Características } & \multicolumn{4}{|c|}{ Valores } & \multicolumn{2}{|r|}{ Métodos } \\
\hline & CAP & CAP & CAP & CAP & \multirow{2}{*}{ ABNT } & \multirow{2}{*}{ ASTM } \\
\hline & $30 / 45$ & $50 / 60$ & $85 / 100$ & $150 / 200$ & & \\
\hline Penetração $\left(100 \mathrm{~g}, 5 \mathrm{~s}, 25^{\circ} \mathrm{C}\right), 0,1 \mathrm{~mm}$ & 30 a 45 & 50 a 60 & 85 a 100 & 150 a 200 & MB-107 & D5 \\
\hline Ductilidade a $25^{\circ} \mathrm{C}, \mathrm{cm}$ & 60 mín. & 60 mín. & 100 mín. & 100 mín. & & \\
\hline Índice de Susceptibildade Térmica & $-1,5 \mathrm{a}+1$ & $-1,5 \mathrm{a}+1$ & $-1,5 \mathrm{a}+1$ & $-1,5 \mathrm{a}+1$ & (1) & \\
\hline Ponto de Fulgor, ${ }^{\circ} \mathrm{C}$ & 235 mín. & 235 mín. & 235 mín. & 220 mín. & MB-50 & D92 \\
\hline Solubilidade ao tricloroetileno, $\%$ & 99,5 mín. & 99,5 mín. & 99,5 mín. & 99,5 mín. & MB-166 & D2042 \\
\hline Viscosidade Saybolt-Furol a $135^{\circ} \mathrm{C}, \mathrm{s}$ & 110 mín. & 110 mín. & 85 mín. & 70 mín. & MB-517 & E102;D2170; D2161 (2) \\
\hline \multicolumn{7}{|c|}{ Efeito do Calor e do $\mathrm{Ar}$ (ECA) a $163^{\circ} \mathrm{C}$ por 5 horas } \\
\hline \% Penetração original & 50 mín. & 50 mín. & 47 mín. & 40 mín. & MB-107 & D5 \\
\hline \% Variação em massa & 1,0 máx. & 1,0 máx. & 1,0 máx. & 1,0 máx. & MB-425 & D1757 \\
\hline
\end{tabular}

Nota: $\mathrm{O}$ produto Não deve produzir espuma quando aquecido a $175^{\circ} \mathrm{C}$ 
Esta tabela se aplica aos tipos de CAP produzidos pela ASFOR e RLAM.

(1) Índice de Susceptibilidade Térmica $=\left[500 .(\log P E N)+20 .\left(t^{\circ} \mathrm{C}\right)-1951\right] /\left[120-50 .(\log P E N)+\left(t^{\circ} C\right)\right]$ onde, $\left(\mathrm{t}^{\circ} \mathrm{C}\right)$ - ponto de amolecimento.

(2) Permitida sua determinação pelo método ASTM D2170 e sua posterior conversão pelo método ASTM D2161.

Os classificados por viscosidade absoluta a $60^{\circ} \mathrm{C}$, são os oriundos de misturas de petróleos brasileiros, argentino, árabes e venezuelanos e classificam-se como: CAP-7, CAP- 20 e CAP- 40 (LEITE, 1999). Essa classificação foi adotada por medir a consistência do CAP em uma temperatura próxima daquela que a superfície do pavimento apresenta no verão (temperatura máxima). A Tabela 3.02 exibe as especificações dos cimentos asfálticos classificados por viscosidade.

Tabela 3.02. Especificação para o Cimento Asfáltico de Petróleo - Classificação por Viscosidade - Regulamento Técnico 01/92 - REV.02 - DNC

\begin{tabular}{cccccc}
\hline \hline Características & \multicolumn{3}{c}{ Valores } & \multicolumn{2}{c}{ Métodos } \\
\cline { 2 - 5 } & CAP-7 & CAP-20 & CAP-40 & ABNT & ASTM \\
\hline \hline Viscosidade a $60^{\circ} \mathrm{C}$, Poises & 700 a 1.500 & 2.000 a 3.500 & 4.000 a 8.000 & MB-827 & D2171 \\
Viscosidade SSF $135^{\circ} \mathrm{C}, \mathrm{s}$ & 100 mín. & 120 mín. & 170 mín. & MB-517 & E102;D2170; D2161 (1) \\
$177^{\circ} \mathrm{C}, \mathrm{s}$ & 15 a 60 & 30 a 150 & 40 a 150 & & \\
Ductilidade a $25^{\circ} \mathrm{C}, \mathrm{cm}$ & 50 mín. & 20 mín. & 10 mín. & MB-167 & D113 \\
Índice de Susceptibildade Térmica & $-1,5 \mathrm{a}+1$ & $-1,5 \mathrm{a}+1$ & $-1,5 \mathrm{a}+1$ & $(2)$ & \\
Penetração $\left(100 \mathrm{~g}, 5 \mathrm{~s}, 25^{\circ} \mathrm{C}\right), 0,1 \mathrm{~mm}$ & 90 mín. & 50 mín. & 30 mín. & MB-107 & D5 \\
Ponto de Fulgor, ${ }^{\circ} \mathrm{C}$ & 220 mín. & 235 mín. & 235 mín. & MB-50 & D92 \\
Solubilidade ao tricloroetileno, \% & 99,5 mín. & 99,5 mín. & 99,5 mín. & MB-166 & D2042 \\
\% Variação em massa & Efeito do Calor e do Ar (ECA) a 163 C por 5 horas & & D5 \\
Relação de viscosidade & 1,0 máx. & 1,0 máx. & 1,0 máx. & MB-425 & D1757 \\
\hline \hline
\end{tabular}

O produto Não deve produzir espuma quando aquecido a $175^{\circ} \mathrm{C}$.

Esta tabela Não se aplica aos tipos de CAP produzidos pela ASFOR e RLAM.

(1) Permitida sua determinação pelo método ASTM D2170 e sua posterior conversão pelo método ASTM2161.

(2) Índice de Susceptibilidade Térmica $=\left[500 .(\log P E N)+20 .\left(t^{\circ} \mathrm{C}\right)-1951\right] /\left[120-50 .(\log \mathrm{PEN})+\left(\mathrm{t}^{\circ} \mathrm{C}\right)\right]$

(3) Relação de viscosidade $=$ Visc. a $60^{\circ} \mathrm{C}$ (Poises) depois do ECA $/$ Visc. a $60^{\circ} \mathrm{C}$ (Poises) antes do ECA onde, $\left(\mathrm{t}^{\mathrm{O}} \mathrm{C}\right)$ - ponto de amolecimento.

Essas classificações apresentam vantagens e desvantagens: se na classificação por penetração, os ensaios são mais rápidos e menos onerosos, não oferecem subsídios capazes de avaliar o desempenho à temperatura de mistura e de compactação. Na classificação por viscosidade, os ensaios são mais demorados e mais dispendiosos, não se aplicam a materiais não-Newtonianos, cujas propriedades são dependentes da taxa de cisalhamento, mas oferecem subsídios para se obter as temperaturas de mistura e de compactação. 
A seguir serão comentados sucintamente os ensaios realizados nas duas classificações.

O ensaio de penetração mede a distância em décimos de milímetro que uma agulhapadrão penetra verticalmente na amostra de material sob condições preestabelecidas de carga, tempo e temperatura. Para esta finalidade, a amostra deve ser aquecida, cuidadosamente, para evitar superaquecimento local, até que ela se torne fluida. Em seguida, com agitação constante, a temperatura deve ser elevada de no máximo $90^{\circ} \mathrm{C}$ acima do Ponto de Amolecimento - Anel e Bola. A inclusão de bolhas de ar deve ser evitada. A amostra deve ser derramada no recipiente de penetração de forma a ter uma espessura de material, após o resfriamento, de no mínimo $10 \mathrm{~mm}$ maior que a penetração esperada. Quando variar as condições de ensaio preparar uma amostra para cada variação. A amostra deve ser esfriada numa temperatura entre 20 e $30^{\circ} \mathrm{C}$, durante pelo menos 90 minutos e no máximo 120 minutos no caso do recipiente de $55 \mathrm{~mm}$ de diâmetro. Após esta fase, o material e a cuba de transferência são colocados no banho de água, mantido à temperatura do ensaio $\pm 0,1^{\circ} \mathrm{C}$, durante os mesmos intervalos de tempo citados para resfriamento à temperatura ambiente e ensaiado no penetrômetro, imediatamente (DNER-ME 003/99).

Viscosidade absoluta é a relação entre a tensão de cisalhamento aplicada e a velocidade de distorção de um líquido viscoso colocado entre duas placas paralelas. $\mathrm{O}$ objetivo desse ensaio é classificar o Cimento Asfáltico de Petróleo analisado na classificação por viscosidade.

A viscosidade absoluta pode ser obtida por meio do viscosímetro Brookfield, onde a amostra é colocada à temperatura de $60^{\circ} \mathrm{C}$, controlada por meio de um equipamento de banho-maria, sendo o equipamento ligado quando esta temperatura estiver estabilizada. Quando no mostrador a viscosidade estabilizar, esta é considerada como a viscosidade absoluta do material (NBR 5847/01; FABBRI, 2001).

$\mathrm{O}$ ensaio de ductilidade visa indicar se o material é dúctil ou não. A ductilidade de material betuminoso é medida por meio da distância, em cm, que um corpo-de-prova padronizado atinge, até se romper, ao ser submetido a uma tração em condições específicas. Quanto mais alta a ductilidade dos asfaltos, mais susceptíveis serão às mudanças de temperatura (NBR 6293/01).

Ponto de amolecimento (método anel e bola) é a temperatura em que uma pequena bola de aço $\left(\mathrm{d}=3 / 8^{\prime \prime}\right.$, aproximadamente, 9,50 $\left.\mathrm{mm}\right)$, que empurra para baixo o CAP contido em um anel $\left(\phi\right.$ interno $\left.=5 / 8^{\prime \prime}-15,88 \mathrm{~mm} \mathrm{e} \mathrm{h}=1 / 4^{\prime \prime}-6,35 \mathrm{~mm}\right)$, toca o fundo do recipiente (colocado 1" abaixo do anel), tendo como objetivo a determinação da temperatura em que 
ocorre uma mudança de fase no CAP, passando do estado inicial para o fluido. (NBR 6560/00; DNER, 1996; FABBRI, 2001)

$\mathrm{O}$ índice de susceptibilidade térmica (índice de Pfeiffer-Van Doormal) possibilita a avaliação da influência das variações de temperatura na consistência do asfalto, sendo determinado com base na penetração a $25^{\circ} \mathrm{C}$ e no ponto de amolecimento. Índices maiores que +2 indicam asfaltos pouco susceptíveis à mudança de temperatura e que apresentam elasticidade; índice entre -2 e +2 , na especificação brasileira -2 e +1 , são denominados de asfaltos normais e correspondem a asfaltos que apresentam elasticidade e são apropriados aos serviços de pavimentação; índices menores que -2 correspondem aos asfaltos muitos susceptíveis às mudanças de temperatura. Estes se tornam quebradiços a baixas temperaturas e moles às altas temperaturas (ROBERTS, et al.,1991; SENÇO, 1997; FABBRI, 2001).

Ponto de fulgor consiste na determinação da temperatura para a qual uma amostra de produto asfáltico começa a liberar gases inflamáveis. Tem como objetivo a determinação da máxima temperatura que o cimento asfáltico de petróleo pode ser manipulado sem perigo de fogo, podendo ser utilizado, também para verificar a contaminação por solventes (a temperatura do ponto de fulgor diminuirá). Pode ser determinado utilizando o vaso aberto de Cleveland e consiste em aquecer-se gradualmente a amostra de asfalto e, periodicamente, expô-la à chama. A temperatura na qual os vapores desprendidos do asfalto provocam chama é ponto de Fulgor (DNER ME - 148/94; DNER, 1996; FABBRI, 2001).

Viscosidade Saybolt-Furol é definida como o tempo necessário, em segundos, para uma amostra de $60 \mathrm{ml}$ de cimento asfáltico fluir, de modo contínuo, no viscosímetro Saybol-Furol, através do orifício furol $\left(0,169^{\prime \prime}-4,3 \mathrm{~mm}\right)$, sob condições especificadas. $O$ objetivo deste ensaio é determinar o estado de fluidez dos asfaltos em temperaturas préfixadas. Por meio deste ensaio pode-se determinar as temperaturas de misturação e compactação das misturas asfálticas, onde o asfalto deve apresentar o comportamento de um fluido para facilitar a ligação com os agregados minerais, proporcionando resultado eficiente na execução dessas etapas (FABBRI, 2001; NBR 14950/03).

\subsection{Agregados}

Os agregados podem ser definidos como materiais inertes, granulares, sem forma e dimensões definidas, mas que apresentam propriedades adequadas para suportarem esforços e/ou desgastes, quando compõem qualquer elemento estrutural na construção 
civil. Estes elementos na engenharia de estruturas podem ser, vigas, lajes, pilares, muros de arrimo, etc, quando executados com concreto estrutural. $\mathrm{Na}$ engenharia de pavimentação esses elementos são as camadas do pavimento. Estes materiais são empregados, principalmente, na execução da capa e da base.

Neste trabalho o maior interesse é relativo a pavimentação, mais precisamente, na composição dos revestimentos asfálticos. Os agregados são preponderantes nas misturas asfálticas, visto que representam o seu principal componente, cerca de 91\% (teor máximo de asfalto - 9\% para a faixa "C" - camada de rolamento- DNER) a 96\% (teor mínimo de asfalto - 4\% para a faixa "A" - camada de ligação - DNER) em peso. Desta forma, pode-se avaliar a importância do agregado no desempenho das misturas asfálticas, sendo estes capazes de suportarem as forças oriundas do tráfego e os desgastes impostos pelo intemperismo, sem alteração significativa em suas características. Não se deseja, com isto, dizer que o desempenho do pavimento é em virtude, principalmente, do agregado, mas sim da mistura como um todo e que todos os seus componentes têm a sua devida importância. Se um componente falhar, automaticamente, a estrutura do pavimento executada com esta mistura estará comprometida.

Os agregados podem ser classificados quanto à natureza, forma, tamanho e graduação (distribuição dos grãos).

Quanto à natureza, podem ser: natural, que são aqueles utilizados como encontrados na natureza (seixo rolado, pedregulho, areia) e artificial, que são aqueles que necessitam ser trabalhados antes da utilização. Estes passam por operações, como extração, britagem e classificação.

Quanto à forma, podem ser: esféricos (cúbicos), quando apresentam forma aproximada da esfera (grau de esfericidade), podendo ser: esferoidais, achatados, prismáticos e lamelares; e alongados (grau de arredondamento), quando a forma está ligada à resistência mecânica e a abrasão da rocha-mãe ao longo do tempo, dividem-se em: angulosos, subangulosos, subarredondados e arredondados.

Quanto ao tamanho, dividem-se em: graúdo é o material retido na peneira 10 (2 $\mathrm{mm}$ ). Para pavimentação com concreto betuminoso como agregado graúdo, podem ser empregados, pedra, escória, seixo rolado ou qualquer outro material indicado nas especificações complementares, devendo ser constituídos de fragmentos duráveis, livres de torrões de argila e de quaisquer substâncias nocivas, e apresentar as características, a saber (DNER-ES 313/97): desgaste Los Angeles igual ou inferior a 40\% (DNER-ME 
035/94), podendo ser empregado agregado com valores superiores, desde que tenham apresentado desempenho satisfatório em obras anteriores; índice de forma superior a 0,5 (DNER-ME 086/94); durabilidade, perda inferior a 12\% (DNER-ME 089/94); miúdo é o material passante na peneira $10(2 \mathrm{~mm})$ e retido na peneira $200(74 \mu \mathrm{m})$. Para este fim, podem ser utilizados: pó-de-pedra, areia ou mistura de ambos, devendo as partículas destes apresentar, individualmente, resistência e angulosidade moderada, estando livres de torrões de argilas e de quaisquer substâncias que venham a comprometer o desempenho da mistura (DNER-ES 313/97), além de apresentar equivalente de areia igual ou superior a 55\% (DNER-ME 054/94); fíler (material de enchimento) é a fração passante $100 \%$ na peneira $40(0,42 \mathrm{~mm})$, no mínimo $95 \%$ passante na peneira $80(0,18 \mathrm{~mm})$ e pelo menos 65\% na peneira $200(74 \mu \mathrm{m})$ (DNERME 083/94). Deve ser constituído por materiais minerais, finamente divididos, como: pós calcários, cal extinta, cinza volante, cimento portland, pó-de-pedra, etc e ao serem aplicados devem estar secos e isentos de grânulos (grumo) (DNER-ES 313/97).

Quanto à graduação (distribuição dos grãos), podem ser: denso (granulometria contínua), quando são constituídos de frações de diâmetro que permitem melhor interação entre os grãos e melhor preenchimento dos vazios, isto é, quando apresenta uma curva granulométrica bem distribuída e contínua, com fino, em quantidade necessária, para preencher os espaços entre as partículas maiores; aberto, quando apresenta uma curva granulométrica bem distribuída e contínua, mas com material fino insuficiente para preencher os vazios entre as partículas maiores; macadame (granulometria uniforme), quando o agregado é constituído de partículas de tamanho único, isto é, quando constituído de partículas parecidas entre si.

Estes materiais podem ser oriundos de rochas ígneas (magmáticas ou eruptivas), como: o granito, o gabro, o sienito, o diabásio e o basalto; sedimentares, como: o arenito e o calcário (cal, mármore) ou metamórficas, como o gnaisse e o quartzito. A maioria destas rochas apresenta absorção de água menor que 1,0\%, sendo exceção o calcário e o arenito, que a absorção de água é variável (SENÇO, 1997).

Para a caracterização de agregado para pavimentação, pode-se fazer uso de ensaios, como: granulometria, resistência ao desgaste, sanidade, adesividade, índice de forma, massa específica aparente e massa específica real.

No ensaio de granulometria (análise granulométrica), o material é passado por um conjunto de peneiras, devidamente especificado para o fim que se destina. Desta forma, determina-se a quantidade de material que passa (ou retido) em cada peneira e com 
estes dados, traça-se a curva de distribuição granulométrica do agregado em estudo. A combinação de agregados para compor uma determinada faixa granulométrica é altamente dependente deste ensaio, bem como, o teor ótimo de asfalto para se fazer a dosagem, quando se usa o método da superfície específica.

A resistência ao desgaste é estimada por meio do ensaio de Abrasão Los Angeles. Este ensaio consiste em submeter ao equipamento de Abrasão Los Angeles, uma quantidade de agregado (graduação específica) com uma carga abrasiva, que depende da graduação a ser ensaiada. O equipamento deve girar a uma velocidade angular de 30 a 33 rotações por minuto (rpm) e dependendo do material ensaiado, deve ser submetido a 500 (graduações: A, B, C e D) ou a 1000 (E, F e G) revoluções. O desgaste Los Angeles de agregados é a relação, expressa em porcentagem, da massa de material passado na peneira $12(1,68 \mathrm{~mm})$, produzida quando a amostra é preparada e ensaiada de acordo com o DNER-ME 035/94, pela massa total da amostra (massa inicial). Quanto menor for esta porcentagem, maior a resistência do agregado ao desgaste. Segundo o DNER-ES 313/97, o desgaste Los Angeles de agregado para concreto betuminoso deve ser igual ou inferior a $40 \%$.

A durabilidade é avaliada pelo ensaio de sanidade, que consiste em atacar a amostra de agregado com uma solução de sulfato saturado de sódio ou de magnésio. O ensaio consiste na imersão do agregado na solução de sulfato (sódio ou magnésio) por um determinado número de ciclos de 16 a 18 horas, de modo que o nível da solução fique $1 \mathrm{~cm}$ acima da superfície do agregado. O recipiente que contém a amostra em ensaio deve ficar coberto, durante todo o procedimento, para diminuir a evaporação e evitar contaminação. A temperatura da solução, durante o ensaio, deve ser de $21 \pm 1^{\circ} \mathrm{C}$. A amostra deve ser retirada da solução e drenada por $15 \pm 5$ min e colocada em estufa $\left(105\right.$ a $\left.110^{\circ} \mathrm{C}\right)$, até constância de peso (DNER-ES 89/94). Um ciclo corresponde ao processo de imersão e secagem alternadas. A durabilidade é estimada pela perda de material que, segundo o DNER-ES $313 / 97$, deve ser inferior a $12 \%$.

O ensaio de adesividade de agregado verifica a interação ligante/agregado. Esta interação decorre de vários fatores, como, por exemplo, da rocha da qual o agregado foi extraído, pois as forças livres na superfície deste são dependentes dos seus elementos constituintes, como: alumínio, magnésio, cálcio, ferro, silício, lítio, sódio, potássio e titânio. Agregados hidrófilos (ácido e com alto teor de sílica) têm geralmente melhor afinidade com a água do que com o asfalto e os hidrofóbicos (básico e com baixo teor de sílica) têm maior atração pelo ligante asfáltico do que pela água (HICKS, 1991). 
No Brasil, a adesividade é geralmente verificada, utilizando-se mistura de agregadoligante (graúdo ou miúdo), antes de incorporá-los na mistura asfáltica. Desta forma, adesividade de agregado a materiais betuminosos, segundo O DNER-ME 078/94, é a propriedade que possui os agregados de ser aderido pelo material betuminoso, sendo avaliada pelo não desprendimento (deslocamento) da película asfáltica da superfície do agregado.

Para avaliá-la, é necessário submeter a mistura agregado-ligante à ação de água destilada, numa temperatura específica, por um determinado período e/ou soluções molares de carbonato de sódio ferventes. A(s) substância(s) utilizada(s) depende(m) do tamanho de agregado que se deseja avaliar. No caso de agregado graúdo, água destilada, a $40^{\circ} \mathrm{C}$, por 72 horas, sendo satisfatória, quando não houver nenhum descolamento e insatisfatória se houver parcial ou total deslocamento da película (DNER-ME 078/94). Para o agregado miúdo, água destilada fervente (uma) e soluções molares de carbonato de sódio ferventes (nove), por um período de 1 min, após a solução entrar em ebulição. Se houver descolamento com a solução de água destilada (zero), é classificada como má; 1 , ou 2 e ou 3, satisfatória; 4, ou 5 , ou 6 , ou 7,ou 8 e ou 9, boa e se não houver descolamento em nenhuma solução, a adesividade é classificada como ótima (10) (DNER-ME 079/94). Desta forma, pode-se comprovar que a análise da adesividade é, apenas, visual, pois não é verificado o comportamento mecânico. Além disso, o fato do ligante não estar misturado ao fíler mineral contribui para que viscosidade do ligante seja menor do que o ocorre na prática, o que pode favorecer o descolamento do asfalto.

Segundo Hicks (1991), os fatores que mais influenciam no mecanismo do dano da umidade nos concretos asfálticos, são: a natureza do agregado, a qualidade do cimento asfáltico e o tipo de mistura, sendo que as características, mais importantes no agregado, dizem respeito, principalmente, a sua superfície, como: textura, umidade, substâncias impregnadas (revestindo o grão) e composição química e relacionado com agregado como um todo, a porosidade e a mineralogia. Para este pesquisador, acredita-se que viscosidade do cimento asfáltico é uma propriedade importante a ser considerada, contudo, as características do agregado são mais importantes. Terrel ${ }^{10}$ (1990 apud Hicks, 1991, p.7) entende que as misturas de graduação densa são mais susceptíveis ao dano da umidade do que as de graduação aberta, visto que, nas misturas abertas, a água

\footnotetext{
10 TERREL, R. L. (1990). Water sensivity of asphalt concrete. Proceedings, Symposium on Pavement Performance, Monitoring and Rehabilitation, University of New México apud HICKS, R. G. (1991). Moisture damage in asphalt concrete. TRB - Transportation Research Board, NCHRP - Synthesis of highway practice, n. 175. p.7.
} 
ou umidade não tem como permanecer no concreto asfáltico, portanto, a chance de ocorrer falha no mesmo, em virtude da falta de coesão ou de adesividade, é bastante reduzida. A conclusão de Terrel é verdadeira, quando as misturas abertas têm drenagem livre, mas também pode ser afirmativo no caso de misturas de graduação densa, onde a água ou umidade é impedida de adentrá-las (HICKS, 1991).

Para se avaliar adesividade asfalto/agregado, pode-se fazer uso de vários procedimentos, mas, atualmente, tem-se usado, com uma certa freqüência, o ensaio de dano por umidade induzida ou Lottman modificado, AASHTO T-283/99. Neste ensaio é avaliada a adesividade em corpos-de-prova (CPs) de misturas asfálticas, compactados. O teor de vazios desses CPs deve estar na faixa de $7 \pm 1 \%$ ou o teor de vazios esperado no campo, que é, freqüentemente, $4 \%$. Este avalia a adesividade, visualmente, (Figura 3.01) e por meio do comportamento mecânico da mistura, pois se determina a resistência a tração da mistura antes e depois do condicionamento do dano de umidade induzida. Visualmente, verifica-se, após a ruptura do CP se houve descolamento do filme asfáltico da superfície do agregado.

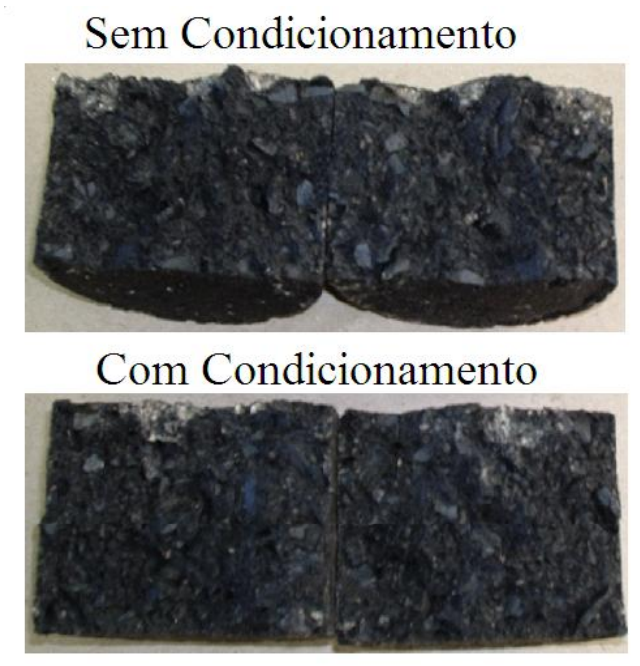

Figura 3.01. Análise visual do CP submetido ao dano de umidade induzida

O ensaio para determinação do índice de forma visa determinar a variação dos eixos multidirecionais dos grãos que constituem o agregado. O ensaio para determinação do índice de forma, segundo o DNER-ME 086/94, consiste, basicamente, após análise granulométrica, em: determinar a graduação, em que o agregado se enquadra, selecionando-se as frações de quantidades especificadas no método, usando-se as peneiras com crivos de abertura circular; de cada fração, separam-se os grãos retidos no 
crivo redutor de abertura igual a $1 / 2$ do tamanho diretriz ${ }^{11}$ correspondente, registrandose o seu peso (crivo I); o material passante no primeiro crivo redutor deve ser passado em um segundo crivo redutor, de abertura igual a $1 / 3$ do tamanho diretriz da fração, registrando-se o peso do agregado retido neste crivo (crivo II); repetem-se os passos acima, com todas as frações que fazem parte da graduação escolhida. $O$ índice de forma (f) é calculado usando-se a expressão 3.01. Os agregados graúdos para concretos betuminosos, segundo o DNER-ES 313/97, devem apresentar índice de forma superior a 0,5 .

$$
f=\left(P_{1}+0,5 P_{2}\right) / 100 n
$$

onde:

$\mathrm{P}_{1}$ - é o somatório das porcentagens retidas nos crivos I, de todas as frações que compõem a graduação;

$\mathrm{P}_{2}$ - é o somatório das porcentagens retidas nos crivos II, de todas as frações que compõem a graduação;

$\mathrm{n}$ - número de frações (ou tamanho diretriz) que compõem a graduação escolhida.

A massa específica do agregado (massa específica dos sólidos) caracteriza a rocha que o originou. Se agregado basáltico, por exemplo, tem-se uma massa específica em torno de $3 \mathrm{~g} / \mathrm{cm}^{3}$, se granítico, em torno de $2,65 \mathrm{~g} / \mathrm{cm}^{3}$. A massa específica é determinada porque há necessidade de se transformar, rotineiramente, na construção civil, unidades de peso (gravimétrica) em unidade de volume ou ainda, para estudo de dosagem, visto que, alguns parâmetros, neste, são determinados com base nessa propriedade do agregado. A massa específica aparente é a relação entre a massa do agregado e o volume dos sólidos $\left(\mathrm{V}_{\mathrm{s}}\right)$ adicionados aos volumes dos vazios permeáveis $\left(\mathrm{V}_{\text {perm. }}\right)$ e impermeáveis $\left(\mathrm{V}_{\text {imp. }}\right)$, enquanto a massa específica real é considerada a relação entre a massa do agregado e o volume dos sólidos adicionado ao volume dos vazios impermeáveis, a rigor, seria a massa do agregado dividida pelo volume da parte sólida, sem considerar os vazios impermeáveis (Figura 30.2). As massas específicas podem ser determinadas pelos métodos de ensaio DER-ME 194/97 (agregado miúdo) e DER-ME 195/97 (agregado graúdo).

\footnotetext{
11 Tamanho diretriz - é o valor do diâmetro do menor crivo de abertura circular, especificado, em que passam todos os grãos de uma fração, das que compõem a graduação escolhida.
} 


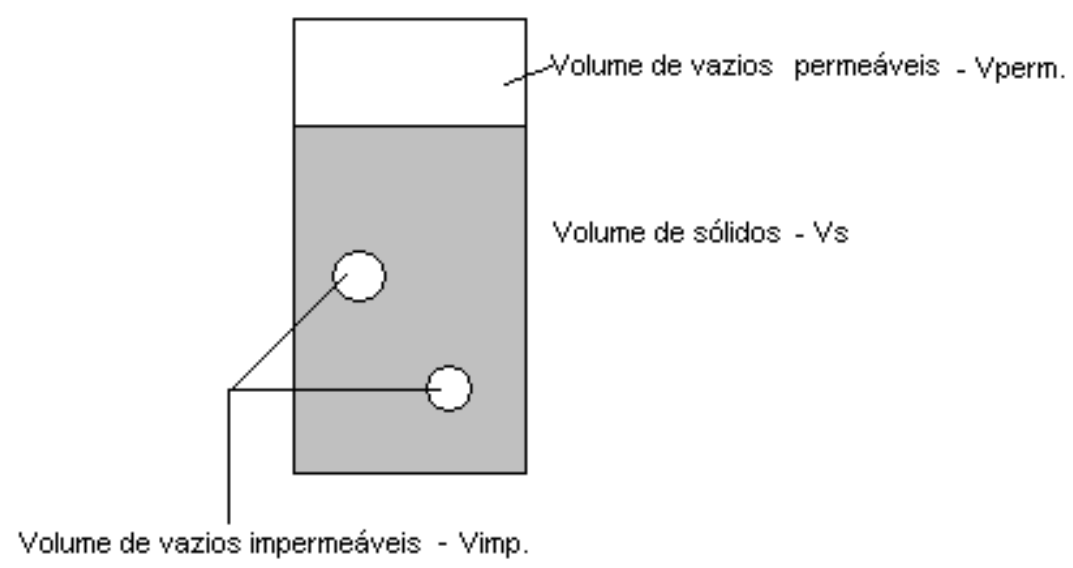

Figura 3.02. Representação de uma partícula de agregado

Por meio das massas específicas, determinam-se as densidades real e específica. A densidade real dos grãos (apparent specific gravity) é a relação entre a massa específica real e a massa específica da água, nas mesmas condições de temperatura e pressão, sendo, portanto, um parâmetro adimensional. Para a determinação da densidade aparente dos grãos (bulk specific gravity), em vez da massa específica real, utiliza-se a massa específica aparente.

Vale salientar, que o inverso também pode ser feito, isto é, de posse das densidades, determinam-se as massas específicas. Como, geralmente, utiliza-se $1 \mathrm{~g} / \mathrm{cm}^{3}$ como a massa específica da água, acaba-se confundindo densidade com massa específica ou peso específico.

\subsection{Projeto de misturas asfálticas}

Como dito anteriormente, para se chegar a uma mistura final é necessário, inicialmente, se avaliar algumas, para verificar qual a mais viável do ponto de vista de durabilidade, de resistência e de economia para o local onde o pavimento será executado. Para tanto, é necessário estudar o agregado disponível na região, verificando-se as propriedades deste que são importantes para a boa execução da obra e mais ainda, para o desempenho eficiente da mistura ao longo do tempo. Faz-se necessário, também, a escolha do tipo de material asfáltico que será empregado, sendo realizada com base na localização geográfica da pavimentação e do tipo de estrutura que se deseja executar. De posse destes parâmetros, necessita-se verificar, se as propriedades estão dentro do especificado nas normas ou se há necessidade de melhorá-las. Se houver, faz-se uso de aditivo para esta finalidade. 
Para o projeto de mistura geralmente utilizam-se, desde a década de 1940, os métodos Marshall (estabilidade e fluência) e Hveem (estabilidade e coesão). Estes são mundialmente usados e oferecem resultados satisfatórios, embora alguns, pareçam não refletir o que ocorre no campo.

Os critérios, em que cada método se baseia, foram empiricamente desenvolvidos, correlacionando os resultados dos ensaios obtidos em laboratório, em misturas compactadas, com o desempenho das misturas na pavimentação em condições de serviço, isto é, sob o carregamento do tráfego e ação do intemperismo. Para os projetos de mistura, independente do método, é preparado um conjunto de corpos-de-prova com os materiais especificados. Os procedimentos utilizados, basicamente, são:

$\checkmark$ seleção e caracterização dos materiais (abordado nos itens anteriores);

$\checkmark$ compactação das amostras;

$\checkmark$ ensaios para a determinação das propriedades volumétricas e estabilidade (resistência);

$\checkmark$ análise dos resultados.

Segundo o ASPHALT INSTITUTE (1995), a compactação é realizada com o intuito de simular o que ocorre no campo com as misturas asfálticas a quente, em termos de densidade, após resistirem a vários anos de tráfego. Os procedimentos de compactação utilizados nos métodos Marshall e Hveem são, respectivamente, por impacto e por amassamento (um equipamento hidráulico aplica uma pressão no corpo-de-prova por meio de uma base móvel).

Para a realização de dosagem, seleciona-se uma graduação de agregado e variam-se os teores de cimento asfáltico, sendo, normalmente, cinco teores. Para garantir, estatisticamente, os resultados é necessário preparar, pelo menos, três réplicas de cada variação (agregado + teor de asfalto).

Após a compactação, determinam-se as propriedades volumétricas (densidade e teor de vazios) e de resistências dos corpos-de-prova, analisam-se os resultados, com base nos gráficos traçados (propriedades, tais como: estabilidade, teor de vazios e densidade versus teor de asfalto) e determina-se o teor ótimo de asfalto.

Em 1987, o programa SHRP (Strategic Highway Research Program) iniciou, dentre outros, estudos para o desenvolvimento de um novo método para projeto de misturas, o SUPERPAVE (SUperior PERforming asphalt PAVEment), sendo finalizado em 1992. Este estudo foi motivado, pelo fato de muitos pesquisadores acreditarem que, a 
compactação por impacto, utilizada no método Marshall, não produzia, satisfatoriamente, as densidades observadas no campo (pavimento).

Segundo Roberts et al. (2002), o sistema Superpave consiste de três áreas interrelacionadas, a saber:

$\checkmark$ grau de desempenho (Performance-Grading) do ligante asfáltico - ensaios e especificações, baseados na faixa de temperatura que o pavimento é submetido ao longo do ano. É considerado vantajoso em relação à classificação por viscosidade e penetração, visto que, os ensaios para este sistema são realizados em condições que melhor simulam o estado real do pavimento, além de contar com os parâmetros de engenharia relacionados com os reais mecanismos de deterioração do pavimento;

$\checkmark$ critério e ensaios utilizados na seleção dos agregados, como: graduação (a principal recomendação - zona de restrição e pontos de controle), forma, dureza, sanidade, materiais deletérios;

$\checkmark$ o projeto de mistura é realizado com o compactador giratório superpave (medidas e análise dos resultados das propriedades volumétricas das misturas).

Para esses autores, o projeto de mistura SUPERPAVE envolve quatro passos: seleção dos materiais; projeto da estrutura do agregado; projeto do teor de asfalto e avaliação da susceptibilidade a umidade (AASHTO T-283/99).

Nesta pesquisa, utilizou-se, como método de dosagem, o Marshall (DNER-ME 043/95), portanto, a seguir, serão comentados sucintamente os parâmetros que norteiam este procedimento, como: estabilidade, densidade aparente, vazios no agregado mineral, fluência, teor de vazios e relação betume-vazios (Tabela 3.03).

Tabela 3.03. Faixas dos parâmetros Marshall para camadas asfálticas

\begin{tabular}{ccc}
\hline \hline Discriminação & Camada de Rolamento & $\begin{array}{c}\text { Camada de Ligação } \\
\text { (Binder) }\end{array}$ \\
\hline \hline Porcentagem de vazios & 3 a 5 & 4 a 6 \\
Relação Betume/Vazios (\%) & 75 a 82 & 65 a 72 \\
Estabilidade, mínima (kgf) & $350(75$ golpes $)$ & $350(75$ golpes $)$ \\
Fluência (mm) & $250(50$ golpes $)$ & $250(50$ golpes $)$ \\
\hline
\end{tabular}

Fonte: DNER-ES 313/97 
Estabilidade Marshall é definida como a carga máxima de compressão que um corpo-de-prova pode suportar, quando ensaiado na prensa Marshall, à temperatura de $60^{\circ} \mathrm{C}$ e com o êmbolo da prensa se movimentando a uma velocidade de $5 \mathrm{~cm} / \mathrm{min}(0,83$ $\mathrm{mm} / \mathrm{s}$ ). Esse parâmetro é muito dependente do ângulo interno de fricção do agregado e da viscosidade do cimento asfáltico nesta temperatura. Portanto, uma forma de aumentar a estabilidade é substituir o CAP por outro mais viscoso ou ainda, substituir o agregado por outro de mesma graduação, mas que apresente grau de arredondamento diferente, isto é, mudar de arredondado ou subarredondado (seixo rolado, por exemplo) para agregado mais anguloso (material britado). A estabilidade Marshall e a estabilidade da mistura em serviço não estão necessariamente correlacionadas. Uma mistura asfáltica que apresenta uma estabilidade alta no laboratório (Marshall), nem sempre mostra um bom desempenho quanto à estabilidade no campo, podendo, portanto, exibir problemas acentuados de deformação permanente. Isto acontece, em virtude de vários fatores, como, temperatura, taxa de carregamento, pressão de pneus e outros, não serem controlados, como ocorre no laboratório.

Fluência é a deformação vertical do corpo-de-prova (CP), medida no início da aplicação do carregamento até o ponto em que a estabilidade do CP começa a cair. Como visto, é obtida, simultaneamente, com a estabilidade e é medida em centésimos de polegada ou em décimos de centímetros (milímetro). Altos valores de fluência, geralmente, indicam uma mistura plástica que desenvolverá deformação permanente quando submetida ao tráfego, enquanto baixos valores podem indicar uma mistura com teor de vazios mais alto do que o normal e com teor de asfalto insuficiente, o que compromete a durabilidade da mistura (ROBERTS et al., 1991). Asfalto insuficiente na mistura produz um pavimento asfáltico frágil (quebradiço), favorecendo o aparecimento prematuro de trincas e com isto, diminuindo a vida útil do pavimento.

Densidade de massa aparente é obtida do corpo-de-prova compactado, imerso em água, podendo ou não ser protegido por parafina e/ou fita adesiva para evitar a entrada de água nos vazios. É a relação entre a massa do corpo de prova ao ar e o volume de água deslocado quando o CP é pesado, imerso em água (DNER-ME 117/94).

A densidade aparente, inicialmente, aumenta com o teor de asfalto, até atingir um valor máximo, a partir do qual, começa a decrescer. O aumento inicial acontece, em virtude da lubrificação das partículas pelo cimento asfáltico quente, o que força, com o mesmo esforço de compactação, os grãos a ficarem muito mais próximos, até a densidade atingir um valor máximo. Contudo, a adição de mais asfalto, a partir deste 
ponto, produz películas de asfaltos mais espessas em torno dos agregados, fazendo com que estes fiquem mais afastados, resultando, assim, em uma densidade aparente mais baixa. Isto ocorre, em virtude da densidade do asfalto ser menor do que a do agregado.

A densidade aparente do pavimento pode ser especificada como uma porcentagem da densidade teórica máxima (expressão 3.02), portanto, a densidade no campo pode ser alcançada pelo aumento na compactação, por aumento no teor de asfalto, por aumento no teor de fíler ou por qualquer método que reduza o volume de vazios (ROBERTS et al., 1991).

O teor de vazios nas misturas asfálticas a quente de graduação densa, por várias razões, deve permanecer numa faixa de 3 a 5\%. Para a determinação do teor de vazios pode-se usar a expressão 3.03. Uma das razões é a necessidade da capa apresentar uma superfície que seja relativamente impermeável ao ar e a umidade, pois baixo teor de vazios diminui a possibilidade de envelhecimento da película asfáltica no agregado e minimiza, também, a possibilidade da água permanecer dentro da mistura, evitando, desta forma, a penetração da mesma na película asfáltica, o que causaria o seu descolamento da superfície do agregado. Se o teor de vazios no campo estiver, levemente, acima da faixa desejada, provavelmente, a permeabilidade (umidade e ar) da mistura é bastante baixa, visto que os vazios presentes não estão conectados entre si, mas isolados dentro do agregado e massa asfáltica.

Segundo Roberts et al. (1991), para se atingir o teor de vazios desejado (3 a 5\%), durante a construção, aconselha-se compactar a mistura. A adição de cimento asfáltico à mistura com esta finalidade não é a melhor solução, visto que, esta pode interferir no seu desempenho: diminuindo a densidade, aumentando a possibilidade de ocorrer deformação permanente (trilha de roda), através de migração e deposição do ligante na superfície do pavimento, em virtude da compactação adicional do tráfego. Ainda, segundo esses autores, é muito importante que as misturas asfálticas a quente, em laboratório, sejam compactadas para atingirem uma densidade que se aproxime da densidade final no campo (sob a ação do tráfego) e ao mesmo tempo apresentem um teor de vazios na faixa de 3 a 5\%. O teor de vazios no campo, inicialmente, deve ser um pouco mais alto do que o desejado, para permitir a compactação adicional imposta pelo tráfego.

$$
D_{t}=\frac{100}{\frac{P_{a s f}}{D_{a s f}}+\frac{P_{a g}}{D_{a g}}}
$$




$$
V_{v}=100 \times \frac{\left(D_{t}-D_{a p}\right)}{D_{t}}
$$

onde:

$D_{t}-$ densidade teórica máxima;

$P_{a s f}-$ porcentagem de material asfáltico utilizado, expressa em relação ao peso total da mistura asfáltica;

$P_{a g}$ - porcentagem de agregado utilizado, expressa em relação ao peso total da mistura asfáltica $\left(100-P_{a s f}\right)$;

$D_{a s f}$ - densidade do material asfáltico utilizado;

$D_{a g}$ - densidade média da composição de agregado utilizada (determinada pela expressão 3.04);

$V_{v}$ - teor de vazios no corpo-de-prova (\%);

$D_{a p}-$ densidade aparente do corpo-de-prova.

$$
D_{a g}=\frac{100}{\frac{P_{g}}{D_{g}}+\frac{P_{m}}{D_{m}}+\frac{P_{f}}{D_{f}}}
$$

onde:

$P_{g}, \quad P_{m}, P_{f}-$ porcentagem de cada componente do agregado mineral, respectivamente, agregado graúdo, miúdo e fíler;

$D_{g}, D_{m}, D_{f}$ - densidade de cada componente do agregado mineral, respectivamente, agregado graúdo, miúdo e fíler.

Vazios do agregado mineral (VAM) é o volume total de vazios existente na massa compactada, considerando, apenas, o agregado. Desta forma, pode-se dizer que o VAM (expressão 3.05 e 3.06), considerando a mistura asfáltica como um todo, é o volume de vazios preenchido por asfalto adicionado ao teor de vazios da mistura asfáltica compactada. Analisando essa definição, pode-se concluir que, se o volume de vazios preenchido por asfalto for muito baixo, o desempenho da mistura, no que diz respeito à durabilidade será comprometido. A durabilidade do pavimento é bastante dependente do volume de cimento asfáltico, visto que, é ele que determina a espessura da película asfáltica em torno do agregado (Figura 3.03); se for muito alto, poderá apresentar problemas de estabilidade e ser economicamente inviável, visto que o cimento asfáltico é o componente mais oneroso da mistura. Volume de asfalto insatisfatório produz uma 
película muito fina, o que causa uma oxidação mais rápida do asfalto e facilita a penetração da água na mistura, diminuindo a vida em serviço do pavimento, pois a resistência à tração da camada asfáltica é seriamente afetada (ROBERTS et al., 1991).

É importante salientar que o teor de vazios que compõe o VAM (Figura 3.04), também, é bastante importante, pois permite a expansão térmica do asfalto, quando o pavimento está submetido a altas temperaturas. Contudo, deve permanecer na faixa desejada pelos motivos supracitados.

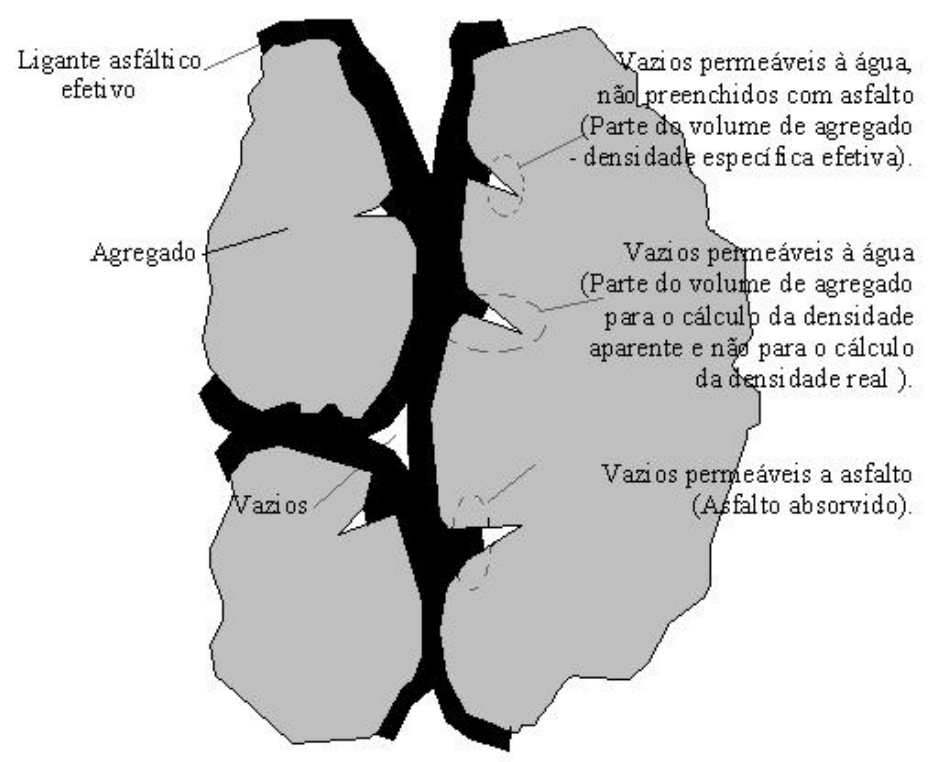

Figura 3.03. Representação das densidades: aparente, real e efetiva; teor de vazios e teor de asfalto efetivo em mistura compactadas no pavimento (adaptada do ASPHALT INSTITUTE, 1995)

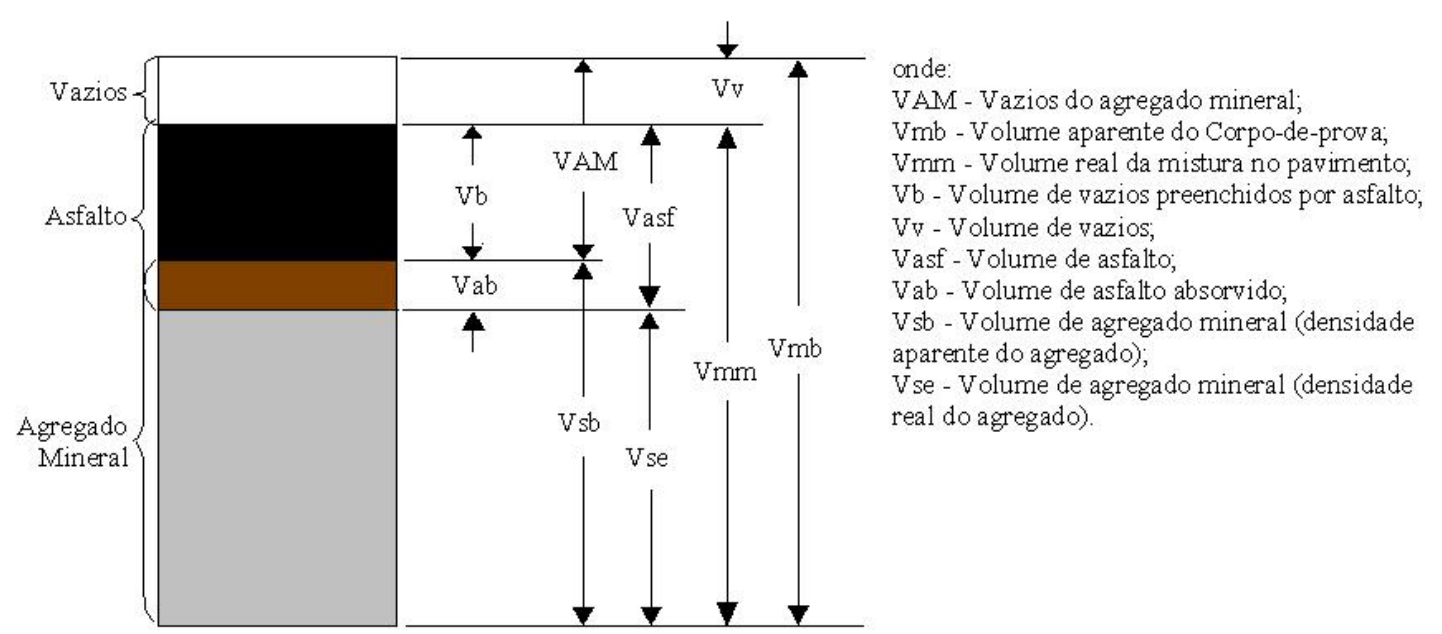

Figura 3.04. Representação dos volumes em uma amostra de asfalto compactada (adaptada do ASPHALT INSTITUTE, 1995) 
O volume de vazios do agregado mineral (\% mínima) é determinado em função do diâmetro máximo do agregado (DNER-ES 313/97). Quanto menor o diâmetro máximo, maior a porcentagem mínima do VAM, isto é explicado, pelo fato da superfície específica do agregado aumentar, exigindo, portanto um maior teor de asfalto efetivo (teor de asfalto total menos o teor de asfalto absorvido pelo agregado) para garantir a durabilidade da mistura (película de asfalto).

$$
\begin{aligned}
& V A M=100 \times\left(1-\frac{D_{a p} \times P_{a g}}{100 \times D_{a g}}\right) \\
& V A M=V_{v}+V_{b} \\
& V_{b}=P_{a s f} \times \frac{D_{a p}}{D_{a s f}}
\end{aligned}
$$

onde:

$V A M$ - vazios do agregado mineral;

$P_{a g}$ - porcentagem de agregado utilizado, expressa em relação ao peso total da mistura asfáltica $\left(100-P_{a s f}\right)$;

$P_{a s f}-$ porcentagem de material asfáltico utilizado, expressa em relação ao peso total da mistura asfáltica;

$D_{a g}$ - densidade média da composição de agregado utilizada;

$D_{a p}$ - densidade aparente do corpo-de-prova;

$V_{v}$ - teor de vazios no corpo-de-prova (\%);

$V_{b}$ - teor de vazios preenchido por cimento asfáltico (\%);

$D_{a s f}$ - densidade do material asfáltico utilizado.

Relação Betume-vazios $(R B V)$ é a porcentagem dos vazios do agregado mineral que é ocupada pelo cimento asfáltico, podendo ser estimado pela expressão 3.08 .

$$
R B V=100 \times \frac{V_{b}}{V A M}
$$

\subsection{Deformação permanente}

Há dois tipos principais de defeitos que contribuem para a deterioração do pavimento: o trincamento por fadiga e o afundamento de trilha de roda (deformação permanente). Segundo Mahboub (1990), a deformação permanente de trilha de roda (rutting) é um dos principais defeitos dos pavimentos flexíveis, sendo causada por 
deformação plástica que pode ocorrer em qualquer camada do pavimento. Contudo, a principal preocupação é com a deformação permanente na camada asfáltica, que pode ter origem, tanto por problemas de execução, quanto por falhas em projetos (dosagem e/ou dimensionamento) ou em ambos.

O efeito da deformação permanente é, freqüentemente, visível como depressões ao longo da trajetória das rodas dos veículos, sendo o processo de acúmulo destas deformações denominado de afundamento de trilhas de rodas (DRESCHER et al., 1993).

A forma de relacionar tensões e deformações, ou suas derivadas em relação ao tempo é por meio da equação constitutiva, que, em conjunto com as equações de equilíbrio ou de movimento e as condições de contorno, permite a avaliação da resposta estrutural do pavimento, tanto analiticamente quanto numericamente. Dentre as várias formas de relacioná-las na equação constitutiva, uma que oferece bom resultado, é considerar o pavimento com comportamento elástico, viscoso e plástico. Desta forma, a deformação é constituída de uma porção elástica, uma viscosa e uma plástica. As deformações de origem elástica são totalmente recuperáveis e independem do tempo, enquanto as viscosas são irrecuperáveis (permanentes) e dependem do tempo, isto é, a sua magnitude depende da duração do carregamento e da taxa de carregamento e descarregamento. As deformações plásticas são permanentes e independem do tempo. Pelo exposto, verifica-se que as deformações permanentes (afundamento de trilhas de rodas) são resultantes das propriedades viscosas e plásticas dos materiais que compõem o pavimento (DRESCHER et al., 1993).

No sentido de avaliar o desempenho dos pavimentos flexíveis, quanto à deformação permanente, são relatadas a seguir, algumas pesquisas nessa linha, ou por ser considerado pelo pesquisador como um estudo relevante, considerando a bibliografia consultada, ou por representar um marco na pesquisa de deformações permanentes.

Segundo Vand de Loo (1974), a introdução de novos métodos de ensaio, faz-se necessária, visto que os existentes, assim como o ensaio Marshall para concreto asfáltico, têm limitações no que diz respeito à avaliação e projeto de misturas, embora sejam úteis para fins de controle, são empíricos e não são aplicáveis para todos os tipos de mistura. Para esse mesmo pesquisador, as propriedades de estabilidade de uma mistura asfáltica não são bem definidas, porém podem ser expressas como a resistência de uma mistura a trilhas de rodas no pavimento, sob condições variáveis de clima, densidade de tráfego e carregamento. É muito comum, que pavimentos projetados pelo 
método Marshall mostrem um comportamento insatisfatório a estabilidade. Assim, era necessário encontrar um método de ensaio em laboratório que permitisse a predição da deformação permanente que pudesse ocorrer no pavimento. O programa de pesquisa consistiu de três estágios, a saber:
A. o desenvolvimento de modelos teóricos (HILLS, 1973);
B. a correlação desses modelos com os ensaios de creep estáticos não confinados (HILLS, 1973);
C. a correlação do ensaio de fluência com experimentos laboratoriais de deformação permanente.

Segundo a pesquisa de Anani et al. (1990), as propriedades das misturas têm mais influência na susceptibilidade a trilhas de rodas do que as propriedades dos materiais constituintes (asfalto ou agregado), isoladamente e que apesar de muitas pesquisas indicarem que as deformações plásticas ocorrem, basicamente, na capa, esta revelou que a base tem uma significante contribuição na deformação permanente dos pavimentos asfálticos.

Segundo Jimenez (1993), o programa de computador, ASPHALT, objetiva estimar um teor de asfalto, com o intuito de diminuir a possibilidade de ocorrer problemas de deformação de trilhas de rodas (por fluência) e garantir uma boa durabilidade para a camada asfáltica. Obter este equilíbrio no teor asfáltico é uma tarefa complexa, visto que para diminuir o problema de trilhas de rodas é necessário um baixo teor e para garantir a durabilidade, necessita-se de um alto teor.

Este sistema computacional (software) simula uma mistura submetida ao tráfego por cinco anos, que, segundo Jimenez (1993), é a idade em que o pavimento apresenta suas propriedades físicas estabilizadas e que a camada asfáltica com esta idade, apresentando teor de vazios maior do que $2 \%$, não exibe afundamento de trilhas de rodas. Em relação à durabilidade, com 5 anos, a espessura da película asfáltica deve estar na faixa de $\mathbf{6}$ a $12 \mu \mathbf{m}$ de espessura, para apresentar boa resistência ao fissuramento e ao descolamento (stripping). O agregado, dentre outras propriedades, deve apresentar uma absorção de água menor do que 2,5\% e a absorção de asfalto, em média, 0,6 a 0,7\%.

Um estudo realizado na Arábia Saudita, iniciado em 1987 e finalizado em 1992 (WAHHAB et al., 1995), teve os objetivos, a saber:

$\checkmark$ identificação dos fatores que podem estar relacionados com a deformação permanente de trilhas de roda; 
recomendações para solucionar os problemas de trilhas de roda existentes; a seleção de um modelo para identificar o potencial de deformação permanente de trilhas de roda em diferentes misturas de concreto asfáltico.

Para alcançar esses objetivos, foram estudadas 19 seções (cada seção com um quilômetro de extensão, com duas ou três faixas, dependendo da classificação da rodovia) distribuídas nas 12 principais rodovias do país, sendo monitorado o peso dos caminhões, a intensidade do tráfego, a pressão dos pneus $\left(50 \%\right.$ excedia a $8,43 \mathrm{~kg} / \mathrm{cm}^{2}-$ $120 \mathrm{lb} / \mathrm{in}^{2}$ ) e características climáticas. As temperaturas do pavimento (excedia a $60^{\circ} \mathrm{C}$ ) e do ar $\left(\mathrm{a} 40^{\circ} \mathrm{C}\right)$, no período de maio a setembro, eram extremamente altas, entre 9 e 16 horas. Neste período do dia também se concentrava o tráfego pesado, aproximadamente, $60 \%$, o qual representava mais de $25 \%$ do tráfego em todas as seções. A temperatura mais alta ocorria, aproximadamente, a $2 \mathrm{~cm}$ da superfície do pavimento, sendo que a temperatura na superfície era ligeiramente menor, aparentemente, em virtude do vento em sua superfície. Vale salientar, que todas as seções avaliadas tinham espessura de capa, em torno de $5 \mathrm{~cm}$, portanto, a temperatura máxima, ocorria, aproximadamente, na metade da espessura da camada.

As seções sem problemas de deformação bem como aquelas que apresentaram trilhas de roda menor do que $10 \mathrm{~mm}$ de profundidade também foram retratadas.

Os resultados indicaram que existe uma relação direta entre a deformação permanente e os seguintes parâmetros: teor de vazios, vazios no agregado mineral, porcentagem de vazios preenchidos com asfalto, módulo de resiliência a $25^{\circ} \mathrm{C}$ e a viscosidade do ligante asfáltico.

Segundo Ulmgren (1996), o Wheel tracking test tem demonstrado (dependendo da variante do método) uma boa correlação com as deformações permanentes medidas no campo, contudo é um tanto complicado para execução e outros ensaios mais simples devem ser pesquisados para substituí-lo. Com esta finalidade, o autor realizou um estudo, comparando os resultados obtidos com o ensaio de Creep dinâmico com os obtidos com o Wheel tracking test, nas seguintes condições:

1. ensaio padrão, onde, tanto o corpo-de-prova, quanto o prato superior do equipamento têm $100 \mathrm{~mm}$ de diâmetro;

2. corpo-de-prova com $150 \mathrm{~mm}$ de diâmetro e prato com $100 \mathrm{~mm}$;

3. corpo-de-prova com $150 \mathrm{~mm}$ de diâmetro e prato com $100 \mathrm{~mm}$, mas com confinamento lateral; 
4. corpo-de-prova com $150 \mathrm{~mm}$ de diâmetro e prato com $50 \mathrm{~mm}$;

5. corpo-de-prova com $150 \mathrm{~mm}$ de diâmetro e prato com $50 \mathrm{~mm}$, mas com confinamento lateral.

Os resultados obtidos com os pratos superiores reduzidos, sem confinamento lateral (condições 2 e 4), foram os melhores. O coeficiente de correlação foi de 0,91 $\left(\mathrm{R}^{2}=0,83\right)$, tanto para o prato superior com $100 \mathrm{~mm}$ de diâmetro, quanto para o de 50 mm, contudo, para o procedimento padrão (condição 1), o coeficiente de correlação foi o mais baixo, 0,36 $\left(\mathrm{R}^{2}=0,13\right)$. Nas condições 3 e 5 , os coeficientes de correlação foram, respectivamente, $0,63\left(R^{2}=0,40\right)$ e $0,82\left(R^{2}=0,67\right)$.

Segundo Ulmgren (1997), o método padrão do creep (condição 1) subestima o desempenho das misturas, visto que a estabilidade destas não é só obtida pelas forças de coesão, mas também pelo atrito interno dos agregados (maior parcela), tendo como resultado uma pobre correlação entre os resultados obtidos neste ensaio com o desempenho real dos pavimentos asfálticos. Os pratos superiores reduzidos (menores do que o diâmetro do $\mathrm{CP}$ ) criam uma pressão lateral (falso confinamento), fazendo com que haja resposta da componente da estabilidade, devido ao atrito interno do agregado. Neste tipo de ensaio as componentes da estabilidade são solicitadas.

\subsection{Fadiga}

De um modo geral, a fadiga e a deformação permanente, com base na bibliografia consultada, parecem ser os principais problemas (defeitos) nas camadas asfálticas, sendo, inclusive, os maiores responsáveis pela redução da vida útil de um pavimento.

A fadiga na camada asfáltica é a subtração gradativa de sua resistência com posterior trincamento (ruptura), por efeito de solicitações repetidas das cargas do tráfego. O parâmetro estrutural responsável por esta deficiência é a tensão de tração horizontal (deformação de tração), que se desenvolve na face inferior do revestimento. Portanto, este dano pode ser limitado por meio do ensaio de resistência à tração, com amostras preparadas pelo método Marshall. Utilizando um programa computacional de análise mecanística, como por exemplo, o ELSYM5, procura-se obter uma tensão de tração na fibra inferior da capa, que seja menor do que a tensão de ruptura do corpo-de-prova submetido ao ensaio de compressão diametral. Pode-se também utilizar o ensaio de compressão diametral com carga repetida para determinar a deformação de tração e por meio desta o módulo de resiliência da mistura em estudo. 
Segundo Pinto (1991), o principal defeito nos pavimentos rodoviários brasileiros tem como causa o fendilhamento por fadiga, decorrente das solicitações repetidas do tráfego, em conjunto com a elevada elasticidade (flexibilidade) das camadas de base e sub-base granulares.

Segundo Porter e Kennedy ${ }^{12}$ (1975 apud Queiroz e Visser, 1978, p.265), uma forma de se determinar o número de repetições $(\mathrm{N})$, para uma determinada mistura, é relacioná-lo com a deformação de tração induzida na amostra ensaiada. Essa relação, de um modo geral, é linear quando representada em escala log-log e pode ser determinada pela expressão 3.09 .

$$
N=K_{1}\left(\frac{1}{\varepsilon_{t}}\right)^{K_{2}}
$$

onde:

$N$ - número de repetições de uma carga $\mathrm{P}$, até a ruptura da amostra, no caso da tensão controlada;

$\varepsilon_{t}-$ deformação específica de tração provocada pela carga $\mathrm{P}$;

$K_{1}$ e $K_{2}$ - parâmetros que dependem da qualidade da mistura e são estimados com base na análise de regressão dos resultados obtidos em laboratório. Desta forma, essas constantes descrevem as propriedades de fadiga das misturas asfálticas.

Para misturas asfálticas densas, para o modelo acima, $\mathrm{K}_{1}$ pode assumir valores entre $10^{-6}$ a $10^{-16}$ e $K_{2}$ entre 2,8 a 5 (EPPS e MONISMITH ${ }^{13}, 1969$ apud PINTO, 1991, p.117).

No ensaio de fadiga à tensão controlada, o critério de parada está vinculado à ruptura completa do corpo-de-prova. Neste, a tensão permanece constante e as deformações atingem um valor máximo, até que o estágio de colapso da amostra seja atingido. Contudo, no ensaio à deformação controlada (deformação constante e diminuição do

\footnotetext{
${ }^{12}$ PORTER, B. W. e KENNEDY, T. W. (1975). Comparison of fatigue test methods for asphalt materials - Reseach Reporr 183-4, CHR, The University of Texas at Austin apud QUEIROZ, C. A. V e VISSER, A. T. (1978). Uma investigação dos módulos de resiliência de revestimentos betuminosos brasileiros. Grupo de Estudos do Desempenho e Conservação de Pavimentos - Pesquisa do Inter-relacionamento de Custos Rodoviários. IBP - Instituto Brasileiro do Petróleo. p.265.

${ }^{13}$ EPPS, J. A. e MONISMITH, C. L. (1969). Influence of mixtures on the flexural fatigue properties of asphalt concrete. Proc. Association of Asphalt Paving Technologists, vol.38, USA apud PINTO, S. (1991). Estudo do comportamento à fadiga de misturas betuminosas e aplicação na avaliação estrutural de pavimentos. 478p. Tese (Doutorado) - COPPE - Universidade Federal do Rio de Janeiro. Rio de Janeiro. P. 117.
} 
carregamento ao longo do ensaio), o critério de parada não está associado à fratura completa da amostra, mas ao número de solicitações capaz de reduzir à carga necessária para manter a deformação constante, em $40 \%$ a $50 \%$ da carga inicial ou reduzir o desempenho ou rigidez inicial da amostra a um valor determinado previamente. A redução, na faixa de 50\%, para o módulo de rigidez ou de resiliência, determina este valor, conseqüentemente, define a vida de fadiga da mistura (SANTUCCI e SCHMIDT $^{14}, 1969$ apud PINTO, 1991, p.117).

Dentre os principais fatores, que afetam a vida de fadiga das misturas betuminosas, podem ser citados os seguintes (PINTO, 1991):

$\checkmark$ fatores de carga: grandeza do carregamento; tipo de carregamento (tensão ou deformação controlada); freqüência, duração e intervalo de tempo, entre aplicações sucessivas do carregamento; história de tensões -carregamento simples ou composto; forma do carregamento - triangular, quadrado, etc;

$\checkmark$ fatores de mistura: tipo de agregado, forma e textura; granulometria do agregado; penetração do asfalto; teor de asfalto e temperatura;

$\checkmark$ fatores ambientais: temperatura e umidade;

$\checkmark$ outras variáveis: módulo de resiliência ou de rigidez e índice de vazios.

Prever precisamente a vida de fadiga de um concreto asfáltico é uma tarefa difícil, em virtude da complexidade do fenômeno de fadiga, sob a variação da mistura, carregamento e condições ambientais. A caracterização da fadiga em concreto asfáltico pode ter duas principais abordagens: a fenomenológica e a mecanística (LEE et al., 2000). Os modelos, comumente, usados são os fenomenológicos, que diz respeito à resposta inicial (deformação de tração) da vida de fadiga da mistura asfáltica. Este modelo é o mais utilizado, principalmente pela sua simplicidade, pois necessita, apenas, da resposta no estágio inicial do ensaio de fadiga, contudo, não avalia como os danos se desenvolvem ao longo das solicitações até a ruptura. Desta forma, não prediz, apuradamente, a evolução complexa do dano sob as condições realísticas de carga, mas, apenas, para uma condição específica de carregamento (solicitação simples). Na abordagem mecanística, é adotado o mecanismo da deterioração, com ou sem visco-

\footnotetext{
${ }^{14}$ SANTUCCI, L. E. e SCHMIDT, R. J. (1969). The effect of asphalt properties on the fatigue resistence of asphalt paving mixtures. Proc. Association of Asphalt Paving Technologists, vol.58, USA apud PINTO, S. (1991). Estudo do comportamento à fadiga de misturas betuminosas e aplicação na avaliação estrutural de pavimentos. 478p. Tese (Doutorado) - COPPE - Universidade Federal do Rio de Janeiro. Rio de Janeiro. P. 117.
} 
elasticidade, para descrever como o dano da fadiga se desenvolve na mistura asfáltica. Desta forma, pode ser aplicada para uma ampla faixa de carregamento e condições ambientais, conduzindo a uma melhor avaliação da vida em fadiga de um pavimento novo ou da vida remanescente de um pavimento existente. Em virtude da relação tensão-deformação formar a base desta abordagem, inerentemente, as propriedades do material estão inclusas, podendo, então, fornecer relações entre as propriedades e o desempenho a fadiga. Este pode ser usado para selecionar ligantes ou projetar misturas que sejam, efetivamente, mais resistentes à fadiga. Esta abordagem exige equipamentos mais sofisticados e dispendiosos.

Segundo Lee et al. (2000), muitos modelos, usuais, de fadiga, desenvolvido em laboratório, não predizem, satisfatoriamente, a vida de fadiga real do concreto asfáltico no campo, devido, principalmente, as condições no campo e laboratório serem diferentes, no que diz respeito ao carregamento (por exemplo: carregamento multinível, período de repouso, cura, etc.) e ao ambiente (por exemplo: variação de temperatura, envelhecimento, ect.). O período de repouso afeta, significativamente, a vida de fadiga da mistura e no entanto, a maioria desses modelos não considera, efetivamente, este fenômeno.

\subsection{Ensaios para avaliação das propriedades mecânicas das misturas}

Há uma relativa gama de ensaios com esta finalidade, contudo neste item serão abordados os ensaios de fluência por compressão uniaxial estática, resistência à tração por compressão diametral, módulo de resiliência por compressão diametral dinâmica, cantabro, dano por umidade induzida e envelhecimento em curto e longo prazos.

\subsubsection{Ensaio de fluência por compressão uniaxial estática}

Este ensaio tem sido utilizado para estimar a susceptibilidade das misturas asfálticas convencionais a deformação permanente sob diferentes condições de carregamento e temperatura. O trabalho pioneiro neste sentido é o dos pesquisadores da SHELL, sendo que os modelo teóricos para este ensaio foi desenvolvido por Hills (1973). Valkering et al. (1990) confirmaram a validade deste ensaio como uma forma de predizer a resistência a deformação permanente de misturas asfálticas com ligantes convencionais. Estes pesquisadores observaram, também, que o acréscimo de estabilidade na mistura devido à adição de um modificador, no caso o CARIFLEX TR-1101, não era refletido no ensaio de creep estático. Isto acontece, em virtude dos cimentos asfálticos, com ou 
sem polímeros, serem, reologicamente, diferentes, o que não é caracterizada neste ensaio. O ensaio de creep dinâmico mostra-se mais adequado para misturas com asfaltos modificados, visto que permite a verificação dos efeitos de recuperação de deformação.

De Hilster e Van de Loo (1977) desenvolveram um método (SHELL) para a avaliação do potencial das misturas asfálticas a deformação permanente de trilha de roda, com base no ensaio de Creep uniaxial estático. Os dados obtidos neste ensaio são utilizados como entrada em um procedimento para estimar a deformação permanente no pavimento. Para esta avaliação devem ser preparados pelo menos dois corpos-de-prova (CPs), que podem ser compactados pelo método Marshall (recomendam-se CPs com

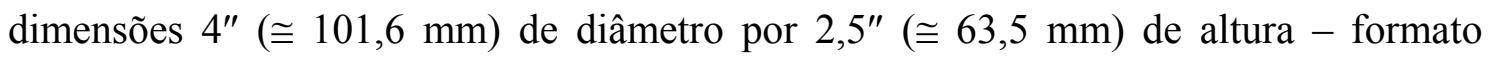
Marshall) para cada amostra analisada (combinação de agregado e tipo ou teor de asfalto). O número de corpo-de-prova (CP) é em função da repetibilidade desejada, que depende de parâmetros, como: tipo de dispositivo, método de compactação e do atrito da superfície de contato do CP (polimento) com o prato do equipamento. O corpo-deprova deve ser ensaiado, por $3600 \mathrm{~s}$, numa temperatura de $40^{\circ} \mathrm{C}$ e com uma tensão de $1 \mathrm{kgf} / \mathrm{cm}^{2}$.

Little et al. (1993) desenvolveram critérios para avaliar o potencial do concreto asfáltico à deformação permanente, por meio do ensaio uniaxial de Creep, que, segundo eles, é um ensaio eficaz para identificar a sensibilidade das misturas de concreto asfáltico à deformação permanente ou ao afundamento de trilhas de rodas. Este ensaio apresenta sensibilidade as variáveis da mistura, como: tipo de asfalto, teor de ligante, tipo de agregado, teor de vazios, temperatura de ensaio e estado de tensões. Para tanto, o ensaio deve ser realizado em condições de temperatura e nível de tensão próximo das observadas no campo: a temperatura deve ser de $40^{\circ} \mathrm{C}$, tensão na faixa de 3,5 a 4,15 $\mathrm{kgf} / \mathrm{cm}^{2}$ (adequadas, na maioria dos casos) e a duração do ensaio é de uma hora. Os dados obtidos do ensaio de Creep, indicadores eficazes da sensibilidade à deformação permanente da mistura, segundo esses autores, são: a deformação total para uma hora de carregamento $\left(\varepsilon_{\mathrm{p}}\right)$, a inclinação do estado secundário da curva deformação versus tempo de carregamento $(m)$, nesta pesquisa em escala log-log, e o módulo de fluência $\left(\mathrm{S}_{\mathrm{c}}\right)$. $\mathrm{O}$ estágio secundário (trecho de fluência constante) é determinado, entre 1000 e 3600 segundos. A Figura 3.05 apresenta uma configuração dos estágios da fluência, referentes a um ensaio de Creep por compressão uniaxial (LITTLE et al., 1993). O estágio primário é caracterizado pelo crescimento da taxa de deformação, rapidamente, 
enquanto no estágio secundário ou de fluência uniforme, a taxa de deformação é constante (ângulo de inclinação constante); no estágio terciário ou de colapso, a taxa de deformação torna a crescer rapidamente, até a ruptura do corpo-de-prova.

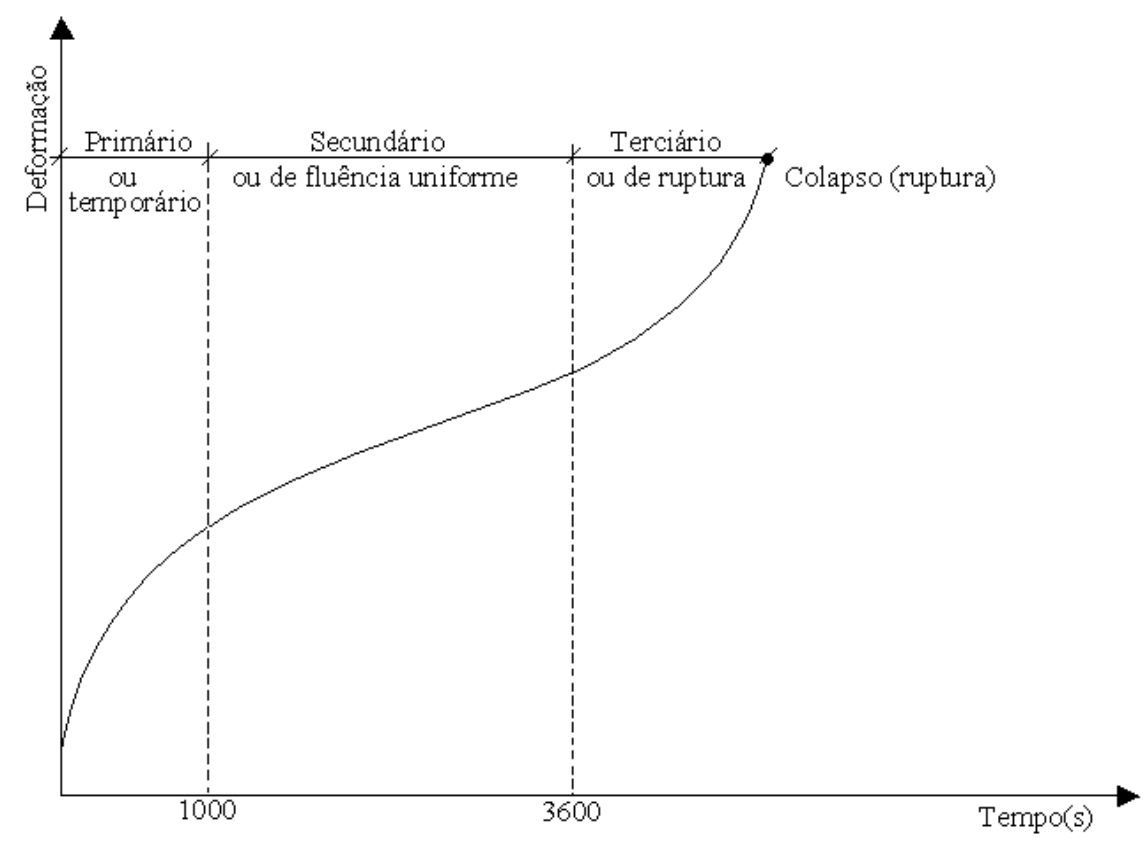

Figura 3.05. Estágios da curva de fluência (adaptado de LITTLE et al.,1993)

O método proposto por Hilster e Van de Loo (1977) e o proposto por Little et al. (1993) discordam, apenas, no que diz respeito à tensão, que para os primeiros autores deve ser de $1 \mathrm{kgf} / \mathrm{cm}^{2}$ e para os segundos, deve ser mais alta $\left(3,5\right.$ a $\left.4,15 \mathrm{kgf} / \mathrm{cm}^{2}\right)$, a fim de compatibilizar, de forma mais adequada, com a que ocorre no campo.

\subsubsection{Procedimento para o ensaio de fluência por compressão uniaxial estática}

Podem ser utilizados diversos equipamentos para a realização deste ensaio. Na pesquisa de De Hilster e Van de Loo (1977), foi investigado o efeito do tipo de dispositivo, em um estudo interlaboratorial, no qual quatro tipos foram empregados. Estes são especificados pelo nome de seus fabricantes, como a seguir:

$\checkmark$ Wykeham Farrance (WF) - Inglaterra, é uma versão modificada da prensa de adensamento de solos;

$\checkmark$ Freundl(FR) - Alemanha;

$\checkmark$ B\&S Tool Co. (B\&S) - Holanda;

$\checkmark$ State Road Laboratory (RWL) - Holanda. 
Estes pesquisadores concluíram que não há nenhuma razão técnica para preterir ou um outro tipo de equipamento, mas na escolha devem prevalecer os fatores econômicos.

Atualmente, pode-se dispor de dispositivos mais aprimorados do que os utilizados na pesquisa dos autores supracitados, dotados de medidores, tipo LVDT (Linear Variable Differential Transducer). Estes medidores permitem o registro eletrônico das cargas e deformações, bem como o posterior processamento dos resultados, tornando, desta forma, todo o procedimento mais rápido e eficaz.

Utiliza-se, freqüentemente, para a realização deste ensaio, prensa composta de sistema pneumático, com temperatura controlada por meio de um dispositivo automático conectado a uma fonte de calor. Para evitar a dissipação de calor, pode-se colocar a prensa dentro de uma câmara, dotada de abertura para permitir o manuseio (colocação e retirada) do corpo-de-prova (Figura 3.06).

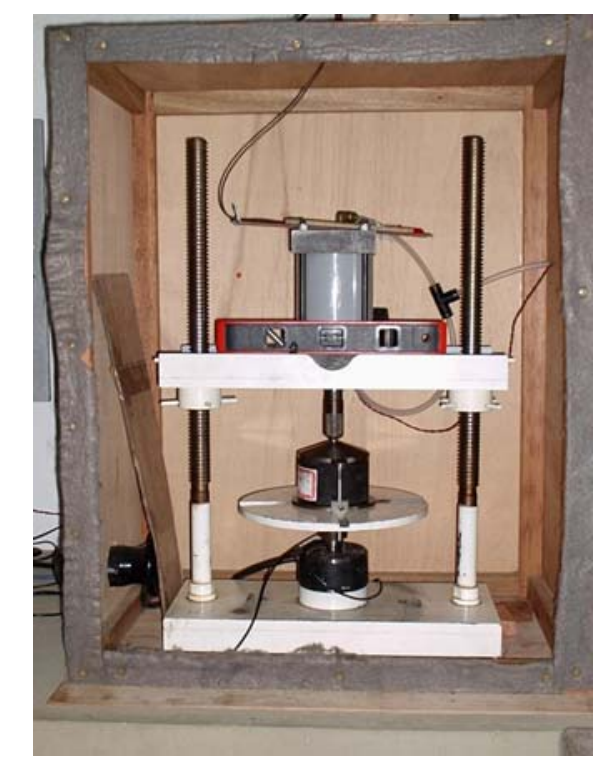

Figura 3.06. Ensaio de fluência por compressão uniaxial estática

Os procedimentos para o ensaio de fluência por compressão axial estático, com base em diversos trabalhos publicados (DE HILSTER e VAN DE LOO, 1977 (SHELL); VON QUINTUS et al., 1991 (AAMAS); LITTLE et al., 1993, COELHO, 1996; GRECO, 2004), em linhas gerais, são:

$\checkmark$ preparação dos corpos-de-prova para o ensaio (polimento e medições);

$\checkmark$ condicionamento em estufa, na temperatura prevista para o ensaio, comumente, $40^{\circ} \mathrm{C}$, por um período que garanta a uniformidade da temperatura em todo o CP, geralmente, seis horas são suficientes; 
precondicionamento (estabilização da temperatura de ensaio na câmara) dois minutos de aplicação do nível de tensão de ensaio (carga de ensaio), seguido de um período de descarregamento ou recuperação do corpo-deprova de cinco minutos;

$\checkmark$ imediatamente, após o período de recuperação, inicia-se o ensaio, submetido aos parâmetros preestabelecidos (nível de tensão e temperatura) durante 60 minutos, quando as deformações são medidas e gravadas em intervalos de tempo prefixados;

$\checkmark$ após esse período, o corpo-de-prova é descarregado, automaticamente e inicia-se o período de recuperação, com duração de 15 minutos;

$\checkmark$ as deformações permanentes específicas viscosas ou visco-plásticas $\left(\varepsilon_{\mathrm{vp}}\right)$, por meio dos deslocamentos axiais medidos em cada LVDT, durante todo o ensaio (75 minutos), são calculadas mediante a expressão 3.10 , bem como todos os indicadores eficazes da sensibilidade à deformação permanente da mistura: deformação total média para uma hora de carregamento $\left(\varepsilon_{\mathrm{p}}\right)$,expressão 3.11, a inclinação do estado secundário da curva deformação versus tempo de carregamento $(m)$, expressão 3.12, e o módulo de fluência $\left(\mathrm{S}_{\mathrm{c}}\right)$, expressão 3.13. O estágio secundário (trecho de fluência constante) é determinado, entre 1000 e 3600 segundos.

$$
\begin{aligned}
& \varepsilon_{v p}=\frac{\Delta h_{75}}{h_{o}} \\
& \varepsilon_{p}=\frac{\Delta h_{60}}{h_{o}} \\
& m=\frac{\log \varepsilon_{3600}-\log \varepsilon_{1000}}{\log 3600-\log 1000} \\
& S_{c}=\frac{\sigma}{\varepsilon_{v p}}
\end{aligned}
$$

As deformações axiais específicas $\left(\varepsilon_{t}\right)$ em qualquer instante $t$, podem ser calculadas pela expressão 3.14 .

$$
\varepsilon_{t}=\frac{\Delta h_{t}}{h_{o}}
$$

onde: 
$\Delta h_{75}$ - variação da altura do corpo-de-prova, após o período de recuperação, isto é, após 75 minutos do início do ensaio $(\mathrm{mm})$;

$h_{o}$ - medida inicial da altura do corpo-de-prova $(\mathrm{mm})$;

$\Delta h_{60}$ - variação da altura do corpo-de-prova, após 60 minutos do início do ensaio $(\mathrm{mm})$;

$\Delta h_{t}$ - variação da altura do corpo-de-prova em qualquer instante $t$;

$\varepsilon_{3600}$ - deformação para 3600 s de ensaio;

$\varepsilon_{1000}$ - deformação para 1000 s de ensaio;

$\sigma$ - nível de tensão do ensaio.

Por meio dos resultados obtidos, pode-se traçar a curva de fluência, podendo ser feito pelo próprio sistema computacional do ensaio ou pelo usuário utilizando uma ferramenta computacional com esta finalidade.

\subsubsection{Ensaio de resistência à tração por compressão diametral (ensaio de tração indireta)}

Este ensaio foi desenvolvido por Lobo Carneiro, inicialmente, para condições estáticas, com o objetivo de estimar a resistência de tração de corpos-de-prova de concreto de cimento portland. Este ensaio é conhecido internacionalmente como "ensaio brasileiro" (brazilian or indirect tensile test). Esse método tem sido utilizado, tanto no Brasil, como em outros países, para a determinação de propriedades mecânicas de misturas asfálticas (módulo de resiliência, resistência à tração, coeficiente de Poisson), portanto, pode-se usá-lo com carregamento dinâmico (módulo de resiliência) ou com carregamento estático (resistência à tração). $\mathrm{O}$ ensaio de tração indireta consiste no carregamento de um corpo-de-prova cilíndrico com cargas de compressão distribuídas ao longo de duas geratrizes opostas. Esta forma de carregamento gera uma tensão de tração normal à direção da carga aplicada e ao longo do plano diametral vertical, podendo, assim, levar a amostra à ruptura (Figura 3.07).

Por meio dos resultados obtidos no ensaio de tração indireta é possível determinar, com base na teoria da elasticidade, equações para estimar o módulo de resiliência e coeficiente de Poisson da amostra ensaiada (QUEIROZ e VISSER, 1978).

Aconselha-se para a determinação de parâmetros elásticos de misturas betuminosas, a utilização do ensaio de tração indireta, por apresentar vantagens, como: simplicidade 
de realização, rapidez e reprodutibilidade dos valores (PINTO e PREUSSLER, 1980). A variação da resistência a tração $\left(25^{\circ} \mathrm{C}\right)$ que estes autores encontraram para o CAP 50/60 (teor de asfalto de 4,3\% a 6,5\%) foi de 0,67 a $0,96 \mathrm{MPa}\left(6,70\right.$ a $\left.9,60 \mathrm{kgf} / \mathrm{cm}^{2}\right)$ e para o CAP 85/100 (mesma variação de teor asfáltico) foi de 0,44 a $0,71 \mathrm{MPa}(4,41$ a 7,10 $\mathrm{kgf} / \mathrm{cm}^{2}$ ), que segundo estes, foram bastante influenciadas pela consistência do cimento asfáltico.

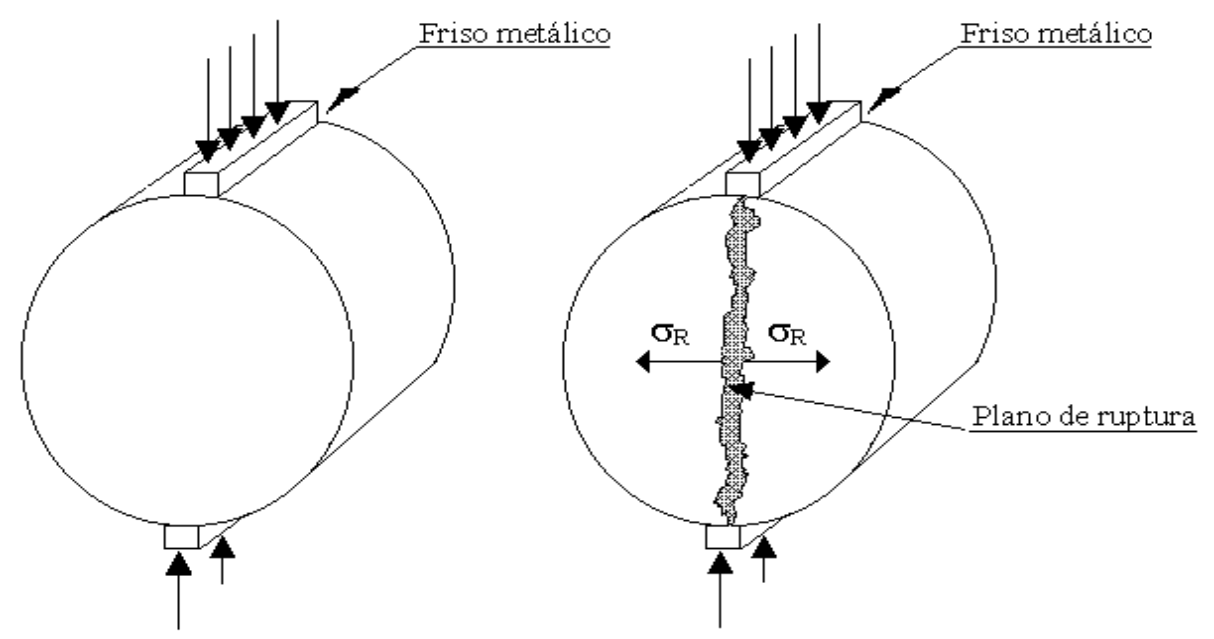

Figura 3.07. Ensaio de resistência à tração por compressão diametral (adaptado de DNER ME - 138/94)

\subsubsection{Ensaio do módulo de resiliência por compressão diametral dinâmica}

Segundo Pinto e Preussler (1980), os materiais que compõe a estrutura de um pavimento, quando sujeitos a carregamento dinâmico de curta duração e submetidos a tensões muito abaixo de sua plastificação, exibem comportamento elástico e não necessariamente linear. Para esses pesquisadores, o módulo de resiliência é o módulo de elasticidade obtido por meio de ensaios laboratoriais, com equipamentos que simulem as condições de campo. Estudos realizados na universidade do Texas para avaliar os métodos, freqüentemente, utilizados em laboratório para estimar as propriedades fundamentais dos materiais, considerando os ensaios de módulo dinâmico (complexo), de módulo de resiliência com carga axial, de módulo de resiliência a flexão e módulo de resiliência a tração indireta, concluíram que o ensaio de tração indireta, por compressão diametral, é o mais indicado para a determinação das características resiliente da misturas asfálticas. As razões que 
conduziram a esta conclusão são as seguintes (GONZLAEZ et al $^{15}$., 1975 apud QUEIROZ E VISSER, 1978, p. 248):

1. a realização do ensaio é relativamente simples;

2. o tipo de amostra e o equipamento são os mesmos utilizados nos ensaios de compressão;

3. a ruptura não é seriamente afetada pelas condições superficiais;

4. a ruptura inicia-se em uma região de tensão de tração relativamente uniforme;

5. o coeficiente de variação dos resultados é baixo, quando comparado com os outros métodos estudados;

6. o ensaio, no caso do módulo de resiliência é realizado com carga repetida, mas no caso da resistência a tração a carga é estática;

7. o ensaio pode dar informações sobre parâmetros, como: resistência à tração, módulo de resiliência, coeficiente de Poisson, características de fadiga e deformações permanentes.

O módulo de resiliência pode ser utilizado na avaliação estrutural ou no dimensionamento racional de pavimentos por meio de programas destinados à análise mecanística destes, tais como BISAR, CHEVRON, WESLEA, ELSYM5, ABAQUS, FEPAVE.

Segundo Queiroz e Visser (1978), o conhecimento do módulo de resiliência do revestimento de um pavimento flexível é um importante parâmetro para a determinação do número de repetições do eixo padrão que esse pavimento pode suportar, até a ruptura por fadiga.

Motta e Pinto (1994) recomendam o uso do ensaio de compressão diametral estático (DNER-ME 138/94), como parâmetro de estimativa do módulo de resiliência, aos laboratórios que não dispõem de equipamentos para a realização do ensaio desse parâmetro elástico. Segundo esses autores, para anteprojetos, ou projetos de estradas secundárias é possível a estimativa do módulo de resiliência utilizando este método indireto (expressão 3.15, em MPa) e desta forma, dimensionar os pavimentos mais racionalmente. Com esta finalidade, citam-se ainda as expressões 3.16 e 3.17 .

\footnotetext{
${ }^{15}$ GONZALEZ, G. W. Et al. (1975). Evaluation of the resilient elastic characteristics of asphalt mixtures using the indirect tensile test. Reseach Reporr 183-6, CHR, The University of Texas at Austin apud QUEIROZ, C. A. V e VISSER, A. T. (1978). Uma investigação dos módulos de resiliência de revestimentos betuminosos brasileiros. Grupo de Estudos do Desempenho e Conservação de Pavimentos - Pesquisa do Inter-relacionamento de Custos Rodoviários. IBP - Instituto Brasileiro do Petróleo. p.248.
} 


$$
\begin{aligned}
& M R=343+4028 \sigma_{R} \quad\left(\mathrm{n}=96 \text { pontos e } \mathrm{R}^{2}=0,550\right) \\
& M R=5000 \sigma_{\mathrm{R}}(\mathrm{DNER}-\mathrm{PRO} 269 / 96) \\
& M R=3000 \text { a } 3500 \sigma_{\mathrm{R}}(\text { MOTTA, 1998) }
\end{aligned}
$$

Para Motta (1998), de uma forma mais simples, pode-se enunciar que o módulo de resiliência varia com o tipo de ligante asfáltico, sendo maior, quanto menor for a penetração ou maior a viscosidade, contudo, não é muito sensível ao teor de asfalto, considerando a faixa normal de dosagem e quanto a granulometria da mistura, o módulo de resiliência é maior, quanto mais grossa for a faixa adotada.

A variação do módulo de resiliência $\left(25^{\circ} \mathrm{C}\right)$, encontrada por Pinto e Preussler (1980), para o CAP 50/60 (teor de asfalto de 4,3\% a 6,5\% - Capa) foi de 2.700 a $4.300 \mathrm{MPa}$ (27.000 a $\left.43.000 \mathrm{kgf} / \mathrm{cm}^{2}\right)$ e para o CAP 85/100, nas mesmas condições, foi de $1.900 \mathrm{a}$ $3.000 \mathrm{MPa}\left(19.000\right.$ a $\left.30.000 \mathrm{kgf} / \mathrm{cm}^{2}\right)$, que segundo estes, foram bastante influenciados pela consistência do ligante. Como pode ser observado, quanto menor a penetração, maior o módulo de resiliência. Vale salientar, que os agregados utilizados por Pinto e Preussler (1980) é do tipo gnaisse e gnaisse granitóide.

O ensaio de módulo de resiliência, normatizado no Brasil pelo DNER-ME 134/94, é baseado no ensaio de resistência à tração por compressão diametral com carregamento repetido, e prescreve o seguinte:

a. corpos-de-prova obtidos diretamente do campo, por meio de sonda rotativa, ou fabricados em laboratório, com D (diâmetro) $=10 \pm 0,2 \mathrm{~cm}$ e H (altura) entre 3,50 a $6,5 \mathrm{~cm}$;

b. colocação do corpo-de-prova na base da estrutura de suporte, entre dois cabeçotes curvos (Figura 3.08);

c. fixação e ajuste dos LVDTs (Linear Variable Differential Transducer) para a obtenção do registro dos deslocamentos;

d. assentamento correto do pistão de carga e dos cabeçotes no corpo-de-prova;

e. fase de condicionamento do corpo-de-prova: aplicação de 200 repetições de uma carga vertical (F), diametralmente, no corpo-de-prova, de forma a se obter uma tensão de tração $\left(\sigma_{t}\right)$ menor ou igual a $30 \%$ da resistência à tração $\left(\sigma_{R}\right)$, determinada no ensaio de compressão diametral estático. Recomenda-se a aplicação da menor carga (F) capaz de fornecer um registro mensurável, sendo a 
freqüência de aplicação de carga (F) de 60 ciclos por minuto, com duração de 0,1 segundo (Figura 3.09);

f. com as deformações horizontais resilientes (Figuras 3.09 e 3.10), calculam-se os módulos por meio da expressão 3.18. O módulo de resiliência do corpo-de-prova ensaiado será a média aritmética dos valores determinados a 300, 400 e 500 aplicações de carga (F).

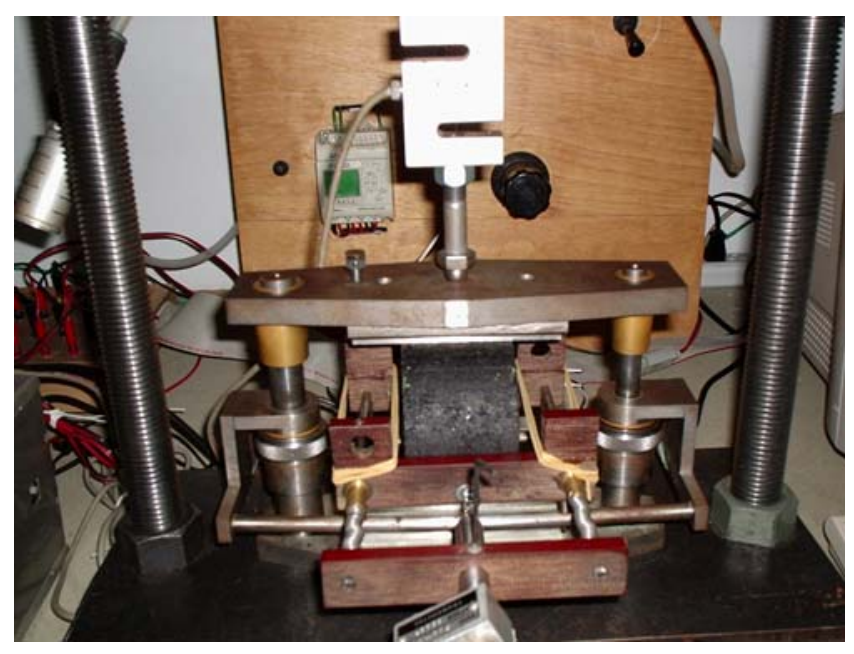

Figura 3.08. Montagem do ensaio do Módulo de resiliência

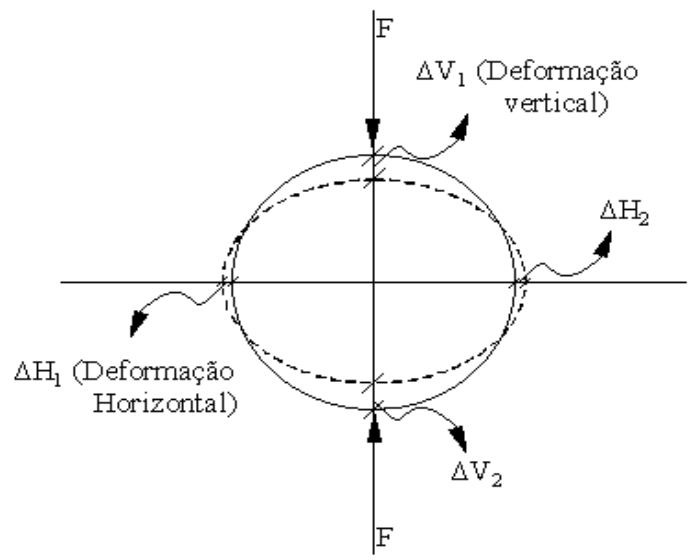

Figura 3.09. Representação das deformações verticais e horizontais no ensaio de módulo de resiliência 


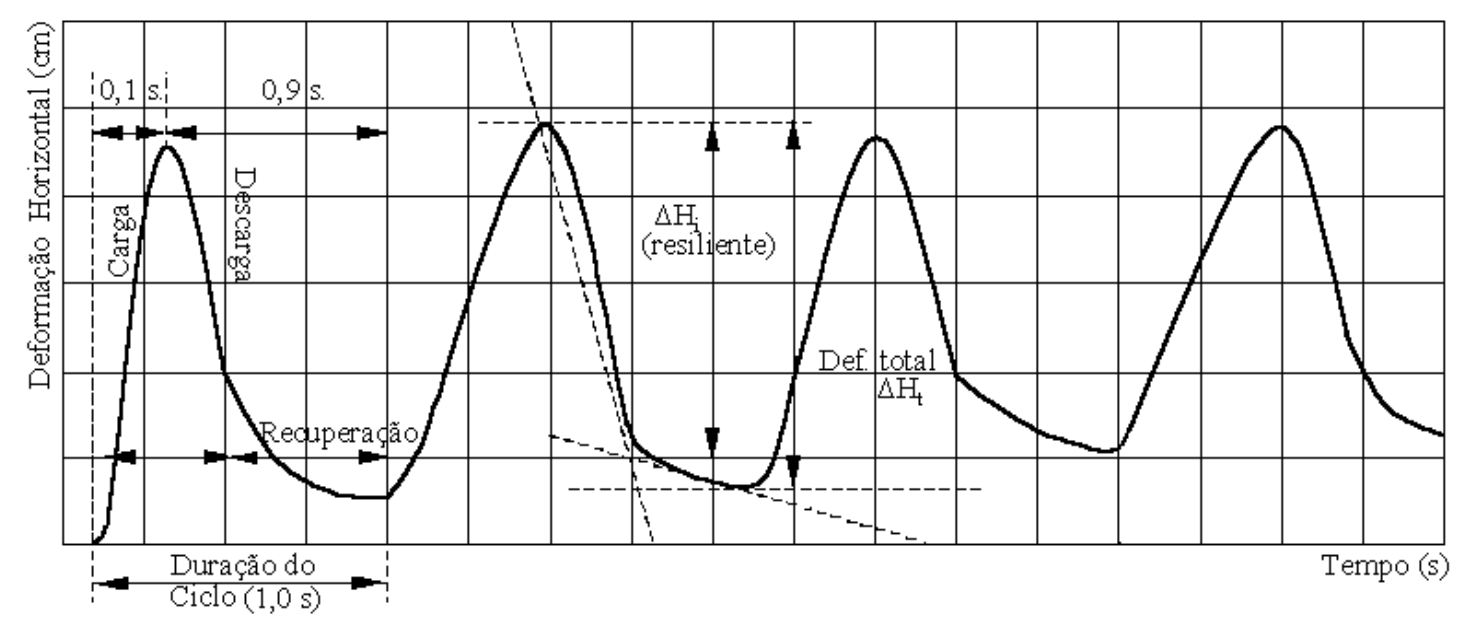

Figura 3.10. Parte do gráfico do ensaio do Módulo de Resiliência - adaptado (ASTM D 4123/82; VON QUINTUS et al. 1991)

$$
M R=\frac{F}{100 \Delta H}(0,997 \mu+0,2692)
$$

Considerando o coeficiente de Poisson $(\mu), 0,30$, conforme recomendação do método (DNER-ME 134/94), o módulo pode ser calculado pela expressão 3.19. O método recomenda, também, que quando a temperatura de ensaio não for especificada, o ensaio deverá ser realizado na temperatura de $30 \pm 1{ }^{\circ} \mathrm{C}$ (corpos-de-prova condicionados nesta temperatura).

$$
M R=\frac{0,56848 F}{100 \Delta H}
$$

onde:

$M R$ - módulo de resiliência $(\mathrm{MPa})$;

$F$ - carga vertical repetida aplicada diametralmente no corpo-de-prova $(\mathrm{N})$;

$\mu$ - Coeficiente de Poisson;

$\Delta$ - deformação elástica ou resiliente para 300, 400 e 500 aplicações de carga (cm);

$H$ - altura do corpo-de-prova (cm).

Se as deformações verticais (Figura 3.09) também forem medidas, o coeficiente de Poisson pode ser estimado para cada mistura ou corpo-de-prova, pela expressão 3.20, no caso do diâmetro de quatro polegadas $(101,6 \mathrm{~mm})$ e pela expressão 3.21 para corpos-deprova com diâmetro de seis polegadas (152,4 mm) (ROBERTS, F. L. et al.,1991). 


$$
\begin{array}{ll}
\mu=3,59 \frac{\Delta H}{\Delta V}-0,27 & \text { para corpos-de-prova com 101,6 mm de diâmetro } \\
\mu=4,09 \frac{\Delta H}{\Delta V}-0,27 & \text { para corpos-de-prova com } 152,4 \mathrm{~mm} \text { de diâmetro }
\end{array}
$$

onde:

$\mu$ - Coeficiente de Poisson;

$\Delta H$ - deslocamento horizontal $(\mathrm{mm})$;

$\Delta V$ - deslocamento vertical (mm).

Segundo o ASTM D 4123/82, o coeficiente de Poisson resiliente instantâneo, pode ser calculado pela expressão 3.20 ou 3.21, substituindo os valores dos deslocamentos horizontal e vertical recuperáveis totais pelos (horizontal e vertical) recuperáveis instantâneos.

Para Von Quintus et al. (1991), o módulo de resiliência instantâneo para cada ciclo de carregamento deve ser o correspondente a deformação horizontal, medida no período de tempo igual a duas vezes o tempo de aplicação do carregamento, ou seja, nesta pesquisa, após 0,2 segundo do início do ciclo de carregamento.

\subsubsection{Ensaio Cantabro}

A inexistência de um método, para dosagem e projeto em função das propriedades das misturas abertas, encorajou os pesquisadores espanhóis a investir em pesquisa para avaliá-las. Antes de estudar o procedimento e o desenvolvimento de um ensaio específico, os pesquisadores tentaram avaliar a desagregação dessas misturas por meio de ensaios já existentes, como o coesímetro Hveem e o ensaio de tração indireta. Contudo, estes ensaios ofereceram resultados pouco confiáveis, visto que o ensaio de tração indireta se mostrara pouco sensível à variação do teor do ligante na mistura e o coesímetro Hveem fora idealizado para a coesão de misturas rígidas e frágeis e não para misturas flexíveis e plásticas. No caso das misturas abertas, o coesímetro não mede a coesão, e sim o esforço necessário para deformá-la e este diminui com o teor de ligante. Com base nestes insucessos, eles desenvolveram, no final da década de 1970, o ensaio cantabro (PÉREZ-JIMENEZ, 1990).

O ensaio cantabro (NLT-325/86) tem por finalidade a determinação da perda por desgaste de misturas betuminosas empregando o equipamento de abrasão Los Angeles, permitindo, também, avaliar indiretamente a coesão, assim como a resistência à 
desagregação da mistura, perante a sucção e os efeitos abrasivos originados pelo tráfego.

Os resultados, obtidos nesta pesquisa, mostraram que esse ensaio é particularmente sensível ao teor de ligante, fíler e ao agregado fino, que são os parâmetros que proporcionam a coesão e a resistência à desagregação das misturas. Destes parâmetros, o mais influente é o teor de ligante, principalmente, para teores baixos, com o aumento do teor, o efeito sobre a coesão vai diminuindo. Um outro aspecto observado na pesquisa foi a repetibilidade (no laboratório) e a reprodutibilidade (entre laboratórios) do ensaio cantabro nesse estudo, promovido pelo Serviço de Tecnologia da Direção de Estradas na Espanha, no qual participaram 18 laboratórios (PÉREZ-JIMENEZ, 1990).

A repetibilidade de um ensaio se avalia a partir das dispersões nos resultados, quando vários corpos-de-prova de uma mesma mistura são ensaiados em um mesmo laboratório, enquanto a reprodutibilidade é caracterizada pela dispersão obtida, quando vários laboratórios preparam e ensaiam a mesma mistura. O ensaio não só deve ser sensível à variação dos parâmetros medidos, mas também preciso, no momento de avaliá-los, desta forma, se o operador repetir o ensaio, o resultado é o mesmo ou muito próximo e se outro operador repeti-lo, em outro laboratório, o resultado deve também ter as mesmas características.

Silveira (1999) utilizou o ensaio cantabro na avaliação da resistência ao desgaste de misturas de areia asfáltica com polímero e concluiu que estas misturas são resistentes ao desgaste, pois apresentaram valores de desgaste baixo, sendo 5,17\%, o maior valor e $0,91 \%$, o menor valor. $\mathrm{O}$ autor sugere que o ensaio cantabro seja adotado na avaliação da resistência ao desgaste de misturas de areia-asfalto, por ser simples de realizar, ter grande repetibilidade e por utilizar equipamentos, geralmente, disponíveis em laboratórios de pavimentação.

De Castro Neto (2000) empregou o ensaio cantabro para estudar a influência do envelhecimento do ligante na adesividade em dosagem de concreto betuminoso reciclado a quente. Para tanto, foram ensaiados corpos-de-prova com zero, 0,4 e $0,8 \%$ de agente de reciclagem e os resultados foram, respectivamente, $10,8,3$ e $6,3 \%$, mostrando que a perda de massa é inversamente proporcional ao teor de agente de reciclagem, indicando uma possível melhora da adesividade da nova mistura de ligante aos agregados.

De Moura (2001) utilizou o ensaio cantabro para avaliar o desgaste em misturas asfálticas densas convencionais (CAP 20) e modificadas com polímero (SBS - estireno butadieno estireno, SBR - estireno butadieno borracha e EVA - copolímero Etileno 
Acetato de Vinila) sem e com agentes melhoradores de adesividade (aditivo químico e cal). Os corpos-de-prova extraídos de placas virgens foram avaliados sem e com condicionamento de alta severidade (AASHTO T 283/89) e os corpos-de-prova extraídos de placas submetidas ao simulador de tráfego, tipo LCPC, foram avaliados sem e com condicionamento de baixa severidade (ASTMA 4867/96). Este autor concluiu que os corpos-de-prova, oriundos de placas virgens, mostram, claramente, que o desgaste maior é em virtude do condicionamento e que a adição de $2 \%$ de cal foi a que melhor promoveu uma pequena perda de massa, sem e com condicionamento.

Bertollo (2002) utilizou o ensaio cantabro como uma tentativa de verificar se a adição de borracha proporcionava alguma melhoria às misturas asfálticas densas modificadas. Contudo, a pesquisadora concluiu que com o ensaio cantabro não foi possível avaliar, por meio de análise comparativa, a influência da granulometria e do teor de borracha na resistência à desagregação, pois as diferenças entre as misturas modificadas não se retrataram nos resultados do ensaio. As perdas de massa variaram de 10,7\%, para a mistura com $2 \%$ de borracha com granulometria grossa (passando na peneira 3/8" e retido na peneira 30 ) a $4,3 \%$, para a mistura com $2 \%$ de borracha com granulometria fina (passando na peneira 16 e retido na peneira 30$)$.

O ensaio cantabro consiste, basicamente, em moldar corpo-de-prova Marshall e submeter um a um, ao desgaste na máquina de abrasão Los Angeles, sem carga abrasiva, a 300 revoluções (30 a $33 \mathrm{rpm}$ ), no caso de misturas asfálticas a quente e a 200 revoluções para misturas asfálticas a frio, a temperatura de $25 \pm 1{ }^{\circ} \mathrm{C}$. Depois de pesado o corpo-de-prova é colocado na máquina de abrasão Los Angeles e submetido ao número de revoluções específico para o tipo de mistura. Ao final do ensaio, o corpo-deprova é pesado novamente e determinada a perda por desgaste, por meio da expressão 3.22. São necessários, pelo menos quatro corpos-de-prova para cada teor de ligante.

$$
P=\frac{\left(P_{1}-P_{2}\right) \times 100}{P_{1}}
$$

\subsubsection{Ensaio de dano por umidade induzida (AASHTO T 283/99- Metodologia Lottman Modificada)}

A durabilidade de uma mistura asfáltica depende, dentre outros fatores, do grau de adesão entre o cimento asfáltico e o agregado, podendo ser comprometida, seriamente, pela presença de água ou de umidade no seu interior. 
Segundo Hicks (1991), o dano por água ou umidade nos pavimentos de concreto asfáltico pode estar associado a dois mecanismos comuns, adesão e/ou coesão. No mecanismo de adesão, geralmente, a água fica entre a película do cimento asfáltico e o agregado, visto que a superfície do agregado tem maior afinidade pela água do que o asfalto. Desta forma, a água fica entre a película asfáltica e o agregado, rompendo o vínculo adesivo entre eles, deixando o agregado sem proteção. A perda de adesão pode ser visualizada em termos de desligamento ou redução do ângulo de contato entre o asfalto e a superfície do agregado e esse mecanismo depende de fatores, como: temperatura, viscosidade e composição do asfalto, tipo de agregado e espessura da película asfáltica. No segundo mecanismo, a interação da água com o cimento asfáltico, causa uma redução na coesão dentro deste (cimento asfáltico), com uma séria diminuição na integridade e resistência da mistura. Ainda, segundo Hicks (1991), quatro fatores influenciam o dano por umidade, a saber:

1. as características do concreto asfáltico, abrangendo o agregado (textura superficial, porosidade, composição mineralógica, composição química da superfície, umidade superficial e recobrimento), o cimento asfáltico e o tipo de mistura;

2. as condições climáticas (temperatura, vento, umidade), durante a construção;

3. os efeitos ambientais (clima e carregamento do tráfego), após a construção;

4. drenagem sub-superficial do pavimento.

Há vários métodos para avaliar a susceptibilidade de misturas ao dano de umidade, neste estudo é abordado o método AASHTO T 283/99 (Lottman modificado), pois foi o método escolhido para analisar as misturas asfálticas aqui pesquisadas.

Segundo a AASHTO T 283/99, o ensaio de umidade induzida é executado para predizer, em longo prazo (quatro a 12 anos), a susceptibilidade da mistura ao descolamento (stripping) da película asfáltica do agregado, considerando o efeito deletério da água, e avaliar a necessidade de usar um aditivo antistripping (dope). Os corpos-de-prova cilíndricos para esse ensaio podem ser preparados em laboratório ou serem extraídos da pista e devem ter diâmetro de $101,6 \mathrm{~mm}\left(4^{\prime \prime}\right)$ e altura de 63,5 mm $\left(2,5^{\prime \prime}\right)$ ou $150 \mathrm{~mm}$ de diâmetro $\left(6^{\prime \prime}\right)$ e altura de $95 \mathrm{~mm}\left(3,75^{\prime \prime}\right)$ com teor de vazios de $7 \pm 1 \%$ ou o teor esperado no campo (item 6.5 da AASHTO T 283/99). 


\subsubsection{Envelhecimento}

As misturas asfálticas sofrem o processo de envelhecimento por terem cimento asfáltico em sua composição e este acontece em virtude do ligante asfáltico ser composto de moléculas orgânicas que reagem com o oxigênio do ar. Segundo Ramadham et al. (1998), a reação de oxidação na mistura asfáltica altera a estrutura e a composição de suas moléculas e pode ocorrer durante os processos de usinagem e construção ou após a compactação (vida em serviço do pavimento). Durante a vida em serviço (envelhecimento em longo prazo), a oxidação ocorre, em virtude do teor de vazios presente na mistura favorecer a penetração do ar, causando um endurecimento ao longo do tempo. Contudo, durante o processo de misturação, em temperaturas elevadas (maiores do $150^{\circ} \mathrm{C}$ ), o endurecimento devido à oxidação acontece rapidamente (envelhecimento em curto prazo). Ainda, segundo esses autores, uma outra forma de endurecimento das misturas asfálticas é a volatilização, que ocorre no processo de misturação e compactação (altas temperaturas), na qual os constituintes voláteis do ligante asfáltico evaporam.

O envelhecimento do asfalto origina-se principalmente das reações de oxidação que afeta, em maior ou menor grau, certas funcionalidades na composição complexa das moléculas que constituem sua estrutura, levando geralmente a uma perda de adesão, a uma redução na ductilidade, a um aumento da fragilidade e, finalmente, conduz a uma redução na serventia do pavimento sob o tráfego induzido e condições climáticas (MAJIDZADEH e SCHWEYER ${ }^{16}, 1968$ apud RAMADHAM et al., 1998, p. 26).

Como supracitado, o cimento asfáltico, quando compõe uma mistura asfáltica, fica submetido a dois tipos de envelhecimento: em curto prazo, que é o ocorrido durante a fase de fabricação (aquecimento e misturação) e lançamento (compactação e esfriamento) e o em longo prazo, o que ocorre, lentamente, durante a vida em serviço, em virtude dos fatores climáticos. Os fatores que afetam o envelhecimento em serviço (em longo prazo) de um pavimento, segundo Verhasselt e Choquet (1993), são:

1. susceptibilidade do ligante ao envelhecimento, isto é, a facilidade em oxidarse;

\footnotetext{
${ }^{16}$ MAJIDZADEH, K. e SCHWEYER, H. E .(1968). Viscoelastic response of aged asphalt cements. Hwy. Res. Record 231, Nat. Res. Council, Washington, D.C. p. 50-61 apud RAMADHAM, R. H. et al. (1998). Evaluation of Arabian asphalt binder for low-temperature cracking. Journal of Materials in Civil Engineering, vol. 10, n. 1, p. 26-33. p.26.
} 
2. porosidade do cimento asfáltico, caracterizada pelo teor de vazios;

3. reações de oxidação, estimulada por um aumento na temperatura de exposição;

4. radiação solar, da qual a componente ultravioleta afeta somente uma camada muito fina do ligante na superfície, e a infravermelho aumenta a temperatura média do pavimento, quando é absorvida;

5. natureza do agregado;

6. outros fatores, como: umidade, precipitação e sais de descongelamento.

Segundo Button et al. (1993), o objetivo dos procedimentos dos ensaios de envelhecimento é simular o endurecimento que ocorre durante a misturação, compactação e vida em serviço do pavimento.

O ensaio de envelhecimento, segundo a AASHTO PP2-00 (Standard practice for mixture conditioning of Hot-Mix Asphalt (HMA)), realizado em curto e em longo prazos para simular, respectivamente, o envelhecimento da mistura na fase de précompactação no processo de construção e o envelhecimento que ocorre ao longo da vida em serviço (7 a 10 anos) do pavimento.

Para simular o envelhecimento em curto prazo, a mistura é colocada em uma estufa com ventilação, a uma temperatura de $135 \pm 3^{\circ} \mathrm{C}$, por um período de 4 horas \pm 5 minutos. Para o envelhecimento em longo prazo, a mistura é colocada na estufa com ventilação, a uma temperatura de $85 \pm 3{ }^{\circ} \mathrm{C}$, por um período de 120 horas $(5$ dias $) \pm 30$ minutos. 


\section{APRESENTAÇÃO, ANÁLISE E DISCUSSÃO DOS RESULTADOS}

Neste capítulo, abordam-se, sucintamente, os procedimentos estatísticos utilizados para tratar os resultados dos ensaios e, posteriormente, apresentam-se os resultados obtidos dos ensaios laboratoriais realizados para a avaliação das misturas estudadas, bem como a análise e discussão destes. O tratamento estatístico dos resultados foi realizado utilizando o aplicativo EXCEL (Microsoft@ Office 2000).

Para verificar o efeito (interferência) dos fatores (varáveis independentes - volume de vazios, teor de areia e condições de envelhecimento) sobre as respostas (variáveis dependentes - ensaios abordados), utilizou-se a Análise de Variância (ANOVA), adotando nível de significância $(\alpha)$ igual a 5\%. A ANOVA é baseada na suposição de que as amostras são aleatórias e independentes, mas retiradas de populações com distribuição normal e mesma variância. Essa técnica, desenvolvida por Fischer, faz uso da distribuição $\mathrm{F}$ e tem por objetivo verificar se as amostras foram extraídas de populações com a mesma média $\left(\mathrm{H}_{\mathrm{o}}\right.$ - Hipótese nula aceita). Para isto, é necessário testar, se a significância das diferenças entre três ou mais médias não é relevante, caso isto ocorra, a hipótese nula é aceita, do contrário é rejeitada, isto é, a hipótese alternativa $\left(\mathrm{H}_{1}\right)$ é aceita, que afirma que nem todas as médias dos k tratamentos são iguais, pelo menos duas são diferentes.

No caso da hipótese nula ser rejeitada, é conveniente ter conhecimento sobre quais os tratamentos que serão iguais $\left(\mathrm{H}_{\mathrm{o}}: \mu_{\mathrm{i}}=\mu_{\mathrm{j}}\right)$ e quais os que serão diferentes $\left(\mathrm{H}_{1}: \mu_{\mathrm{i}} \neq \mu_{\mathrm{j}}\right)$, ou seja, contrastar os tratamentos, e para isto, faz-se necessário a realização de novos testes de hipótese. Com esta finalidade, foi utilizado o método da Diferença Menos Significativa (Least Significant Difference - LSD) (MONTGOMERY, 1997) e o teste $F^{1}$. No método da diferença menos significativa, dois tratamentos são considerados significativamente diferentes se:

\footnotetext{
${ }^{1}$ Conhecidos dois tratamentos com qualquer tamanho, o teste $\mathrm{F}$ dá embasamento para determinar se os dois tratamentos pertencem à mesma população, sendo o numerador para o cálculo de $\mathrm{F}_{\mathrm{o}}$, a variância do tratamento que apresentar maior variabilidade, assim $\mathrm{F}_{\mathrm{o}}$ será sempre maior que um.
} 
$\left|\mu_{i}-\mu_{j}\right|>t_{\alpha / 2, v_{2}} \sqrt{s_{d}{ }^{2}\left(\frac{1}{n_{i}}+\frac{1}{n_{j}}\right)}$

onde:

$\mu_{\mathrm{i}}$ e $\mu_{\mathrm{j}}$ - média, respectivamente, dos tratamento i e $\mathrm{j}$;

$\mathrm{t}_{\alpha / 2}, v_{2}$ - valor crítico da distribuição de Student (valor tabelado);

$\mathrm{s}_{\mathrm{d}}{ }^{2}$ - variabilidade (quadrado médio) dentro de tratamentos;

$\alpha$ - nível de significância;

$v_{2}$ - grau de liberdade dentro;

$\mathrm{n}_{\mathrm{i}}$ e $\mathrm{n}_{\mathrm{j}}$ - número de amostras, respectivamente, dos tratamentos $\mathrm{i}$ e $\mathrm{j}$.

Considerando a apresentação, análise e discussão dos resultados, inicialmente, exibem-se os resultados referentes à dosagem Marshall para as misturas, a saber: $5 \% \mathrm{AF}$ - composição de agregado com 5\% de areia de fundição, 10\%AF - com 10\% de areia de fundição, $15 \% \mathrm{AF}$ - com $15 \%$ de areia de fundição e da mistura que serve como referência, 10\%AV - com 10\% de areia virgem. Em seguida, são apresentados, analisados e discutidos os resultados dos ensaios que avaliam as propriedades mecânicas dessas misturas, como: cantabro, umidade induzida, resistência à tração por compressão diametral, módulo de resiliência por tração indireta e fluência por compressão uniaxial estática, em dois níveis de tensão (0,1 e 0,4 MPa). Para a tensão de 0,4 MPa, apresentam-se os resultados dos ensaios de fluência estática executados com as placas de apoio superiores normal (diâmetro do corpo-de-prova) e reduzida (diâmetro de $51 \mathrm{~mm})$.

Além das abordagens mencionadas anteriormente, exibem-se, também, as relativas aos ensaios de avaliação de risco ambiental: lixiviação, solubilização e massa bruta da areia de fundição utilizada, isoladamente, isto é, antes de sua inclusão na massa asfáltica e do material com a incorporação desta areia na situação mais desfavorável, no caso, o teor de $15 \%$. Os resultados dos ensaios de lixiviação, solubilização e massa bruta, para as areias de fundição e virgem, foram os executados pela BIOAGRI AMBIENTAL LTDA. Apresentam-se, como padrão (parâmetro de controle), os resultados dos ensaios ambientais para a areia virgem, isoladamente, e para a massa asfáltica com a inclusão desta areia no teor de $10 \%$.

A abordagem dos resultados da análise química no extrato do ensaio de lixiviação com extrator soxhlet, em corpo-de-prova de mistura asfáltica com 15\% de areia de 
fundição (5\% de vazios), é apresentada em cinco condições distintas a saber: com 12 (um dia), 84 (sete dias), 252 (21 dias), 540 (45 dias) e 1080 horas (90 dias) de lixiviação, enquanto os resultados da análise química no extrato oriundo da amostra de Cimento Asfáltico de Petróleo (CAP 20) são apresentados apenas em uma condição, sendo esta referente a 84 horas de ensaio (sete dias). Vale relembrar que, cada dia corresponde a 12 horas de condicionamento e 12 horas de repouso (equipamento desligado).

\subsection{Dosagem Marshall}

$\mathrm{Na}$ Tabela 5.01, são apresentados os valores das superfícies específicas e dos parâmetros Marshall e de outros originados destes, como: o coeficiente de suporte Marshall (CSM), superfície específica do agregado, considerando $1 \mathrm{~kg}$ de mistura asfáltica e a espessura da película asfáltica. A espessura da película asfáltica e a superfície específica do agregado $\left(\mathrm{m}^{2}\right)$ foram calculadas pelas expressões 5.02 e 5.03, respectivamente.

Tabela 5.01. Resultados da dosagem Marshall, superfície específica e espessura de película asfáltica

\begin{tabular}{|c|c|c|c|c|c|c|c|c|c|c|c|c|}
\hline \multirow{4}{*}{ Parâmetros } & \multicolumn{12}{|c|}{ Misturas } \\
\hline & \multicolumn{3}{|c|}{ 5\%AF } & \multicolumn{3}{|c|}{$10 \%$ AF } & \multicolumn{3}{|c|}{$15 \%$ AF } & \multicolumn{3}{|c|}{$10 \%$ AV } \\
\hline & \multicolumn{3}{|c|}{ Volume de vazios } & \multicolumn{3}{|c|}{ "Volume de vazios } & \multicolumn{3}{|c|}{ Volume de vazios } & \multicolumn{3}{|c|}{ Volume de vazios } \\
\hline & $3 \%$ & $4 \%$ & $5 \%$ & $3 \%$ & $4 \%$ & $5 \%$ & $3 \%$ & $4 \%$ & $5 \%$ & $3 \%$ & $4 \%$ & $5 \%$ \\
\hline $\mathrm{P}_{\text {asf }}(\%)$ & 5,50 & 5,20 & 4,90 & 6,00 & 5,50 & 5,10 & 6,50 & 6,00 & 5,80 & 5,85 & 5,30 & 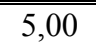 \\
\hline $\mathrm{D}_{\mathrm{t}}$ & 2,618 & 2,631 & 2,645 & 2,584 & 2,606 & 2,623 & 2,553 & 2,574 & 2,582 & 2,591 & 2,614 & 2,628 \\
\hline $\mathrm{D}_{\mathrm{ap}}$ & 2,540 & 2,526 & 2,513 & 2,506 & 2,502 & 2,492 & 2,483 & 2,476 & 2,453 & 2,513 & 2,509 & 2,497 \\
\hline $\mathrm{E}\left(10^{3} \mathrm{~N}\right)$ & 11,9 & 11,8 & 11,3 & 11,52 & 12,65 & 12,25 & 10,60 & 12,10 & 12,40 & 11,90 & 12,70 & 12,33 \\
\hline $\mathrm{F}\left(10^{-3} \mathrm{~m}\right)$ & 3,20 & 3,05 & 2,95 & 3,55 & 2,90 & 2,60 & 3,55 & 3,30 & 3,25 & 4,00 & 3,40 & 3,20 \\
\hline $\operatorname{CSM}\left(10^{4} \mathrm{~N} / \mathrm{m}\right)$ & 371,9 & 386,9 & 383,0 & 324,5 & 436,2 & 471,2 & 298,6 & 366,7 & 381,5 & 297,5 & 373,5 & 385,3 \\
\hline $\mathrm{V}_{\mathrm{b}}(\%)$ & 13,73 & 12,94 & 12,09 & 14,71 & 13,51 & 12,47 & 15,85 & 14,59 & 14,07 & 14,42 & 13,07 & 12,25 \\
\hline RBV (\%) & 82 & 76 & 71 & 83 & 77 & 71 & 84 & 78 & 74 & 83 & 77 & 71 \\
\hline VAM (\%) & 16,73 & 16,94 & 17,09 & 17,71 & 17,51 & 17,47 & 18,85 & 18,59 & 19,07 & 17,42 & 17,07 & 17,25 \\
\hline$S\left(\mathrm{~m}^{2} / \mathrm{kg}\right)$ & 11,43 & 11,43 & 11,43 & 12,68 & 12,68 & 12,68 & 13,83 & 13,83 & 13,83 & 12,68 & 12,68 & 12,68 \\
\hline$S_{a}\left(\mathrm{~m}^{2}\right)$ & 10,80 & 10,84 & 10,87 & 11,92 & 11,98 & 12,03 & 12,93 & 13,00 & 13,03 & 11,94 & 12,00 & 12,05 \\
\hline$E P A^{*}(\mu \mathrm{m})$ & 5,00 & 4,71 & 4,29 & 4,95 & 4,51 & 4,16 & 4,94 & 4,53 & 4,37 & 4,81 & 4,34 & 4,08 \\
\hline
\end{tabular}

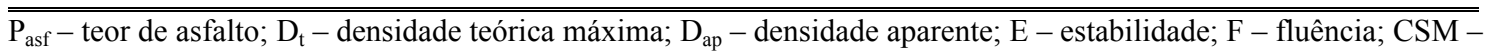
coeficiente de suporte Marshall; $\mathrm{V}_{\mathrm{b}}$ - volume de vazios preenchido por cimento asfáltico; RBV - relação betume/vazios; VAM - vazios do agregado mineral; EPA - espessura da película asfáltica $\left(\mu \mathrm{m}=10^{-6} \mathrm{~m}\right)$; $\mathrm{S}$ superfície específica da combinação de agregado; $S_{a}$ - superfície específica do agregado, considerando $1 \mathrm{~kg}$ de mistura asfáltica. 


$$
\begin{aligned}
& E P A=\frac{M_{a s f}}{\delta_{a s f} \times S_{a}} \times 10^{6} \\
& S_{a}=M_{a g} \times S
\end{aligned}
$$

onde:

EPA- espessura da película asfáltica $(\mu \mathrm{m}) ;$

$M_{a s f}$ - massa de asfalto, considerando $1 \mathrm{~kg}$ de mistura asfáltica $(\mathrm{kg})$;

$\delta_{a s f}$ - massa específica do asfalto $\left(\mathrm{kg} / \mathrm{m}^{3}\right)$;

$S_{a}$ - superfície específica do agregado, considerando $1 \mathrm{~kg}$ de mistura asfáltica $\left(\mathrm{m}^{2}\right)$;

$M_{a g-}$ massa de agregado, considerando $1 \mathrm{~kg}$ de mistura asfáltica $(\mathrm{kg})$;

$S$ - superfície específica da combinação de agregado $\left(\mathrm{m}^{2} / \mathrm{kg}\right)$.

Os resultados das dosagens Marshall encontram-se nas tabelas A.01 a A.04 do Apêndice A (página 198) e os gráficos, referentes aos parâmetros desses ensaios, podem ser visualizados nas Figuras A.01 a A.04 desse anexo.

Nos resultados da dosagem Marshall (Tabela 5.01) pode ser verificado que os teores de asfalto são maiores para as misturas com maior teor de areia, seja de fundição ou virgem, isto acontece pelo fato dos teores de finos e fíler aumentarem com o teor de areia (Tabelas 4.04 a 4.07). Entretanto, considerando as misturas 10\%AF e 10\% AV (mistura de referência), que apresentam o mesmo teor de areia e teoricamente o mesmo teor de finos e fíler (7,25\% de material passando na peneira $0,074 \mathrm{~mm})$, observa-se que os teores de asfalto são ligeiramente maiores para as misturas com areia de fundição, considerando os três volumes de vazios estudados. Essas diferenças, conforme a análise de variância, não são estatisticamente significantes, contudo, acredita-se decorrer do fato da areia de fundição apresentar em sua superfície uma fina camada de pó, originada da combustão da resina fenólica, no caso desta pesquisa, exigindo, portanto, um maior consumo de asfalto.

Considerando como teor ótimo de asfalto o encontrado para o volume de vazios $4 \%$, assim, todas as misturas apresentam valores dos parâmetros Marshall acima dos especificadas para as misturas asfálticas para camada de rolamento (DNER-ES 313/97).

\subsection{Cantabro (NLT 325/86)}

Os resultados dos ensaios cantabro são referentes a todas as misturas $(10 \%$ de areia virgem, 5, 10 e 15\% de areia de fundição), sem envelhecimento e nos teores de vazios 
de 3, 4 e 5\%. As Tabelas 5.02, 5.03, 5.04 e 5.05 apresentam os resultados destes ensaios, para as misturas com 5, 10 e 15\% de areia de fundição e com 10\% de areia virgem, respectivamente. Alguns valores foram descartados por diferirem da média em mais ou em menos de $20 \%$.

Tabela 5.02. Resultados do ensaio cantabro - misturas com 5\% de areia de fundição

\begin{tabular}{|c|c|c|c|c|c|c|c|c|c|c|}
\hline $\begin{array}{l}\text { Corpos- } \\
\text { de-prova }\end{array}$ & $\begin{array}{c}\mathrm{T}_{\text {inicial }} \\
\left({ }^{\circ} \mathrm{C}\right)\end{array}$ & $\begin{array}{c}M_{\text {inicial }} \\
(\mathrm{g})\end{array}$ & $\begin{array}{c}M_{\text {final }} \\
(\mathrm{g})\end{array}$ & $\begin{array}{l}\mathrm{T}_{\text {final }} \\
\left({ }^{\circ} \mathrm{C}\right)\end{array}$ & $\begin{array}{l}\mathrm{Vv} \\
(\%)\end{array}$ & $\begin{array}{c}\mathrm{V}_{\mathrm{V}_{\text {médio }}} \\
(\%)\end{array}$ & $\begin{array}{l}\mathrm{P}_{\text {asf }} \\
(\%)\end{array}$ & $\begin{array}{c}\mathrm{P} \\
(\%)\end{array}$ & $\begin{array}{c}\mathrm{P}_{\text {média }} \\
(\%)\end{array}$ & $\begin{array}{l}\mathrm{t}_{\text {cond.. }} \\
\text { (min) }\end{array}$ \\
\hline 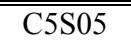 & 24 & 1246,52 & 11154,84 & 23 & "4,36 & \multirow{4}{*}{4,41} & \multirow{4}{*}{4,90} & 7,35 & \multirow{4}{*}{7,85} & 1206 \\
\hline $\mathrm{C} 5 \mathrm{~S} 01$ & 24 & 1246,10 & 1133,10 & 23 & 4,42 & & & 9,07 & & 1222 \\
\hline C5S15 & 24 & 1253,21 & 1095,92 & 23 & 4,39 & & & $12,55^{*}$ & & 1238 \\
\hline C5S04 & 24 & 1250,27 & 1161,09 & 23 & 4,44 & & & 7,13 & & 1254 \\
\hline $\mathrm{C} 4 \mathrm{~S} 16$ & 24 & 1247,53 & 1121,01 & 24 & 3,76 & \multirow{4}{*}{4,01} & \multirow{4}{*}{5,20} & $10,14^{*}$ & \multirow{4}{*}{7,72} & 1270 \\
\hline $\mathrm{C} 4 \mathrm{~S} 15$ & 24 & 1249,65 & 1141,80 & 23 & 3,73 & & & 8,63 & & 1286 \\
\hline $\mathrm{C} 4 \mathrm{~S} 02$ & 24 & 1249,00 & 1145,27 & 24 & 4,27 & & & 8,31 & & 1302 \\
\hline $\mathrm{C} 4 \mathrm{~S} 01$ & 24 & 1241,67 & 1164,48 & 24 & 4,28 & & & 6,22 & & 1318 \\
\hline $\mathrm{C} 3 \mathrm{~S} 02$ & 24 & 1242,83 & 1159,39 & 24 & 3,06 & \multirow{4}{*}{3,03} & \multirow{4}{*}{5,50} & 6,71 & \multirow{4}{*}{6,25} & 1334 \\
\hline $\mathrm{C} 3 \mathrm{~S} 01$ & 24 & 1248,43 & 1171,35 & 24 & 3,08 & & & 6,17 & & 1350 \\
\hline $\mathrm{C} 3 \mathrm{~S} 16$ & 24 & 1234,73 & 1162,25 & 24 & 2,95 & & & 5,87 & & 1366 \\
\hline $\mathrm{C} 3 \mathrm{~S} 12$ & 24 & 1246,98 & 1126,18 & 24 & 2,88 & & & $9,69^{*}$ & & 1382 \\
\hline
\end{tabular}

Tabela 5.03. Resultados do ensaio cantabro - misturas com 10\% de areia de fundição

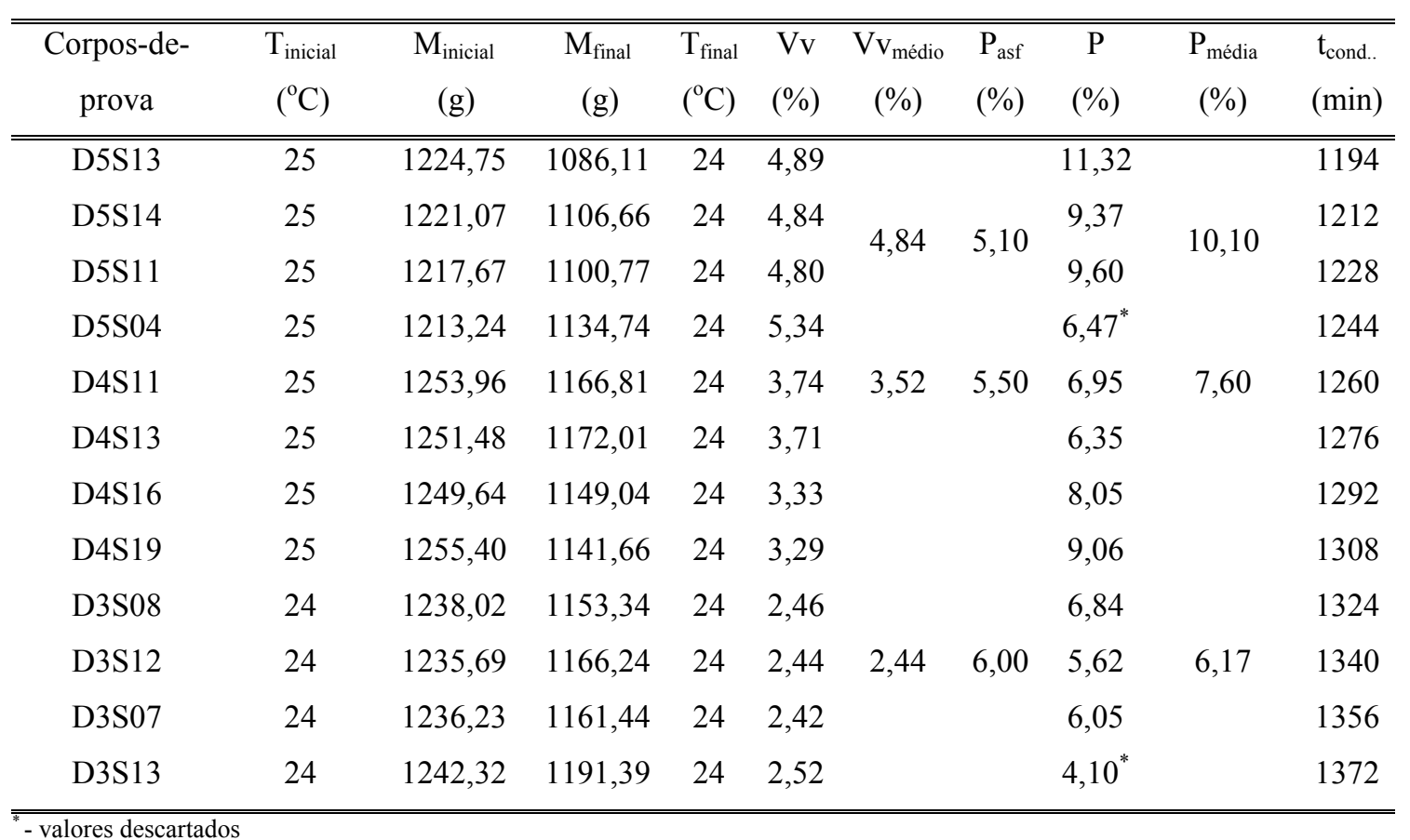


Tabela 5.04. Resultados do ensaio cantabro - misturas com 15\% de areia de fundição

\begin{tabular}{|c|c|c|c|c|c|c|c|c|c|c|}
\hline $\begin{array}{l}\text { Corpos- } \\
\text { de-prova }\end{array}$ & $\begin{array}{l}\mathrm{T}_{\text {inicial }} \\
\left({ }^{\circ} \mathrm{C}\right)\end{array}$ & $\begin{array}{c}\mathrm{M}_{\text {inicial }} \\
(\mathrm{g})\end{array}$ & $\begin{array}{c}\mathrm{M}_{\text {final }} \\
(\mathrm{g})\end{array}$ & $\begin{array}{l}\mathrm{T}_{\text {final }} \\
\left({ }^{\circ} \mathrm{C}\right)\end{array}$ & $\begin{array}{l}\mathrm{Vv} \\
(\%)\end{array}$ & $\begin{array}{c}\mathrm{VV}_{\text {médio }} \\
(\%)\end{array}$ & $\begin{array}{l}\mathrm{P}_{\text {asf }} \\
(\%)\end{array}$ & $\begin{array}{c}\mathrm{P} \\
(\%)\end{array}$ & $\begin{array}{c}\mathrm{P}_{\text {média }} \\
(\%)\end{array}$ & $\begin{array}{l}t_{\text {cond.. }} \\
(\min )\end{array}$ \\
\hline $\begin{array}{l}\text { Q5S07 } \\
\end{array}$ & 25 & 1242,87 & 11154,51 & 24 & $\bar{~} 5,10$ & \multirow{5}{*}{5,07} & \multirow{4}{*}{5,80} & 7,11 & \multirow{4}{*}{6,90} & 1068 \\
\hline Q5S08 & 25 & 1246,29 & 1160,09 & 25 & 5,12 & & & 6,92 & & 1084 \\
\hline Q5S09 & 25 & 1244,67 & 1159,54 & 25 & 4,92 & & & 6,84 & & 1100 \\
\hline Q5S10 & 25 & 1244,39 & 1160,64 & 24 & 5,14 & & & 6,73 & & 1116 \\
\hline Q4S07 & 25 & 1245,49 & 1178,83 & 24 & 3,47 & & \multirow{4}{*}{6,00} & 5,35 & \multirow{4}{*}{4,86} & 940 \\
\hline Q4S17 & 25 & 1242,84 & 1157,34 & 24 & 3,26 & \multirow{3}{*}{3,37} & & $6,88^{*}$ & & 956 \\
\hline Q4S13 & 25 & 1245,05 & 1191,54 & 24 & 3,41 & & & 4,30 & & 972 \\
\hline Q4S16 & 25 & 1240,03 & 1178,75 & 24 & 3,23 & & & 4,94 & & 988 \\
\hline Q3S09 & 24 & 1238,19 & 1185,45 & 24 & 2,52 & \multirow{4}{*}{2,44} & \multirow{4}{*}{6,50} & 4,26 & \multirow{4}{*}{4,15} & 1004 \\
\hline Q3S16 & 25 & 1245,01 & 1177,65 & 24 & 2,47 & & & $5,41^{*}$ & & 1020 \\
\hline Q3S11 & 25 & 1236,91 & 1189,98 & 25 & 2,39 & & & 3,79 & & 1036 \\
\hline Q3S08 & 24 & 1239,78 & 1185,17 & 25 & 2,40 & & & 4,40 & & 1052 \\
\hline
\end{tabular}

- valores descartados

Tabela 5.05. Resultados do ensaio cantabro - misturas com $10 \%$ de areia virgem

\begin{tabular}{|c|c|c|c|c|c|c|c|c|c|c|}
\hline $\begin{array}{l}\text { Corpos- } \\
\text { de-prova }\end{array}$ & $\begin{array}{l}\mathrm{T}_{\text {inicial }} \\
\left({ }^{\circ} \mathrm{C}\right)\end{array}$ & $\begin{array}{c}M_{\text {inicial }} \\
(\mathrm{g})\end{array}$ & $\begin{array}{c}M_{\text {final }} \\
(\mathrm{g})\end{array}$ & $\begin{array}{l}\mathrm{T}_{\text {final }} \\
\left({ }^{\circ} \mathrm{C}\right)\end{array}$ & $\begin{array}{l}\mathrm{Vv} \\
(\%)\end{array}$ & $\begin{array}{c}\mathrm{VV}_{\text {médio }} \\
(\%)\end{array}$ & $\begin{array}{l}\mathrm{P}_{\text {asf }} \\
(\%)\end{array}$ & $\begin{array}{c}\mathrm{P} \\
(\%)\end{array}$ & $\begin{array}{c}\mathrm{P}_{\text {média }} \\
(\%)\end{array}$ & $\begin{array}{l}\mathrm{t}_{\text {cond.. }} \\
\text { (min) }\end{array}$ \\
\hline T5S15 & 25 & 1249,45 & 1150,29 & 24 & 5,49 & \multirow{4}{*}{5,21} & \multirow{4}{*}{5,00} & 7,94 & \multirow{4}{*}{7,60} & 1278 \\
\hline T5S16 & 25 & 1249,78 & 1164,73 & 24 & 4,46 & & & 6,80 & & 1294 \\
\hline T5S02 & 25 & 1247,51 & 1158,39 & 24 & 5,54 & & & 7,14 & & 1310 \\
\hline T5S05 & 25 & 1246,25 & 1139,94 & 24 & 5,33 & & & 8,53 & & 1326 \\
\hline T4S03 & 25 & 1249,95 & 1158,61 & 24 & 4,47 & \multirow{4}{*}{4,45} & \multirow{4}{*}{5,30} & 7,31 & \multirow{4}{*}{6,92} & 1214 \\
\hline T4S09 & 25 & 1245,17 & 1170,94 & 24 & 4,47 & & & 5,96 & & 1230 \\
\hline T4S01 & 25 & 1243,49 & 1147,32 & 24 & 4,41 & & & 7,73 & & 1246 \\
\hline $\mathrm{T} 4 \mathrm{~S} 02$ & 25 & 1256,22 & 1172,22 & 24 & 4,44 & & & 6,69 & & 1262 \\
\hline T3S16 & 25 & 1250,05 & 1178,43 & 24 & 2,77 & \multirow{4}{*}{2,98} & \multirow{4}{*}{5,85} & 5,73 & \multirow{4}{*}{5,57} & 1342 \\
\hline T3S02 & 25 & 1247,24 & 1183,38 & 24 & 3,23 & & & 5,12 & & 1358 \\
\hline T3S11 & 25 & 1244,58 & 1170,77 & 24 & 3,12 & & & 5,93 & & 1374 \\
\hline T3S09 & 25 & 1239,84 & 1171,44 & 24 & 2,81 & & & 5,52 & & 1390 \\
\hline
\end{tabular}

Os gráficos das Figuras 5.01 e 5.02 apresentam, respectivamente, a perda de massa em função do volume de vazios e do teor de asfalto para as misturas supracitadas. Ressalta-se que os teores de vazios utilizados foram os obtidos (valores médios) e não os projetados (3, 4 e 5\%) como pode ser verificado nas Tabelas 5.02 a 5.05 . 


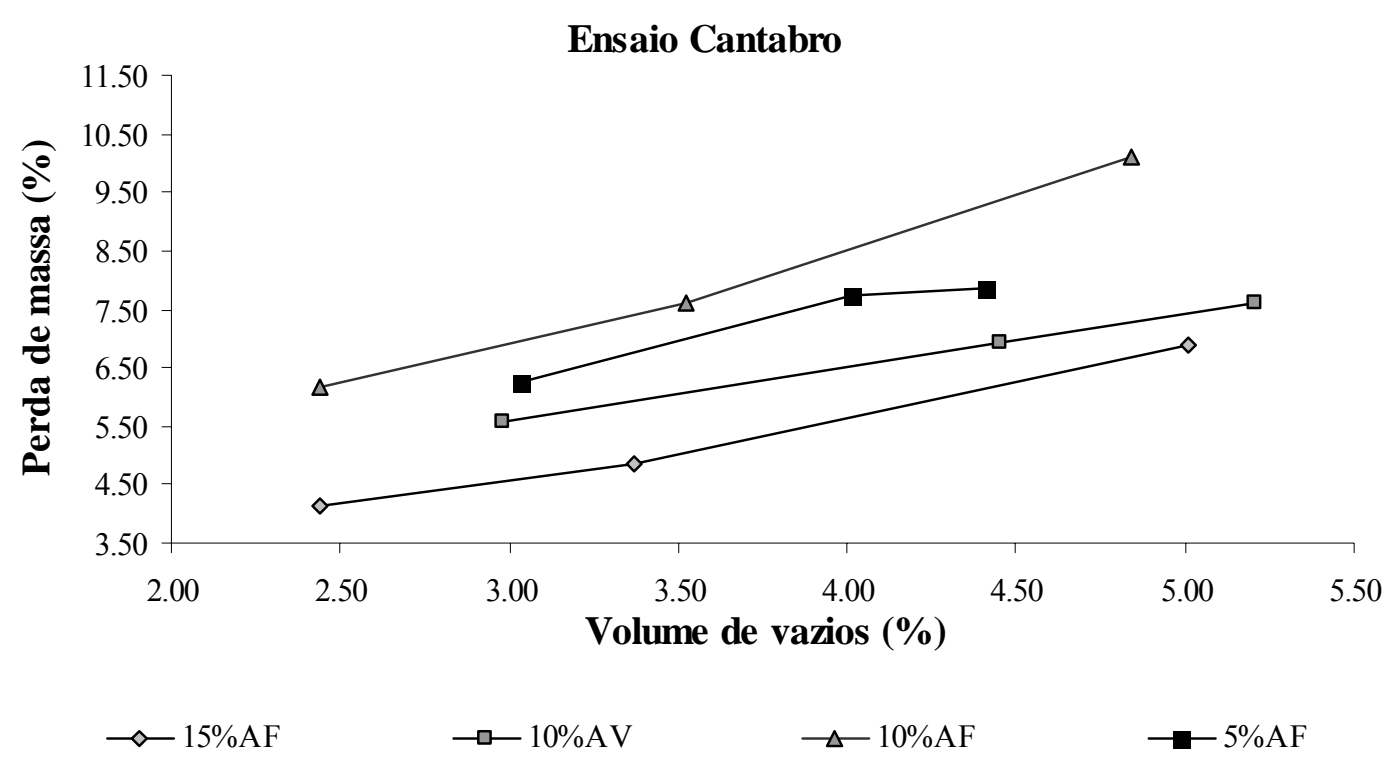

Figura 5.01. Perda de massa versus volume de vazios

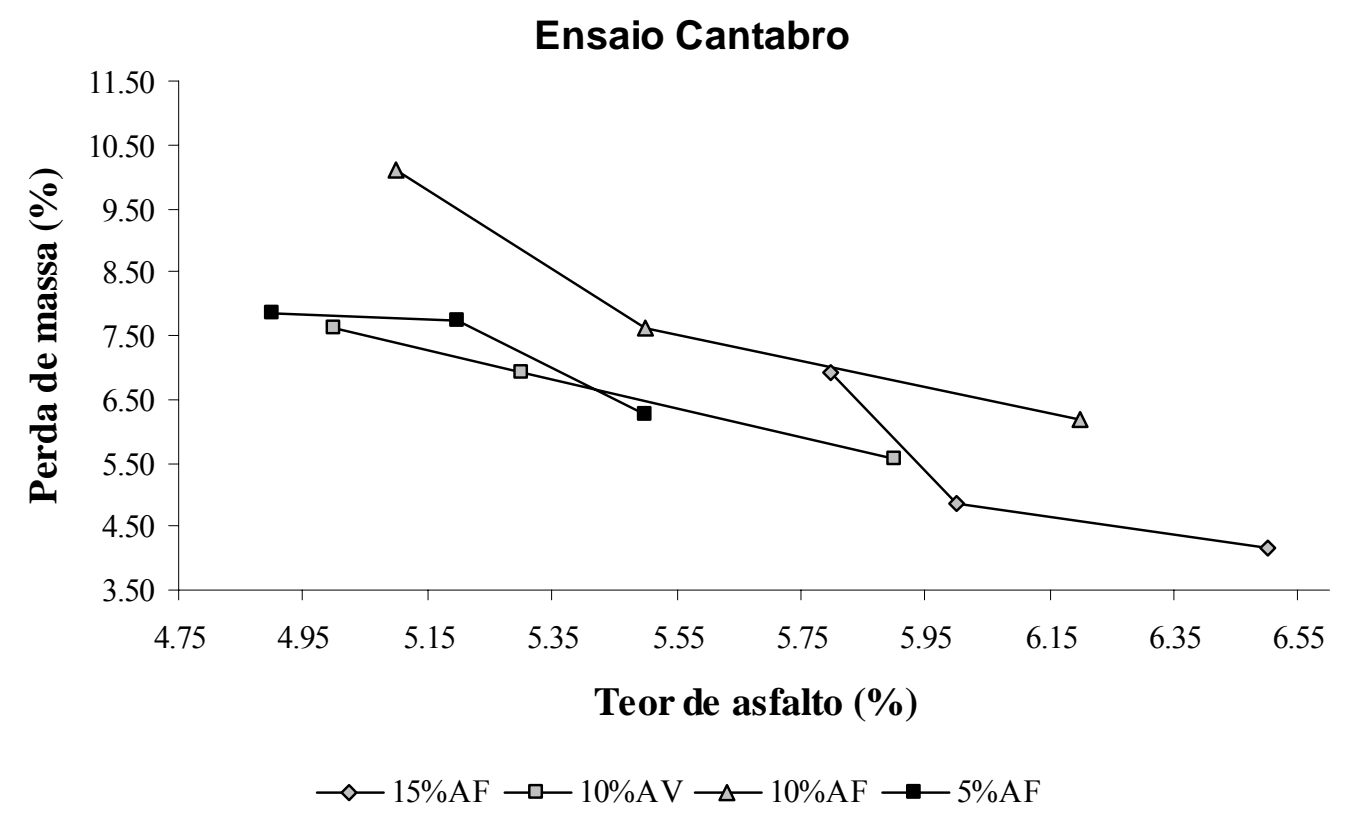

Figura 5.02. Perda de massa versus teor de asfalto

Considerando as misturas com 10\% de areia virgem e com 10\% de areia de fundição no ensaio Cantabro (Tabelas 5.02 a 5.05 e gráficos das Figuras 5.01 e 5.02), as misturas com areia de fundição apresentam maior desgaste que as de referência $(10 \%$ de areia virgem). O maior valor de perda de massa para a mistura com $10 \%$ de areia de fundição é de $10,10 \%$ (teor de asfalto de $5,10 \%$ e $\mathrm{Vv}$ médio de 4,84\%), enquanto o maior desgaste para a de referência é de 7,60\% (teor de asfalto de 5,00\% e Vv médio de 
5,21\%). As misturas com 10\% de areia de fundição, mesmo apresentando maior teor de asfalto que as misturas com $10 \%$ de areia virgem, apresentam maior desgaste.

A análise de variância, realizada entre as misturas com 10\% de areia de fundição e a de referência, concluiu que as diferenças entre as perdas de massa, considerando a média dos três teores de vazios ( 3,4 e 5), não são estatisticamente significantes.

Como podem ser observadas, nas Tabelas e gráficos das Figuras anteriormente citadas, as perdas de massa diminuem com o aumento do teor de asfalto e, conseqüentemente, aumentam com o teor de vazios, conforme o esperado. Para as misturas com 5\% de areia de fundição a influência do teor de asfalto no desgaste da mistura (Tabela 5.02) não é estatisticamente significante, enquanto para as misturas com 10 e 15\% de areia de fundição, foi detectada interferência do teor de asfalto na perda de massa, somente para as análises de variância entre os teores de asfalto referentes a $5 \%$ e a $4 \%$ de vazios e entre os referentes a 5 e $3 \%$ de vazios. Para as misturas com $10 \%$ de areia virgem há influência do teor de asfalto nos desgastes referentes a 5 e $3 \%$ de vazios e entre 4 e $3 \%$ de vazios.

Pôde-se verificar também, por meio da análise de variância, que o teor de areia $(5,10$ e $15 \%$ de areia de fundição e $10 \%$ de areia virgem), considerando a perda média para os três teores de vazios, não interfere significativamente na perda de massa das misturas abordadas neste trabalho.

Os resultados de perda de massa (Tabelas 5.02 a 5.05) se mostram compatíveis com os encontrados na literatura para misturas asfálticas densas, considerando o teor de asfalto correspondente a $4 \%$ de volume de vazios. O maior desgaste, 7,72\% (teor de asfalto - 5,20\% e Vv médio de 4.01\%), é o da mistura com 5\% de areia de fundição e o menor, $4,86 \%$ (teor de asfalto - 6,00\% e Vv médio de 3,37\%), para a mistura com $15 \%$ de areia de fundição. A mistura com $15 \%$ de areia de fundição (15\%AF) apresenta maior teor de asfalto $(6,00 \%)$, fíler $(7,75 \%)$ e agregado fino $(56,80 \%)$ que a mistura com $5 \%$ de $\mathrm{AF}$, que são, respectivamente, $5,20 \%, 6,75 \%$ e $41,35 \%$.

Os resultados obtidos por Pérez-Jimenez (1990) indicaram que o ensaio Cantabro é particularmente sensível ao teor de ligante, de fíler e de agregado fino, que são os parâmetros que proporcionam a coesão e a resistência à desagregação das misturas, sendo o teor de ligante o mais influente, principalmente para teores baixos; com o aumento do teor, o efeito sobre a coesão vai diminuindo. A mistura com $15 \%$ de areia de fundição parece retratar o que acontece com influência do teor de asfalto sobre a perda de massa (Figura 5.02). 
A influência desses parâmetros (teor de ligante, fíler e agregado fino) pode ser observada também nesta pesquisa (Tabelas 4.04 a 4.07 e 5.02 a 5.05),ou seja, quanto maior os teores destes, menor a perda de massa, principalmente no que diz respeito ao teor de asfalto correspondente a $4 \%$ de volume de vazios nominal. Verifica-se, nas Tabelas 4.04 a 4.05, que o teor de fíno é de 41,35, 49,08 e 56,80\%, e fíler de 6,75, 7,25 e 7,75\%, respectivamente, para as mistura com 5, 10 e 15\% de areia de fundição; as misturas com $10 \%$ de areia virgem apresentam o mesmo teor de finos e fíler das misturas com $10 \%$ de areia de fundição.

A título de exemplo, para pré-misturado a quente com asfalto polímero - camada porosa de atrito, a norma (DNER-ES 386/99) estabelece um desgaste de no máximo $25 \%$, contudo o volume de vazios destas misturas deve estar entre 18 e $25 \%$.

\subsection{Dano por Umidade Induzida (AASHTO T 283-99)}

Os resultados dos ensaios de dano por umidade induzida dizem respeito às misturas $5 \% \mathrm{AF}$ e $15 \% \mathrm{AF}$, com $4 \%$ de vazios e às misturas $10 \% \mathrm{AF}$ e $10 \% \mathrm{AV}$ com $4 \%$ e $7 \%$ de volumes de vazios nominais e sem envelhecimento. Este ensaio foi conduzido na condição sem envelhecimento, pois o condicionamento em estufa a $60^{\circ} \mathrm{C}$ por 16 horas simula o envelhecimento a curto prazo (Colorado Procedure L 5109) e o método prediz a susceptibilidade ao descolamento a longo prazo. Os resultados de resistência à tração dos corpos-de-prova condicionados e dos não condicionados, no ensaio de umidade induzida, podem ser visualizados no gráfico da Figura 5.03. A relação entre a resistência dos corpos-de-prova condicionados e não condicionados podem ser avaliadas no gráfico da Figura 5.04.

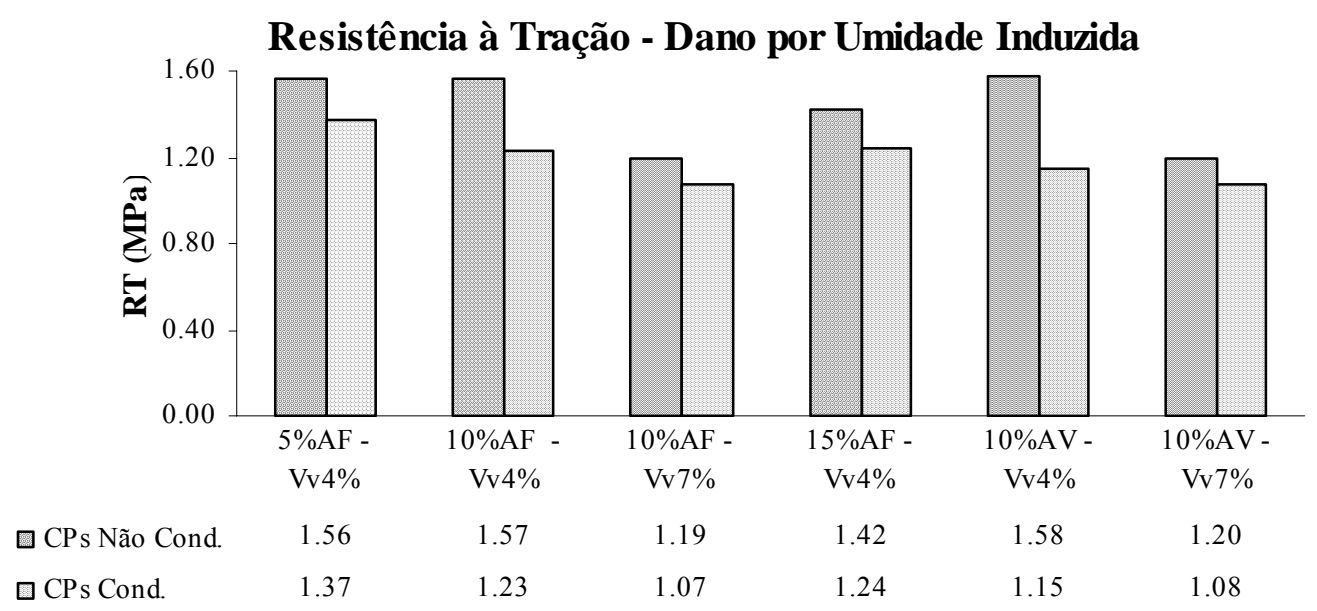

Figura 5.03. Resistências à tração dos corpos-de-prova condicionados e não condicionados - ensaios de dano por umidade induzida 


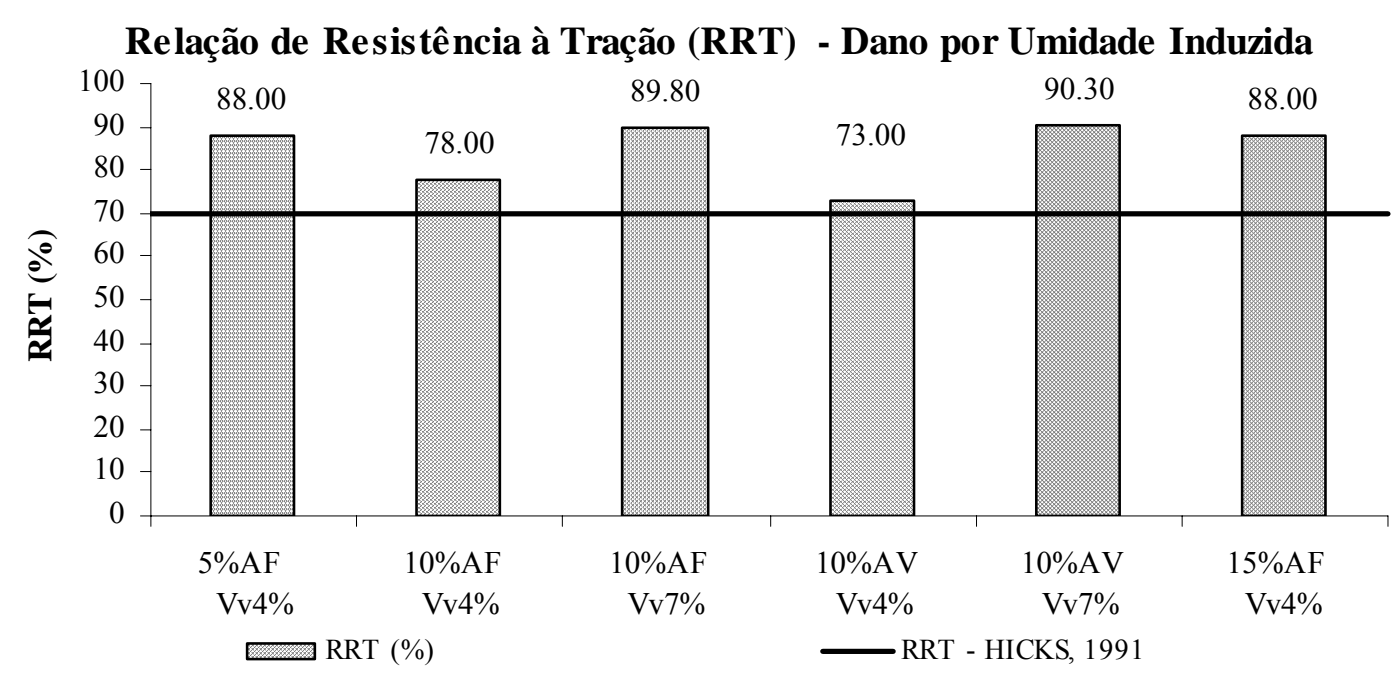

Figura 5.04. Relações de resistência à tração dos ensaios de dano por umidade induzida

Os volumes de vazios médios para os corpos-de-prova das misturas 5\% AF e 15\%AF, utilizados nos ensaio de umidade induzida, foram, respectivamente, 3,83\% e 3,73\% e para as misturas $10 \% \mathrm{AF}$ e $10 \% \mathrm{AV}$, para o volume de vazios nominal de $4 \%$, foram, respectivamente, $4,36 \%$ e $4,40 \%$ e no teor nominal de $7 \%$, foram, respectivamente, $7,58 \%$ e $7,87 \%$.

No gráfico da Figura 5.05, pode-se verificar os resultados de resistência à tração para os corpos-de-prova moldados para o ensaio de umidade induzida e para os moldados para o ensaio de resistência à tração nas condições normais (Marshall). Estes valores referem-se ao teor de 4\% de vazios para as misturas estudadas nas seguintes condições: umidade induzida dos corpos-de-prova não condicionados (U.I - S/C), sem envelhecimento (S.E), com envelhecimento a curto prazo (E.C.P), com envelhecimento a longo prazo (E.L.P) e com envelhecimento a curto e a longo prazos (E.C.L.P) para as condições normais de moldagem.

As Tabelas (B.01 a B.06) com todos os dados referentes aos ensaios de umidade induzidas podem ser observados no Apêndice B (página 207). Nestas Tabelas podem ser verificados, entre outros, as características geométrica dos corpos-de-prova, volume de vazios, carga de ruptura, o tempo e a pressão necessários para a saturação dos corpos-de-prova condicionados, bem como o grau de saturação. 


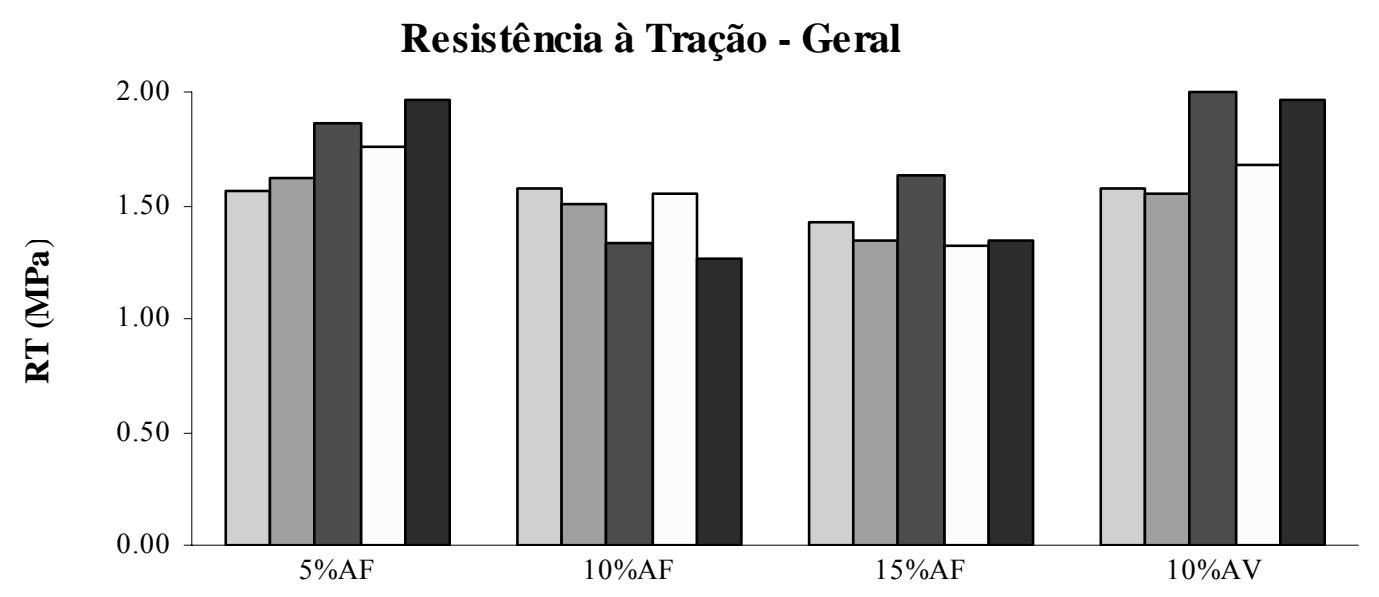

$\begin{array}{lllll}\square \text { RT - Não cond. } & 1.56 & 1.57 & 1.42 & 1.58 \\ \square \text { RT - S.E } & 1.62 & 1.51 & 1.34 & 1.55 \\ \square \text { RT - E.C. P } & 1.86 & 1.33 & 1.63 & 2.00 \\ \square \text { RT - E. L. P } & 1.76 & 1.55 & 1.32 & 1.68 \\ \square \text { RT - E.C.L.P } & 1.97 & 1.27 & 1.34 & 1.96\end{array}$

Figura 5.05. Resistências à tração dos corpos-de-prova não condicionados no ensaio de umidade induzida e dos corpos-de-prova no ensaio de tração indireta (normal)

Estes resultados mostram que as relações da resistência à tração (RRT) para todas as misturas, sejam com 4 ou 7\% de volume de vazios, são superiores a 70\% (gráficos da Figura 5.04), portanto, consideradas de boa qualidade, quanto à adesividade (HICKS, 1991). Nos ensaios realizados em corpos-de-prova com Vv nominal de 4\%, o melhor resultado (88\%) é para a mistura com $15 \%$ de areia de fundição, sendo ligeiramente menor (87\%) para a mistura com 5\% de areia de fundição, um valor intermediário para a mistura com $10 \%$ de areia de fundição (78\%), enquanto o menos favorável foi apresentado pela mistura de referência $(10 \% \mathrm{AV})$. Vale ressaltar que a porcentagem de saturação da mistura com $15 \%$ de areia de fundição foi inferior $\left(\mathrm{S}_{15 \% \mathrm{AF}}=34,46 \%\right)$ ao estipulado pela norma que é de 55\%.

Os melhores resultados para as misturas com areia de fundição, considerando as misturas com 5 e 10\%, talvez sejam em conseqüência dela apresentar substâncias que podem melhorar a interação asfalto/agregado, como ferro, cálcio, magnésio e alumínio, e também uma textura ligeiramente mais rugosa. $O$ que pode ser observado, desconsiderando o resultado da mistura com $15 \% \mathrm{AF}$ por razões expostas anteriormente, é que o próprio teor de areia (maior teor de sílica), de fundição ou virgem, parece influenciar na adesividade. 
As misturas com areia virgem e de fundição (10\%AV e 10\%AF) apresentam, aproximadamente, a mesma RRT, considerando os ensaios de dano por umidade induzida em corpos-de-prova com Vv nominal de 7\%, igual a 90\% (Figura 5.04). Este resultado é contrário às expectativas, visto que eram esperados valores mais desfavoráveis que os encontrados para o volume de vazios nominal de 4\% (73 e 78\%, respectivamente, para a areia virgem e de fundição), pois o volume de água absorvido é maior. As porcentagens de saturação foram maiores para o $\mathrm{Vv}$ de $7 \%\left(\mathrm{~S}_{10 \% \mathrm{AV}}=65,98 \%\right.$ e $\left.\mathrm{S}_{10 \% \mathrm{AF}}=61,81 \%\right)$ do que para o $\mathrm{Vv}$ de $4 \%$ (55,62 e 56,02\%, respectivamente).

Acredita-se que a explicação para esse resultado não esperado seja o fato dos corposde-prova com 7\% de vazios apresentarem maior volume de vazios interconectados, facilitando a migração da água para outros vazios (expansão) na fase de congelamento, diminuindo, desta forma, o efeito deletério na interação asfalto/agregado. Ou ainda, a facilidade de saturação neste teor pode diminuir o efeito da pressão de sucção nesta interação.

O estudo estatístico (ANOVA) realizado com os resultados dos ensaios de dano por umidade induzida, para Vv nominal de 4\%, indicou que o condicionamento interferiu significativamente na Resistência à Tração (RT) de quase todas as misturas, visto que as médias de resistência antes e após o condicionamento são expressivamente diferentes entre si $\left(5 \% \mathrm{AF}-\alpha_{0}=0,36 \%, 10 \% \mathrm{AF}-\alpha_{0}=0,27 \%\right.$ e $\left.10 \% \mathrm{AV}-\alpha_{0}=0,09 \%\right)$. No entanto, para a mistura com $15 \%$ de areia de fundição (15\%AF), o condicionamento não interferiu significativamente na RT, apresentando $\alpha_{0}=10,23 \%$. Isto deve ter ocorrido em conseqüência da saturação $\left(\mathrm{S}_{15 \% \mathrm{AF}}=34,46 \%\right)$ não ter atendido à faixa de variação da norma, que é de 55 a 80\% (AASHTO T 283/99). No caso dos ensaios com Vv nominal de $7 \%$, realizado apenas para as misturas com $10 \%$ de AF e com $10 \%$ de AV, o condicionamento interferiu expressivamente na RT $\left(10 \% \mathrm{AF}-\alpha_{\mathrm{o}}=1,30 \%\right.$ e $10 \% \mathrm{AV}$ $\left.\alpha_{0}=4,18 \%\right)$.

Com a análise de variância também foi possível detectar que o teor de areia de fundição não interfere na relação de resistência à tração $\left(\alpha_{0}=6,07 \%\right)$, considerando as misturas com 5 e 10\% deste resíduo e que a natureza da areia, se de fundição ou virgem, no teor de $10 \%$ na mistura, não interfere nesta resposta $\left(\mathrm{Vv}=4 \%-\alpha_{0}=24,13 \%\right.$ e $\mathrm{Vv}=7 \%-\alpha_{\mathrm{o}}=57,38 \%$ ).

As médias das resistências à tração dos corpos-de-prova não condicionados, no ensaio de dano por umidade induzida com Vv 4\%, não são significativamente diferentes $\left(\alpha_{0}=77,14 \%\right)$ das médias de resistência à tração do ensaio usual (DNER-ME 138/94) 
para as condições de envelhecimento estudadas nesta pesquisa. Entretanto, a menor diferença $(0,0275)$ entre as médias de resistências à tração é entre os corpos-de-prova não condicionados (dano por umidade induzida) e sem envelhecimento (ensaio usual) (gráficos da Figura 5.05).

\subsection{Resistência à Tração por Compressão Diametral (DNER-ME 138/94)}

Os resultados do ensaio de resistência à tração são relativos às misturas $(5 \% \mathrm{AF}$, $10 \% \mathrm{AF}, 15 \% \mathrm{AF}$ e $10 \% \mathrm{AV}$ ) em todas as condições de envelhecimento (sem envelhecimento, com envelhecimento a curto prazo, com envelhecimento a longo prazo e com ambos os envelhecimentos) para o volume de vazio de $4 \%$ e para os volumes de 3 e $5 \%$ (projetados) somente na condição sem envelhecimento. Estes resultados podem ser observados nos gráficos da Figura 5.06 (sem envelhecimento - volumes de vazios reais médios) e 5.07 (sem envelhecimento - teores de asfalto para 3, 4 e 5\% projetados) e da Figura 5.08 (em todas as condições de envelhecimento - volume de vazios projetado de $4 \%$ ).

Os dados (condições experimentais, carga, tensão, temperatura, volumes de vazios unitários, volumes de vazios médios, geometria dos corpos-de-prova e outros) referentes aos ensaios de tração são apresentados na Tabela B.07 do Apêndice B (página 207).

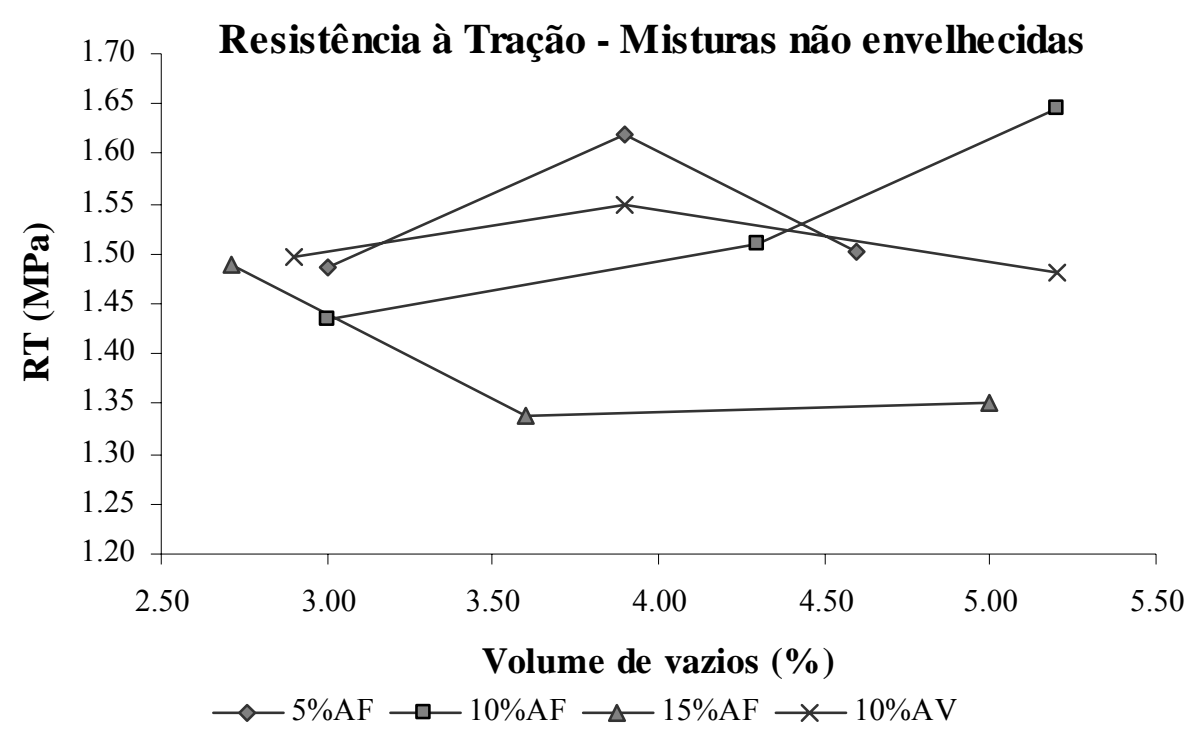

Figura 5.06. Resistência à tração versus volume de vazios reais médios 


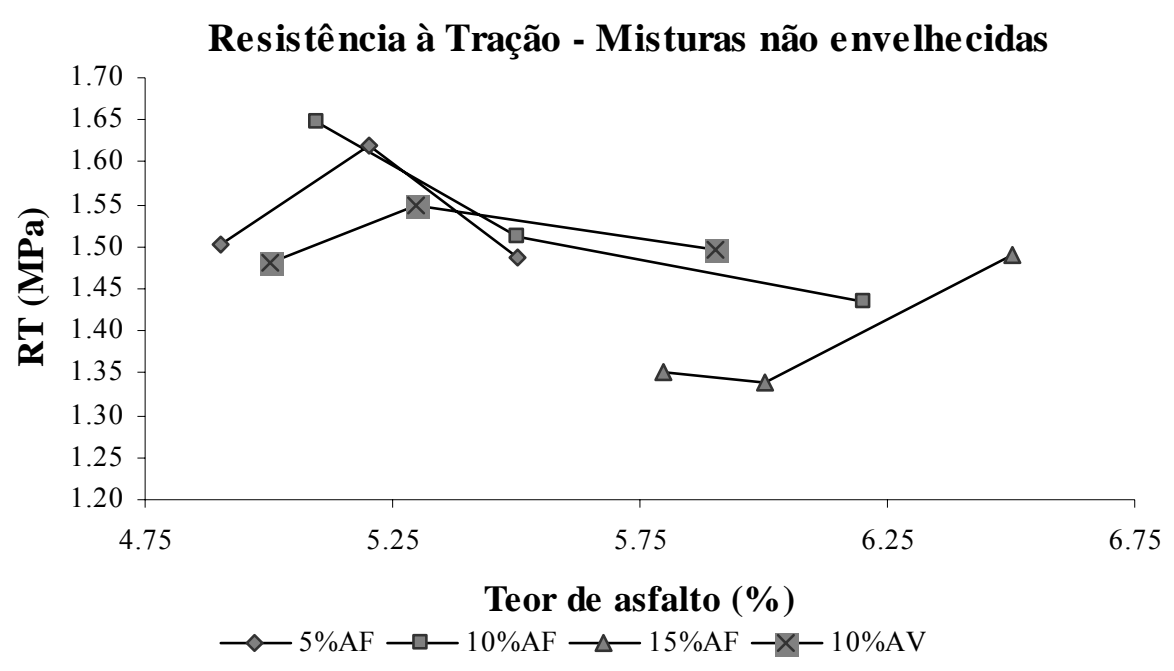

Figura 5.07. Resistência à tração versus teor de asfalto

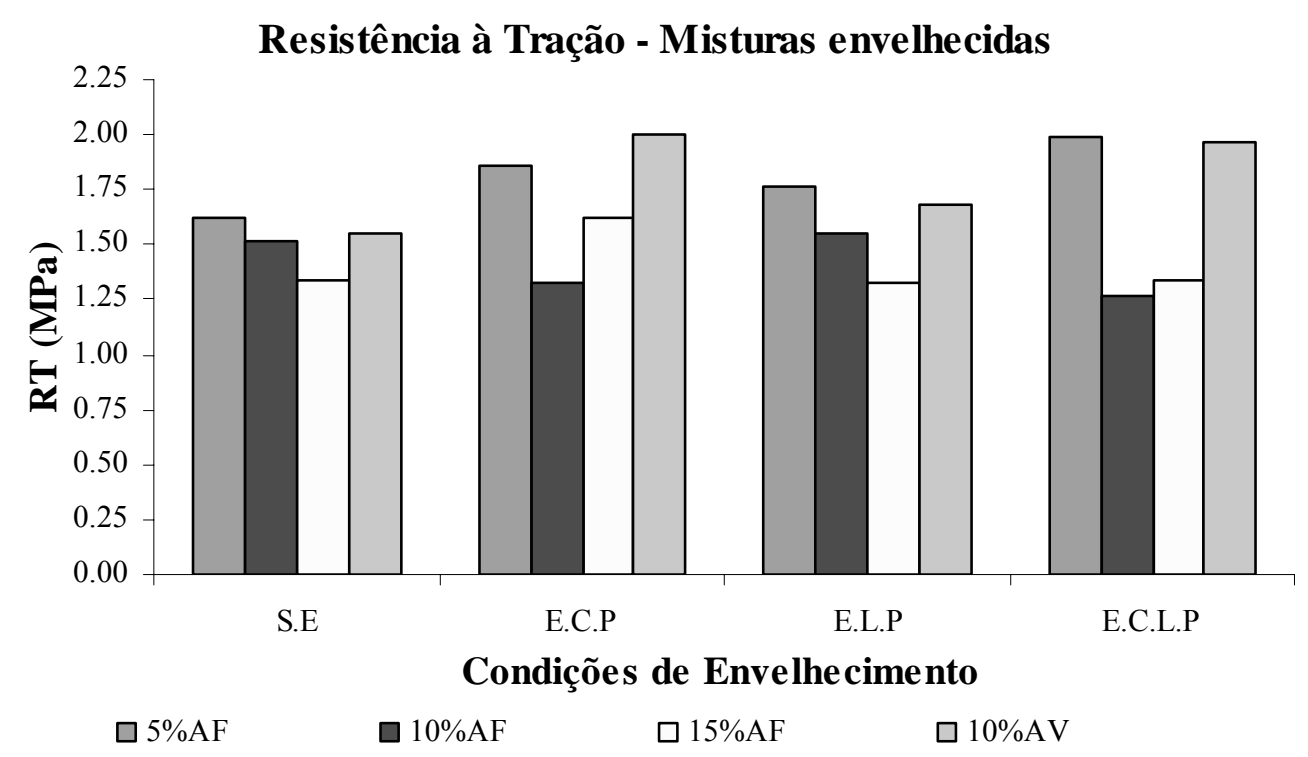

Figura 5.08. Resistência à tração versus condições de envelhecimento $-4 \%$ de vazios

No ensaio de resistência à tração por compressão diametral, no caso da misturas não envelhecidas, verificam-se valores muito parecidos, quase todas não mudam expressivamente com o teor de asfalto (volume de vazios), como pode ser observado nos gráficos das Figuras 5.06 e 5.07, sendo exceção a mistura com 10\% de areia de fundição $\left(\alpha_{0}=0,95 \%\right)$. Nesta mistura, há diferença significativa entre as resistências à tração referentes ao volumes de vazios 3 e 5\% e entre 4 e 5\% (com DMS (Diferença menos significativa $)=0,086 \mathrm{MPa}$ e diferença entre tratamentos $\left(\mathrm{D}_{\text {entre }}\right)$ de $0,212 \mathrm{e}$ $0,136 \mathrm{MPa}$, respectivamente). 
Os gráficos não apresentam tendência definida, no entanto, observa-se que para o volume de vazios nominal 4\% (Figura 5.06), quanto maior o teor de areia de fundição, menor a resistência à tração. No teor ótimo de asfalto $\left(\mathrm{Vv}_{\text {nominal }}=4 \%\right)$, a mistura $5 \% \mathrm{AF}$ apresenta a maior resistência à tração, seguida da mistura $10 \% \mathrm{AV}$. O menor valor é da mistura 15\%AF.

As análise de variância, no entanto, não identificaram diferença significativa entre as médias de resistências à tração das misturas sem envelhecimento( $\left.\alpha_{0}=17,22 \%\right)$, indicando que o teor de areia, seja de fundição ou virgem, não interfere significativamente na resposta desse parâmetro.

Para os ensaio de resistência à tração das misturas nas condições de envelhecimento abordadas, nota-se que os gráficos (Figura 5.08) também não têm uma tendência definida, sendo os valores referentes ao envelhecimento a curto prazo (E.C.P) similares aos obtidos para o envelhecimento a curto e a longo prazos (E.C.L.P). Nota-se também que os valores das misturas sem envelhecimento (S.E) são análogos aos encontrados para as misturas envelhecidas a longo prazo. Pelo exposto, no caso da presente pesquisa, pode-se inferir que o envelhecimento a longo prazo (E.L.P) praticamente não interfere na resistência à tração. Quase todas as misturas ganham resistência quando envelhecidas a curto prazo (E.C.P), com exceção, a mistura com 10\% de areia de fundição $(10 \% \mathrm{AF})$.

As análises de variância, para essas condições de ensaios, indicaram que o envelhecimento interfere na resistência à tração das misturas $5 \% \mathrm{AF}, 15 \% \mathrm{AF}$ e $10 \% \mathrm{AV}$ $\left(\alpha_{05 \% \mathrm{AF}}=4,55 \%, \alpha_{015 \% \mathrm{AF}}=4,82 \%\right.$ e $\left.\alpha_{010 \% \mathrm{AV}}=0,95 \%\right)$, sendo exceção, a $10 \% \mathrm{AF}$ $\left(\alpha_{0}=23,50 \%\right)$, como pode ser verificado na Tabela 5.06.

Tabela 5.06. Efeito do envelhecimento na RT (MPa) das misturas analisadas

\begin{tabular}{|c|c|c|c|c|c|c|c|c|c|c|}
\hline \multirow{3}{*}{$\begin{array}{l}\text { DIFERENÇA } \\
\text { (valor absoluto) }\end{array}$} & \multicolumn{10}{|c|}{ MISTURAS } \\
\hline & \multicolumn{3}{|c|}{ 5\%AF } & \multirow{2}{*}{$\begin{array}{c}10 \% A F \\
\text { DS? }\end{array}$} & \multicolumn{3}{|c|}{$15 \% \mathrm{AF}$} & \multicolumn{3}{|c|}{$10 \% A V$} \\
\hline & DMS & $\mathbf{D}_{\text {entre }}$ & DS? & & DMS & $\mathbf{D}_{\text {entre }}$ & DS? & DMS & $\mathbf{D}_{\text {entre }}$ & DS? \\
\hline $\mid \overline{\mid S . E-\text { E.C.P } \mid}$ & 0,231 & 0,237 & $\mathrm{~S}$ & $\mathrm{~N}$ & 0,224 & 0,290 & $\mathrm{~S}$ & 0,208 & 0,456 & $\mathrm{~S}$ \\
\hline |S.E -E.L.P $\mid$ & 0,231 & 0,142 & $\mathrm{~N}$ & $\mathrm{~N}$ & 0,224 & 0,016 & $\mathrm{~N}$ & 0,208 & 0,136 & $\mathrm{~N}$ \\
\hline $\mid$ S.E - E.C.L.P $\mid$ & 0,231 & 0,368 & $\mathrm{~S}$ & $\mathrm{~N}$ & 0,224 & 0,003 & $\mathrm{~N}$ & 0,208 & 0,415 & $\mathrm{~S}$ \\
\hline $\mid$ E.C.P - E.L.P $\mid$ & 0,231 & 0,095 & $\mathrm{~N}$ & $\mathrm{~N}$ & 0,224 & 0,305 & $\mathrm{~S}$ & 0,208 & 0,320 & $\mathrm{~S}$ \\
\hline $\mid$ E.C.P-E.C.L.P $\mid$ & 0,231 & 0,131 & $\mathrm{~N}$ & $\mathrm{~N}$ & 0,224 & 0,293 & $\mathrm{~S}$ & 0,208 & 0,041 & $\mathrm{~N}$ \\
\hline |E.L.P-E.C.L.P| & 0,231 & 0,226 & $\mathrm{~N}$ & $\mathrm{~N}$ & 0,224 & 0,012 & $\mathrm{~N}$ & 0,208 & 0,279 & $\mathrm{~S}$ \\
\hline
\end{tabular}

$\overline{\text { DMS - Diferença Menos Significativa }} \mathrm{D}_{\text {entre }}$ - Diferença entre tratamentos $\mathrm{DS}$ - Diferença Significativa $\mathrm{S}-\mathrm{Sim}$ N - Não 
Por meio das ANOVAS, pôde-se identificar também diferença significativa entre as resistências à tração das misturas nas condições de envelhecimento $\left(\alpha_{\mathrm{oE} . \mathrm{C} . \mathrm{P}}=2,63 \%\right.$, $\alpha_{\mathrm{oE} . \mathrm{L} . \mathrm{P}}=1,58 \%$ e $\alpha_{\mathrm{oE} . \mathrm{C} . \mathrm{L} . \mathrm{P}}=0,30 \%$ ) e desta forma verificar a interferência do teor e/ou tipo (fundição e virgem) de areia, como pode ser observado na Tabela 5.07.

Tabela 5.07. Efeito do teor e do tipo de areia na RT (MPa) - considerando as condições de envelhecimento

\begin{tabular}{cccccccccc}
\hline \hline \multirow{2}{*}{$\begin{array}{c}\text { DIFERENÇA } \\
\text { (valor absoluta) }\end{array}$} & \multicolumn{7}{c}{ CONDIÇÕES DE ENVELHECIMENTO } \\
\cline { 2 - 10 } & EMS & $\mathbf{D}_{\text {entre }}$ & DS? & DMS & D $_{\text {entre }}$ & DS? & DMS & D $_{\text {entre }}$ & DS? \\
\hline \hline$|5 \mathrm{AF}-10 \mathrm{AF}|$ & 0,370 & 0,524 & $\mathrm{~S}($ teor) & 0,209 & 0,207 & $\mathrm{~N}$ & 0,270 & 0,714 & $\mathrm{~S}($ teor) \\
$|5 \mathrm{AF}-15 \mathrm{AF}|$ & 0,370 & 0,227 & $\mathrm{~N}$ & 0,209 & 0,437 & $\mathrm{~S}($ teor) & 0,270 & 0,651 & $\mathrm{~S}$ (teor) \\
$|5 \mathrm{AF}-10 \mathrm{AV}|$ & 0,370 & 0,149 & $\mathrm{~N}$ & 0,209 & 0,076 & $\mathrm{~N}$ & 0,270 & 0,023 & $\mathrm{~N}$ \\
$|10 \mathrm{AF}-15 \mathrm{AF}|$ & 0,370 & 0,297 & $\mathrm{~N}$ & 0,209 & 0,230 & $\mathrm{~S}($ teor) & 0,270 & 0,063 & $\mathrm{~N}$ \\
$|10 \mathrm{AF}-10 \mathrm{AV}|$ & 0,370 & 0,673 & $\mathrm{~S}($ tipo) & 0,209 & 0,131 & $\mathrm{~N}$ & 0,270 & 0,691 & $\mathrm{~S}$ (tipo) \\
$|15 \mathrm{AF}-10 \mathrm{AV}|$ & 0,370 & 0,376 & $\mathrm{~S}$ (teor) & 0,209 & 0,361 & $\mathrm{~S}$ (teor) & 0,270 & 0,628 & $\mathrm{~S}$ (teor) \\
\hline \hline
\end{tabular}

DMS - Diferença Menos Significativa $\quad \mathrm{D}_{\text {entre }}$ - Diferença entre tratamentos $\quad$ DS - Diferença Significativa $\mathrm{S}$ - Sim N - Não

\subsection{Módulo de Resiliência (DNER-ME 133/94)}

Os resultados dos ensaios de módulo de resiliência referem-se às misturas estudadas para o volume de vazios projetado de 4\%, em todas as condições de envelhecimento (sem, a curto prazo, a longo prazo e simultâneo, em curto e longo prazos), contudo para os volumes de vazios de 3 e 5\% (projetados), dizem respeito apenas à condição sem envelhecimento.

Vale relembrar que cada corpo-de-prova foi ensaiado em duas direções (0 e $\left.90^{\circ}\right)$, sendo testado na direção $90^{\circ}$ imediatamente após o término do ensaio na direção $0^{\circ}$. Os resultados apresentados são relativos a 96 ensaios (24 condições experimentais, dois corpos-de-prova por condição e duas direções de ensaio).

Esses resultados podem ser vistos nos gráficos das Figuras 5.09 (misturas não envelhecidas versus volumes de vazios reais médios), 5.10 e 5.11 (misturas não envelhecidas versus volumes de vazios projetados: 3, 4 e 5\%), considerando, respectivamente, a média das duas direções (média total) com descartes dos pontos que diferiram da média em mais ou em menos de $20 \%$, a média na direção $0^{\circ}$ (todos os pontos) e a média na direção $90^{\circ}$ (todos os pontos). Apresentam-se, nos gráficos das Figuras 5.12 (descartando valores), 5.13 e 5.14 (todos os pontos), os resultados referentes ao volume de vazios de $4 \%$ (projetado) em todas as condições de 
envelhecimento (misturas condicionadas). Na Figura 5.15, pode-se observar o módulo de resiliência das misturas não envelhecidas, considerando a média total e descartando os pontos que diferiram da média em mais ou em menos de $20 \%$, em função do teor de asfalto.

Os gráficos das Figuras 5.10, 5.11, 5.13 e 5.14 dizem respeito aos resultados desses ensaios considerando todos os pontos (valores), ou seja, sem tratamento estatístico. Estes valores são apresentados, para que se tenha idéia do comportamento do corpo-deprova ao ser ensaiado nas duas direções sem tempo de recuperação; terminado o ensaio na direção $0^{\circ}$, imediatamente em seguida era ensaiado a $90^{\circ}$. Assim, verifica-se que na direção $90^{\circ}$ geralmente os módulos são menores, indicando maiores deformações horizontais.

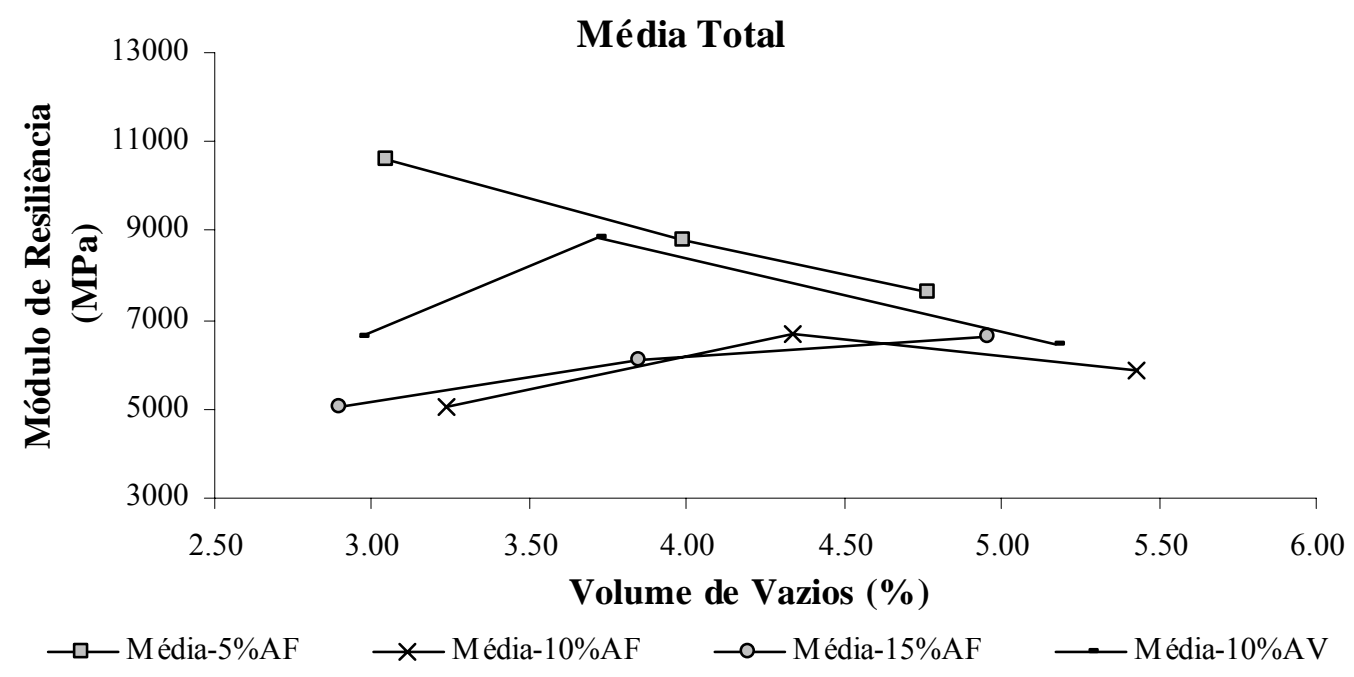

Figura 5.09. Módulo de resiliência das misturas não envelhecidas - média total

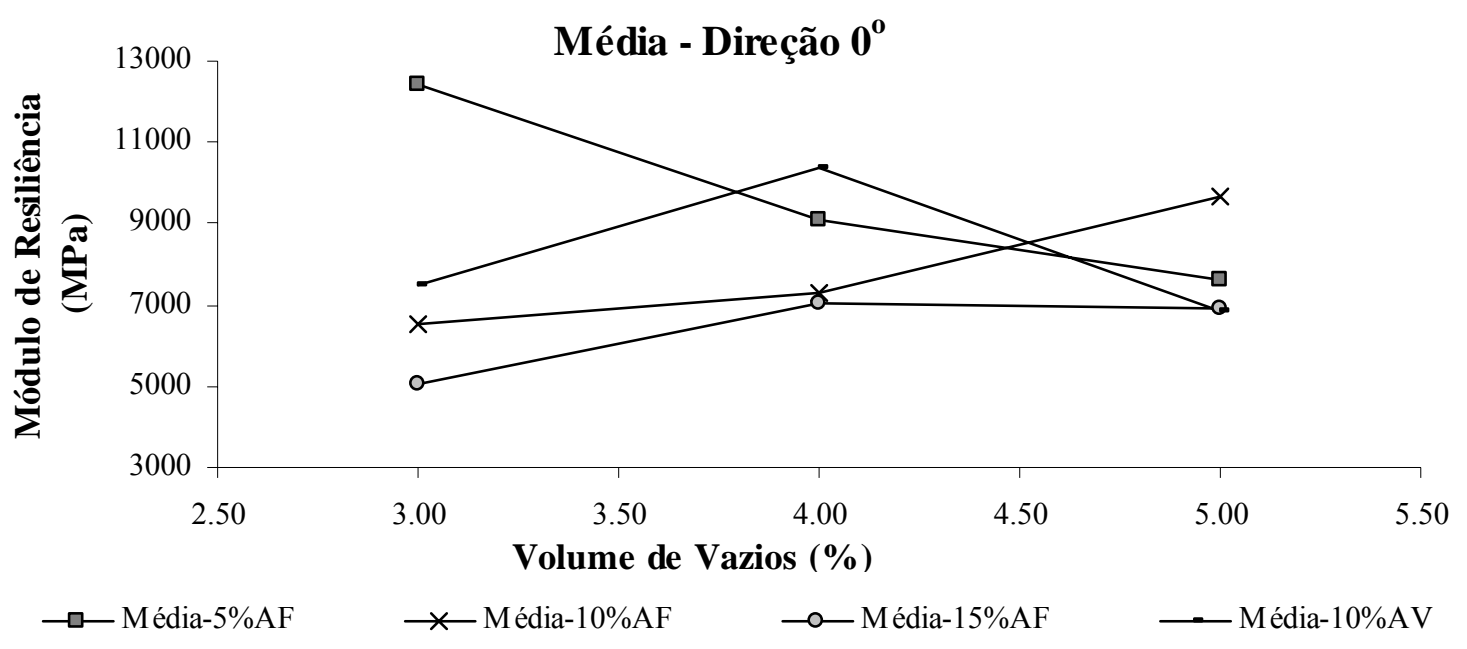

Figura 5.10. Módulo de resiliência das misturas não envelhecidas - direção $0^{\circ}$ 


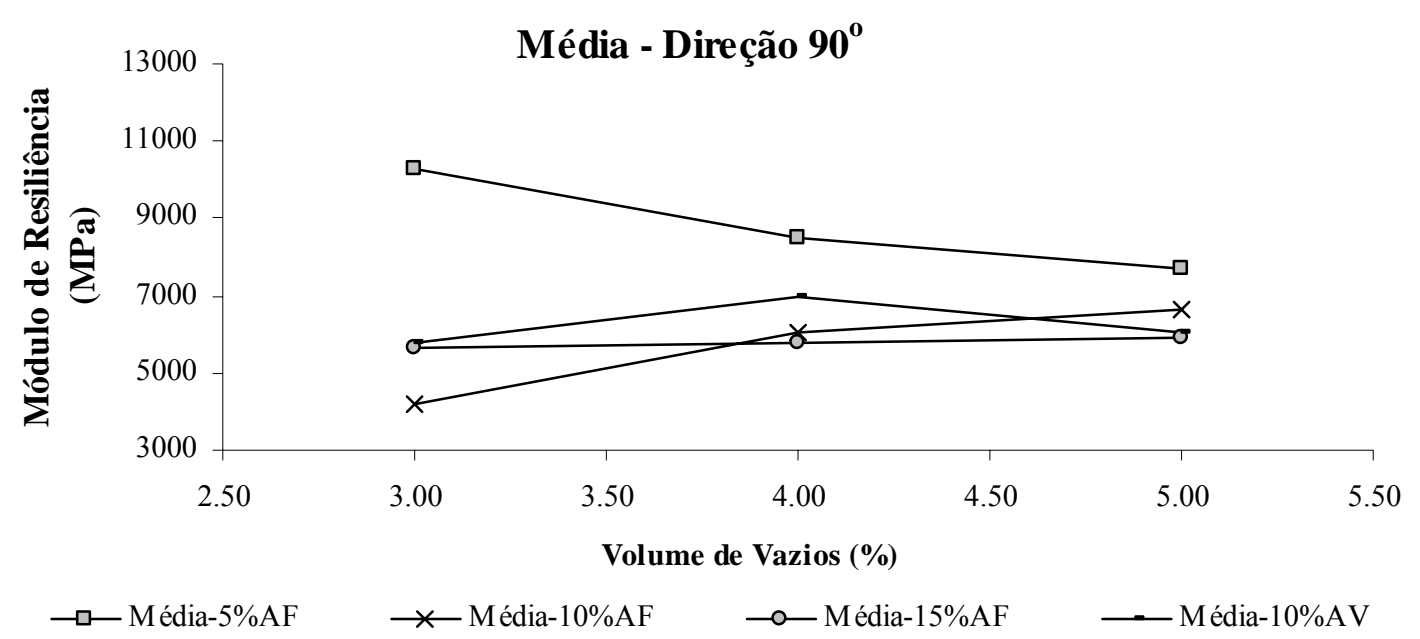

Figura 5.11. Módulo de resiliência das misturas não envelhecidas - direção $90^{\circ}$

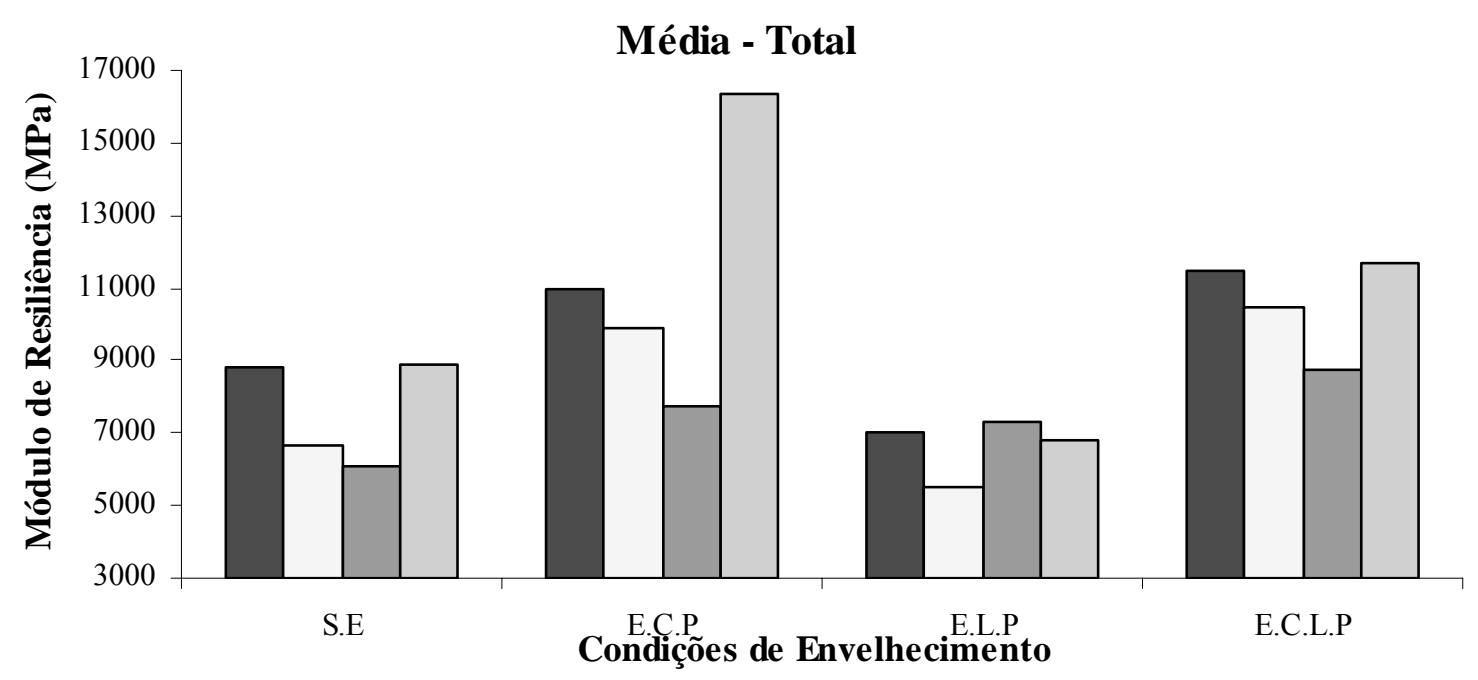

๑ Média-5\%AF $\square$ Média-10\%AF $\square$ Média-15\%AF $\square$ Média-10\%AV

Figura 5.12. Módulo de resiliência versus condições de envelhecimento (4\% de vazios)

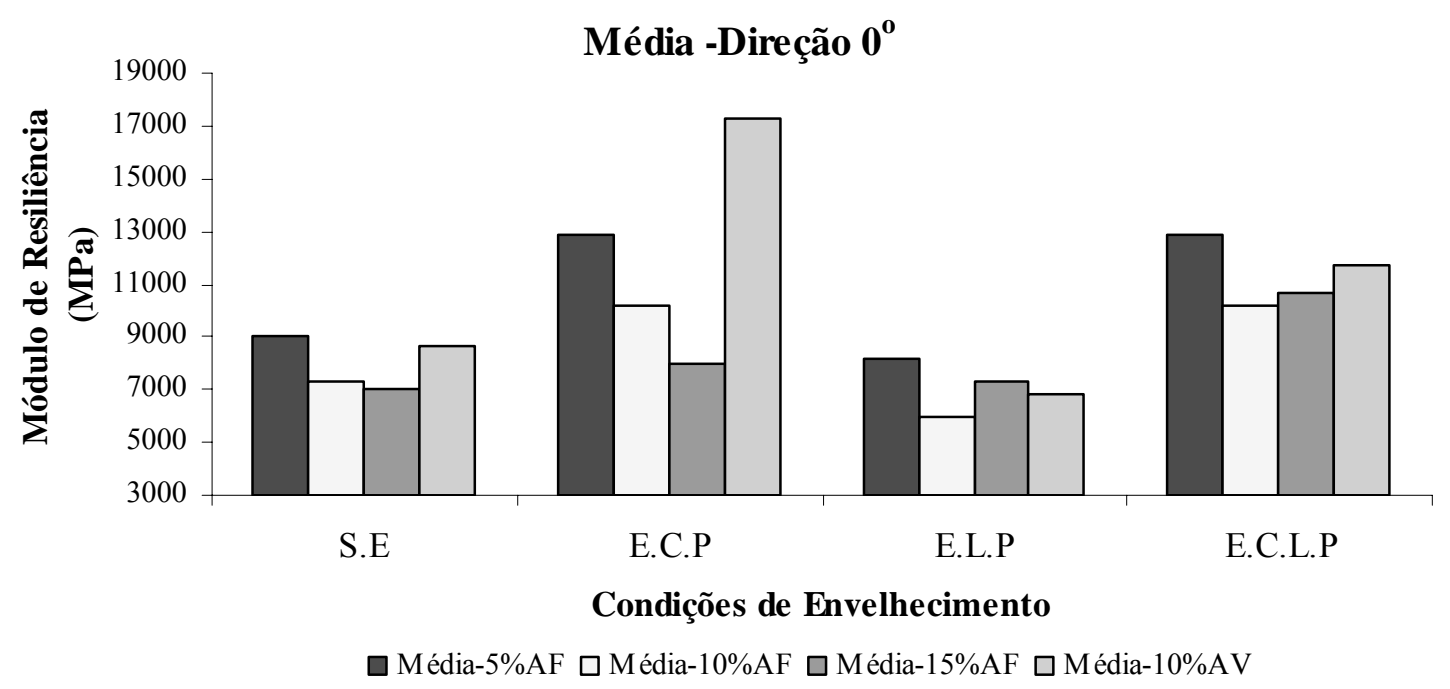

Figura 5.13. Módulo de resiliência versus condições de envelhecimento (4\% de vazios) 


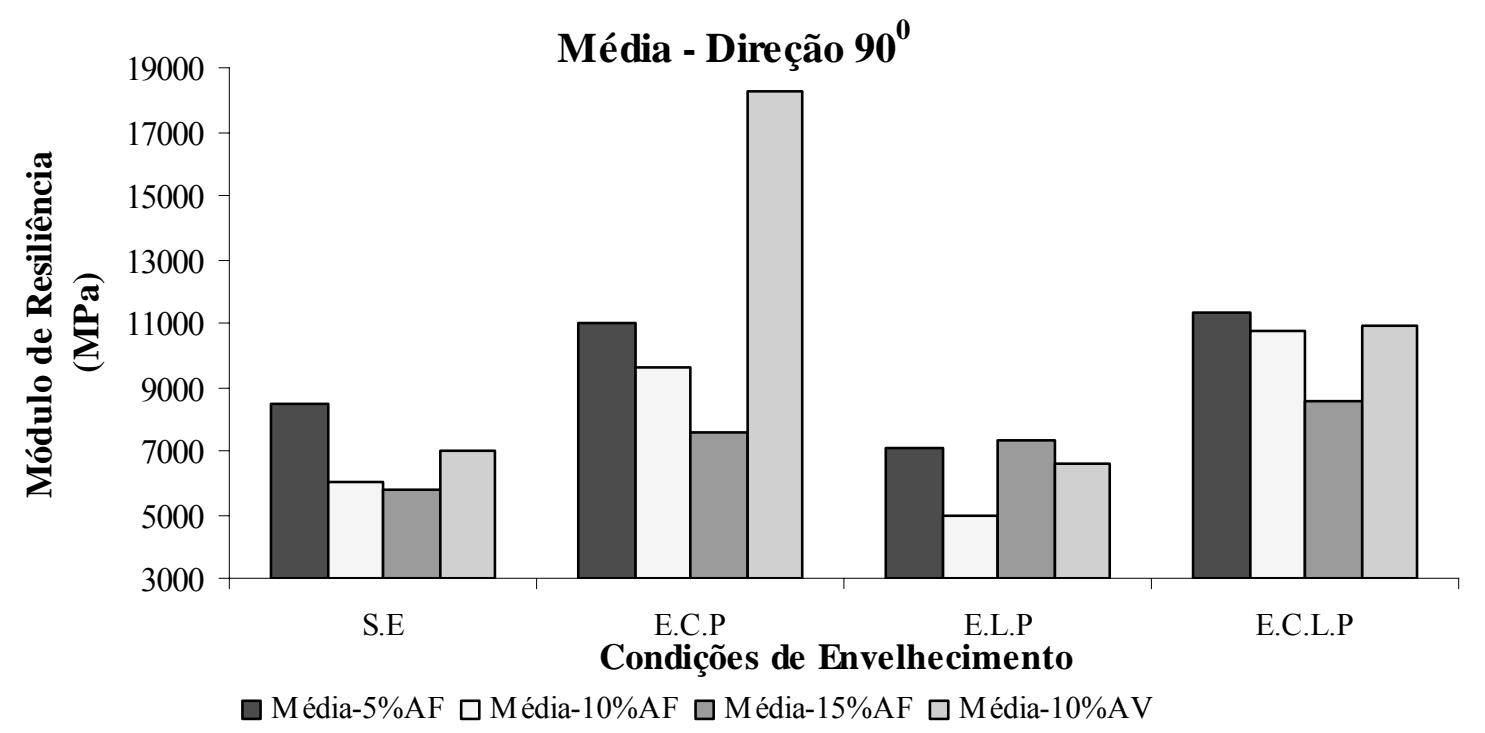

Figura 5.14. Módulo de resiliência versus condições de envelhecimento (4\% de vazios)

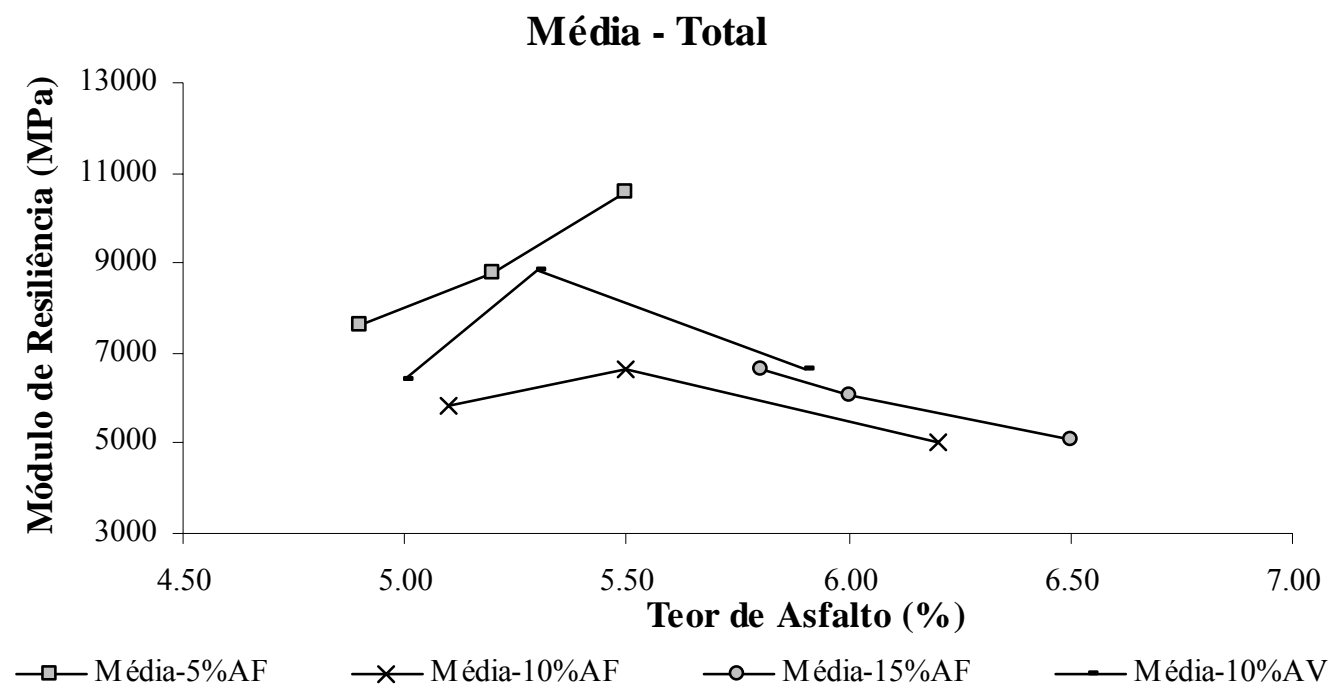

Figura 5.15. Módulo de resiliência das misturas não envelhecidas versus teor de asfalto - média nas duas direções

Nos gráficos das Figuras 5.16 a 5.18, apresentam-se as relações entre os módulos de resiliência e as resistências à tração $(\mathrm{MR} / \mathrm{RT})$ das misturas estudadas. Nas Figuras 5.16 e 5.17, apresentam-se, respectivamente, essas relações, considerando as misturas não envelhecidas em função do volume de vazios reais médios e do teor de asfalto. $\mathrm{Na}$ Figura 5.18, são apresentadas as relações MR/RT para as misturas, considerando o envelhecimento (4\% de vazios). Vale ressaltar que os gráficos aqui apresentados referem-se aos módulos resilientes totais, considerando as duas direções (0 e $\left.90^{\circ}\right)$, mas descartando pontos com grande variabilidade (em mais ou em menos de $20 \% \mathrm{em}$ relação à média). Os dados referentes aos ensaios de módulo de resiliência são apresentados nas Tabelas B.08 a B.10 do Apêndice B (página 207). 


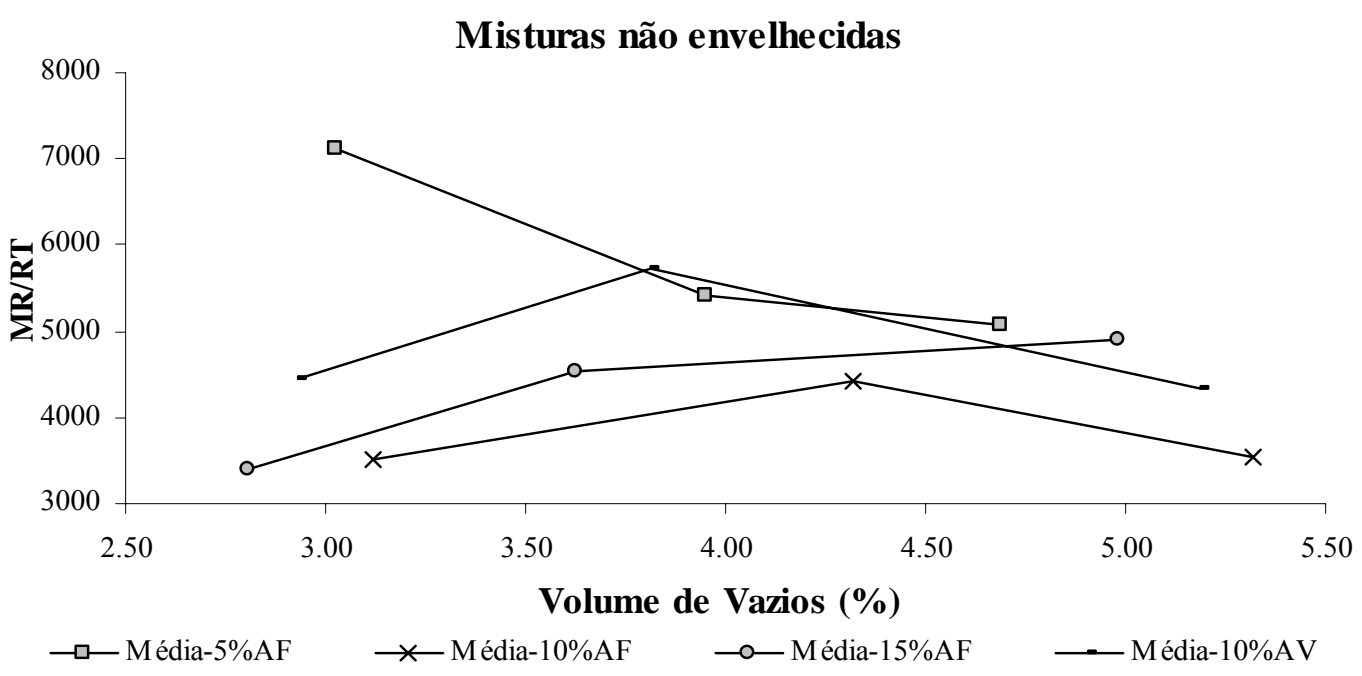

Figura 5.16. Relação MR/RT versus volume de vazios reais médios

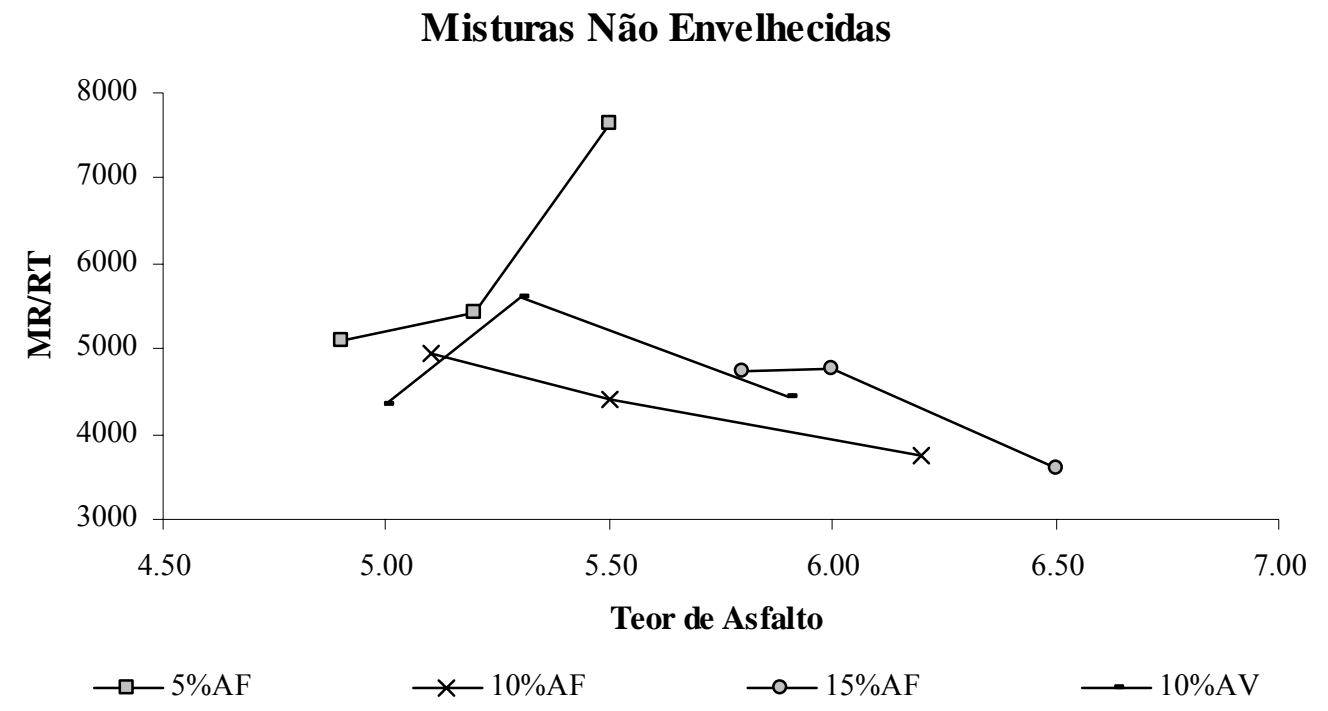

Figura 5.17. Relação MR/RT versus teor de asfalto

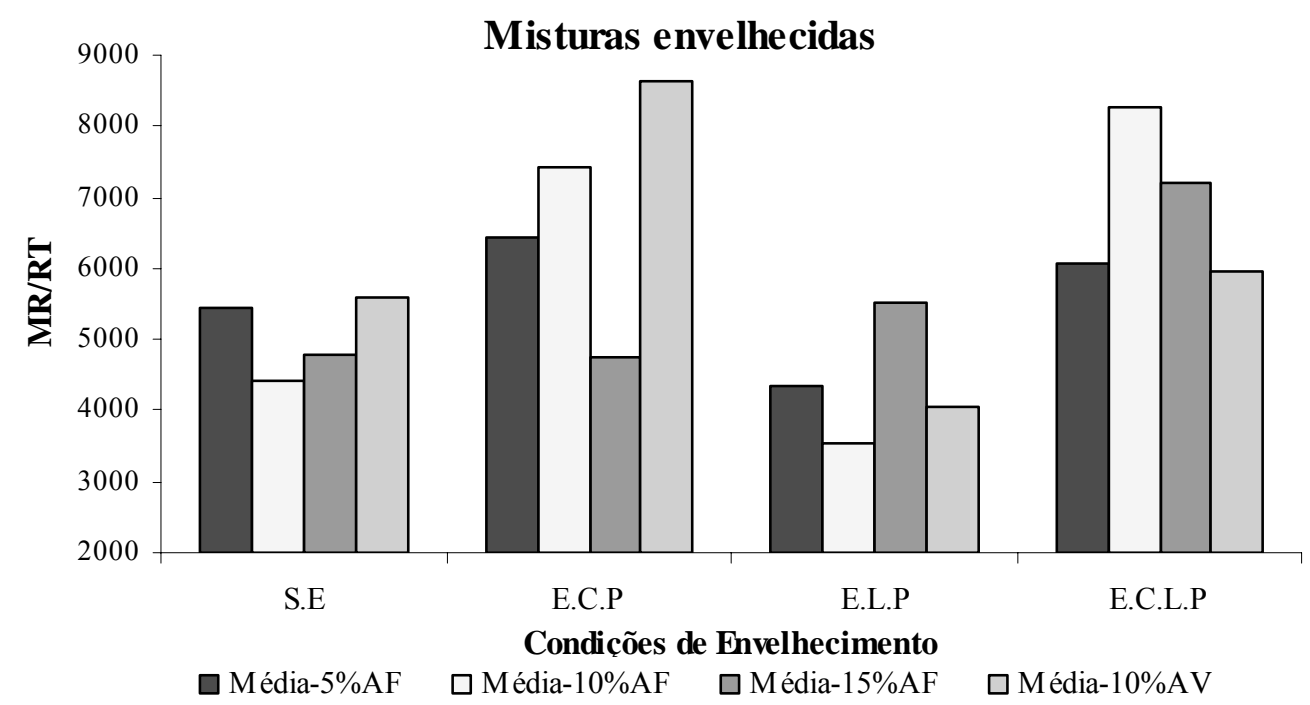

Figura 5.18. Relação MR/RT versus condições de envelhecimento (4\% de vazios) 
Os módulos de resiliência utilizados para o cálculo das relações MR/RT são os referentes à média total, isto é, considerando os módulos para as direções $0^{\circ}$ e $90^{\circ}$ de cada corpo-de-prova, portanto, quatro valores para cada condição experimental, exceto nos caso em que pontos (resultados de ensaio) foram descartados por apresentarem grande variabilidade. Nas Tabelas B.11 a B.13 do Apêndice B (página 207), são apresentados os dados referentes aos gráficos das Figuras 5.16 a 5.18.

Nos ensaios de módulo de resiliência para as misturas virgens (sem envelhecimento), verifica-se que todas apresentam módulos com valores superiores a $5000 \mathrm{MPa}$ e inferiores a $11000 \mathrm{MPa}$ (Figuras 5.09 e 5.15). Após a análise de variância, verificou-se que em quase todas as misturas os módulos não mudam expressivamente com o teor de asfalto (volume de vazios). Aparentemente, a mistura 5\%AF expressa mudança significativa com o volume de vazios (teor de asfalto), contudo a análise de variância $\left(\alpha_{0}=6,60 \%\right)$ indicou que não existe diferença expressiva entre esses módulos (médias). A exceção é a mistura $10 \% \mathrm{AV}\left(\alpha_{0}=3,65 \%\right)$, que visualmente parece menos significante do que a mudança que ocorre na 5\%AF. Nessa mistura (10\%AF), há diferença significativa entre os módulos referentes ao volumes de vazios nominais 3 e $4 \%$ e entre 4 e $5 \%(\mathrm{DMS}=1819,32 \mathrm{MPa})$.

Os gráficos das mistura 10\% AF e 10\%AV apresentam a mesma tendência (Figura 5.09 e 5.15), ocorrendo o módulo máximo no volume de vazios nominal ( $\left.\mathrm{VV}_{\text {nominal }}\right) 4 \%$ (teor ótimo de asfalto), com valores de 6663 e $8860 \mathrm{MPa}$, respectivamente. As misturas $5 \% \mathrm{AF}$ e $15 \% \mathrm{AF}$ apresentam comportamento inverso, enquanto o módulo da 5\% AF decresce com o aumento no volume de vazios, o módulo da $15 \%$ AF aumenta. De todas as misturas, a que apresenta maior módulo de resiliência é a mistura com $5 \%$ de areia de fundição $(5 \% \mathrm{AF})$. No teor ótimo de asfalto $\left(\mathrm{VV}_{\text {nominal }}=4 \%\right)$ as misturas $5 \% \mathrm{AF}$ e $10 \% \mathrm{AV}$ apresentam módulos muito semelhantes, respectivamente, 8783 e $8860 \mathrm{MPa}$ e as misturas $10 \% \mathrm{AF}$ e $15 \% \mathrm{AF}$ exibem esta mesma característica, com valores iguais a 6663 e $6085 \mathrm{MPa}$, respectivamente (Figuras 5.09 e 5.15).

As análises de variância identificaram $\left(\alpha_{0}=3,23 \%\right)$ que para as misturas não envelhecidas, nem todas apresentam médias dos módulo iguais, que pelo menos duas são significativamente diferentes entre si. Isto indica que o teor de areia interfere significativamente na resposta desse parâmetro, em pelo menos duas misturas. Ao se realizar o contraste, comprovou-se que a diferença existente, diz respeito às misturas $5 \% \mathrm{AF}$ e $10 \% \mathrm{AF}$ e entre $5 \% \mathrm{AF}$ e $15 \% \mathrm{AF}(\mathrm{DMS}=2718,17 \mathrm{MPa})$. 
Para os ensaio de módulo de resiliência das misturas nas condições de envelhecimento estudadas, nota-se que todas as misturas apresentam a mesma tendência: têm um acréscimo no módulo com o envelhecimento a curto prazo (E.C.P), com o envelhecimento a longo prazo (E.L.P), apresentam um decréscimo e crescem com o envelhecimento simultâneo, em curto e a longo prazos (E.C.L.P). Nota-se também que todos os valores são superiores a $5000 \mathrm{MPa}$ e inferiores a $17000 \mathrm{MPa}$ (E.C.P) e que a mistura com $10 \%$ de areia virgem, de um modo geral, apresenta os maiores valores, sendo seguida pela 5\%AF. Quase todas as misturas têm um decréscimo no módulo de resiliência quando envelhecidas a longo prazo (E.L.P), com exceção da mistura com $15 \%$ de areia de fundição $(15 \% \mathrm{AF})$.

As análises de variância, para essas condições de ensaios, indicaram que o envelhecimento interfere no módulo de resiliência, detectando diferença significativa nas misturas 5\%AF, $10 \% \mathrm{AF}$ e $10 \% \mathrm{AV}\left(\alpha_{05 \% \mathrm{AF}}=0,09 \%, \alpha_{010 \% \mathrm{AF}}=0,002 \%\right.$ e $\left.\alpha_{\mathrm{o} 10 \% \mathrm{AV}}=0,0008 \%\right)$, sendo exceção, a $15 \% \mathrm{AF}\left(\alpha_{\mathrm{o}}=6,23 \%\right)$, como pode ser verificado na Tabela 5.08.

Tabela 5.08. Efeito do envelhecimento no MR (MPa) das misturas analisadas

\begin{tabular}{ccccccccccc}
\hline \hline \multirow{2}{*}{$\begin{array}{c}\text { DIFERENÇA } \\
\text { (valor absoluto) }\end{array}$} & \multicolumn{10}{c}{ MISTURAS } \\
\cline { 2 - 11 } & $\mathbf{5 M S}$ & $\mathbf{D}_{\text {entre }}$ & DS? & DMS & $\mathbf{D}_{\text {entre }}$ & DS? & DS? & DMS & $\mathbf{D}_{\text {entre }}$ & DS? \\
\hline \hline $\mid$ S.E - E.C.P $\mid$ & 1728,30 & 2210 & $\mathbf{S}$ & 1471,85 & 3204 & $\mathbf{S}$ & $\mathbf{N}$ & 1991,22 & 7511 & $\mathbf{S}$ \\
$\mid$ S.E -E.L.P $\mid$ & 1458,13 & 1785 & $\mathbf{S}$ & 1471,85 & 1177 & $\mathbf{N}$ & $\mathbf{N}$ & 1724,45 & 2038 & $\mathbf{S}$ \\
$\mid$ S.E - E.C.L.P $\mid$ & 1458,13 & 2679 & $\mathbf{S}$ & 1471,85 & 3836 & $\mathbf{S}$ & $\mathbf{N}$ & 1724,45 & 2853 & $\mathbf{S}$ \\
$\mid$ E.C.P - E.L.P $\mid$ & 1742,79 & 3996 & $\mathbf{S}$ & 1471,85 & 4380 & $\mathbf{S}$ & $\mathbf{N}$ & 1724,45 & 9549 & $\mathbf{S}$ \\
$\mid$ E.C.P-E.C.L.P $\mid$ & 1742,79 & 468 & $\mathbf{N}$ & 1471,85 & 632 & $\mathbf{N}$ & $\mathbf{N}$ & 1724,45 & 4658 & $\mathbf{S}$ \\
$\mid$ E.L.P-E.C.L.P $\mid$ & 1558,80 & 4464 & $\mathbf{S}$ & 1471,85 & 5013 & $\mathbf{S}$ & $\mathbf{N}$ & 1408,00 & 4891 & $\mathbf{S}$ \\
\hline \hline
\end{tabular}

DMS - Diferença Menos Significativa $\quad \mathrm{D}_{\text {entre }}$ - Diferença entre tratamentos $\quad$ DS - Diferença Significativa $\mathrm{S}-\mathrm{Sim}$ N - Não

Por meio das análise de variância, pôde-se identificar também diferença significativa entre os módulos de resiliência médio das misturas envelhecidas $\left(\alpha_{\mathrm{oE} . \mathrm{C.} . \mathrm{P}}=0,015 \%\right.$, $\alpha_{o \text { E.L..P }}=3,51 \%$ e $\alpha_{o \text { E.C.L.P }}=1,02 \%$ ) e com isto verificar a interferência do teor e/ou tipo de areia nestes parâmetros, como pode ser observado na Tabela 5.09. 
Tabela 5.09. Efeito do teor e do tipo de areia no MR (MPa) - considerando as condições de envelhecimento

\begin{tabular}{|c|c|c|c|c|c|c|c|c|c|}
\hline \multirow{3}{*}{$\begin{array}{l}\text { DIFERENÇA } \\
\text { (valor absoluto) }\end{array}$} & \multicolumn{9}{|c|}{ CONDIÇÕES DE ENVELHECIMENTO } \\
\hline & \multicolumn{3}{|c|}{ E.C.P } & \multicolumn{3}{|c|}{ E.L.P } & \multicolumn{3}{|c|}{ E.C.L.P } \\
\hline & DMS & $\mathbf{D}_{\text {entre }}$ & DS? & DMS & $\mathbf{D}_{\text {entre }}$ & DS? & DMS & $\mathbf{D}_{\text {entre }}$ & DS? \\
\hline$|5 \mathrm{AF}-10 \mathrm{AF}|$ & 2222,38 & 1127 & $\mathbf{N}$ & 1311,88 & 1512 & S (teor) & 1614,55 & 963 & $\mathbf{N}$ \\
\hline$|5 \mathrm{AF}-15 \mathrm{AF}|$ & 2222,38 & 3236 & S (teor) & 1311,88 & 288 & $\mathbf{N}$ & 1726,03 & 2731 & $S$ (teor) \\
\hline$|5 \mathrm{AF}-10 \mathrm{AV}|$ & 2566,18 & 5375 & $\mathrm{~S}$ (teor) & 1311,88 & 179 & $\mathbf{N}$ & 1614,55 & 248 & $\mathbf{N}$ \\
\hline$|10 \mathrm{AF}-15 \mathrm{AF}|$ & 1814,56 & 2109 & $\mathrm{~S}$ (teor) & 1214,56 & 1800 & S (teor) & 1614,55 & 1768 & $S$ (teor) \\
\hline$|10 \mathrm{AF}-10 \mathrm{AV}|$ & 2222,38 & 6501 & S (tipo) & 1214,56 & 1333 & S (tipo) & 1494,78 & 1211 & $\mathbf{N}$ \\
\hline$|15 \mathrm{AF}-10 \mathrm{AV}|$ & 2222,38 & 8611 & $S$ (teor) & 1214,56 & 467 & $\mathbf{N}$ & 1614,55 & 2979 & $S$ (teor) \\
\hline
\end{tabular}

DMS - Diferença Menos Significativa $\quad \mathrm{D}_{\text {entre }}$ - Diferença entre tratamentos $\quad$ DS - Diferença Significativa $\mathrm{S}-\mathrm{Sim}$ N - Não

Nas relações módulos de resiliência/resistências à tração $(\mathrm{MR} / \mathrm{RT})$ para as misturas virgens (sem envelhecimento), cujos gráficos podem ser observados na Figuras 5.16 e 5.17, verifica-se que todas apresentam valores superiores a 3000 e inferiores a 6000 , com exceção da mistura 5\%AF, que apresenta para o $\mathrm{VV}_{\text {nominal }} 4 \%$ valor superior a 7000 (7120).

Os gráficos das mistura 10\%AF e 10\%AV apresentam a mesma tendência, ocorrendo a relação MR/RT máxima no volume de vazios de 4\%, com valores iguais, respectivamente, a 5722 e 4413 . As misturas 5\%AF e 15\%AF têm comportamento inverso, enquanto a relação $\mathrm{MR} / \mathrm{RT}$ da $5 \% \mathrm{AF}$ decresce com o aumento do volume de vazios, a relação da 15\%AF aumenta. De todas as misturas, a que apresenta maior relação $\mathrm{MR} / \mathrm{RT}$, de um modo geral, é a mistura com 5\% de areia de fundição (5\%AF), sendo o maior valor no volume de vazios de 3\% e corresponde a 7119 (Figuras 5.16 e 5.17). Para o volume de vazios de 5\%, as misturas 5\%AF e $15 \% \mathrm{AF}$ apresentam MR/RT praticamente iguais, respectivamente, 5069 e 4914. Os valores máximo e mínimo para $\mathrm{MR} / \mathrm{RT}$, no teor ótimo de asfalto $\left(\mathrm{VV}_{\text {nominal }}=4 \%\right)$, são referentes às misturas $10 \% \mathrm{AV} \mathrm{e}$ 10\%AF e são, respectivamente, 5722 e 4413 (Figuras 5.16 e 5.17).

Para as relações MR/RT nas condições de envelhecimento estudadas (Figura 5.18), nota-se que quase todas as misturas apresentam a mesma tendência (exceção a 15\%AF): têm um acréscimo na MR/RT quando envelhecidas a curto prazo (E.C.P), com o envelhecimento a longo prazo (E.L.P) apresentam um decréscimo e crescem com o envelhecimento a curto e a longo prazos (E.C.L.P). Nota-se também que todos os valores são superiores a 3500 (E.L.P) e inferiores a 9000 (E.C.P). Quase todas as misturas têm um decréscimo na MR/RT quando envelhecidas a longo prazo (E.L.P), com exceção da mistura com $15 \%$ de areia de fundição $(15 \% \mathrm{AF})$. A mistura que 
apresenta a menor MR/RT (4413) na condição sem envelhecimento ( $\mathrm{Vv}=4 \%)$ é a $10 \% \mathrm{AF}$, contudo ao ser envelhecida simultaneamente em curto e longo prazos é a que apresenta o maior valor (8254).

\subsection{Fluência por Compressão Uniaxial Estática}

Os resultados dos ensaios de fluência uniaxial estática (EFUE) dizem respeito às misturas estudadas (mistura de referência (10\%AV), 5\%AF, $10 \% \mathrm{AF}$ e $15 \% \mathrm{AF}$ ) para o volume de vazio de 4\%, em todas as condições de envelhecimento (sem, a curto prazo, a longo prazo e a curto e a longo prazos), no entanto, para os volumes de vazios de 3 e $5 \%$ (projetados), estes são relativos apenas a condição sem envelhecimento. Os parâmetros avaliados no ensaio de fluência são: deformação total (3600 s), inclinação da curva de fluência no estágio secundário (entre 1000 e 3600 s), recuperação, módulos de fluência para $3600 \mathrm{~s}$ de ensaio e para $4500 \mathrm{~s}$ (após a recuperação). O número de ensaios de fluência uniaxial realizado foi de 144 (24 condições experimentais, dois corpos-de-prova e dois níveis de tensões $(0,1$ e $0,4 \mathrm{MPa})$ para cada condição, sendo que, para a tensão de $0,4 \mathrm{MPa}$, utilizaram-se dois tipos de prato superior para a aplicação de carregamento).

No caso dos ensaios no nível de 0,4 MPa, são abordados os resultados com os pratos superiores de carregamento normal $(102 \mathrm{~mm})$ e reduzido $(51 \mathrm{~mm})$. Assim, achou-se mais conveniente discutir e analisar do ponto de vista estatístico (análise de variância) apenas o parâmetro deformação total para todos os casos. Os outros parâmetros são discutidos com base apenas nas informações obtidas diretamente dos ensaios (sem outliers), ou seja, com base nos gráficos apresentados neste item.

\subsubsection{Fluência por Compressão Uniaxial Estática com tensão de 0,1 MPa}

Os gráficos das Figuras 5.19 a 5.28 dizem respeito aos resultados do ensaio de fluência uniaxial para o nível de tensão de 0,1 MPa. Os gráficos das Figuras 5.19 e 5.20 são relativos, respectivamente, à deformação total e à recuperação das misturas não envelhecidas (teores de 3, 4 e 5\%), enquanto os gráficos 5.21 e 5.22 referem-se a estes parâmetros, mas para as misturas nas condições de envelhecimento estudadas (4\% de vazio). Nos gráficos das Figuras 5.23 e 5.24, apresenta-se, respectivamente, a inclinação do trecho secundário da curva de fluência para as misturas não envelhecidas e para as envelhecidas (condições de envelhecimento). 


\section{Misturas não envelhecidas (Tensão - 0,1 MPa)}

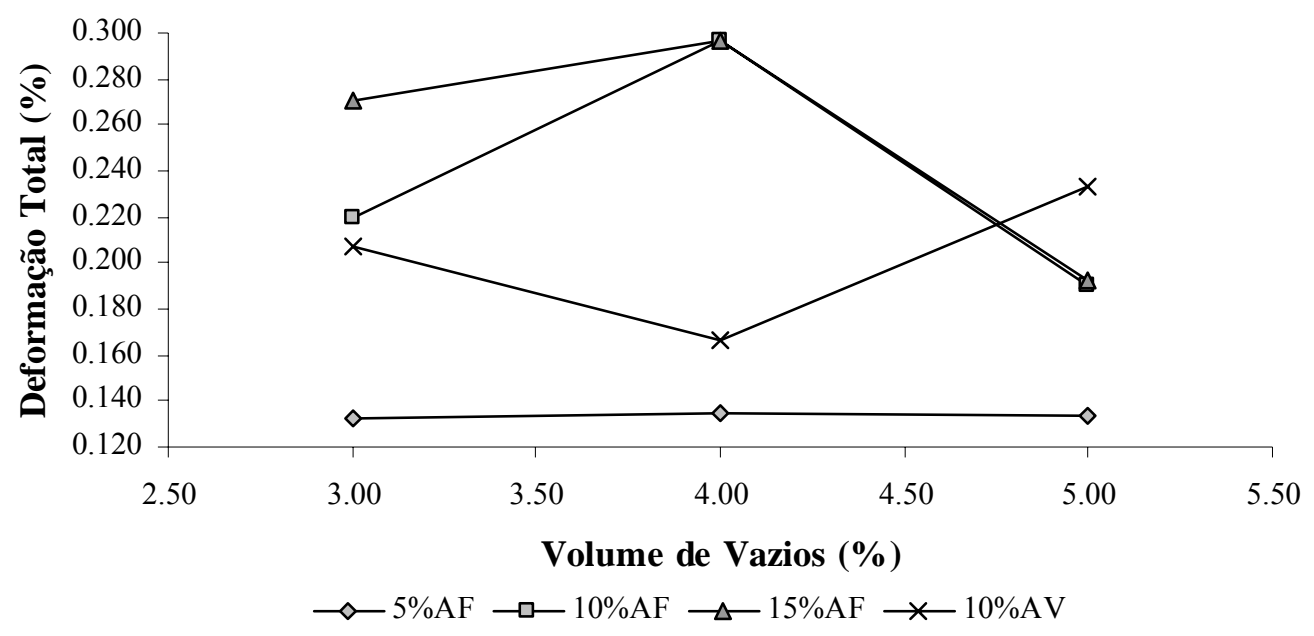

Figura 5.19. Deformação total versus volume de vazios (EFUE)

Misturas Não envelhecidas (Tensão - 0,1 MPa)

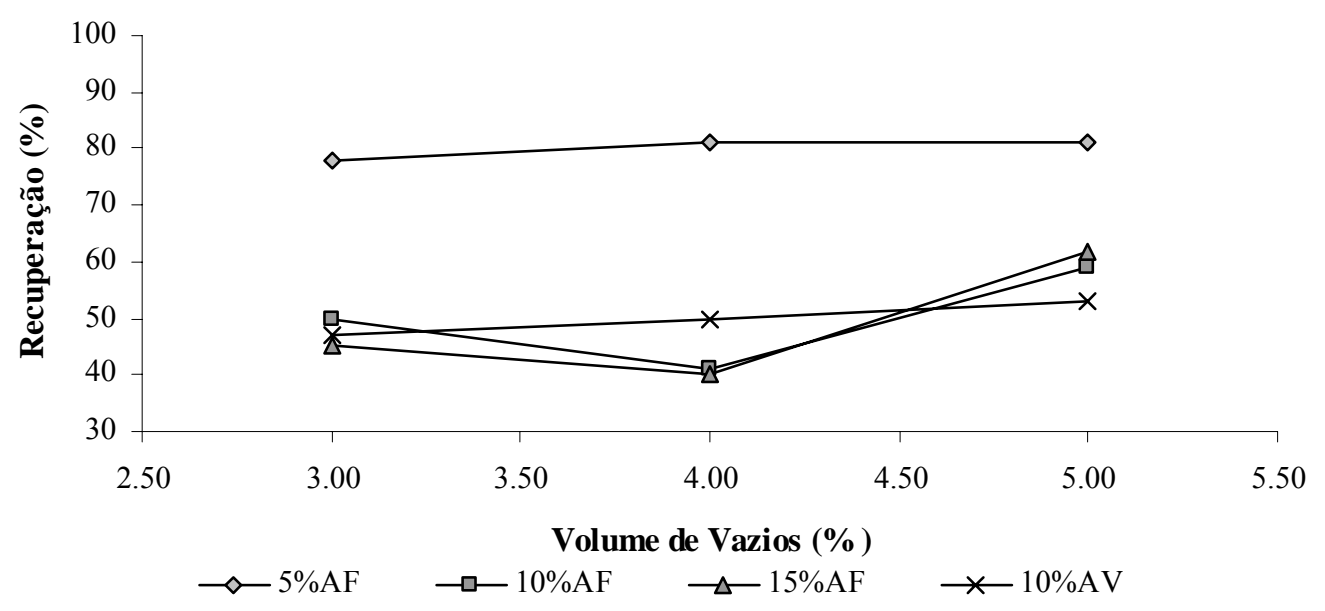

Figura 5.20. Recuperação de deformação versus volume de vazios (EFUE)

Misturas envelhecidas (Tensão - 0,1 MPa)

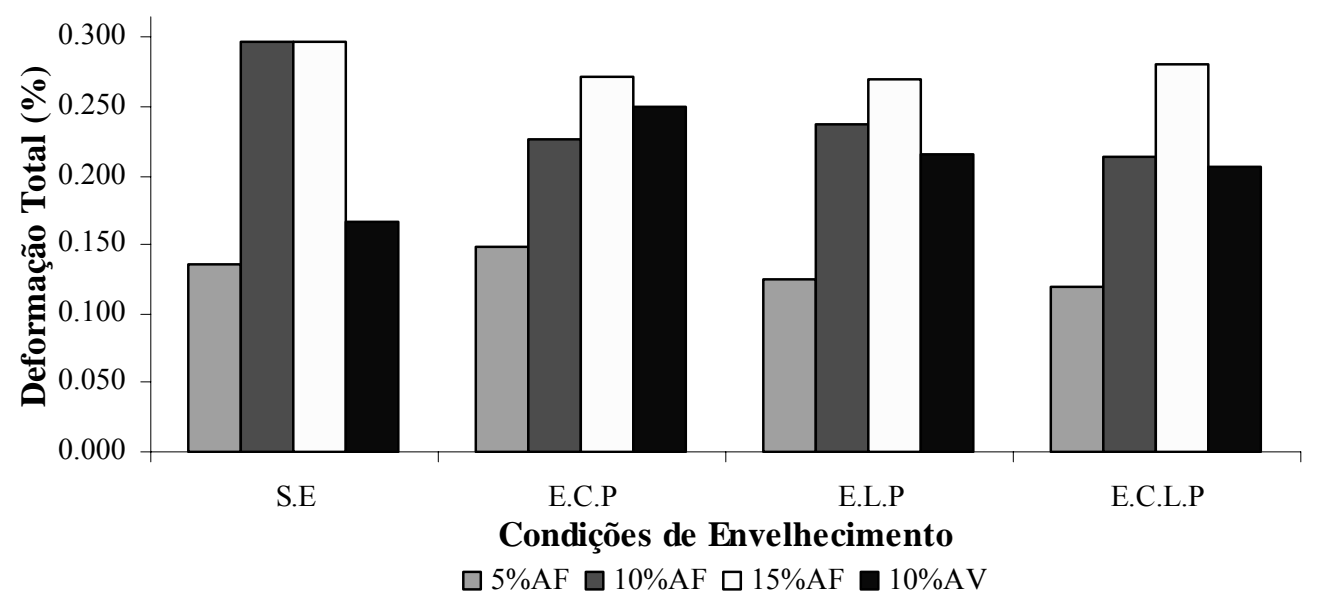

Figura 5.21. Deformação total versus condições de envelhecimento (EFUE) 


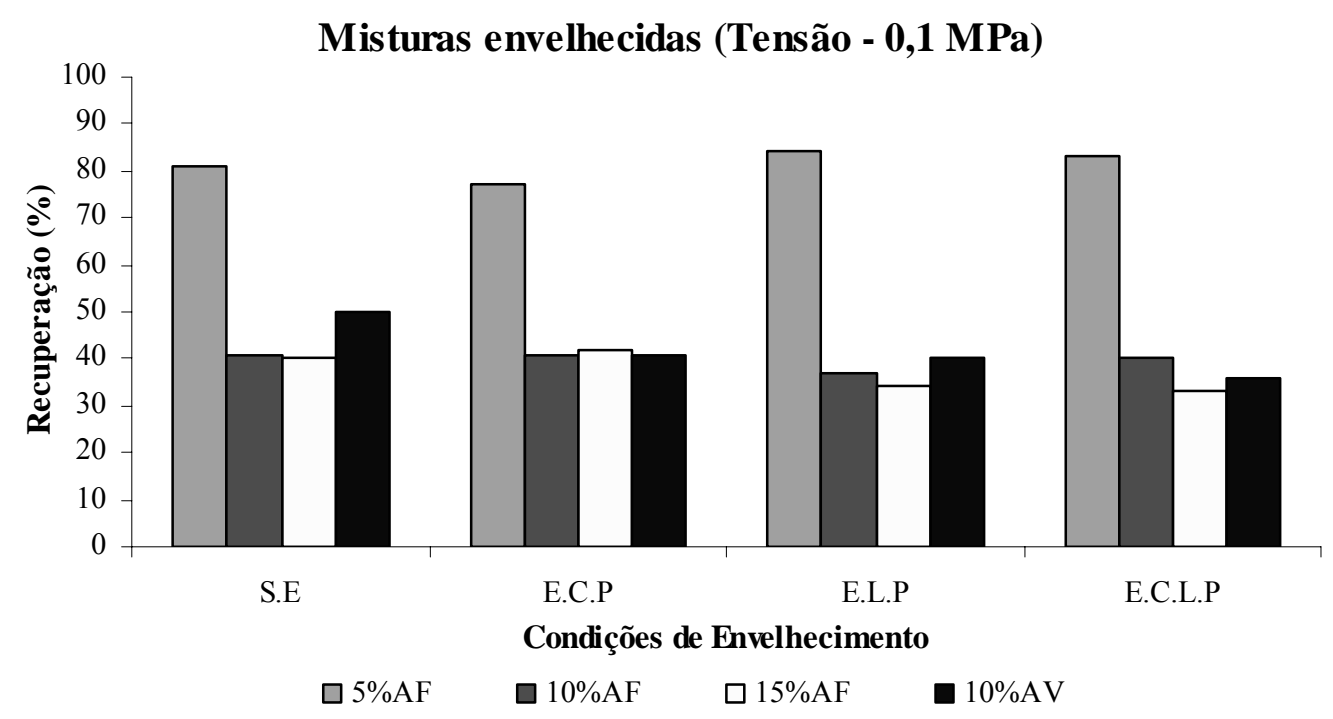

Figura 5.22. Recuperação de deformação versus condiç̃es de envelhecimento (EFUE)

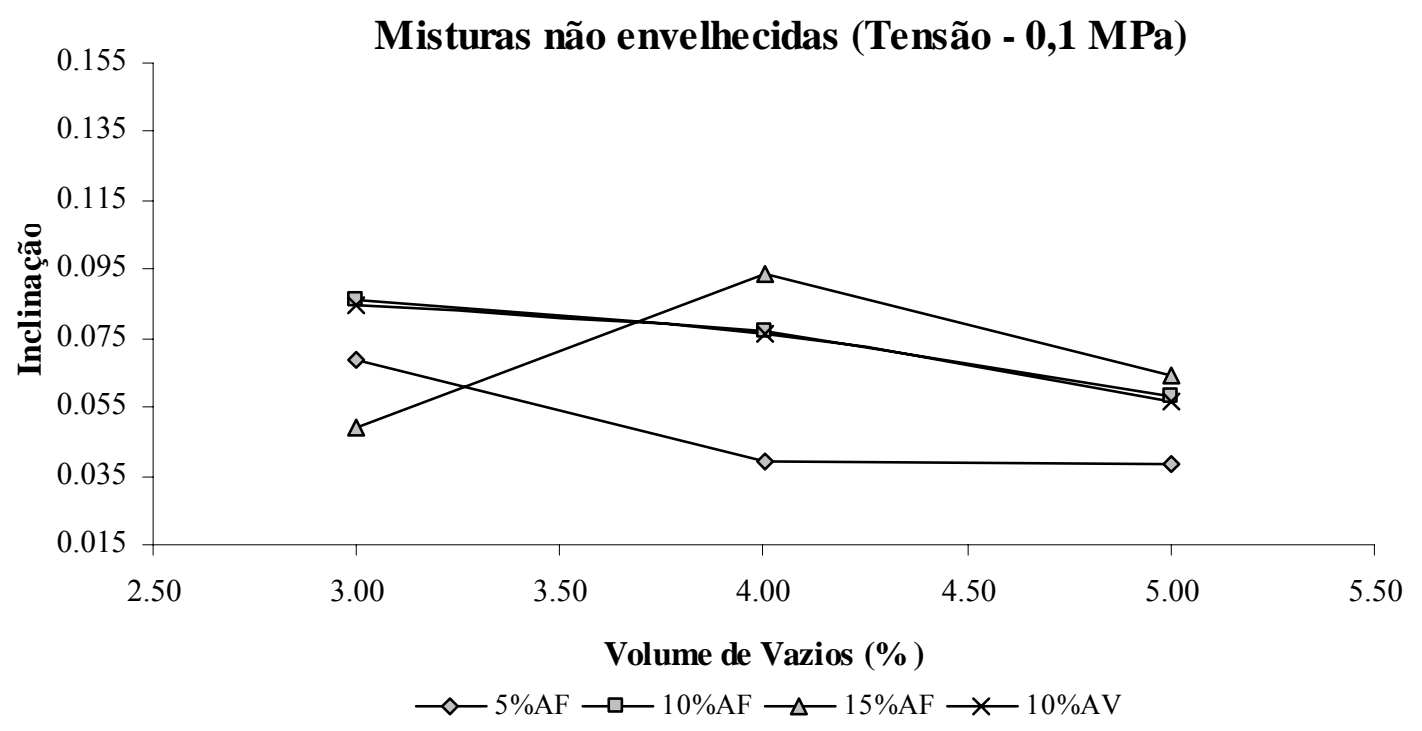

Figura 5.23. Inclinação do estágio secundário versus volume de vazios (EFUE)

\section{Misturas envelhecidas (Tensão - 0,1 MPa)}

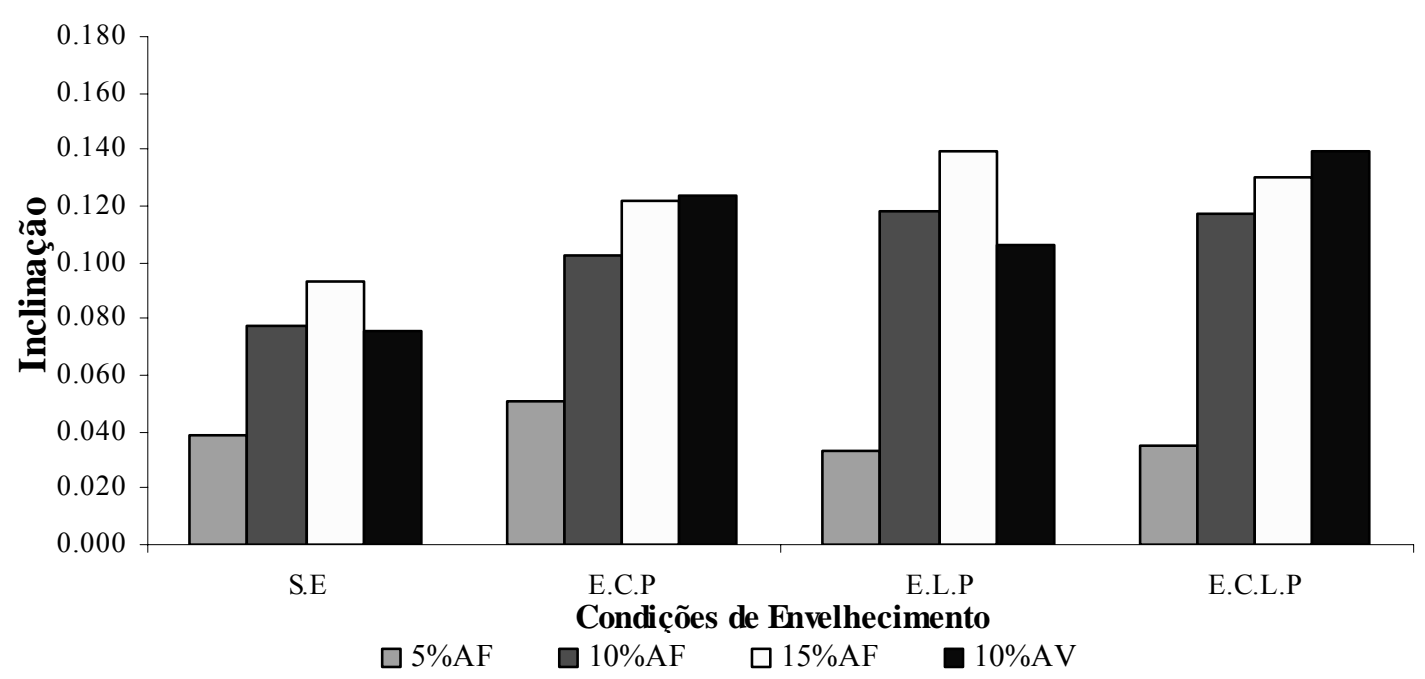

Figura 5.24. Inclinação do estágio secundário versus condições de envelhecimento (EFUE) 
Nos gráficos das Figuras 5.25 a 5.28, exibem-se os módulos de fluência, antes da recuperação (3600 s) e após a recuperação (4500 s) para todas as misturas pesquisadas. Nos gráficos das Figuras 5.25 e 5.26, apresentam-se, respectivamente, os módulos de fluência, antes da recuperação e após a recuperação, para as misturas não envelhecidas (3, 4 e 5\% de vazios) e nos gráficos das figuras 5.27 e 5.28, estes módulos, para as misturas condicionadas (4\% de vazios). Vale ressaltar, que os cálculos dos módulos de fluência antes (3600 segundos de ensaio) e após a recuperação (4500 segundos de ensaio) foram efetuados considerando a tensão nominal, isto é, $0,1 \mathrm{MPa}$ e não as tensões de ensaio, que são ligeiramente diferentes da nominal (média de 0,0983 MPa).

Misturas não envelhecidas (Tensão - 0,1 MPa e 3600 s)

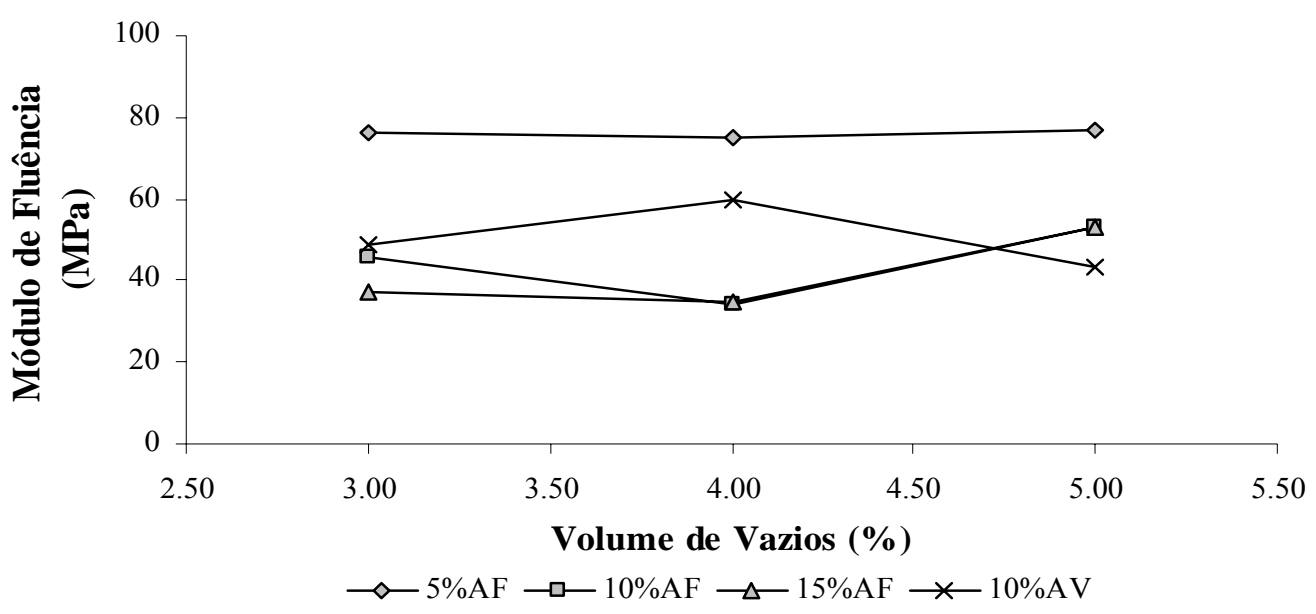

Figura 5.25. Módulo de fluência antes da recuperação versus volume de vazios (EFUE)

Misturas não envelhecidas (Tensão - 0,1 MPa e 4500 s)

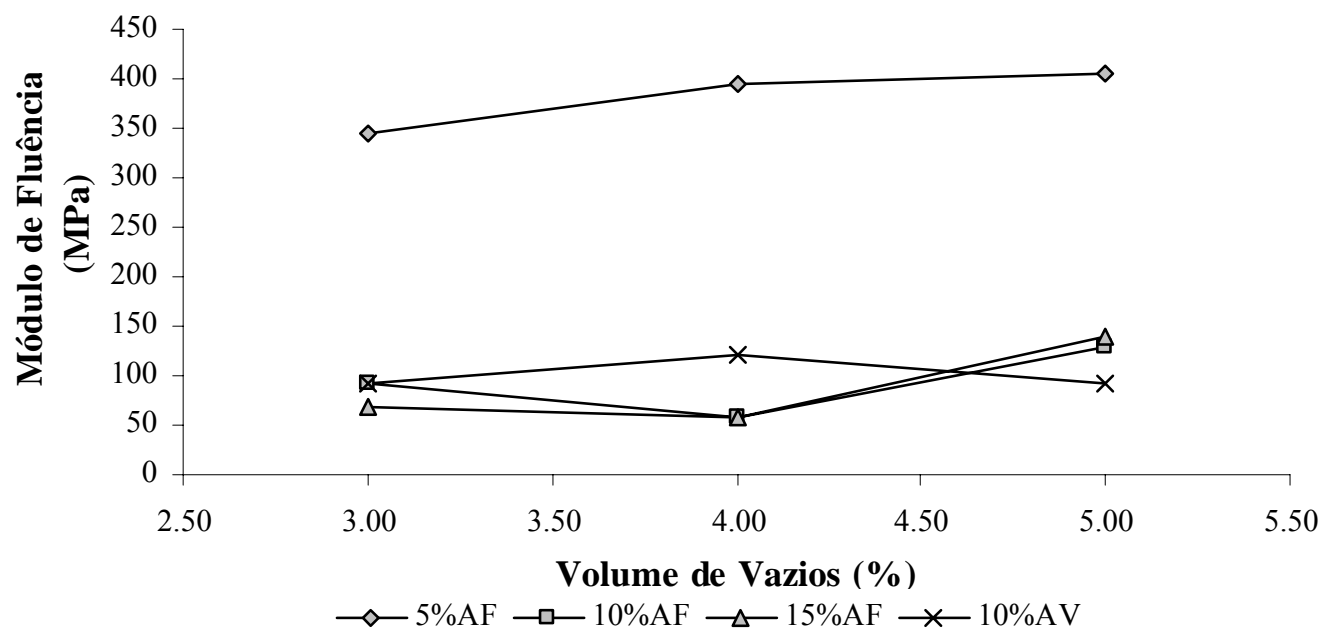

Figura 5.26. Módulo de fluência após a recuperação versus volumes de vazios (EFUE) 


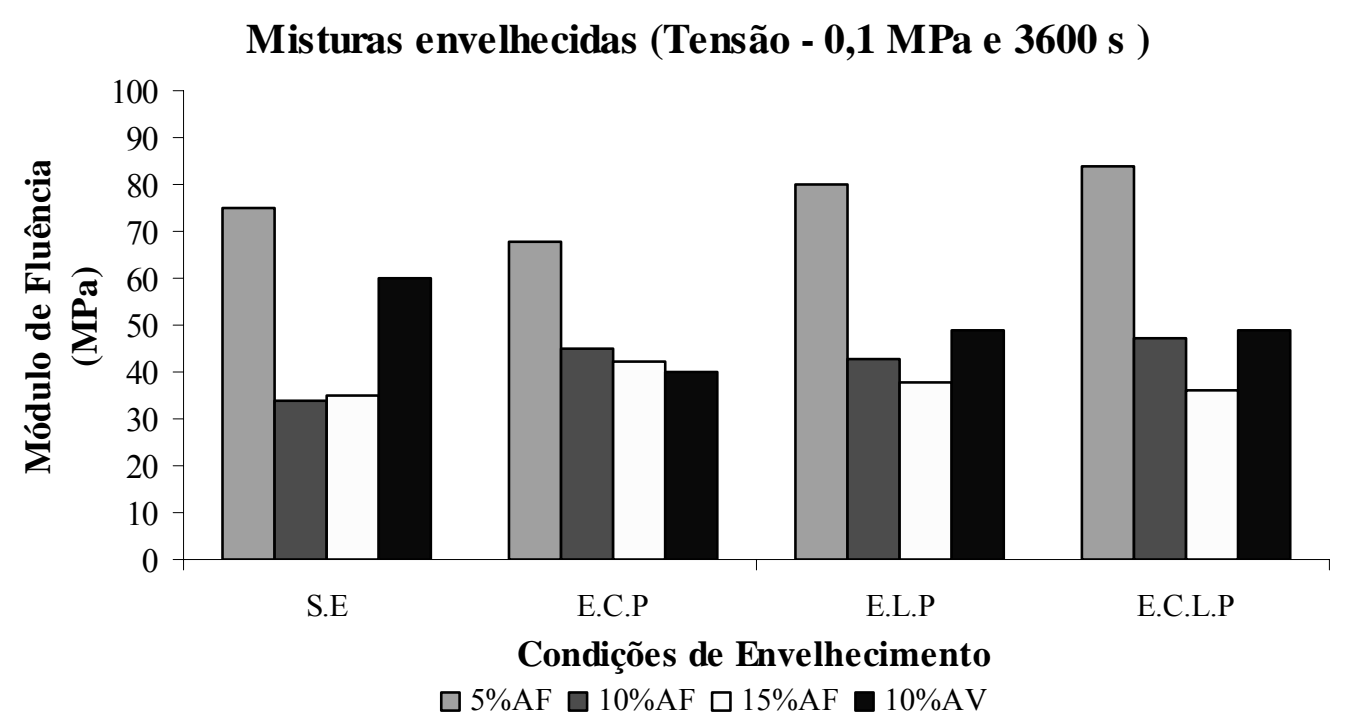

Figura 5.27. Módulo de fluência antes da recuperação versus condições de envelhecimento (EFUE)

\section{Misturas não envelhecidas (Tensão - 0,1 MPa e 4500 s)}

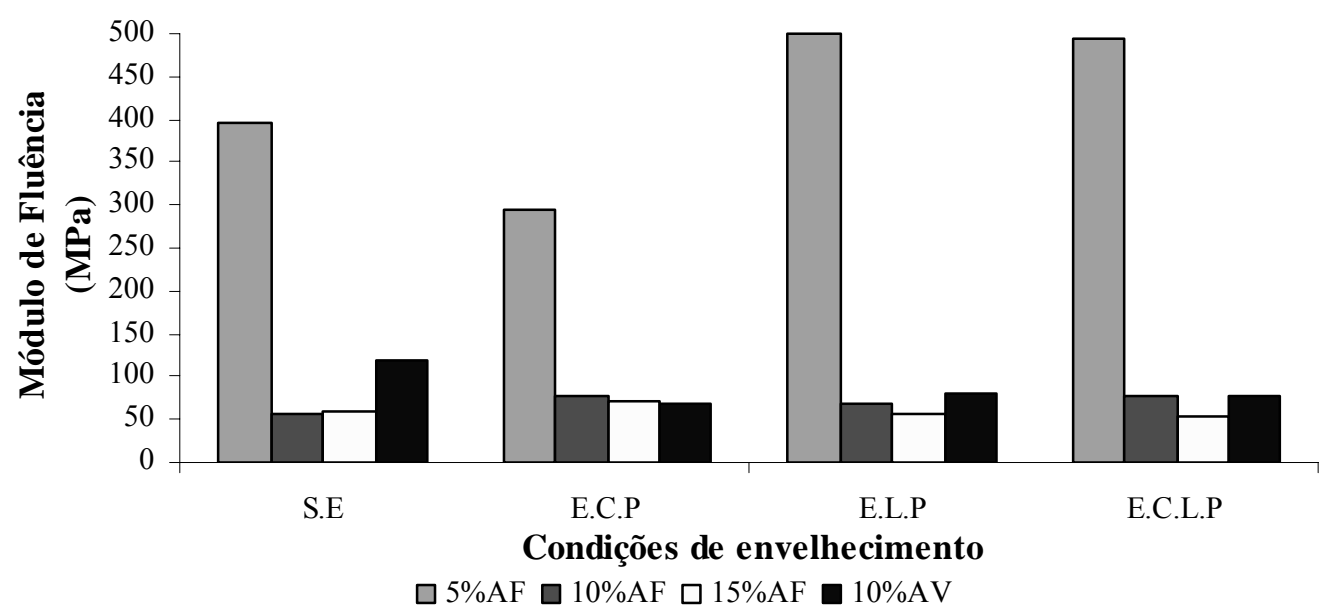

Figura 5.28. Módulo de fluência após a recuperação versus condições de envelhecimento (EFUE)

Nos resultados das deformações totais para as misturas não envelhecidas (Figura 5.19), verifica-se que todas as misturas apresentam valores superiores a $0,12 \%\left(1,2 \times 10^{-3}\right) \mathrm{e}$ inferiores a $0,30 \%\left(3,0 \times 10^{-3}\right)$. Aparentemente, apenas a mistura 5\%AF não apresenta mudança significativa com o volume de vazios (teor de asfalto), contudo a análise de variância indicou que o mesmo acontece com a mistura 15\% AF $\left(\alpha_{0}=9,96 \%\right)$.

Por meio do estudo estatístico, verificou-se que há expressiva mudança nas deformações totais com o volume de vazios para as mistura $10 \% \mathrm{AF}$ e $10 \% \mathrm{AV}$. Na mistura $10 \% \mathrm{AF}$, existe diferença significativa (DMS $=0,0382 \%$ ) entre as deformações totais para os volumes de vazios: 3 e $4 \%$ e entre 4 e $5 \%$. Para a mistura $10 \% \mathrm{AV}$ as 
diferenças significativas entre as deformações totais dizem respeito aos volumes de vazios: 3 e $4 \%(\mathrm{DMS}=0,0387 \%)$ e 4 e $5 \%(\mathrm{DMS}=0,0408 \%)$.

Os gráficos das misturas 10\%AF e 15\%AF apresentam a mesma tendência e mesmo valor máximo (0,297\%), e este ocorre para o volume de vazios de $4 \%$, enquanto para a $10 \% \mathrm{AV}$, o valor máximo $(0,233 \%)$ ocorre no volume de vazios de $5 \%$ e o mínimo $(0,166 \%)$ para o teor ótimo de asfalto (Figura 5.19).

As análises de variância identificaram $\left(\alpha_{0}=0,000067 \%\right)$ que para as misturas não envelhecidas, nem todas apresentam médias de deformações totais iguais, que pelo menos duas são significativamente diferentes entre si. Isto indica que o teor de areia interfere expressivamente na resposta desse parâmetro, em pelo menos duas misturas. Ao se realizar o contraste, comprovou-se que a diferença existente diz respeito às misturas: 5\%AF e 10\%AF (DMS =0,0373), 5\%AF e 15\%AF (DMS =0,044), 5\%AF e $10 \%$ AV $(\mathrm{DMS}=0,0392), 15 \% \mathrm{AF}$ e 10\%AV $(\mathrm{DMS}=0,045)$.

$\mathrm{Na}$ Figura 5.21, que ilustra as deformações totais para as condições de envelhecimento estudadas, nota-se que os gráficos das misturas não apresentam tendência definida. Nota-se também que todos os valores são superiores a $0,1 \% \mathrm{e}$ inferiores a $0,30 \%$ (E.C.P) e que a mistura com $15 \%$ de areia de fundição apresenta os maiores valores, sendo seguida pela 10\%AF (com exceção no E.C.P). Quase todas as misturas têm um decréscimo na deformação quando envelhecidas a longo prazo (E.L.P), com exceção da mistura $10 \% \mathrm{AV}$.

As análises de variância, para essas condições de ensaios, indicaram que o envelhecimento não interfere na deformação total de todas as misturas $\left(\alpha_{05 \% \mathrm{AF}}=7,39 \%\right.$, $\alpha_{010 \% \mathrm{AF}}=7,68 \%, \alpha_{015 \% \mathrm{AF}}=9,72 \%$ e $\left.\alpha_{0105 \% \mathrm{AV}}=22,79 \%\right)$. Por meio dos gráficos da Figura 5.21, é possível verificar que praticamente não há variação das deformações totais, o que foi corroborado pela análise de variância.

Por meio das ANOVAS, pôde-se identificar também diferença significativa entre as deformações totais médias das misturas envelhecidas nas condições de envelhecimento E.L.P e E.C.L.P $\left(\alpha_{o \text { E.L.P }}=1,17 \%\right.$ e $\left.\alpha_{\text {oE.C.L..P }}=0,0054 \%\right)$ e com isto verificar a interferência do teor e/ou tipo de areia nos resultados destes parâmetros como pode ser observado na Tabela 5.10. 
Tabela 5.10. Efeito do teor e do tipo de areia na deformação total $\left(10^{-3}\right)-$ considerando as condições de envelhecimento

\begin{tabular}{|c|c|c|c|c|c|c|c|c|c|}
\hline \multirow{3}{*}{$\begin{array}{l}\text { DIFERENÇA } \\
\text { (valor absoluto) }\end{array}$} & \multicolumn{9}{|c|}{ " CONDIÇÕES DE ENVELHECIMENTO } \\
\hline & \multicolumn{3}{|c|}{ E.C.P } & \multicolumn{3}{|c|}{ E.L.P } & \multicolumn{3}{|c|}{ E.C.L.P } \\
\hline & DMS & $\mathbf{D}_{\text {entre }}$ & DS? & DMS & $\mathbf{D}_{\text {entre }}$ & DS? & DMS & $\mathbf{D}_{\text {entre }}$ & DS? \\
\hline $\mid \overline{|5 \mathrm{AF}-10 \mathrm{AF}|}$ & 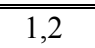 & 0,78 & $\overline{\mathbf{N}}$ & 0,85 & 1,12 & S (teor) & 0,38 & 0,94 & S (teor) \\
\hline$|5 \mathrm{AF}-15 \mathrm{AF}|$ & 1,2 & 1,2 & $\mathbf{N}$ & 0,71 & 1,44 & $\mathrm{~S}$ (teor) & 0,38 & 1,61 & $S$ (teor) \\
\hline$|5 \mathrm{AF}-10 \mathrm{AV}|$ & 1,2 & 1,0 & $\mathbf{N}$ & 0,85 & 0,90 & S (teor) & 0,31 & 0,87 & $S$ (teor) \\
\hline$|10 \mathrm{AF}-15 \mathrm{AF}|$ & 1,4 & 0,45 & $\mathbf{N}$ & 0,81 & 0,32 & $\mathbf{N}$ & 0,43 & 0,67 & S (teor) \\
\hline$|10 \mathrm{AF}-10 \mathrm{AV}|$ & 1,4 & 0,23 & $\mathbf{N}$ & 0,93 & 0,22 & $\mathbf{N}$ & 0,38 & 0,065 & $\mathbf{N}$ \\
\hline$|15 \mathrm{AF}-10 \mathrm{AV}|$ & 1,4 & 0,23 & $\mathbf{N}$ & 0,81 & 0,54 & $\mathbf{N}$ & 0,38 & 0,74 & S (teor) \\
\hline
\end{tabular}

DMS - Diferença Menos Significativa $\quad D_{\text {entre }}$ - Diferença entre tratamentos $\quad$ DS - Diferença Significativa $\mathrm{S}-\mathrm{Sim}$ N - Não

Em alguns casos, ao se observar os gráficos, nota-se claramente que existe mudança significativa entre os tratamentos, como por exemplo, na Figura 5.21 na condição de envelhecimento a curto prazo (E.C.P). Nesta condição, verifica-se que existe mudança "significativa" entre a mistura 5\%AF e as demais, contudo a análise de variância não detectou esta mudança expressiva.

Nos resultados de Recuperação (\%) (Figuras 5.20 e 5.22), pode-se verificar que a mistura 5\%AF apresenta valores superiores, tanto na condição de misturas não envelhecidas (Figura 5.20) quanto na condição de misturas envelhecidas(Figura 5.22). Nesses gráficos, pode-se verificar também que existe diferença expressiva entre as recuperações dessa mistura e de todas as outras, mas que para todas as misturas, esse parâmetro não muda expressivamente com o volume de vazios nem com as condições de envelhecimento. Os valores da recuperação da mistura 5\%AF estão em torno de $80 \%$, enquanto nas misturas remanescentes esses variam entre 40 e $62 \%$, no caso das misturas não envelhecidas, e entre 33 e $50 \%$ para as misturas envelhecidas.

As misturas 5\%AF e 10\% AV apresentam gráficos das misturas não envelhecidas com comportamentos semelhantes (mesma tendência), a recuperação cresce sutilmente com aumento no volume de vazios, sendo que os valores da recuperação da $10 \% \mathrm{AV}$ variam de 47 a 53\%. As misturas 10\%AF e 15\%AF apresentam gráficos também com tendência e valores similares. Os valores mínimos de recuperação, em torno de 40\%, para estas misturas correspondem ao volume de vazios de $4 \%$.

Pelo exposto verifica-se a superioridade das misturas com 5\% de areia de fundição, apresentando valores altos de recuperação (77 a 84\%). Vale ressalta que esta mistura é a 
que apresenta menor teor de finos $(41,35 \%)$, fíler $(6,75 \%)$ e ligante (teor médio de $5,20 \%)$.

Nos resultados de Inclinação do estágio secundário (Figuras 5.23 e 5.24), nota-se que a mistura 5\% AF apresenta valores inferiores, com exceção do valor referente ao volume de vazios de 3\%, tanto na condição de misturas não envelhecidas (Figura 5.23) quanto na condição de misturas envelhecidas (Figura 5.24). Nesses gráficos, pode-se verificar também que existe diferença expressiva entre os resultados dessa mistura e de todas as outras e que há mudança significativa em sua inclinação com o volume de vazios, principalmente entre os Vv: 3\% e 4\%, e 3 e 5\%. As inclinações para as misturas $10 \% \mathrm{AF}$ e $10 \% \mathrm{AV}$ são praticamente iguais e não sofrem alteração expressiva com o volume de vazios nem com as condições de envelhecimento. Os valores da inclinação da mistura 5\%AF variam de 0,038 a 0,068 e 0,033 a 0,050 , para as misturas não envelhecidas e envelhecidas, respectivamente, enquanto nas misturas remanescentes esses variam entre 0,049 e 0,093, no caso das misturas não envelhecidas, e entre 0,077 e 0,139 , no caso das envelhecidas.

Nos gráficos das misturas envelhecidas (Figura 5.24), observa-se que, dentro de cada condição de envelhecimento, parece não haver mudança expressiva nos valores da inclinação com o teor de areia, no que diz respeito às misturas $10 \% \mathrm{AF}, 10 \% \mathrm{AV}$ e $15 \%$ AF. Contudo, nota-se que a condição de envelhecimento interfere nesses resultados, principalmente, comparando as condições S.E com as demais. No caso da mistura 5\% AF, as condições de envelhecimento não modificam expressivamente a inclinação, demonstrando, desta forma, pouco suscetibilidade ao envelhecimento.

As misturas 5\% AF e 15\% AF apresentam gráficos, misturas não envelhecidas, com comportamento inverso. A inclinação do estágio secundário da mistura $15 \% \mathrm{AF}$ cresce com aumento no volume de vazios, atingindo um valor máximo $(0,093)$ no $\mathrm{Vv}$ de $4 \%$, enquanto a mistura 5\% AF apresenta valor mínimo de 0,038 para o $\mathrm{Vv}$ de $5 \%$. As misturas $10 \% \mathrm{AF}$ e $10 \% \mathrm{AV}$ apresentam gráficos com a mesma tendência e valores praticamente iguais. Os valores da inclinação do estágio secundário destas mistura para Vv de 4\% (teor ótimo de asfalto) estão em torno de 0,075 .

Nos resultados dos módulos de fluência antes da recuperação (MPa), considerando as misturas não envelhecidas (Figura 5.25), verifica-se que todas as misturas apresentam valores superiores a $30 \mathrm{MPa}$ e inferiores a $80 \mathrm{MPa}$. Aparentemente, apenas a mistura 5\%AF não apresenta mudança significativa com o volume de vazios (teor de asfalto), contudo o mesmo acontece com a mistura 15\%AF (verificar a análise referente 
à deformação total), mais visível, entre os $\mathrm{Vv}$ de $3 \%$ e $4 \%$ (valores de módulo de fluência muito próximos, 37 e $35 \mathrm{MPa}$, respectivamente). Em relação às outras misturas verificar a análise de variância realizada para as deformações totais.

$\mathrm{Na}$ Figura 5.27, que ilustra os módulos de fluência antes da recuperação para as condições de envelhecimento estudadas, nota-se que os gráficos das misturas não apresentam tendência definida. Nota-se também que todos os valores são superiores a $30 \mathrm{MPa}$ e inferiores a $90 \mathrm{MPa}$ e que a mistura com 5\% de areia de fundição apresenta os maiores valores, sendo seguida em quase todos os casos pela 10\%AV. Quase todas as misturas têm um aumento no módulo de fluência quando envelhecidas a longo prazo (E.L.P), com exceção da mistura 10\%AV. No envelhecimento a curto prazo (E.C.P), as misturas 5\% AF e 10\%AV apresentam um decréscimo nesse parâmetro.

Por meio dos gráficos da Figura 5.27, é possível verificar que há variação dos módulos de fluência com as condições de envelhecimento, o que pode ser comprovado verificando-se a análise de variância realizada para as deformações totais nestas condições.

Nota-se que o teor de areia interfere mais no módulo de fluência do que o tipo de areia (Figura 5.25), quanto maior o teor menor o módulo, lembrando que nas misturas $10 \% \mathrm{AF}$ e $15 \% \mathrm{AF}$ essa diferença é pouco expressiva. Verifica-se ainda que, no volume de vazios de $4 \%$, a mistura $10 \%$ AV apresenta maior (60 MPa) módulo de fluência que a 10\%AF (34 MPa), indicando que no teor ótimo de asfalto o tipo de areia interfere.

Nos resultados dos módulos de fluência após recuperação (MPa) (Figuras 5.26 e 5.28 ), verifica-se que a mistura 5\% AF apresenta valores muito superiores a todos os outros, tanto na condição de misturas não envelhecidas (345 a $405 \mathrm{MPa}$ ) (Figura 5.26) quanto na condição de misturas envelhecidas (296 a $500 \mathrm{MPa}$ ) (Figura 5.28). Aparentemente, todas as misturas não apresentam mudança significativa no módulo com o volume de vazios (teor de asfalto).

$\mathrm{Na}$ Figura 5.28, que ilustra os módulos de fluência após recuperação para as condições de envelhecimento estudadas, nota-se que os gráficos das misturas não apresentam tendência definida. Verifica-se ainda que todos os valores são superiores a $50 \mathrm{MPa}$ e inferiores a $100 \mathrm{MPa}$, com exceção dos apresentados para a mistura com 5\% de areia de fundição, comentado anteriormente. A mistura $10 \% \mathrm{AV}$ exibe módulos após recuperação bem menores que o da mistura 5\% AF e ligeiramente maiores que as outras mistura, sendo exceção para o envelhecimento a curto prazo (E.C.P). Quase todas as misturas têm um aumento no módulo de fluência quando envelhecidas a longo prazo 
(E.L.P), com exceção da mistura 10\%AV. No envelhecimento a curto prazo (E.C.P), as misturas 5\%AF e 10\%AV apresentam uma diminuição razoável nesse parâmetro.

Por meio dos gráficos da Figura 5.28, é possível verificar que quase não há variação dos módulos de fluência com as condições de envelhecimento, com exceção da mistura $5 \%$ AF. Neste gráfico é possível observar que não há mudança significativa nos módulo desta mistura entre as condições E.L.P e E.C.L.P.

Verifica-se ainda que, no volume de vazios de 4\%, as misturas 5\%AF, 10\%AF, $15 \% \mathrm{AF}$ e 10\% AV apresentam módulo de fluência após recuperação iguais a 395, 58, 58 e $120 \mathrm{MPa}$, respectivamente.

Os dados referentes aos ensaios de fluência por compressão uniaxial estática com tensão de 0,1 MPa estão apresentados nas Tabelas B.14 e B.17do Apêndice B (página 207).

\subsubsection{Fluência por Compressão Uniaxial Estática com tensão de $0,4 \mathrm{MPa}$}

Os gráficos das Figuras 5.29 a 5.38 referem-se aos resultados das misturas estudadas, considerando a tensão de ensaio de $0,4 \mathrm{MPa}$ e pratos de distribuição de carregamento com diâmetros de $102 \mathrm{~mm}$ (aproximadamente igual ao do corpo-de-prova) e $51 \mathrm{~mm}$ (diâmetro reduzido). Neste nível de tensão, foram executados 96 ensaios, sendo 48 com o prato de carregamento normal (102 mm de diâmetro) e 48 com o prato reduzido (51 mm de diâmetro). Em cada gráfico, visualizam-se, simultaneamente, os parâmetros relativos ao prato superior (de distribuição de carregamento) normal e ao prato superior reduzido.

Como mencionado anteriormente, os cálculos dos módulos de fluência antes e após a recuperação foram realizados considerando a tensão nominal, isto é, 0,4 MPa e não as tensões de ensaio, que são ligeiramente diferentes (média de 0,3924 MPa para os ensaios com o prato normal e de 0,4033 MPa para os ensaios com o prato reduzido).

Nos gráficos das Figuras 5.29 e 5.30, exibem-se, respectivamente, a deformação total e a recuperação das misturas não envelhecidas (volumes de vazios de 3, 4 e 5\%), enquanto nos gráficos 5.31 e 5.32, apresentam-se estes parâmetros, mas para as misturas envelhecidas (condições de envelhecimento) e com volumes de vazios iguais a 4\%. Os gráficos das Figuras 5.33 e 5.34 são relativos, respectivamente, a inclinação do trecho secundário da curva de fluência para as misturas não envelhecidas (3, 4 e 5\% de vazios) e para as envelhecidas ( $4 \%$ de vazios). 


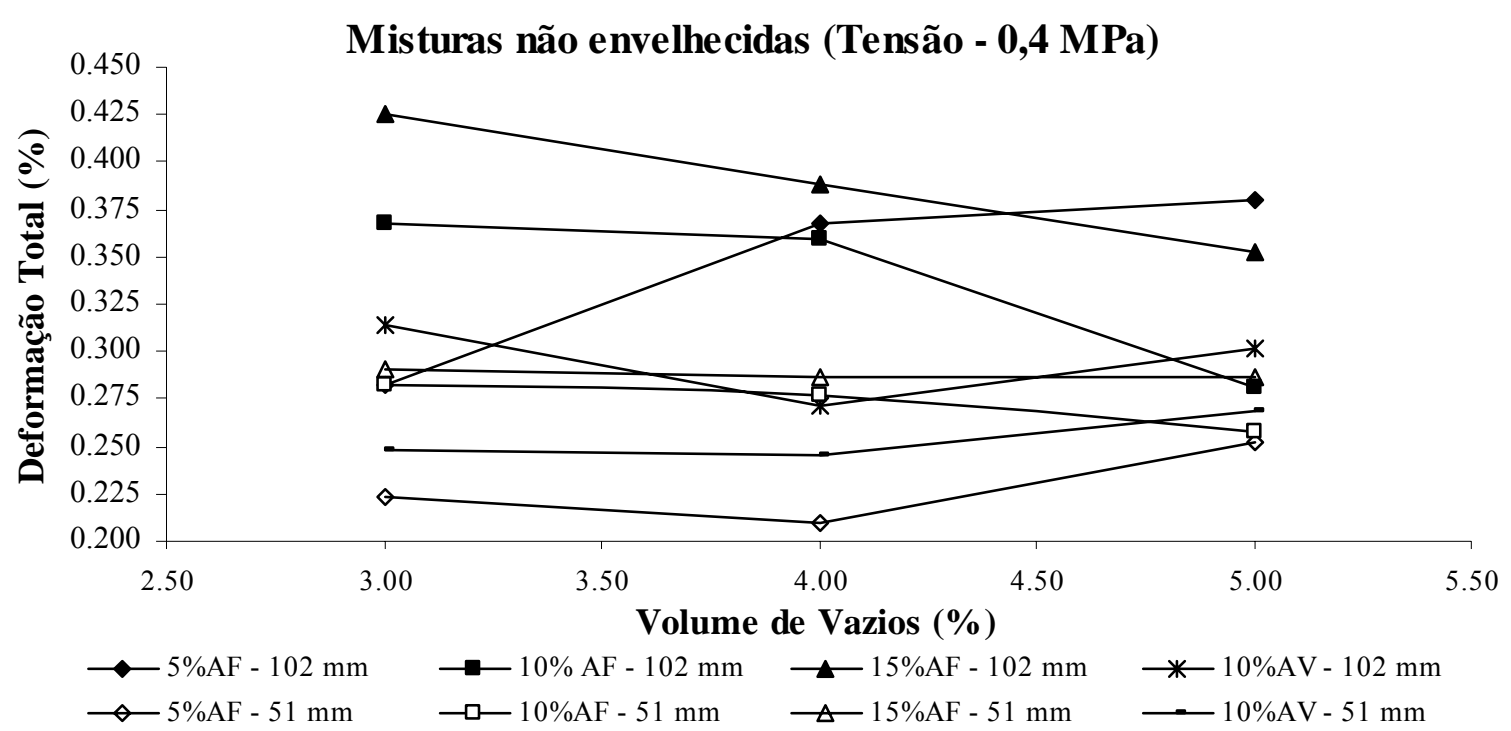

Figura 5.29. Deformação total versus volume de vazios - pratos normal (PN) e reduzido (PR) (EFUE)

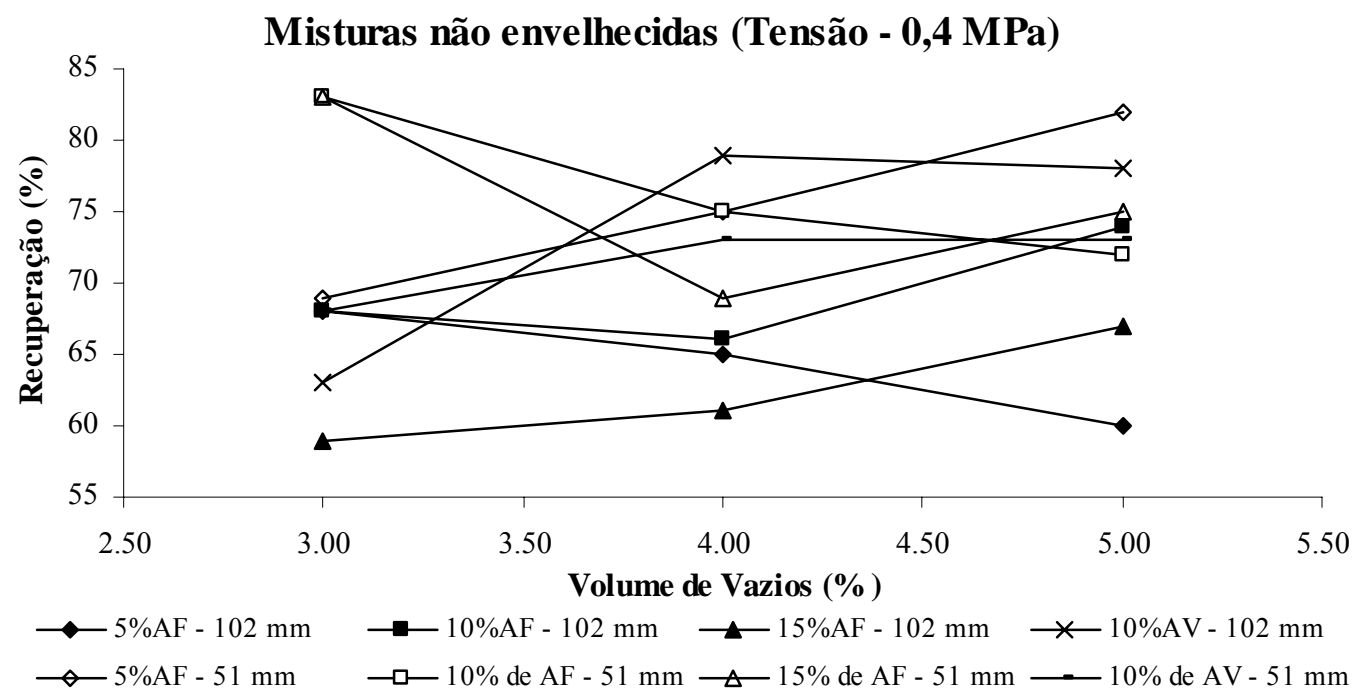

Figura 5.30. Recuperação de deformação versus volume de vazios - PN e PR (EFUE)

Misturas envelhecidas - (Tensão - 0,4 MPa)

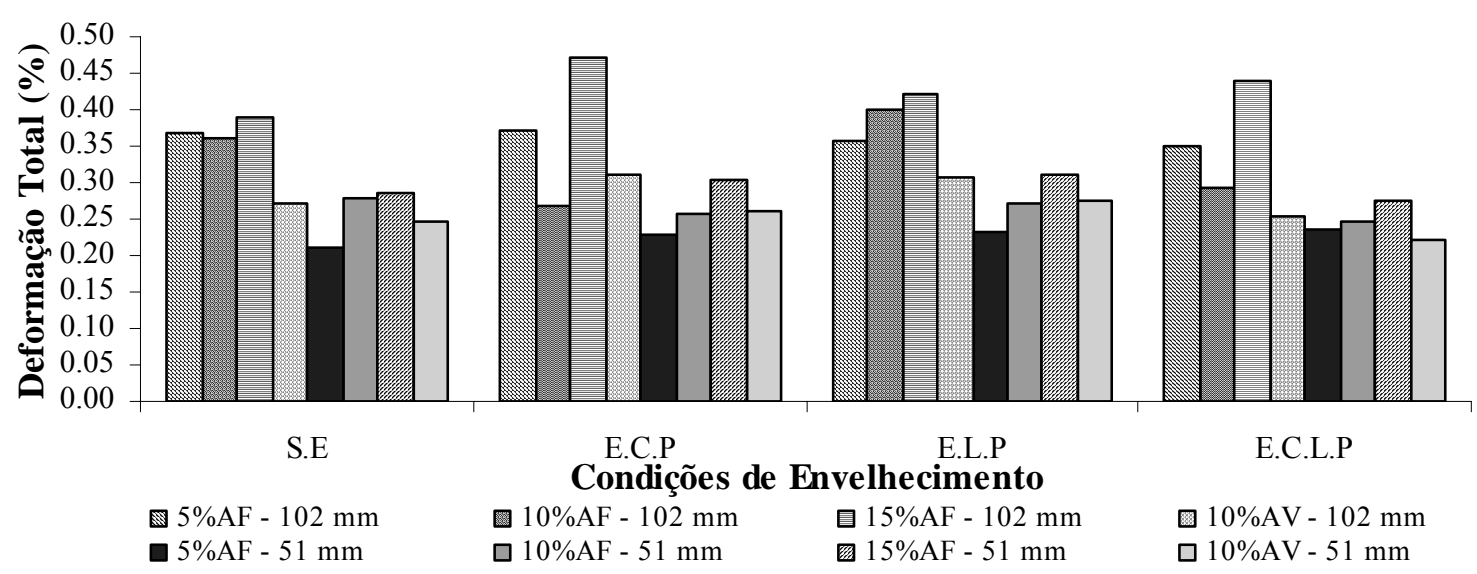

Figura 5.31. Deformação total versus condições de envelhecimento- PN e PR (EFUE) 
Misturas envelhecidas (Tensão - 0,4 MPa)

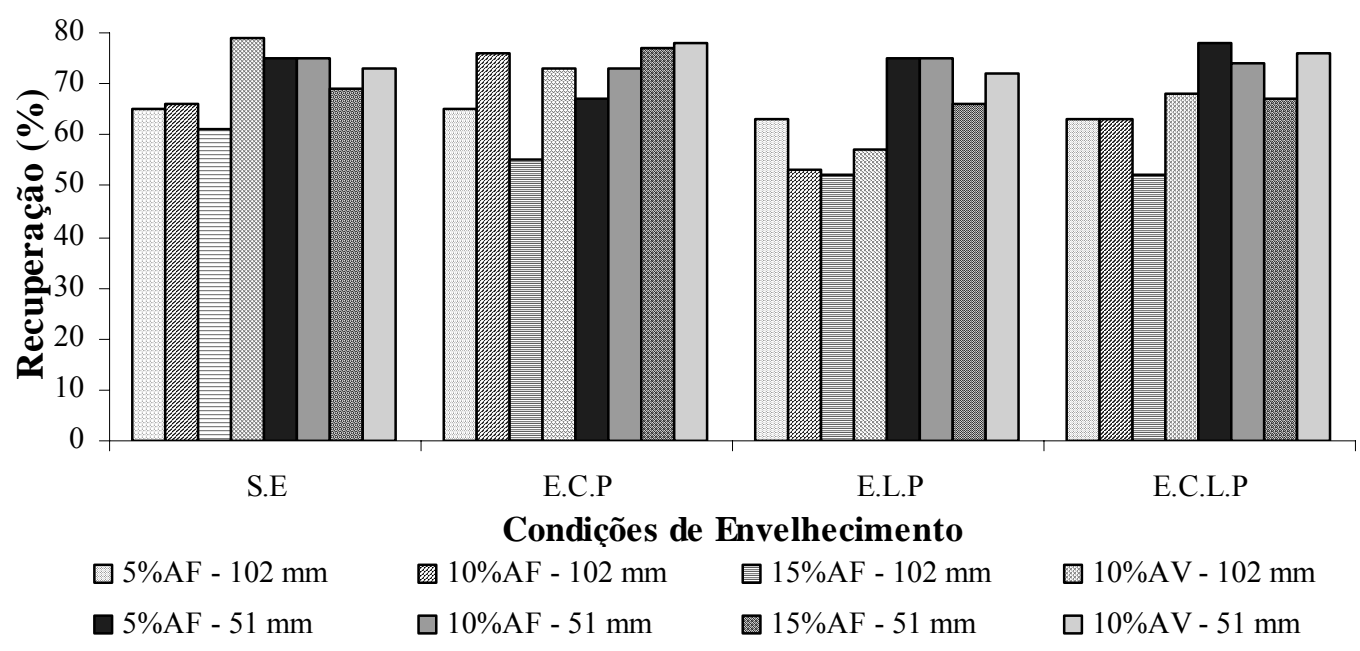

Figura 5.32. Recuperação de deformação versus condições de envelhecimento - PN e PR (EFUE)

\section{Misturas não envelhecidas (Tensão - 0,4 MPa)}

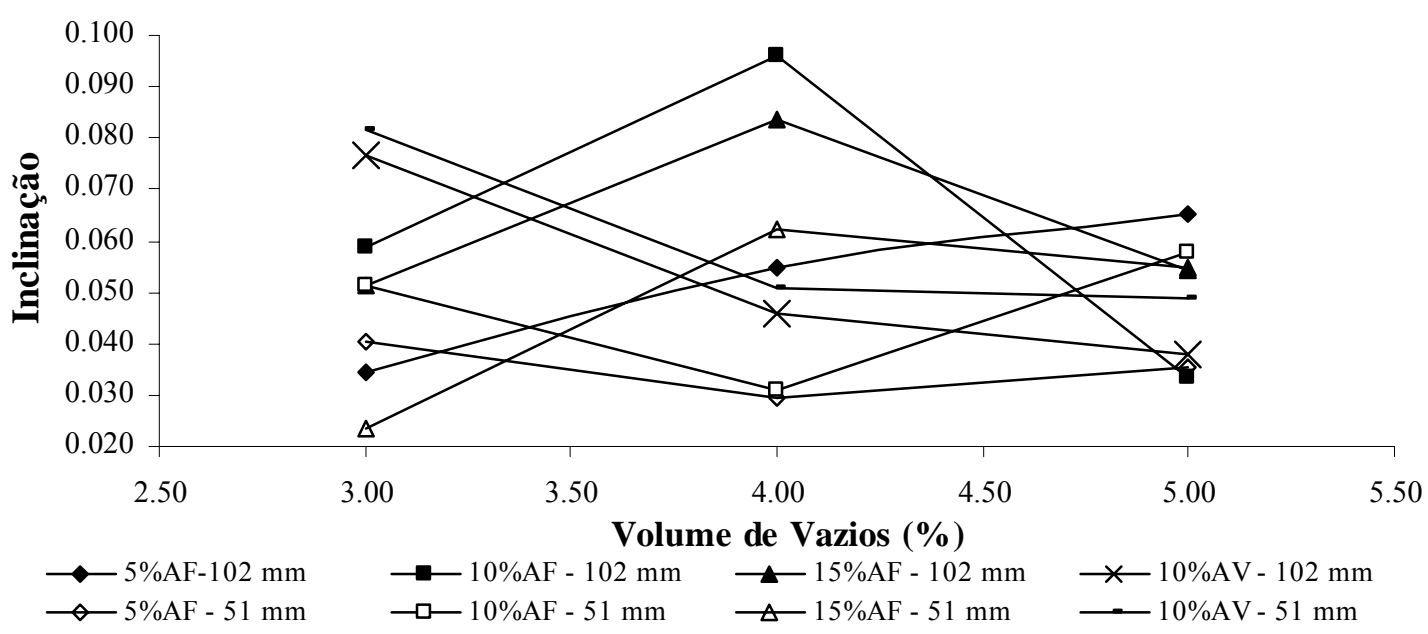

Figura 5.33. Inclinação do estágio secundário versus volume de vazios - PN e PR (EFUE)

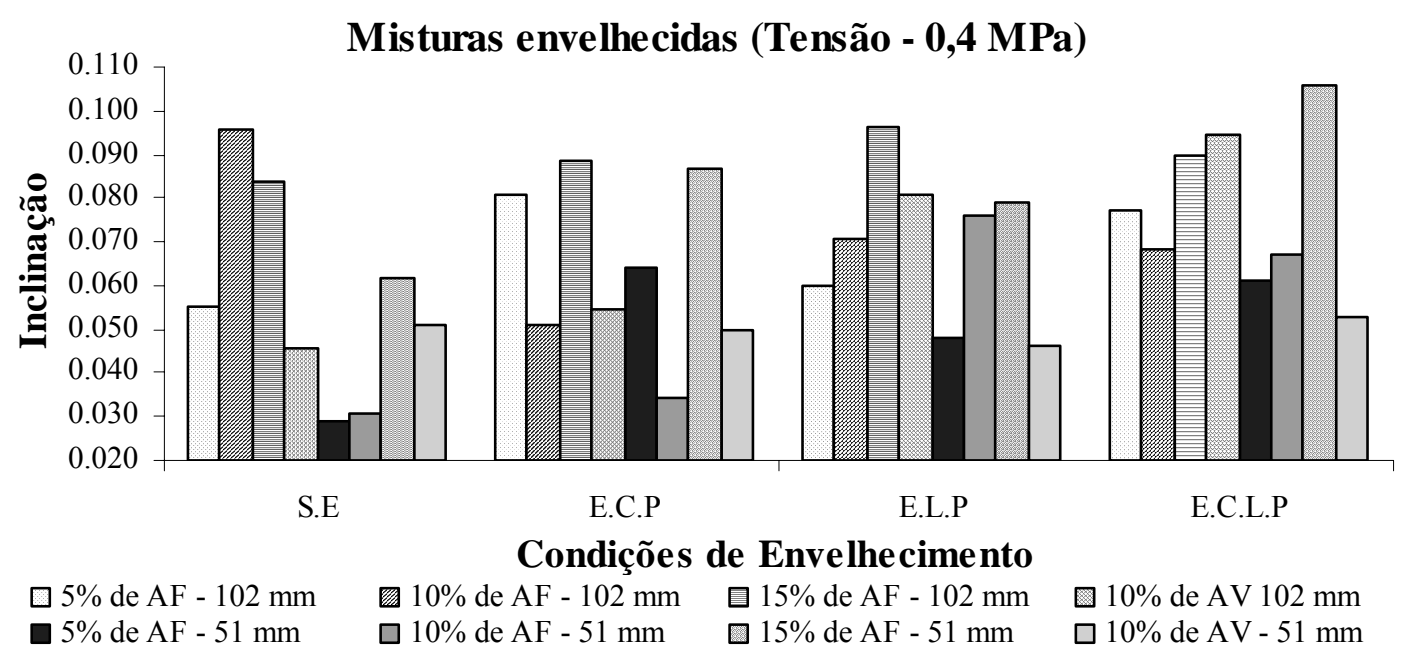

Figura 5.34. Inclinação do estágio secundário versus condições de envelhecimento- PN e PR (EFUE) 
Nos gráficos das Figuras 5.35 a 5.38, expõem-se os módulos de fluência, antes da recuperação (3600 s) e após a recuperação (4500 s) para as misturas pesquisadas, considerando o nível de tensão de 0,4 MPa (prato reduzido e normal). Os gráficos das Figuras 5.35 e 5.36 dizem respeito, respectivamente, aos módulos de fluência antes e após a recuperação para as misturas não envelhecidas (3, 4 e 5\% de vazios). Os gráficos das figuras 5.37 e 5.38 apresentam estes mesmos parâmetros, contudo para as misturas envelhecidas ( $4 \%$ de vazios).

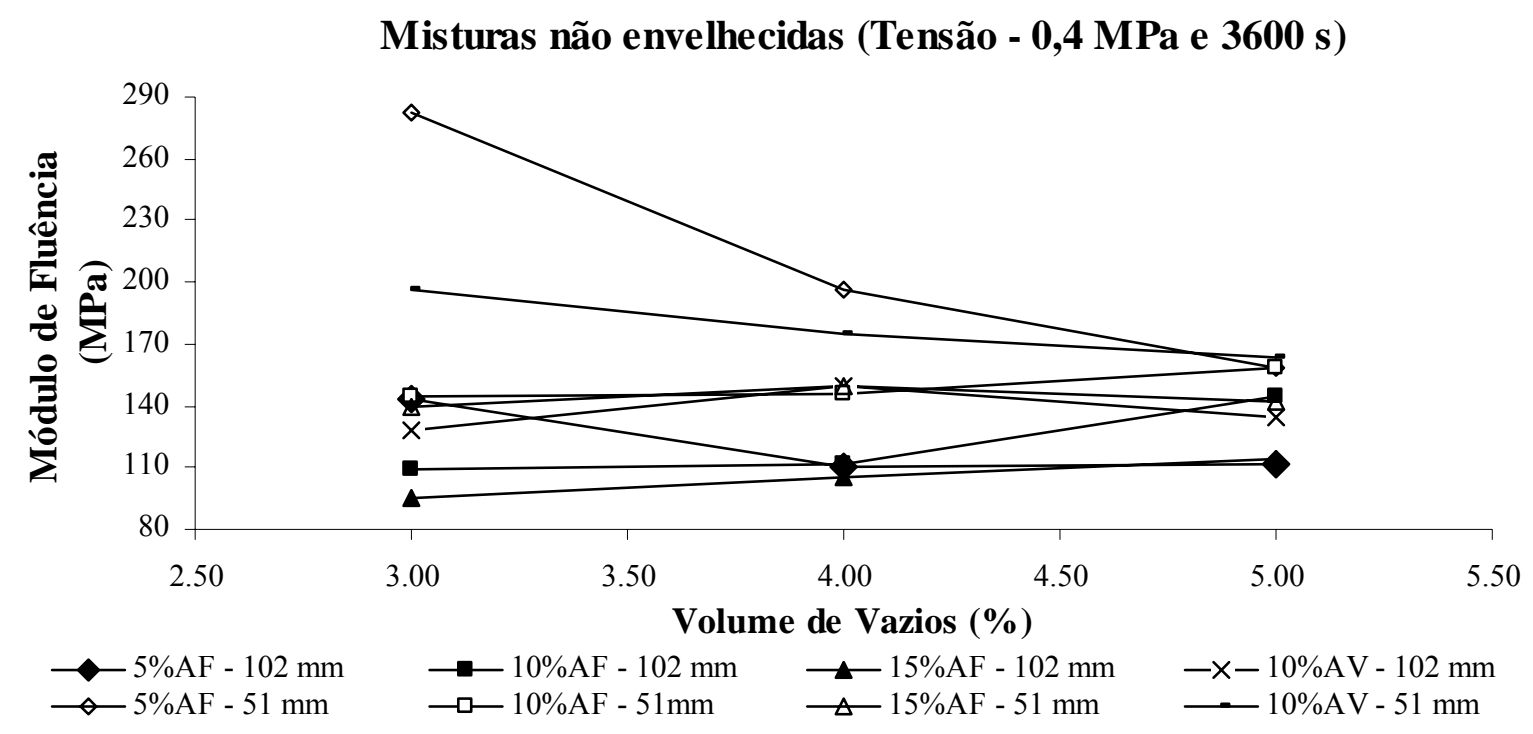

Figura 5.35. Módulo de fluência antes da recuperação versus volume de vazios - PN e PR (EFUE)

Misturas não envelhecidas (Tensão - 0,4 MPa e 4500 s)

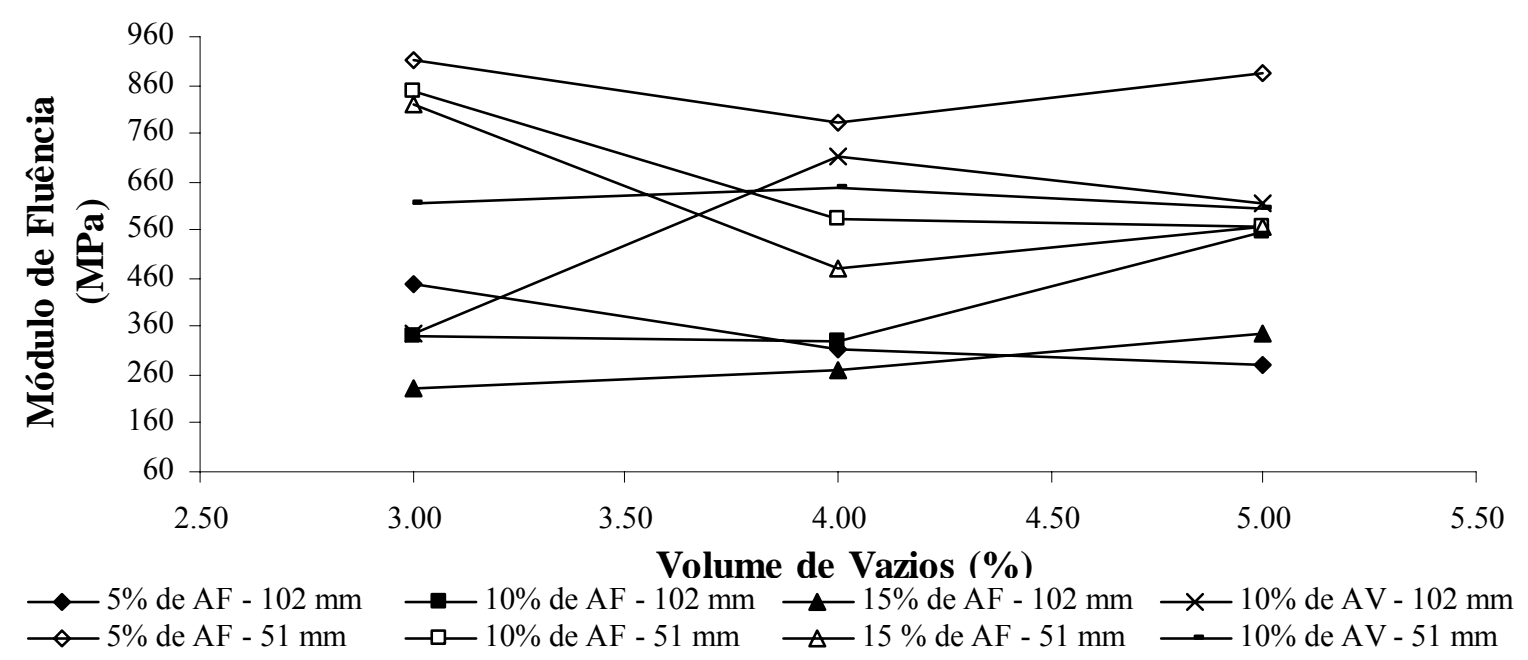

Figura 5.36. Módulo de fluência após a recuperação versus volume de vazios - P N e PR (EFUE) 


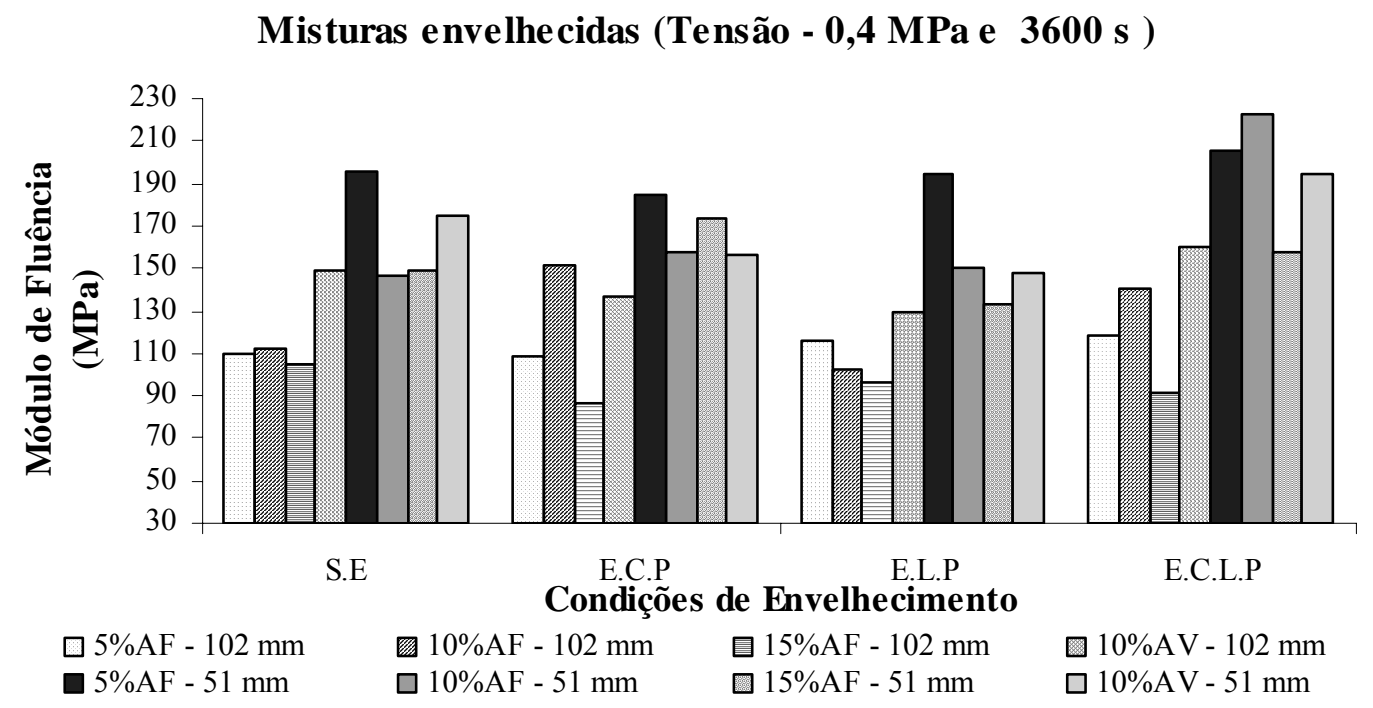

Figura 5.37. Módulo de fluência antes da recuperação versus condições de envelhecimento - PN e PR (EFUE)

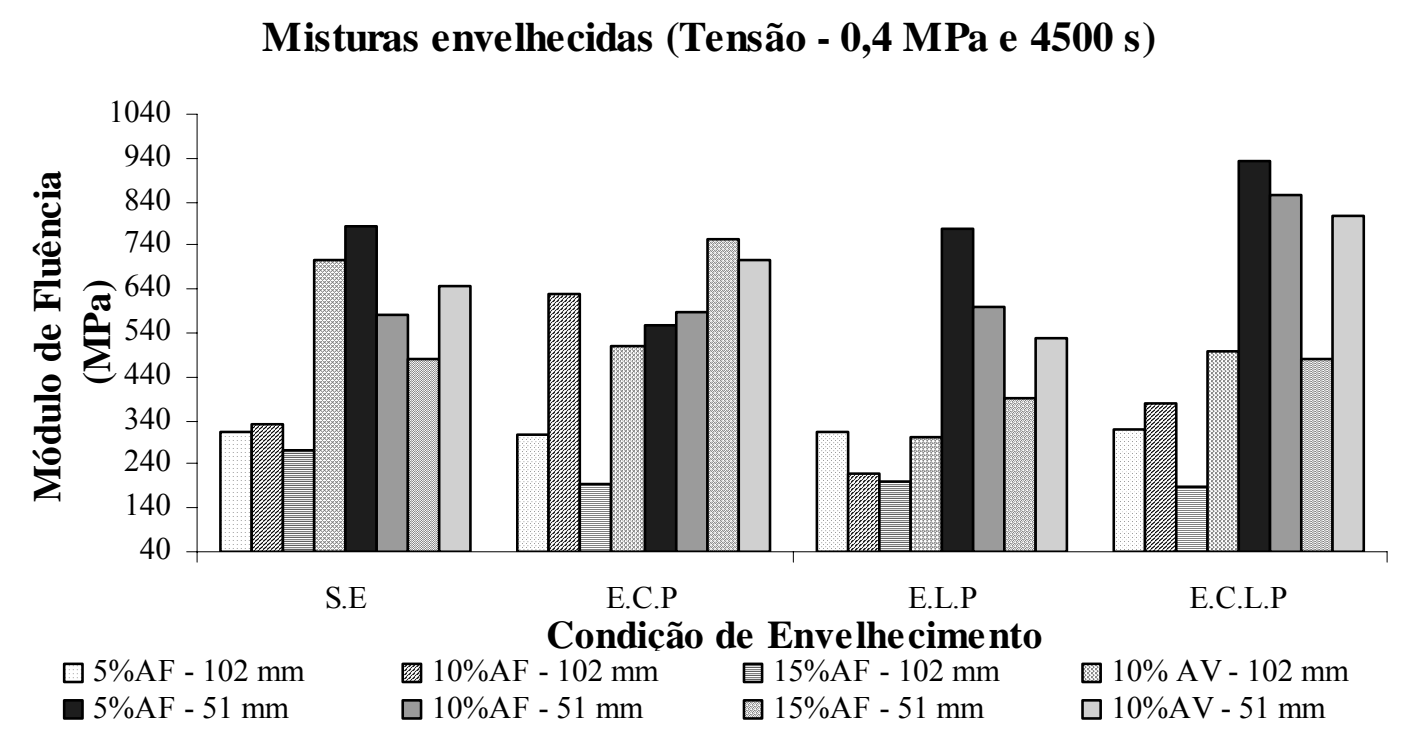

Figura 5.38. Módulo de fluência, após a recuperação, para as misturas condicionadas Prato Normal e Prato Reduzido

Os dados para a confecção dos gráficos (Figuras 5.19 a 5.38) bem como todos os resultados referentes aos ensaios de fluência por compressão uniaxial com tensão de 0,4 MPa estão apresentados nas Tabelas B.15 e B.18 (prato superior de $102 \mathrm{~mm}$ ) e nas Tabelas B.16 e B.19 (prato superior de 51 mm)do Apêndice B (página 207).

\subsubsection{Análise e discussão dos resultados do ensaio de Fluência por Compressão}

\section{Uniaxial Estática - tensão de 0,4 MPa e prato superior normal (102 mm)}

Nos resultados das deformações totais para as misturas não envelhecidas (Figura 5.29), verifica-se que todas as misturas apresentam valores superiores a $0,27 \%\left(2,7 \times 10^{-3}\right) \mathrm{e}$ 
inferiores a $0,45 \%\left(4,5 \times 10^{-3}\right)$. Aparentemente, apenas as mistura $10 \% \mathrm{AV}$ não apresenta mudança significativa com o volume de vazios (teor de asfalto), contudo a análise de variância indicou que o mesmo acontece com as misturas 5\%AF $\left(\alpha_{0}=52,34 \%\right)$ e $15 \%$ AF $\left(\alpha_{0}=37,38 \%\right)$.

Por meio do estudo estatístico, verificou-se que há expressiva mudança nas deformações totais com o volume de vazios para as mistura 10\%AF. Nesta mistura, existe diferença significativa entre as deformações totais para os volumes de vazios: $3 \mathrm{e}$ $5 \%(\mathrm{DMS}=0,069 \%)$ e 4 e $5 \%(\mathrm{DMS}=0,056 \%)$. Os gráficos das misturas $5 \% \mathrm{AF}$ e $10 \% \mathrm{AF}$ apresentam comportamento inverso, mas valores discretamente diferentes para o volume de vazios referente ao teor ótimo de asfalto $(\mathrm{Vv}=4 \%)$, em torno de $0,37 \%$, enquanto para a $10 \% \mathrm{AV}$, o valor mínimo $(0,271 \%)$ ocorre nesse volume de vazios e o máximo (0,314\%) para o $\mathrm{Vv}$ de 3\% (Figura 5.29). A deformação total para a mistura $15 \% \mathrm{AF}$ diminui com o aumento do volume de vazios.

As análises de variância identificaram $\left(\alpha_{0}=1,77 \%\right)$ que para as misturas não envelhecidas (misturas virgens), nem todas apresentam médias das deformações totais iguais, que pelo menos duas são significativamente diferentes entre si. Isto indica que o teor de areia interfere expressivamente na resposta desse parâmetro, em pelo menos duas misturas. Ao se realizar o contraste, comprovou-se que a diferença existente diz respeito às misturas: $10 \% \mathrm{AF}$ e $15 \% \mathrm{AF}(\mathrm{DMS}=0,056 \%)$ e $15 \% \mathrm{AF}$ e $10 \% \mathrm{AV}$ $(\mathrm{DMS}=0,059 \%)$.

Na Figura 5.31, que ilustra as deformações totais neste ensaio (o primeiro grupo de quatro barras) para as condições de envelhecimento estudadas, nota-se que os gráficos das misturas não apresentam tendência definida. Nota-se também que todos os valores são superiores a $0,25 \%$ e inferiores a $0,50 \%$ (E.C.P) e que a mistura com $15 \%$ de areia de fundição apresenta os maiores valores, sendo seguida pela 5\%AF (com exceção no E.L.P). Quase todas as misturas têm um decréscimo na deformação quando envelhecidas a curto e a longo prazos (E.C.L.P), com exceção da mistura 15\%AF.

As análise de variância para essas condições de ensaios indicaram que o envelhecimento não interfere significativamente na deformação total das misturas $5 \% \mathrm{AF}, 15 \% \mathrm{AF}$ e $10 \% \mathrm{AV}\left(\alpha_{\mathrm{o} 5 \% \mathrm{AF}}=97,67 \%, \alpha_{\mathrm{o} 15 \% \mathrm{AF}}=53,48 \%\right.$ e $\left.\alpha_{\mathrm{o} 10 \% \mathrm{AV}}=51,90 \%\right)$, sendo exceção, a $10 \% \operatorname{AF}\left(\alpha_{0}=1,84 \%\right)$. O contraste para esta mistura indicou diferença significativa entre as condições de envelhecimento (Figura 5.31): S.E e E.C.P (DMS = 0,08\%); E.C.P e E.L.P (DMS =0,08\%) e E.L.P e E.C.L.P $(\mathrm{DMS}=0,098 \%)$. 
Mediante as análises de variância, pôde-se identificar também diferença significativa entre as deformações totais médias das misturas envelhecidas nas condições de envelhecimento E.C.P e E.C.L.P $\left(\alpha_{\text {oE.C..P }}=2,07 \%\right.$ e $\left.\alpha_{\text {oE.C.L.P }}=1,58 \%\right)$ e com isto verificar a interferência do teor e/ou tipo de areia nos resultados destes parâmetros, como pode ser verificado na Tabela 5.11 .

Tabela 5.11. Efeito do teor e do tipo de areia na deformação total $\left(10^{-3}\right)$ - considerando as condições de envelhecimento (0,4 $\mathrm{MPa}$ - prato normal)

\begin{tabular}{cccccccccc}
\hline \hline \multirow{2}{*}{$\begin{array}{c}\text { DIFERENÇA } \\
\text { (valor absoluto) }\end{array}$} & \multicolumn{9}{c}{ CONDIÇÕES DE ENVELHECIMENTO } \\
\cline { 2 - 10 } & DMS & $\mathbf{D}_{\text {entre }}$ & DS? & DMS & $\mathbf{D}_{\text {entre }}$ & DS? & DMS & D $_{\text {entre }}$ & DS? \\
\hline \hline$|5 \mathrm{AF}-10 \mathrm{AF}|$ & 1,16 & 1,04 & $\mathbf{N}$ & 1,15 & 0,44 & $\mathbf{N}$ & 1,11 & 0,58 & $\mathbf{N}$ \\
$|5 \mathrm{AF}-15 \mathrm{AF}|$ & 1,24 & 1,01 & $\mathbf{N}$ & 1,15 & 0,63 & $\mathbf{N}$ & 1,11 & 0,89 & $\mathbf{N}$ \\
$|5 \mathrm{AF}-10 \mathrm{AV}|$ & 1,39 & 0,61 & $\mathbf{N}$ & 1,33 & 0,49 & $\mathbf{N}$ & 0,95 & 0,96 & $\mathbf{S}$ (teor) \\
$|10 \mathrm{AF}-15 \mathrm{AF}|$ & 1,16 & 2,05 & $\mathbf{S ~ ( t e o r )}$ & 0,94 & 0,19 & $\mathbf{N}$ & 1,11 & 1,47 & $\mathbf{S}$ (teor) \\
$|10 \mathrm{AF}-10 \mathrm{AV}|$ & 1,32 & 0,43 & $\mathbf{N}$ & 1,15 & 0,93 & $\mathbf{N}$ & 0,95 & 0,39 & $\mathbf{N}$ \\
$|15 \mathrm{AF}-10 \mathrm{AV}|$ & 1,39 & 1,62 & $\mathbf{S ~ ( t e o r )}$ & 1,15 & 1,11 & $\mathbf{N}$ & 0,95 & 1,85 & $\mathbf{S}$ (teor) \\
\hline \hline
\end{tabular}

DMS - Diferença Menos Significativa $\mathrm{D}_{\text {entre }}$ - Diferença entre tratamentos $\quad$ DS - Diferença Significativa $\mathrm{S}-\mathrm{Sim}$ N - Não

Nos resultados de Recuperação (\%) para as misturas não envelhecidas (Figura 5.30), pode-se verificar que as misturas que apresentam maior e menor recuperação no volume de vazios de $4 \%$, são, respectivamente, a $10 \% \mathrm{AV}$ e a $15 \% \mathrm{AF}$. Estes valores são aproximadamente $80 \%$ e $60 \%$. Nesses gráficos, pode-se verificar também que existe diferença expressiva entre as recuperações da $10 \% \mathrm{AV}$ e de todas as outras no $\mathrm{Vv}$ de $4 \%$, mas que para as misturas com areia de fundição (5\% AF, $10 \% \mathrm{AF}$ e $15 \% \mathrm{AF})$, esse parâmetro parece não mudar tão expressivamente com o volume de vazios, como acontece com a 10\% AV, principalmente nos $\mathrm{Vv} 3$ e $4 \%$ e 3 e $5 \%$. Os valores de recuperação das misturas não envelhecidas variam entre 55 e $80 \%$.

As misturas $10 \% \mathrm{AF}$ e $10 \% \mathrm{AV}$ apresentam gráficos das misturas não envelhecidas com comportamento inverso. Para a $10 \% \mathrm{AV}$, a recuperação cresce com aumento no volume de vazios, alcançando valor máximo no $\mathrm{Vv}$ de $4 \%$, quando então começa a decrescer sutilmente, enquanto na $10 \% \mathrm{AF}$, decresce atingindo um valor mínimo no $\mathrm{Vv}$ de $4 \%$ e começa a crescer praticamente na mesma proporção. As misturas 5\%AF e $15 \% \mathrm{AF}$ apresentam gráficos também com comportamento inverso, na primeira a recuperação decresce com o aumento no $\mathrm{Vv}$, enquanto na segunda esse parâmetro cresce. 
No caso das misturas envelhecidas (primeiro grupo de quatro barras da Figura 5.32), os valores da recuperação estão entre 50 e $80 \%$, sendo que a mistura 15\%AF (52 a $61 \%$ ) apresenta a menor recuperação no E.L.P e E.C.L.P e a $10 \% \mathrm{AV}$, a maior na condição S.E. A recuperação da mistura 5\%AF mostra alteração pouco expressiva (63 a $65 \%$ ) com o envelhecimento. A mistura 10\%AV (57 a 79\%) apresenta melhor recuperação que a 10\% AF (53 a 76\%) na maioria das condições de envelhecimento, com exceção na condição de envelhecimento a curto prazo (E.C.P). Estas misturas $(10 \% \mathrm{AF}$ e $10 \% \mathrm{AV})$ mostram-se mais susceptíveis ao envelhecimento do que as demais.

Vale lembrar que a mistura 5\%AF é a que apresenta menor teor de finos (41,35\%), fíler $(6,75 \%)$ e ligante (teor médio de 5,20\%) e menor susceptibilidade ao envelhecimento, enquanto a 15\%AF é a que apresenta maior teor destes componentes e a menor recuperação, embora apresente menor susceptibilidade ao envelhecimento do que a $10 \% \mathrm{AV}$ e $10 \% \mathrm{AF}$. A 5\%AF não apresente a maior recuperação, contudo, é a que mostra melhor desempenho quanto ao envelhecimento, praticamente nenhuma susceptibilidade.

Nos resultados de Inclinação do estágio secundário (Figuras 5.33 e 5.34), nota-se que a mistura $10 \% \mathrm{AV}$ é a que apresenta menor inclinação $(0,046)$ no Vv de $4 \%$ (teor ótimo de asfalto). Nesses gráficos, pode-se verificar que existe diferença expressiva entre os resultados dessa mistura e da $10 \% \mathrm{AF}$ e $15 \% \mathrm{AF}$ e que há mudança significativa em sua inclinação com o volume de vazios, o que ocorre também para as misturas $10 \% \mathrm{AF}$ e $15 \% \mathrm{AF}$. As inclinações para as misturas $10 \% \mathrm{AF}$ variam de 0,034 a $0,096 \mathrm{e}$ para a $10 \% \mathrm{AV}$, variam de 0,038 a 0,077 . Os gráficos das misturas $10 \% \mathrm{AF}$ e $15 \% \mathrm{AF}$ apresentam comportamentos afins, com inclinação máxima no teor ótimo de asfalto $(\mathrm{Vv}=4 \%)$. A inclinação da mistura $10 \% \mathrm{AV}$ diminui com o aumento no volume de vazios, ocorrendo o inverso para a $5 \% \mathrm{AF}$.

Nos gráficos das misturas envelhecidas (primeiro grupo de quatro barras do gráfico da Figura 5.34), observa-se que, dentro de cada condição de envelhecimento, há mudança expressiva nos valores da inclinação com o teor de areia e menor expressividade com a natureza (virgem ou de fundição), com exceção do que ocorre nas condições sem envelhecimento e com envelhecimento a curto e a longo prazos (E.C.L.P). Todas as misturas apresentam inclinação com grande sensibilidade ao envelhecimento.

A $10 \% \mathrm{AV}$ sofre um aumento desse parâmetro com o envelhecimento, sendo maior quando envelhecida simultaneamente em curto e longo prazos $(0,094)$, enquanto a 
mistura 10\%AF apresenta maior inclinação na condição S.E, 0,096 e 0,068 na E.C.L.P. Vale ressaltar que na condição S.E, o menor valor de inclinação, 0,046, é apresentado pela $10 \% \mathrm{AV}$ e na condição E.C.L.P, o maior valor, referido anteriormente, é apresentado por esta mistura. No gráfico é possível, verificar ainda que o envelhecimento a longo prazo interfere (aumentando) mais no valor da inclinação desta mistura do que o envelhecimento a curto prazo, ocorrendo o inverso para a mistura $10 \% \mathrm{AF}$.

Nos resultados dos módulos de fluência antes da recuperação (MPa) para misturas não envelhecidas (Figura 5.35), verifica-se que todas apresentam valores superiores a $80 \mathrm{MPa}$ e inferiores a $170 \mathrm{MPa}$. Aparentemente nenhuma mistura apresenta mudança expressiva com o volume de vazios, contudo a mistura $10 \% \mathrm{AF}$ é exceção, principalmente entre os Vv: 3 e 5\% e 4 e 5\%, verificar a análise referente à deformação total. A mistura $10 \% \mathrm{AV}$ é a que apresenta maior módulo (135 $\mathrm{MPa})$ no volume de vazios de $4 \%$, seguida pela $10 \% \mathrm{AF}(112 \mathrm{MPa})$ e a que apresenta menor valor é a mistura 15\%AF (105 MPa).

Na Figura 5.37 (primeiro grupo de quatro barras), que ilustra os módulos de fluência antes da recuperação para as misturas envelhecidas, nota-se que os gráficos das misturas não apresentam tendência definida. Nota-se também que todos os valores são superiores a $70 \mathrm{MPa}$ e inferiores a $170 \mathrm{MPa}$ e que a mistura com 10\% de areia virgem apresenta os maiores valores, com exceção do valor referente ao envelhecimento em curto, onde o maior é o da mistura 10\%AF. Quase todas as misturas têm um aumento no módulo de fluência, quando envelhecidas em curto e longo prazos (E.C.L.P), com exceção da mistura 15\%AF. No envelhecimento a curto prazo (E.C.P), as misturas 15\%AF e $10 \% \mathrm{AV}$ apresentam uma diminuição nesse parâmetro.

Por meio dos gráficos da Figura 5.37, é possível verificar que a variação dos módulos de fluência das misturas 5\%AF, 15\%AF é pouco expressiva com o envelhecimento. Isto pode ser comprovado, verificando-se a análise de variância realizada para as deformações totais nestas condições. Verifica-se também que o módulo de fluência da mistura $10 \% \mathrm{AV}$ não sofre interferência significativa das condições de envelhecimento.

Nas condições S.E e E.L.P, o teor de areia tem pouca interferência no módulo de fluência, sendo mais importante a natureza da areia (comparar a $10 \% \mathrm{AV}$ com a $10 \% \mathrm{AF}$ ). No que diz respeito às condições E.C.P e E.C.L.P, verifica-se que o teor de 
areia, de um modo geral, tem maior interferência sobre o módulo do que o tipo de areia (comparar $10 \% \mathrm{AV}$ e $10 \% \mathrm{AF}$ ).

Nos resultados dos módulos de fluência após recuperação (MPa) (Figuras 5.36 e 5.38), nota-se que a mistura $10 \% \mathrm{AV}$ apresenta valores muito superiores a todos no $\mathrm{Vv}$ 4\% (710 MPa). A mistura que apresenta os menores módulos após recuperação é a 15\%AF, nos Vv de $3(232 \mathrm{MPa})$ e 4\% (269 MPa). Aparentemente, todas as misturas, com exceção da $10 \% \mathrm{AV}$, não apresentam mudança significativa no módulo com o volume de vazios (teor de asfalto). Esta apresenta gráfico com comportamento inverso ao da mistura 10\%AF (329 MPa), que apresenta módulo mínimo no teor ótimo de asfalto; o módulo da mistura 5\% AF diminui com o aumento do volume de vazios e o da $15 \% \mathrm{AF}$ cresce.

Na Figura 5.38 (primeiro grupo de quatro barras), que ilustra os módulos de fluência após recuperação para as misturas envelhecidas, verifica-se que os gráficos das misturas não apresentam tendência definida. Nota-se ainda que todos os valores são superiores a $140 \mathrm{MPa}$ e inferiores a $740 \mathrm{MPa}$. As misturas 5\%AF e 15\%AF mostram-se pouco sensíveis ao envelhecimento, enquanto as misturas $10 \% \mathrm{AV}$ e $10 \% \mathrm{AF}$ mostram maior susceptibilidade. Verifica-se também que o módulo de fluência da mistura $10 \% \mathrm{AV}$ decresce com o envelhecimento, mostrando-se menos sensível ao envelhecimento a curto prazo (S.E - 710 e no E.C.P - $507 \mathrm{MPa}$ ) e mais sensível ao envelhecimento a longo prazo (S.E - 710 e no E.L.P - $302 \mathrm{MPa}$ ). Para a mistura 10\%AF, o módulo após a recuperação decresce apenas nesta condição de envelhecimento (E.L.P), mostrando-se mais sensível (S.E - $329 \mathrm{MPa}$ e no E.C.P - $629 \mathrm{MPa}$ ) ao envelhecimento a curto prazo. Quase todas as misturas apresentam decréscimo no módulo de fluência quando envelhecidas a longo prazo (E.L.P), com exceção da mistura 5\%AF.

A mistura 5\%AF, tanto no módulo de fluência antes da recuperação (varia de 108 a $118 \mathrm{MPa})$ como após a recuperação (309 a $319 \mathrm{MPa}$ ), mostra pouca ou nenhuma susceptibilidade ao envelhecimento.

\subsubsection{Análise e discussão dos resultados do ensaio de Fluência por Compressão Uniaxial Estática - tensão de 0,4 MPa e prato superior reduzido (51 mm)}

Nos resultados das deformações totais, considerando as misturas não envelhecidas (Figura 5.29), verifica-se que todas as misturas apresentam valores superiores a 0,20\% $\left(2,0 \times 10^{-3}\right)$ e inferiores a $0,30 \%\left(3,0 \times 10^{-3}\right)$. Aparentemente, todas as mistura não apresentam mudanças significativas com o volume de vazios (teor de asfalto), o que foi 
corroborado pela análise de variância, apresentando $\alpha_{05 \% \mathrm{AF}}=91,16 \%$, $\alpha_{\mathrm{o} 10 \% \mathrm{AF}}=87,04 \%, \alpha_{\mathrm{o} 15 \% \mathrm{AF}}=99,69 \%$ e $\alpha_{\mathrm{o} 10 \% \mathrm{AV}}=97,36 \%$. As misturas $5 \% \mathrm{AF}$ e $10 \% \mathrm{AV}$ apresentam gráficos com a mesma tendência, exibindo valores mínimos no teor ótimo de asfalto $(\mathrm{Vv}=4 \%), 0,21$ e $0,246 \%$, respectivamente, . As misturas $10 \% \mathrm{AF}$ e $15 \% \mathrm{AF}$ apresentam, praticamente, a mesma tendência, a deformação decresce com o aumento no volume de vazios, e valores muito próximos, sendo um pouco mais expressivo (maior) no $\mathrm{Vv}$ de $5 \%(0,258 \%$ e $0,287 \%$, respectivamente).

As análises de variância identificaram que para as misturas não envelhecidas, todas apresentam médias das deformações totais iguais. Isto indica que o teor de areia (granulometria das misturas) não interfere expressivamente na resposta desse parâmetro.

Na Figura 5.31 (o segundo grupo de quatro barras), que ilustra as deformações totais neste ensaio para as misturas envelhecidas, nota-se que os gráficos das misturas não apresentam tendência definida. Nota-se também que todos os valores são superiores a $0,20 \%$ e inferiores a $0,35 \%$ (E.L.P) e que a mistura com $15 \%$ de areia de fundição apresenta os maiores valores, sendo seguida pela 10\%AF e 10\%AV. Quase todas as misturas têm um decréscimo na deformação total quando envelhecidas a curto e a longo prazos (E.C.L.P), com exceção da mistura 5\%AF.

As análises de variância para essas condições de ensaios indicaram que o fator envelhecimento não interfere significativamente nas médias das deformações totais de todas as misturas $\left(\alpha_{05 \% \mathrm{AF}}=99,08 \%, \alpha_{010 \% \mathrm{AF}}=98,60 \%, \quad \alpha_{015 \% \mathrm{AF}}=99,19 \% \quad \mathrm{e}\right.$ $\left.\alpha_{\mathrm{o} 10 \% \mathrm{AV}}=76,53 \%\right)$.

As deformações totais da mistura 5\%AF apresentam a menor variação com o envelhecimento (de 0,21 a 0,235\%), seguidas das deformações das misturas: $10 \% \mathrm{AF}$ $(0,246$ a $0,277 \%)$ e $15 \% \mathrm{AF}(0,274$ a $0,310 \%)$. A mistura $10 \% \mathrm{AV}$ é a mais susceptível ao fator envelhecimento, apresentando deformações que variam de 0,221 a $0,276 \%$.

As misturas $10 \% \mathrm{AF}$ e $10 \% \mathrm{AV}$ apresentam decréscimo na deformação total quando submetidas ao envelhecimento a curto e a longo prazos (E.C.L.P), o mesmo acontece com a 15\%AF. Quase todas as misturas são mais susceptíveis ao envelhecimento a curto e a longo prazos (E.C.L.P), com exceção da 15\%AF, que é mais susceptível ao envelhecimento a longo prazo.

Mediante as análises de variância, pôde-se identificar também, que dentro de cada condição de envelhecimento não há diferença significativa entre as deformações totais médias das misturas. Isto indica que o teor de areia, bem como o tipo de areia (fundição 
ou virgem) não interfere significativamente nessa resposta (deformação total), considerando o fator envelhecimento. A análise de variância apresentou os resultados a seguir: E.C.P $\left(\alpha_{o}=90,83 \%\right)$, E.L.P $\left(\alpha_{o}=61,12 \%\right)$ e E.C.L.P $\left(\alpha_{o}=97,43 \%\right)$, indicando que não interferência significativa do teor e nem do tipo de areia.

Nos resultados de Recuperação (\%) para as misturas não envelhecidas (Figuras 5.30), pode ser verificado que as misturas que apresentam maior e menor recuperação no volume de vazios de 4\%, são as misturas 5\%AF e 10\%AF, ambas apresentam 75\%, e a 15\%AF (69\%), respectivamente. Nesses gráficos, pode-se verificar também que aparentemente não existe diferença significativa entre as recuperações das misturas entre si, no $\mathrm{Vv}$ de 4\%, com exceção da mistura 15\%AF. Para as misturas com areia de fundição $(5 \% \mathrm{AF}, 10 \% \mathrm{AF}$ e $15 \% \mathrm{AF})$, esse parâmetro demonstra mudança "expressiva" com o volume de vazios, o que não acontece com a 10\%AV. Os valores de recuperação das misturas não envelhecidas variam de 68 a 83\%. A mistura 15\%AF aparenta ser mais sensível ao volume de vazios (teor de asfalto) do que as demais.

As misturas 5\% AF e 10\% AF apresentam gráficos, misturas não envelhecidas, com comportamento inverso. Para a 5\%AV, a recuperação cresce com o volume de vazios, com valor máximo no $\mathrm{Vv} 5 \%$ e apresentando $75 \%$ de recuperação no $\mathrm{Vv} 4 \%$, enquanto para a $10 \% \mathrm{AF}$, a recuperação decresce atingindo um valor mínimo de $72 \%$ no Vv 5\%. $\mathrm{Na}$ mistura $10 \% \mathrm{AV}$, a recuperação cresce até o $\mathrm{Vv} 4 \%$, apresentando o mesmo valor para o Vv 5\% e na mistura $15 \% \mathrm{AF}$, esse parâmetro decresce com o volume de vazios, atingido valor mínimo no Vv 4\% (69\%), quando começa a crescer.

No caso das misturas envelhecidas (segundo grupo de quatro barras da Figura 5.32), os valores da recuperação estão entre 65 e 80\%, sendo que a mistura 15\%AF (66 a $77 \%$ ) apresenta, em quase todas as condições de envelhecimento (três de quatro), a menor recuperação e as 5\% AF e 10\% AV, as maiores (ambas 78\%), respectivamente, nas condições E.C.L.P e E.C.P. Todas as misturas mostram alteração pouco expressiva com o envelhecimento. As misturas 5\%AF e 10\%AF não mostram nenhuma susceptibilidade ao envelhecimento, quando envelhecidas a curto prazo (comparar S.E com E.C.P), inclusive, dentro destes condicionamentos, apresentam o mesmo valor, indicando que a granulometria (teor de areia de fundição, principalmente) não interfere na recuperação. No geral, as misturas que apresentam a maior susceptibilidade ao envelhecimento, considerando a recuperação, são: a 5\%AF (75\% no S.E a $67 \%$ no E.C.P - variação de $8 \%$ ) e a $15 \%$ AF (69\% no S.E a $77 \%$ no E.C.P - variação de $8 \%)$. A menor susceptibilidade é apresentada pela $10 \% \mathrm{AF}$. 
De um modo geral, o teor e o tipo de areia (fundição ou virgem) não apresentam, aparentemente, interferência significativa na recuperação das misturas estudadas, pois a variação da recuperação, considerando todas as misturas, é de 66 a 78\%. As variações de recuperação para as misturas $10 \% \mathrm{AV}$ e $10 \% \mathrm{AF}$ são de 73 a $78 \%$ e de 73 a $75 \%$, respectivamente.

Nos resultados de Inclinação do estágio secundário (Figuras 5.33 e 5.34), nota-se que a mistura 5\%AF é a que apresenta menor inclinação $(0,029)$ no $\mathrm{Vv}$ de $4 \%$ (teor ótimo de asfalto). Nesses gráficos, pode-se verificar que existe diferença "expressiva" entre os resultados dessa mistura $(5 \% \mathrm{AF})$ e da $10 \% \mathrm{AV}$ e $15 \% \mathrm{AF}$ e que não há aparentemente mudança significativa em sua inclinação com o volume de vazios, contudo, para as demais parece ocorrer o contrário. As inclinações para as misturas $10 \% \mathrm{AV}$ variam de 0,051 a 0,086 e para a $15 \% \mathrm{AF}$, variam de 0,024 a 0,062 . Os gráficos das misturas 5\%AF e 10\%AF apresentam comportamentos afins, com inclinação mínima (0,029 e 0,031, respectivamente) no teor ótimo de asfalto, ocorrendo o inverso com a 15\%AF, com valor máximo, 0,062, no Vv 4\%. A inclinação da mistura $10 \% \mathrm{AV}$ diminui com o aumento do volume de vazios, sendo de 0,051 no teor ótimo de asfalto $(\mathrm{Vv}=4 \%)$.

Nos gráficos das misturas envelhecidas (segundo grupo de quatro barras do gráfico da Figura 5.34), observa-se que, dentro de cada condição de envelhecimento, há mudança expressiva nos valores da inclinação com o teor e tipo de areia (virgem ou de fundição). Todas as misturas apresentam visualmente o parâmetro inclinação com grande sensibilidade ao envelhecimento, com exceção da mistura $10 \% \mathrm{AV}$, onde a variação é de 0,046 a $0,053 \% \mathrm{~s}^{-1}$.

Com o envelhecimento, a 10\%AV sofre um decréscimo na inclinação e a 10\%AF um acréscimo, com exceção do que acontece no E.C.L.P (a primeira cresce e a segunda decresce). Quando envelhecidas a longo prazo (E.L.P), a 10\%AV apresenta o menor valor $(0,046)$ e a $10 \% \mathrm{AF}$, o maior $(0,076)$.

Vale ressaltar que na condição S.E, o menor valor de inclinação, 0,029, é apresentado pela 5\%AF e o maior, 0,062, pela 15\%AF, e na condição E.C.L.P, o menor valor, 0,053 , é apresentado pela $10 \% \mathrm{AV}$ e o maior, 0,106 , pela $15 \% \mathrm{AF}$. No gráfico da Figura 5.34, é possível verificar ainda que o envelhecimento a curto e a longo prazos interfere (aumentando) mais no valor da inclinação da 15\%AF do que o envelhecimento a curto prazo e que a mistura 5\%AF sofre maior interferência $(0,029$ na S.E a 0,064 na E.C.P) do envelhecimento a curto prazo. 
Nos resultados dos módulos de fluência antes da recuperação (MPa) para as misturas não envelhecidas (Figura 5.35), verifica-se que todas apresentam valores superiores a $110 \mathrm{MPa}$ e inferiores a $290 \mathrm{MPa}$. Aparentemente, quase todas as misturas não apresentam mudança expressiva com o volume de vazios, com exceção da mistura $5 \% \mathrm{AF}$, principalmente entre os Vv: 3 e 4\% e 3 e 5\%, contudo, verificando a análise de variância referente à deformação total para esta condição de ensaio, nota-se que esta mistura também não sofre interferência expressiva com o volume de vazios. A mistura $5 \% \mathrm{AF}$ é a que apresenta maior módulo (196 MPa) no volume de vazios 4\%, seguida pela $10 \% \mathrm{AV}(175 \mathrm{MPa})$.

Na Figura 5.37 (segundo grupo de quatro barras), que ilustra os módulos de fluência antes da recuperação para as condições de envelhecimento estudadas, nota-se que os gráficos das misturas não apresentam tendência definida. Verifica-se também que todos os valores são superiores a $130 \mathrm{MPa}$ e inferiores a $230 \mathrm{MPa}$ e que a mistura com $5 \%$ de areia de fundição apresenta os maiores valores, com exceção do valor referente ao envelhecimento a curto e a longo prazos (E.C.L.P), onde o maior é o da mistura 10\%AF (223 $\mathrm{MPa}$ - valor máximo). Todas as misturas mostram um aumento no módulo de fluência quando envelhecidas a curto e a longo prazos (E.C.L.P). No envelhecimento a curto prazo (E.C.P), as misturas 5\%AF e 10\%AV apresentam uma diminuição nesse parâmetro.

Por meio dos gráficos da Figura 5.37, é possível verificar que a variação dos módulos de fluência da mistura 5\%AF é pouco expressiva com o envelhecimento. Entretanto, verificando-se a análise de variância realizada para as deformações totais nestas condições, observa-se que todas misturas não sofrem influência significativa deste fator.

Nos resultados dos módulos de fluência após recuperação (MPa) (Figuras 5.36 e 5.37), verifica-se que a mistura 5\% AF apresenta valores superiores a todos. No teor ótimo de asfalto esta mistura apresenta o valor $784 \mathrm{MPa}$, a 10\%AV, $648 \mathrm{MPa}$, a $10 \% \mathrm{AF}, 584 \mathrm{MPa}$ e a $15 \% \mathrm{AV}, 481 \mathrm{MPa}$. Aparentemente, todas as misturas, com exceção da $10 \% \mathrm{AV}$, apresentam mudança significativa no módulo com o volume de vazios (teor de asfalto). A mistura 5\% AF apresenta gráfico com comportamento similar ao da mistura 15\%AF, ambas apresentam módulo mínimo no teor ótimo de asfalto, respectivamente, 784 e $481 \mathrm{MPa}$ e a mistura 10\%AV apresenta gráfico com comportamento contrário aos dessas misturas, módulo máximo para o volume de vazios 4\%; o módulo da mistura 10\%AF diminui com o aumento do volume de vazios. 
Na Figura 5.38 (segundo grupo de quatro barras), que ilustra os módulos de fluência após recuperação para as condições de envelhecimento estudadas, verifica-se que os gráficos das misturas não apresentam tendência definida. Nota-se ainda que todos os valores são superiores a $340 \mathrm{MPa}$ e inferiores a $940 \mathrm{MPa}$. Todas as misturas demonstram mudança expressiva com o envelhecimento. Verifica-se também que o módulo de fluência da mistura 5\% AF cresce quando a mistura é submetida ao envelhecimento simultâneo (curto e logo prazos), no entanto decresce, quando esta é envelhecida em curto (E.C.P) ou a longo prazo (E.L.P). Para a mistura 10\%AF, o módulo após a recuperação cresce, quando submetido a qualquer condição de envelhecimento (E.C.P ou E.L.P ou E.C.L.P), sendo mais sensível ao envelhecimento a curto e a longo prazos (comparar S.E com E.C.L.P). O módulo após recuperação da mistura $10 \% \mathrm{AV}$ cresce, quando esta é submetida ao E.C.P ou ao E.C.L.P, no entanto decresce, quando submetida ao envelhecimento a longo prazo (E.L.P), sendo mais sensível, da mesma forma que a $10 \% \mathrm{AF}$, ao último condicionamento a curto e a longo prazos (variação do S.E para E.C.L.P - $160 \mathrm{MPa}$ ).

Os módulos antes da recuperação da mistura 5\%AF mostram pouca sensibilidade ao envelhecimento (varia de 184 a $205 \mathrm{MPa}$ ), mas após a recuperação esses parâmetros mostram-se bem mais susceptíveis a este fator (de 558 a $932 \mathrm{MPa}$ ).

\subsubsection{Comparação entre resultados do ensaio com o prato superior padrão e os resultados do ensaio com o prato superior reduzido (tensão - 0,4 MPa)}

Os resultados analisados (visualmente) e discutidos nesta seção são referentes apenas àqueles encontrados para o volume de vazios nominal igual a $4 \%$, considerando as condições com envelhecimento a curto prazo (E.C.P) e envelhecimento a curto e a longo prazos (E.C.L.P). Escolheu-se comentar estes resultados neste volume de vazios (teor ótimo de asfalto), porque o primeiro (E.C.P) simboliza (representa) a camada asfáltica logo após construção, portanto, levando-se em conta o envelhecimento ocorrido durante a fase de fabricação da mistura (aquecimento e misturação) e lançamento (compactação e esfriamento) e o segundo (E.C.L.P) por representá-la após vida em serviço, ou seja, considerando o envelhecimento da fase de fabricação, lançamento e o ocorrido lentamente durante a vida útil do revestimento asfáltico.

Analisando-se os parâmetros extraídos dos ensaios de fluência por compressão uniaxial estática, nota-se que no caso da deformação total (recuperável mais visco-plástica), apresentada na Figura 5.31 (misturas envelhecidas), os valores obtidos dos ensaios com o 
prato de dimensões reduzidas são sempre menores, variando, no caso das misturas submetidas ao envelhecimento a curto prazo, de $62(5 \% \mathrm{AF})$ até $96,3 \%(10 \% \mathrm{AF})$ e, no caso das com envelhecidas simultaneamente, de 61,40 (5\%AF) a 88\% (10\%AV) em relação aos obtidos com o prato padrão, maiores, entretanto, que a relação entre as áreas dos pratos experimentados. Além disso, as curvas não apresentam tendências similares (Figura 5.29), com menores variações nas deformações totais para os ensaios executados com o prato de dimensões reduzidas, independentemente do teor de areia, fundição ou virgem, contido na mistura em análise.

Já na Figura 5.32, onde se expõem as recuperações elásticas das misturas envelhecidas, observa-se que os valores obtidos dos ensaios com prato de dimensões reduzidas são altos em relação aos obtidos com o prato padrão, no caso do condicionamento E.C.P (entre 1,03 e 1,40 vezes). Esses resultados demonstram que a recuperação elástica, avaliada com o ensaio com prato de dimensões reduzidas, mostra-se mais presente, com valores maiores, indicando que deve haver contribuição de algum fator, possivelmente advindo do pseudoconfinamento do corpo-de-prova ou da resposta da matriz granular, não aquilatado no ensaio quando efetuado com o prato padrão.

No caso das inclinações dos estágios secundários das curvas de fluência por compressão uniaxial estática (Figura 5.33), percebe-se que as tendências (formas) das curvas das misturas $10 \% \mathrm{AV}$ e $15 \% \mathrm{AF}$ são muito parecidas para os resultados obtidos dos ensaios com os dois pratos, porém, as misturas 5 e $10 \% \mathrm{AF}$ apresentam, no ensaio com prato reduzido, tendências inversas àquelas apresentadas para o ensaio padrão.

No caso dos ensaios com o prato reduzido e misturas envelhecidas(Figura 5.34), os valores das inclinações são, quase sempre, menores, indicando que as deformações se processam mais lentamente nesses casos. No condicionamento E.C.P, os valores das inclinações no ensaio com prato reduzido variam de 68,6 a 90,9\% em relação aos obtidos para o ensaio padrão e no E.C.L.P de 56,4 a 98,5\%, com exceção do valor observado para a mistura $15 \% \mathrm{AF}$, que aumenta de $0,09 \%$ para $0,106 \%$.

Os módulos de fluência antes da recuperação (3600 s de ensaio) (Figura 5.37), obtidos dos ensaios com prato reduzido, foram sempre maiores que os obtidos com prato padrão, independentemente da condição de envelhecimento, E.C.P ou E.C.L.P, e da mistura considerada. Os valores de módulo referente ao prato reduzido são, no caso das condições de envelhecimento E.C.P e E.C.L.P, respectivamente, 1,05 a 2,00 e 1,21 a 1,74 vezes maiores que os provenientes dos ensaios com prato padrão (Figura 5.37). Já no caso dos módulos de fluência calculados após o período de recuperação elástica (Figura 5.38), os valores oriundos dos ensaios com prato reduzido são, quase sempre, substancialmente 
maiores, variando de 1,40 até 3,92, na condição E.C.P, e de 1,62 a 2,92, na E.C.L.P, vezes os obtidos com o prato padrão, ressaltando o efeito da recuperação elástica, evidenciada no ensaio efetuado com o prato de dimensões reduzidas. A exceção refere-se ao módulo da mistura 10\%AF no condicionamento E.C.P, onde o módulo para o ensaio padrão é $629 \mathrm{MPa}$ e para o reduzido, $585 \mathrm{MPa}$, havendo, portanto, uma redução.

\subsection{Ensaios ambientais de classificação de resíduo sólidos}

Os ensaios de classificação de resíduos (lixiviação, solubilização e massa bruta) foram realizados no resíduo de fundição, aqui denominado de areia de fundição, e na areia virgem, material a ser preparado para emprego no processo de moldagem em fundição de ligas e/ou metais. Os resultados da análise para a classificação da areia de fundição e da areia virgem podem ser observados nas Tabelas C.01 e C.02 do Apêndice C (página 238), respectivamente.

Os resultados relativos à areia de fundição no extrato lixiviado e na massa bruta para todos os parâmetros foram abaixo dos valores permitidos pela NBR 10004/87 (ANEXO G Listagem $n^{0} 7$ e ANEXO I Listagem $n^{0}$ 9, respectivamente). Contudo, as concentrações $(\mathrm{mg} / \mathrm{L})$ para os parâmetros fenóis, fluoretos, alumínio, cloretos e ferro (Tabela 5.12) ultrapassaram os limites máximos no extrato para o teste de solubilização (ANEXO H - Listagem $n^{\circ} 8$ da NBR 10004). Desta forma, este material foi classificado como resíduo classe II - Não Inerte.

Tabela 5.12. Resultados Analíticos dos parâmetros que ultrapassaram o limite de norma no ensaio de solubilização em amostra de areia de fundição

\begin{tabular}{|c|c|c|c|c|}
\hline Parâmetros & Unidade & $L Q^{*}$ & $\begin{array}{c}\text { Resultados analíticos da } \\
\text { amostra no } .05498 / 03 \text { Areia } \\
\text { de Fundição }\end{array}$ & $\begin{array}{c}A B N T N B R 10004 \\
V M P^{* *}\end{array}$ \\
\hline \multicolumn{5}{|c|}{ 1- SOLUBILIZADO } \\
\hline Fenóis & $\mathrm{mg} / \mathrm{L}$ & 0,001 & 0,38 & 0,001 \\
\hline Fluoretos & $\mathrm{mg} / \mathrm{L}$ & 0,1 & 3,71 & 1,5 \\
\hline Alumínio & $\mathrm{mg} / \mathrm{L}$ & 0,05 & 1,77 & 0,2 \\
\hline Cloretos & $\mathrm{mg} / \mathrm{L}$ & 5 & 370 & 250,0 \\
\hline Ferro & $\mathrm{mg} / \mathrm{L}$ & 0,05 & $\mathbf{0 , 7 8}$ & 0,3 \\
\hline
\end{tabular}


Os resultados analíticos relativos à areia virgem para os parâmetros lixiviados, solubilizados e massa bruta foram abaixo dos valores permitidos pela NBR 10004/87 (ANEXO G Listagem $n^{\circ}$ 7, ANEXO H Listagem $n^{\circ} 8$ e ANEXO I Listagem $n^{\circ}$ 9, respectivamente). Desta forma, este material foi classificado como resíduo de classe III - Inerte.

Foram também realizados ensaios de classificação de resíduo, segundo a NBR 10004/87, em amostra de massa asfáltica (asfalto + agregados graúdo + agregado miúdo + fíler) com $15 \%$ de areia de fundição e amostra de massa asfáltica com 10\% de areia virgem. Os resultados analíticos das amostras com 10\% de areia virgem e com 15\% de areia de fundição podem ser verificados nas Tabelas C.03 e C.04 do Apêndice C, respectivamente. Tanto para a amostra asfáltica com $10 \%$ de areia virgem quanto para a amostra asfáltica com $15 \%$ de areia de fundição, as concentrações dos parâmetros não ultrapassaram os limites máximos nos extratos, lixiviado e solubilizado, e na massa

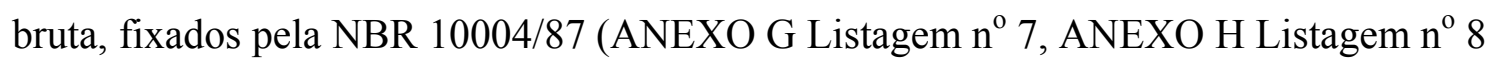
e ANEXO I Listagem $n^{\circ}$ 9, respectivamente). Desta forma, estes materiais foram classificados como resíduo de classe III - Inerte. Esta classificação pode ser comprovada no Anexo A (página 272) desta pesquisa.

Os parâmetros, Arsênio e Selênio nos ensaios de lixiviação e solubilização, e os parâmetros, Arsênio, berílio, Selênio,Vanádio, hidrocarbonetos líquidos ou bombeáveis e óleos e graxas na massa bruta, não foram analisados para as amostras de massas asfálticas com $10 \%$ de areia virgem e com $15 \%$ de areia de fundição, como podem ser observados nas Tabelas C.03 e C.04 (Apêndice C - página 238). Contudo, vale lembrar que na areia de fundição e na areia virgem essas substâncias não foram detectadas em concentrações superiores às limitadas pela NBR 10004/87 (Tabelas C.01 e C.02 Apêndice C) . Pelo exposto, pode se concluir que a ausência de análise desses parâmetros não acarretou prejuízo para a pesquisa, visto que o objetivo é a avaliação do resíduo (areia de fundição) incorporado à massa asfáltica e não do asfalto em si.

Os resultados da classificação das areias virgem e de fundição foram os esperados (BIOAGRI AMBIENTAL LTDA, 2003a; 2003b). A areia virgem foi classificada como resíduo Classe III - Inerte (Apêndice C - Tabela C.02), dado que é um material como encontrado na natureza, tanto que as concentrações nos parâmetros lixiviados, solubilizados e massa bruta apresentaram-se abaixo dos limites de norma (NBR 10004/87). A areia de fundição foi classificada como resíduo Classe II - Não Inerte (Apêndice C - Tabela C.01), visto que é oriunda de um processo de moldagem com 
resina fenólica e os metais conformados, de natureza tanto ferrosa quanto não ferrosa, apresentando valores superiores ao da norma para os parâmetros Fenóis, Fluoretos, Alumínio, Cloretos e Ferro no ensaio de solubilização.

Entretanto, após a incorporação da areia de fundição no teor de $15 \%$ à mistura asfáltica, o material resultante foi classificado como resíduo Classe III - Inerte (Apêndice C, Tabela C.04). Este resultado também foi o esperado, visto que se imaginava que houvesse alguma retenção das substâncias contaminantes após o envolvimento deste material/resíduo pelo asfalto, o que parece ter ocorrido.

\subsection{Ensaio de lixiviação com extrator soxhlet}

Este ensaio foi realizado em corpo-de-prova de massa asfáltica com $15 \%$ de areia de fundição e com volume de vazios ( $\mathrm{Vv}$ ) em torno de 5\% e em amostra de Cimento Asfáltico de petróleo (CAP 20) utilizado na moldagem das misturas asfálticas.

Os resultados parciais da análise química do extrato obtido do ensaio no corpo-deprova de massa asfáltica para cada coleta (coletas 1, 2, 3, 4 e 5) estão listados nas Tabelas C.05 a C.09 do Apêndice C (página240) e os resultados acumulados de cada coleta $\left(1^{\mathrm{a}}-12\right.$ horas, $2^{\mathrm{a}}-84$ horas, $3^{\mathrm{a}}-252$ horas, $4^{\mathrm{a}}-540$ horas e $5^{\mathrm{a}}-792$ ou 1080 horas, dependendo da situação considerada) estão apresentados nas Tabelas C.10 a C.13 desse Apêndice.

Durante a execução do ensaio, ocorreram fatos, relatados a seguir, que podem explicar algumas alterações nas concentrações parciais dos parâmetros na análise da quarta coleta - 45 dias (Tabela C.08 - Apêndice C) e que interferiram também nos resultados parciais e acumulados da quinta coleta.

No décimo dia de ensaio para a quarta coleta $\left(31^{\circ}\right.$ dia do início do ensaio), o corpode-prova começou a se desintegrar, caindo pequenos pedaços de massa asfáltica no extrato em ebulição. Estes fragmentos permaneceram nesta condição (extrato em ebulição) por pelo menos 10 horas e imersos, após desligar o equipamento, por aproximadamente, 12 horas. No entanto, os fragmentos foram retirados antes do equipamento ser religado para dar continuidade ao ensaio. Este fato tornou a ocorrer mais duas vezes e então ( $39^{\circ}$ dia do início do ensaio), o corpo-de-prova foi colocado em um béquer com o fundo perfurado para que o ensaio continuasse sem nova queda de material no extrato. Todavia, a partir deste momento, o ensaio passou a ser mais severo do que o proposto, visto que houve um aumento na superfície exposta do material à lixiviação (corpo-de-prova desintegrado). 
Os resultados analíticos, apresentados nas Tabela C.10 e C.11 do Apêndice C, foram multiplicados por 0,418, originando as Tabelas C.12 e C.13 deste Apêndice, uma vez que para o teste de solubilização de resíduos deve-se fazer uso de uma amostra representativa de $250 \mathrm{~g}$ (base seca) para um litro de água destilada (ABNT NBR 10006/87). O peso do corpo-de-prova utilizado neste ensaio foi de 1255,5 gf (material compactado), portanto, deveriam ser utilizados 5,02 litros. Utilizou-se este critério em virtude dos padrões empregados (limite máximo no extrato $-\mathrm{mg} / \mathrm{L}$ ) serem referentes ao teste de solubilização e não existir um ensaio padronizado com esta finalidade. Contudo, por limitação do recipiente do equipamento, utilizaram-se apenas 2,1 litros. Assim, o coeficiente 0,418 foi obtido dividindo-se a quantidade de água inserida no recipiente (2,1 litros) pela que deveria ser utilizada (5,02 litros).

Pelo exposto anteriormente, achou-se conveniente desprezar-se os valores parciais relativos à $4^{\mathrm{a}}$ coleta e apresentar os resultados do ensaio de lixiviação com extrator soxhlet, corrigindo as concentrações por meio da multiplicação dos resultados analíticos da Tabela C.11 por 0,418. Os resultados analíticos, com estas considerações, estão apresentados na Tabela 5.13.

Nos gráficos das Figuras 5.39 a 5.43, são apresentados os comportamentos dos parâmetros químicos com base nos resultados do ensaio de lixiviação com extrator soxhlet da Tabela 5.13. Esses resultados são as concentrações acumuladas do parâmetro analisado, em mg/L, baseado nos padrões para o teste de solubilização (ANEXO H Listagem $n^{\circ} 8$ da NBR 10004/87) versus o tempo de ensaio, em horas. Esses gráficos foram obtidos com quatro pontos, relativos às coletas 1 (12 horas), 2 (84 horas), 3 (252 horas) e 5 (792 horas). Vale ressaltar, que, como o período parcial relativo à quarta coleta foi desprezado, o período referente à quinta coleta passou a ser 792 horas $(1080 \mathrm{~h}-288 \mathrm{~h})$.

As outras considerações (situações I, II e III), referentes aos resultados analíticos, período de ensaio e concentração dos parâmetros, estão apresentadas no apêndice C (página 238). 
Tabela 5.13. Resultado Total da análise química do extrato oriundo do corpo-de-prova de mistura asfáltica com $15 \%$ de Areia de Fundição, submetido ao ensaio de lixiviação com extrator soxhlet

\begin{tabular}{|c|c|c|c|c|c|c|c|}
\hline \multirow{3}{*}{ Parâmetros } & \multirow{3}{*}{ Unidade } & \multirow{3}{*}{ LQ } & \multicolumn{4}{|c|}{ Resultado analítico por coleta } & \multirow{3}{*}{$\begin{array}{c}\text { NBR } 10004 \\
\text { VMP }\end{array}$} \\
\hline & & & $\overline{1^{\mathbf{a}}}$ & $\overline{2^{\mathrm{a}}}$ & $3^{\mathrm{a}}$ & $\overline{5^{\mathbf{a}}}$ & \\
\hline & & & $12 \mathrm{~h}$ & $84 \mathrm{~h}$ & $252 \mathrm{~h}$ & $792 \mathrm{~h}$ & \\
\hline Arsênio (As) & $\mathrm{mg} / \mathrm{L}$ & 0,001 & NA & $\overline{\mathrm{NA}}$ & NA & NA & 0,05 \\
\hline Bário (Ba) & $\mathrm{mg} / \mathrm{L}$ & 0,01 & $<0,01$ & $<0,01$ & $<0,01$ & 0,028 & 1,0 \\
\hline Cádmio (Cd) & $\mathrm{mg} / \mathrm{L}$ & 0,001 & $<0,001$ & $<0,001$ & $<0,001$ & $<0,001$ & 0,005 \\
\hline Chumbo (Pb) & $\mathrm{mg} / \mathrm{L}$ & 0,001 & $<0,001$ & $<0,001$ & $<0,001$ & 0,019 & 0,05 \\
\hline Cianetos $(\mathrm{CN})$ & $\mathrm{mg} / \mathrm{L}$ & 0,001 & $<0,001$ & $<0,001$ & $<0,001$ & $<0,001$ & 0,1 \\
\hline Cromo total $(\mathrm{Cr})$ & $\mathrm{mg} / \mathrm{L}$ & 0,001 & $<0,001$ & $<0,001$ & $<0,001$ & 0,01 & 0,05 \\
\hline Índice de Fenóis & $\mathrm{mg} / \mathrm{L}$ & 0,001 & $<0,001$ & $<0,001$ & $<0,001$ & $<0,001$ & 0,001 \\
\hline Fluoretos (F) & $\mathrm{mg} / \mathrm{L}$ & 0,01 & 0,03 & 0,12 & 0,28 & 1,26 & 1,5 \\
\hline Mercúrio (Hg) & $\mathrm{mg} / \mathrm{L}$ & 0,001 & $<0,001$ & $<0,001$ & $<0,001$ & $<0,001$ & 0,001 \\
\hline Nitratos $\left(\mathrm{N}-\mathrm{NO}_{3}\right)$ & $\mathrm{mg} / \mathrm{L}$ & 0,01 & 0,1354 & 0,2832 & 0,5639 & 9,0836 & 10,0 \\
\hline Prata (Ag) & $\mathrm{mg} / \mathrm{L}$ & 0,001 & $<0,001$ & $<0,001$ & $<0,001$ & 0,003 & 0,05 \\
\hline Selênio (Se) & $\mathrm{mg} / \mathrm{L}$ & 0,01 & NA & NA & NA & NA & 0,01 \\
\hline Alumínio (Al) & $\mathrm{mg} / \mathrm{L}$ & 0,001 & 0,01 & 0,32 & 0,61 & 1,21 & 0,2 \\
\hline Cloretos $(\mathrm{Cl})$ & $\mathrm{mg} / \mathrm{L}$ & 0,5 & 0,26 & 0,75 & 1,30 & 1,63 & 250,0 \\
\hline Cobre $(\mathrm{Cu})$ & $\mathrm{mg} / \mathrm{L}$ & 0,001 & 0,004 & 0,008 & 0,009 & 0,029 & 1,0 \\
\hline Dureza Total $\left(\mathrm{CaCO}_{3}\right)$ & $\mathrm{mg} / \mathrm{L}$ & 1,00 & 5,85 & 11,29 & 17,56 & 22,99 & 500,0 \\
\hline Ferro $(\mathrm{Fe})$ & $\mathrm{mg} / \mathrm{L}$ & 0,05 & 0,056 & 0,124 & 0,170 & 0,409 & 0,3 \\
\hline Manganês (Mn) & $\mathrm{mg} / \mathrm{L}$ & 0,001 & $<0,001$ & $<0,001$ & $<0,001$ & 0,015 & 0,1 \\
\hline Sódio (Na) & $\mathrm{mg} / \mathrm{L}$ & 0,1 & 3,55 & 11,91 & 27,80 & 69,60 & 200,0 \\
\hline Surfactantes & $\mathrm{mg} / \mathrm{L}$ & 0,01 & $<0,01$ & $<0,01$ & 0,108 & 0,403 & 0,2 \\
\hline Sulfatos $\left(\mathrm{SO}_{4}\right)$ & $\mathrm{mg} / \mathrm{L}$ & 1,00 & $<1,00$ & $<1,00$ & 5,85 & 12,95 & 400,0 \\
\hline Zinco (Zn) & $\mathrm{mg} / \mathrm{L}$ & 0,001 & 0,003 & 0,059 & 0,059 & 0,134 & 5,0 \\
\hline $\mathrm{pH}$ & & & 8,70 & 8,75 & 8,85 & 9,90 & \\
\hline
\end{tabular}

Os resultados analíticos, destacados em negrito na Tabela 5.13, referem-se aos parâmetros que ultrapassaram os limites máximos permitidos pela NBR 10004/87. Desta forma, verifica-se que o alumínio ultrapassa o limite da norma a partir da segunda coleta (84 horas de condicionamento), o ferro e os surfactantes ultrapassam na quinta coleta (792 horas de condicionamento). Os gráficos referentes aos parâmetros que ultrapassaram os limites estabelecidos pela NBR 10004/87, alumínio, ferro e 
surfactantes, contém uma linha horizontal indicando o valor máximo permitido por essa norma (Figuras 5.41 a 5.43).

Os resultados da análise química realizada no extrato oriundo da amostra asfáltica de CAP 20, obtido por meio do ensaio de lixiviação com extrator soxhlet, são apresentados na Tabela 5.14. Esse ensaio foi efetuado com a finalidade de qualificar os materiais (elementos e substâncias químicas) que poderiam ser encontrados no cimento asfáltico, considerando os mesmo parâmetros pesquisados na areia de fundição (parâmetros solubilizados) e desta forma, verificar se os parâmetros obtidos da análise química do corpo-de-prova de massa asfáltica deviam-se apenas à areia de fundição ou em parte ao cimento asfáltico.

Vale ressaltar que a severidade desse ensaio foi muito alta, visto que, logo no início, após aproximadamente três horas do equipamento ser ligado, parte da amostra caiu dentro do extrato em ebulição, permanecendo nesta condição durante o período remanescente de ensaio (81 horas, sendo o sistema de funcionamento do extrator soxhlet intermitente, 12 horas ligado e 12 horas desligado). Também não foi considerada a proporção na diluição, que para o teste de solubilização de resíduos é $250 \mathrm{~g}$ para um litro de água destilada (ABNT NBR - 10006/87), como feito no ensaio realizado no corpo-de-prova de massa asfáltica, visto que o objetivo, como supracitado, era saber quais os materiais que poderiam estar presentes no cimento asfáltico, sem a intenção de compará-los com o valor máximo permitido pela norma.

Caso a intenção fosse comparar com o limite permitido pela norma (NBR 10004/87), teria que haver uma correção dos parâmetros da Tabela 5.14, considerando os mesmos critérios utilizados nos resultados analíticos da mistura asfáltica com $15 \%$ de areia de fundição (Tabela 5.13). Assim, estes resultados deveriam ser multiplicados por 2,589 (1/0,3863), visto que a quantidade de água destilada a ser utilizada seria de 722, 4 mililitros de água, no entanto, utilizaram-se 1870 mililitros. Desta forma, por exemplo, os resultados dos parâmetros cádmio, chumbo, índice de fenóis e alumínio, passariam a ser, respectivamente, 0,202, 1,882, 0,142 e 1,654 mg/L. Valores estes bem maiores que os valores máximos permitidos pela NBR 10004/87 para o teste de solubilização, como pode ser verificado na coluna oito da Tabela 5.13.

O peso de cimento asfáltico (CAP 20) no corpo-de-prova com $15 \%$ de areia de fundição, submetido à lixiviação com extrator soxhlet, é da ordem de 72,82 gf (teor de asfalto - 5,80\%), 40,32\% do peso da amostra de cimento asfáltico submetida a este ensaio (180,6 gf), ou seja, 180,6 é igual a 2,48 vezes 72,82. Mantendo as proporções do 
ensaio de solubilização (250 g de resíduo para um litro de água destilada), as concentrações para o peso de 72,82 gf correspondem aos resultados da Tabela 5.14 multiplicados por $1,044(2,589 / 2,48)$.

Tabela 5.14. Resultado da análise química do extrato oriundo da amostra de CAP $20^{2}$, submetida ao ensaio de lixiviação com extrator soxhlet

\begin{tabular}{|c|c|c|c|}
\hline Parâmetros & Unidade & $\begin{array}{c}\text { Limite de } \\
\text { Quantificação }\end{array}$ & $\begin{array}{c}\text { Resultado } \\
\text { Analítico }\end{array}$ \\
\hline Arsênio (As) & $\overline{\mathrm{mg} / \mathrm{L}}$ & 0,001 & 0,0015 \\
\hline Bário (Ba) & $\mathrm{mg} / \mathrm{L}$ & 0,001 & $<0,001$ \\
\hline Cádmio $(\mathrm{Cd})$ & $\mathrm{mg} / \mathrm{L}$ & 0,001 & 0,078 \\
\hline Chumbo $(\mathrm{Pb})$ & $\mathrm{mg} / \mathrm{L}$ & 0,001 & 0,727 \\
\hline Cianetos $(\mathrm{CN})$ & $\mathrm{mg} / \mathrm{L}$ & 0,001 & $<0,001$ \\
\hline Cromo total $(\mathrm{Cr})$ & $\mathrm{mg} / \mathrm{L}$ & 0,001 & $<0,001$ \\
\hline Índice de Fenóis & $\mathrm{mg} / \mathrm{L}$ & 0,001 & 0,055 \\
\hline Fluoretos (F) & $\mathrm{mg} / \mathrm{L}$ & 0,01 & 0,13 \\
\hline Mercúrio (Hg) & $\mathrm{mg} / \mathrm{L}$ & 0,001 & $<0,001$ \\
\hline Nitratos $\left(\mathrm{N}-\mathrm{NO}_{3}\right)$ & $\mathrm{mg} / \mathrm{L}$ & 0,01 & 0,547 \\
\hline Prata (Ag) & $\mathrm{mg} / \mathrm{L}$ & 0,001 & 0,021 \\
\hline Selênio (Se) & $\mathrm{mg} / \mathrm{L}$ & 0,01 & $<0,01$ \\
\hline Alumínio (Al) & $\mathrm{mg} / \mathrm{L}$ & 0,001 & 0,639 \\
\hline Cloretos $(\mathrm{Cl})$ & $\mathrm{mg} / \mathrm{L}$ & 0,5 & 2,66 \\
\hline Cobre $(\mathrm{Cu})$ & $\mathrm{mg} / \mathrm{L}$ & 0,001 & $<0,001$ \\
\hline Dureza Total $\left(\mathrm{CaCO}_{3}\right)$ & $\mathrm{mg} / \mathrm{L}$ & 1,00 & $<1,00$ \\
\hline Ferro $(\mathrm{Fe})$ & $\mathrm{mg} / \mathrm{L}$ & 0,05 & 0,111 \\
\hline Manganês (Mn) & $\mathrm{mg} / \mathrm{L}$ & 0,001 & $<0,001$ \\
\hline Sódio (Na) & $\mathrm{mg} / \mathrm{L}$ & 0,1 & 5,28 \\
\hline Surfactantes (tensoativos) & $\mathrm{mg} / \mathrm{L}$ & 0,01 & 0,016 \\
\hline Sulfatos $\left(\mathrm{SO}_{4}\right)$ & $\mathrm{mg} / \mathrm{L}$ & 1,00 & 2,42 \\
\hline Zinco (Zn) & $\mathrm{mg} / \mathrm{L}$ & 0,001 & $<0,001$ \\
\hline $\mathrm{pH}$ & & & 8,69 \\
\hline
\end{tabular}

VMP - Valor Máximo Permitido pela NBR 10004

\footnotetext{
${ }^{2}$ com peso de 180,6 gf, sendo utilizado no ensaio $1870 \mathrm{ml}$ de água destilada. A duração do ensaio foi de sete dias ( 84 horas), sendo o sistema de funcionamento do extrator soxhlet, intermitente, 12 horas ligado e 12 horas desligado.
} 
Bário

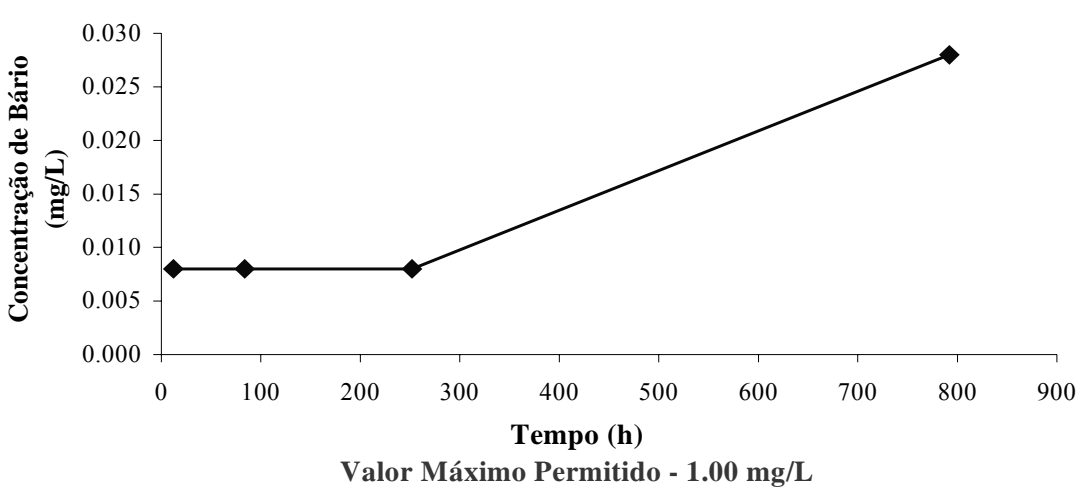

Valor Máximo Permitido - $1.00 \mathrm{mg} / \mathrm{L}$

Método - absorção atômica

\section{Chumbo}

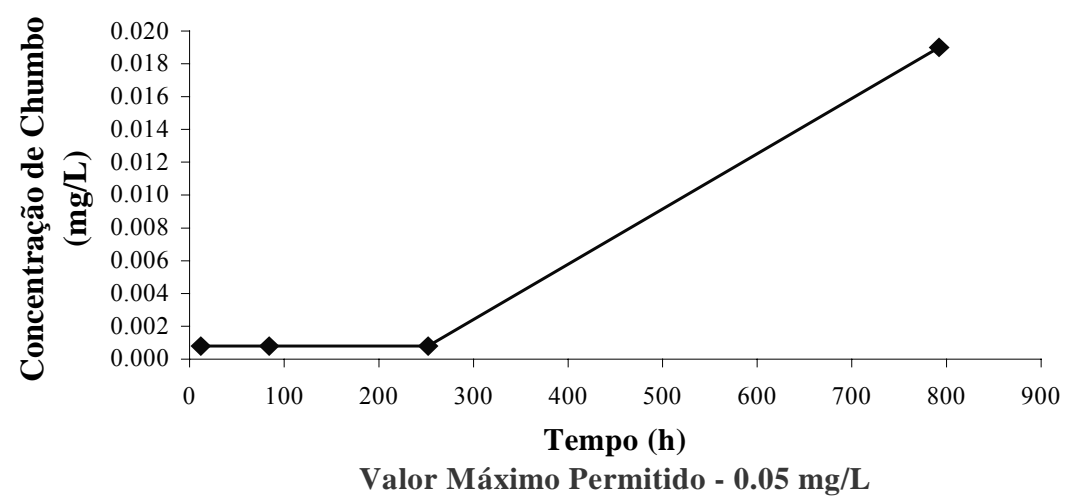

Método - absorção atômica
Cádmio

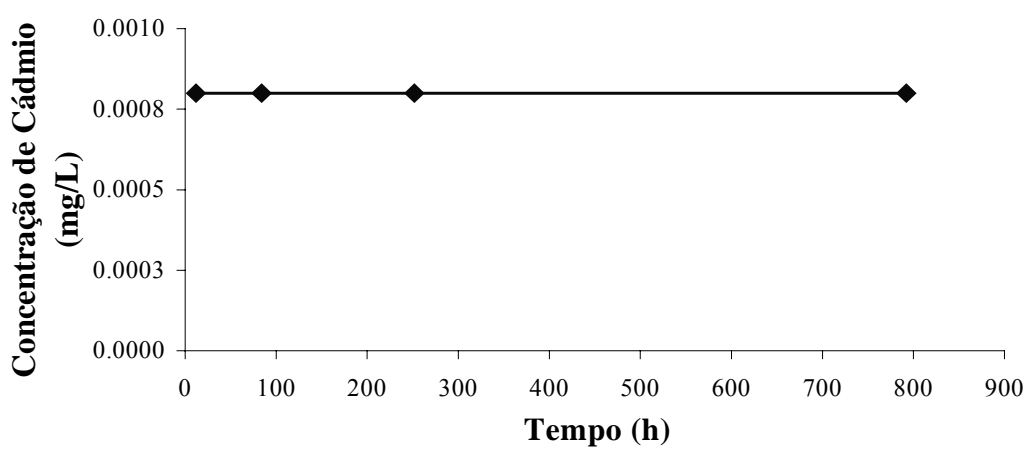

Valor Máximo Permitido - $0.005 \mathrm{mg} / \mathrm{L}$

Método - absorção atômica

\section{Cianetos}

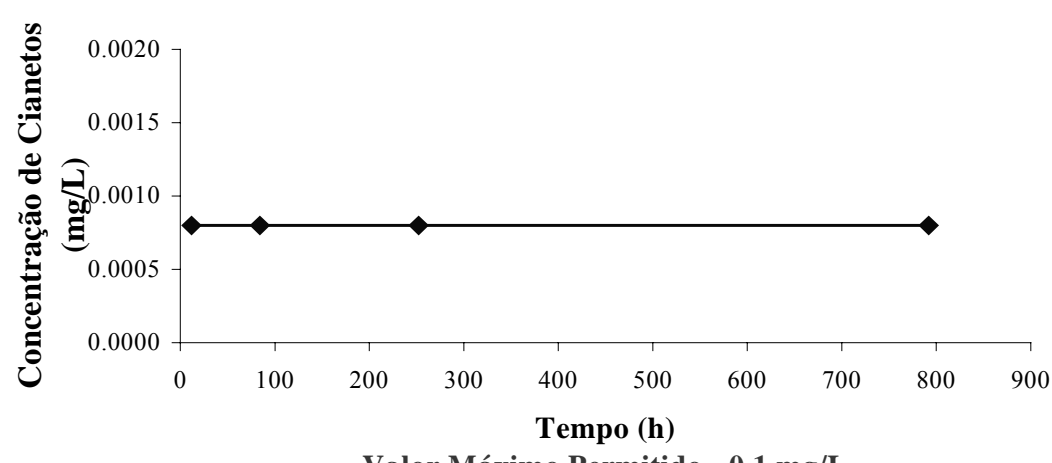

Valor Máximo Permitido - 0.1 mg/L

Método - colorimetria espectrofotometria visível

Figura 5.39. Comportamento de parâmetros químicos ao longo do tempo (lixiviação com extrator soxhlet) 
Cromo Total

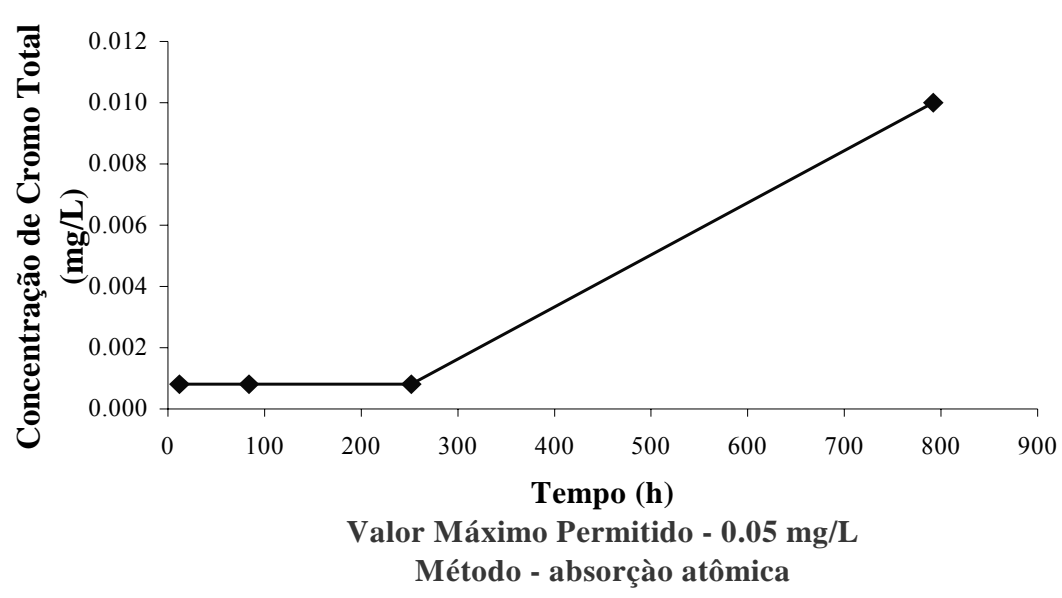

Fluoretos

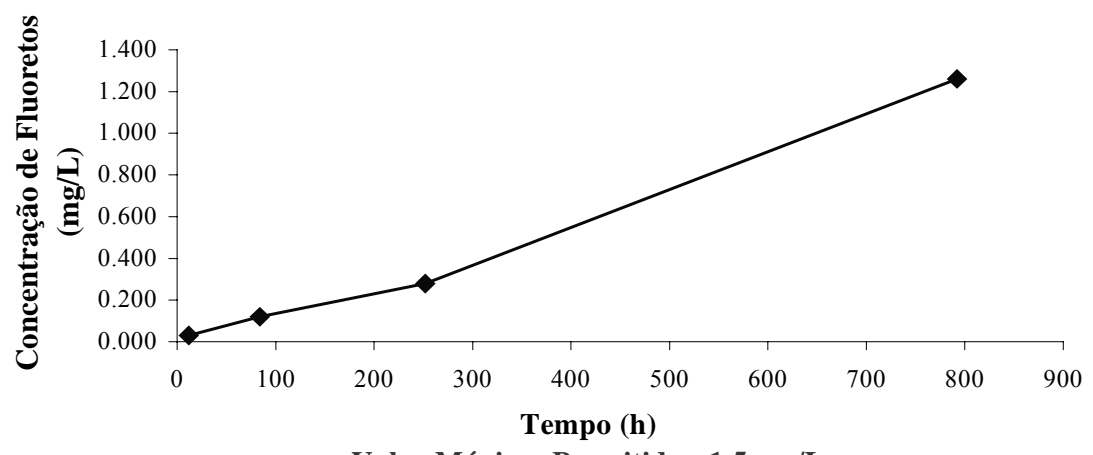

Valor Máximo Permitido - $1.5 \mathrm{mg} / \mathrm{L}$

Método - colorimetria espectrofotometria visível
Índice de Fenóis

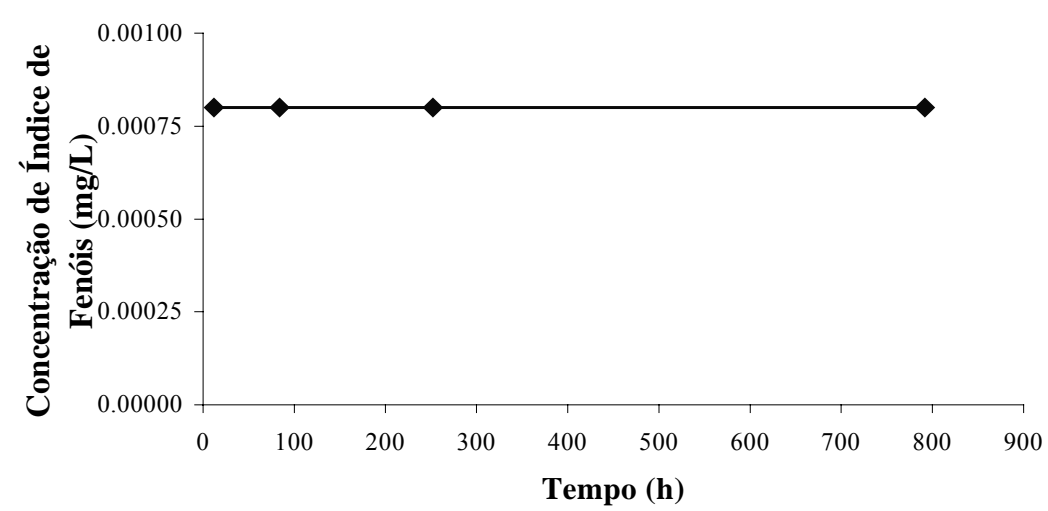

Valor Máximo Permitido - 0.001 mg/L

Método - colorimetria espectrofotometria visível

\section{Mercúrio}

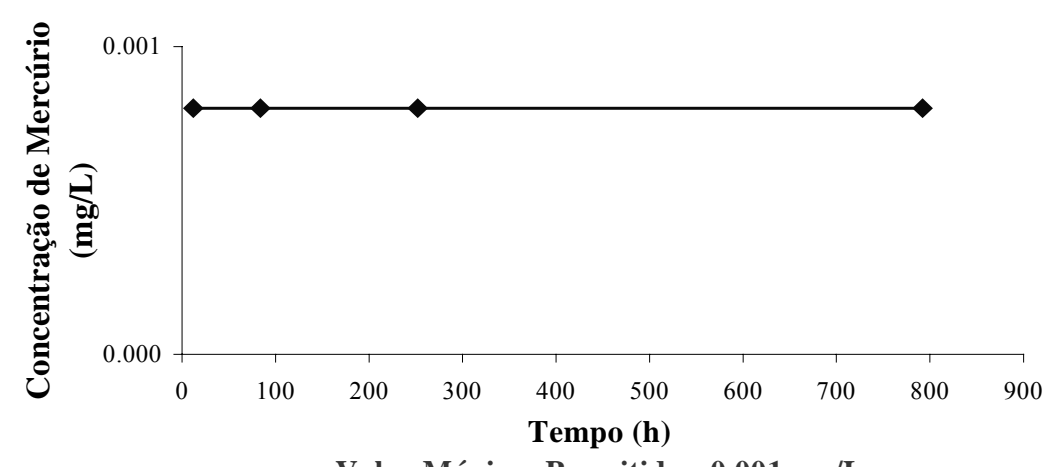

Valor Máximo Permitido - 0.001 mg/L

Método - absorçào atômica com gerador de hireto

Figura 5.40. Comportamento de parâmetros químicos ao longo do tempo (lixiviação com extrator soxhlet) 
Nitratos

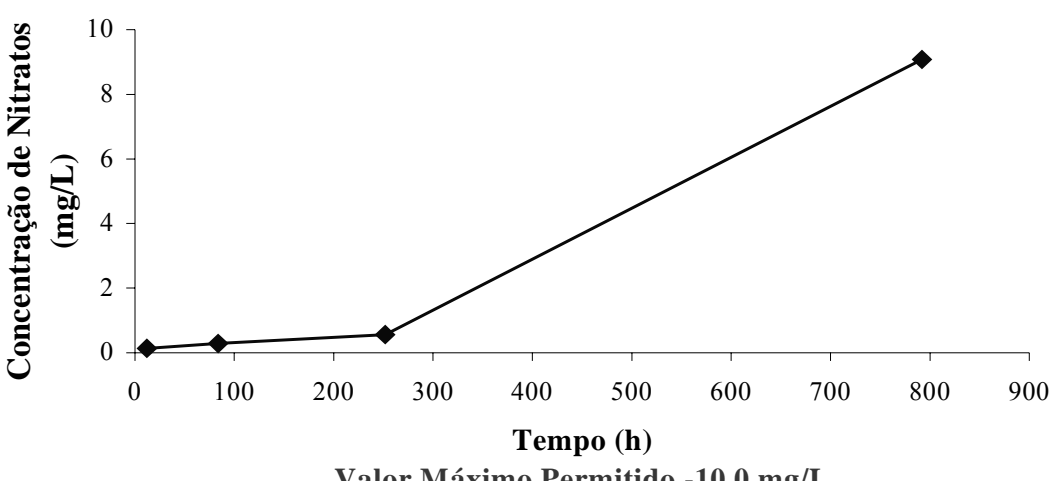

Método - colorimetria espectrofotometria ultravioleta

Alumínio

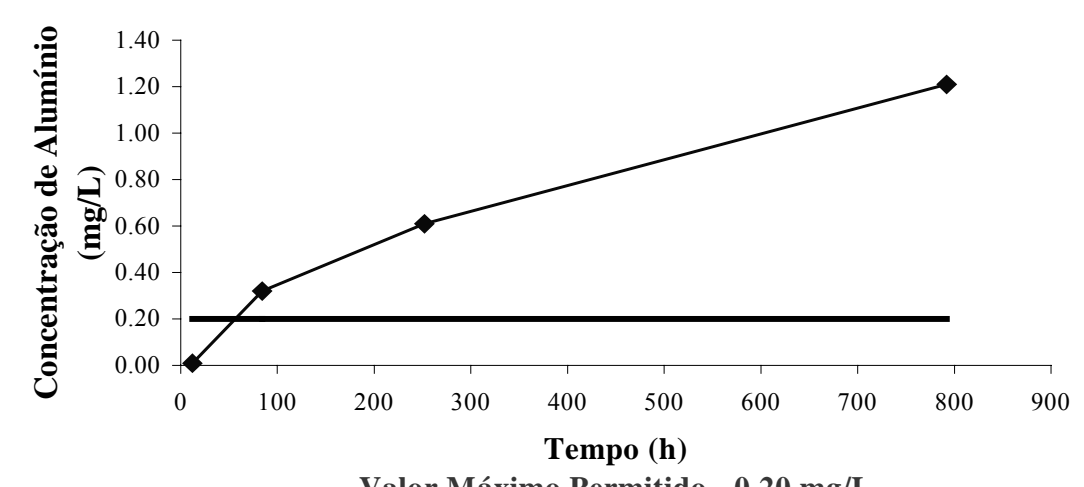

Valor Máximo Permitido - $0.20 \mathrm{mg} / \mathrm{L}$

Método - absorção atômica com forno de grafite
Prata

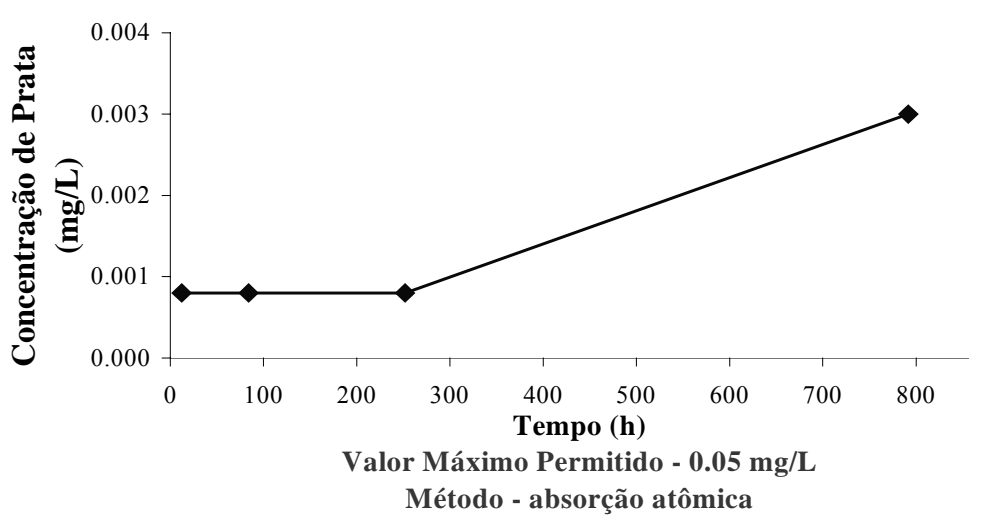

Cloretos

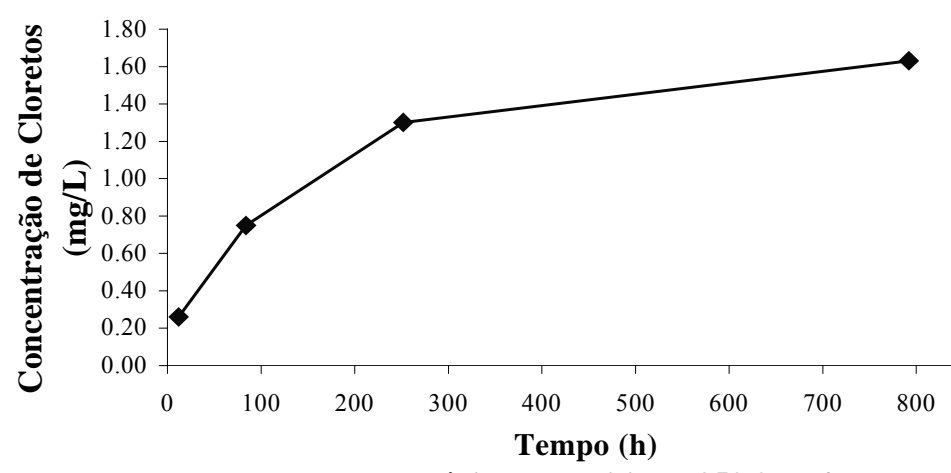

Valor Máximo Permitido - $250.0 \mathrm{mg} / \mathrm{L}$

Método - titrimetria

Figura 5.41. Comportamento de parâmetros químicos ao longo do tempo (lixiviação com extrator soxhlet) 
Cobre

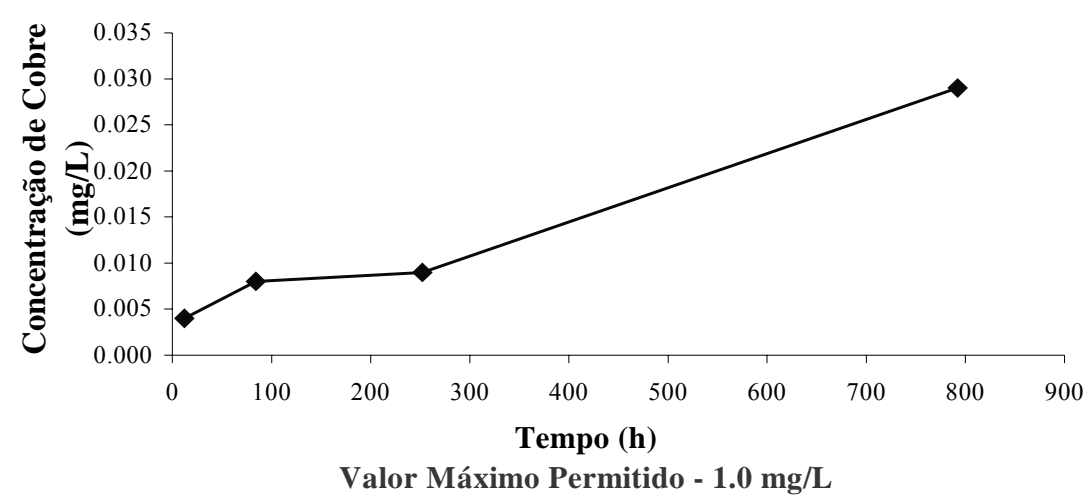

Método - absorção atômica

\section{Ferro}

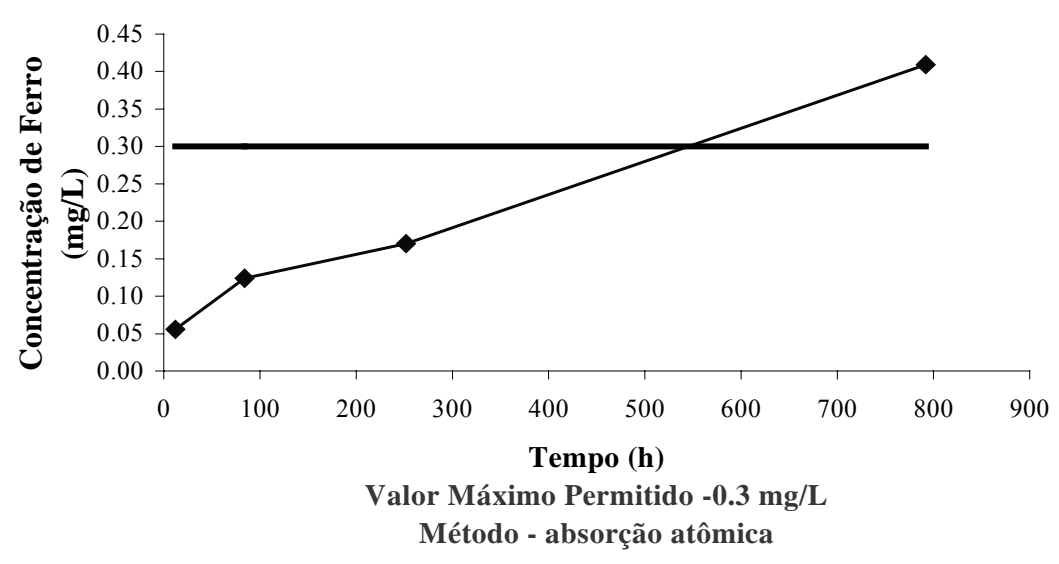

Dureza Total

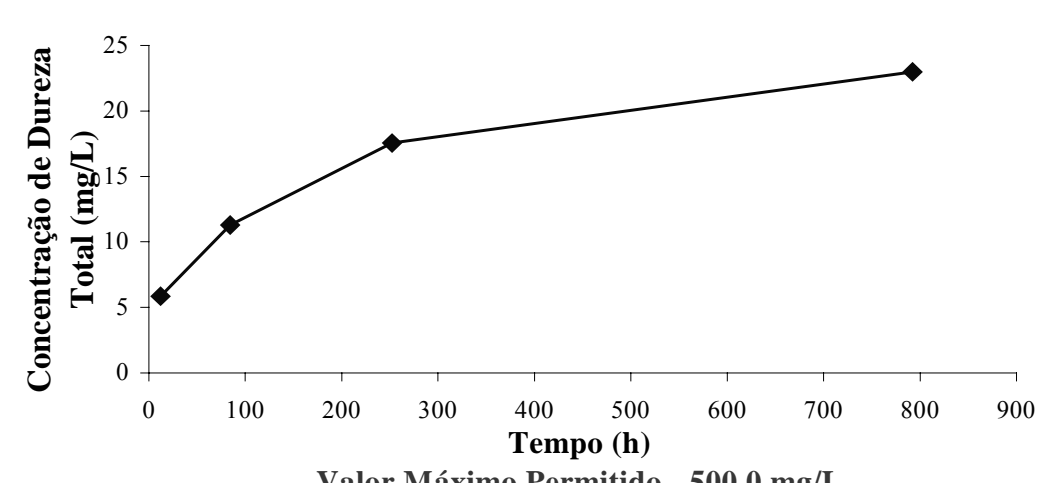

Valor Máximo Permitido - $500.0 \mathrm{mg} / \mathrm{L}$

Método - titrimetria

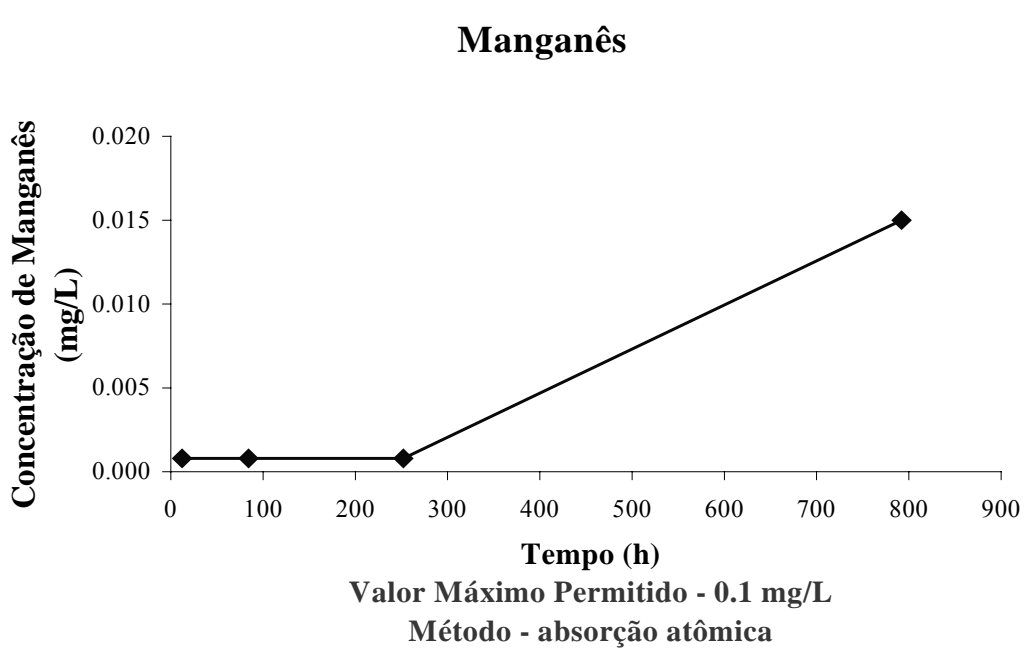

Figura 5.42. Comportamento de parâmetros químicos ao longo do tempo (lixiviação com extrator soxhlet) 
Sódio

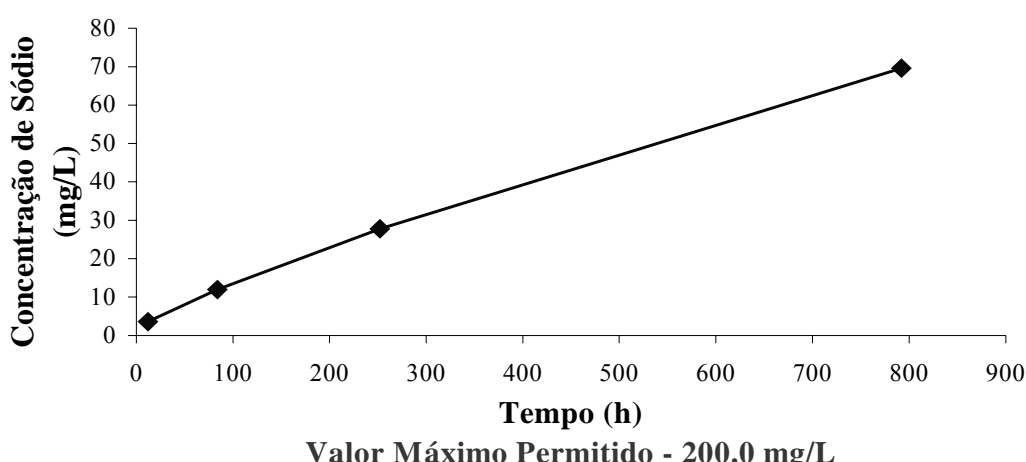

Vor Máxinc

étodo - fotometria de chama

\section{Sulfatos}

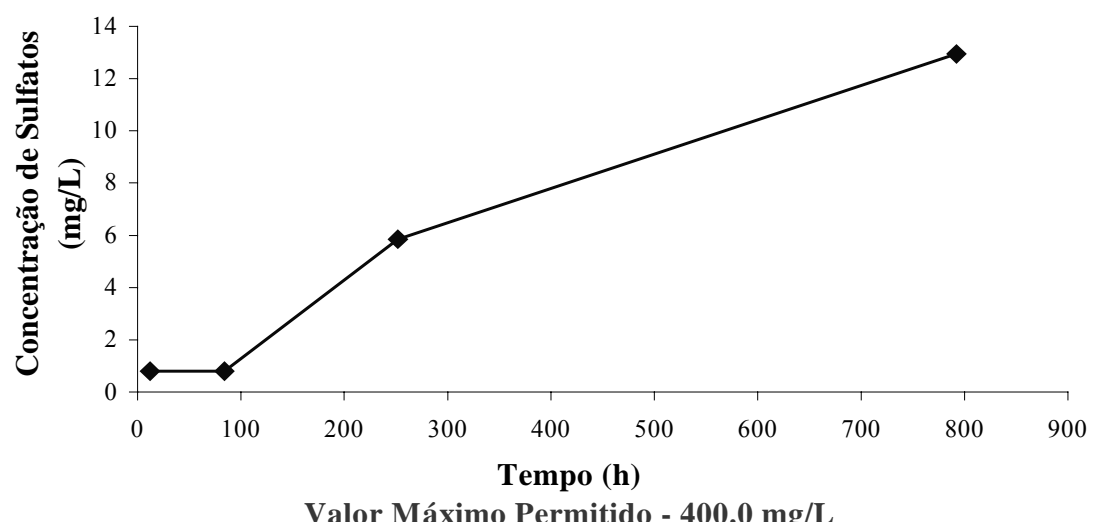

Valor Máximo Permitido - 400.0 mg/L

Método - colorimetria espectrofotometria visível
Surfactantes

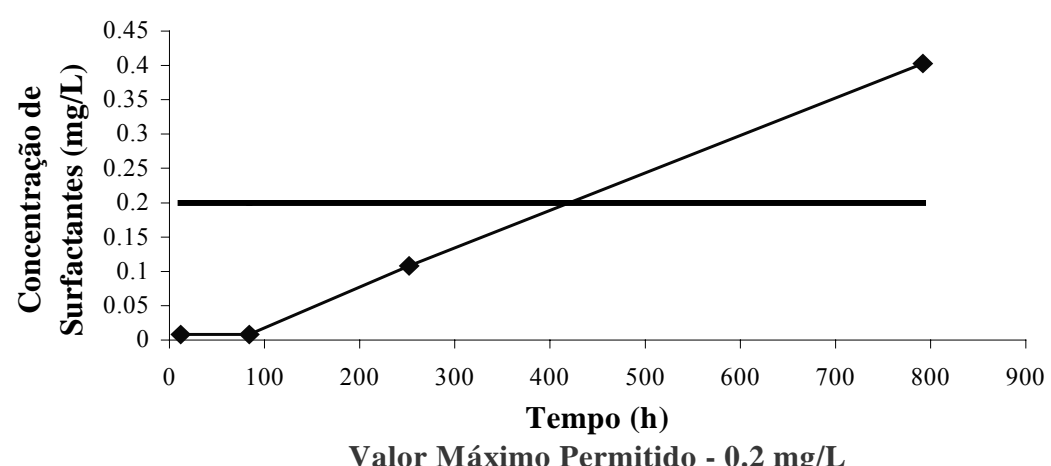

Valor Máximo Permitido - $0.2 \mathrm{mg} / \mathrm{L}$

Método - colorimetria

\section{Zinco}

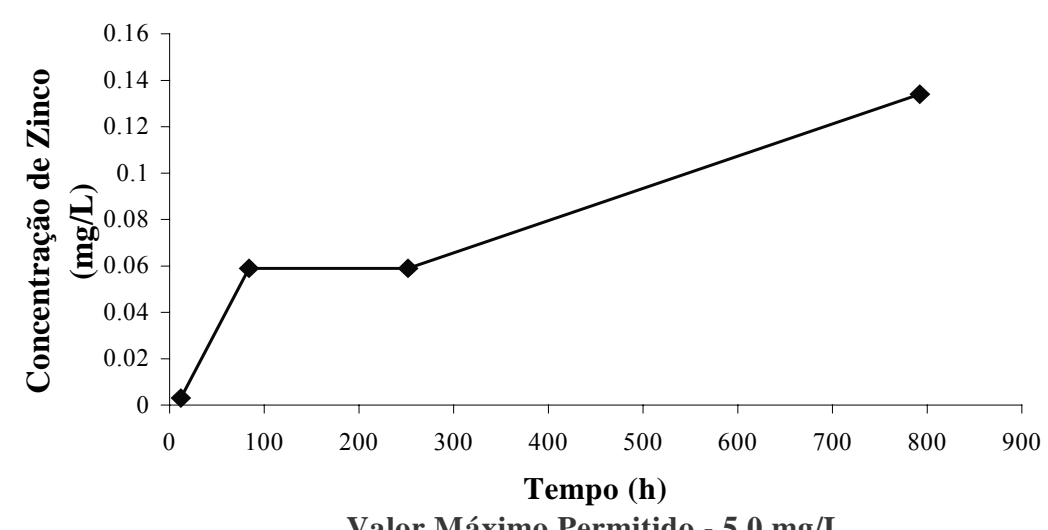

Valor Máximo Permitido - $5.0 \mathrm{mg} / \mathrm{L}$ Método - absorção atômica

Figura 5.43. Comportamento de parâmetros químicos ao longo do tempo (lixiviação com extrator soxhlet) 
No ensaio de lixiviação com extrator soxhlet (Tabela 5.13), realizado em corpo-deprova com $15 \%$ de areia de fundição, verificou-se, por exemplo, que o chumbo, parâmetro não quantificado na areia de fundição (Tabela 5.13 e Figura 5.39), mas presente no asfalto $(0,727 \mathrm{mg} / \mathrm{L})$, foi detectado (quantificado) somente após 792 horas de ensaio na concentração $0,019 \mathrm{mg} / \mathrm{L}$. Este valor corresponde a $38 \%$ do valor máximo permitido pela norma $(0,05 \mathrm{mg} / \mathrm{L})$. Os Fenóis, detectados tanto na areia de fundição $(0,38 \mathrm{mg} / \mathrm{L})$ quanto no asfalto $(0,055 \mathrm{mg} / \mathrm{L})$, não foram quantificados em nenhuma coleta de extrato oriundo do corpo-de-prova com $15 \%$ de areia de fundição, como pode ser verificado na Tabela 5.13 e na Figura 5.40.

A partir da segunda coleta, a concentração acumulada de alumínio (parâmetro detectado na areia de fundição, acima do limite preconizado pela norma, e detectado também no CAP 20) no extrato lixiviado do corpo-de-prova de misturas asfálticas apresentou-se maior que o valor máximo permitido pela NBR 10004/87 e que no extrato da quinta coleta, os parâmetros ferro e surfactantes (ambos presentes na areia de fundição e no CAP 20) também ultrapassaram os limites fixados pela norma (Tabela 5.13 e Figuras 5.41 a 5.43 )

Estes parâmetros, como exposto, podem ter sido originados também do CAP 20 e não só da areia de fundição, como pode ser observado na Tabela 5.14. Nesta Tabela, verifica-se que só não foram quantificados no asfalto (lixiviação com extrator soxhlet), considerando os parâmetros pesquisados na areia de fundição: bário, cianetos, cromo total, mercúrio, selênio, cobre, dureza total, manganês e zinco; parâmetros estes que também foram pesquisados na areia de fundição e contudo, não foram quantificados (ensaio de solubilização), com exceção da dureza total $\left(\mathrm{CaCO}_{3}\right)$.

O tempo de lixiviação, com o extrator soxhlet, na amostra de CAP 20 (84 horas) corresponde ao mesmo tempo de ensaio relativo à segunda coleta do extrato do corpode-prova de mistura asfáltica com $15 \%$ de areia de fundição ( $5^{\text {a }}$ coluna da Tabela 5.13$)$. As análises químicas nestes extratos quantificaram concentrações (acumuladas) de alumínio, ferro e surfactantes, respectivamente, de $0,32,0,124$ e menor do que 0,01 $\mathrm{mg} / \mathrm{L}$ para a mistura asfáltica, e de 0,639, 0,111 e 0,016 mg/L para o CAP 20.

Apesar de o alumínio, ferro e surfactantes ultrapassarem os limites permitidos pela norma (NBR 10004/87), vale ressaltar que as condições (temperatura e umidade) utilizadas no ensaio de lixiviação, com extrator soxhlet, foram muito mais severas do que as que ocorrem na natureza e que essas substâncias podem ter saído também do cimento asfáltico. 


\section{CONCLUSÕES E RECOMENDAÇÕES}

Neste capítulo, expõem-se as conclusões e sugestões fundamentadas nos resultados, nas análises e nas discussões apresentadas no capítulo 5. Vale relembrar que a avaliação da areia de fundição para reaproveitamento em misturas asfálticas densas foi feita com base em ensaios ambientais e naqueles de interesse à pavimentação do ponto de vista desta pesquisa. A avaliação de interesse à pavimentação baseou-se nos resultados dos ensaios: dosagem Marshall, Cantabro, dano por umidade induzida, resistência à tração, módulo de resiliência e fluência por compressão axial estática. A apreciação ambiental fundamentou-se nos ensaios de lixiviação, solubilização e massa bruta e, ainda, no ensaio de lixiviação com extrator soxhlet.

\subsection{Dosagem Marshall}

Da dosagem Marshall pôde-se concluir que todas as misturas no teor ótimo de asfalto $(\mathrm{Vv}=4 \%)$ apresentaram parâmetros Marshall que satisfazem os requisitos das especificações.

Pode-se concluir também que as misturas com areia de fundição requereram maior consumo de asfalto que a mistura padrão, considerando as mesmas porcentagens de areia (nessa pesquisa 10\%AF e 10\%AV), e que as misturas com areia virgem, embora com menores teores de asfalto, apresentaram quase todos os parâmetros Marshall ligeiramente mais favoráveis. Entretanto, vale ressaltar que as diferenças nos teores de asfalto das duas misturas (10\%AF e 10\%AV) não foram estatisticamente significantes.

De um modo geral, pode-se concluir que as misturas asfálticas com o resíduo areia de fundição apresentam propriedades adequadas para camada de rolamento no que diz respeito aos parâmetros obtidos da dosagem Marshall.

\subsection{Ensaio Cantabro}

Dos resultados deste ensaio, concluiu-se que as misturas com areia de fundição são mais sensíveis ao desgaste que as misturas com areia virgem. 
Essa conclusão, baseou-se principalmente no fato das misturas $10 \% \mathrm{AF}$ e $10 \% \mathrm{AV}$ apresentarem os mesmos teores de fino e fíler e apesar da mistura com areia de fundição utilizar maior teor de asfalto, ela (10\%AF) apresentou maior desgaste.

No entanto, a análise de variância indicou que as médias de perda de massa das misturas $10 \% \mathrm{AV}$ e $10 \% \mathrm{AF}$ não são estatisticamente diferentes entre si, permitindo concluir, portanto, que se pode utilizar na mistura asfáltica areia de fundição ou virgem, no teor de $10 \%$, que esta propriedade não mudará significativamente.

As misturas, de um modo geral, apresentaram desgastes compatíveis (máximo de $7,72 \%(5 \% \mathrm{AF})$ e mínimo de 4,86\% (15\%AF)) com os encontrados para misturas asfálticas densas, considerando o teor de asfalto de trabalho $\left(\mathrm{VV}_{\text {nominal }}=4 \%\right)$. Os desgastes mínimos apresentados pelas misturas com 15\%AF, são devidos principalmente ao teor de asfalto destas misturas, que foram os mais altos.

\subsection{Ensaio de Dano por Umidade Induzida}

Com base na pesquisa de Hicks (1991) e nos resultados obtidos, concluiu-se que todas as misturas são de boa qualidade quanto à deterioração por umidade, pois todas apresentaram, tanto no Vv nominal 4\% quanto no Vv 7\%, Relação de Resistência à Tração (RRT) superior a 70\%.

Concluiu-se ainda que as amostras (10\%AF e 10\%AV) com maior volume de vazios, no caso $7 \%$, apresentaram menor susceptibilidade ao dano por umidade induzida que aquelas com 4\%. Dos resultados da 5\%AF, $10 \% \mathrm{AF}$ e $10 \% \mathrm{AV}$ no $\mathrm{Vv} 4 \%$, respectivamente, 88,78 e $73 \%$, pôde-se concluir que a maior quantidade de areia, virgem ou de fundição, ou seja, maior teor de sílica, parece diminuir a interação asfalto/agregado.

Por meio da análise de variância pôde-se concluir que a saturação inadequada de $34,46 \%$ das amostras com $15 \% \mathrm{AF}$ não interferiu significativamente no resultado das resistências à tração dos corpos-de-prova condicionados. Contudo, todas as amostras que apresentaram saturação superior a $55 \%$ (55,62 a 65,98\%), mostraram que o condicionamento interferiu significativamente nesta resposta (Resistência à Tração).

Da análise de variância, pôde-se concluir também que a cura da mistura antes da compactação em estufa ventilada a $60^{\circ} \mathrm{C}$ por 16 horas, próprio do ensaio de dano por umidade induzida, não interferiu significativamente na resistência à tração dos corposde-prova não condicionados $(\mathrm{Vv}=4 \%)$. Haja vista que as médias das resistências à tração desses corpos-de-prova (CPs não condicionados) nesse ensaio não foram 
significativamente diferentes das médias de resistência à tração dos corpos-de-prova do ensaio padrão (DNER-ME 138/94).

Sugere-se a realização deste ensaio em outros tipos de mistura nos volumes de vazios de 4 e $7 \%(7 \pm 1 \%)$, ambos no teor ótimo de asfalto, para que se possa obter resultados que corroborem ou discordem dos encontrados nesta pesquisa.

\subsection{Ensaio de Resistência à Tração por Compressão Diametral}

Dos resultados deste ensaio pôde-se concluir que as misturas estudadas apresentaram variação pouco expressiva com o volume de vazios (teor de asfalto), com exceção da mistura $10 \% \mathrm{AF}$, que por meio da ANOVA mostrou diferença significativa entre as resistências referentes aos Vv 3 e 5,20\% e entre 4,30 e 5,20\%.

Os resultados mostraram que, aparentemente, quanto maior o teor de areia menor a resistência à tração das misturas no teor ótimo de asfalto, todavia, por meio da análise de variância, pôde-se concluir que o teor de areia, de fundição ou virgem, não interferiu significativamente na resistência a tração das misturas não envelhecidas.

Com base na análise de variância, concluiu-se também que o fator envelhecimento interferiu significativamente na resistência à tração das misturas $5 \% \mathrm{AF}, 15 \% \mathrm{AF}$ e 10\%AV. Nos envelhecimentos em curto prazo e simultâneo (em curto e em longo prazos) houve interferência significativa do teor e da natureza da areia na resistência à tração das misturas, enquanto no envelhecimento em longo prazo apenas o teor de areia interferiu significativamente.

Concluiu-se que a mistura com $10 \%$ de areia virgem mostrou mais susceptibilidade ao envelhecimento, considerando a resistência à tração, que a mistura com 10\% de areia de fundição.

\subsection{Ensaio de Módulo de Resiliência}

Como o que ocorreu no ensaio de resistência à tração, pôde-se concluir que os módulos das misturas não envelhecidas mostraram-se pouco sensíveis ao volume de vazios (teor de asfalto), com exceção da mistura $10 \% \mathrm{AV}$, que segundo a análise de variância, apresentaram diferença significativa entre os módulos referentes aos Vv: 2,96 e 3,72\% e 3,72 e $5,17 \%$. Concluiu-se também que o teor de areia interferiu significativamente nos módulos de resiliência, pois foram encontradas mudanças expressivas entre os módulos das misturas: $5 \% \mathrm{AF}$ e $10 \% \mathrm{AF}$ e $5 \% \mathrm{AF}$ e $15 \% \mathrm{AF}$, mas que a natureza da areia não interferiu significativamente nesses parâmetros. Assim, tanto faz incorporar $10 \%$ de 
areia virgem quanto $10 \%$ de areia de fundição nas misturas que não haverá mudança expressiva nos valores dos módulos de resiliência.

Por meio da análise de variância pôde-se concluir que o fator envelhecimento interfere nos valores do módulo de resiliência, pois esta detectou diferença significativa em quase todas as misturas, com exceção da 15\%AF. A mistura $10 \% \mathrm{AF}$ só não mostrou susceptibilidade significativa com o envelhecimento em longo prazo, quando comparado com a condição sem envelhecimento, enquanto a 10\%AV mostrou mudança significativa em qualquer condição de envelhecimento. No envelhecimento em curto prazo houve interferência significativa do teor e da natureza da areia no módulo de resiliência das misturas, pois se verificou diferença expressiva entre quase todos os módulos, com exceção entre os da 5\%AF e 10\%AF, o que aconteceu também no envelhecimento em longo prazo (5\% AF e 10\%AF, 10\%AF e $15 \% \mathrm{AF}$ e $10 \% \mathrm{AF}$ e $10 \% \mathrm{AV})$. No envelhecimento em curto e em longo prazos, houve interferência apenas do teor de areia.

Concluiu-se que a mistura com $10 \%$ de areia virgem se mostrou mais susceptível ao envelhecimento, considerando o módulo de resiliência, que a mistura com $10 \%$ de areia de fundição.

A maior e a menor relação MR/RT no teor ótimo de asfalto foram apresentadas pelas misturas 10\%AV (5722) e 10\%AF (4413), respectivamente. A mistura 5\%AF foi a que mostrou menor sensibilidade ao fator envelhecimento. Também foi verificado nas misturas condicionadas que a maior relação $\mathrm{MR} / \mathrm{RT}$ foi apresentada pela mistura 10\%AF (8254) no envelhecimento simultâneo, em curto e em longo prazos, enquanto nesta condição, a 10\%AV apresentou MR/RT correspondente a 5965.

Sugere-se que, se o ensaio de módulo de resiliência for realizado em duas direções, seja preestabelecido um período de recuperação e não proceder como nesta pesquisa: ensaio executado em duas direções $\left(0\right.$ e $\left.90^{\circ}\right)$, mas sem tempo de recuperação, ou seja, o ensaio na segunda direção era realizado imediatamente após o término do ensaio na primeira direção. Com isto, resultaram na segunda direção $\left(90^{\circ}\right)$ valores de módulo de resiliência quase sempre menores que os valores de módulo na primeira direção $\left(90^{\circ}\right)$, indicando, desta forma, uma recuperação da deformação vertical, ocorrida por ocasião do primeiro carregamento (ensaio na primeira direção). 


\subsection{Ensaio de Fluência por Compressão Uniaxial Estática}

As conclusões aqui apresentadas dizem respeito à deformação total, ao módulo de fluência antes da recuperação e à inclinação do estágio secundário da curva de fluência. Estas são apresentadas, considerando as três condições do ensaio de fluência abordadas nesta pesquisa: tensão de $0,1 \mathrm{MPa}$ e $0,4 \mathrm{MPa}$ com o prato de carregamento com diâmetro normal $(102 \mathrm{~mm})$ e tensão de $0,4 \mathrm{MPa}$ com o prato de carregamento com diâmetro reduzido $(51 \mathrm{~mm})$.

\subsubsection{Deformação total}

Do ensaio com tensão de 0,1 MPa (prato com diâmetro de $102 \mathrm{~mm}$ ), pôde-se concluir, que apenas as misturas 10\% AF e 10\%AV apresentaram mudança expressiva nas deformações totais com o volume de vazios. Entretanto, concluiu-se também que o teor de areia interferiu expressivamente nas deformações totais das misturas virgens. Por meio da análise de variância, concluiu-se que o fator envelhecimento não interveio na deformação total de nenhuma mistura, mas que $\mathrm{o}$ teor de areia interferiu significativamente neste parâmetro nas condições de envelhecimento em longo prazo e simultânea (em curto e em longo prazos).

No ensaio com tensão de 0,4 MPa e prato normal (102 mm), quase todas as misturas não apresentaram mudança significativa da deformação total com volume de vazios, sendo exceção a mistura 10\%AF. Entretanto, pôde-se concluir que o teor de areia interferiu expressivamente nas deformações totais das misturas virgens. Ainda, pela análise de variância, concluiu-se que o fator envelhecimento não interveio na deformação total de quase todas as misturas, com exceção da $10 \% \mathrm{AF}$. Contudo, detectou-se que o teor de areia interferiu significativamente neste parâmetro nas condições de envelhecimento em curto prazo e simultânea, em curto e longo prazos.

Já do ensaio neste nível de tensão $(0,4 \mathrm{MPa})$ e com o prato reduzido $(51 \mathrm{~mm})$, pôdese concluir, por meio da ANOVA, que as deformações totais de todas as misturas não envelhecidas mostraram-se pouco sensíveis ao volume de vazios (teor de asfalto) e ao teor de areia, isto é, não mudaram expressivamente. Ainda, pela análise de variância, concluiu-se que o fator envelhecimento não interveio na deformação total de nenhuma mistura e que o teor e natureza da areia não interferiram expressivamente nestes parâmetros, considerando todas as condições de envelhecimento.

Os valores das deformações totais no teor ótimo de asfalto para todas as misturas, no ensaio com tensão 0,4 MPa e prato reduzido, estiveram entre 0,21 e 0,29\%, indicando, 
pelo critério de Little et al. (1993), que estas misturas podem ser utilizadas para pavimentação de rodovias de tráfego de alta ou de altíssima intensidades. Para decidir a classe de uso, devem ser observadas outras condições que não foram verificadas nesta pesquisa. Já no ensaio com prato normal, estes valores estiveram entre 0,27 e $0,39 \%$, mas corroboraram a indicação anterior, visto que estão entre os valores de 0,25 e $0,40 \%$.

\subsubsection{Módulo de fluência}

Do ensaio com tensão de $0,1 \mathrm{MPa}$, pôde-se concluir que apenas as misturas $10 \% \mathrm{AF}$ e 10\%AV apresentaram mudança expressiva nos módulos de fluência (antes da recuperação) com o volume de vazios. Entretanto, concluiu-se também que o teor de areia interferiu expressivamente nos módulos de fluência das misturas não envelhecidas. Por meio da ANOVA concluiu-se que o envelhecimento não interveio de forma significante nos módulos de fluência de nenhuma mistura, mas que o teor de areia interferiu significativamente nestes parâmetros nas condições de envelhecimento em longo prazo e simultânea, em curto e em longo prazos.

A mistura 10\%AF apresentou módulo de fluência variando de 34 a $53 \mathrm{MPa}$, sendo que no teor ótimo de asfalto $\left(\mathrm{Vv}_{\text {nominal }}=4 \%\right)$ este parâmetro apresentou $34 \mathrm{MPa}$, indicando, segundo Kronfuss et al. ${ }^{1}$ (1984 apud Little et al. 1993, p.51), que esta pode ser utilizada para a pavimentação de rodovias com tráfego de alta intensidade, pois o módulo de fluência se encontra entre 31 e 45,3 MPa. Entretanto, a mistura 10\%AV, que apresentou módulo de fluência igual a $60 \mathrm{MPa}$ no teor ótimo de asfalto, segundo estes pesquisadores, pode ser utilizada para pavimentar vias com tráfego de baixa intensidade, pois este parâmetro é superior a 20,7 MPa (baixa intensidade de tráfego 20,7 MPa ou acima). O critério proposto por Kronfuss et al. (1984) é apresentado em faixas de variação do módulo de fluência e não em valores mínimos deste parâmetro.

No ensaio com tensão de $0,4 \mathrm{MPa}$ e prato normal, quase todas as misturas não apresentaram mudança significativa no módulo de fluência antes da recuperação com volume de vazios, sendo exceção a mistura 10\%AF. Entretanto, pôde-se concluir que o teor de areia interferiu expressivamente nos módulos de fluência das misturas virgens.

\footnotetext{
${ }^{1}$ KRONFUSS, R.; KRZERMIEN, R.; NIEVELT, G.; PUTZ, P. (1984). Verformungsfestigkjeit von Asphalten Ermittlung in Kriechtest. Bundesministerium fur Bauten and Technik, Strassenforschung, Heft 240, Wien, Autria apud LITTLE, D. N. et al. (1993). Development of criteria to evaluate uniaxial creep data and asphalt concrete permanent deformation potential. Transportation Research Record, n. 1417, $\mathrm{p}$. 49-57. p.51.
} 
Ainda, pela análise de variância, concluiu-se que o envelhecimento não interveio no módulo de fluência de quase todas as misturas, com exceção da 10\%AF. Contudo, detectou-se que o teor de areia interferiu significativamente neste parâmetro nas condições de envelhecimento em curto prazo e simultânea, em curto e longo prazos.

Para ensaio no nível de tensão de $0,4 \mathrm{MPa}$ e prato reduzido $(51 \mathrm{~mm})$, pôde-se concluir, por meio da ANOVA, que os módulos de fluência antes da recuperação de todas as misturas não envelhecidas mostraram-se pouco sensíveis ao volume de vazios (teor de asfalto) e ao teor de areia, isto é, não mudaram expressivamente. Ainda, pela análise de variância, concluiu-se que o fator envelhecimento não interveio no módulo de fluência de nenhuma mistura e que o teor e a natureza da areia não interferiram expressivamente nestes parâmetros, considerando todas as condições de envelhecimento.

Os valores dos módulos de fluência no teor ótimo de asfalto para todas as misturas, no ensaio com tensão $0,4 \mathrm{MPa}$ e prato reduzido, estiveram entre 146 e $196 \mathrm{MPa}$, indicando, pelo critério de Little et al. (1993), que estas misturas apresentam alta resistência à formação de trilhas-de-roda, quando empregadas para tráfego de altíssima intensidade $\left(\mathrm{N}>10^{6}\right)$, pois apresentaram módulo de fluência superior a $137 \mathrm{MPa}$. Os módulos de fluência para as misturas 10\%AF e 10\%AV foram, respectivamente, $146 \mathrm{e}$ $175 \mathrm{MPa}$. Nos casos das misturas envelhecidas em curto e em longo prazo (simultâneo), a 10\%AF apresentou $223 \mathrm{MPa}$ e 10\%AV, $194 \mathrm{MPa}$.

Já no ensaio com prato normal (102 mm), estes valores estiveram entre 105 e 149 $\mathrm{MPa}$ para misturas não envelhecidas, indicando, pelo critério mencionado anteriormente, que estas misturas apresentam alta resistência à deformação permanente, quando empregada na pavimentação de vias com tráfego de altíssima intensidade, $\mathrm{N}>$ $10^{6}$, (módulo de fluência superior a $137 \mathrm{MPa}$ ) ou na pavimentação de via de tráfego de alta intensidade, $5 \times 10^{5}<\mathrm{N}<10^{6}$, (superior a 82 e inferior a $137 \mathrm{MPa}$ ). Ou ainda, misturas que apresentam faixa de variação entre 82 e $137 \mathrm{MPa}$ podem ser utilizadas para a pavimentação de vias com altíssima intensidade de tráfego, porém o nível de resistência desta misturas à deformação permanente passa a ser moderado.

As misturas $10 \% \mathrm{AF}$ e $10 \% \mathrm{AV}$ apresentaram, no teor ótimo de asfalto, módulo de fluência igual a $112 \mathrm{MPa}$ e $149 \mathrm{MPa}$, respectivamente. As misturas $10 \% \mathrm{AF}$ e $10 \% \mathrm{AV}$, quando submetidas ao envelhecimento simultâneo, apresentaram módulo de fluência igual a 140 e a $160 \mathrm{MPa}$, respectivamente. 


\subsubsection{Inclinação do estágio secundário}

Todas as misturas, tanto as não envelhecidas quanto as envelhecidas, nas três condições de ensaio de fluência (0,1 $\mathrm{MPa}$, e 0,4 $\mathrm{MPa}$ com prato normal e 0,4 $\mathrm{MPa}$ com prato reduzido), apresentaram inclinação do estágio secundário inferior a $0,17 \% \mathrm{~s}^{-1} \mathrm{e}$ deformação total inferior a $0,50 \%$. Desta forma, utilizando os critérios de Little et al. (1993), concluiu-se que estas misturas podem ser utilizadas para pavimentar vias com altíssima intensidade de tráfego, desde que atendam ao seguinte critério: $\varepsilon_{\mathrm{rt}}+\varepsilon_{\mathrm{p}}<0,5$ $\varepsilon_{\text {qu. }}$ Sendo $\varepsilon_{\mathrm{rt}}$, a deformação resiliente total obtida do ensaio de módulo resiliente uniaxial (ASTM D 3497); $\varepsilon_{\mathrm{p}}$, a deformação total ao término dos $3600 \mathrm{~s}$ de carregamento, e $\varepsilon_{\text {qu}}$, deformação obtida do ensaio de compressão não-confinada (AASHTO T 167).

Desta forma, pôde-se concluir que todas as misturas apresentaram inclinação do estágio secundário muito baixa, indicando baixa susceptibilidade destas à deformação permanente. Esta conclusão está embasada no critério de Little et al. (1993 - Tabela 5, página 55), que apresenta como menor valor de inclinação do estágio secundário, $0,17 \%$.

Concluiu-se, de um modo geral, que os parâmetros obtidos do ensaio de fluência por compressão uniaxial estática $(0,4 \mathrm{MPa})$ com prato superior reduzido $(51 \mathrm{~mm})$, apresentaram-se: menores, no caso da deformação total e da inclinação do estágio secundário; maiores, no caso da recuperação e módulos de fluência. Este ensaio realça a presença da recuperação elástica nas misturas, além de produzir tendência de variação desses parâmetros semelhantes às obtidas do ensaio padrão, com exceção das curvas da $5 \% \mathrm{AF}$, que mostraram tendência inversa. Vale lembrar que o ensaio de fluência com prato superior reduzido $(51 \mathrm{~mm})$ modela mais adequadamente o que acontece no campo, visto que apresenta uma área de confinamento. Segundo Ulmgren (1997), no ensaio com o prato superior reduzido a componente da estabilidade representada pelo atrito interno do agregado é solicitada, o que não ocorre com os ensaios realizados com o prato superior normal, o que parece ter sido confirmado por meio dos resultados desta pesquisa.

Como recomendação, sugere-se que os testes com pratos de dimensões reduzidas sejam estendidos a outros tipos de misturas asfálticas e que seja testada a possibilidade de reduzir também o prato inferior, produzindo, então, um pseudoconfinamento na superfície lateral do corpo-de-prova limitada pelos pratos inferior e superior. 
Notou-se, também, que as irregularidades das faces do corpo-de-prova e o não paralelismo destas parece ter interferido mais no ensaio com o prato de diâmetro reduzido, causando maior variabilidade. Portanto, também se sugere que as faces superiores e inferiores sejam polidas até ficarem tão lisas e paralelas quanto possíveis.

No ensaio com prato superior normal, sugere-se utilizar a técnica alternativa de Vianna et al. (2003) para medir as deformações durante a execução deste ensaio. Nessa alternativa, as irregularidades das faces do corpo-de-prova não produzem efeito na medida das deformações, visto que o registro dos deslocamentos é feito entre pontos (próximos às faces) localizados ao longo do corpo-de-prova, e não na superfície. Desta forma, a preocupação com as irregularidades das faces deve ser apenas com a distribuição do carregamento.

\subsection{Ensaios de avaliação do risco ambiental}

Dos resultados dos ensaios de classificação de resíduo realizados em amostras de areia virgem e em massa asfáltica com $10 \%$ desta areia, conclui-se que estes são materiais que não representam nenhum risco ambiental, visto que foram classificados como resíduos classe III - Inerte. No entanto, estes ensaios classificaram a areia de fundição como resíduo classe II - Não inerte, concluindo, desta forma, que é um resíduo industrial que representa risco para o meio ambiente e que, portanto, deve ser disposto de forma ambientalmente adequada.

Dos ensaios de classificação de resíduos sólidos realizados em massa asfáltica com $15 \%$ de areia de fundição, pôde-se concluir que, ao se transportar esta massa asfáltica não compactada, caso ela seja acidentalmente jogada na natureza, não causará desastre ambiental, visto que foi classificada como resíduo classe III - Inerte, ou seja, as concentrações nos parâmetros lixiviados, solubilizados e massa bruta foram abaixo do limite de norma (NBR 10004/87).

Se a mistura asfáltica não compactada não oferece risco ambiental (classe III Inerte), é de se esperar que ela no pavimento, onde é compactada $(\mathrm{Vv}=4 \%)$, o risco seja ainda menor, visto que, além da superfície disponível diminuir, a entrada de água é dificultada, pois a mistura asfáltica compactada fica muito pouco permeável.

Dos resultados do ensaio de lixiviação com extrator soxhlet em amostra de CAP 20, concluiu-se que os parâmetros alumínio, ferro e surfactantes se apresentaram em concentrações maiores (o alumínio e os surfactantes) ou ligeiramente menor (o ferro) às encontradas no ensaio com extrator soxhlet em corpo-de-prova compactado de mistura 
asfáltica com $15 \%$ de areia de fundição, considerando o mesmo período de ensaio, ou seja, 84 horas. Na análise química realizada no extrato ( 84 horas de ensaio de lixiviação com extrator soxhlet) procedente do CAP 20 foram detectados em altas concentrações elementos como o chumbo, o cádmio e o alumínio.

Dos resultados do ensaio de lixiviação com extrator soxhlet em corpo-de-prova de mistura asfáltica compactada com 15\% de areia de fundição, concluiu-se que apesar de o alumínio, o ferro e os surfactantes ultrapassarem os limites permitidos pela norma, é perfeitamente viável o reaproveitamento de areia de fundição na composição do agregado para misturas asfálticas densas, visto que as condições de ensaio (temperatura e umidade) foram muito mais severas do que as que ocorrem na natureza, e que estes materiais (elementos e substância) provavelmente também saíram do asfalto, conforme exposto no parágrafo anterior. Vale ressaltar que substâncias, como o fenol, e elementos de alta toxicidade como: mercúrio, cádmio, chumbo e cromo não se apresentaram acima do limite máximo permitido pela norma (10004/87) nas análises químicas realizadas nos extratos provenientes do corpo-de-prova de misturas asfáltica com $15 \%$ de areia de fundição.

Em relação aos ensaios de interesse ambiental, a recomendação diz respeito ao ensaio de lixiviação com extrator soxhlet. Sugere-se que este ensaio seja realizado simultaneamente em corpo-de-prova moldado com a mistura asfáltica de referência para, desta forma, permitir uma comparação mais adequada das análises químicas.

\subsection{Conclusão geral (Resumo)}

Embasado nos resultados obtidos, pode-se concluir que o reaproveitamento de areia de fundição como parte do agregado fino em misturas asfálticas densas é viável, tanto do ponto de vista ambiental quanto no que diz respeito às propriedades mecânicas de interesse à engenharia de pavimentação. Essa asserção pode ser feita, visto que as misturas asfálticas nas condições de envelhecimento testadas (sem envelhecimento, envelhecimento em curto prazo, envelhecimento em longo prazo e envelhecimento em curto e em longo prazos), com a incorporação de 5, 10 e 15\% em peso desse resíduo sólido industrial, apresentaram propriedades mecânicas, referentes à pavimentação, satisfatórias e as análises químicas realizadas em amostras não compactadas de massa asfáltica, contendo $15 \%$ de areia de fundição, caracterizaram esse material (mistura asfáltica) como resíduo Classe III - Inerte. Além disso, as análises químicas efetuadas nos extratos coletados no ensaio de lixiviação com extrator soxhlet mostraram que 
substâncias, como os fenóis, e elementos de alta toxicidade, como: mercúrio, cádmio, chumbo e cromo não se apresentaram acima dos limites previstos em norma (NBR 10004/87).

Embora os resultados desta pesquisa sejam favoráveis ao reaproveitamento de areia de fundição em misturas asfálticas densas, se permitido pelos órgãos ambientais competentes, sugere-se adotar algumas precauções antes de utilizá-la com este propósito. Para tanto, fazem-se necessários a classificação da mistura asfáltica, contendo este resíduo (avaliação ambiental), bem como a realização de um projeto de mistura para avaliar as propriedades mecânicas de interesse à pavimentação, ou seja, proceder como nesta pesquisa. Estas medidas são necessárias, haja vista que a qualidade do resíduo é altamente dependente do processo de moldagem utilizado e do material moldado (metais ferrosos e/ou não ferrosos).

Com base nos resultados obtidos, fazem-se as seguintes recomendações para pesquisas futuras:

$\checkmark$ avaliação mecânica e ambiental de mistura asfáltica com areia de fundição proveniente do processo de moldagem em areia verde, visto que é a técnica mais utilizada no Brasil, portanto, é a que gera maior quantidade de resíduo. O aglomerante neste processo é argila, geralmente, a bentonita, que apresenta como principal mineral constituinte a montmorillonita (grande capacidade de expansão e absorção de umidade);

$\checkmark$ avaliar a adição deste resíduo na composição de material para base, sub-base e reforço do subleito, misturando-o aos materiais utilizados habitualmente na região de estudo;

$\checkmark$ avaliar este resíduo como agregado total e/ou parcial em misturas de areiasasfalto usinadas a quente e a frio. 


\section{REFERÊNCIAS}

AMERICAN ASSOCIATION OF STATE HIGHWAY AND TRANSPORTATION OFFICIALS (1999). AASTHO DESIGNATION: T 283-99: Standard Method of Test for Resistance of Compacted Bituminous Mixture to Moisture Induced Damage. Washington. . (2000). AASTHO DESIGNATION: PP2-00: Standard Practice for Mixture Conditioning of Hot-Mix Asphalt (HMA). Washington.

ANANI, B. A. et al. (1990). Laboratory and field study of pavement rutting in Saudi Arabia. Transportation Research Record, n. 1259, p. 79-90.

ASPHALT INSTITUTE (1995). Mix design methods for asphalt concrete and other hot-mix types. Manual series No. 2 (MS-2). Sixth edition. Lexington, Kentucky/USA: Executive offices and research center.

ASSOCIAÇÃO BRASILEIRA DE FUNDIÇÃO (2002). Índices de mercados: Produção de Fundidos em 2003. Disponível em:http://www.abifa.org.Br. Acesso em: 22jan.2004.

ASSOCIAÇÃO BRASILEIRA DE NORMAS TÉCNICAS (1987). NBR 10004/87: Resíduos sólidos. Rio de Janeiro. . (1987). NBR 10005/87: Lixiviação de resíduos. Rio de Janeiro. . (1987). NBR 10006/87: Solubilização de resíduos. Rio de Janeiro. . (1987). NBR 10007/87: amostragem de resíduos. Rio de Janeiro. . (1993). NBR 12891/93: Dosagem de misturas betuminosas pelo método Marshall. Rio de Janeiro. . (2000). NBR 6560/00: Materiais betuminosos - determinação do ponto de amolecimento. Rio de Janeiro.

. (2001). NBR 5847/01: Materiais betuminosos - determinação da viscosidade absoluta. Rio de Janeiro. Rio de Janeiro. . (2001). NBR 6293/01: Materiais betuminosos - determinação da ductilidade. . (2003). NBR 14950/03: Materiais betuminosos - determinação da viscosidade Saybolt Furol. Rio de Janeiro.

AMERICAN SOCIETY FOR TESTING AND MATERIALS (1982). ASTM D 412382: Standard Method of Indirect Tension Test for Resilient Modulus of Bituminous Mixtures. Philadelphia.

BARSA (2003). Enciclopédia Barsa eletrônica. Barsa Planeta Internacional LTDA. Barsa CD 3.1. São Paulo/SP. 
BINA, P.; CASTRO, P. R. F. de; ALVES, J. H. (2003). Utilização de areia de fundição descartada na pavimentação: como aprovar e transformar resíduo em faturamento. $34^{\mathrm{a}}$ reunião anual de pavimentação - Campinas/SP.

BLASS, A. (1985). Processamento de polímeros. Série didática. Florianópolis : Editora da UFCS.

BERNDT, H. (1989). Processo Shell:materiais e tecnologia.Tradução de Herbert Schwarz e outros. ABIFA - Associação Brasileira de Fundição. São Paulo:

ABIFA/JUNDU.

BIOAGRI AMBIENTAL LTDA (2003a) Caracterização de resíduos segundo NBR 10004 - Areia virgem. Boletim de análise N 1347/03 - amostra Nº3656/03. Piracicaba/SP.

. (2003b). Caracterização de resíduos segundo NBR 10004 - Areia de fundição. Boletim de análise N ${ }^{\circ}$ 1997/03 - amostra Nº5498/03. Piracicaba/SP.

BERTOLLO, S. A. M. (2002). Avaliação laboratorial de misturas asfálticas densas modificadas com borracha reciclada de pneus. 198p. Tese (Doutorado) - Escola de Engenharia de São Carlos - Universidade de São Paulo. São Carlos.

BONIN, A. L.; ROSSINI, A. J. (1994). Reutilização da areia preta de fundição na construção civil. Relatório Técnico do Departamento de Tecnologia Sanitária - Centro Superior de Educação Tecnológica da Unicamp (CESET-UNICAMP). Limeira/SP.

BRADASCHIA, C. et al. (1981). Fundição de ligas não ferrosas. Notas de aulas. ABM -Associação Brasileira de Metais. 3. ${ }^{a}$ ed. São Paulo: Édile Serviços gráficos e editora Ltda.

CÂNTABRO, Proposta de norma de Ensayo (1986). NLT 325/86: Determinación de la perdida por esgaste de Mesclas el Empleo de La Maquina de Los Angeles. Centro de Estudos de Carreteras. Madri, Espanha.

COELHO, V. (1996). Contribuição ao estudo das deformações permanentes, nas condições do Brasil, em camada de concreto asfáltico de pavimentação. 281p. Tese (Doutorado) - Escola de Engenharia de São Carlos - Universidade de São Paulo. São Carlos.

COLORADO PROCEDURE L 5109 (2002). CP-L 5109: Method of Test for Resistance of Compacted Bituminous Mixture to Moisture Induced Damage. Colorado.

DE CASTRO NETO, A. M. (2000). Proposta de projeto de dosagem de concreto betuminoso reciclado a quente. Dissertação - Escola Politécnica da Universidade de São Paulo - Universidade de São Paulo. São Paulo.

DELAGE, K. P. et al. (2001). Performance Testing of Hot Mix Asphalt Produced with Recycled Foundry Sand. Paper 01-2844 presented at the 2001 meeting of the Transportation Research Board, Washington DC.

DE HILSTER, E.; VAN DE LOO, P. J. (1977). The creep test: influence of teste parameters. Report, Shell Laboratories, Amsterdam, The Netherlands. 
DE MOURA, E. (2001). Estudo do efeito de aditivos químicos e da cal como melhoradores de adesividade em misturas asfálticas densas. 122p. Dissertação - Escola Politécnica da Universidade de São Paulo - Universidade de São Paulo. São Paulo.

DEPARTAMENTO NACIONAL DE ESTRADAS DE RODAGEM (1994). ME 004/94: Material betuminoso - determinação da viscosidade Saybolt-Furol a alta temperatura (ABNT - MB 517/71). Rio de Janeiro.

. (1994). ME 133/94: Misturas betuminosas - determinação do módulo de resiliência. Rio de Janeiro.

. (1994). ME 138/94: Misturas betuminosas - determinação da resistência à tração. Rio de Janeiro.

. (1994). ME 148/94: Material betuminoso - determinação do ponto de fulgor e de combustão (vaso aberto de Cleveland) ABNT-(NBR 11341/00). Rio de Janeiro.

Janeiro. (1995). ME 043/95: Misturas betuminosas a quente - ensaio Marshall. Rio de . (1995). ME 084/95: Agregado miúdo - determinação de densidade real. Rio de Janeiro.

. (1996). Avaliação estrutural de pavimentos. Volume 2. Rio de Janeiro.

. (1996). ME 193/96: Produtos betuminosos líquidos e semi-sólidos determinação da densidade $20{ }^{\circ} \mathrm{C} / 4{ }^{\circ} \mathrm{C}$. Rio de Janeiro.

. (1996). PRO 269/96: Projeto de restauração de pavimentos flexíveis TECNAPAV. Rio de Janeiro.

. (1997). ES 313/97: Pavimentação - concreto betuminoso. Rio de Janeiro. de Janeiro.

(1998). ME 035/98: Agregados - determinação da abrasão “Los Angeles”. Rio (1998). ME 081/98: Agregados - determinação da absorção e da densidade de agregado graúdo. Rio de Janeiro.

. (1998). ME 083/98: Agregados - análise granulométrica. Rio de Janeiro.

Janeiro.

(1999). ME 003/99: Material betuminoso - determinação da penetração. Rio de

. (1999). ES 386/99: Pavimentação - Pré-misturado a quente com asfalto polímero - camada porosa de atrito. Rio de Janeiro.

DRESCHER, A. et al. (1993). Permanent deformation in asphalt concrete. Journal of Materials in Civil Engineering, vol. 5, n. 1, p. 112-128.

DURIEZ, M.; ARRAMBIDE, J. (1962). Nouveau Traité de Materiaux de Construción, vol.1. Dunod, Paris. 
FABBRI, G. T. P. (2001). Notas de aula da Disciplina Misturas Betuminosas. Departamento de Transportes da Escola de Engenharia de São Carlos - USP. São Carlos.

FERREIRA, A. B. H. (1999). Dicionário Aurélio eletrônico - século XXI. Versão 3.0. MGB Informática Ltda.

GRECO, J. A. S. (2004). Análise da influência de alguns fatores nas propriedades mecânicas de misturas asfálticas densas, à luz da técnica de planejamento e análise de experimentos fatoriais fracionários assimétricos. 340p. Tese (Doutorado) - Escola de Engenharia de São Carlos - Universidade de São Paulo. São Carlos.

GRUBBS, F. (1969). Procedures for detecting outlying observations in samples. Technometrics, V. 11, n. 1, p. 1-21.

HICKS, R. G. (1991). Moisture damage in asphalt concrete. TRB - Transportation Research Board, NCHRP - Synthesis of highway practice, n. 175.

HILLS, J. F. (1973). The creep of asphalt mixes. Journal of the Institute of Petroleum, vol. 59, n. 570, p. 247-262.

JAVED, S.; LOVELL, C. W. (1995). Uses of Waste Foundry Sands in Civil Engineering. Transportation Research Record, n. 1486, p. 109-113.

JIMENEZ, R. A. (1993). ASPHALT: Mixture design meted to minimize rutting. Transportation Research Record, n. 1417, p. 109-116.

KONDIC, V. (1973). Princípios metalúrgicos de fundição.Tradução de Cláudio Luiz Mariotto e outros. São Paulo: Polígono, Ed. da Universidade de São Paulo.

LEE, H. J. (2000). Continuum damage mechanics-based fatigue model of asphalt concrete. Journal of Materials in Civil Engineering, vol. 12, n. 2, p. 105-112.

LITTLE, D. N.; BUTTON, J. W.; YOUSSEF, H. (1993). Development of criteria to evaluate uniaxial creep data and asphalt concrete permanent deformation potential. Transportation Research Record, n. 1417, p. 49-57.

LEITE, L. F. M. (1999). Estudos de preparo e caracterização de asfaltos modificados por polímero. 266p. Tese (Doutorado) - Instituto de Macromoléculas Professora Eloísa B. Mano - Universidade Federal do Rio de Janeiro. Rio de Janeiro.

MAHBOUB, K. (1990). Asphalt concrete creep as related to rutting. Journal of Materials in Civil Engineering, vol. 2, n. 3, p. 147-163.

MARIOTTO, C.L. (2000). Regeneração de areias de fundição. Seminário Nacional sobre Reuso/Reciclagem de Resíduos Sólidos Industriais - SMA/SP. p. 203-211.

MATOS, S.V. (1997). Proposta de minimização de resíduos sólidos industriais: estudo de caso com areia de fundição. 107p. Dissertação (Mestrado) - Escola de Engenharia de São Carlos - Universidade de São Paulo. São Carlos. 
MCINTYRE, S. W. et al. (1992). Benefication and Reuse of Foundry Sand Residuals: A Preliminary Report. Transactions of the American Foundrymen's Society, vol. 100, p.201-208.

MONTGOMERY, D. C. (1997). Design and analysis of experiments - 4th Ed. - New York: John Willey \& Sons, Inc.

MOTTA, L. M. G.; PINTO, S. (1994). O uso de ensaio estáticos na definição de parâmetros de comportamento das misturas asfálticas. $12^{\circ}$ Encontro de Asfalto.- IBPRio de janeiro. p. 152-178.

MOTTA, L. M. G. (1998). Contribuição para a estimativa do módulo resiliente de misturas asfálticas. $14^{\circ}$ Encontro de Asfalto - IBP-Rio de janeiro. p. 30-39.

NOGAMI, J. S.; VILLIBOR, D. F. (1995). Pavimentação de baixo custo com solos lateríticos. São Paulo: Ed. Villibor.

PÉREZ-JIMENEZ, F. E. (1990). Estudio, metodología de dosificación y análisis de mezclas bituminosas drenantes: problemática de su diseño. Seminario sobre Mezclas Bituminosas Drenantes. Madrid.

PINTO, S.; PREUSSLER, E. S. (1980). Módulo de resiliência de concreto asfáltico. $16^{\mathrm{a}}$ reunião anual de pavimentação - Belo Horizonte/MG.

PINTO, S. (1991). Estudo do comportamento à fadiga de misturas betuminosas e aplicação na avaliação estrutural de pavimentos. 478p. Tese (Doutorado) - COPPE Universidade Federal do Rio de Janeiro. Rio de Janeiro.

PARTRIDGE, B. K. et al. (1999). Field Demonstration of Highway Embankment Construction Using Waste Foundry Sand. Transportation Research Record, n. 1670, p. 98-105.

QUEIROZ, C. A. V.; VISSER, A. T. (1978). Uma investigação dos módulos de resiliência de revestimentos betuminosos brasileiros. Grupo de Estudos do Desempenho e Conservação de Pavimentos - Pesquisa do Inter-relacionamento de Custos Rodoviários. IBP - Instituto Brasileiro do Petróleo. p.265.

RAMADHAM, R. H. et al. (1998). Evaluation of Arabian asphalt binder for lowtemperature cracking. Journal of Materials in Civil Engineering, vol. 10, n. 1, p. 26-33.

ROBERTS, F. L. et al. (1991). Hot mix asphalt materials, mixture design, and construction. First edition. Lanham, Maryland (USA): NAPA Education Foundation.

ROBERTS, F. L. et al. (2002). History of hot mix asphalt mixture design in the United States. Journal of Materials in Civil Engineering, vol. 14, n. 4, p. 279-293.

SCHALCH, V. et al. (2000). Parecer Técnico - Avaliação das condições ambientais de área com depósito de resíduos industriais pertencente à Companhia Brasileira de Tratores - Município de Ibaté/SP. FIPAI/EESC. 
SCHALCH, V. Et al. (2002). Prevenção da poluição, análise de ciclo de vida, redução, reutilização e reciclagem de resíduos sólidos. Apostila. Departamento de Hidráulica e Saneamento. Escola de Engenharia de São Carlos. São Carlos.

SENÇO, W. de (1997). Manual de Técnicas de Pavimentação. Volume 1. 1. ${ }^{\mathrm{a}}$ Ed. 3. ${ }^{\mathrm{a}}$ Tiragem. São Paulo: Editora PINI Ltda.

SIEGEL, M. et al. (1982). Fundição. Notas de aulas. ABM -Associação Brasileira de Metais. 13. a ed. São Paulo: Édile Serviços gráficos e editora Ltda.

SILVEIRA, M. A. (1999). Estudo sobre a adição de polímero em areia-asfalto a frio. 96p. Dissertação - Escola de Engenharia de São Carlos - Universidade de São Paulo. São Carlos.

STRAUSS, K. (1970). Applied Science in the Casting of Metals. Oxford: Pergamon Press Ltd.

ULMGREN, N. (1996). Functional testing of asphalt mixes for permanent deformation by dynamic creep test modification of method and round robin test. EAPA/Eurobitume Congress, Strasbourg.

ULMGREN, N. (1997). Dynamic creep test - validation of modified (Swedish) method by comparison with wheel tracking test. EAPA/Eurobitume Congress, Strasbourg.

UNIVERSIDADE DE SÃO PAULO. Escola de Engenharia de São Carlos. Serviço de Biblioteca (2002). Diretrizes para elaboração de dissertações e teses na EESC-USP. 3.ed. São Carlos.

VALKERING, C. P. et al. (1990). Rutting resistence of asphalt mixes containing nonconventional and polymer-modified binders. Symposium - Improved Rut Resistance, Association of Asphalt Paving Technologists (AAPT), Proceedings, p. 590-609.

VAN DE LOO, P. J. (1974). Creep testing, a simple tool to judge asphalt mix stability. Association of Asphalt Paving Technologists (AAPT), Proceedings, vol. 43, p. 117-153.

VERHASSELT, A. F.; CHOQUET, F. S. (1993). Comparing field and laboratory aging of bitumen on a kinetic basis. Transportation Research Record, n. 1670, p. 30-38.

VIANNA, A. A. D.; MOTTA, L. M. G.; DOMINGUES, R. G. (2003). Ensaio de Compressão Axial de CBUQ - Uma Nova Técnica de Medição das Deformações. Anais do XVII Congresso de Pesquisa e Ensino em Transportes, ANPET, Rio de Janeiro, v. 1, p. 30-40.

VON QUINTUS, H. L. et al. (1991). Asphalt-aggregate mixture analysis systems (AAMAS). Washington. D.C., Publ. Transportation Research Board, NCHRP Report 338.

WAHHAB, H. I. A. et al. (1995). National study of asphalt pavement rutting in Saudi Arabia. Transportation Research Record, n. 1473, p. 35-42. 
APÊNDICE A - Resultados das dosagens Marshall 
Tabela A.01. Resultado da dosagem Marshall para a mistura com 5\% de Areia de Fundição

\begin{tabular}{|c|c|c|c|c|c|c|c|c|c|c|c|c|c|c|c|c|c|c|c|}
\hline & & & & & & & Identific & Ição: Are & $\begin{array}{l}\text { saio } \mathrm{Ma} \\
\text { la de } \mathrm{Fu}\end{array}$ & $\begin{array}{l}\text { arshall } \\
\text { Indição n }\end{array}$ & 0 teor d & $5 \%$ & & & & & & & \\
\hline & & & & & esquisa: & Benedito C & Coutinho I & eto & & & & & & ata: $02 / 0$ & 4/03 & & & & \\
\hline & & & & & & & & Fai & xa C do & DNER & & & & & & & & & \\
\hline CPs & $\begin{array}{l}\mathbf{P}_{\text {asf }} \\
(\%)\end{array}$ & $\begin{array}{l}P_{a g} \\
(\%)\end{array}$ & $\begin{array}{c}\mathbf{M}_{\mathrm{ar}} \\
(\mathrm{g})\end{array}$ & $\begin{array}{c}\text { Mparf ar } \\
\text { (g) }\end{array}$ & $\begin{array}{c}\text { Mparf }_{\text {im }} \\
\text { (g), }\end{array}$ & $\begin{array}{c}\text { Mparaf, } \\
\text { (g) }\end{array}$ & $\begin{array}{c}\text { Vparaf, } \\
\text { cm }^{3}\end{array}$ & $\begin{array}{c}\mathrm{Vt} \\
\mathrm{cm}^{3}\end{array}$ & $\begin{array}{l}\mathrm{Vcp}, \\
\mathrm{cm}^{3}\end{array}$ & $\begin{array}{c}\text { Dap, } \\
\left(\mathrm{g} / \mathrm{cm}^{3}\right)\end{array}$ & $\begin{array}{c}\text { Danel } \\
\text { (cm) }\end{array}$ & Fc & $\begin{array}{c}\mathrm{E} \\
\mathrm{kgf}\end{array}$ & $\begin{array}{c}\text { Dt, } \\
\left(\mathrm{g} / \mathrm{cm}^{3}\right)\end{array}$ & $\begin{array}{c}F \\
\left(0,01^{\prime \prime}\right)\end{array}$ & $\begin{array}{c}F \\
(\mathrm{~mm})\end{array}$ & $\begin{array}{l}\mathrm{Vb} \\
(\%)\end{array}$ & $\begin{array}{l}\mathrm{Vv} \\
(\%)\end{array}$ & $\begin{array}{l}\text { RBV } \\
(\%)\end{array}$ \\
\hline 1 & 4,3 & 95,7 & 1246,2 & 1261,5 & 744,7 & 15,30 & 17,19 & 516,80 & 499,6 & 2,494 & 22,90 & 1,04 & 1084 & 2,672 & 10 & 2,54 & 10,54 & 6,64 & 61,35 \\
\hline 2 & 4,3 & 95,7 & 1244,1 & 1265,2 & 740,7 & 21,10 & 23,71 & 524,50 & 500,8 & 2,484 & 23,00 & 1,04 & 1088 & 2,672 & 11 & 2,79 & 10,49 & 7,01 & 59,94 \\
\hline 3 & 4,3 & 95,7 & 1242,1 & 1268,4 & 738,2 & 26,30 & 29,55 & 530,20 & 500,6 & 2,481 & 22,80 & 1,04 & 1079 & 2,672 & 10 & 2,54 & 10,48 & 7,14 & 59,49 \\
\hline 4 & 4,8 & 95,2 & 1245 & 1268,5 & 740,3 & 23,50 & 26,40 & 528,20 & 501,8 & 2,481 & 23,50 & 1,04 & 1112 & 2,649 & 11 & 2,79 & 11,70 & 6,34 & 64,84 \\
\hline 5 & 4,8 & 95,2 & 1246,7 & 1273,5 & 749,1 & 26,80 & 30,11 & 524,40 & 494,3 & 2,522 & 24,00 & 1,09 & 1190 & 2,649 & 11 & 2,79 & 11,89 & 4,79 & 71,28 \\
\hline 6 & 4,8 & 95,2 & 1249,3 & 1276,7 & 748,8 & 27,40 & 30,79 & 527,90 & 497,1 & 2,513 & 23,80 & 1,04 & 1126 & 2,649 & 13 & 3,30 & 11,85 & 5,14 & 69,76 \\
\hline 7 & 5,3 & 94,7 & 1249,6 & 1295,6 & 751,6 & 46,00 & 51,69 & 544,00 & 492,3 & 2,538 & 23,70 & 1,09 & 1175 & 2,627 & 13 & 3,30 & 13,21 & 3,38 & 79,62 \\
\hline 8 & 5,3 & 94,7 & 1245,1 & 1277,5 & 751,4 & 32,40 & 36,40 & 526,10 & 489,7 & 2,543 & 25,30 & 1,04 & 1197 & 2,627 & 11 & 2,79 & 13,24 & 3,21 & 80,46 \\
\hline 9 & 5,3 & 94,7 & 1252,5 & 1276,5 & 754,5 & 24,00 & 26,97 & 522,00 & 495,0 & 2,530 & 25,20 & 1,04 & 1192 & 2,627 & 12 & 3,05 & 13,17 & 3,69 & 78,12 \\
\hline 10 & 5,8 & 94,2 & 1255,9 & 1281,2 & 759,6 & 25,30 & 28,43 & 521,60 & 493,2 & 2,547 & 23,00 & 1,09 & 1141 & 2,605 & 13 & 3,30 & 14,51 & 2,25 & 86,55 \\
\hline 11 & 5,8 & 94,2 & 1246,7 & 1281,1 & 753,1 & 34,40 & 38,65 & 528,00 & 489,3 & 2,548 & 23,00 & 1,09 & 1141 & 2,605 & 13 & 3,30 & 14,52 & 2,21 & 86,77 \\
\hline 12 & 5,8 & 94,2 & 1253,3 & 1278,7 & 754,2 & 25,40 & 28,54 & 524,50 & 496,0 & 2,527 & 24,50 & 1,04 & 1159 & 2,605 & 14 & 3,56 & 14,40 & 3,01 & 82,73 \\
\hline 13 & 6,3 & 93,7 & 1259,3 & 1288,3 & 756,4 & 29,00 & 32,58 & 531,90 & 499,3 & 2,522 & 21,00 & 1,04 & 994 & 2,584 & 15 & 3,81 & 15,61 & 2,39 & 86,70 \\
\hline 14 & 6,3 & 93,7 & 1258,5 & 1288,9 & 757,5 & 30,40 & 34,16 & 531,40 & 497,2 & 2,531 & 23,10 & 1,04 & 1093 & 2,584 & 15 & 3,81 & 15,66 & 2,05 & 88,43 \\
\hline 15 & 6,3 & 93,7 & 1253,2 & 1296,2 & 754 & 43,00 & 48,31 & 542,20 & 493,9 & 2,537 & 20,70 & 1,09 & 1027 & 2,584 & 16 & 4,06 & 15,70 & 1,80 & 89,72 \\
\hline
\end{tabular}


Tabela A.02. Resultado da dosagem Marshall para a mistura com 10\% de Areia de Fundição

\begin{tabular}{|c|c|c|c|c|c|c|c|c|c|c|c|c|c|c|c|c|c|c|c|}
\hline & & & & & & & Identific & En & $\begin{array}{l}\text { saio Ma } \\
\text { a de Fuı }\end{array}$ & $\begin{array}{l}\text { arshall } \\
\text { ndição no }\end{array}$ & o teor de & $10 \%$ & & & & & & & \\
\hline & & & & & esquisa: I & Benedito C & Coutinho & eto & & & & & & ata: $09 / 0$ & $4 / 03$ & & & & \\
\hline & & & & & & & & Fai & xa C do & DNER & & & & & & & & & \\
\hline$\overline{\mathrm{CPs}}$ & $\begin{array}{l}P_{\text {asf }} \\
(\%)\end{array}$ & $\begin{array}{l}P_{\text {ag }} \\
(\%)\end{array}$ & $\begin{array}{c}M_{a r} \\
(g)\end{array}$ & $\begin{array}{c}\text { Mparf ar } \\
\text { (g) }\end{array}$ & $\begin{array}{c}\text { Mparf }_{\text {im }} \\
\text { (g), }\end{array}$ & $\begin{array}{c}\text { Mparaf, } \\
\text { (g) }\end{array}$ & $\begin{array}{c}\text { Vparaf, } \\
\mathbf{c m}^{3}\end{array}$ & $\begin{array}{c}\mathrm{Vt} \\
\mathrm{cm}^{3}\end{array}$ & $\begin{array}{l}\text { Vcp, } \\
\text { cm }^{3}\end{array}$ & $\begin{array}{c}\text { Dap, } \\
\left(\mathrm{g} / \mathrm{cm}^{3}\right)\end{array}$ & $\begin{array}{c}\text { Danel } \\
(\mathrm{cm})\end{array}$ & Fc & $\begin{array}{c}E \\
\text { kgf }\end{array}$ & $\begin{array}{c}\text { Dt, } \\
\left(\mathrm{g} / \mathrm{cm}^{3}\right)\end{array}$ & $\begin{array}{c}\mathbf{F} \\
(\mathbf{0 , 0 1})\end{array}$ & $\begin{array}{c}F \\
(\mathrm{~mm})\end{array}$ & $\begin{array}{l}\mathrm{Vb} \\
(\%)\end{array}$ & $\begin{array}{l}\mathrm{Vv} \\
(\%)\end{array}$ & $\begin{array}{c}\text { RBV } \\
(\%)\end{array}$ \\
\hline 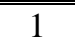 & 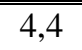 & 95,6 & 1235,6 & $=1257,4$ & $\overline{7732,3}$ & 21,80 & 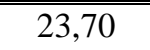 & $=525,10$ & "501,4 & 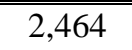 & 24,20 & "1,04 & 1145 & $2,2,654$ & 10 & 2,54 & 1010,65 & $7,7,15$ & $\bar{~} 59,84$ \\
\hline 2 & 4,4 & 95,6 & 1236,5 & 1259,7 & 732,4 & 23,20 & 25,22 & 527,30 & 502,1 & 2,463 & 24,40 & 1,04 & 1155 & 2,654 & 10 & 2,54 & 10,64 & 7,21 & 59,63 \\
\hline 3 & 4,4 & 95,6 & 1233,3 & 1257,1 & 729,6 & 23,80 & 25,87 & 527,50 & 501,6 & 2,459 & 24,70 & 1,03 & 1158 & 2,654 & 10 & 2,54 & 10,63 & 7,36 & 59,07 \\
\hline 4 & 4,9 & 95,1 & 1239,8 & 1252,7 & 739,9 & 12,90 & 14,02 & 512,80 & 498,8 & 2,486 & 26,30 & 1,04 & 1245 & 2,632 & 10 & 2,54 & 11,96 & 5,56 & 68,29 \\
\hline 5 & 4,9 & 95,1 & 1241,8 & 1255,6 & 739,1 & 13,80 & 15,00 & 516,50 & 501,5 & 2,476 & 24,40 & 1,02 & 1132 & 2,632 & 12 & 3,05 & 11,92 & 5,92 & 66,83 \\
\hline 6 & 4,9 & 95,1 & 1244,9 & 1277,5 & 741,9 & 32,60 & 35,43 & 535,60 & 500,2 & 2,489 & 24,80 & 1,05 & 1185 & 2,632 & 11 & 2,79 & 11,98 & 5,43 & 68,81 \\
\hline 7 & 5,4 & 94,6 & 1247,6 & 1265,3 & 746,8 & 17,70 & 19,24 & 518,50 & 499,3 & 2,499 & 25,00 & 1,05 & 1194 & 2,610 & 11 & 2,79 & 13,26 & 4,26 & 75,67 \\
\hline 8 & 5,4 & 94,6 & 1246,6 & 1265,7 & 746,4 & 19,10 & 20,76 & 519,30 & 498,5 & 2,501 & 26,90 & 1,02 & 1248 & 2,610 & 11 & 2,79 & 13,26 & 4,20 & 75,95 \\
\hline 9 & 5,4 & 94,6 & 1248,8 & 1262,4 & 748,1 & 13,60 & 14,78 & 514,30 & 499,5 & 2,500 & 26,70 & 1,04 & 1263 & 2,610 & 12 & 3,05 & 13,26 & 4,22 & 75,86 \\
\hline 10 & 5,9 & 94,1 & 1248,0 & 1266,3 & 746,9 & 18,30 & 19,89 & 519,40 & 499,5 & 2,498 & 22,60 & 1,04 & 1069 & 2,589 & 15 & 3,81 & 14,48 & 3,49 & 80,59 \\
\hline 11 & 5,9 & 94,1 & 1243,6 & 1264 & 744,3 & 20,40 & 22,17 & 519,70 & 497,5 & 2,500 & 24,40 & 1,05 & 1166 & 2,589 & 13 & 3,30 & 14,49 & 3,44 & 80,79 \\
\hline 12 & 5,9 & 94,1 & 1248,0 & 1270 & 744,7 & 22,00 & 23,91 & 525,30 & 501,4 & 2,489 & 25,20 & 1,04 & 1192 & 2,589 & 13 & 3,30 & 14,43 & 3,85 & 78,94 \\
\hline 13 & 6,4 & 93,6 & 1248,3 & 1270,2 & 747,2 & 21,90 & 23,80 & 523,00 & 499,2 & 2,501 & 21,90 & 1,04 & 1036 & 2,568 & 14 & 3,56 & 15,72 & 2,61 & 85,75 \\
\hline 14 & 6,4 & 93,6 & 1249,5 & 1266,8 & 748,5 & 17,30 & 18,80 & 518,30 & 499,5 & 2,502 & 22,20 & 1,04 & 1051 & 2,568 & 14 & 3,56 & 15,73 & 2,58 & 85,92 \\
\hline 15 & 6,4 & 93,6 & 1252,9 & 1272,6 & 748,1 & 19,70 & 21,41 & 524,50 & 503,1 & 2,490 & 23,30 & 1,04 & 1103 & 2,568 & 15 & 3,81 & 15,66 & 3,01 & 83,88 \\
\hline
\end{tabular}

CPs - Corpos-de-prova; $\mathrm{P}_{\text {asf }}$ - Teor de asfalto; $\mathrm{P}_{\mathrm{ag}}$ - Teor de agregado; $\mathrm{M}_{\mathrm{ar}}$ - Massa do corpo-de-prova ao ar; $\quad$ Mparf $\mathrm{ar}_{\mathrm{ar}}$ - Massa do corpo-de-prova parafinado ao ar; Mparf ${ }_{\mathrm{im}}$ - Massa do corpo-de-prova parafinado imerso; Mparaf - Massa da parafina; Vparaf, - Volume da parafina; Vt - Volume total; Vcp - Volume do corpo-de-prova; Dap - Densidade aparente; Danel - Deformação do anel; Fc - Fator de correção; E - Estabilidade; F - Fluência; Vb - Volume de betume; Vv - Volume de vazios; RBV - Relação betume-vazios,

Densidade da parafina - 0,89; vDensidade do agregado - 2,866; vDensidade do asfalto -1,018; Constante do anel - 45,5; Superfície específica - 12,68 $\mathrm{m}^{2} / \mathrm{kg}$, 
Tabela A.03. Resultado da dosagem Marshall para a mistura com 15\% de Areia de Fundição

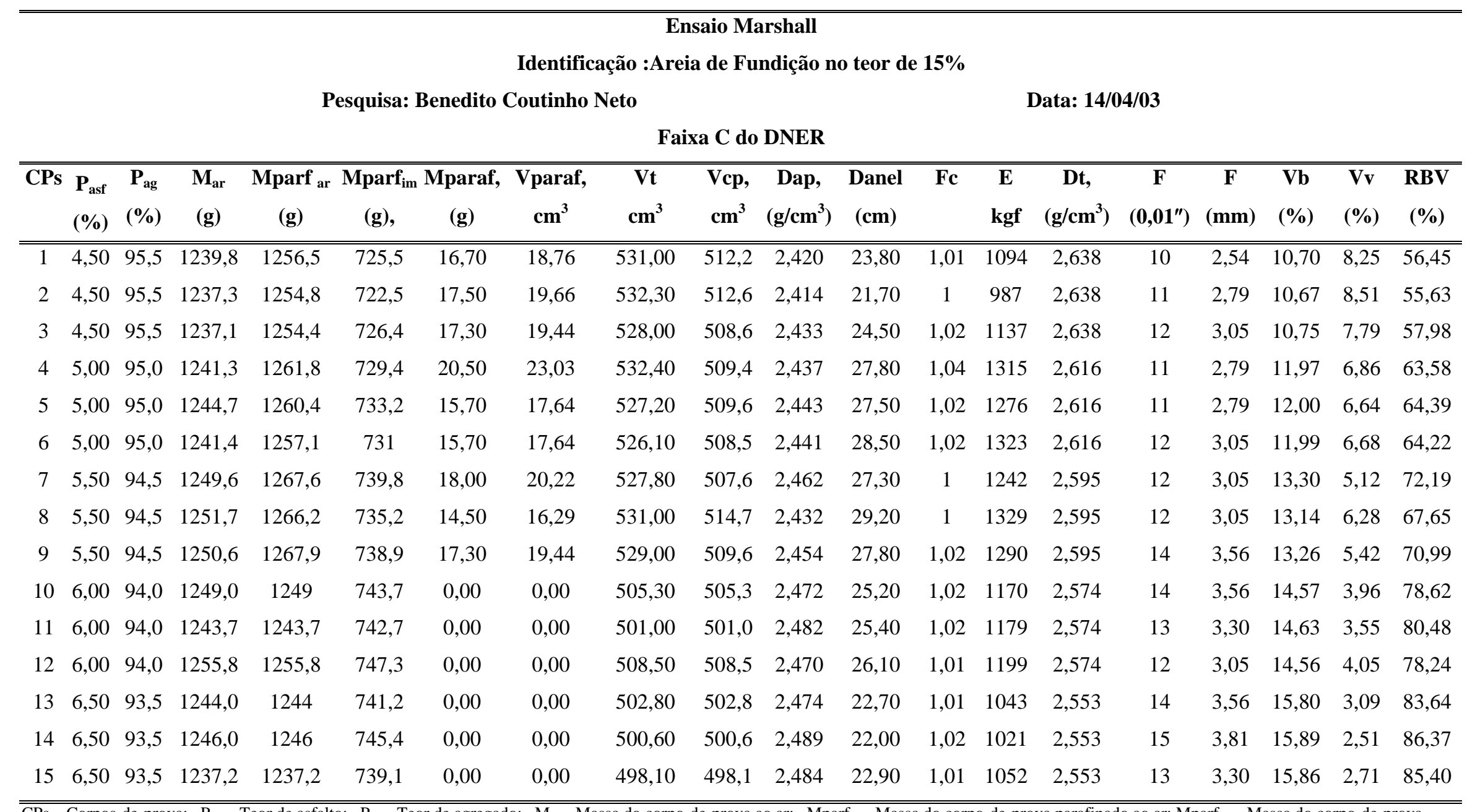

CPs - Corpos-de-prova; $\mathrm{P}_{\text {asf }}$ - Teor de asfalto; $\mathrm{P}_{\mathrm{ag}}$ - Teor de agregado; $\mathrm{M}_{\mathrm{ar}}$ - Massa do corpo-de-prova ao ar; Mparf $_{\mathrm{ar}}$ - Massa do corpo-de-prova parafinado ao ar; Mparf ${ }_{\mathrm{im}}$ - Massa do corpo-de-prova de correção; E - Estabilidade; F - Fluência; Vb - Volume de betume; Vv - Volume de vazios; RBV - Relação betume-vazios,

Densidade da parafina - 0,89; vDensidade do agregado - 2,852; vDensidade do asfalto - 1,018; Constante do anel - 45,5; Superfície específica - 13,83 $\mathrm{m}^{2} / \mathrm{kg}$, 
Tabela A.04. Resultado da dosagem Marshall para a mistura com 10\% de Areia Virgem

\section{Ensaio Marshall}

\section{Identificação :Areia Virgem no teor de 10\%}

\section{Pesquisa: Benedito Coutinho Neto}

Data: $24 / 04 / 03$

Faixa C do DNER

\begin{tabular}{|c|c|c|c|c|c|c|c|c|c|c|c|c|c|c|c|c|c|c|c|}
\hline CPs & $\begin{array}{l}P_{\text {asf }} \\
(\%)\end{array}$ & $\begin{array}{l}P_{a g} \\
(\%)\end{array}$ & $\begin{array}{l}M_{\mathrm{ar}} \\
\text { (g) }\end{array}$ & $\begin{array}{c}\text { Mparf }_{\text {ar }} \\
\text { (g) }\end{array}$ & $\begin{array}{c}\text { Mparf }_{\text {im }} \\
\text { (g), }\end{array}$ & $\begin{array}{c}\text { Mparaf, } \\
\text { (g) }\end{array}$ & $\begin{array}{c}\text { Vparaf, } \\
\mathrm{cm}^{3}\end{array}$ & $\begin{array}{c}\mathrm{Vt} \\
\mathrm{cm}^{3}\end{array}$ & $\begin{array}{l}\text { Vcp, } \\
\mathrm{cm}^{3}\end{array}$ & $\begin{array}{c}\text { Dap, } \\
\left(\mathrm{g} / \mathrm{cm}^{3}\right)\end{array}$ & $\begin{array}{c}\text { Danel } \\
\text { (cm) }\end{array}$ & Fc & $\begin{array}{c}\text { E } \\
\text { kgf }\end{array}$ & $\begin{array}{c}\text { Dt, } \\
\left(\mathrm{g} / \mathrm{cm}^{3}\right)\end{array}$ & $\begin{array}{c}F \\
(0,01 ")\end{array}$ & $\begin{array}{c}F \\
(\mathrm{~mm})\end{array}$ & $\begin{array}{l}\mathrm{Vb} \\
(\%)\end{array}$ & $\begin{array}{l}\mathrm{Vv} \\
(\%)\end{array}$ & $\begin{array}{l}\text { RBV } \\
\text { (\%) }\end{array}$ \\
\hline 1 & 4,4 & 95,6 & 1238,3 & 1254,4 & 735,5 & $\bar{~} 16,10$ & 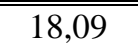 & 518,90 & 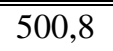 & 2,473 & 27,20 & "1,04 & 1287 & 2,654 & 10 & 2,54 & 10,69 & 6,84 & 60,99 \\
\hline 2 & 4,4 & 95,6 & 1236,5 & 1252,3 & 735,5 & 15,80 & 17,75 & 516,80 & 499,0 & 2,478 & 25,40 & 1,03 & 1190 & 2,654 & 11 & 2,79 & 10,71 & 6,64 & 61,72 \\
\hline 3 & 4,4 & 95,6 & 1236,9 & 1253,4 & 736,1 & 16,50 & 18,54 & 517,30 & 498,8 & 2,480 & 26,80 & 1,04 & 1268 & 2,654 & 10 & 2,54 & 10,72 & 6,56 & 62,04 \\
\hline 4 & 4,9 & 95,1 & 1243,6 & 1260,4 & 743,4 & 16,80 & 18,88 & 517,00 & 498,1 & 2,497 & 24,00 & 1,04 & 1136 & 2,632 & 12 & 3,05 & 12,02 & 5,14 & 70,03 \\
\hline 5 & 4,9 & 95,1 & 1242,0 & 1259,2 & 741,9 & 17,20 & 19,33 & 517,30 & 498,0 & 2,494 & 24,60 & 1,05 & 1175 & 2,632 & 13 & 3,30 & 12,01 & 5,24 & 69,63 \\
\hline 6 & 4,9 & 95,1 & 1239,4 & 1256,5 & 738 & 17,10 & 19,21 & 518,50 & 499,3 & 2,482 & 27,40 & 1,03 & 1284 & 2,632 & 12 & 3,05 & 11,95 & 5,68 & 67,77 \\
\hline 7 & 5,4 & 94,6 & 1245,5 & 1263,1 & 746,8 & 17,60 & 19,78 & 516,30 & 496,5 & 2,508 & 26,60 & 1,03 & 1247 & 2,610 & 13 & 3,30 & 13,31 & 3,90 & 77,35 \\
\hline 8 & 5,4 & 94,6 & 1245,8 & 1264 & 747 & 18,20 & 20,45 & 517,00 & 496,6 & 2,509 & 26,20 & 1,03 & 1228 & 2,610 & 14 & 3,56 & 13,31 & 3,88 & 77,43 \\
\hline 9 & 5,4 & 94,6 & 1249,7 & 1269,6 & 751,5 & 19,90 & 22,36 & 518,10 & 495,7 & 2,521 & 25,50 & 1,05 & 1218 & 2,610 & 14 & 3,56 & 13,37 & 3,42 & 79,63 \\
\hline 10 & 5,9 & 94,1 & 1244,6 & 1263,4 & 747,5 & 18,80 & 21,12 & 515,90 & 494,8 & 2,515 & 25,70 & 1,05 & 1228 & 2,589 & 15 & 3,81 & 14,58 & 2,83 & 83,74 \\
\hline 11 & 5,9 & 94,1 & 1245,3 & 1265,8 & 746,9 & 20,50 & 23,03 & 518,90 & 495,9 & 2,511 & 24,90 & 1,05 & 1190 & 2,589 & 16 & 4,06 & 14,56 & 2,99 & 82,96 \\
\hline 12 & 5,9 & 94,1 & 1249,7 & 1270,7 & 747,7 & 21,00 & 23,60 & 523,00 & 499,4 & 2,502 & 21,80 & 1,04 & 1032 & 2,589 & 16 & 4,06 & 14,50 & 3,34 & 81,30 \\
\hline 13 & 6,4 & 93,6 & 1246,5 & 1268,3 & 745,6 & 21,80 & 24,49 & 522,70 & 498,2 & 2,502 & 20,00 & 1,04 & 946 & 2,568 & 18 & 4,57 & 15,73 & 2,56 & 86,01 \\
\hline 14 & 6,4 & 93,6 & 1250,9 & 1271,2 & 748,8 & 20,30 & 22,81 & 522,40 & 499,6 & 2,504 & 20,60 & 1,04 & 975 & 2,568 & 18 & 4,57 & 15,74 & 2,49 & 86,36 \\
\hline 15 & 6,4 & 93,6 & 1254,2 & 1277,6 & 751,1 & 23,40 & 26,29 & 526,50 & 500,2 & 2,507 & 19,70 & 1,03 & 923 & 2,568 & 19 & 4,83 & 15,76 & 2,35 & 87,03 \\
\hline
\end{tabular}

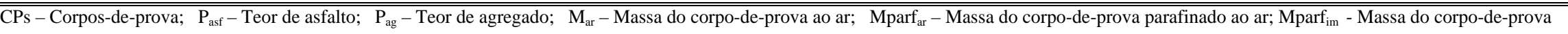
parafinado imerso; Mparaf - Massa da parafina; Vparaf, - Volume da parafina; Vt - Volume total; Vcp - Volume do corpo-de-prova; Dap - Densidade aparente; Danel - Deformação do anel; Fc - Fator de correção; E - Estabilidade; F - Fluência; Vb - Volume de betume; Vv - Volume de vazios; RBV - Relação betume-vazios,,

Densidade da parafina - 0,89; vDensidade do agregado - 2,866; vDensidade do asfalto -1,018; Constante do anel - 45,5; Superfície específica $-12,68 \mathrm{~m}^{2} / \mathrm{kg}$ 

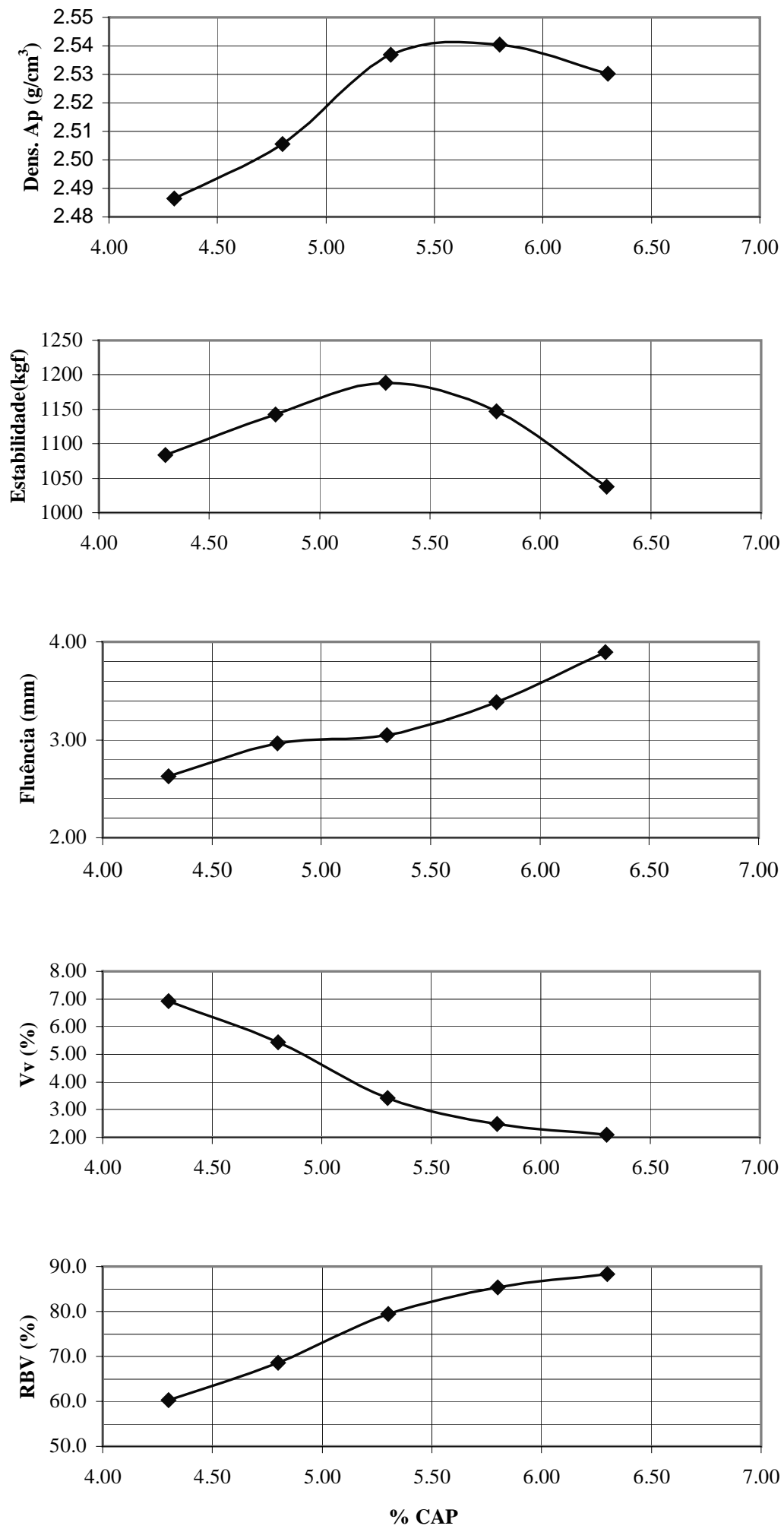

Figura A.01. Gráficos dos parâmetros Marshall para a mistura com 5\% de areia de fundição 

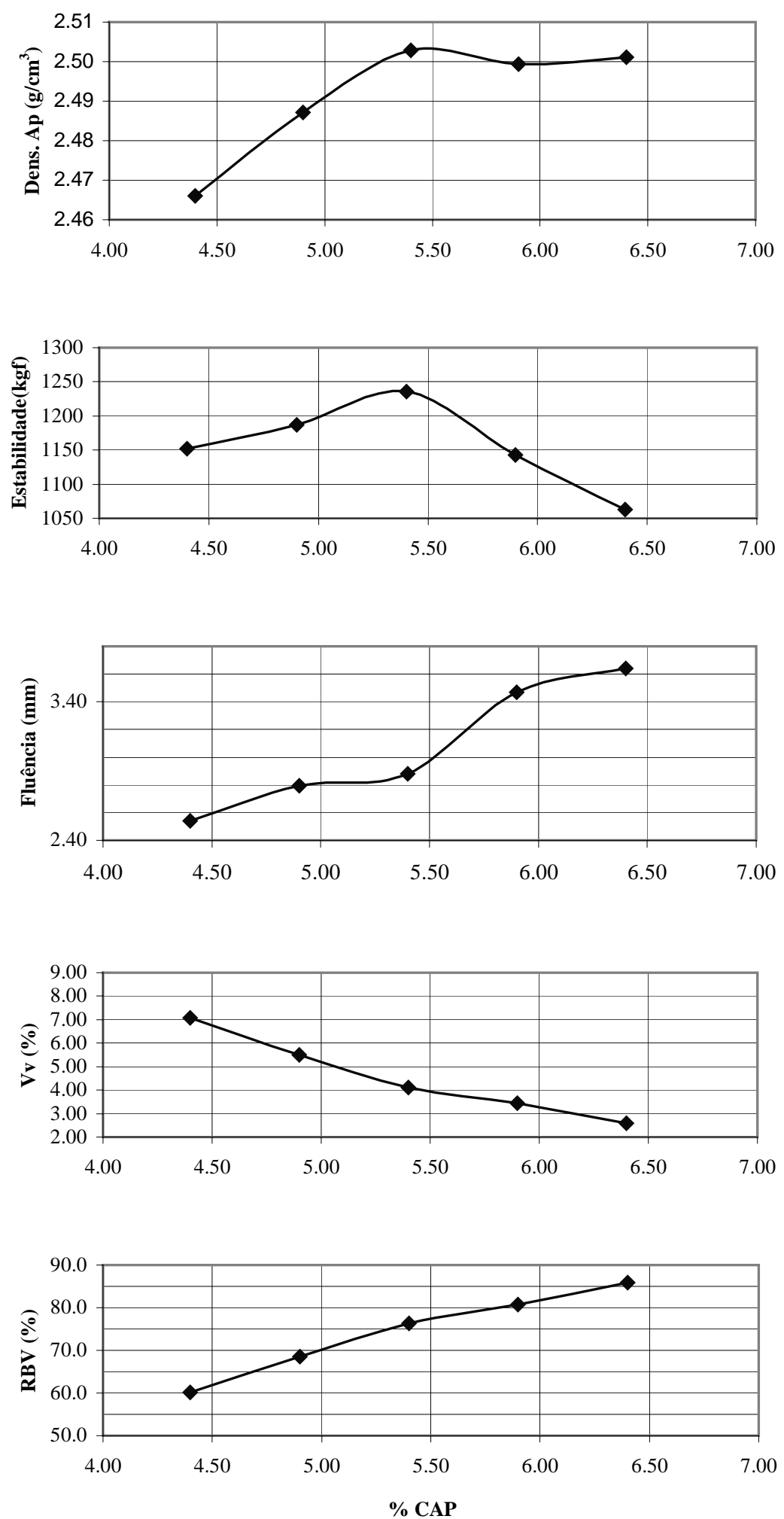

Figura A.02. Gráficos dos parâmetros Marshall para a mistura com 10\% de Areia de fundição 

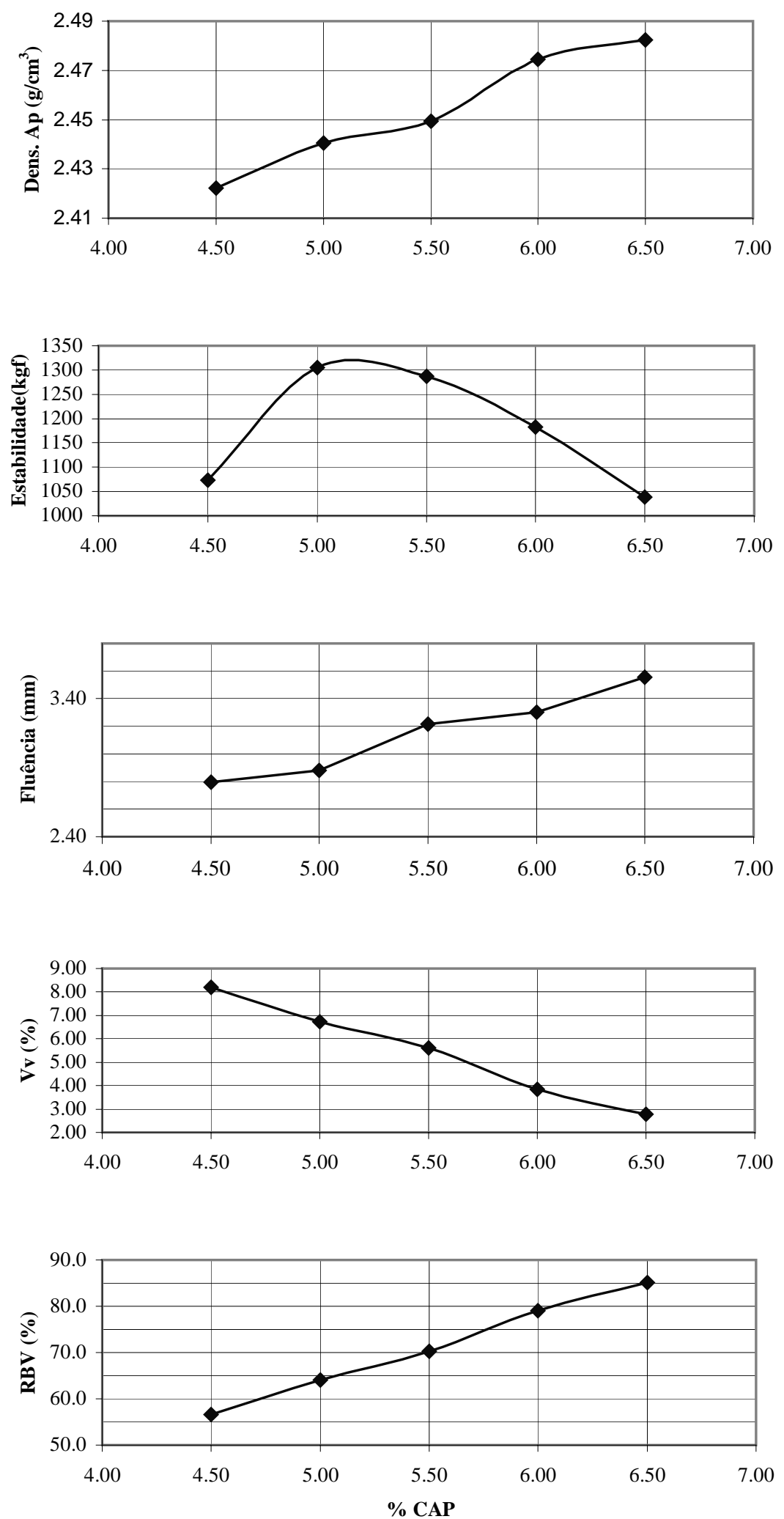

Figura A.03. Gráficos dos parâmetros Marshall para a mistura com 15\% de areia de fundição 

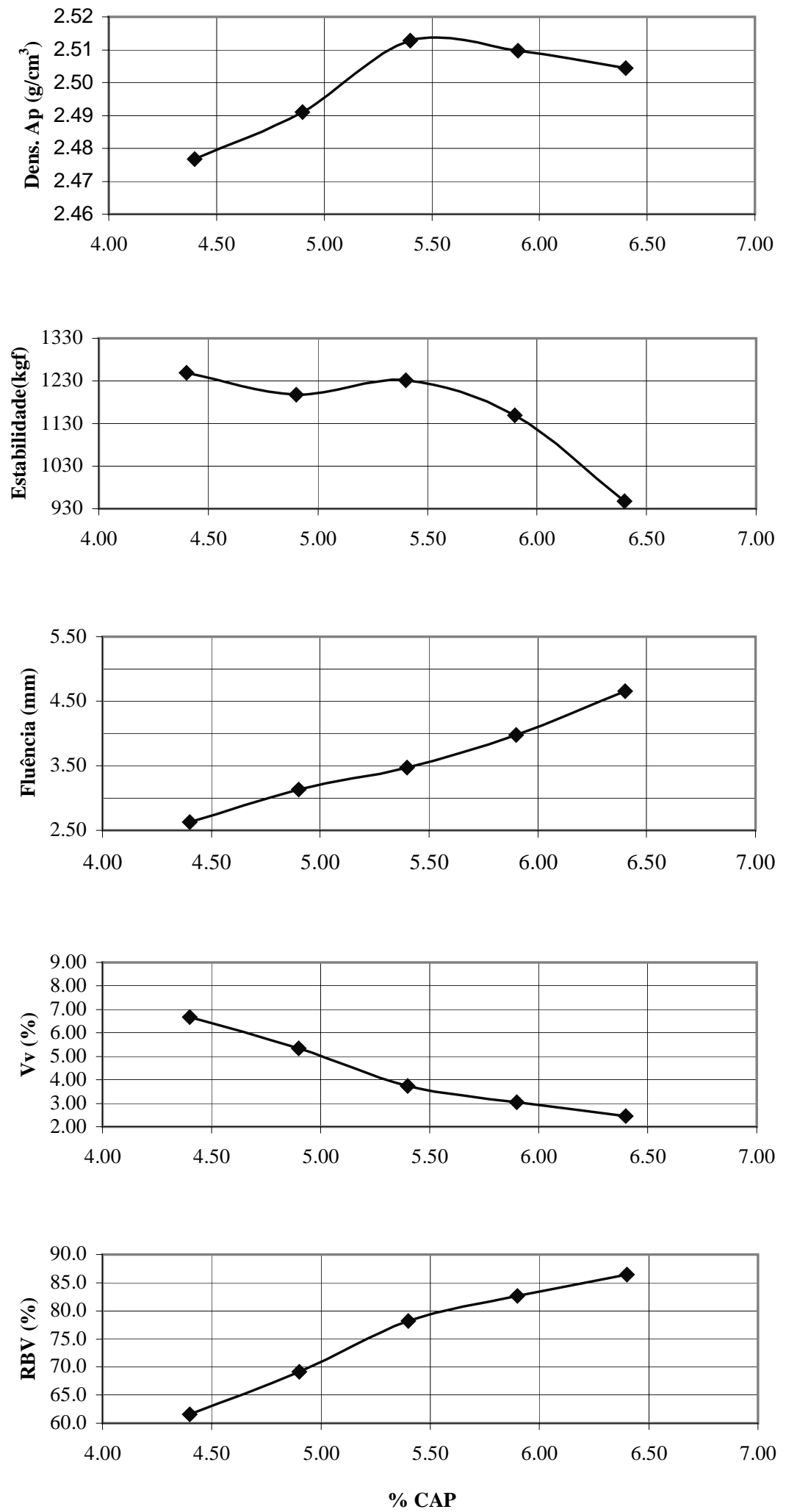

Figura A.04. Gráficos dos parâmetros Marshall para a mistura com 10\% de areia virgem 
APÊNDICE B - Ensaios mecânicos

Cantabro

Umidade Induzida

Resistência à Tração

Módulo de Resiliência

Fluência Uniaxial Estática 
Tabela B.01. Dados dos danos da umidade Induzida para a mistura com 5\% de Areia de Fundição - Volume de vazios 4\%

\begin{tabular}{|c|c|c|c|c|c|c|}
\hline \multicolumn{7}{|c|}{ Ensaio de Umidade Induzida } \\
\hline \multicolumn{7}{|l|}{ Aditivo: sem aditivo } \\
\hline Método de compactação: Marshall & \multicolumn{6}{|c|}{ Esforço: 75 golpes } \\
\hline Data do Ensaio: 16/08/03 & \multicolumn{6}{|c|}{ Laboratorista: Benedito Coutinho Neto } \\
\hline \multirow{3}{*}{ Identificação dos Corpos-de-Prova (CP) } & \multirow{2}{*}{\multicolumn{3}{|c|}{$\begin{array}{c}\text { Condicionados } \\
\text { Grupo } 01\end{array}$}} & \multirow{2}{*}{\multicolumn{3}{|c|}{$\begin{array}{c}\text { Não Condicionados } \\
\text { Grupo } 02\end{array}$}} \\
\hline & & & & & & \\
\hline & 20 & 23 & 24 & 21 & 22 & 23 \\
\hline Diâmetro (mm) & 101,8 & 101,7 & 101,8 & 101,7 & 101,7 & 101,7 \\
\hline Altura do (mm) & 62,15 & 62,05 & 61,48 & 61,53 & 61,45 & 62,05 \\
\hline Massa ao ar (g) & 1253,2 & 1246,4 & 1246,8 & 1244,4 & 1247,0 & 1246,4 \\
\hline Massa, antes da saturação parcial a vácuo (g) & 1253,2 & 1246,4 & 1246,8 & 1244,4 & 1247,0 & 1246,4 \\
\hline Massa imersa (g) & 756,0 & 754,5 & 755,5 & 752,0 & 754,2 & 754,5 \\
\hline Volume $\left(\mathrm{cm}^{3}\right)$ & 497,2 & 491,9 & 491,3 & 492,4 & 492,8 & 491,9 \\
\hline Densidade específica aparente $\left(\mathrm{g} / \mathrm{cm}^{3}\right)$ & 2,521 & 2,534 & 2,538 & 2,527 & 2,530 & 2,534 \\
\hline Densidade específica máxima $\left(\mathrm{g} / \mathrm{cm}^{3}\right)$ & 2,631 & 2,631 & 2,631 & 2,631 & 2,631 & 2,631 \\
\hline Teor de vazios (\%) & 4,22 & 3,71 & 3,56 & 3,96 & 3,84 & 3,71 \\
\hline Volume de vazios $\left(\mathrm{cm}^{3}\right)$ & 20,96 & 18,24 & 17,49 & 19,50 & 18,92 & 18,24 \\
\hline Vol. mínimo de água que pode ser absorvido $\left(\mathrm{cm}^{3}\right)$ & 11,53 & 10,03 & 9,62 & 10,73 & 10,40 & 10,03 \\
\hline Vol. máximo de água que pode ser absorvido $\left(\mathrm{cm}^{3}\right)$ & 16,77 & 14,60 & 13,99 & 15,60 & 15,13 & 14,60 \\
\hline Massa mínima, após saturação parcial a vácuo (g) & 1264,7 & 1256,4 & 1256,4 & 1255,1 & 1257,4 & 1256,4 \\
\hline Massa máxima, após saturação parcial a vácuo (g) & 1270,0 & 1261,0 & 1260,8 & 1260,0 & 1262,1 & 1261,0 \\
\hline Carga de ruptura do CP não condicionado & Pméc & $\mathrm{dia}=15$ & 5377 & 15268 & 15237 & 15626 \\
\hline Tempo de saturação (min) / Pressão (pol de Hg) & \multicolumn{6}{|c|}{$32 / 20$} \\
\hline Massa, após saturação parcial a vácuo (g) & \multicolumn{6}{|c|}{$1265,01257,91256,5$} \\
\hline Massa imersa em g, após saturação a vácuo (g) & \multicolumn{6}{|c|}{$765,0 \quad 766,9 \quad 764,4$} \\
\hline Altura, após condicionamento (mm) & \multicolumn{6}{|c|}{$62,03 \quad 61,97 \quad 61,33$} \\
\hline Volume $\left(\mathrm{cm}^{3}\right)$ & \multicolumn{6}{|c|}{$500 \quad 491 \quad 492$} \\
\hline Densidade específica aparente $\left(\mathrm{g} / \mathrm{cm}^{3}\right)$ & \multicolumn{6}{|c|}{$2,506 \quad 2,538 \quad 2,534$} \\
\hline Volume de água absorvido $\left(\mathrm{cm}^{3}\right)$ & \multicolumn{6}{|c|}{$11,80 \quad 11,50 \quad 9,70$} \\
\hline Porcentagem de saturação & 56,30 & 63,03 & 55,45 & \multicolumn{3}{|c|}{ S'média $=58,26 \%$} \\
\hline Carga de ruptura do CP condicionado (N) & 13206 & 13328 & 14012 & \multicolumn{3}{|c|}{ Pmédia = 13515,33 } \\
\hline \multicolumn{2}{|l|}{ Resist. Média (kPa) - Resist. à tração Sem condic, (kPa) } & 1560,63 & & 1553,3 & 1552,2 & 1576,4 \\
\hline \multicolumn{2}{|c|}{ Resist. à tração Com condic, (kPa) - Resist. Média (kPa) 1331,4 } & 1346,3 & 1428,8 & \multicolumn{3}{|c|}{1368,83} \\
\hline Relação de Resistência à Tração (\%) & & 87,71 & & & & \\
\hline \multicolumn{7}{|l|}{ Danos da umidade induzida (visual) } \\
\hline Falha/esmagamento do agregado & & & & & & \\
\hline
\end{tabular}


Tabela B.02. Dados dos danos da umidade Induzida para a mistura com 10\% de Areia de Fundição - Volume de vazios 4\%

\begin{tabular}{|c|c|c|c|c|c|c|}
\hline \multicolumn{7}{|c|}{ Ensaio de Umidade Induzida } \\
\hline Aditivo: sem aditivo & \multicolumn{4}{|c|}{ Dosagem: D4 } & & \\
\hline Método de compactação: Marshall & \multicolumn{4}{|c|}{ Esforço: 75 golpes } & & \\
\hline Data do Ensaio: 16/08/03 & \multicolumn{6}{|c|}{ Laboratorista: Benedito Coutinho Neto } \\
\hline \multirow{3}{*}{ Identificação dos Corpos-de-Prova (CP) } & \multirow{2}{*}{\multicolumn{3}{|c|}{$\begin{array}{c}\text { Condicionados } \\
\text { Grupo } 01\end{array}$}} & \multirow{2}{*}{\multicolumn{3}{|c|}{$\begin{array}{c}\text { Não Condicionados } \\
\text { Grupo } 02\end{array}$}} \\
\hline & & & & & & \\
\hline & 20 & 25 & 26 & 22 & 23 & 24 \\
\hline Diâmetro (mm) & 101,7 & 101,6 & 101,7 & 101,7 & 101,6 & 101,6 \\
\hline Altura do (mm) & 62,53 & 62,65 & 62,55 & 62,93 & 62,60 & 62,48 \\
\hline Massa ao ar (g) & 1250,5 & 1250,7 & 1249,7 & 1251,0 & 1248,9 & 1251,4 \\
\hline Massa, antes da saturação parcial a vácuo (g) & 1250,5 & 1250,7 & 1249,7 & 7251,0 & 1248,9 & 1251,4 \\
\hline Massa imersa (g) & 747,0 & 750,0 & 748,5 & 747,5 & 747,0 & 752,3 \\
\hline Volume $\left(\mathrm{cm}^{3}\right)$ & 503,5 & 500,7 & 501,2 & 503,5 & 501,9 & 499,1 \\
\hline Densidade específica aparente $\left(\mathrm{g} / \mathrm{cm}^{3}\right)$ & 2,484 & 2,498 & 2,493 & 2,485 & 2,488 & 2,507 \\
\hline Densidade específica máxima (g/cm³) & 2,606 & 2,606 & 2,606 & 2,606 & 2,606 & 2,606 \\
\hline Teor de vazios (\%) & 4,70 & 4,15 & 4,32 & 4,66 & 4,51 & 3,79 \\
\hline Volume de vazios $\left(\mathrm{cm}^{3}\right)$ & 23,65 & 20,77 & 21,65 & 23,45 & 22,66 & 18,90 \\
\hline Vol. mínimo de água que pode ser absorvido $\left(\mathrm{cm}^{3}\right)$ & 13,01 & 11,42 & 11,91 & 12,90 & 12,46 & 10,40 \\
\hline Vol. máximo de água que pode ser absorvido $\left(\mathrm{cm}^{3}\right)$ & 18,92 & 16,62 & 17,32 & 18,76 & 18,13 & 15,12 \\
\hline Massa mínima, após saturação parcial a vácuo (g) & 1263,5 & 1262,1 & 1261,6 & 1263,9 & 1261,4 & 1261,8 \\
\hline Massa máxima, após saturação parcial a vácuo (g) & 1269,4 & 1267,3 & 1267,0 & 1269,8 & 1267,0 & 1266,5 \\
\hline Carga de ruptura do CP não condicionado (N) & Pmé & dia $=15$ & 5716 & 15596 & 15567 & 15985 \\
\hline Tempo de saturação (min) / Pressão (pol de Hg) & \multicolumn{6}{|c|}{$15 / 20$} \\
\hline Massa, após saturação parcial a vácuo (g) & \multicolumn{6}{|c|}{$1263,71262,51261,7$} \\
\hline Massa imersa em g, após saturação a vácuo (g) & \multicolumn{6}{|c|}{$759,5 \quad 760,6 \quad 759,8$} \\
\hline Altura, após condicionamento (mm) & \multicolumn{6}{|c|}{$62,57 \quad 62,57 \quad 62,63$} \\
\hline Volume $\left(\mathrm{cm}^{3}\right)$ & \multicolumn{6}{|c|}{$504,2 \quad 501,9 \quad 501,9$} \\
\hline Densidade específica aparente $\left(\mathrm{g} / \mathrm{cm}^{3}\right)$ & \multicolumn{6}{|c|}{$2,480 \quad 2,492 \quad 2,490$} \\
\hline Volume de água absorvido $\left(\mathrm{cm}^{3}\right)$ & 13,20 & 11,80 & 12,00 & & & \\
\hline Porcentagem de saturação & 55,82 & 56,82 & 55,42 & \multicolumn{3}{|c|}{ S'média = 56,02\% } \\
\hline Carga de ruptura do CP condicionado $(\mathrm{N})$ & 11562 & 13206 & 11981 & \multicolumn{3}{|c|}{ Pmédia = 12249,67 } \\
\hline Resist. Média (kPa) - Resist. à tração Sem condic, (kPa) & \multicolumn{3}{|c|}{1570,9} & \multicolumn{3}{|c|}{$1551,4 \quad 1558,2 \quad 1603,1$} \\
\hline Resist. à tração Com condic, (kPa) - Resist. Média (kPa) & 1156,7 & 1322,5 & 1199,8 & & 1226,33 & \\
\hline Relação de Resistência à Tração (\%) & & 78 & & & & \\
\hline \multicolumn{7}{|l|}{ Danos da umidade induzida (visual) } \\
\hline Falha/esmagamento do agregado & & & & & & \\
\hline
\end{tabular}


Tabela B.03. Dados dos danos da umidade Induzida para a mistura com 15\% de Areia de Fundição - Volume de vazios 4\%

\begin{tabular}{|c|c|c|c|c|c|c|}
\hline \multicolumn{7}{|c|}{ Ensaio de Umidade Induzida } \\
\hline \multicolumn{7}{|l|}{ Aditivo: sem aditivo } \\
\hline Método de compactação: Marshall & \multicolumn{6}{|c|}{ Esforço: 75 golpes } \\
\hline Data do Ensaio: 16/08/03 & \multicolumn{6}{|c|}{ Laboratorista: Benedito Coutinho Neto } \\
\hline \multirow{3}{*}{ Identificação do Corpos-de-Prova (CP) } & \multicolumn{3}{|c|}{ Condicionados } & \multirow{2}{*}{\multicolumn{3}{|c|}{$\begin{array}{c}\text { Não Condicionados } \\
\text { Grupo } 02\end{array}$}} \\
\hline & & & & \\
\hline & 20 & 24 & 25 & 22 & 23 & 26 \\
\hline Diâmetro (mm) & 101,6 & 101,6 & 101,7 & 101,8 & 101,6 & 101,6 \\
\hline Altura do (mm) & 62,28 & 62,55 & 62,35 & 62,23 & 62,70 & 62,33 \\
\hline Massa ao ar (g) & 1255,8 & 1250,0 & 1249,3 & 1250,6 & 1253,6 & 1261,6 \\
\hline Massa, antes da saturação parcial a vácuo (g) & 1255,8 & 1250,0 & 1249,3 & 1250,6 & 1253,6 & 1261,6 \\
\hline Massa imersa (g) & 747,3 & 746,1 & 745,7 & 746,4 & 747,7 & 752,3 \\
\hline Volume $\left(\mathrm{cm}^{3}\right)$ & 508,5 & 503,9 & 503,6 & 504,2 & 505,9 & 509,3 \\
\hline Densidade específica aparente $\left(\mathrm{g} / \mathrm{cm}^{3}\right)$ & 2,470 & 2,481 & 2,481 & 2,480 & 2,478 & 2,477 \\
\hline Densidade específica máxima $\left(\mathrm{g} / \mathrm{cm}^{3}\right)$ & 2,574 & 2,574 & 2,574 & 2,574 & 2,574 & 2,574 \\
\hline Teor de vazios (\%) & 4,05 & 3,62 & 3,62 & 3,63 & 3,72 & 3,76 \\
\hline Volume de vazios $\left(\mathrm{cm}^{3}\right)$ & 20,58 & 18,23 & 18,21 & 18,30 & 18,84 & 19,13 \\
\hline Vol. mínimo de água que pode ser absorvido $\left(\mathrm{cm}^{3}\right)$ & 11,32 & 10,03 & 10,01 & 10,07 & 10,36 & 10,52 \\
\hline Vol. máximo de água que pode ser absorvido $\left(\mathrm{cm}^{3}\right)$ & 16,47 & 14,59 & 14,57 & 14,64 & 15,07 & 15,30 \\
\hline Massa mínima, após saturação parcial a vácuo (g) & 1267,1 & 1260,0 & 1259,3 & 1260,7 & 1264,0 & 1272,1 \\
\hline Massa máxima, após saturação parcial a vácuo (g) & 1272,3 & 1264,6 & 1263,9 & 1265,2 & 1268,7 & 1276,9 \\
\hline Carga de ruptura do CP não condicionado (N) & Pméc & dia $=14$ & 4122 & 13117 & 14072 & 15177 \\
\hline Tempo de saturação (min) / Pressão (pol de Hg) & & & & 5 / 25 & & \\
\hline Massa, após saturação parcial a vácuo (g) & 1264,2 & 1255,5 & 1255,2 & & & \\
\hline Massa imersa em g, após saturação a vácuo (g) & 754,0 & 750,2 & 750,0 & & & \\
\hline Altura, após condicionamento (mm) & 63,23 & 62,43 & 62,30 & & & \\
\hline Volume $\left(\mathrm{cm}^{3}\right)$ & 510,2 & 505,3 & 505,2 & & & \\
\hline Densidade específica aparente $\left(\mathrm{g} / \mathrm{cm}^{3}\right)$ & 2,461 & 2,474 & 2,473 & & & \\
\hline Volume de água absorvido $\left(\mathrm{cm}^{3}\right)$ & 8,40 & 5,50 & 5,90 & & & \\
\hline Porcentagem de saturação & 40,81 & 30,16 & 32,41 & S'mé & édia = 34, & $1,46 \%$ \\
\hline Carga de ruptura do CP condicionado (N) & 11772 & 13475 & 12042 & Pméd & dia $=1242$ & 429,67 \\
\hline Resist. Média (kPa) - Resist. à tração Sem condic, $(\mathrm{kPa})$ & & 1416,77 & & 1318,2 & 1406,3 & 1525,8 \\
\hline Resist. à tração Com condic, (kPa) - Resist. Média (kPa) & 1166,6 & 1352,5 & 1210,0 & & 1243,03 & \\
\hline Relação de Resistência à Tração (\%) & & 87,7 & & & & \\
\hline Danos da umidade induzida (visual) & & & & & & \\
\hline Falha/esmagamento do agregado & & & & & & \\
\hline
\end{tabular}


Tabela B.04. Dados dos danos da umidade Induzida para a mistura com 10\% de Areia Virgem - Volume de vazios 4\%

\begin{tabular}{|c|c|c|c|c|c|c|}
\hline \multicolumn{7}{|c|}{ Ensaio de Umidade Induzida } \\
\hline \multicolumn{7}{|l|}{ Aditivo: sem aditivo } \\
\hline Método de compactação: Marshall & \multicolumn{6}{|c|}{ Esforço: 75 golpes } \\
\hline Data do Ensaio: $16 / 08 / 03$ & \multicolumn{6}{|c|}{ Laboratorista: Benedito Coutinho Neto } \\
\hline \multirow{3}{*}{ Identificação do Corpos-de-Prova (CP) } & \multicolumn{3}{|c|}{ Condicionados } & \multicolumn{3}{|c|}{ Não Condicionados } \\
\hline & \multicolumn{3}{|c|}{ Grupo 01} & \multicolumn{3}{|c|}{ Grupo 02} \\
\hline & 19 & 21 & 25 & 20 & 23 & 24 \\
\hline Diâmetro (mm) & 101,7 & 101,6 & 101,8 & 101,8 & 101,7 & 101,7 \\
\hline Altura do (mm) & 62,75 & 62,63 & 62,73 & 62,88 & 62,68 & 62,55 \\
\hline Massa ao ar (g) & 1255,6 & 1257,3 & 1258,1 & 1255,8 & 1255,9 & 1255,8 \\
\hline Massa, antes da saturação parcial a vácuo (g) & 1255,6 & 1257,3 & 1258,1 & 1255,8 & 1255,9 & 1255,8 \\
\hline Massa imersa (g) & 752,4 & 754,8 & 755,1 & 752,1 & 752,9 & 755,2 \\
\hline Volume $\left(\mathrm{cm}^{3}\right)$ & 503,2 & 502,5 & 503,0 & 503,7 & 503,0 & 500,6 \\
\hline Densidade específica aparente $\left(\mathrm{g} / \mathrm{cm}^{3}\right)$ & 2,495 & 2,502 & 2,501 & 2,493 & 2,497 & 2,509 \\
\hline Densidade específica máxima $\left(\mathrm{g} / \mathrm{cm}^{3}\right)$ & 2,614 & 2,614 & 2,614 & 2,614 & 2,614 & 2,614 \\
\hline Teor de vazios (\%) & 4,56 & 4,30 & 4,33 & 4,64 & 4,50 & 4,05 \\
\hline Volume de vazios $\left(\mathrm{cm}^{3}\right)$ & 22,95 & 21,60 & 21,79 & 23,37 & 22,63 & 20,27 \\
\hline Vol. mínimo de água que pode ser absorvido $\left(\mathrm{cm}^{3}\right)$ & 12,62 & 11,88 & 11,99 & 12,85 & 12,45 & 11,15 \\
\hline Vol. máximo de água que pode ser absorvido $\left(\mathrm{cm}^{3}\right)$ & 18,36 & 17,28 & 17,43 & 18,70 & 18,11 & 16,22 \\
\hline Massa mínima, após saturação parcial a vácuo (g) & 1268,2 & 1269,2 & 1270,1 & 1268,7 & 1268,3 & 1266,9 \\
\hline Massa máxima, após saturação parcial a vácuo (g) & 1274,0 & 1274,6 & 1275,5 & 1274,5 & 1274,0 & 1272,0 \\
\hline Carga de ruptura do CP não condicionado (N) & Pmé & dia $=15$ & 805 & 15148 & 15865 & 16402 \\
\hline Tempo de saturação (min) / Pressão (pol de Hg) & & & & / 20 & & \\
\hline Massa, após saturação parcial a vácuo (g) & 1268,4 & 1269,3 & 1270,2 & & & \\
\hline Massa imersa em g, após saturação a vácuo (g) & 765,8 & 763,5 & 765,7 & & & \\
\hline Altura, após condicionamento (mm) & 62,96 & 62,83 & 62,73 & & & \\
\hline Volume $\left(\mathrm{cm}^{3}\right)$ & 502,6 & 505,8 & 504,5 & & & \\
\hline Densidade específica aparente $\left(\mathrm{g} / \mathrm{cm}^{3}\right)$ & 2,498 & 2,486 & 2,494 & & & \\
\hline Volume de água absorvido $\left(\mathrm{cm}^{3}\right)$ & 12,80 & 12,00 & 12,10 & & & \\
\hline Porcentagem de saturação & 55,78 & 55,56 & 55,53 & \multicolumn{3}{|c|}{ S'média = 55,62\% } \\
\hline Carga de ruptura do CP condicionado (N) & 11085 & 11981 & 11622 & \multicolumn{3}{|c|}{ Pmédia = 11562.67} \\
\hline Resist. Média (kPa) - Resist. à tração Sem condic, (kPa) & & 1577,53 & & 1506,6 & 1584,5 & 1641,5 \\
\hline Resist. à tração Com condic. (kPa) - Resist. Média (kPa) & 1102,2 & 1194,9 & 1158,6 & & 1151,90 & \\
\hline Relação de Resistência à Tração (\%) & & 73 & & & & \\
\hline \multicolumn{7}{|l|}{ Danos da umidade induzida (visual) } \\
\hline Falha/esmagamento do agregado & & & & & & \\
\hline
\end{tabular}


Tabela B.05. Dados dos danos da umidade Induzida para a mistura com 10\% de Areia de Fundição - volume de vazios $7 \pm 1 \%$

\section{Ensaio de Dano por Umidade Induzida}

Aditivo: sem aditivo

Método de compactação: Marshall

Data do Ensaio:14 a 16/07/04

Identificação dos Corpos-de-prova (CP)

Diâmetro (mm)

Altura do (mm)

Massa ao ar (g)

Massa, antes da saturação parcial a vácuo (g)

Massa imersa (g)

Volume $\left(\mathrm{cm}^{3}\right)$

Densidade específica aparente $\left(\mathrm{g} / \mathrm{cm}^{3}\right)$

Densidade específica máxima $\left(\mathrm{g} / \mathrm{cm}^{3}\right)$

Teor de vazios (\%)

Volume de vazios $\left(\mathrm{cm}^{3}\right)$

Vol. mínimo de água que pode ser absorvido $\left(\mathrm{cm}^{3}\right)$

Vol. máximo de água que pode ser absorvido $\left(\mathrm{cm}^{3}\right)$

Massa mínima, após saturação parcial a vácuo (g)

Massa máxima, após saturação parcial a vácuo (g)

Carga de ruptura do $\mathrm{CP}$ não condicionado $(\mathrm{N})$

Tempo de saturação (min) / Pressão (pol de Hg)

Massa, após saturação parcial a vácuo (g)

Massa imersa em g, após saturação a vácuo (g)

Altura, após condicionamento (mm)

$$
\text { Volume }\left(\mathrm{cm}^{3}\right)
$$

Densidade específica aparente $\left(\mathrm{g} / \mathrm{cm}^{3}\right)$

Volume de água absorvido $\left(\mathrm{cm}^{3}\right)$

Porcentagem de saturação

Carga de ruptura do $\mathrm{CP}$ condicionado (N)

Resist. Média (kPa) - Resist. à tração Sem condic, (kPa)

Resist. à tração Com condic. (kPa) - Resist. Média (kPa)

Relação de Resistência à Tração (\%)

Danos da umidade induzida (visual)

Falha/esmagamento do agregado

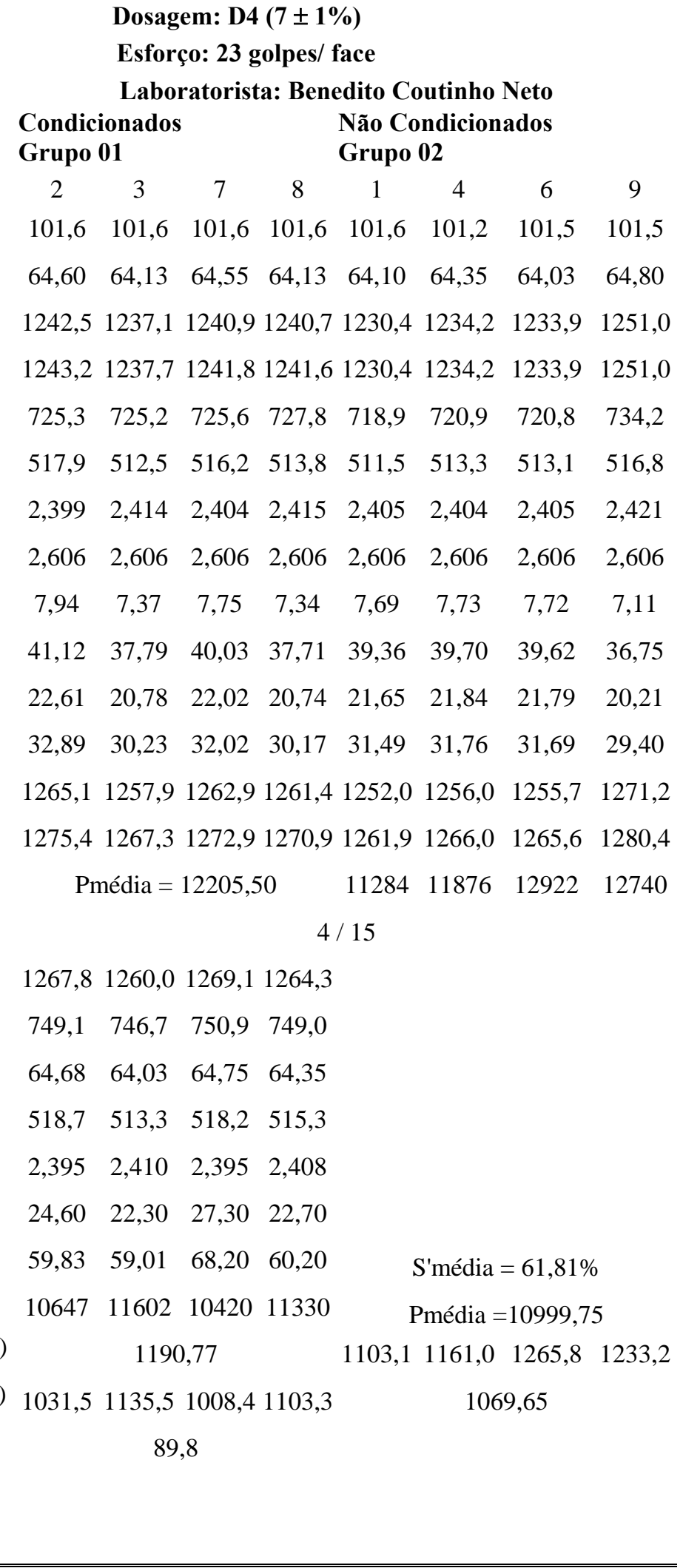


Tabela B.06. Dados dos danos da umidade Induzida para a mistura com 10\% de Areia de Virgem - Volume de vazios $7 \pm 1 \%$

\section{Ensaio de Dano por Umidade Induzida}

Aditivo: sem aditivo

Método de compactação: Marshall

Data do Ensaio: 14 a 16/07/04

\section{Identificação da Amostra}

Diâmetro (mm)

Altura do (mm)

Massa ao ar (g)

Massa, antes da saturação parcial a vácuo (g)

Massa imersa (g)

Volume $\left(\mathrm{cm}^{3}\right)$

Densidade específica aparente $\left(\mathrm{g} / \mathrm{cm}^{3}\right)$

Densidade específica máxima $\left(\mathrm{g} / \mathrm{cm}^{3}\right)$

Teor de vazios (\%)

Volume de vazios $\left(\mathrm{cm}^{3}\right)$

Vol. mínimo de água que pode ser absorvido $\left(\mathrm{cm}^{3}\right)$

Vol. máximo de água que pode ser absorvido $\left(\mathrm{cm}^{3}\right)$

Massa mínima, após saturação parcial a vácuo (g)

Massa máxima, após saturação parcial a vácuo (g)

Carga de ruptura do CP não condicionado (N)

Tempo de saturação (min) / Pressão (pol de Hg)

Massa, após saturação parcial a vácuo (g)

Massa imersa em g, após saturação a vácuo (g)

Altura, após condicionamento (mm)

Volume $\left(\mathrm{cm}^{3}\right)$

Densidade específica aparente $\left(\mathrm{g} / \mathrm{cm}^{3}\right)$

Volume de água absorvido $\left(\mathrm{cm}^{3}\right)$

Porcentagem de saturação

Carga de ruptura do CP condicionado (N)

Resist. Méd. (kPa) -Resist. à tração Sem condic, $(\mathrm{kPa})$

Resist. à tração Com condic.(kPa) - Resist. Méd. (kPa)

Relação de Resistência à Tração (\%)

Danos da umidade induzida (visual)

Falha/esmagamento do agregado

\begin{tabular}{ccccccccc}
\multicolumn{7}{c}{ Dosagem: T4 (7 \pm 1\%) } \\
\multicolumn{7}{c}{ Esforço: 25 golpes/ face } \\
Laboratorista: Benedito Coutinho Neto \\
Condicionados \\
Grupo 01
\end{tabular}

1251,7 1263,0 1258,4 1266,3

$740,2 \quad 747,0 \quad 747,1 \quad 747,8$

$64,00 \quad 64,38 \quad 63,60 \quad 64,85$

511,5 516,0 511,3 518,5

$2,389 \quad 2,393 \quad 2,408 \quad 2,386$

$27,80 \quad 26,10 \quad 25,40 \quad 27,10$

$67,91 \quad 64,40 \quad 66,70 \quad 64,91$

10784111021219410374

S'média = 65,98\%

Pmédia $=11113,50$

1201,30

1212,2 1214,0 1230,2 1148,8

1056,9 1080,6 1199,0 1002,4

1084,73

\section{0,3}


Tabela B.07. Dados dos ensaios de resistência à tração para todas as condições experimentais (misturas)

\begin{tabular}{|c|c|c|c|c|c|c|c|c|c|c|c|c|c|}
\hline \multicolumn{14}{|c|}{ Pesquisa: Doutorado - Benedito Coutinho Neto } \\
\hline \multirow[b]{3}{*}{$\begin{array}{l}\text { Corpos-de- } \\
\text { Prova }\end{array}$} & \multirow[b]{3}{*}{$\begin{array}{c}\mathbf{P} \\
(\mathbf{N})\end{array}$} & \multirow[b]{3}{*}{$\begin{array}{c}\text { Tensão } \\
\text { (kPa) }\end{array}$} & \multicolumn{5}{|c|}{ Método de compactação: Marshall } & \multicolumn{3}{|c|}{ Esforço: 75 golpes } & & & \\
\hline & & & \multicolumn{4}{|c|}{ Data do Ensaio: 29/08/03 } & \multicolumn{7}{|c|}{ Laboratorista: Benedito Coutinho Neto } \\
\hline & & & $\begin{array}{c}\text { Tensão } \\
\text { Média (kPa) }\end{array}$ & $\begin{array}{c}\text { EMR } \\
(\%)\end{array}$ & $\begin{array}{l}\text { Temp, } \\
\text { (oC) }\end{array}$ & $\begin{array}{c}\text { Temp, } \\
\text { Média( oC) }\end{array}$ & Vv (\%) & $\begin{array}{c}\text { Vv } \\
\text { Médio (\%) }\end{array}$ & $\begin{array}{c}\text { h } \\
(\mathrm{mm})\end{array}$ & $\begin{array}{c}\text { d } \\
(\mathrm{mm})\end{array}$ & $\begin{array}{c}\text { 5\% P(kgf) } \\
\text { Média }\end{array}$ & $\begin{array}{c}\text { 15\% P(kgf) } \\
\text { Média }\end{array}$ & $\begin{array}{c}30 \% \text { P(kgf) } \\
\text { Média }\end{array}$ \\
\hline C3S09 & 13713,8 & 1375,77 & \multirow{2}{*}{1485,74} & \multirow{2}{*}{15,99} & 23,2 & \multirow{2}{*}{23,4} & 3,0 & \multirow{2}{*}{3,0} & 62,4 & 101,7 & \multirow{2}{*}{73,72} & \multirow{2}{*}{221,17} & \multirow{2}{*}{442,35} \\
\hline C3S11 & 15775,9 & 1595,70 & & & 23,6 & & 3,0 & & 61,95 & 101,6 & & & \\
\hline C4S03 & 15148 & 1539,62 & \multirow{2}{*}{1618,31} & \multirow{2}{*}{10,22} & 23,6 & \multirow{2}{*}{23,6} & & \multirow{2}{*}{3,9} & 61,53 & 101,8 & \multirow{2}{*}{79,92} & \multirow{2}{*}{239,77} & \multirow{2}{*}{479,54} \\
\hline C4S07 & 16821 & 1697,00 & & & 23,6 & & 3,9 & & 62,05 & 101,7 & & & \\
\hline C4L14 & 17628,7 & 1779,92 & \multirow{2}{*}{1760,00} & \multirow{2}{*}{2,24} & 23,6 & \multirow{2}{*}{23,6} & 3,8 & \multirow{2}{*}{3,8} & 62 & 101,7 & \multirow{2}{*}{87,69} & \multirow{2}{*}{263,07} & \multirow{2}{*}{526,14} \\
\hline C4L18 & 17447,6 & 1740,07 & & & 23,6 & & 3,8 & & 62,83 & 101,6 & & & \\
\hline C5S08 & 15268 & 1540,05 & \multirow{2}{*}{1501,91} & \multirow{2}{*}{4,95} & 23,6 & 236 & 4,6 & 46 & 62 & 101,8 & 7497 & 22475 & 44950 \\
\hline C5S12 & 14698,9 & 1463,76 & & & 23,6 & & 4,6 & & 62,8 & 101,8 & & & \\
\hline C4P02 & 17956,7 & 1814,77 & & & 24,4 & & 4,6 & & 61,88 & 101,8 & & & \\
\hline С4P09 & 18763,2 & 1895,75 & & & 24,6 & & 4,7 & 4,0 & 62,08 & 101,5 & (1, & $275,+0$ & (1) \\
\hline C4PL12 & 18913,7 & 1911,54 & 100506 & 770 & 24,4 & 24 & 4,4 & 2 & 62 & 101,6 & 00 & 20467 & 50025 \\
\hline C4PL15 & 20376,1 & 2060,37 & 1500,50 & , & 24,4 & 24,4 & 4,1 & 4,2 & 62,03 & 101,5 & 30,22 & 254,07 & كנ, \\
\hline D3S03 & 13833,7 & 1404,44 & 143459 & 429 & 24,8 & 247 & 2,9 & 30 & 61,6 & 101,8 & 7074 & 2127 & 42441 \\
\hline D3S06 & 14460,3 & 1464,74 & & & 24,6 & & 3,1 & & 61,8 & 101,7 & & & \\
\hline D4S03 & 15208 & 1514,74 & 1510.35 & 0.58 & 24,4 & 24.5 & 4,5 & 4.3 .3 & 62,85 & 101,7 & 75.59 & 226.77 & 453.54 \\
\hline D4S10 & 15028,1 & 1505,96 & & & 24,6 & & 4,2 & & 62,53 & 101,6 & & & \\
\hline D4L08 & 14909,4 & 1494,24 & 155200 & 705 & 24,6 & 240 & 3,7 & 27 & 62,4 & 101,8 & 77 & 272 & 164 \\
\hline D4L12 & 16014,5 & 1611,55 & נט,טלטו & (ס) & 25 & & 3,7 & & 62,33 & 101,5 & & & \\
\hline D5S06 & 16253,2 & 1659,25 & 1646,59 & 1,53 & 25,2 & 24,9 & 5,2 & 5,2 & 61,38 & 101,6 & 80,52 & 241,57 & 483,14 \\
\hline
\end{tabular}




\begin{tabular}{|c|c|c|c|c|c|c|c|c|c|c|c|c|c|}
\hline $\begin{array}{c}\text { Corpos-de- } \\
\text { Prova }\end{array}$ & $\begin{array}{c}P \\
(N)\end{array}$ & $\begin{array}{c}\text { Tensão } \\
(\mathrm{kPa})\end{array}$ & $\begin{array}{c}\text { Tensão } \\
\text { Média (kPa) }\end{array}$ & $\begin{array}{c}\text { EMR } \\
(\%)\end{array}$ & $\begin{array}{l}\text { Temp, } \\
(\text { oC) }\end{array}$ & $\begin{array}{c}\text { Temp, } \\
\text { Média( oC) }\end{array}$ & Vv (\%) & $\begin{array}{c}\mathrm{Vv} \\
\text { Médio (\%) }\end{array}$ & $\begin{array}{c}\mathrm{h} \\
(\mathrm{mm})\end{array}$ & $\begin{array}{c}d \\
(\mathrm{~mm})\end{array}$ & $\begin{array}{c}\text { 5\% P(kgf) } \\
\text { Média }\end{array}$ & $\begin{array}{c}15 \% \text { P(kgf) } \\
\text { Média }\end{array}$ & $\begin{array}{c}30 \% \text { P(kgf) } \\
\text { Média }\end{array}$ \\
\hline 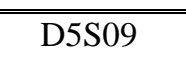 & 15955,8 & $\begin{array}{l}1633,94 \\
\end{array}$ & & & 24,6 & & 5,2 & & 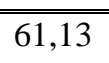 & $\overline{101,7}$ & & & \\
\hline D4P07 & 14758,9 & 1472,82 & \multirow{2}{*}{1331,25} & \multirow{2}{*}{19,22} & 25,2 & \multirow{2}{*}{25,2} & 4,0 & \multirow{2}{*}{4,0} & & 101,7 & \multirow{2}{*}{66,85} & \multirow{2}{*}{200,55} & \multirow{2}{*}{401,10} \\
\hline D4P10 & 11980,9 & 1189,68 & & & 25,2 & & 4,0 & & 62,98 & 101,8 & & & \\
\hline D4PL03 & 13653,8 & 1375,70 & \multirow{2}{*}{1272,30} & \multirow{2}{*}{15,03} & 25,2 & \multirow{2}{*}{25,1} & 3,8 & \multirow{2}{*}{3,8} & 62,13 & 101,7 & \multirow{2}{*}{63,56} & \multirow{2}{*}{190,69} & \multirow{2}{*}{381,38} \\
\hline D4PL16 & 11771,6 & 1168,90 & & & 25 & & 3,8 & & 62,98 & 101,8 & & & \\
\hline Q3S05 & 14072,4 & 1426,16 & \multirow{2}{*}{1488,96} & \multirow{2}{*}{8,81} & 25,6 & \multirow{2}{*}{25,2} & 2,68 & \multirow{2}{*}{2,72} & 61,83 & 101,6 & \multirow{2}{*}{73,27} & \multirow{2}{*}{219,82} & \multirow{2}{*}{439,65} \\
\hline Q3S15 & 15237,4 & 1551,76 & & & 24,8 & & 2,76 & & 61,53 & 101,6 & & & \\
\hline Q4S14 & 13475,2 & 1350,75 & \multirow{2}{*}{1338,71} & \multirow{2}{*}{1,78} & 25,6 & \multirow{2}{*}{25,5} & 3,6 & \multirow{2}{*}{3,60} & 62,45 & 101,7 & \multirow{2}{*}{66,55} & \multirow{2}{*}{199,66} & \multirow{2}{*}{ 399,32 } \\
\hline Q4S12 & 13146 & 1326,67 & & & 25,4 & & 3,6 & & 62,03 & 101,7 & & & \\
\hline Q4L01 & 12428,8 & 1237,34 & \multirow{2}{*}{1323,13} & \multirow{2}{*}{13,87} & 25,8 & 257 & 4,2 & 38 & 62,88 & 101,7 & 6618 & 19853 & 39706 \\
\hline Q4L10 & 14041,8 & 1408,93 & & & 25,6 & $25, /$ & 3,3 & 3,8 & 62,45 & 101,6 & 66,18 & & 39/,00 \\
\hline Q5S06 & 13265,9 & 1310,62 & 135123 & 620 & 25,8 & 256 & 5,0 & 50 & 63,3 & 101,8 & 6835 & 20504 & 41007 \\
\hline Q5S13 & 14072,4 & 1391,84 & 1351,23 & 6,20 & 25,4 & 25,6 & 5,0 & 5,0 & 63,23 & 101,8 & 68,35 & 205,04 & 410,07 \\
\hline Q4P14 & 15686,5 & 1567,39 & 162801 & 774 & 25,4 & 25.3 & 3,4 & 3.4 & 62,65 & 101,7 & 81.42 & 24426 & 488.51 \\
\hline Q4P15 & 16881 & 1688,63 & & & 25,2 & & 3,4 & & 62,58 & 101,7 & 81,42 & $\angle 44, \angle 0$ & 488,ذ1 \\
\hline Q4PL03 & 13803,1 & 1378,36 & 2035 132 & 625 & 25,4 & 254 & 3,8 & 37 & 62,75 & 101,6 & 6603 & 20078 & 10156 \\
\hline Q4PL05 & 12967,3 & 1292,22 & 1030,29 & $0, \angle J$ & 25,4 & 20,4 & 3,6 & o, & 62,88 & 101,6 & (50, & 200,10 & 4 \\
\hline T3S12 & 14938,8 & 1518,62 & 14960 & 297 & 25,4 & 254 & 3,0 & 29 & 61,58 & 101,7 & 7380 & 22139 & 44279 \\
\hline T3S13 & 14580,2 & 1473,53 & & & 25,4 & 25,4 & 2,9 & 2,9 & 61,88 & 101,8 & 13,80 & 221,39 & 442,19 \\
\hline T4S05 & 15206,8 & 1531,68 & 1548.13 & 2.15 & 25,6 & 25,5 & 4,2 & 3,9 & 62,15 & 101,7 & 77.31 & 231.92 & \\
\hline $\mathrm{T} 4 \mathrm{~S} 15$ & 15715,9 & 1564,58 & 1548,13 & 2,15 & 25,4 & 25,5 & 3,7 & 3,9 & 62,88 & 101,7 & 7/,31 & 231,92 & 463,84 \\
\hline T4L13 & 16790,4 & 1694,22 & 168414 & 110 & 25,6 & 256 & 3,8 & 38 & 62,1 & 101,6 & 8403 & 25209 & 50417 \\
\hline T4L14 & 16821 & 1674,07 & 1684,14 & 1,19 & 25,6 & 25,6 & 3,8 & & 62,9 & 101,7 & 84,03 & & 504,17 \\
\hline T5S07 & 14640,2 & 1458,65 & 1479,98 & 2,92 & 25,4 & 25,2 & 5,2 & 5,2 & 62,83 & 101,7 & 74,62 & 223,86 & 447,72 \\
\hline
\end{tabular}




\begin{tabular}{|c|c|c|c|c|c|c|c|c|c|c|c|c|c|}
\hline $\begin{array}{c}\text { Corpos-de- } \\
\text { Prova }\end{array}$ & $\begin{array}{c}P \\
(N)\end{array}$ & $\begin{array}{c}\text { Tensão } \\
(\mathbf{k P a})\end{array}$ & $\begin{array}{c}\text { Tensão } \\
\text { Média (kPa) }\end{array}$ & $\begin{array}{c}\text { EMR } \\
(\%)\end{array}$ & $\begin{array}{l}\text { Temp, } \\
(\text { oC) }\end{array}$ & $\begin{array}{c}\text { Temp, } \\
\text { Média( oC) }\end{array}$ & $\begin{array}{ll}\text { Vv (\%) } \\
\end{array}$ & $\begin{array}{c}\mathrm{Vv} \\
\text { Médio (\%) }\end{array}$ & $\begin{array}{c}\mathrm{h} \\
(\mathrm{mm})\end{array}$ & $\begin{array}{c}d \\
(\mathrm{~mm})\end{array}$ & $\begin{array}{c}\text { 5\% P(kgf) } \\
\text { Média }\end{array}$ & $\begin{array}{c}15 \% \text { P(kgf) } \\
\text { Média }\end{array}$ & $\begin{array}{c}30 \% \text { P(kgf) } \\
\text { Média }\end{array}$ \\
\hline T5S09 & 15208 & 1501,31 & & & 25 & & 5,2 & & 63,35 & $\begin{array}{l}101,8 \\
\end{array}$ & & & \\
\hline T4P08 & 18972,4 & 1903,66 & \multirow{2}{*}{ 2003,89 } & \multirow{2}{*}{10,53} & 25,2 & \multirow{2}{*}{25,2} & 4,0 & \multirow{2}{*}{4,2} & 62,45 & 101,6 & \multirow{2}{*}{99,94} & \multirow{2}{*}{299,82} & \multirow{2}{*}{599,64} \\
\hline $\mathrm{T} 4 \mathrm{P} 13$ & 21003,9 & 2104,13 & & & 25,2 & & 4,5 & & 62,55 & 101,6 & & & \\
\hline T4PL09 & 19301,6 & 1934,43 & \multirow{2}{*}{1963,02} & \multirow{2}{*}{2,96} & 25,4 & \multirow{2}{*}{25,4} & 4,4 & \multirow{2}{*}{4,4} & 62,4 & 101,8 & \multirow{2}{*}{98,15} & \multirow{2}{*}{294,44} & \multirow{2}{*}{588,89} \\
\hline T4PL15 & 19957,6 & 1991,61 & & & 25,4 & & 4,4 & & 62,73 & 101,7 & & & \\
\hline
\end{tabular}

Tabela B.08. Resultados dos ensaios de módulo de resiliência para todas as condições experimentais (misturas)

\begin{tabular}{|c|c|c|c|c|c|c|c|c|c|c|}
\hline \multicolumn{11}{|c|}{$\begin{array}{c}\text { Planilha dos Resultados dos ensaios de Módulo de resiliência } \\
\text { Pesquisa: Doutorado - Benedito Coutinho Neto }\end{array}$} \\
\hline \multirow[b]{2}{*}{ CPs } & \multicolumn{4}{|c|}{$\begin{array}{l}\text { Método de compactação: Marshall } \\
\text { Data do Ensaio: } 14 / 09 / 03\end{array}$} & \multicolumn{4}{|c|}{$\begin{array}{c}\text { Esforço: } 75 \text { golpes Coeficiente de Poisson } \\
\text { Laboratorista: Benedito Coutinho Neto }\end{array}$} & \multirow[b]{2}{*}{$\begin{array}{l}\text { DP } \\
\text { kgf }\end{array}$} & \multirow[b]{2}{*}{$\begin{array}{l}\mathrm{N}^{\mathbf{0}} \text { de } \\
\text { Pontos }\end{array}$} \\
\hline & $\begin{array}{c}\text { MTM } \\
\mathbf{k g f} / \mathrm{cm}^{2}\end{array}$ & $\begin{array}{c}\mathrm{DP} \\
\mathrm{kgf} / \mathrm{cm}^{2}\end{array}$ & $\begin{array}{c}\text { DP } \\
\% \text { MTM }\end{array}$ & $\begin{array}{c}\text { MIM } \\
\mathbf{k g f} / \mathrm{cm}^{2}\end{array}$ & $\begin{array}{c}\mathrm{DP} \\
\mathrm{kgf} / \mathrm{cm}^{2}\end{array}$ & $\begin{array}{c}\text { DP } \\
\% \text { MIM }\end{array}$ & $\begin{array}{c}\mathrm{N}^{\mathbf{0}} \mathrm{de} \\
\text { Pontos }\end{array}$ & $\begin{array}{l}\text { Carga Média } \\
\text { kgf }\end{array}$ & & \\
\hline C3S13-0 & 153309,64 & 33853,40 & 22,08 & 174484,87 & 41293,67 & 23,67 & 459 & 1777,91 & 3,67 & 496 \\
\hline C3S13-90 & 89984,29 & 11357,75 & 12,62 & 107244,31 & 13595,72 & 12,68 & 477 & 173,29 & 4,48 & 505 \\
\hline C3S14-0 & 95513,34 & 13016,10 & 13,63 & 116961,22 & 16284,53 & 13,92 & 471 & 176,13 & 2,09 & 507 \\
\hline C3S14-90 & 116069,9 & 23670,17 & 20,39 & 137860,27 & 26909,95 & 19,52 & 469 & 180,64 & 3,85 & 151 \\
\hline C4S12-0 & 94231,1 & 15221,91 & 16,15 & 115828,84 & 20272,30 & 17,50 & 469 & 173,78 & 3,34 & 503 \\
\hline C4S12-90 & 85490,86 & 10617,04 & 12,42 & 105834,57 & 13907,81 & 13,14 & 485 & 175,85 & 2,47 & 503 \\
\hline C4S13-0 & 87239,52 & 10771,11 & 12,35 & 105437,21 & 13024,48 & 12,35 & 469 & 296,91 & 5,26 & 506 \\
\hline C4S13-90 & 84370,97 & 9532,93 & 11,30 & 101510,63 & 11662,79 & 11,49 & 473 & 184,02 & 4,61 & 509 \\
\hline C5 S13-0 & 66474,66 & 7777,03 & 11,70 & 77690,81 & 8788,73 & 11,31 & 474 & 318,66 & 4,23 & 507 \\
\hline C5 S13-90 & 60345,82 & 6742,43 & 11,17 & 70956,79 & 7970,41 & 11,23 & 474 & 317,22 & 3,56 & 505 \\
\hline
\end{tabular}




\begin{tabular}{|c|c|c|c|c|c|c|c|c|c|c|}
\hline CPs & $\begin{array}{c}\text { MTM } \\
\mathrm{kgf} / \mathrm{cm}^{2}\end{array}$ & $\begin{array}{c}\mathrm{DP} \\
\mathrm{kgf} / \mathrm{cm}^{2}\end{array}$ & $\begin{array}{c}\text { DP } \\
\% \text { MTM }\end{array}$ & $\begin{array}{c}\text { MIM } \\
\mathrm{kgf} / \mathrm{cm}^{2}\end{array}$ & $\begin{array}{c}\text { DP } \\
\mathrm{kgf} / \mathrm{cm}^{2}\end{array}$ & $\begin{array}{c}\text { DP } \\
\% \text { MIM }\end{array}$ & $\begin{array}{c}\mathrm{N}^{\mathbf{0}} \mathrm{de} \\
\text { Pontos }\end{array}$ & $\begin{array}{c}\text { Carga Média } \\
\text { kgf }\end{array}$ & $\begin{array}{l}\text { DP } \\
\text { kgf }\end{array}$ & $\begin{array}{c}\mathrm{N}^{0} \mathrm{de} \\
\text { Pontos }\end{array}$ \\
\hline C5 S14-0 & $\begin{array}{l}85799,8 \\
\end{array}$ & 8411,56 & $\begin{array}{l}9,80 \\
\end{array}$ & $\begin{array}{l}102876,75 \\
\end{array}$ & 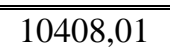 & $\overline{10,12}$ & 4779 & 317,02 & $\begin{array}{l}3,4 \\
\end{array}$ & 2505 \\
\hline C5 S14-90 & 93663,26 & 10520,82 & 11,23 & 104539,39 & 11407,30 & 10,91 & 462 & 318,29 & 3,29 & 505 \\
\hline C4P11-0 & 86187,58 & 13326,05 & 15,46 & 105860,38 & 16800,84 & 15,87 & 480 & 319,83 & 1,71 & 416 \\
\hline C4P11-90 & 93885,52 & 14408,34 & 15,35 & 112550,36 & 17213,56 & 15,29 & 477 & 318,77 & 3,4 & 503 \\
\hline C4P16-0 & 171634,11 & 33003,14 & 19,23 & 208910,79 & 41826,31 & 20,02 & 470 & 314,42 & 3,09 & 505 \\
\hline C4P16-90 & 125982,4 & 17833,83 & 14,16 & 155212,92 & 24295,04 & 15,65 & 469 & 310,92 & 3,34 & 502 \\
\hline C4L06-0 & 68058,15 & 5528,13 & 8,12 & 81431,73 & 6859,66 & 8,42 & 471 & 312,72 & 3,87 & 504 \\
\hline C4L06-90 & 69834,08 & 9522,72 & 13,64 & 81085,35 & 10416,41 & 12,85 & 465 & 310,87 & 5,83 & 502 \\
\hline C4L08-0 & 95781,69 & 13327,13 & 13,91 & 116669,99 & 16804,17 & 14,40 & 475 & 316,68 & 2,96 & 506 \\
\hline C4L08-90 & 72048,61 & 15193,97 & 21,09 & 87884,95 & 18654,84 & 21,23 & 476 & 321,84 & 1,89 & 245 \\
\hline C4PL04-0 & 117984,23 & 21714,61 & 18,40 & 144347,75 & 27382,90 & 18,97 & 476 & 316,69 & 3,17 & 507 \\
\hline C4PL04-90 & 112392,82 & 16183,20 & 14,40 & 138778,34 & 20774,75 & 14,97 & 464 & 318,68 & 2,25 & 499 \\
\hline C4PL14-90 & 113487,95 & 16607,62 & 14,63 & 140426,31 & 21564,41 & 15,36 & 476 & 317,65 & 2,41 & 505 \\
\hline D3S01-0 & 52741,74 & 4393,98 & 8,33 & 62139,48 & 5179,31 & 8,33 & 471 & 310,75 & 3,17 & 467 \\
\hline D3S01-90 & 36296,45 & 2814,98 & 7,76 & 42729,71 & 3256,58 & 7,62 & 470 & 315,12 & 2,85 & 507 \\
\hline D3S02-0 & 78171,14 & 12315,89 & 15,76 & 83550,77 & 12579,50 & 15,06 & 470 & 312,25 & 4,26 & 504 \\
\hline D3S02-90 & 47666,88 & 3328,75 & 6,98 & 53940,54 & 3621,92 & 6,71 & 334 & 311,81 & 3,33 & 365 \\
\hline D4S02-0 & 70702,82 & 9499,97 & 13,44 & 86326,15 & 11682,21 & 13,53 & 471 & 203,9 & 4,52 & 506 \\
\hline D4S02-90 & 61224,3 & 10266,02 & 16,77 & 70035,04 & 11153,02 & 15,92 & 461 & 196,84 & 5,5 & 505 \\
\hline D4S04-0 & 75391,06 & 9268,35 & 12,29 & 88410,50 & 11406,37 & 12,90 & 474 & 193,65 & 6,02 & 504 \\
\hline D4S04-90 & 59212,66 & 6235,08 & 10,53 & 67598,60 & 7101,21 & 10,50 & 465 & 207,97 & 3,76 & 496 \\
\hline D5S07-0 & 64449,32 & 5205,58 & 8,08 & 75138,77 & 6241,58 & 8,31 & 475 & 309,1 & 2,66 & 506 \\
\hline D5S07-90 & 52556,24 & 6195,36 & 11,79 & 59442,72 & 5449,96 & 9,17 & 423 & 310,3 & 2,71 & 458 \\
\hline D5S12-0 & 128505,14 & 23410,74 & 18,22 & 140200,12 & 24995,4 & 17,83 & 467 & 313,58 & 2,21 & 505 \\
\hline
\end{tabular}




\begin{tabular}{|c|c|c|c|c|c|c|c|c|c|c|}
\hline CPs & $\begin{array}{c}\text { MTM } \\
\mathbf{k g f} / \mathrm{cm}^{2}\end{array}$ & $\begin{array}{c}\mathrm{DP} \\
\mathrm{kgf} / \mathrm{cm}^{2}\end{array}$ & $\begin{array}{c}\text { DP } \\
\% \text { MTM }\end{array}$ & $\begin{array}{c}\text { MIM } \\
\mathrm{kgf} / \mathrm{cm}^{2}\end{array}$ & $\begin{array}{c}\mathrm{DP} \\
\mathrm{kgf} / \mathrm{cm}^{2}\end{array}$ & $\begin{array}{c}\text { DP } \\
\% \text { MIM }\end{array}$ & $\begin{array}{c}\mathrm{N}^{\mathbf{0}} \mathrm{de} \\
\text { Pontos }\end{array}$ & $\begin{array}{c}\text { Carga Média } \\
\text { kgf }\end{array}$ & $\begin{array}{l}\text { DP } \\
\text { kgf }\end{array}$ & $\begin{array}{c}\mathrm{N}^{\mathbf{0}} \mathrm{de} \\
\text { Pontos }\end{array}$ \\
\hline "D5S12-90 & 80286,49 & $\begin{array}{l}9975,65 \\
\end{array}$ & 12,43 & 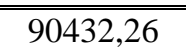 & $\begin{array}{l}10412,76 \\
\end{array}$ & 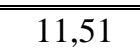 & 4771 & 313,01 & $\begin{array}{l}3,14 \\
\end{array}$ & 507 \\
\hline D4P05-0 & 110832,78 & 15522,19 & 14,01 & 132528,74 & 18487,66 & 13,95 & 472 & 304,19 & 2,32 & 430 \\
\hline D4P05-90 & 89572,63 & 8696,95 & 9,71 & 107143,74 & 9996,63 & 9,33 & 473 & 308,25 & 3,25 & 504 \\
\hline D4P11-0 & 92244,66 & 13147,84 & 14,25 & 114842,21 & 16972,53 & 14,78 & 471 & 304,56 & 2,02 & 323 \\
\hline D4P11-90 & 102031,63 & 15054,80 & 14,76 & 117823,80 & 16655,44 & 14,14 & 467 & 309,39 & 3,37 & 506 \\
\hline D4L07-0 & 61006,64 & 5093,22 & 8,35 & 73120,09 & 6198,04 & 8,48 & 478 & 309,7 & 3,7 & 505 \\
\hline D4L07-90 & 51305,78 & 4712,24 & 9,18 & 61119,48 & 5506,83 & 9,01 & 436 & 309,75 & 2,97 & 428 \\
\hline D4L09-0 & 59349,89 & 5673,66 & 9,56 & 71364,22 & 6860,66 & 9,61 & 480 & 314,05 & 2,2 & 505 \\
\hline D4L09-90 & 47786,76 & 3984,35 & 8,34 & 57192,48 & 4686,13 & 8,19 & 477 & 313,48 & 2,68 & 508 \\
\hline D4PL06-0 & 98111,54 & 13936,37 & 14,20 & 119028,19 & 16869,31 & 14,17 & 468 & 310,3 & 1,27 & 392 \\
\hline D4PL06-90 & 92822,74 & 12007,45 & 12,94 & 114840,05 & 15509,23 & 13,51 & 466 & 311,54 & 3,05 & 495 \\
\hline D4PL14-0 & 106251,91 & 13122,17 & 12,35 & 131355,68 & 16889,39 & 12,86 & 465 & 309,85 & 2,83 & 506 \\
\hline D4PL14-90 & 122782,98 & 17760,05 & 14,46 & 150459,15 & 22686,72 & 15,08 & 476 & 312,09 & 2,72 & 506 \\
\hline T3S01-0 & 74633,75 & 8196,53 & 10,98 & 84389,04 & 8804,27 & 10,43 & 474 & 312,91 & 2,65 & 507 \\
\hline T3S01-90 & 58901,67 & 9303,14 & 15,79 & 65355,60 & 9147,31 & 14,00 & 146 & 313,44 & 3,96 & 163 \\
\hline T3S04-0 & 75001,45 & 8943,14 & 11,92 & 84522,95 & 9422,63 & 11,15 & 470 & 309,1 & 2,78 & 509 \\
\hline T3S04-90 & 57381,12 & 4162,16 & 7,25 & 65657,56 & 4635,25 & 7,06 & 301 & 312,07 & 2,78 & 324 \\
\hline T4S10-0 & 110702,25 & 22587,34 & 20,40 & 127358,68 & 23336,78 & 18,32 & 455 & 311,09 & 3,29 & 495 \\
\hline T4S10-90 & 59220,58 & 5014,74 & 8,47 & 65846,66 & 5569,73 & 8,46 & 472 & 310,82 & 2,58 & 507 \\
\hline T4S12-0 & 96766,84 & 15370,88 & 15,88 & 111411,58 & 16711,53 & 15,00 & 466 & 310,91 & 2,09 & 498 \\
\hline T4S12-90 & 80377,15 & 8948,54 & 11,13 & 91423,74 & 9462,59 & 10,35 & 474 & 311,23 & 2,55 & 508 \\
\hline T5S08-0 & 62336,46 & 10505,12 & 16,85 & 73203,26 & 12299,19 & 16,80 & 477 & 323,74 & 2,6 & 505 \\
\hline T5S08-90 & 59346,33 & 14539,90 & 24,50 & 68007,75 & 16473,61 & 24,22 & 279 & 326,06 & 2,89 & 300 \\
\hline T5S13-0 & 74320,99 & 6381,28 & 8,59 & 90356,14 & 7881,41 & 8,72 & 325 & 322,11 & 3,28 & 349 \\
\hline
\end{tabular}




\begin{tabular}{|c|c|c|c|c|c|c|c|c|c|c|}
\hline CPs & $\begin{array}{c}\text { MTM } \\
\mathrm{kgf} / \mathrm{cm}^{2}\end{array}$ & $\begin{array}{c}\mathrm{DP} \\
\mathrm{kgf} / \mathrm{cm}^{2}\end{array}$ & $\begin{array}{c}\text { DP } \\
\% \text { MTM }\end{array}$ & $\begin{array}{c}\text { MIM } \\
\mathrm{kgf} / \mathrm{cm}^{2}\end{array}$ & $\begin{array}{c}\text { DP } \\
\mathrm{kgf} / \mathrm{cm}^{2}\end{array}$ & $\begin{array}{c}\text { DP } \\
\% \text { MIM }\end{array}$ & $\begin{array}{c}\mathrm{N}^{\mathbf{0}} \mathrm{de} \\
\text { Pontos }\end{array}$ & $\begin{array}{c}\text { Carga Média } \\
\text { kgf }\end{array}$ & $\begin{array}{l}\text { DP } \\
\text { kgf }\end{array}$ & $\begin{array}{c}\mathrm{N}^{0} \mathrm{de} \\
\text { Pontos }\end{array}$ \\
\hline T5S13-90 & 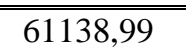 & $\begin{array}{l}12616,14 \\
\end{array}$ & 20,64 & $\begin{array}{l}71768,52 \\
\end{array}$ & $\begin{array}{l}14923,14 \\
\end{array}$ & 20,79 & 312 & 326,73 & 3,21 & 337 \\
\hline T4P05-0 & 171507,78 & 29142,87 & 16,99 & 204336,49 & 35729,40 & 17,49 & 470 & 384,3 & 2,57 & 507 \\
\hline T4P05-90 & 128951,11 & 15311,98 & 11,87 & 159406,08 & 19567,31 & 12,28 & 473 & 374,82 & 2,74 & 492 \\
\hline Т4P06-0 & 155849,93 & 26919,74 & 17,27 & 189091,11 & 32665,18 & 17,27 & 478 & 377,52 & 2,26 & 476 \\
\hline Т4P06-90 & 236505,08 & 46101,71 & 19,49 & 268918,84 & 55008,30 & 20,46 & 466 & 376,24 & 2,38 & 353 \\
\hline T4L06-0 & 70311,76 & 10277,01 & 14,62 & 83824,82 & 10113,22 & 12,06 & 230 & 382,46 & 2,62 & 246 \\
\hline T4L06-90 & 66342,98 & 13358,67 & 20,14 & 77626,87 & 15319,53 & 19,73 & 388 & 385,34 & 2,7 & 413 \\
\hline T4L11-0 & 70870,59 & 8623,90 & 12,17 & 85187,81 & 9405,38 & 11,04 & 364 & 380,19 & 2,44 & 389 \\
\hline T4L11-90 & 65245,67 & 14548,02 & 22,30 & 78392,47 & 17560,04 & 22,40 & 471 & 380,5 & 3,29 & 506 \\
\hline T4PL03-0 & 119173,95 & 15073,09 & 12,65 & 147427,74 & 19330,81 & 13,11 & 477 & 379,97 & 2,31 & 507 \\
\hline T4PL03-90 & 113335,94 & 19950,06 & 17,60 & 138832,79 & 23869,99 & 17,19 & 471 & 383,02 & 3,05 & 505 \\
\hline T4PL11-0 & 130111,36 & 15728,25 & 12,09 & 161189,15 & 20451,26 & 12,69 & 470 & 378,05 & 2,58 & 507 \\
\hline T4PL11-90 & 105781,8 & 10072,63 & 9,52 & 130217,33 & 12467,85 & 9,57 & 473 & 380,69 & 2,56 & 508 \\
\hline Q3S01-0 & 45496,45 & 4986,67 & 10,96 & 53677,94 & 5951,72 & 11,09 & 468 & 198,78 & 4,22 & 507 \\
\hline Q3S01-90 & 40043,29 & 8043,99 & 20,09 & 47398,83 & 9387,74 & 19,81 & 474 & 197,74 & 4,02 & 505 \\
\hline Q3S02-0 & 55699,58 & 8551,33 & 15,35 & 67188,06 & 10433,52 & 15,53 & 474 & 117,55 & 2,15 & 506 \\
\hline Q3S02-90 & 73224,59 & 17636,88 & 24,09 & 87541,81 & 21332,46 & 24,37 & 483 & 117,46 & 2,2 & 503 \\
\hline Q4S02-0 & 53098,54 & 7141,33 & 13,45 & 64262,10 & 8597,97 & 13,38 & 474 & 214,27 & 2,68 & 505 \\
\hline Q4S02-90 & 46550,17 & 7325,37 & 15,74 & 55836,71 & 8700,73 & 15,58 & 461 & 213,25 & 3,12 & 507 \\
\hline Q4S06-0 & 87258,45 & 14918,42 & 17,10 & 105723,18 & 18920,07 & 17,90 & 475 & 211,93 & 3,78 & 506 \\
\hline Q4S06-90 & 68613,4 & 13392,09 & 19,52 & 80844,74 & 16575,33 & 20,50 & 476 & 211,43 & 3,66 & 507 \\
\hline Q5S03-0 & 60914,42 & 9229,59 & 15,15 & 74781,97 & 11264,80 & 15,06 & 472 & 310,99 & 3,59 & 505 \\
\hline Q5S03-90 & 45816,21 & 7696,09 & 16,80 & 52949,73 & 7263,73 & 13,72 & 154 & 247,85 & 4,27 & 173 \\
\hline Q5S05-0 & 77579,69 & 8791,76 & 11,33 & 95849,06 & 11030,64 & 11,51 & 474 & 243,62 & 3,8 & 506 \\
\hline
\end{tabular}




\begin{tabular}{|c|c|c|c|c|c|c|c|c|c|c|}
\hline CPs & $\begin{array}{c}\text { MTM } \\
\mathrm{kgf} / \mathrm{cm}^{2}\end{array}$ & $\begin{array}{c}\mathrm{DP} \\
\mathrm{kgf} / \mathrm{cm}^{2}\end{array}$ & $\begin{array}{c}\text { DP } \\
\% \text { МTM }\end{array}$ & $\begin{array}{c}\text { MIM } \\
\mathrm{kgf} / \mathrm{cm}^{2}\end{array}$ & $\begin{array}{c}\text { DP } \\
\mathrm{kgf} / \mathrm{cm}^{2}\end{array}$ & $\begin{array}{c}\text { DP } \\
\% \text { MIM }\end{array}$ & $\begin{array}{c}\mathrm{N}^{0} \mathrm{de} \\
\text { Pontos }\end{array}$ & $\begin{array}{c}\text { Carga Média } \\
\text { kgf }\end{array}$ & $\begin{array}{l}\text { DP } \\
\text { kgf }\end{array}$ & $\begin{array}{c}\mathrm{N}^{\mathbf{0}} \mathrm{de} \\
\text { Pontos }\end{array}$ \\
\hline Q25S05-90 & $\begin{array}{l}71878,69 \\
\end{array}$ & 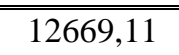 & $\begin{array}{l}17,63 \\
\end{array}$ & $\begin{array}{c}86687,27\end{array}$ & $\begin{array}{l}15267,44 \\
\end{array}$ & $\begin{array}{ll}17,61 \\
\end{array}$ & 4479 & 240,08 & 4,11 & 2505 \\
\hline Q4P01-0 & 76027,79 & 11620,36 & 15,28 & 92855,69 & 14346,13 & 15,45 & 470 & 212,4 & 3,51 & 505 \\
\hline Q4P01-90 & 71841,65 & 9668,32 & 13,46 & 86578,74 & 10951,30 & 12,65 & 433 & 209,06 & 3,84 & 460 \\
\hline Q4P04-0 & 83229,81 & 12499,99 & 15,02 & 102016,63 & 15328,05 & 15,03 & 474 & 209,34 & 3,73 & 507 \\
\hline Q4P04-90 & 79203,44 & 107848,17 & 136,17 & 107350,94 & 100739,99 & 93,84 & 479 & 209,34 & 3,73 & 507 \\
\hline Q4L04-0 & 58928,89 & 7115,68 & 12,08 & 69914,99 & 8454,99 & 12,09 & 478 & 212,81 & 3,64 & 507 \\
\hline Q4L04-90 & 64729,1 & 10021,79 & 15,48 & 77701,58 & 11962,39 & 15,40 & 477 & 212,12 & 4,25 & 506 \\
\hline Q4L08-0 & 86552,71 & 9125,78 & 10,54 & 104202,24 & 11329,23 & 10,87 & 474 & 212,24 & 3,5 & 506 \\
\hline Q4L08-90 & 81232,76 & 13026,21 & 16,04 & 97314,34 & 15631,38 & 16,06 & 467 & 215,45 & 3,02 & 507 \\
\hline Q4PL02-0 & 90212,16 & 13269,40 & 14,71 & 112483,05 & 17075,97 & 15,18 & 477 & 210,49 & 4,79 & 504 \\
\hline Q4PL02-90 & 90380,84 & 11404,61 & 12,62 & 112414,75 & 14389,65 & 12,80 & 435 & 208,54 & 3,16 & 468 \\
\hline Q4PL09-0 & 123490,84 & 28269,81 & 22,89 & 151390,11 & 35529,19 & 23,47 & 476 & 206,64 & 3,56 & 505 \\
\hline Q4PL09-90 & 81350,24 & 10617,97 & 13,05 & 99899,59 & 13174,08 & 13,19 & 473 & 208,63 & 3,95 & 505 \\
\hline
\end{tabular}

CPs - Corpos-de-prova $\quad$ MTM - Módulo de resiliência total médio $\quad$ DP - Desvio padrão $\quad$ MIM - Módulo instantâneo médio 
Tabela B.09. Resultados dos ensaios de módulo de resiliência para todas as misturas não envelhecidas (Média Total)

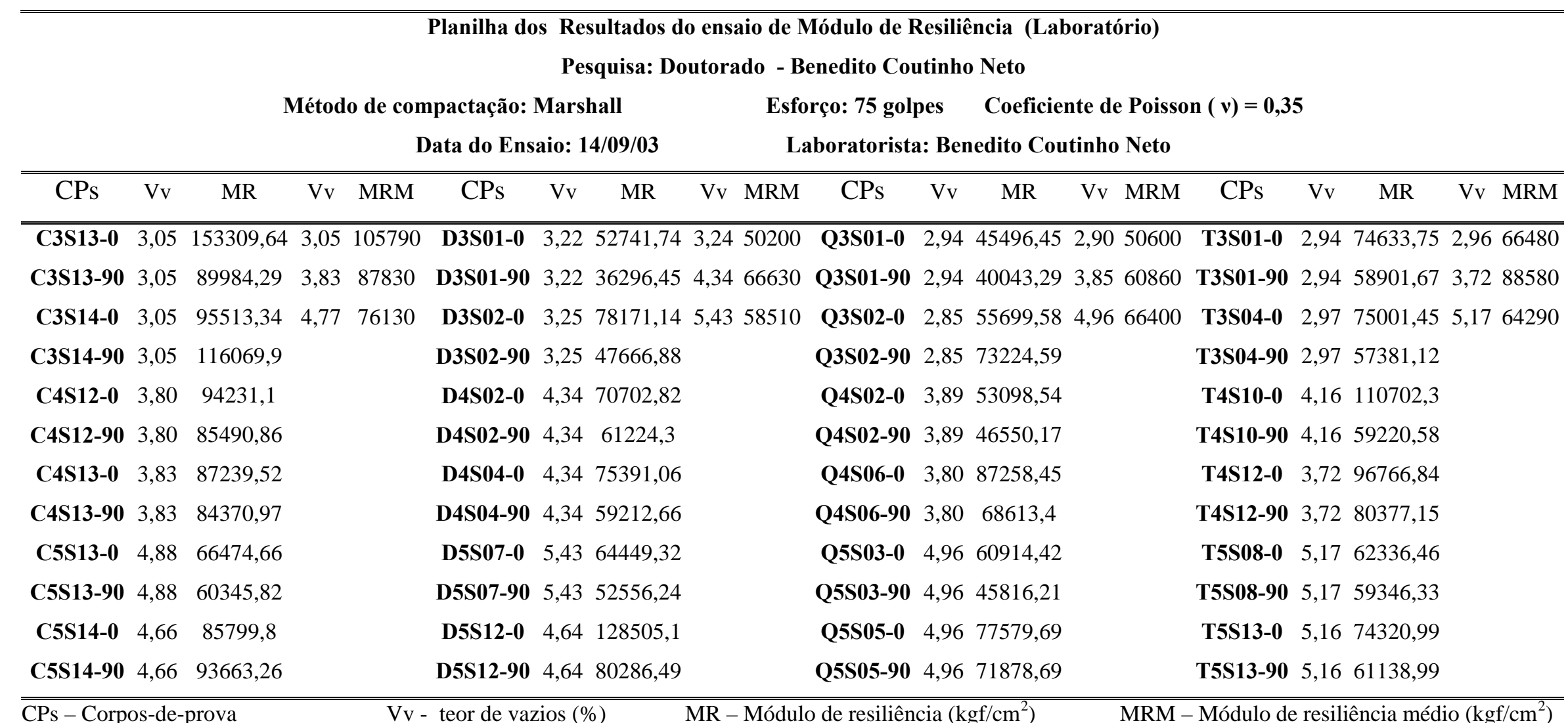


Tabela B.10. Resultados dos ensaios de módulo de resiliência para todas as misturas envelhecidas - 4\% de vazios (Média Total)

\begin{tabular}{|c|c|c|c|c|c|c|c|c|c|c|c|c|c|}
\hline \multicolumn{14}{|c|}{$\begin{array}{c}\text { Planilha dos } \\
\text { Pesultados do ensaio de Módulo de Resiliência (Laboratório) } \\
\text { Pesquisa: Doutorado - Benedito Coutinho Neto }\end{array}$} \\
\hline \multicolumn{14}{|c|}{$\begin{array}{l}\text { Método de compactação: Marshall } \\
\text { Data do Ensaio: 14/09/03 }\end{array}$} \\
\hline CPs & Cond & MR (kgf/cm2) & Cond, & MRM (kgf/cm2) & CPs & MR & MRM & CPs & MR & MRM & CPs & MR & MRM \\
\hline C4S12-0 & S.E & 94231,1 & S.E & 87833,11 & D4S02-0 & 70702,82 & 666632,71 & Q4S02-0 & 53098,54 & 60855 & T4S10-0 & 110702,25 & 88575 \\
\hline C4S13-0 & S.E & 87239,52 & E.L.P & 69980 & D4S04-0 & 75391,06 & 54862,27 & Q4S06-0 & 87258,45 & 72860,87 & T4S12-0 & 96766,84 & 68192,8 \\
\hline C4S13-90 & S.E & 84370,97 & E.L.C.P & 114620 & D4S04-90 & 59212,66 & 104992,29 & Q4S06-90 & 68613,40 & 87313,33 & T4S12-90 & 80377,15 & 117100,8 \\
\hline C4P11-0 & E.C.P & 86187,58 & & & D4P05-0 & 110832,78 & & Q4P01-0 & 76027,79 & & T4P05-0 & 171507,78 & \\
\hline C4P11-90 & E.C.P & 93885,52 & & Vv (\%) & D4P05-90 & 89572,63 & Vv (\%) & Q4P01-90 & 71841,65 & Vv (\%) & T4P05-90 & 128951,11 & Vv $(\%)$ \\
\hline C4P16-0 & E.C.P & 171634,11 & & S.E $-3,83$ & D4P11-0 & 92244,66 & 4,34 & Q4P04-0 & 83229,81 & 3,85 & T4P06-0 & 155849,93 & 3,72 \\
\hline C4L06-0 & E.L.P & 68058,15 & & E.L.P - 3,84 & D4L07-0 & 61006,64 & 3,83 & Q4L04-0 & 58928,89 & 3,86 & T4L06-0 & 70311,76 & 3,86 \\
\hline C4L06-90 & E.L.P & 69834,08 & & E.L.C.P - 4,51 & D4L07-90 & 51305,78 & 3,75 & Q4L04-90 & 64729,10 & 3,86 & T4L06-90 & 66342,98 & 4,58 \\
\hline C4L08-0 & E.L.P & 95781,69 & & & D4L09-0 & 59349,89 & & Q4L08-0 & 86552,71 & & T4L11-0 & 70870,59 & \\
\hline C4L08-90 & E.L.P & 72048,61 & & & D4L09-90 & 47786,76 & & Q4L08-90 & 81232,76 & & T4L11-90 & 65245,67 & \\
\hline C4PL04-0 & E.L.C.P & 117984,23 & & & D4PL06-0 & 98111,54 & & Q4PL02-0 & 90212,16 & & T4PL03-0 & 119173,95 & \\
\hline C4PL04-90 & E.L.C.P & 112392,82 & & & D4PL06-90 & 92822,74 & & Q4PL02-90 & 90380,84 & & T4PL03-90 & 113335,94 & \\
\hline C4PL14-0 & E.L.C.P & 138727,34 & & & D4PL14-0 & 106251,91 & & Q4PL09-0 & 123490,84 & & T4PL11-0 & 130111,36 & \\
\hline C4PL14-90 & E.L.C.P & 113487,95 & & & D4PL14-90 & 122782,98 & & Q4PL09-90 & 81350,24 & & T4PL11-90 & 105781,80 & \\
\hline
\end{tabular}

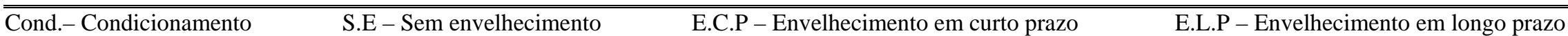

E.L.C.P - Envelhecimento em curto e em longo prazos $\quad$ MR - Módulo de resiliência $\quad$ MRM - Módulo de resiliência médio 
Tabela B.11. Resultados da Relação Módulo de Resiliência por Resistência à Tração - misturas não envelhecidas - teor de vazios (Média Total)

\begin{tabular}{|c|c|c|c|c|c|c|c|c|c|c|c|c|c|c|c|c|c|c|c|}
\hline \multicolumn{20}{|c|}{$\begin{array}{c}\text { Planilha dos Resultados da Relação Módulo de Resiliência por Resistência à Tração } \\
\text { Pesquisa: Doutorado - Benedito Coutinho Neto }\end{array}$} \\
\hline \multicolumn{20}{|c|}{$\begin{array}{l}\text { Método de compactação: Marshall } \\
\text { Data do Ensaio: } 17 / 09 / 03\end{array}$} \\
\hline $5 \%$ AF & $\mathbf{V v}$ & $\begin{array}{c}\text { MR } \\
\text { kgf/cm2 }\end{array}$ & $\begin{array}{c}\text { RT } \\
\mathrm{kgf} / \mathrm{cm} 2\end{array}$ & MR/RT & $10 \%$ AF & $\mathbf{V v}$ & $\begin{array}{c}\text { MR } \\
\mathrm{kgf} / \mathrm{cm} 2\end{array}$ & $\begin{array}{c}\text { RT } \\
\mathrm{kgf} / \mathrm{cm} 2\end{array}$ & MR/RT & $15 \%$ AF & $\mathbf{V v}$ & $\begin{array}{c}\text { MR } \\
\text { kgf/cm2 }\end{array}$ & $\begin{array}{c}\mathrm{RT} \\
\mathrm{kgf} / \mathrm{cm} 2\end{array}$ & MR/RT & $10 \%$ AV & $\mathbf{V v}$ & $\begin{array}{c}\text { MR } \\
\text { kgf/cm2 }\end{array}$ & $\begin{array}{c}\text { RT } \\
\text { kgf/cm2 }\end{array}$ & MR/RT \\
\hline C3S & 3,03 & 105790 & 14,86 & 7119,11 & D3S & 3,12 & 50200 & 14,35 & 3498,26 & Q3S & 2,81 & 50600 & 14,89 & 3398,25 & T3S & 2,93 & (266480 & 14,96 & 4443,85 \\
\hline $\mathrm{C} 4 \mathrm{~S}$ & 3,95 & 87830 & 16,18 & 5428,31 & D4S & 4,32 & 66630 & 15,1 & 4412,58 & Q4S & 3,63 & 60860 & 13,39 & 4545,18 & T4S & 3,81 & 88580 & 15,48 & 5722,22 \\
\hline $\mathrm{C} 5 \mathrm{~S}$ & 4,69 & 76130 & 15,02 & 5068,58 & D5S & 5,32 & 58510 & 16,47 & 3552,52 & Q5S & 4,98 & 66400 & 13,51 & 4914,88 & T5S & 5,19 & 64290 & 14,8 & 4343,92 \\
\hline
\end{tabular}

Tabela B.12. Resultados da Relação Módulo de Resiliência por Resistência à Tração - misturas não envelhecidas - teor de asfalto (Média

Total)

\begin{tabular}{|c|c|c|c|c|c|c|c|c|c|c|c|c|c|c|c|c|c|c|c|}
\hline \multicolumn{20}{|c|}{$\begin{array}{c}\text { Planilha dos Resultados da Relação Módulo de Resiliência por Resistência à Tração } \\
\text { Pesquisa: Doutorado - Benedito Coutinho Neto }\end{array}$} \\
\hline \multicolumn{20}{|c|}{$\begin{array}{l}\text { Método de compactação: Marshall } \\
\text { Data do Ensaio: } 17 / 09 / 03\end{array}$} \\
\hline $5 \%$ AF & $\mathrm{Ta}$ & $\begin{array}{c}\text { MR } \\
\text { kgf/cm2 }\end{array}$ & $\begin{array}{c}\mathrm{RT} \\
\mathrm{kgf} / \mathrm{cm} 2\end{array}$ & MR/RT & $10 \% A F$ & $\mathrm{Ta}$ & $\begin{array}{c}\text { MR } \\
\text { kgf/cm2 }\end{array}$ & $\begin{array}{c}\mathrm{RT} \\
\mathrm{kgf} / \mathrm{cm} 2\end{array}$ & MR/RT & $15 \% A F$ & $\mathrm{Ta}$ & $\begin{array}{c}\text { MR } \\
\text { kgf/cm2 }\end{array}$ & $\begin{array}{c}\text { RT } \\
\text { kgf/cm2 }\end{array}$ & MR/RT & $10 \% A V$ & $\mathrm{Ta}$ & $\begin{array}{c}\text { MR } \\
\text { kgf/cm2 }\end{array}$ & $\begin{array}{c}\text { RT } \\
\text { kgf/cm2 }\end{array}$ & MR/RT \\
\hline ב3S & 5,50 & 105790 & $\begin{array}{l}14,86 \\
\end{array}$ & $7 \overline{7119,11}$ & $\begin{array}{c}\text { D3S } \\
\end{array}$ & "6,20 & " 50200 & $\begin{array}{l}14,35 \\
\end{array}$ & $\begin{array}{l}3498,26 \\
\end{array}$ & 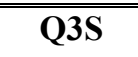 & "6,50 & 50600 & $\begin{array}{l}14,89 \\
\end{array}$ & 3398,25 & T3S & "5,90 & "66480 & 1414,96 & 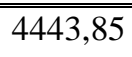 \\
\hline $\mathrm{C} 4 \mathrm{~S}$ & 5,20 & 87830 & 16,18 & 5428,31 & D4S & 5,50 & 66630 & 15,10 & 4412,58 & Q4S & 6,00 & 60860 & 13,39 & 4545,18 & T4S & 5,30 & 88580 & 15,48 & 5722,22 \\
\hline C5S & 4,90 & 76130 & 15,02 & 5068,58 & D5S & 5,10 & 58510 & 16,47 & 3552,52 & Q5S & 5,80 & 66400 & 13,51 & 4914,88 & T5S & 5,00 & 64290 & 14,80 & 4343,92 \\
\hline
\end{tabular}

AF - areia de fundição $\quad$ Ta - Teor de asfalto $\quad$ MR - Módulo de resiliência $\quad$ RT - Resistência à tração 
Tabela B.13. Resultados da Relação Módulo de Resiliência por Resistência à Tração - misturas envelhecidas - 4\% de vazios (Média Total)

Planilha dos Resultados da Relação Módulo de Resiliência por Resistência à Tração

Pesquisa: Doutorado - Benedito Coutinho Neto

Método de compactação: Marshall

Esforço: 75 golpes Coeficiente de Poisson ( v) $=0,35$

Data do Ensaio: 17/09/03

Laboratorista: Benedito Coutinho Neto

\begin{tabular}{|c|c|c|c|c|c|c|c|c|c|c|c|c|c|c|c|c|}
\hline $5 \%$ AF & $\begin{array}{c}\text { MR } \\
\mathrm{kgf} / \mathrm{cm} 2\end{array}$ & $\begin{array}{c}\text { RT } \\
\text { kgf/cm2 }\end{array}$ & & & & $\begin{array}{c}\text { MR } \\
\mathrm{kgf} / \mathrm{cm} 2\end{array}$ & $\begin{array}{c}\text { RT } \\
\mathrm{kgf} / \mathrm{cm} 2\end{array}$ & & & $\begin{array}{c}\text { MR } \\
\text { kgf/cm2 }\end{array}$ & $\begin{array}{c}\text { RT } \\
\mathrm{kgf} / \mathrm{cm} 2\end{array}$ & & & $\begin{array}{c}\text { MR } \\
\text { kgf/cm2 }\end{array}$ & $\begin{array}{c}\text { RT } \\
\mathrm{kgf} / \mathrm{cm} 2\end{array}$ & MR/RT \\
\hline $\mathrm{C} 4 \mathrm{~S}$ & & & & & & & & & & & & & & & & \\
\hline C4P & 109930 & 18,55 & E.C.P & 5926,15 & D4P & 98670 & 13,31 & 7413,22 & Q4P & 77580 & 16,28 & 4765,36 & T4P & 163680 & 20,04 & 8167,66 \\
\hline C4L & 69980 & 17,6 & E.L.P & 3976,14 & & 54870 & 15,53 & 3533,16 & Q4L & 72860 & 13,23 & 5507,18 & T4L & 68190 & 16,84 & \\
\hline C4PL & 114620 & 19,86 & E.L.C.P & 5771,40 & D4PL & 104990 & 12,72 & 8253,93 & Q4PL & 87310 & 13,35 & 6540,07 & T4PL & 117100 & 19,63 & 5965,36 \\
\hline
\end{tabular}

AF - areia de fundição $\quad$ Ta - Teor de asfalto $\quad$ MR - Módulo de resiliência

$\begin{array}{ll}\text { E.C.P - Envelhecimento em curto prazo } & \text { E.L.P - Envelhecimento em longo prazo }\end{array}$

RT - Resistência à tração

S.E - Sem envelhecimento

E.L.C.P - Envelhecimento em curto e em longo prazos 
Tabela B.14. Resultados dos ensaios de fluência uniaxial para todas as condições experimentais (misturas) no nível de tensão de 0,1 MPa, exceto os dos módulos de fluência

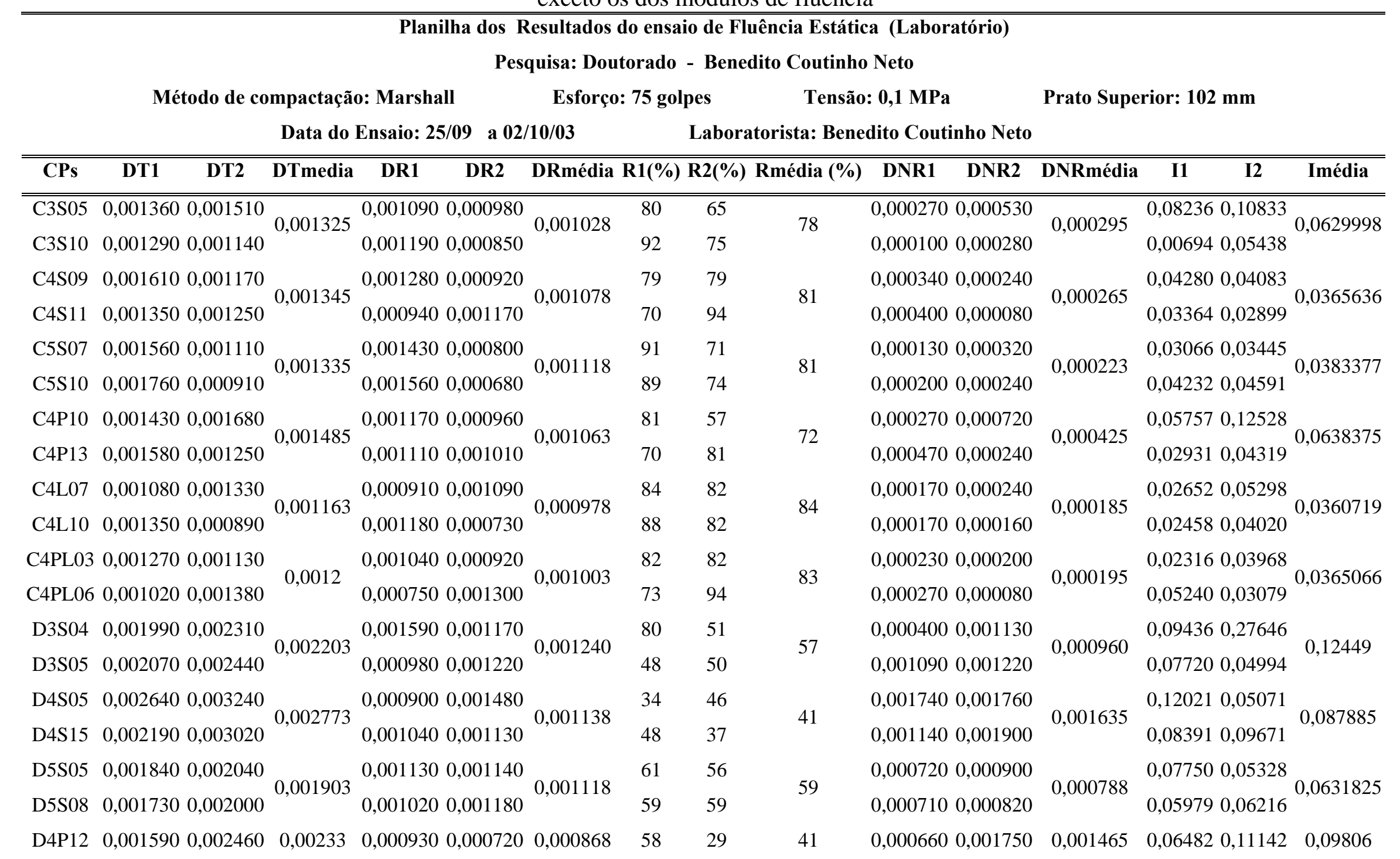




\begin{tabular}{|c|c|c|c|c|c|c|c|c|c|c|c|c|c|c|c|}
\hline CPs & 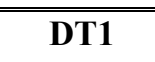 & $\overline{\text { DT2 }}$ & DTmedia & $\overline{\text { DR1 }}$ & $\overline{\text { DR2 }}$ & DRmédia & R1(\%) & R2(\%) & Rmédia (\%) & " DNR1 & " DNR2 & DNRmédia & 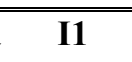 & 12 & Imédia \\
\hline D4P15 & 0,002070 & 0,003200 & & 0,001100 & 0,000720 & & 53 & 22 & & 0,000970 & 0,002480 & & 0,09354 & 0,12246 & \\
\hline D4L06 & 0,003500 & 0,001360 & \multirow{2}{*}{0,002403} & 0,001130 & 0,000840 & \multirow{2}{*}{0,000925} & 32 & 62 & \multirow{2}{*}{42} & 0,002370 & 0,000520 & \multirow{2}{*}{ 0,001475 } & 0,15301 & 0,09893 & \multirow{2}{*}{0,121555} \\
\hline D4L14 & 0,002620 & 0,002130 & & 0,000970 & 0,000760 & & 37 & 36 & & 0,001640 & 0,001370 & & 0,13767 & 0,09661 & \\
\hline D4PL01 & 0,002270 & 0,002000 & \multirow{2}{*}{0,002283} & 0,000840 & 0,000880 & \multirow{2}{*}{0,000905} & 37 & 44 & \multirow{2}{*}{39} & 0,001440 & 0,001120 & \multirow{2}{*}{ 0,001383 } & 0,11910 & 0,09836 & \multirow{2}{*}{0,1170475} \\
\hline D4PL02 & 0,003230 & 0,001630 & & 0,001300 & 0,000600 & & 40 & 37 & & 0,001930 & 0,001040 & & 0,13568 & 0,11505 & \\
\hline Q3S06 & 0,002610 & 0,002810 & \multirow{2}{*}{0,002783} & 0,001140 & 0,001200 & \multirow{2}{*}{0,001220} & 44 & 43 & \multirow[b]{2}{*}{44} & 0,001470 & 0,001600 & \multirow[b]{2}{*}{0,001563} & 0,07543 & 0,04113 & \multirow{2}{*}{0,0537375} \\
\hline Q3S07 & 0,002010 & 0,003700 & & 0,001010 & 0,001530 & & 50 & 41 & & 0,001010 & 0,002170 & & 0,04502 & 0,05338 & \\
\hline Q4S05 & 0,002330 & 0,003750 & \multirow{2}{*}{0,002943} & 0,001160 & 0,001080 & \multirow{2}{*}{0,001085} & 50 & 29 & \multirow{2}{*}{40} & 0,001170 & 0,002670 & \multirow[b]{2}{*}{ 0,001855 } & 0,07040 & 0,11643 & \multirow{2}{*}{0,1201473} \\
\hline Q4S11 & 0,002080 & 0,003610 & & 0,001100 & 0,001000 & & 53 & 28 & & 0,000970 & 0,002610 & & 0,06692 & 0,22684 & \\
\hline Q5S01 & 0,002180 & 0,001500 & \multirow{2}{*}{0,001948} & 0,001290 & 0,000910 & \multirow{2}{*}{0,001123} & 59 & 61 & \multirow{2}{*}{56} & 0,000890 & 0,000590 & \multirow{2}{*}{ 0,000825 } & 0,05627 & 0,07182 & \multirow{2}{*}{0,0733565} \\
\hline Q5S02 & 0,001650 & 0,002460 & & 0,000660 & 0,001630 & & 40 & 66 & & 0,000990 & 0,000830 & & 0,12212 & 0,04321 & \\
\hline Q4P07 & 0,003840 & 0,001160 & \multirow{2}{*}{0,002608} & 0,001440 & 0,000680 & \multirow{2}{*}{0,001015} & 37 & 59 & \multirow{2}{*}{43} & 0,002410 & 0,000480 & 0001505 & 0,11808 & 0,06643 & \\
\hline Q4P10 & 0,003630 & 0,001800 & & 0,001100 & 0,000840 & & 30 & 47 & & 0,002530 & 0,000960 & 0,001393 & 0,10253 & 0,14578 & \\
\hline Q4L15 & 0,003150 & 0,002410 & & 0,001240 & 0,000720 & & 39 & 30 & & 0,001910 & 0,001680 & & 0,12003 & 0,15077 & \\
\hline Q4L18 & 0,002380 & 0,002850 & 0,002698 & 0,001070 & 0,000920 & 0,000988 & 45 & 32 & 37 & 0,001310 & 0,001930 & 0,001708 & 0,12334 & 0,16277 & \\
\hline Q4Pl11 & 0,001500 & 0,005340 & & 0,001000 & 0,001000 & & 67 & 19 & & 0,000500 & 0,004350 & & 0,11092 & 0,24963 & \\
\hline Q4PL12 & 0,002930 & 0,002680 & 0,003113 & 0,001000 & 0,000840 & 0,000960 & 34 & 31 & 38 & 0,001930 & 0,001840 & 0,002155 & 0,14004 & 0,14026 & \\
\hline T3S03 & 0,001970 & 0,002270 & & 0,000910 & 0,001010 & & 47 & 45 & & 0,001050 & 0,001260 & & 0,08759 & 0,11885 & \\
\hline T3S14 & 0,002160 & 0,001860 & 0,002065 & 0,001010 & 0,000890 & 0,000955 & 47 & 48 & 40 & 0,001150 & 0,000970 & 0,001108 & 0,09015 & 0,07598 & 0,093141 \\
\hline T4S16 & 0,001670 & 0,001640 & & 0,000430 & 0,001360 & & 26 & 83 & & 0,001230 & 0,000280 & & 0,09671 & 0,03565 & \\
\hline T4S17 & 0,001140 & 0,002320 & 0,001693 & 0,000430 & 0,001440 & 0,000915 & 38 & 62 & 52 & 0,000700 & 0,000880 & 0,000773 & 0,11276 & 0,05556 & \\
\hline T5S06 & 0,002560 & 0,001720 & 0002175 & 0,001300 & 0,000960 & 0001140 & 51 & 56 & 53 & 0,001270 & 0,000760 & 0001038 & 0,05916 & 0,05753 & \\
\hline T5S14 & 0,002120 & 0,002300 & $0,0021 / 5$ & 0,001230 & 0,001070 & 0,001140 & 58 & 47 & 53 & 0,000890 & 0,001230 & 0,001030 & 0,05277 & 0,07615 & \\
\hline Т4P07 & 0,001240 & 0,004090 & & 0,000970 & 0,000920 & & 78 & 23 & 16 & 0,000270 & 0,003170 & & 0,05342 & 0,22955 & \\
\hline T4P10 & 0,002700 & 0,002280 & $0,00_{2}$ & 0,001200 & 0,000840 & 0,000983 & 44 & 37 & 46 & 0,001500 & 0,001440 & 0,001595 & 0,14318 & 0,10521 & \\
\hline
\end{tabular}




\begin{tabular}{|c|c|c|c|c|c|c|c|c|c|c|c|c|c|c|c|}
\hline CPs & DT1 & DT2 & DTmedia & DR1 & DR2 & DRmédia & R1(\%) & R2(\%) & Rmédia (\%) & 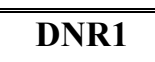 & DNR2 & DNRmédia & I1 & 12 & Imédia \\
\hline "T4L04 & 0,002710 & 0,001650 & \multirow{2}{*}{0,002048} & 0,001210 & 0,000520 & \multirow[t]{2}{*}{0,000838} & 44 & 32 & \multirow[t]{2}{*}{40} & 0,001510 & 0,001120 & \multirow[t]{2}{*}{0,001210} & "0,09339 & $0,11966 \mathrm{C}$ & \multirow[t]{2}{*}{0,1030095} \\
\hline T4L18 & 0,002660 & 0,001170 & & 0,001180 & 0,000440 & & 44 & 38 & & 0,001480 & 0,000730 & & 0,06779 & 0,13120 & \\
\hline T4PL14 & 0,001760 & 0,002150 & \multirow{2}{*}{0,00207} & 0,000900 & 0,000640 & \multirow{2}{*}{0,000773} & 51 & 30 & \multirow{2}{*}{38} & 0,000860 & 0,001510 & \multirow{2}{*}{0,001298} & 0,11630 & 0,14402 & \multirow{2}{*}{0,139677} \\
\hline T4PL16 & 0,002260 & 0,002110 & & 0,000830 & 0,000720 & & 37 & 34 & & 0,001430 & 0,001390 & & 0,15369 & 0,14470 & \\
\hline
\end{tabular}

DRmédia - Deformação recuperável média (mm/mm) R - Recuperação no extensômetro ～DNR - Deformação não recuperável $\quad$ I - Inclinação

Tabela B.15. Resultados dos ensaios de fluência uniaxial para todas as condições experimentais (misturas) no nível de tensão 0,4 MPa, com prato superior de $102 \mathrm{~mm}$, exceto os dos módulos de fluência

Planilha dos Resultados do ensaio de Fluência Estática (Laboratório)

Pesquisa: Doutorado - Benedito Coutinho Neto

Método de compactação: Marshall

Esforço: 75 golpes

Tensão: 0,4 MPa

Prato Superior: $102 \mathrm{~mm}$

Data do Ensaio: 22 a 24/09 e 02 a $08 / 10 / 03$

Laboratorista: Benedito Coutinho Neto

\begin{tabular}{|c|c|c|c|c|c|c|c|c|c|c|c|c|c|c|c|}
\hline CPs & DT1 & DT2 & DTmedia & DR1 & DR2 & DRmédia & R1(\%) & R2(\%) & Rmédia (\%) & DNR1 & DNR2 & DNRmédia & I1 & 12 & Imédia \\
\hline C3S05 & 0,00313 & 0,00419 & \multirow{2}{*}{0,00328} & 0,00251 & 0,00232 & \multirow{2}{*}{0,00219} & 80 & 55 & \multirow{2}{*}{68} & 0,00061 & 0,00187 & \multirow{2}{*}{0,00108} & 0,02904 & 0,08094 & \multirow{2}{*}{0,0498377} \\
\hline C3S10 & 0,00258 & 0,00252 & & 0,00264 & 0,00175 & & 103 & 69 & & $-0,00007$ & 0,00077 & & $-0,02272$ & 0,03953 & \\
\hline C4S09 & 0,00403 & 0,00330 & \multirow{2}{*}{0,00360} & 0,00346 & 0,00129 & \multirow{2}{*}{0,00232} & 86 & 39 & \multirow{2}{*}{63} & 0,00057 & 0,00201 & \multirow{2}{*}{0,00128} & 0,01566 & 0,05716 & \multirow{2}{*}{0,0489994} \\
\hline C4S11 & 0,00435 & 0,00271 & & 0,00273 & 0,00178 & & 63 & 66 & & 0,00162 & 0,00093 & & 0,07044 & 0,05273 & \\
\hline C5S07 & 0,00469 & 0,00247 & \multirow{2}{*}{0,00372} & 0,00286 & 0,00151 & \multirow{2}{*}{0,00225} & 61 & 61 & \multirow{2}{*}{60} & 0,00183 & 0,00095 & \multirow{2}{*}{0,00147} & 0,01255 & 0,11092 & \multirow{2}{*}{0,0652409} \\
\hline C5S10 & 0,00481 & 0,00290 & & 0,00315 & 0,00147 & & 66 & 51 & & 0,00166 & 0,00143 & & 0,03220 & 0,10530 & \\
\hline C4P10 & 0,00500 & 0,00387 & \multirow{2}{*}{0,00404} & 0,00173 & 0,00304 & \multirow{2}{*}{0,00236} & 35 & 78 & \multirow{2}{*}{61} & 0,00327 & 0,00084 & \multirow{2}{*}{0,00168} & 0,10154 & 0,12884 & \multirow{2}{*}{0,0858484} \\
\hline C4P13 & 0,00380 & 0,00347 & & 0,00225 & 0,00242 & & 59 & 70 & & 0,00155 & 0,00105 & & 0,05977 & 0,05325 & \\
\hline C4L07 & 0,00273 & 0,00420 & \multirow{2}{*}{0,00371} & 0,00189 & 0,00230 & \multirow{2}{*}{0,00208} & 69 & 55 & \multirow{2}{*}{58} & 0,00084 & 0,00190 & \multirow{2}{*}{0,00164} & 0,03294 & 0,06430 & \multirow{2}{*}{0,0609407} \\
\hline C4L10 & 0,00294 & 0,00498 & & 0,00193 & 0,00219 & & 66 & 44 & & 0,00101 & 0,00280 & & 0,05571 & 0,09082 & \\
\hline
\end{tabular}




\begin{tabular}{|c|c|c|c|c|c|c|c|c|c|c|c|c|c|c|c|}
\hline CPs & DT1 & DT2 & DTmedia & DR1 & DR2 & DRmédia & R1(\%) & R2(\%) & Rmédia (\%) & DNR1 & DNR2 & DNRmédia & I1 & I2 & Imédia \\
\hline C4PL03 & $\begin{array}{l}0,00292 \\
\end{array}$ & $\begin{array}{l}0,00406 \\
\end{array}$ & \multirow[t]{2}{*}{0,00353} & 0,00137 & 0,00285 & \multirow[t]{2}{*}{0,00208} & 47 & 70 & \multirow[t]{2}{*}{59} & 0,00154 & $\begin{array}{l}0,00120 \\
\end{array}$ & \multirow[t]{2}{*}{0,00145} & 0,07354 & 0,05000 & \multirow[t]{2}{*}{0,0702765} \\
\hline C4PL06 & 0,00247 & 0,00467 & & 0,00163 & 0,00248 & & 66 & 53 & & 0,00085 & 0,00219 & & 0,08375 & 0,07382 & \\
\hline D3S04 & 0,00368 & 0,00368 & \multirow{2}{*}{0,00352} & 0,00283 & 0,00178 & \multirow{2}{*}{0,00230} & 77 & 48 & \multirow{2}{*}{68} & 0,00084 & 0,00190 & \multirow{2}{*}{0,00122} & 0,04092 & 0,10381 & \multirow{2}{*}{0,0606946} \\
\hline D3S05 & 0,00441 & 0,00232 & & 0,00261 & 0,00199 & & 59 & 86 & & 0,00180 & 0,00033 & & 0,07634 & 0,02172 & \\
\hline D4S05 & 0,00401 & 0,00364 & \multirow{2}{*}{0,00359} & 0,00287 & 0,00160 & \multirow{2}{*}{0,00217} & 72 & 44 & \multirow{2}{*}{60} & 0,00114 & 0,00204 & \multirow{2}{*}{0,00142} & 0,02232 & 0,12275 & \multirow{2}{*}{0,0874497} \\
\hline D4S15 & 0,00316 & 0,00355 & & 0,00222 & 0,00197 & & 70 & 56 & & 0,00094 & 0,00157 & & 0,06899 & 0,13575 & \\
\hline D5S05 & 0,00324 & 0,00282 & \multirow{2}{*}{0,00281} & 0,00239 & 0,00184 & \multirow{2}{*}{0,00208} & 74 & 65 & \multirow{2}{*}{74} & 0,00085 & 0,00098 & \multirow{2}{*}{0,00073} & 0,03119 & 0,04008 & \multirow{2}{*}{ 0,0363299 } \\
\hline D5S08 & 0,00285 & 0,00232 & & 0,00245 & 0,00163 & & 86 & 70 & & 0,00041 & 0,00069 & & 0,02962 & 0,04442 & \\
\hline D4P12 & 0,00232 & 0,00274 & \multirow{2}{*}{0,00268} & 0,00199 & 0,00167 & \multirow{2}{*}{0,00192} & 86 & 61 & \multirow{2}{*}{71} & 0,00033 & 0,00107 & \multirow{2}{*}{0,00076} & 0,03255 & 0,05309 & \multirow{2}{*}{0,0522648} \\
\hline D4P15 & 0,00317 & 0,00248 & & 0,00260 & 0,00140 & & 82 & 56 & & 0,00057 & 0,00108 & & 0,04837 & 0,07505 & \\
\hline D4L06 & 0,00407 & 0,00432 & \multirow{2}{*}{0,00401} & 0,00213 & 0,00232 & \multirow{2}{*}{0,00214} & 52 & 54 & \multirow{2}{*}{53} & 0,00193 & 0,00200 & & 0,09673 & 0,06199 & \\
\hline D4L14 & 0,00463 & 0,00301 & & 0,00255 & 0,00157 & & 55 & 52 & & 0,00208 & 0,00145 & 0,00187 & 0,08461 & 0,06561 & \\
\hline D4PL01 & 0,00331 & 0,00252 & & 0,00217 & 0,00152 & & 66 & 60 & & 0,00114 & 0,00100 & & 0,06026 & 0,06513 & \\
\hline D4PL02 & 0,00466 & 0,00235 & & 0,00299 & 0,00104 & & 64 & 44 & & 0,00166 & 0,00131 & & 0,07147 & 0,11473 & \\
\hline Q3S06 & 0,00472 & 0,00385 & & 0,00274 & 0,00249 & & 58 & 65 & 54 & 0,00197 & 0,00136 & & 0,07017 & 0,04847 & \\
\hline Q3S07 & 0,00419 & 0,00603 & $0,004 / 0$ & 0,00252 & 0,00326 & 0,0027 & 60 & 54 & J5 & 0,00168 & 0,00277 & $0,0015 J$ & 0,04356 & 0,06182 & ל. \\
\hline Q4S05 & 0,00489 & 0,00335 & 00397 & 0,00336 & 0,00172 & ( 00 & 69 & 51 & 60 & 0,00153 & 0,00164 & & 0,06884 & 0,11768 & \\
\hline Q4S11 & 0,00301 & 0,00441 & 0,00392 & 0,00207 & 0,00233 & $0,00<3 /$ & 69 & 53 & 60 & 0,00094 & 0,00209 & 0,00155 & 0,08035 & 0,08733 & 0,088548 \\
\hline Q5S01 & 0,00373 & 0,00332 & & 0,00284 & 0,00214 & & 76 & 64 & & 0,00089 & 0,00119 & & 0,02728 & 0,04750 & \\
\hline Q5S02 & 0,00453 & 0,00273 & 0,00358 & 0,00291 & 0,00178 & 0,00242 & 64 & 65 & $6 /$ & 0,00162 & 0,00095 & 0,00116 & 0,07105 & 0,06124 & $0,051 / 658$ \\
\hline Q4P07 & 0,00181 & 0,00569 & & 0,00144 & 0,00321 & & 80 & 56 & & 0,00037 & 0,00248 & & $-0,01300$ & 0,11894 & \\
\hline Q4P10 & 0,00473 & 0,00375 & $0,004 / 2$ & 0,00263 & 0,00196 & $0,00 \angle 00$ & 56 & 52 & 55 & 0,00210 & 0,00180 & 0,00213 & 0,08009 & 0,09698 & \\
\hline Q4L15 & 0,00402 & 0,00465 & 00420 & 0,00204 & 0,00229 & R & 51 & 49 & 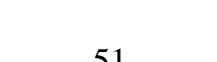 & 0,00198 & 0,00237 & & 0,08915 & 0,09072 & \\
\hline Q4L18 & 0,00389 & 0,00422 & $0,004<0$ & 0,00204 & 0,00225 & $0,00<10$ & 53 & 53 & J1 & 0,00184 & 0,00197 & $0,00<04$ & 0,11324 & 0,09206 & 0,0902932 \\
\hline Q4Pl11 & 0,00715 & 0,00195 & 0,00447 & 0,00306 & 0,00128 & 0,00216 & 43 & 65 & 51 & 0,00409 & 0,00068 & 0,00231 & 0,10584 & 0,04115 & 0,0817216 \\
\hline
\end{tabular}




\begin{tabular}{|c|c|c|c|c|c|c|c|c|c|c|c|c|c|c|c|}
\hline CPs & DT1 & DT2 & DTmedia & DR1 & DR2 & DRmédia & R1(\%) & R2(\%) & Rmédia (\%) & DNR1 & DNR2 & DNRmédia & I1 & 12 & Imédia \\
\hline Q44PL12 & $\begin{array}{l}0,00437 \\
\end{array}$ & $\begin{array}{c}0,00439 \\
\end{array}$ & & 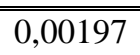 & 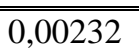 & & $4 \overline{45}$ & $\overline{53}$ & & $\begin{array}{c}0,00240 \\
\end{array}$ & $\begin{array}{c}0,00208 \\
\end{array}$ & & (0,09558 & 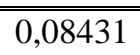 & \\
\hline T3S03 & 0,00471 & 0,00260 & \multirow{2}{*}{0,00340} & 0,00274 & 0,00163 & \multirow{2}{*}{0,00212} & 58 & 63 & \multirow[b]{2}{*}{63} & 0,00197 & 0,00096 & \multirow{2}{*}{0,00128} & 0,07303 & 0,05169 & \multirow{2}{*}{0,070538} \\
\hline T3S14 & 0,00341 & 0,00287 & & 0,00209 & 0,00202 & & 61 & 70 & & 0,00132 & 0,00085 & & 0,08368 & 0,07375 & \\
\hline T4S16 & 0,00366 & 0,00176 & \multirow{2}{*}{0,00271} & 0,00320 & 0,00084 & \multirow{2}{*}{0,00201} & 87 & 48 & \multirow{2}{*}{71} & 0,00047 & 0,00092 & \multirow{2}{*}{0,00070} & 0,02263 & 0,06484 & \multirow{2}{*}{0,044720} \\
\hline T4S17 & 0,00297 & 0,00244 & & 0,00197 & 0,00204 & & 66 & 84 & & 0,00100 & 0,00040 & & 0,04836 & 0,04306 & \\
\hline T5S06 & 0,00253 & 0,00351 & \multirow{2}{*}{0,00301} & 0,00206 & 0,00255 & \multirow{2}{*}{0,00232} & 82 & 73 & \multirow{2}{*}{78} & 0,00047 & 0,00096 & \multirow{2}{*}{0,00069} & 0,01924 & 0,05292 & \multirow{2}{*}{0,0371042} \\
\hline T5S14 & 0,00305 & 0,00294 & & 0,00242 & 0,00226 & & 79 & 77 & & 0,00063 & 0,00068 & & 0,03385 & 0,04240 & \\
\hline T4P07 & 0,00385 & 0,00213 & \multirow{2}{*}{0,00307} & 0,00248 & 0,00185 & \multirow{2}{*}{0,00217} & 64 & 87 & \multirow{2}{*}{73} & 0,00137 & 0,00028 & \multirow{2}{*}{0,00091} & 0,05093 & 0,06993 & \multirow{2}{*}{0,0524165} \\
\hline T4P10 & 0,00394 & 0,00236 & & 0,00257 & 0,00176 & & 65 & 75 & & 0,00137 & 0,00060 & & 0,05853 & 0,03028 & \\
\hline T4L04 & 0,00425 & 0,00253 & \multirow{2}{*}{0,00324} & 0,00265 & 0,00149 & \multirow{2}{*}{0,00198} & 62 & 59 & \multirow[b]{2}{*}{61} & 0,00161 & 0,00104 & \multirow{2}{*}{0,00126} & 0,04544 & 0,08233 & \multirow{2}{*}{0,0791071} \\
\hline T4L18 & 0,00293 & 0,00323 & & 0,00219 & 0,00157 & & 75 & 49 & & 0,00074 & 0,00165 & & 0,07953 & 0,10913 & \\
\hline T4PL14 & 0,00272 & 0,00246 & \multirow{2}{*}{0,00253} & 0,00202 & 0,00143 & \multirow{2}{*}{0,00173} & 74 & 58 & \multirow{2}{*}{68} & 0,00070 & 0,00103 & \multirow{2}{*}{0,00080} & 0,06573 & 0,11189 & \multirow{2}{*}{0,0916115} \\
\hline T4PL16 & 0,00279 & 0,00215 & & 0,00202 & 0,00143 & & 73 & 67 & & 0,00076 & 0,00072 & & 0,08981 & 0,09901 & \\
\hline
\end{tabular}

CPs - corpos-de-prova

DT1 - Deformação total no extensômetro 1

DT2 - Deformação total no extensômetro 2

DR - Deformação recuperável

DRmédia - Deformação recuperável média (mm/mm) R - Recuperação no extensômetro ～DNR - Deformação não recuperável $\quad$ I - Inclinação 
Tabela B.16. Resultados dos ensaios de fluência uniaxial para todas as condições experimentais (misturas) no nível de tensão 0,4 MPa, com prato superior de $51 \mathrm{~mm}$, exceto os dos módulos de fluência

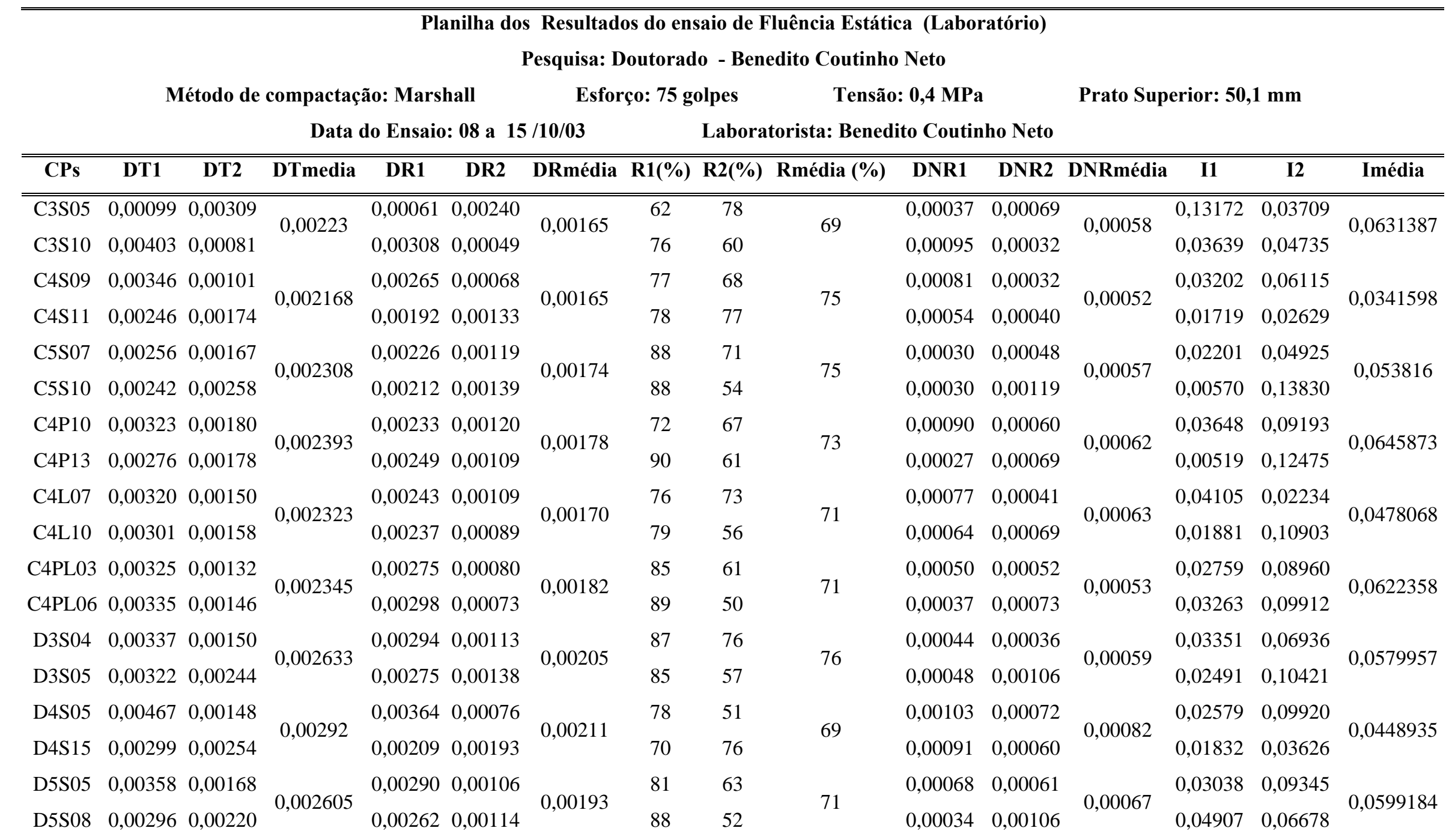




\begin{tabular}{|c|c|c|c|c|c|c|c|c|c|c|c|c|c|c|c|}
\hline CPs & DT1 & DT2 & DTmedia & DR1 & DR2 & DRmédia & R1(\%) & R2(\%) & Rmédia (\%) & DNR1 & DNR2 & DNRmédia & I1 & 12 & Imédia \\
\hline D4P12 & 0,00282 & 0,00230 & \multirow{2}{*}{0,002555} & 0,00212 & 0,00163 & \multirow{2}{*}{0,00195} & 75 & 71 & \multirow{2}{*}{73} & 0,00070 & 0,00067 & \multirow{2}{*}{0,00061} & 0,02353 & 0,04195 & \multirow{2}{*}{0,0443903} \\
\hline D4P15 & 0,00330 & 0,00180 & & 0,00307 & 0,00096 & & 93 & 53 & & 0,00023 & 0,00084 & & 0,02720 & 0,08489 & \\
\hline D4L06 & 0,00300 & 0,00240 & \multirow{2}{*}{0,002763} & 0,00243 & 0,00156 & \multirow{2}{*}{0,00196} & 81 & 65 & \multirow{2}{*}{68} & 0,00057 & 0,00084 & \multirow{2}{*}{0,00080} & 0,05201 & 0,09976 & \multirow{2}{*}{0,0859533} \\
\hline D4L14 & 0,00376 & 0,00189 & & 0,00292 & 0,00093 & & 78 & 49 & & 0,00084 & 0,00096 & & 0,03417 & 0,15788 & \\
\hline D4PL01 & 0,00364 & 0,00120 & \multirow{2}{*}{0,002458} & 0,00277 & 0,00076 & \multirow{2}{*}{0,00183} & 76 & 63 & & 0,00087 & 0,00044 & \multirow{2}{*}{0,00063} & 0,05882 & 0,07545 & \multirow{2}{*}{0,0641011} \\
\hline D4PL02 & 0,00383 & 0,00116 & & 0,00313 & 0,00064 & & 82 & 55 & & 0,00070 & 0,00052 & & 0,03467 & 0,08746 & \\
\hline Q3S06 & 0,00345 & 0,00181 & \multirow{2}{*}{0,002765} & 0,00301 & 0,00144 & \multirow{2}{*}{0,00231} & 87 & 80 & & 0,00044 & 0,00036 & \multirow{2}{*}{0,00046} & 0,02299 & 0,02621 & \multirow{2}{*}{0,0263698} \\
\hline Q3S07 & 0,00315 & 0,00265 & & 0,00272 & 0,00205 & & 86 & 77 & & 0,00044 & 0,00060 & & 0,02183 & 0,03446 & \\
\hline Q4S05 & 0,00493 & 0,00156 & \multirow[t]{2}{*}{0,003053} & 0,00320 & 0,00116 & \multirow[t]{2}{*}{0,00212} & 65 & 74 & \multirow[t]{2}{*}{69} & 0,00173 & 0,00040 & \multirow[t]{2}{*}{0,00093} & 0,05910 & 0,06437 & \multirow[t]{2}{*}{0,0865677} \\
\hline Q4S11 & 0,00355 & 0,00217 & & 0,00291 & 0,0012 & & 82 & 56 & & 0,00064 & 0,00096 & & 0,06246 & 0,16034 & \\
\hline Q5S01 & 0,00284 & 0,00305 & \multirow{2}{*}{0,002868} & 0,00221 & 0,00218 & \multirow{2}{*}{0,00216} & 78 & 71 & \multirow{2}{*}{74} & 0,00063 & 0,00087 & & 0,01965 & 0,05676 & \\
\hline Q5S02 & 0,00324 & 0,00234 & & 0,00288 & 0,00135 & & 89 & 58 & & 0,00036 & 0,00099 & 0,00071 & 0,00760 & 0,13443 & \\
\hline Q4P07 & 0,00421 & 0,00168 & & 0,00354 & 0,00096 & & 84 & 57 & & 0,00067 & 0,00072 & & 0,04754 & 0,09261 & \\
\hline Q4P10 & 0,0048 & 0,00144 & & 0,0031 & 0,00116 & & 65 & 81 & & 0,0017 & 0,00028 & & 0,08118 & 0,10067 & 4988 \\
\hline Q4L15 & 0,00412 & 0,00148 & & 0,00295 & 0,00088 & & 72 & 59 & & 0,00117 & 0,0006 & & 0,07836 & 0,08273 & \\
\hline Q4L181 & 0,00362 & 0,00257 & 2540 & 0,00254 & 0,0016 & & 70 & 62 & & 0,00107 & 0,00096 & & 0,07645 & 0,13566 & (075) \\
\hline Q4PL11 & 0,00396 & 0,00159 & & 0,00326 & 0,0008 & & 82 & 50 & 66 & 0,0007 & 0,0008 & & 0,06239 & 0,12774 & \\
\hline Q4PL12 & 0,00347 & 0,002 & 0,002753 & 0,0026 & 0,00116 & 0,00196 & 75 & 58 & 60 & 0,00087 & 0,00084 & 0,00080 & 0,08356 & 0,15183 & $0,1063 / 95$ \\
\hline T3S03 & 0,00363 & 0,00134 & & 0,00342 & 0,00049 & & 94 & 36 & & 0,0002 & 0,00085 & & 0,00551 & 0,19150 & \\
\hline T3S14 & 0,00341 & 0,00154 & 0,00248 & 0,00307 & 0,00081 & 0,00195 & 90 & 53 & 68 & 0,00034 & 0,00073 & 0,00053 & 0,03367 & 0,09557 & \\
\hline T4S16 & 0,00357 & 0,00128 & & 0,00353 & 0,00052 & & 99 & 41 & & 0,00003 & 0,00076 & & 0,01772 & 0,07467 & \\
\hline T4S17 & 0,00311 & 0,0018 & $0,00<44$ & 0,00284 & 0,00108 & ,00199 & 91 & 60 & 13 & 0,00027 & 0,00072 & 0,00045 & 0,01783 & 0,09305 & 0,0508189 \\
\hline T5S06 & 0,00346 & 0,00132 & & 0,0033 & 0,00072 & & 95 & 55 & & 0,00017 & 0,0006 & & 0,01287 & 0,08402 & \\
\hline T5S14 & 0,00364 & 0,00191 & 0,00<J0د & 0,00318 & 0,00111 & $0,00 \angle 00$ & 87 & 58 & 14 & 0,00046 & 0,0008 & 0,00031 & 0,01376 & 0,08449 & $0,040 / 0$ \\
\hline T4P07 & 0,00291 & 0,00229 & 0,002698 & 0,00211 & 0,00205 & 0,00210 & 72 & 90 & 78 & 0,0008 & 0,00024 & 0,00060 & 0,05541 & 0,02045 & 0,0489609 \\
\hline
\end{tabular}




\begin{tabular}{|c|c|c|c|c|c|c|c|c|c|c|c|c|c|c|c|}
\hline CPs & DT1 & $\begin{array}{l}\text { DT2 } \\
\end{array}$ & DTmedia & DR1 & DR2 & DRmédia & R1(\%) & R2(\%) & Rmédia (\%) & DNR1 & DNR2 & DNRmédia & I1 & 12 & Imédia \\
\hline T4P10 & 0,00387 & $\begin{array}{l}0,00172 \\
\end{array}$ & & 0,00304 & 0,0012 & & 78 & 70 & & 0,00083 & 0,00052 & & 0,04384 & $\overline{0,07614}$ & \\
\hline T4L04 & 0,00288 & 0,00289 & \multirow{2}{*}{0,002755} & 0,00234 & 0,00181 & \multirow{2}{*}{0,00205} & 81 & 62 & \multirow{2}{*}{73} & 0,00054 & 0,00108 & \multirow{2}{*}{0,00071} & 0,04693 & 0,04592 & \multirow{2}{*}{0,0445594} \\
\hline T4L18 & 0,00219 & 0,00306 & & 0,00121 & 0,00282 & & 55 & 92 & & 0,00098 & 0,00024 & & 0,05730 & 0,02808 & \\
\hline T4PL14 & 0,00289 & 0,00143 & \multirow{2}{*}{0,002185} & 0,00255 & 0,00095 & \multirow{2}{*}{0,00174} & 89 & 67 & \multirow{2}{*}{76} & 0,00033 & 0,00048 & \multirow{2}{*}{0,00045} & 0,04023 & 0,06581 & \multirow{2}{*}{0,058996} \\
\hline T4PL16 & 0,00279 & 0,00163 & & 0,00246 & 0,001 & & 88 & 61 & & 0,00033 & 0,00064 & & 0,02751 & 0,10244 & \\
\hline
\end{tabular}

DRmédia - Deformação recuperável média (mm/mm) R - Recuperação no extensômetro ～DNR - Deformação não recuperável ～～I - Inclinação 
Tabela B.17. Resultados dos módulos de fluência uniaxial para todas as condições experimentais (misturas) no nível de tensão de 0,1 MPa

Planilha dos Resultados do ensaio de Fluência Estática (Laboratório) Pesquisa: Doutorado - Benedito Coutinho Neto

Método de compactação: Marshall

Esforço: 75 golpes

Tensão: 0,1 MPa

Prato Superior: $102 \mathrm{~mm}$

Data do Ensaio: 25/09 a 02/10/03

Laboratorista: Benedito Coutinho Neto

\begin{tabular}{|c|c|c|c|c|c|c|}
\hline CPs & MF1 (MPa) & MF2 (MPa) & MFmédio & MFAR1 (MPa) & MFAR2 (MPa) & MFARmédio \\
\hline C3S05 & 71 & 64 & \multirow{2}{*}{75} & 353 & 182 & \multirow{2}{*}{462} \\
\hline C3S10 & 77 & 87 & & 963 & 348 & \\
\hline C4S09 & 62 & 86 & \multirow{2}{*}{75} & 299 & 414 & \multirow{2}{*}{552} \\
\hline C4S11 & 74 & 79 & & 246 & 1251 & \\
\hline C5S07 & 64 & 89 & \multirow{2}{*}{79} & 747 & 313 & \multirow{2}{*}{491} \\
\hline C5S10 & 56 & 107 & & 493 & 409 & \\
\hline C4P10 & 68 & 58 & \multirow{2}{*}{67} & 365 & 136 & \multirow{2}{*}{282} \\
\hline C4P13 & 63 & 80 & & 212 & 414 & \\
\hline C4L07 & 93 & 75 & \multirow{2}{*}{87} & 597 & 416 & \multirow{2}{*}{545} \\
\hline C4L10 & 72 & 108 & & 573 & 595 & \\
\hline C4PL03 & 77 & 87 & \multirow{2}{*}{83} & 418 & 489 & \multirow{2}{*}{619} \\
\hline C4PL06 & 97 & 71 & & 364 & 1207 & \\
\hline D3S04-2 & 48 & 41 & \multirow{2}{*}{43} & 236 & 84 & \multirow{2}{*}{119} \\
\hline D3S05 & 44 & 37 & & 83 & 74 & \\
\hline D4S05 & 38 & 31 & \multirow{2}{*}{37} & 58 & 57 & \multirow{2}{*}{63} \\
\hline D4S15 & 45 & 33 & & 87 & 52 & \\
\hline D5S05-2 & 54 & 48 & \multirow{2}{*}{52} & 138 & 110 & \multirow{2}{*}{127} \\
\hline D5S08-2 & 57 & 50 & & 139 & 122 & \\
\hline D4P12 & 61 & 40 & \multirow{2}{*}{45} & 147 & 56 & \multirow{2}{*}{86} \\
\hline D4P15 & 47 & 30 & & 100 & 39 & \\
\hline D4L06 & 28 & 73 & \multirow{2}{*}{46} & 42 & 192 & \multirow{2}{*}{91} \\
\hline D4L14 & 38 & 46 & & 60 & 72 & \\
\hline D4PL01 & 44 & 50 & \multirow{2}{*}{46} & 69 & 89 & \multirow{2}{*}{77} \\
\hline D4PL02 & 31 & 61 & & 52 & 96 & \\
\hline Q3S06 & 38 & 35 & \multirow{2}{*}{37} & 67 & 62 & \multirow{2}{*}{68} \\
\hline Q3S07 & 49 & 27 & & 98 & 46 & \\
\hline Q4S05 & 43 & 26 & \multirow{2}{*}{36} & 85 & 37 & \multirow{2}{*}{65} \\
\hline Q4S11 & 47 & 27 & & 100 & 37 & \\
\hline Q5S01 & 45 & 65 & \multirow{2}{*}{52} & 110 & 166 & \multirow{2}{*}{123} \\
\hline Q5S02 & 59 & 40 & & 99 & 117 & \\
\hline Q4P07 & 25 & 83 & 47 & 40 & 201 & 95 \\
\hline
\end{tabular}




\begin{tabular}{|c|c|c|c|c|c|c|}
\hline CPs & MF1 (MPa) & MF2 (MPa) & MFmédio & " MFAR1 (MPa) & " MFAR2 (MPa) & MFARmédio \\
\hline QQ4P10 & 27 & 54 & & 38 & 102 & \\
\hline Q4L15 & 32 & 41 & \multirow{2}{*}{37} & 52 & 59 & \multirow{2}{*}{60} \\
\hline Q4L18 & 42 & 35 & & 76 & 52 & \\
\hline Q4PL11 & 65 & 18 & \multirow{2}{*}{39} & 196 & 22 & \multirow{2}{*}{81} \\
\hline Q4PL12 & 34 & 37 & & 51 & 54 & \\
\hline T3S03 & 50 & 43 & \multirow{2}{*}{48} & 94 & 78 & \multirow{2}{*}{89} \\
\hline T3S14 & 45 & 53 & & 85 & 101 & \\
\hline T4S16 & 59 & 60 & \multirow{2}{*}{61} & 79 & 348 & \multirow{2}{*}{169} \\
\hline T4S17 & 86 & 42 & & 139 & 111 & \\
\hline T5S06 & 38 & 57 & \multirow{2}{*}{249} & 77 & 128 & \multirow{2}{*}{531} \\
\hline T5S14 & 469 & 432 & & 1113 & 808 & \\
\hline T4P07 & 798 & 242 & \multirow{2}{*}{460} & 3679 & 312 & \multirow{2}{*}{1334} \\
\hline T4P10 & 366 & 434 & & 659 & 688 & \\
\hline T4L04 & 358 & 591 & \multirow{2}{*}{539} & 645 & 864 & \multirow{2}{*}{880} \\
\hline T4L18 & 368 & 837 & & 661 & 1350 & \\
\hline T4PL14 & 561 & 459 & \multirow{2}{*}{483} & 1143 & 653 & \multirow{2}{*}{801} \\
\hline T4PL16 & 440 & 471 & & 695 & 713 & \\
\hline
\end{tabular}

CPs - Corpos-de-prova $\quad$ MF - Módulo de fluência $\quad$ MFAR - Módulo de fluência, após a recuperação

Tabela B.18. Resultados dos módulos de fluência uniaxial para todas as condições experimentais (misturas) no nível de tensão de 0,4 MPa, com prato superior de $102 \mathrm{~mm}$

Planilha dos Resultados do ensaio de Fluência Estática (Laboratório)

Pesquisa: Doutorado - Benedito Coutinho Neto

Método de compactação: Marshall

Esforço: 75 golpes

Tensão: 0,4 MPa

Prato Superior: $102 \mathrm{~mm}$

Data do Ensaio: 22 a 24/09 e 02 a 08/10/03 Laboratorista: Benedito Coutinho Neto

\begin{tabular}{|c|c|c|c|c|c|c|}
\hline CPs & MF1(MPa) & MF2 (MPa) & Mfmédio & MFAR1 (MPa) & MFAR2 (MPa) & MFARmédio \\
\hline C3S05 & 124 & 92 & \multirow{2}{*}{123} & 632 & 206 & \multirow{2}{*}{447} \\
\hline C3S10 & 150 & 154 & & -5693 & 502 & \\
\hline C4S09 & 96 & 117 & \multirow{2}{*}{113} & 677 & 192 & \multirow{2}{*}{385} \\
\hline C4S11 & 91 & 146 & & 245 & 426 & \\
\hline C5S07 & 82 & 156 & \multirow[t]{2}{*}{113} & 211 & 404 & \multirow[t]{2}{*}{280} \\
\hline C5S10 & 81 & 134 & & 234 & 271 & \\
\hline C4P10 & 78 & 101 & \multirow{2}{*}{98} & 119 & 465 & \multirow{2}{*}{300} \\
\hline C4P13 & 101 & 111 & & 249 & 367 & \\
\hline C4L07 & 143 & 93 & \multirow{2}{*}{111} & 463 & 205 & \multirow{2}{*}{297} \\
\hline C4L10 & 131 & 77 & & 381 & 138 & \\
\hline
\end{tabular}




\begin{tabular}{|c|c|c|c|c|c|c|}
\hline CPs & "MF1(MPa) & MF2 (MPa) & Mfmédio & "MFAR1 (MPa) & "MFAR2 (MPa) & MFARmédio \\
\hline C4PL03 & 134 & 96 & \multirow{2}{*}{117} & 253 & 324 & \multirow{2}{*}{302} \\
\hline C4PL06 & 156 & 83 & & 456 & 176 & \\
\hline D3S04-2 & 108 & 108 & \multirow{2}{*}{118} & 469 & 208 & \multirow{2}{*}{523} \\
\hline D3S05 & 89 & 168 & & 217 & 1196 & \\
\hline D4S05 & 96 & 106 & \multirow{2}{*}{109} & 340 & 189 & \multirow{2}{*}{298} \\
\hline D4S15 & 123 & 110 & & 413 & 248 & \\
\hline D5S05-2 & 120 & 138 & \multirow{2}{*}{141} & 455 & 396 & \multirow{2}{*}{596} \\
\hline D5S08-2 & 138 & 169 & & 965 & 568 & \\
\hline D4P12 & 167 & 142 & \multirow{2}{*}{147} & 1172 & 362 & \multirow{2}{*}{646} \\
\hline D4P15 & 123 & 158 & & 689 & 362 & \\
\hline D4L06 & 96 & 90 & \multirow{2}{*}{101} & 202 & 195 & \multirow{2}{*}{215} \\
\hline D4L14 & 85 & 131 & & 190 & 273 & \\
\hline D4PL01 & 118 & 155 & \multirow{2}{*}{130} & 344 & 390 & \multirow{2}{*}{315} \\
\hline D4PL02 & 83 & 164 & & 231 & 293 & \\
\hline Q3S06 & 83 & 102 & \multirow{2}{*}{86} & 199 & 289 & \multirow{2}{*}{217} \\
\hline Q3S07 & 95 & 66 & & 236 & 143 & \\
\hline Q4S05 & 81 & 118 & \multirow{2}{*}{105} & 257 & 241 & \multirow{2}{*}{277} \\
\hline Q4S11 & 131 & 90 & & 421 & 189 & \\
\hline Q5S01 & 107 & 120 & \multirow{2}{*}{114} & 446 & 335 & \multirow{2}{*}{359} \\
\hline Q5S02 & 87 & 144 & & 243 & 414 & \\
\hline Q4P07 & 218 & 69 & \multirow{2}{*}{86} & 1066 & 158 & \multirow{2}{*}{189} \\
\hline Q4P10 & 84 & 106 & & 189 & 221 & \\
\hline Q4L15 & 99 & 85 & \multirow{2}{*}{94} & 201 & 168 & \multirow{2}{*}{195} \\
\hline Q4L18 & 100 & 92 & & 211 & 198 & \\
\hline Q4PL11 & 55 & 202 & \multirow{2}{*}{110} & 97 & 583 & \multirow{2}{*}{259} \\
\hline Q4PL12 & 91 & 90 & & 165 & 191 & \\
\hline T3S03 & 85 & 154 & כרו & 202 & 414 & 221 \\
\hline T3S14 & 116 & 137 & 123 & 299 & 463 & $34 \mathrm{~J}$ \\
\hline T4S16 & 109 & 227 & 150 & 856 & 434 & 878 \\
\hline T4S17 & 136 & 166 & 105 & 403 & 1011 & 070 \\
\hline T5S06 & 155 & 112 & 134 & 845 & 410 & 624 \\
\hline T5S14 & 133 & 138 & & 642 & 599 & \\
\hline T4P07 & 102 & 185 & 17 & 286 & 1399 & 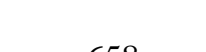 \\
\hline $\mathrm{T} 4 \mathrm{P} 10$ & 100 & 167 & 139 & 288 & 656 & 658 \\
\hline T4L04 & 94 & 158 & 177 & 248 & 382 & (2) \\
\hline T4L18 & 135 & 123 & 127 & 535 & 239 & 351 \\
\hline T4PL14 & 144 & 159 & 157 & 561 & 379 & 501 \\
\hline T4PL16 & 141 & 183 & 15 & 515 & 551 & 501 \\
\hline
\end{tabular}

CPs - Corpos-de-prova MF - Módulo de fluência $\quad$ MFAR - Módulo de fluência, após a recuperação 
Tabela B.19. Resultados dos módulos de fluência uniaxial para todas as condições experimentais (misturas) no nível de tensão de 0,4 MPa, com prato superior de $51 \mathrm{~mm}$

Planilha dos Resultados do ensaio de Fluência Estática (Laboratório)

Pesquisa: Doutorado - Benedito Coutinho Neto

Método de compactação: Marshall

Esforço: 75 golpes

Tensão: 0,4 MPa

Prato Superior: $51 \mathrm{~mm}$

Data do Ensaio: 08 a $15 / 10 / 03$ Laboratorista: Benedito Coutinho Neto

\begin{tabular}{|c|c|c|c|c|c|c|}
\hline CPs & "MF1 (MPa) & "MF2 (MPa) & MFmédio & "MFAR1 (MPa) & "MFAR2 (MPa) & MFARmédio \\
\hline C3S05 & 368 & 118 & \multirow{2}{*}{259} & 984 & 528 & \multirow{2}{*}{766} \\
\hline C3S10 & 92 & 459 & & 392 & 1163 & \\
\hline C4S09 & 106 & 364 & \multirow{2}{*}{208} & 454 & 1150 & \multirow{2}{*}{801} \\
\hline C4S11 & 150 & 211 & & 681 & 920 & \\
\hline C5S07 & 144 & 220 & \multirow{2}{*}{166} & 1227 & 767 & \multirow{2}{*}{886} \\
\hline C5S10 & 154 & 144 & & 1240 & 313 & \\
\hline C4P10 & 116 & 209 & \multirow{2}{*}{173} & 418 & 627 & \multirow{2}{*}{773} \\
\hline C4P13 & 144 & 223 & & 1470 & 575 & \\
\hline C4L07 & 123 & 262 & \multirow{2}{*}{190} & 510 & 959 & \multirow{2}{*}{661} \\
\hline C4L10 & 130 & 247 & & 609 & 565 & \\
\hline C4PL03 & 121 & 298 & \multirow{2}{*}{205} & 788 & 758 & \multirow{2}{*}{802} \\
\hline C4PL06 & 122 & 279 & & 1103 & 559 & \\
\hline D3S04 & 122 & 274 & \multirow{2}{*}{175} & 934 & 1142 & \multirow{2}{*}{840} \\
\hline D3S05 & 131 & 173 & & 887 & 399 & \\
\hline D4S05 & 92 & 290 & \multirow{2}{*}{169} & 414 & 596 & \multirow{2}{*}{532} \\
\hline D4S15 & 136 & 160 & & 448 & 672 & \\
\hline D5S05 & 112 & 240 & \multirow[t]{2}{*}{170} & 589 & 657 & \multirow[t]{2}{*}{712} \\
\hline D5S08 & 140 & 188 & & 1212 & 390 & \\
\hline D4P12 & 148 & 182 & \multirow{2}{*}{169} & 601 & 619 & \multirow{2}{*}{854} \\
\hline D4P15 & 121 & 223 & & 1717 & 478 & \\
\hline D4L06 & 137 & 171 & \multirow{2}{*}{158} & 723 & 488 & \multirow{2}{*}{530} \\
\hline D4L14 & 108 & 215 & & 485 & 422 & \\
\hline D4PL01 & 112 & 339 & \multirow{2}{*}{230} & 470 & 924 & \multirow{2}{*}{697} \\
\hline D4PL02 & 108 & 359 & & 593 & 801 & \\
\hline Q3S06 & 117 & 224 & \multirow{2}{*}{155} & 927 & 1118 & \multirow{2}{*}{910} \\
\hline Q3S07 & 128 & 152 & & 925 & 671 & \\
\hline Q4S05 & 82 & 260 & \multirow{2}{*}{162} & 234 & 1014 & \multirow{2}{*}{579} \\
\hline Q4S11 & 115 & 189 & & 644 & 425 & \\
\hline Q5S01 & 142 & 132 & \multirow{2}{*}{143} & 641 & 462 & \multirow{2}{*}{658} \\
\hline Q5S02 & 126 & 174 & & 1117 & 411 & \\
\hline Q4P07 & 97 & 243 & 179 & 613 & 567 & 730 \\
\hline
\end{tabular}




\begin{tabular}{|c|c|c|c|c|c|c|}
\hline CPs & "MF1(MPa) & MF2 (MPa) & Mfmédio & "MFAR1 (MPa) & "MFAR2 (MPa) & MFARmédio \\
\hline Q4P10 & 87 & 290 & & 246 & 1493 & \\
\hline Q4L15 & 100 & 278 & \multirow{2}{*}{162} & 353 & 686 & \multirow{2}{*}{461} \\
\hline Q4L181 & 113 & 159 & & 381 & 423 & \\
\hline Q4PL11 & 105 & 261 & \multirow{2}{*}{171} & 597 & 523 & \multirow{2}{*}{517} \\
\hline Q4PL12 & 117 & 202 & & 467 & 481 & \\
\hline T3S03 & 110 & 299 & \multirow{2}{*}{199} & 1975 & 470 & \multirow{2}{*}{1056} \\
\hline T3S14 & 120 & 267 & & 1216 & 563 & \\
\hline T4S16 & 117 & 325 & \multirow{2}{*}{202} & 12703 & 548 & \multirow{2}{*}{3847} \\
\hline T4S17 & 134 & 232 & & 1556 & 580 & \\
\hline T5S06 & 118 & 311 & \multirow{2}{*}{191} & 2463 & 685 & \multirow{2}{*}{1144} \\
\hline T5S14 & 115 & 219 & & 901 & 526 & \\
\hline T4P07 & 140 & 179 & \multirow{2}{*}{168} & 508 & 1703 & \multirow{2}{*}{880} \\
\hline $\mathrm{T} 4 \mathrm{P} 10$ & 108 & 244 & & 503 & 807 & \\
\hline T4L04 & 141 & 141 & \multirow{2}{*}{151} & 758 & 375 & \multirow{2}{*}{816} \\
\hline T4L18 & 188 & 135 & & 422 & 1709 & \\
\hline T4PL14 & 144 & 291 & \multirow{2}{*}{207} & 1255 & 872 & \multirow{2}{*}{996} \\
\hline T4PL16 & 145 & 248 & & 1221 & 637 & \\
\hline
\end{tabular}

CPs - Corpos-de-prova $\quad$ MF - Módulo de fluência $\quad$ MFAR - Módulo de fluência, após a recuperação 


\section{APÊNDICE C - Ensaios ambientais}

- Solubilização, lixiviação e massa bruta da areia de fundição

- Solubilização, lixiviação e massa bruta da areia virgem

- Solubilização, lixiviação e massa bruta da massa asfáltica solta com $10 \%$ de areia Virgem

- Solubilização, lixiviação e massa bruta da massa asfáltica solta com $15 \%$ de areia Virgem

- Análise química do extrato oriundo do ensaio de lixiviação com extrator soxhlet (corpo-de-prova com 15\% de areia de fundição), com um, sete, 21, 45 e 90 dias de condicionamento 
Tabela C.01. Resultados Analíticos de ensaios de solubilização, lixiviação e massa bruta da areia de fundição utilizada na pesquisa

\begin{tabular}{|c|c|c|c|c|}
\hline Parâmetros & Unidade & $L Q^{*}$ & $\begin{array}{c}\text { Resultados analíticos da } \\
\text { amostra } n^{o} \text {. 05498/03 Areia } \\
\text { de Fundição }\end{array}$ & $\begin{array}{c}A B N T \text { NBR } \\
10004 \text { VMP** }\end{array}$ \\
\hline \multicolumn{5}{|l|}{ 1- SOLUBILIZADO } \\
\hline Arsênio & $\mathrm{mg} / \mathrm{L}$ & 0,05 & $<0,05$ & 0,05 \\
\hline Bário & $\mathrm{mg} / \mathrm{L}$ & 0,1 & $<0,1$ & 1,0 \\
\hline Cádmio & $\mathrm{mg} / \mathrm{L}$ & 0,005 & $<0,005$ & 0,005 \\
\hline Chumbo & $\mathrm{mg} / \mathrm{L}$ & 0,05 & $<0,05$ & 0,05 \\
\hline Cianetos & $\mathrm{mg} / \mathrm{L}$ & 0,1 & $<0,1$ & 0,1 \\
\hline Cromo total & $\mathrm{mg} / \mathrm{L}$ & 0,05 & $<0,05$ & 0,05 \\
\hline Fenóis & $\mathrm{mg} / \mathrm{L}$ & 0,001 & 0,38 & 0,001 \\
\hline Fluoretos & $\mathrm{mg} / \mathrm{L}$ & 0,1 & 3,71 & 1,5 \\
\hline Mercúrio & $\mathrm{mg} / \mathrm{L}$ & 0,001 & $<0,001$ & 0,001 \\
\hline Nitratos & $\mathrm{mg} / \mathrm{L}$ & 0,1 & 1,3 & 10 \\
\hline Prata & $\mathrm{mg} / \mathrm{L}$ & 0,05 & $<0,05$ & 0,05 \\
\hline Selênio & $\mathrm{mg} / \mathrm{L}$ & 0,01 & $<0,01$ & 0,01 \\
\hline Alumínio & $\mathrm{mg} / \mathrm{L}$ & 0,05 & 1,77 & 0,2 \\
\hline Cloretos & $\mathrm{mg} / \mathrm{L}$ & 5 & 370 & 250,0 \\
\hline Cobre & $\mathrm{mg} / \mathrm{L}$ & 0,05 & $<0,05$ & 1,0 \\
\hline Dureza & $\mathrm{mg} / \mathrm{L}$ & 5 & 400 & 500 \\
\hline Ferro & $\mathrm{mg} / \mathrm{L}$ & 0,05 & 0,78 & 0,3 \\
\hline Manganês & $\mathrm{mg} / \mathrm{L}$ & 0,05 & $<0,05$ & 0,1 \\
\hline Sódio & $\mathrm{mg} / \mathrm{L}$ & 0,5 & 162 & 200,0 \\
\hline Surfactantes & $\mathrm{mg} / \mathrm{L}$ & 0,1 & 0,18 & 0,2 \\
\hline Sulfatos & $\mathrm{mg} / \mathrm{L}$ & 5 & 16 & 400 \\
\hline Zinco & $\mathrm{mg} / \mathrm{L}$ & 0,05 & $<0,05$ & 5 \\
\hline pH inicial & & & 7,8 & \\
\hline $\mathrm{pH}$ final & & & 7,9 & \\
\hline 2-LIXIVIADO & & & & \\
\hline Arsênio & $\mathrm{mg} / \mathrm{L}$ & 0,05 & $<0,05$ & 5,0 \\
\hline Bário & $\mathrm{mg} / \mathrm{L}$ & 0,1 & $<0,1$ & 100 \\
\hline Cádmio & $\mathrm{mg} / \mathrm{L}$ & 0,05 & $<0,05$ & 0,5 \\
\hline Chumbo & $\mathrm{mg} / \mathrm{L}$ & 0,05 & $<0,05$ & 5,0 \\
\hline Cromo total & $\mathrm{mg} / \mathrm{L}$ & 0,05 & $<0,05$ & 5,0 \\
\hline Fluoretos & $\mathrm{mg} / \mathrm{L}$ & 0,1 & 0,36 & 150,0 \\
\hline Mercúrio & $\mathrm{mg} / \mathrm{L}$ & 0,05 & $<0,05$ & 0,1 \\
\hline Prata & $\mathrm{mg} / \mathrm{L}$ & 0,05 & $<0,05$ & 5,0 \\
\hline Selênio & $\mathrm{mg} / \mathrm{L}$ & 0,05 & $<0,01$ & 1,0 \\
\hline
\end{tabular}




\begin{tabular}{|c|c|c|c|c|}
\hline Parâmetros & Unidade & $L Q^{*}$ & $\begin{array}{c}\text { Resultados analíticos da } \\
\text { amostra } n^{\circ} .05498 / 03 \text { Areia } \\
\text { de Fundição } \\
\end{array}$ & $\begin{array}{c}A B N T \text { NBR } \\
10004 \text { VMP** }\end{array}$ \\
\hline $\mathrm{pH}$ inicial & & & $7,7,8$ & \\
\hline $\mathrm{pH}$ final & & & 4,9 & \\
\hline Volume de ác. Acético 0,5 N & $\mathrm{mL}$ & & 3,0 & Até 400 \\
\hline Tempo de Lixiviação & $\mathrm{h}$ & & 24 & $24-28$ \\
\hline \multicolumn{5}{|l|}{ 3-MASSA BRUTA } \\
\hline Umidade & $\%$ & 0,05 & 2,9 & \\
\hline $\mathrm{pH}$ & & 0,1 & 7,5 & $>2<12,5$ \\
\hline Berílio & $\mathrm{mg} / \mathrm{kg}$ & 1 & $<1$ & 100 \\
\hline Cromo VI & $\mathrm{mg} / \mathrm{kf}$ & 1 & $<1$ & 100 \\
\hline Mercúrio & $\mathrm{mg} / \mathrm{kg}$ & 1 & $<1$ & 100 \\
\hline Vanádio & $\mathrm{mg} / \mathrm{kg}$ & 1 & 1,83 & 1000 \\
\hline Chumbo & $\mathrm{mg} / \mathrm{kg}$ & 1 & 1,42 & 1000 \\
\hline Selênio & $\mathrm{mg} / \mathrm{kg}$ & 1 & $<1$ & 100 \\
\hline Arsênio & $\mathrm{mg} / \mathrm{kg}$ & 1 & $<1$ & 1000 \\
\hline Cianetos & $\mathrm{mg} / \mathrm{kg}$ & 1 & $<1$ & 1000 \\
\hline Fenóis & $\mathrm{mg} / \mathrm{kg}$ & 0,5 & 0,90 & 10 \\
\hline Hidrocarb. líquidos/bombeáveis & $\%$ & 0,05 & $<0,05$ & 5 \\
\hline Óleos e graxas & $\%$ & 0,05 & $<0,05$ & 1 \\
\hline Líquidos livres & & Ausente & Ausente & Ausente \\
\hline
\end{tabular}

Fonte: BIOAGRI AMBIENTAL LTDA.

A analise química realizada na amostra de areia de fundição, utilizada neste estudo, pela BIOAGRI AMBIENTAL LTDA (Boletim de Analise N$^{0}$ 1997/03), cujos resultados analíticos estão listados na Tabela C.01, demonstram que:

$\checkmark$ para o ensaio de lixiviação nenhum parâmetro analisado ultrapassou os Limites Máximos Permitidos pela ABNT NBR 10004 (ANEXO G listagem Nº. 7);

$\checkmark$ para o ensaio de solubilização os parâmetros Fenóis, Fluoretos, Alumínio, Cloretos e Ferro ultrapassaram os Limites Máximos Permitidos pela ABNT NBR 10004 (ANEXO H listagem $\mathrm{N}^{0}$. 8);

$\checkmark$ para o ensaio de massa bruta nenhum parâmetro ultrapassou os Limites Máximos Permitidos pela ABNT NBR 10004 (ANEXO I listagem $N^{0}$. 9).

Segundo o Boletim de Analise $\mathrm{N}^{0}$ 1997/03 de 24/04/03 emitido pela BIOAGRI AMBIENTAL LTDA, este resíduo (areia de fundição) deve ser considerado como de Classe II - Não Inerte. 
A analise química da areia virgem utilizada na mistura asfáltica padrão (10\% de areia de Fundição), também realizada pela BIOAGRI AMBIENTAL LTDA (Boletim de Analise $\mathrm{N}^{0}$ 1347/03), está apresentada na Tabela C.02.

Cópias dos laudos emitidos por essa empresa, encontram-se no ANEXO A desta pesquisa.

Tabela C.02. Resultados Analíticos de ensaios de solubilização, lixiviação e massa bruta da areia Virgem utilizada na pesquisa

\begin{tabular}{|c|c|c|c|c|}
\hline Parâmetros & Unidade & $L Q^{*}$ & $\begin{array}{c}\text { Resultados analíticos da } \\
\text { amostra } \\
\text { Areia Virgem }\end{array}$ & $\begin{array}{c}A B N T \text { NBR } \\
10004 \text { VMP** }\end{array}$ \\
\hline \multicolumn{5}{|l|}{ 1- SOLUBILIZADO } \\
\hline Arsênio & $\mathrm{mg} / \mathrm{L}$ & 0,05 & $<0,05$ & 0,05 \\
\hline Bário & $\mathrm{mg} / \mathrm{L}$ & 0,1 & $<0,1$ & 1,0 \\
\hline Cádmio & $\mathrm{mg} / \mathrm{L}$ & 0,005 & $<0,005$ & 0,005 \\
\hline Chumbo & $\mathrm{mg} / \mathrm{L}$ & 0,05 & $<0,05$ & 0,05 \\
\hline Cianetos & $\mathrm{mg} / \mathrm{L}$ & 0,1 & $<0,1$ & 0,1 \\
\hline Cromo total & $\mathrm{mg} / \mathrm{L}$ & 0,05 & $<0,05$ & 0,05 \\
\hline Fenóis & $\mathrm{mg} / \mathrm{L}$ & 0,001 & $<0,001$ & 0,001 \\
\hline Fluoretos & $\mathrm{mg} / \mathrm{L}$ & 0,1 & 0,33 & 1,5 \\
\hline Mercúrio & $\mathrm{mg} / \mathrm{L}$ & 0,001 & $<0,001$ & 0,001 \\
\hline Nitratos & $\mathrm{mg} / \mathrm{L}$ & 0,1 & 1,6 & 10 \\
\hline Prata & $\mathrm{mg} / \mathrm{L}$ & 0,05 & $<0,05$ & 0,05 \\
\hline Selênio & $\mathrm{mg} / \mathrm{L}$ & 0,01 & $<0,01$ & 0,01 \\
\hline Alumínio & $\mathrm{mg} / \mathrm{L}$ & 0,05 & $<0,05$ & 0,2 \\
\hline Cloretos & $\mathrm{mg} / \mathrm{L}$ & 5 & 240 & 250,0 \\
\hline Cobre & $\mathrm{mg} / \mathrm{L}$ & 0,05 & $<0,05$ & 1,0 \\
\hline Dureza & $\mathrm{mg} / \mathrm{L}$ & 5 & 460 & 500 \\
\hline Ferro & $\mathrm{mg} / \mathrm{L}$ & 0,05 & 0,23 & 0,3 \\
\hline Manganês & $\mathrm{mg} / \mathrm{L}$ & 0,05 & $<0,05$ & 0,1 \\
\hline Sódio & $\mathrm{mg} / \mathrm{L}$ & 0,5 & 56,4 & 200,0 \\
\hline Surfactantes & $\mathrm{mg} / \mathrm{L}$ & 0,1 & $<0,1$ & 0,2 \\
\hline Sulfatos & $\mathrm{mg} / \mathrm{L}$ & 5 & 7 & 400 \\
\hline Zinco & $\mathrm{Mg} / \mathrm{L}$ & 0,05 & $<0,05$ & 5 \\
\hline PH inicial & & & 7,8 & \\
\hline pH final & & & 7,7 & \\
\hline $\begin{array}{l}\text { 2-LIXIVIADO } \\
\text { Arsênio }\end{array}$ & $\mathrm{mg} / \mathrm{L}$ & 0,05 & $<0,05$ & 5,0 \\
\hline Bário & $\mathrm{mg} / \mathrm{L}$ & 0,1 & $<0,1$ & 100 \\
\hline
\end{tabular}




\begin{tabular}{|c|c|c|c|c|}
\hline Parâmetros & Unidade & $L Q^{*}$ & $\begin{array}{c}\text { Resultados analíticos da } \\
\text { amostra } \\
\text { Areia Virgem } \\
\end{array}$ & $\begin{array}{c}A B N T N B R \\
10004 V_{M P}^{* *}\end{array}$ \\
\hline Cádmio & $\mathrm{mg} / \mathrm{L}$ & 0,05 & $<0,05$ & 0,5 \\
\hline Chumbo & $\mathrm{mg} / \mathrm{L}$ & 0,05 & 0,06 & 5,0 \\
\hline Cromo total & $\mathrm{mg} / \mathrm{L}$ & 0,05 & $<0,05$ & 5,0 \\
\hline Fluoretos & $\mathrm{mg} / \mathrm{L}$ & 0,1 & $<0,1$ & 150,0 \\
\hline Mercúrio & $\mathrm{mg} / \mathrm{L}$ & 0,05 & $<0,05$ & 0,1 \\
\hline Prata & $\mathrm{mg} / \mathrm{L}$ & 0,05 & $<0,05$ & 5,0 \\
\hline Selênio & $\mathrm{mg} / \mathrm{L}$ & 0,05 & $<0,05$ & 1,0 \\
\hline pH inicial & & & 7,8 & \\
\hline $\mathrm{pH}$ final & & & 4,8 & \\
\hline Volume de ác. Acético 0,5 N & $\mathrm{mL}$ & & 3,0 & Até 400 \\
\hline Tempo de Lixiviação & $\mathrm{h}$ & & 24 & $24-28$ \\
\hline \multicolumn{5}{|l|}{ 3-MASSA BRUTA } \\
\hline Umidade & $\%$ & 0,05 & 1,0 & \\
\hline $\mathrm{pH}$ & & 0,1 & 7,5 & $>2<12,5$ \\
\hline Berílio & $\mathrm{mg} / \mathrm{kg}$ & 1 & $<1$ & 100 \\
\hline Cromo VI & $\mathrm{mg} / \mathrm{kg}$ & 1 & $<1$ & 100 \\
\hline Mercúrio & $\mathrm{mg} / \mathrm{kg}$ & 1 & $<1$ & 100 \\
\hline Vanádio & $\mathrm{mg} / \mathrm{kg}$ & 1 & 2,90 & 1000 \\
\hline Chumbo & $\mathrm{mg} / \mathrm{kg}$ & 1 & 3,18 & 1000 \\
\hline Selênio & $\mathrm{mg} / \mathrm{kg}$ & 1 & $<1$ & 100 \\
\hline Arsênio & $\mathrm{mg} / \mathrm{kg}$ & 1 & $<1$ & 1000 \\
\hline Cianetos & $\mathrm{mg} / \mathrm{kg}$ & 1 & $<1$ & 1000 \\
\hline Fenóis & $\mathrm{mg} / \mathrm{kg}$ & 0,5 & $<0,5$ & 10 \\
\hline Hidrocarb. líquidos/bombeáveis & $\%$ & 0,05 & $<0,05$ & 5 \\
\hline Óleos e graxas & $\%$ & 0,05 & 0,09 & 1 \\
\hline Líquidos livres & & Ausente & Ausente & Ausente \\
\hline
\end{tabular}

LQ* Limite de Quantificação

VMP** - Valor Máximo Permitido pela Norma ABNT NBR 10004.

Fonte: BIOAGRI AMBIENTAL LTDA.

Segundo a BIOAGRI AMBIENTAL LTDA (Boletim de Analise N$^{\circ}$. 1347/03), os resultados analíticos listados na Tabela C.02, demonstram que:

$\checkmark$ para o ensaio de lixiviação nenhum parâmetro analisado ultrapassou os Limites Máximos Permitidos pela ABNT NBR 10004 (ANEXO G listagem Nº. 7); 
$\checkmark$ para o ensaio de solubilização nenhum parâmetro analisado ultrapassou os Limites Máximos Permitidos pela ABNT NBR 10004 (ANEXO H listagem Nº. 8);

$\checkmark$ para o ensaio de massa bruta nenhum parâmetro ultrapassou os Limites Máximos Permitidos pela ABNT NBR 10004 (ANEXO I listagem Nº. 9).

Segundo o Boletim de Analise $\mathrm{N}^{\mathrm{o}}$ 1347/03 de 31/03/03 emitido pela BIOAGRI AMBIENTAL LTDA, este resíduo (areia de fundição) deve ser considerado como de Classe III - Inerte.

Os resultados analíticos, que ultrapassaram os valores máximos permitidos pela ABNT NBR 10004/87 estão destacados em negrito.

Tabela C.03. Resultado Analítico dos ensaios de solubilização, lixiviação e massa bruta de uma amostra de massa asfáltica com 10\% de Areia Virgem - massa solta

\begin{tabular}{|c|c|c|c|c|}
\hline Parâmetro & Unidade & $\begin{array}{c}\text { Limite de } \\
\text { Quantificação }\end{array}$ & $\begin{array}{l}\text { Resultado } \\
\text { Analítico }\end{array}$ & $\begin{array}{c}\text { NBR } 10004 \\
\text { VMP* }^{*}\end{array}$ \\
\hline \multicolumn{5}{|l|}{ 1- SOLUBILIZADO } \\
\hline Arsênio (As) & $\mathrm{mg} / \mathrm{L}$ & 0,001 & NA & 0,05 \\
\hline Bário (Ba) & $\mathrm{mg} / \mathrm{L}$ & 0,01 & $<0,01$ & 1,0 \\
\hline Cádmio (Cd) & $\mathrm{mg} / \mathrm{L}$ & 0,001 & 0,002 & 0,005 \\
\hline Chumbo (Pb) & $\mathrm{mg} / \mathrm{L}$ & 0,001 & 0,001 & 0,05 \\
\hline Cianetos (CN) & $\mathrm{mg} / \mathrm{L}$ & 0,001 & $<0,001$ & 0,1 \\
\hline Cromo total (Cr) & $\mathrm{mg} / \mathrm{L}$ & 0,001 & 0,024 & 0,05 \\
\hline Índice de Fenóis & $\mathrm{mg} / \mathrm{L}$ & 0,001 & $<0,001$ & 0,001 \\
\hline Fluoretos (F) & $\mathrm{mg} / \mathrm{L}$ & 0,01 & 0,06 & 1,5 \\
\hline Mercúrio (Hg) & $\mathrm{mg} / \mathrm{L}$ & 0,001 & $<0,001$ & 0,001 \\
\hline Nitratos $\left(\mathrm{N}-\mathrm{NO}_{3}\right)$ & $\mathrm{mg} / \mathrm{L}$ & 0,01 & 0,2179 & 10,0 \\
\hline Prata (Ag) & $\mathrm{mg} / \mathrm{L}$ & 0,001 & $<0,001$ & 0,05 \\
\hline Selênio (Se) & $\mathrm{mg} / \mathrm{L}$ & 0,01 & NA & 0,01 \\
\hline Alumínio (Al) & $\mathrm{mg} / \mathrm{L}$ & 0,001 & $<0,001$ & 0,2 \\
\hline Cloretos (Cl) & $\mathrm{mg} / \mathrm{L}$ & 0,5 & 1,30 & 250,0 \\
\hline Cobre (Cu) & $\mathrm{mg} / \mathrm{L}$ & 0,001 & 0,011 & 1,0 \\
\hline Dureza Total $\left(\mathrm{CaCO}_{3}\right)$ & $\mathrm{mg} / \mathrm{L}$ & 1,00 & 14 & 500,0 \\
\hline Ferro (Fe) & $\mathrm{mg} / \mathrm{L}$ & 0,001 & $<0,001$ & 0,3 \\
\hline Manganês (Mn) & $\mathrm{mg} / \mathrm{L}$ & 0,001 & $<0,001$ & 0,1 \\
\hline Sódio (Na) & $\mathrm{mg} / \mathrm{L}$ & 0,1 & 6,00 & 200,0 \\
\hline
\end{tabular}




\begin{tabular}{|c|c|c|c|c|}
\hline Parâmetro & Unidade & $\begin{array}{c}\text { Limite de } \\
\text { Quantificação }\end{array}$ & $\begin{array}{l}\text { Resultado } \\
\text { Analítico }\end{array}$ & $\begin{array}{c}\text { NBR } 10004 \\
\text { VMP* }\end{array}$ \\
\hline Surfactantes (tensoativos) & $\overline{\mathrm{mg} / \mathrm{L}}$ & "0,01 & "0,02 & 0,2 \\
\hline Sulfatos $\left(\mathrm{SO}_{4}\right)$ & $\mathrm{mg} / \mathrm{L}$ & 1,00 & $<1,00$ & 400,0 \\
\hline Zinco (Zn) & $\mathrm{mg} / \mathrm{L}$ & 0,001 & 0,003 & 5,0 \\
\hline pH inicial & & & 7,4 & \\
\hline pH final & & & 6,9 & \\
\hline \multicolumn{5}{|l|}{ 2-LIXIVIADO } \\
\hline Arsênio (As) & $\mathrm{mg} / \mathrm{L}$ & 0,001 & NA & 5,0 \\
\hline Bário (Ba) & $\mathrm{mg} / \mathrm{L}$ & 0,01 & $<0,01$ & 100 \\
\hline Cádmio (Cd) & $\mathrm{mg} / \mathrm{L}$ & 0,001 & 0,001 & 0,5 \\
\hline Chumbo (Pb) & $\mathrm{mg} / \mathrm{L}$ & 0,001 & $<0,001$ & 5,0 \\
\hline Cromo total (Cr) & $\mathrm{mg} / \mathrm{L}$ & 0,001 & NA & 5,0 \\
\hline Fluoretos (F) & $\mathrm{mg} / \mathrm{L}$ & 0,01 & 0,05 & 150,00 \\
\hline Mercúrio (Hg) & $\mathrm{mg} / \mathrm{L}$ & 0,001 & $<0,001$ & 0,1 \\
\hline Prata (Ag) & $\mathrm{mg} / \mathrm{L}$ & 0,001 & $<0,001$ & 5,0 \\
\hline Selênio (Se) & $\mathrm{mg} / \mathrm{L}$ & 0,01 & NA & 1,0 \\
\hline pH inicial & & & 5,30 & \\
\hline pH final & & & 5,15 & \\
\hline Volume de ác. Acético 0,5 N & $\mathrm{mL}$ & & 3,0 & Até 400 \\
\hline Tempo de Lixiviação & $\mathrm{h}$ & & 24 & $24-28$ \\
\hline \multicolumn{5}{|l|}{3 - MASSA BRUTA } \\
\hline Umidade & $\%$ & & 0 & \\
\hline $\mathrm{pH}$ & & & & $>2<12,5$ \\
\hline Berílio (Be) & $\mathrm{mg} / \mathrm{kg}$ & 5,0 & NA & 100 \\
\hline Cromo VI $\left(\mathrm{Cr}^{+6}\right)$ & $\mathrm{mg} / \mathrm{kg}$ & 0,01 & $<0,01$ & 100 \\
\hline Mercúrio (Hg) & $\mathrm{mg} / \mathrm{kg}$ & 0,001 & 0,314 & 100 \\
\hline Vanádio (V) & $\mathrm{mg} / \mathrm{kg}$ & 5,0 & NA & 1000 \\
\hline Chumbo (Pb) & $\mathrm{mg} / \mathrm{kg}$ & 5,0 & 10,68 & 1000 \\
\hline Selênio (Se) & $\mathrm{mg} / \mathrm{kg}$ & 5,0 & NA & 100 \\
\hline Arsênio (As) & $\mathrm{mg} / \mathrm{kg}$ & 5,0 & NA & 1000 \\
\hline Cianetos (CN) & $\mathrm{mg} / \mathrm{kg}$ & 0,001 & $<0,001$ & 1000 \\
\hline Índice de Fenóis & $\mathrm{mg} / \mathrm{kg}$ & 0,01 & 0,027 & 10 \\
\hline Hidrocarb. líquidos/bombeáveis & $\%$ & & NA & 5 \\
\hline Óleos e graxas & $\%$ & & NA & 1 \\
\hline Líquidos livres & & Ausente & Ausente & Ausente \\
\hline
\end{tabular}

VMP - Valor Máximo Permitido pela NBR 10004

NA - Não Analisado 
Tabela C.04. Resultado Analítico dos ensaios de solubilização, lixiviação e massa bruta de uma amostra de massa asfáltica com 15\% de Areia de Fundição - massa solta

\begin{tabular}{|c|c|c|c|c|}
\hline Parâmetro & Unidade & $\begin{array}{c}\text { Limite de } \\
\text { Quantificação }\end{array}$ & $\begin{array}{l}\text { Resultado } \\
\text { Analítico }\end{array}$ & $\begin{array}{c}\text { NBR } 10004 \\
\text { VMP }\end{array}$ \\
\hline \multicolumn{5}{|l|}{ 1- SOLUBILIZADO } \\
\hline Arsênio (As) & $\mathrm{mg} / \mathrm{L}$ & 0,001 & NA & 0,05 \\
\hline Bário (Ba) & $\mathrm{mg} / \mathrm{L}$ & 0,01 & $<0,01$ & 1,0 \\
\hline Cádmio (Cd) & $\mathrm{mg} / \mathrm{L}$ & 0,001 & $<0,001$ & 0,005 \\
\hline Chumbo (Pb) & $\mathrm{mg} / \mathrm{L}$ & 0,001 & 0,003 & 0,05 \\
\hline Cianetos (CN) & $\mathrm{mg} / \mathrm{L}$ & 0,001 & $<0,001$ & 0,1 \\
\hline Cromo total (Cr) & $\mathrm{mg} / \mathrm{L}$ & 0,001 & 0,019 & 0,05 \\
\hline Índice de Fenóis & $\mathrm{mg} / \mathrm{L}$ & 0,001 & $<0,001$ & 0,001 \\
\hline Fluoretos (F) & $\mathrm{mg} / \mathrm{L}$ & 0,01 & 0,26 & 1,5 \\
\hline Mercúrio (Hg) & $\mathrm{mg} / \mathrm{L}$ & 0,001 & $<0,001$ & 0,001 \\
\hline Nitratos $\left(\mathrm{N}-\mathrm{NO}_{3}\right)$ & $\mathrm{mg} / \mathrm{L}$ & 0,01 & 0,4880 & 10,0 \\
\hline Prata (Ag) & $\mathrm{mg} / \mathrm{L}$ & 0,001 & $<0,001$ & 0,05 \\
\hline Selênio (Se) & $\mathrm{mg} / \mathrm{L}$ & 0,01 & NA & 0,01 \\
\hline Alumínio (Al) & $\mathrm{mg} / \mathrm{L}$ & 0,001 & 0,024 & 0,2 \\
\hline Cloretos (Cl) & $\mathrm{mg} / \mathrm{L}$ & 0,5 & 1,70 & 250,0 \\
\hline Cobre $(\mathrm{Cu})$ & $\mathrm{mg} / \mathrm{L}$ & 0,001 & 0,015 & 1,0 \\
\hline Dureza Total $\left(\mathrm{CaCO}_{3}\right)$ & $\mathrm{mg} / \mathrm{L}$ & 1,00 & 11 & 500,0 \\
\hline Ferro (Fe) & $\mathrm{mg} / \mathrm{L}$ & 0,001 & $<0,001$ & 0,3 \\
\hline Manganês (Mn) & $\mathrm{mg} / \mathrm{L}$ & 0,001 & $<0,001$ & 0,1 \\
\hline Sódio (Na) & $\mathrm{mg} / \mathrm{L}$ & 0,1 & 16,50 & 200,0 \\
\hline Surfactantes (tensoativos) & $\mathrm{mg} / \mathrm{L}$ & 0,01 & 0,068 & 0,2 \\
\hline Sulfatos $\left(\mathrm{SO}_{4}\right)$ & $\mathrm{mg} / \mathrm{L}$ & 1,00 & 1,00 & 400,0 \\
\hline Zinco (Zn) & $\mathrm{mg} / \mathrm{L}$ & 0,001 & $<0,001$ & 5,0 \\
\hline pH inicial & & & 8,70 & \\
\hline $\mathrm{pH}$ final & & & 6,80 & \\
\hline \multicolumn{5}{|l|}{ 2-LIXIVIADO } \\
\hline Arsênio (As) & $\mathrm{mg} / \mathrm{L}$ & 0,001 & NA & 5,0 \\
\hline Bário (Ba) & $\mathrm{mg} / \mathrm{L}$ & 0,01 & 0,04 & 100 \\
\hline Cádmio (Cd) & $\mathrm{mg} / \mathrm{L}$ & 0,001 & 0,003 & 0,5 \\
\hline Chumbo (Pb) & $\mathrm{mg} / \mathrm{L}$ & 0,001 & 0,071 & 5,0 \\
\hline Cromo total (Cr) & $\mathrm{mg} / \mathrm{L}$ & 0,001 & NA & 5,0 \\
\hline Fluoretos (F) & $\mathrm{mg} / \mathrm{L}$ & 0,01 & 0,09 & 150,00 \\
\hline Mercúrio (Hg) & $\mathrm{mg} / \mathrm{L}$ & 0,001 & $<0,001$ & 0,1 \\
\hline Prata (Ag) & $\mathrm{mg} / \mathrm{L}$ & 0,001 & $<0,001$ & 5,0 \\
\hline Selênio (Se) & $\mathrm{mg} / \mathrm{L}$ & 0,01 & NA & 1,0 \\
\hline
\end{tabular}




\begin{tabular}{|c|c|c|c|c|}
\hline Parâmetro & Unidade & $\begin{array}{c}\text { Limite de } \\
\text { Quantificação }\end{array}$ & $\begin{array}{l}\text { Resultado } \\
\text { analítico }\end{array}$ & $\begin{array}{c}\text { NBR } 10004 \\
\text { VMP }\end{array}$ \\
\hline pH inicial & & & 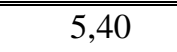 & \\
\hline pH final & & & 4,88 & \\
\hline Volume de ác. Acético 0,5 N & $\mathrm{mL}$ & & 4,0 & Até 400 \\
\hline Tempo de Lixiviação & $\mathrm{h}$ & & 24 & $24-28$ \\
\hline \multicolumn{5}{|l|}{3 - MASSA BRUTA } \\
\hline Umidade & $\%$ & & 0 & \\
\hline $\mathrm{pH}$ & & & & $>2<12,5$ \\
\hline Berílio (Be) & $\mathrm{mg} / \mathrm{kg}$ & 5,0 & NA & 100 \\
\hline Cromo VI $\left(\mathrm{Cr}^{+6}\right)$ & $\mathrm{mg} / \mathrm{kg}$ & 0,01 & $<0,01$ & 100 \\
\hline Mercúrio (Hg) & $\mathrm{mg} / \mathrm{kg}$ & 0,001 & 0,097 & 100 \\
\hline Vanádio (V) & $\mathrm{mg} / \mathrm{kg}$ & 5,0 & NA & 1000 \\
\hline Chumbo (Pb) & $\mathrm{mg} / \mathrm{kg}$ & 5,0 & 17,342 & 1000 \\
\hline Selênio (Se) & $\mathrm{mg} / \mathrm{kg}$ & 5,0 & NA & 100 \\
\hline Arsênio (As) & $\mathrm{mg} / \mathrm{kg}$ & 5,0 & NA & 1000 \\
\hline Cianetos (CN) & $\mathrm{mg} / \mathrm{kg}$ & 0,001 & 0,171 & 1000 \\
\hline Índice de Fenóis & $\mathrm{mg} / \mathrm{kg}$ & 0,01 & 0,096 & 10 \\
\hline Hidrocarb. líquidos/bombeáveis & $\%$ & & NA & 5 \\
\hline Óleos e graxas & $\%$ & & NA & 1 \\
\hline Líquidos livres & & Ausente & Ausente & Ausente \\
\hline
\end{tabular}

VMP - Valor Máximo Permitido pela NBR 10004 NA - Não Analisado 
Tabela C.05. Resultado da análise química do extrato oriundo do corpo-de-prova de mistura asfáltica com 15\% de Areia de Fundição, submetido ao ensaio de lixiviação com extrator soxhlet - (primeiro dia $-1^{\mathrm{a}}$ Coleta)

\begin{tabular}{|c|c|c|c|c|}
\hline Parâmetrso & Unidade & $\begin{array}{c}\text { Limite de } \\
\text { Quantificação }\end{array}$ & $\begin{array}{l}\text { Resultado } \\
\text { Analítico }\end{array}$ & $\begin{array}{c}\text { NBR } 10004 \\
\text { VMP }\end{array}$ \\
\hline Arsênio (As) & $\overline{\mathrm{mg} / \mathrm{L}}$ & 0,001 & NA & 0,05 \\
\hline Bário (Ba) & $\mathrm{mg} / \mathrm{L}$ & 0,01 & $<0,01$ & 1,0 \\
\hline Cádmio (Cd) & $\mathrm{mg} / \mathrm{L}$ & 0,001 & $<0,001$ & 0,005 \\
\hline Chumbo (Pb) & $\mathrm{mg} / \mathrm{L}$ & 0,001 & $<0,001$ & 0,05 \\
\hline Cianetos (CN) & $\mathrm{mg} / \mathrm{L}$ & 0,001 & $<0,001$ & 0,1 \\
\hline Cromo total (Cr) & $\mathrm{mg} / \mathrm{L}$ & 0,001 & $<0,001$ & 0,05 \\
\hline Índice de Fenóis & $\mathrm{mg} / \mathrm{L}$ & 0,001 & $<0,001$ & 0,001 \\
\hline Fluoretos (F) & $\mathrm{mg} / \mathrm{L}$ & 0,01 & 0,08 & 1,5 \\
\hline Mercúrio (Hg) & $\mathrm{mg} / \mathrm{L}$ & 0,001 & $<0,001$ & 0,001 \\
\hline Nitratos $\left(\mathrm{N}-\mathrm{NO}_{3}\right)$ & $\mathrm{mg} / \mathrm{L}$ & 0,01 & 0,3241 & 10,0 \\
\hline Prata (Ag) & $\mathrm{mg} / \mathrm{L}$ & 0,001 & $<0,001$ & 0,05 \\
\hline Selênio (Se) & $\mathrm{mg} / \mathrm{L}$ & 0,01 & NA & 0,01 \\
\hline Aluminio (Al) & $\mathrm{mg} / \mathrm{L}$ & 0,001 & 0,02 & 0,2 \\
\hline Cloretos (Cl) & $\mathrm{mg} / \mathrm{L}$ & 0,5 & 0,60 & 250,0 \\
\hline Cobre (Cu) & $\mathrm{mg} / \mathrm{L}$ & 0,001 & 0,009 & 1,0 \\
\hline Dureza Total $\left(\mathrm{CaCO}_{3}\right)$ & $\mathrm{mg} / \mathrm{L}$ & 1,00 & 14,00 & 500,0 \\
\hline Ferro $(\mathrm{Fe})$ & $\mathrm{mg} / \mathrm{L}$ & 0,05 & 0,134 & 0,3 \\
\hline Manganês (Mn) & $\mathrm{mg} / \mathrm{L}$ & 0,001 & $<0,001$ & 0,1 \\
\hline Sódio (Na) & $\mathrm{mg} / \mathrm{L}$ & 0,1 & 8,50 & 200,0 \\
\hline Surfactantes (tensoativos) & $\mathrm{mg} / \mathrm{L}$ & 0,01 & 0,110 & 0,2 \\
\hline Sulfatos $\left(\mathrm{SO}_{4}\right)$ & $\mathrm{mg} / \mathrm{L}$ & 1,00 & 1,00 & 400,0 \\
\hline Zinco (Zn) & $\mathrm{mg} / \mathrm{L}$ & 0,001 & 0,006 & 5,0 \\
\hline $\mathrm{pH}$ & & & 8,70 & \\
\hline
\end{tabular}

VMP - Valor Máximo Permitido pela NBR 10004 NA - Não Analisado 
Tabela C.06. Resultado Parcial ${ }^{1}$ da análise química do extrato oriundo do corpo-deprova de mistura asfáltica com 15\% de Areia de Fundição, submetido ao ensaio de lixiviação com extrator soxhlet - (sétimo dia do início do ensaio - $2^{\mathrm{a}}$ Coleta)

\begin{tabular}{|c|c|c|c|c|}
\hline Parâmetros & Unidade & $\begin{array}{c}\text { Limite de } \\
\text { Quantificação }\end{array}$ & $\begin{array}{l}\text { Resultado } \\
\text { Analítico }\end{array}$ & $\begin{array}{c}\text { NBR } 10004 \\
\text { VMP }\end{array}$ \\
\hline Arsênio (As) & $\mathrm{mg} / \mathrm{L}$ & 0,001 & NA & 0,05 \\
\hline Bário (Ba) & $\mathrm{mg} / \mathrm{L}$ & 0,01 & $<0,01$ & 1,0 \\
\hline Cádmio (Cd) & $\mathrm{mg} / \mathrm{L}$ & 0,001 & 0,002 & 0,005 \\
\hline Chumbo (Pb) & $\mathrm{mg} / \mathrm{L}$ & 0,001 & $<0,001$ & 0,05 \\
\hline Cianetos (CN) & $\mathrm{mg} / \mathrm{L}$ & 0,001 & $<0,001$ & 0,1 \\
\hline Cromo total (Cr) & $\mathrm{mg} / \mathrm{L}$ & 0,001 & $<0,001$ & 0,05 \\
\hline Índice de Fenóis & $\mathrm{mg} / \mathrm{L}$ & 0,001 & $<0,001$ & 0,001 \\
\hline Fluoretos (F) & $\mathrm{mg} / \mathrm{L}$ & 0,01 & 0,21 & 1,5 \\
\hline Mercúrio (Hg) & $\mathrm{mg} / \mathrm{L}$ & 0,001 & $<0,001$ & 0,001 \\
\hline Nitratos $\left(\mathrm{N}-\mathrm{NO}_{3}\right)$ & $\mathrm{mg} / \mathrm{L}$ & 0,01 & 0,3534 & 10,0 \\
\hline Prata (Ag) & $\mathrm{mg} / \mathrm{L}$ & 0,001 & $<0,001$ & 0,05 \\
\hline Selênio (Se) & $\mathrm{mg} / \mathrm{L}$ & 0,01 & NA & 0,01 \\
\hline Alumínio (Al) & $\mathrm{mg} / \mathrm{L}$ & 0,001 & 0,74 & 0,2 \\
\hline Cloretos (Cl) & $\mathrm{mg} / \mathrm{L}$ & 0,5 & 1,20 & 250,0 \\
\hline Cobre (Cu) & $\mathrm{mg} / \mathrm{L}$ & 0,001 & 0,011 & 1,0 \\
\hline Dureza Total $\left(\mathrm{CaCO}_{3}\right)$ & $\mathrm{mg} / \mathrm{L}$ & 1,00 & 13,00 & 500,0 \\
\hline Ferro (Fe) & $\mathrm{mg} / \mathrm{L}$ & 0,05 & 0,163 & 0,3 \\
\hline Manganês (Mn) & $\mathrm{mg} / \mathrm{L}$ & 0,001 & $<0,001$ & 0,1 \\
\hline Sódio (Na) & $\mathrm{mg} / \mathrm{L}$ & 0,1 & 20,00 & 200,0 \\
\hline Surfactantes (tensoativos) & $\mathrm{mg} / \mathrm{L}$ & 0,01 & 0,127 & 0,2 \\
\hline Sulfatos $\left(\mathrm{SO}_{4}\right)$ & $\mathrm{mg} / \mathrm{L}$ & 1,00 & 1,00 & 400,0 \\
\hline Zinco (Zn) & $\mathrm{mg} / \mathrm{L}$ & 0,001 & 0,008 & 5,0 \\
\hline $\mathrm{pH}$ & & & 8,75 & \\
\hline
\end{tabular}

VMP - Valor Máximo Permitido pela NBR 10004 NA - Não Analisado

1 Referente, apenas, ao período em que a amostra ficou submetida a este condicionamento, desconsiderando o período da coleta anterior. Neste caso, referente a seis dias (72 horas). 
Tabela C.07. Resultado Parcial ${ }^{2}$ da análise química do extrato oriundo do corpo-deprova de mistura asfáltica com 15\% de Areia de Fundição, submetido ao ensaio de lixiviação com extrator soxhlet - (21 ${ }^{\circ}$ dia do início do ensaio - $3^{\mathrm{a}}$ Coleta $)$

\begin{tabular}{|c|c|c|c|c|}
\hline Parâmetros & Unidade & $\begin{array}{c}\text { Limite de } \\
\text { Quantificação }\end{array}$ & $\begin{array}{c}\text { Resultado } \\
\text { Analítico }\end{array}$ & $\begin{array}{c}\text { NBR } 10004 \\
\text { VMP }\end{array}$ \\
\hline Arsênio (As) & $\mathrm{mg} / \mathrm{L}$ & 0,001 & NA & 0,05 \\
\hline Bário (Ba) & $\mathrm{mg} / \mathrm{L}$ & 0,01 & $<0,01$ & 1,0 \\
\hline Cádmio (Cd) & $\mathrm{mg} / \mathrm{L}$ & 0,001 & $<0,001$ & 0,005 \\
\hline Chumbo (Pb) & $\mathrm{mg} / \mathrm{L}$ & 0,001 & $<0,001$ & 0,05 \\
\hline Cianetos (CN) & $\mathrm{mg} / \mathrm{L}$ & 0,001 & $<0,001$ & 0,1 \\
\hline Cromo total (Cr) & $\mathrm{mg} / \mathrm{L}$ & 0,001 & $<0,001$ & 0,05 \\
\hline Índice de Fenóis & $\mathrm{mg} / \mathrm{L}$ & 0,001 & $<0,001$ & 0,001 \\
\hline Fluoretos (F) & $\mathrm{mg} / \mathrm{L}$ & 0,01 & 0,39 & 1,5 \\
\hline Mercúrio (Hg) & $\mathrm{mg} / \mathrm{L}$ & 0,001 & $<0,001$ & 0,001 \\
\hline Nitratos $\left(\mathrm{N}-\mathrm{NO}_{3}\right)$ & $\mathrm{mg} / \mathrm{L}$ & 0,01 & 1,2891 & 10,0 \\
\hline Prata (Ag) & $\mathrm{mg} / \mathrm{L}$ & 0,001 & $<0,001$ & 0,05 \\
\hline Selênio (Se) & $\mathrm{mg} / \mathrm{L}$ & 0,01 & NA & 0,01 \\
\hline Aluminio (Al) & $\mathrm{mg} / \mathrm{L}$ & 0,001 & 0,69 & 0,2 \\
\hline Cloretos (Cl) & $\mathrm{mg} / \mathrm{L}$ & 0,5 & 1,30 & 250,0 \\
\hline Cobre (Cu) & $\mathrm{mg} / \mathrm{L}$ & 0,001 & 0,001 & 1,0 \\
\hline Dureza Total $\left(\mathrm{CaCO}_{3}\right)$ & $\mathrm{mg} / \mathrm{L}$ & 1,00 & 15,00 & 500,0 \\
\hline Ferro (Fe) & $\mathrm{mg} / \mathrm{L}$ & 0,05 & 0,110 & 0,3 \\
\hline Manganês (Mn) & $\mathrm{mg} / \mathrm{L}$ & 0,001 & $<0,001$ & 0,1 \\
\hline Sódio (Na) & $\mathrm{mg} / \mathrm{L}$ & 0,1 & 38,00 & 200,0 \\
\hline Surfactantes (tensoativos) & $\mathrm{mg} / \mathrm{L}$ & 0,01 & 0,022 & 0,2 \\
\hline Sulfatos $\left(\mathrm{SO}_{4}\right)$ & $\mathrm{mg} / \mathrm{L}$ & 1,00 & 12,00 & 400,0 \\
\hline Zinco (Zn) & $\mathrm{mg} / \mathrm{L}$ & 0,001 & $<0,001$ & 5,0 \\
\hline $\mathrm{pH}$ & & & 8,85 & \\
\hline
\end{tabular}

VMP - Valor Máximo Permitido pela NBR 10004 NA - Não Analisado

2 Referente, apenas, ao período em que a amostra ficou submetida a este condicionamento, desconsiderando o período da coleta anterior. Neste caso, 14 dias (168 horas). 
Tabela C.08. Resultado Parcial ${ }^{3}$ da análise química do extrato oriundo do corpo-deprova de mistura asfáltica com 15\% de Areia de Fundição, submetido ao ensaio de lixiviação com extrator soxhlet - ( $45^{\circ}$ dia do início do ensaio - $4^{\mathrm{a}}$ Coleta $)$

\begin{tabular}{|c|c|c|c|c|}
\hline Parâmetros & Unidade & $\begin{array}{c}\text { Limite de } \\
\text { Quantificação }\end{array}$ & $\begin{array}{l}\text { Resultado } \\
\text { Analítico }\end{array}$ & $\begin{array}{c}\text { NBR } 10004 \\
\text { VMP }\end{array}$ \\
\hline Arsênio (As) & $\mathrm{mg} / \mathrm{L}$ & 0,001 & NA & 0,05 \\
\hline Bário (Ba) & $\mathrm{mg} / \mathrm{L}$ & 0,01 & 0,021 & 1,0 \\
\hline Cádmio (Cd) & $\mathrm{mg} / \mathrm{L}$ & 0,001 & 0,004 & 0,005 \\
\hline Chumbo (Pb) & $\mathrm{mg} / \mathrm{L}$ & 0,001 & 0,042 & 0,05 \\
\hline Cianetos (CN) & $\mathrm{mg} / \mathrm{L}$ & 0,001 & $<0,001$ & 0,1 \\
\hline Cromo total (Cr) & $\mathrm{mg} / \mathrm{L}$ & 0,001 & $<0,001$ & 0,05 \\
\hline Índice de Fenóis & $\mathrm{mg} / \mathrm{L}$ & 0,001 & 0,133 & 0,001 \\
\hline Fluoretos (F) & $\mathrm{mg} / \mathrm{L}$ & 0,01 & 2,12 & 1,5 \\
\hline Mercúrio (Hg) & $\mathrm{mg} / \mathrm{L}$ & 0,001 & 0,006 & 0,001 \\
\hline Nitratos $\left(\mathrm{N}-\mathrm{NO}_{3}\right)$ & $\mathrm{mg} / \mathrm{L}$ & 0,01 & 13,6285 & 10,0 \\
\hline Prata (Ag) & $\mathrm{mg} / \mathrm{L}$ & 0,001 & 0,002 & 0,05 \\
\hline Selênio (Se) & $\mathrm{mg} / \mathrm{L}$ & 0,01 & NA & 0,01 \\
\hline Alumínio (Al) & $\mathrm{mg} / \mathrm{L}$ & 0,001 & 0,074 & 0,2 \\
\hline Cloretos (Cl) & $\mathrm{mg} / \mathrm{L}$ & 0,5 & 10,10 & 250,0 \\
\hline Cobre (Cu) & $\mathrm{mg} / \mathrm{L}$ & 0,001 & 0,031 & 1,0 \\
\hline Dureza Total $\left(\mathrm{CaCO}_{3}\right)$ & $\mathrm{mg} / \mathrm{L}$ & 1,00 & 18,00 & 500,0 \\
\hline Ferro (Fe) & $\mathrm{mg} / \mathrm{L}$ & 0,05 & 0,471 & 0,3 \\
\hline Manganês (Mn) & $\mathrm{mg} / \mathrm{L}$ & 0,001 & 0,002 & 0,1 \\
\hline Sódio (Na) & $\mathrm{mg} / \mathrm{L}$ & 0,1 & 120,00 & 200,0 \\
\hline Surfactantes (tensoativos) & $\mathrm{mg} / \mathrm{L}$ & 0,01 & $<0,01$ & 0,2 \\
\hline Sulfatos $\left(\mathrm{SO}_{4}\right)$ & $\mathrm{mg} / \mathrm{L}$ & 1,00 & 27,00 & 400,0 \\
\hline Zinco (Zn) & $\mathrm{mg} / \mathrm{L}$ & 0,001 & 0,061 & 5,0 \\
\hline $\mathrm{pH}$ & & & 9,70 & \\
\hline
\end{tabular}

VMP - Valor máximo Permitido pela NBR 10004 NA - Não Analisado

No décimo dia de ensaio para essa coleta ( $31^{\circ}$ dia do início do ensaio), o corpo-deprova começou a se desintegrar, caindo pequenos pedaços de massa asfáltica no extrato em ebulição. Estes fragmentos permaneceram nesta condição (em ebulição) por pelo menos 10 horas e imerso, após desligar o equipamento, por aproximadamente, 12 horas. No entanto, os fragmentos foram retirados antes do equipamento ser religado para dar continuidade ao ensaio. Este fato tornou a ocorrer mais duas vezes, quando, então (39 dia do início do ensaio), o corpo-de-prova foi colocado em um béquer com o fundo

3 Referente, apenas, ao período em que a amostra ficou submetida a este condicionamento, desconsiderando o período da coleta anterior. Neste caso, 24 dias (288 horas). 
perfurado para que o ensaio continuasse, sem haver problema de queda de material no extrato.

Pelo exposto no parágrafo anterior, achou-se conveniente, apresentar-se, também, os resultados analíticos do ensaio de lixiviação com extrator soxhlet (Tabelas C.11), desprezando-se os valores parciais relativos a $4^{\mathrm{a}}$ coleta $\left(4^{\mathrm{a}}\right.$ coluna da Tabela C.08 Resultado Analítico).

Tabela C.09. Resultado Parcial $^{4}$ da análise química do extrato do corpo-de -prova de mistura asfáltica com 15\% de Areia de Fundição, submetido ao ensaio de lixiviação com extrator soxhlet $-\left(90^{\circ}\right.$ dia do início do ensaio $-5^{\text {a }}$ Coleta $)$

\begin{tabular}{|c|c|c|c|c|}
\hline Parâmetros & Unidade & $\begin{array}{c}\text { Limite de } \\
\text { Quantificação } \\
\end{array}$ & $\begin{array}{c}\text { Resultado } \\
\text { Analítico } \\
\end{array}$ & $\begin{array}{c}\text { NBR } 10004 \\
\text { VMP }\end{array}$ \\
\hline Arsênio (As) & $\mathrm{mg} / \mathrm{L}$ & 0,001 & NA & 0,05 \\
\hline Bário (Ba) & $\mathrm{mg} / \mathrm{L}$ & 0,01 & 0,045 & 1,0 \\
\hline Cádmio (Cd) & $\mathrm{mg} / \mathrm{L}$ & 0,001 & $<0,001$ & 0,005 \\
\hline Chumbo (Pb) & $\mathrm{mg} / \mathrm{L}$ & 0,001 & 0,046 & 0,05 \\
\hline Cianetos (CN) & $\mathrm{mg} / \mathrm{L}$ & 0,001 & $<0,001$ & 0,1 \\
\hline Cromo total (Cr) & $\mathrm{mg} / \mathrm{L}$ & 0,001 & 0,024 & 0,05 \\
\hline Índice de Fenóis & $\mathrm{mg} / \mathrm{L}$ & 0,001 & $<0,001$ & 0,001 \\
\hline Fluoretos (F) & $\mathrm{mg} / \mathrm{L}$ & 0,01 & 2,34 & 1,5 \\
\hline Mercúrio (Hg) & $\mathrm{mg} / \mathrm{L}$ & 0,001 & 0,002 & 0,001 \\
\hline Nitratos $\left(\mathrm{N}-\mathrm{NO}_{3}\right)$ & $\mathrm{mg} / \mathrm{L}$ & 0,01 & 20,382 & 10,0 \\
\hline Prata (Ag) & $\mathrm{mg} / \mathrm{L}$ & 0,001 & 0,005 & 0,05 \\
\hline Selênio (Se) & $\mathrm{mg} / \mathrm{L}$ & 0,01 & NA & 0,01 \\
\hline Alumínio (Al) & $\mathrm{mg} / \mathrm{L}$ & 0,001 & 1,44 & 0,2 \\
\hline Cloretos (Cl) & $\mathrm{mg} / \mathrm{L}$ & 0,5 & 0,80 & 250,0 \\
\hline Cobre (Cu) & $\mathrm{mg} / \mathrm{L}$ & 0,001 & 0,048 & 1,0 \\
\hline Dureza Total $\left(\mathrm{CaCO}_{3}\right)$ & $\mathrm{mg} / \mathrm{L}$ & 1,00 & 13,00 & 500,0 \\
\hline Ferro (Fe) & $\mathrm{mg} / \mathrm{L}$ & 0,05 & 0,601 & 0,3 \\
\hline Manganês (Mn) & $\mathrm{mg} / \mathrm{L}$ & 0,001 & 0,034 & 0,1 \\
\hline Sódio (Na) & $\mathrm{mg} / \mathrm{L}$ & 0,1 & 100,00 & 200,0 \\
\hline Surfactantes (tensoativos) & $\mathrm{mg} / \mathrm{L}$ & 0,01 & 0,705 & 0,2 \\
\hline Sulfatos $\left(\mathrm{SO}_{4}\right)$ & $\mathrm{mg} / \mathrm{L}$ & 1,00 & 17,00 & 400,0 \\
\hline Zinco (Zn) & $\mathrm{mg} / \mathrm{L}$ & 0,001 & 0,180 & 5,0 \\
\hline $\mathrm{pH}$ & & & 9,90 & \\
\hline
\end{tabular}

4 Referente, apenas, ao período em que a amostra ficou submetida a este condicionamento, desconsiderando o período da coleta anterior. Neste caso, 45 dias (540 horas). 
Tabela C.10. Resultado Total ${ }^{5}$ da análise química do extrato do corpo-de-prova de mistura asfáltica com 15\% de Areia de Fundição, submetido ao ensaio de lixiviação com extrator soxhlet - (Resumo)

\begin{tabular}{|c|c|c|c|c|c|c|c|c|}
\hline \multirow{3}{*}{ Parâmetros } & \multirow{3}{*}{ Unidade } & \multirow{3}{*}{$L Q$} & \multicolumn{5}{|c|}{ Resultado Analítico } & \multirow{3}{*}{$\begin{array}{c}\text { NBR } \\
10004 \\
V M P\end{array}$} \\
\hline & & & $\overline{1^{a} C}$ & $2^{a} \mathrm{C}$ & $3^{a} C$ & $\overline{44^{a} C}$ & $\overline{5^{a} C}$ & \\
\hline & & & $12 \mathrm{~h}$ & $84 h$ & $252 \mathrm{~h}$ & $540 \mathrm{~h}$ & $1080 \mathrm{~h}$ & \\
\hline Arsênio (As) & $\begin{array}{l}\mathrm{mg} / \mathrm{L} \\
\end{array}$ & 0,001 & NA & NA & NA & NA & NA & 0,05 \\
\hline Bário (Ba) & $\mathrm{mg} / \mathrm{L}$ & 0,01 & $<0,01$ & $<0,01$ & $<0,01$ & 0,021 & 0,066 & 1,0 \\
\hline Cádmio (Cd) & $\mathrm{mg} / \mathrm{L}$ & 0,001 & $<0,001$ & 0,002 & 0,002 & 0,006 & 0,006 & 0,005 \\
\hline Chumbo (Pb) & $\mathrm{mg} / \mathrm{L}$ & 0,001 & $<0,001$ & $<0,001$ & $<0,001$ & 0,042 & 0,088 & 0,05 \\
\hline Cianetos (CN) & $\mathrm{mg} / \mathrm{L}$ & 0,001 & $<0,001$ & $<0,001$ & $<0,001$ & $<0,001$ & $<0,001$ & 0,1 \\
\hline Cromo total (Cr) & $\mathrm{mg} / \mathrm{L}$ & 0,001 & $<0,001$ & $<0,001$ & $<0,001$ & $<0,001$ & 0,024 & 0,05 \\
\hline Índice de Fenóis & $\mathrm{mg} / \mathrm{L}$ & 0,001 & $<0,001$ & $<0,001$ & $<0,001$ & 0,133 & 0,133 & 0,001 \\
\hline Fluoretos (F) & $\mathrm{mg} / \mathrm{L}$ & 0,01 & 0,08 & 0,29 & 0,68 & 2,80 & 5,14 & 1,5 \\
\hline Mercúrio (Hg) & $\mathrm{mg} / \mathrm{L}$ & 0,001 & $<0,001$ & $<0,001$ & $<0,001$ & 0,006 & 0,008 & 0,001 \\
\hline Nitratos $\left(\mathrm{N}-\mathrm{NO}_{3}\right)$ & $\mathrm{mg} / \mathrm{L}$ & 0,01 & 0,3241 & 0,6775 & 1,3491 & 14,9776 & 35,3596 & 10,0 \\
\hline Prata (Ag) & $\mathrm{mg} / \mathrm{L}$ & 0,001 & $<0,001$ & $<0,001$ & $<0,001$ & 0,002 & 0,007 & 0,05 \\
\hline Selênio (Se) & $\mathrm{mg} / \mathrm{L}$ & 0,01 & NA & NA & NA & NA & NA & 0,01 \\
\hline Alumínio (Al) & $\mathrm{mg} / \mathrm{L}$ & 0,001 & 0,02 & 0,76 & 1,45 & 1,524 & 2,964 & 0,2 \\
\hline Cloretos (Cl) & $\mathrm{mg} / \mathrm{L}$ & 0,5 & 0,60 & 1,80 & 3,10 & 13,20 & 14,00 & 250,0 \\
\hline Cobre (Cu) & $\mathrm{mg} / \mathrm{L}$ & 0,001 & 0,009 & 0,02 & 0,021 & 0,052 & 0,10 & 1,0 \\
\hline $\begin{array}{l}\text { Dureza Total } \\
\left(\mathrm{CaCO}_{3}\right)\end{array}$ & $\mathrm{mg} / \mathrm{L}$ & 1,00 & 14,00 & 27,00 & 42,00 & 60,00 & 73,00 & 500,0 \\
\hline Ferro (Fe) & $\mathrm{mg} / \mathrm{L}$ & 0,05 & 0,134 & 0,297 & 0,407 & 0,878 & 1,449 & 0,3 \\
\hline Manganês (Mn) & $\mathrm{mg} / \mathrm{L}$ & 0,001 & $<0,001$ & $<0,001$ & $<0,001$ & 0,002 & 0,036 & 0,1 \\
\hline Sódio (Na) & $\mathrm{mg} / \mathrm{L}$ & 0,1 & 8,50 & 28,50 & 66,50 & 186,50 & 286,50 & 200,0 \\
\hline Surfactantes & $\mathrm{mg} / \mathrm{L}$ & 0,01 & 0,110 & 0,237 & 0,259 & 0,259 & 0,964 & 0,2 \\
\hline Sulfatos $\left(\mathrm{SO}_{4}\right)$ & $\mathrm{mg} / \mathrm{L}$ & 1,00 & 1,00 & 2,00 & 14,00 & 41,00 & 58,00 & 400,0 \\
\hline Zinco (Zn) & $\mathrm{mg} / \mathrm{L}$ & 0,001 & 0,006 & 0,14 & 0,14 & 0,201 & 0,381 & 5,0 \\
\hline $\mathrm{pH}$ & & & 8,70 & 8,75 & 8,85 & 9,70 & 9,90 & \\
\hline
\end{tabular}

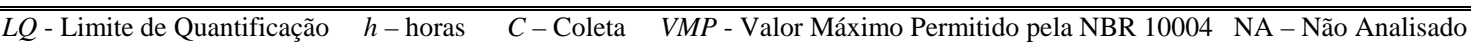

Os resultados analíticos, apresentados nas Tabela C.12 e C.13, foram multiplicados por 0,418, visto que, para o teste de solubilização de resíduos, deve-se utilizar uma amostra representativa de 250 g (base seca) para um litro de água destilada (ABNT NBR - 10006/87). O peso do corpo-de-prova utilizado neste ensaio foi de 1255,5 gf (material compactado), portanto, deveriam ser utilizados 5,02 litros. Utilizou-se este

${ }^{5}$ Referente ao período de condicionamento acumulado de cada coleta, portanto, os resultados (totais) da coleta n são os da coleta n-1, adicionado aos parciais da coleta n. 
critério, em virtude dos padrões empregados (limite máximo no extrato - mg/L) serem referentes ao teste de solubilização e não existir um ensaio padronizado com esta finalidade. Contudo, por limitação do recipiente do equipamento, utilizaram-se, apenas, 2,1 litros. O coeficiente $(0,418)$ multiplicador destes parâmetros (Tabela C.10) foi obtido, dividindo-se a quantidade de água inserida no recipiente (2, 1 litros) pela que deveria ser utilizada (5,02 litros).

Tabela C.11. Resultado Total da análise química do extrato do corpo-de-prova de mistura asfáltica com 15\% de Areia de Fundição, submetido ao ensaio de lixiviação com extrator soxhlet - (Resumo, desprezando-se a $4^{\mathrm{a}}$ coleta)

\begin{tabular}{|c|c|c|c|c|c|c|c|}
\hline \multirow{3}{*}{ Parâmetros } & \multirow{3}{*}{ Unidade } & \multirow{3}{*}{$L Q$} & \multicolumn{4}{|c|}{ Resultado Analítico } & \multirow{3}{*}{$\begin{array}{c}\text { NBR } 10004 \\
\text { VMP }\end{array}$} \\
\hline & & & \multirow{2}{*}{$\begin{array}{l}1^{a} \mathrm{C} \\
12 \mathrm{~h}\end{array}$} & \multirow{2}{*}{$\begin{array}{l}2^{a} \mathrm{C} \\
84 \mathrm{~h}\end{array}$} & \multirow{2}{*}{$\begin{array}{c}3^{a} \mathrm{C} \\
252 \mathrm{~h}\end{array}$} & \multirow{2}{*}{$\begin{array}{c}5^{a} \mathrm{C} \\
792 \mathrm{~h}\end{array}$} & \\
\hline & & & & & & & \\
\hline Arsênio (As) & $\mathrm{mg} / \mathrm{L}$ & 0,001 & $\overline{\mathrm{NR}}$ & $\begin{array}{l}\text { NR } \\
\end{array}$ & NR & $\overline{\mathrm{NR}}$ & 0,05 \\
\hline Bário (Ba) & $\mathrm{mg} / \mathrm{L}$ & 0,01 & $<0,01$ & $<0,01$ & $<0,01$ & 0,045 & 1,0 \\
\hline Cádmio (Cd) & $\mathrm{mg} / \mathrm{L}$ & 0,001 & $<0,001$ & 0,002 & 0,002 & 0,002 & 0,005 \\
\hline Chumbo (Pb) & $\mathrm{mg} / \mathrm{L}$ & 0,001 & $<0,001$ & $<0,001$ & $<0,001$ & 0,046 & 0,05 \\
\hline Cianetos (CN) & $\mathrm{mg} / \mathrm{L}$ & 0,001 & $<0,001$ & $<0,001$ & $<0,001$ & $<0,001$ & 0,1 \\
\hline Cromo total (Cr) & $\mathrm{mg} / \mathrm{L}$ & 0,001 & $<0,001$ & $<0,001$ & $<0,001$ & 0,024 & 0,05 \\
\hline Índice de Fenóis & $\mathrm{mg} / \mathrm{L}$ & 0,001 & $<0,001$ & $<0,001$ & $<0,001$ & $<0,001$ & 0,001 \\
\hline Fluoretos (F) & $\mathrm{mg} / \mathrm{L}$ & 0,01 & 0,08 & 0,29 & 0,68 & 3,02 & 1,5 \\
\hline Mercúrio (Hg) & $\mathrm{mg} / \mathrm{L}$ & 0,001 & $<0,001$ & $<0,001$ & $<0,001$ & 0,002 & 0,001 \\
\hline Nitratos $\left(\mathrm{N}-\mathrm{NO}_{3}\right)$ & $\mathrm{mg} / \mathrm{L}$ & 0,01 & 0,3241 & 0,6775 & 1,3491 & 21,7311 & 10,0 \\
\hline Prata (Ag) & $\mathrm{mg} / \mathrm{L}$ & 0,001 & $<0,001$ & $<0,001$ & $<0,001$ & 0,005 & 0,05 \\
\hline Selênio (Se) & $\mathrm{mg} / \mathrm{L}$ & 0,01 & NR & NR & NR & NR & 0,01 \\
\hline Alumínio (Al) & $\mathrm{mg} / \mathrm{L}$ & 0,001 & 0,02 & 0,76 & 1,45 & 2,89 & 0,2 \\
\hline Cloretos (Cl) & $\mathrm{mg} / \mathrm{L}$ & 0,5 & 0,60 & 1,80 & 3,10 & 3,90 & 250,0 \\
\hline Cobre (Cu) & $\mathrm{mg} / \mathrm{L}$ & 0,001 & 0,009 & 0,02 & 0,021 & 0,069 & 1,0 \\
\hline $\begin{array}{l}\text { Dureza Total } \\
\left(\mathrm{CaCO}_{3}\right)\end{array}$ & $\mathrm{mg} / \mathrm{L}$ & 1,00 & 14,00 & 27,00 & 42,00 & 55,00 & 500,0 \\
\hline Ferro (Fe) & $\mathrm{mg} / \mathrm{L}$ & 0,05 & 0,134 & 0,297 & 0,407 & 0,978 & 0,3 \\
\hline Manganês (Mn) & $\mathrm{mg} / \mathrm{L}$ & 0,001 & $<0,001$ & $<0,001$ & $<0,001$ & 0,034 & 0,1 \\
\hline Sódio (Na) & $\mathrm{mg} / \mathrm{L}$ & 0,1 & 8,50 & 28,50 & 66,50 & 166,50 & 200,0 \\
\hline Surfactantes & $\mathrm{mg} / \mathrm{L}$ & 0,01 & 0,110 & 0,237 & 0,259 & 0,964 & 0,2 \\
\hline Sulfatos $\left(\mathrm{SO}_{4}\right)$ & $\mathrm{mg} / \mathrm{L}$ & 1,00 & 1,00 & 2,00 & 14,00 & 31,00 & 400,0 \\
\hline Zinco (Zn) & $\mathrm{mg} / \mathrm{L}$ & 0,001 & 0,006 & 0,14 & 0,14 & 0,32 & 5,0 \\
\hline pH & & & 8,70 & 8,75 & 8,85 & 9,90 & \\
\hline
\end{tabular}


Tabela C.12. Resultado Total da análise química do extrato do corpo-de-prova de mistura asfáltica com 15\% de Areia de Fundição, submetido ao ensaio de lixiviação com extrator soxhlet - (Resumo multiplicado por 0,418)

\begin{tabular}{|c|c|c|c|c|c|c|c|c|}
\hline \multirow{3}{*}{ Parâmetros } & \multirow{3}{*}{ Unidade } & \multirow{3}{*}{$L Q$} & \multicolumn{5}{|c|}{ Resultado analítico } & \multirow{3}{*}{$\begin{array}{c}\text { NBR } \\
10004 \\
V M P\end{array}$} \\
\hline & & & $\overline{1^{a} C}$ & $\overline{2^{a} C}$ & $3^{a} C$ & $\overline{4^{a} C}$ & $\overline{5^{a} C}$ & \\
\hline & & & $12 \mathrm{~h}$ & $84 h$ & $252 \mathrm{~h}$ & $540 \mathrm{~h}$ & $1080 \mathrm{~h}$ & \\
\hline Arsênio (As) & 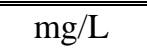 & 0,001 & NA & NA & NA & NA & NA & 0,05 \\
\hline Bário (Ba) & $\mathrm{mg} / \mathrm{L}$ & 0,01 & $<0,01$ & $<0,01$ & $<0,01$ & $<0,01$ & 0,028 & 1,0 \\
\hline Cádmio (Cd) & $\mathrm{mg} / \mathrm{L}$ & 0,001 & $<0,001$ & $<0,001$ & $<0,001$ & 0,002 & 0,002 & 0,005 \\
\hline Chumbo (Pb) & $\mathrm{mg} / \mathrm{L}$ & 0,001 & $<0,001$ & $<0,001$ & $<0,001$ & 0,018 & 0,037 & 0,05 \\
\hline Cianetos (CN) & $\mathrm{mg} / \mathrm{L}$ & 0,001 & $<0,001$ & $<0,001$ & $<0,001$ & $<0,001$ & $<0,001$ & 0,1 \\
\hline Cromo total (Cr) & $\mathrm{mg} / \mathrm{L}$ & 0,001 & $<0,001$ & $<0,001$ & $<0,001$ & $<0,001$ & 0,01 & 0,05 \\
\hline Índice de Fenóis & $\mathrm{mg} / \mathrm{L}$ & 0,001 & $<0,001$ & $<0,001$ & $<0,001$ & 0,056 & 0,056 & 0,001 \\
\hline Fluoretos (F) & $\mathrm{mg} / \mathrm{L}$ & 0,01 & 0,03 & 0,12 & 0,28 & 1,17 & 2,15 & 1,5 \\
\hline Mercúrio (Hg) & $\mathrm{mg} / \mathrm{L}$ & 0,001 & $<0,001$ & $<0,001$ & $<0,001$ & 0,0025 & 0,0033 & 0,001 \\
\hline Nitratos $\left(\mathrm{N}-\mathrm{NO}_{3}\right)$ & $\mathrm{mg} / \mathrm{L}$ & 0,01 & 0,1354 & 0,2832 & 0,5639 & 6,2606 & 14,7803 & 10,0 \\
\hline Prata (Ag) & $\mathrm{mg} / \mathrm{L}$ & 0,001 & $<0,001$ & $<0,001$ & $<0,001$ & $<0,001$ & 0,003 & 0,05 \\
\hline Selênio (Se) & $\mathrm{mg} / \mathrm{L}$ & 0,01 & NA & NA & NA & NA & NA & 0,01 \\
\hline Alumínio (Al) & $\mathrm{mg} / \mathrm{L}$ & 0,001 & 0,01 & 0,32 & 0,61 & 0,64 & 1,24 & 0,2 \\
\hline Cloretos (Cl) & $\mathrm{mg} / \mathrm{L}$ & 0,5 & 0,26 & 0,75 & 1,30 & 5,52 & 5,85 & 250,0 \\
\hline Cobre (Cu) & $\mathrm{mg} / \mathrm{L}$ & 0,001 & 0,004 & 0,008 & 0,009 & 0,022 & 0,042 & 1,0 \\
\hline $\begin{array}{l}\text { Dureza Total } \\
\left(\mathrm{CaCO}_{3}\right)\end{array}$ & $\mathrm{mg} / \mathrm{L}$ & 1,00 & 5,85 & 11,29 & 17,56 & 25,08 & 30,51 & 500,0 \\
\hline Ferro (Fe) & $\mathrm{mg} / \mathrm{L}$ & 0,05 & 0,056 & 0,124 & 0,170 & 0,367 & 0,606 & 0,3 \\
\hline Manganês (Mn) & $\mathrm{mg} / \mathrm{L}$ & 0,001 & $<0,001$ & $<0,001$ & $<0,001$ & $<0,001$ & 0,015 & 0,1 \\
\hline Sódio (Na) & $\mathrm{mg} / \mathrm{L}$ & 0,1 & 3,55 & 11,91 & 27,80 & 77,96 & 119,76 & 200,0 \\
\hline Surfactantes & $\mathrm{mg} / \mathrm{L}$ & 0,01 & $<0,01$ & $<0,01$ & 0,108 & 0,108 & 0,403 & 0,2 \\
\hline Sulfatos $\left(\mathrm{SO}_{4}\right)$ & $\mathrm{mg} / \mathrm{L}$ & 1,00 & $<1,00$ & $<1,00$ & 5,85 & 17,14 & 24,24 & 400,0 \\
\hline Zinco (Zn) & $\mathrm{mg} / \mathrm{L}$ & 0,001 & 0,003 & 0,059 & 0,059 & 0,084 & 0,159 & 5,0 \\
\hline pH & & & 8,70 & 8,75 & 8,85 & 9,70 & 9,90 & \\
\hline
\end{tabular}


Tabela C.13. Resultado da análise química do extrato oriundo da amostra de CAP $20^{6}$, submetida ao ensaio de lixiviação com extrator soxhlet

\begin{tabular}{|c|c|c|c|c|}
\hline Parâmetros & Unidade & $\begin{array}{c}\text { Limite de } \\
\text { Quantificação }\end{array}$ & $\begin{array}{l}\text { Resultado } \\
\text { Analítico }\end{array}$ & $\begin{array}{l}\text { NBR } 10004 \\
\text { VMP }\end{array}$ \\
\hline Arsênio (As) & $\overline{\mathrm{mg} / \mathrm{L}}$ & 0,001 & 0,0015 & 0,05 \\
\hline Bário (Ba) & $\mathrm{mg} / \mathrm{L}$ & 0,001 & $<0,001$ & 1,0 \\
\hline Cádmio (Cd) & $\mathrm{mg} / \mathrm{L}$ & 0,001 & 0,078 & 0,005 \\
\hline Chumbo (Pb) & $\mathrm{mg} / \mathrm{L}$ & 0,001 & 0,727 & 0,05 \\
\hline Cianetos (CN) & $\mathrm{mg} / \mathrm{L}$ & 0,001 & $<0,001$ & 0,1 \\
\hline Cromo total (Cr) & $\mathrm{mg} / \mathrm{L}$ & 0,001 & $<0,001$ & 0,05 \\
\hline Índice de Fenóis & $\mathrm{mg} / \mathrm{L}$ & 0,001 & 0,055 & 0,001 \\
\hline Fluoretos (F) & $\mathrm{mg} / \mathrm{L}$ & 0,01 & 0,13 & 1,5 \\
\hline Mercúrio (Hg) & $\mathrm{mg} / \mathrm{L}$ & 0,001 & $<0,001$ & 0,001 \\
\hline Nitratos $\left(\mathrm{N}-\mathrm{NO}_{3}\right)$ & $\mathrm{mg} / \mathrm{L}$ & 0,01 & 0,547 & 10,0 \\
\hline Prata (Ag) & $\mathrm{mg} / \mathrm{L}$ & 0,001 & 0,021 & 0,05 \\
\hline Selênio (Se) & $\mathrm{mg} / \mathrm{L}$ & 0,01 & $<0,01$ & 0,01 \\
\hline Aluminio (Al) & $\mathrm{mg} / \mathrm{L}$ & 0,001 & 0,639 & 0,2 \\
\hline Cloretos (Cl) & $\mathrm{mg} / \mathrm{L}$ & 0,5 & 2,66 & 250,0 \\
\hline Cobre (Cu) & $\mathrm{mg} / \mathrm{L}$ & 0,001 & $<0,001$ & 1,0 \\
\hline Dureza Total $\left(\mathrm{CaCO}_{3}\right)$ & $\mathrm{mg} / \mathrm{L}$ & 1,00 & $<1,00$ & 500,0 \\
\hline Ferro (Fe) & $\mathrm{mg} / \mathrm{L}$ & 0,05 & 0,111 & 0,3 \\
\hline Manganês (Mn) & $\mathrm{mg} / \mathrm{L}$ & 0,001 & $<0,001$ & 0,1 \\
\hline Sódio (Na) & $\mathrm{mg} / \mathrm{L}$ & 0,1 & 5,28 & 200,0 \\
\hline Surfactantes (tensoativos) & $\mathrm{mg} / \mathrm{L}$ & 0,01 & 0,016 & 0,2 \\
\hline Sulfatos $\left(\mathrm{SO}_{4}\right)$ & $\mathrm{mg} / \mathrm{L}$ & 1,00 & 2,42 & 400,0 \\
\hline Zinco (Zn) & $\mathrm{mg} / \mathrm{L}$ & 0,001 & $<0,001$ & 5,0 \\
\hline $\mathrm{pH}$ & & & 8,69 & \\
\hline
\end{tabular}

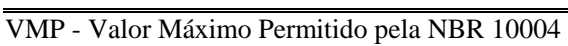

Nos gráficos das Figuras C.01 a C.15 são apresentados os resultados do ensaio de lixiviação com extrator soxhlet em três condições distintas: situação I, II, III, descritas adiante. Esses resultados são as concentrações acumuladas do parâmetro analisado, em mg/L, baseado nos padrões para o teste de solubilização (ANEXO H Listagem $n^{0} 8$ da NBR 10004/87) versus o tempo de realização do ensaio (condicionamento do corpo-deprova), em horas.

\footnotetext{
${ }^{6}$ com peso de 180,6 gf, sendo utilizado no ensaio $1870 \mathrm{ml}$ de água destilada. A duração do ensaio foi de sete dias, sendo o sistema de funcionamento do extrator soxhlet, intermitente, 12 horas ligado e 12 horas desligado.
} 
Os gráficos das Figuras C.01 a C.05 (concentração do parâmetro analisado - mg/L versus o tempo - hora) dizem respeito aos resultados da análise química listada na Tabela C.10. Esses resultados são referentes à condição, onde é considerada a quantidade de água de 2,1 litros como sendo a ideal e com os condicionamentos de todas as coletas em estado normal, isto é, conforme o previsto para todo o ensaio. Denominou-se esta condição de Situação I.

Os gráficos das Figuras C.06 a C.10 dizem respeito à Situação II, considerando um fator de minoração para os resultados da Tabela C.10. A origem deste coeficiente, bem como a sua utilização, já foi justificada anteriormente. Os resultados, considerando esse fator, podem ser verificados na Tabela C.12.

Os gráficos das Figuras C.11 a C.15 são referentes à Situação III, considerando a diluição de 2,1 litros como a indicada, mas desprezando os resultados parciais da quarta coleta, visto que, como explicado anteriormente, ocorreram fatos que tornaram o condicionamento dessa coleta atípico, do ponto de vista do pesquisador, mais severo que os demais. Esses gráficos foram traçados com base nos dados da Tabela C.11. Desta forma, os gráficos referentes a essa situação foram obtidos com quatro pontos, relativos as coletas, 1 (12 horas), 2 (84 horas), 3 (252 horas) e 5 (792 horas). Vale ressaltar, que, como o condicionamento parcial, relativo a quarta coleta foi desprezado, o período referente à quinta coleta passa a ser 792 horas $(1080 \mathrm{~h}$ - 288h). 


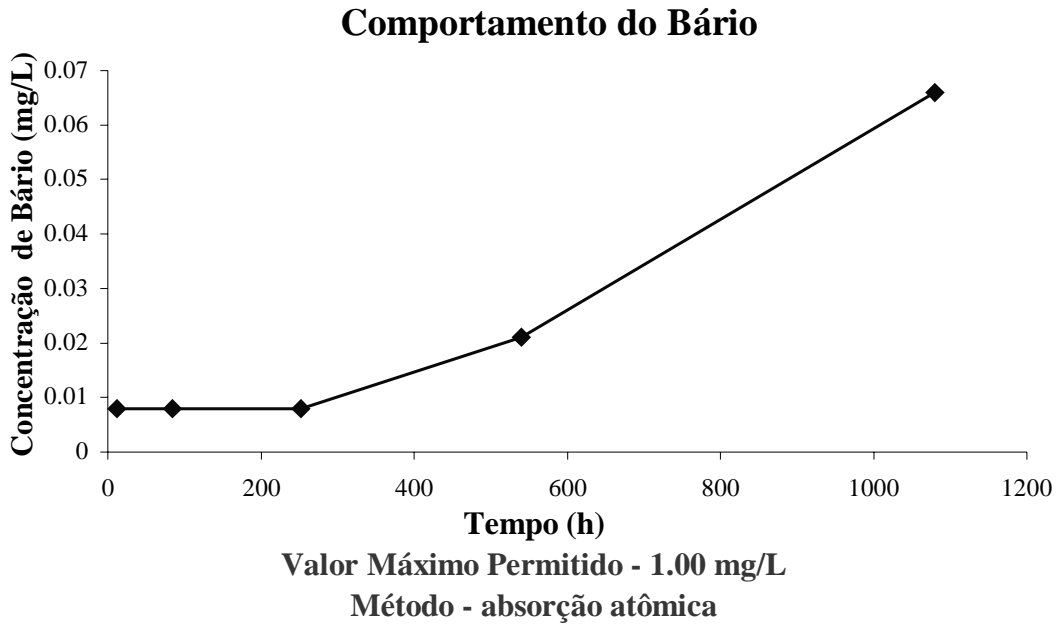

Comportamento do Chumbo

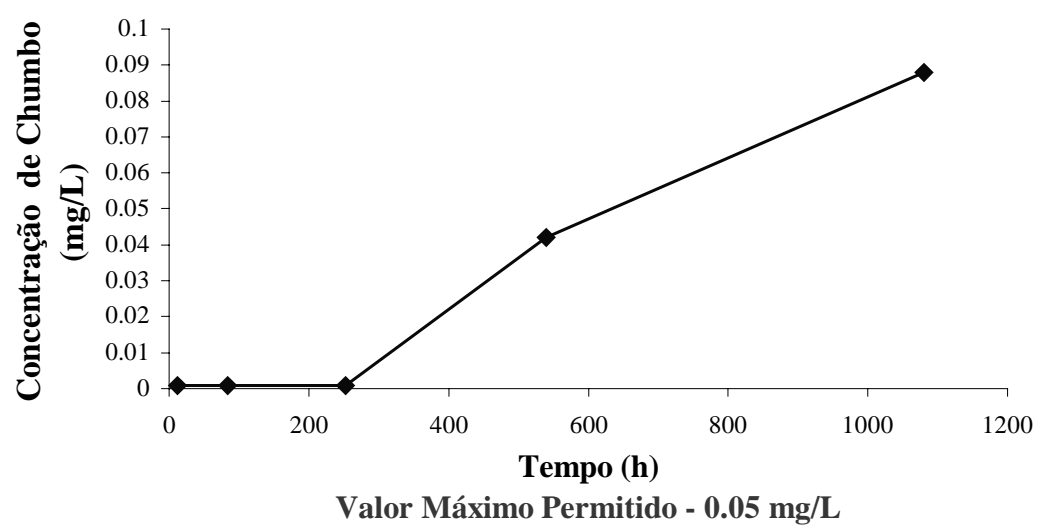

Valor Máximo Permitido - 0.05 mg/L Método - absorção atômica

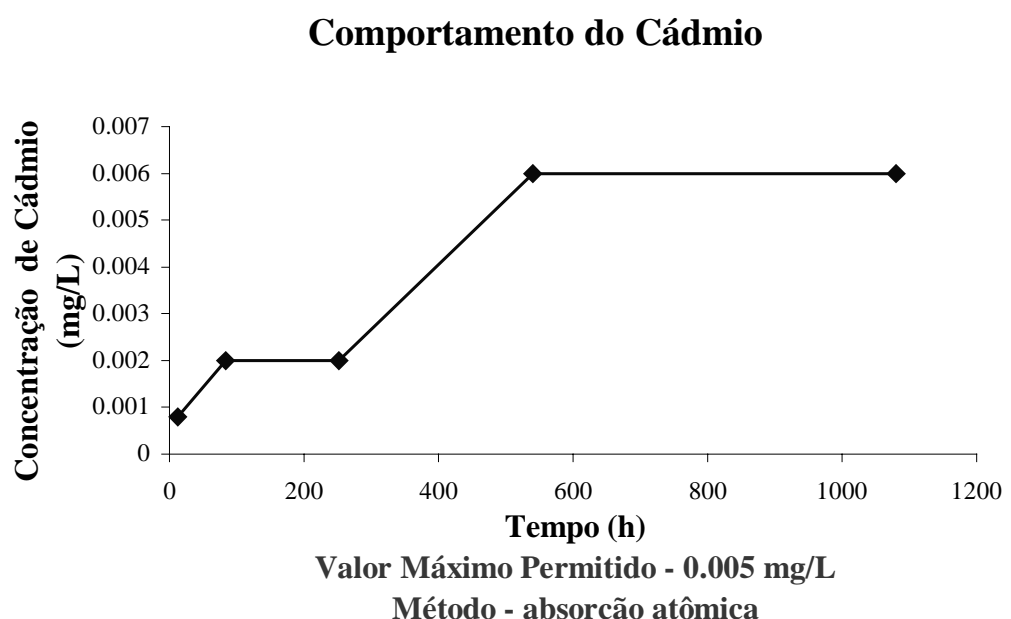

Método - absorção atômica

\section{Comportamento dos Cianetos}

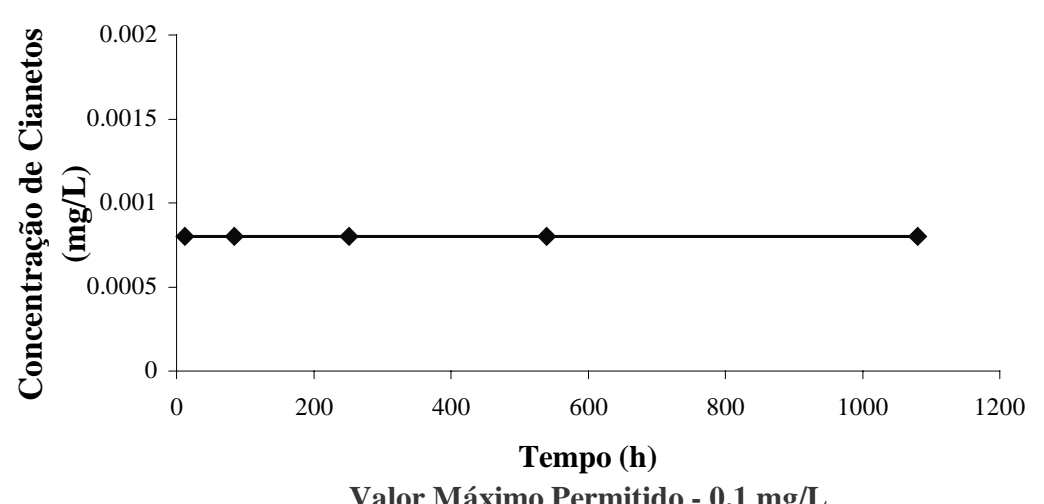

Método - colorimetria espectrofotometria visível

Figura C.01. Comportamento de parâmetros químicos ao longo do tempo (lixiviação com extrator soxhlet) - Situação I 
Comportamento do Cromo Total

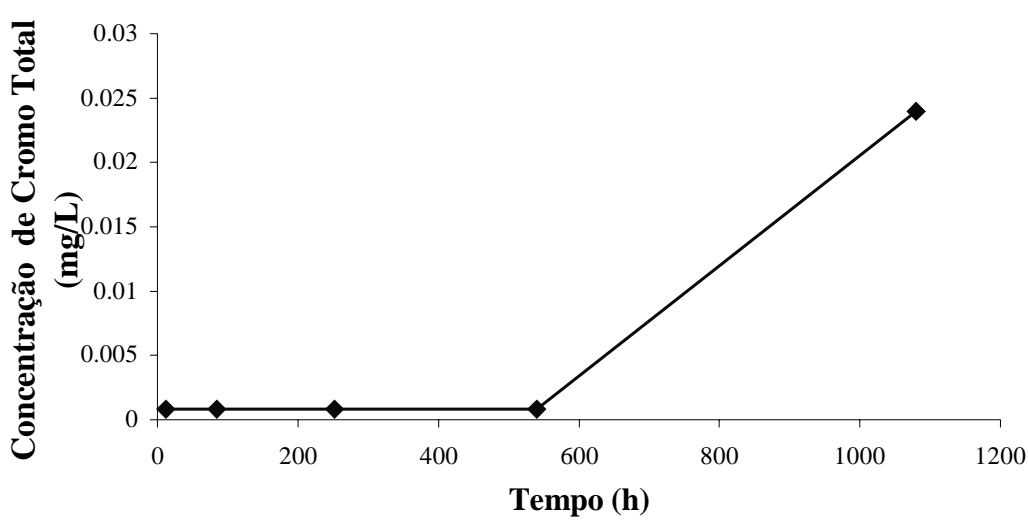

Valor Máximo Permitido - 0.05 mg/L Método - absorção atômica

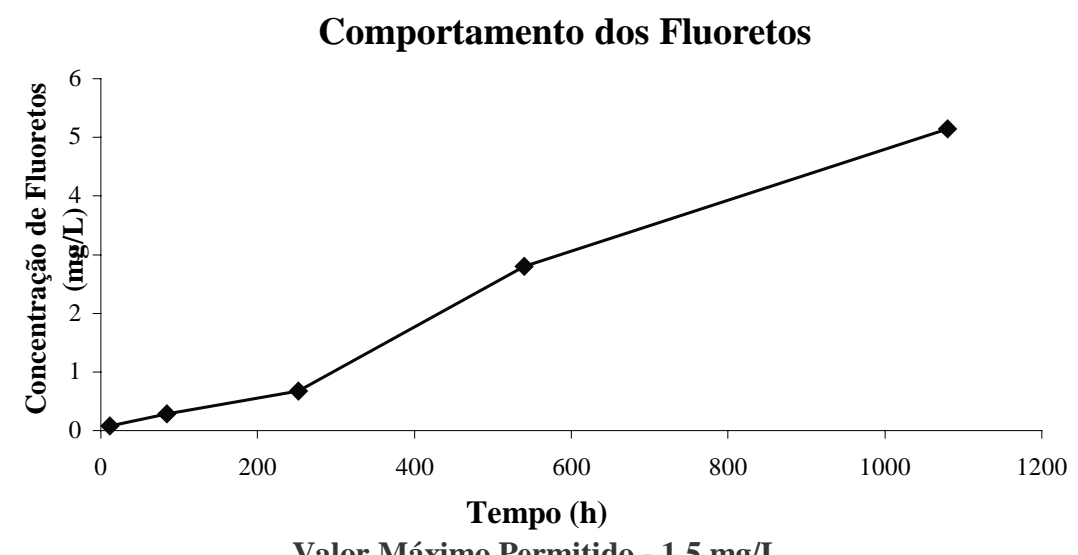

Método - colorimetria espectrofotometria visivel
Comportamento do Índice de Fenóis

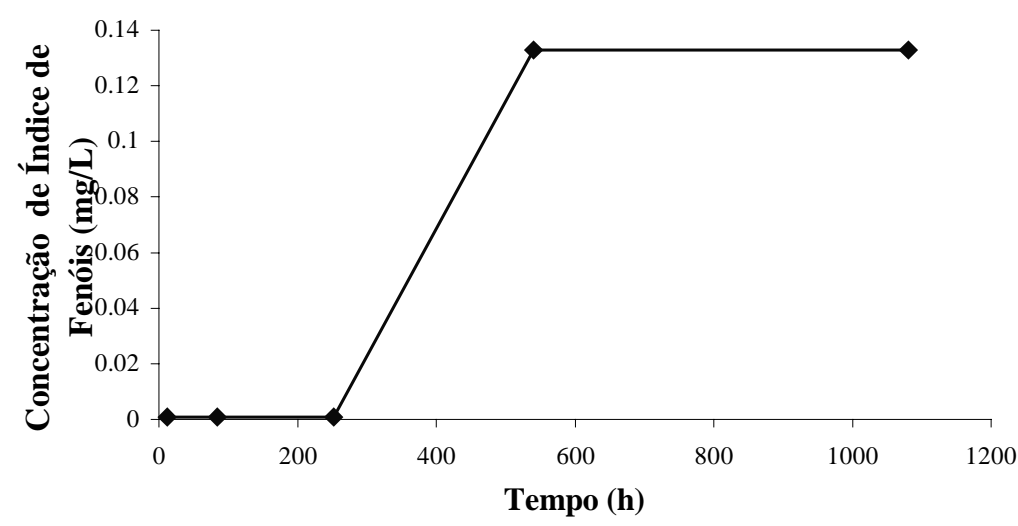

Valor Máximo Permitido - $0.001 \mathrm{mg} / \mathrm{L}$

Método - colorimetria espectrofotometria visível

Comportamento do Mercúrio

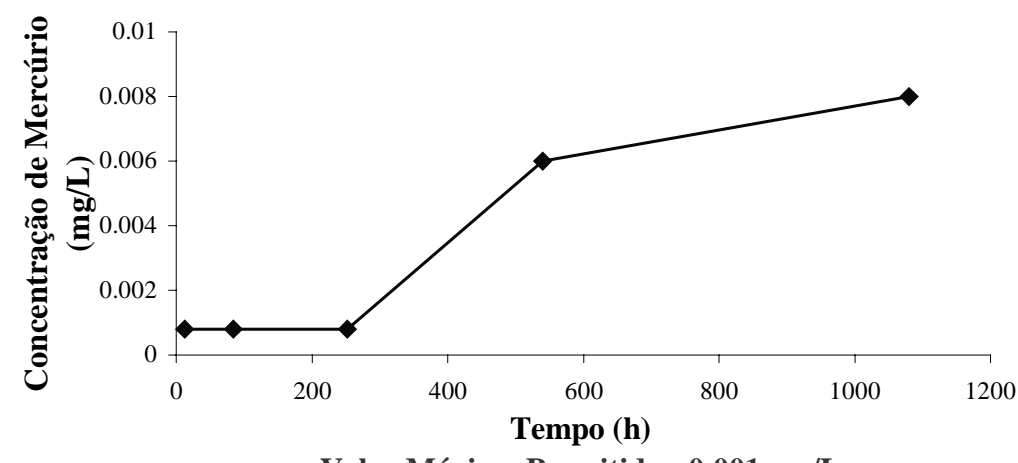

Valor Máximo Permitido - $0.001 \mathrm{mg} / \mathrm{L}$

Método - absorção atômica com gerador de hidreto

Figura C.02. Comportamento de parâmetros químicos ao longo do tempo (lixiviação com extrator soxhlet) - Situação I 
Comportamento dos Nitratos

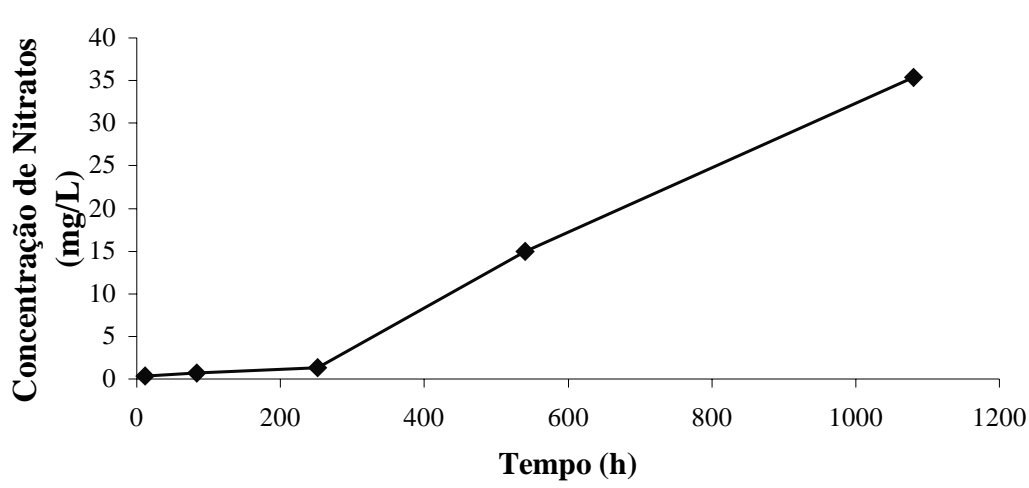

Valor Máximo Permitido -10.0 mg/L

Método - colorimetria espectrofotometria ultravioleta

\section{Comportamento do Alumínio}

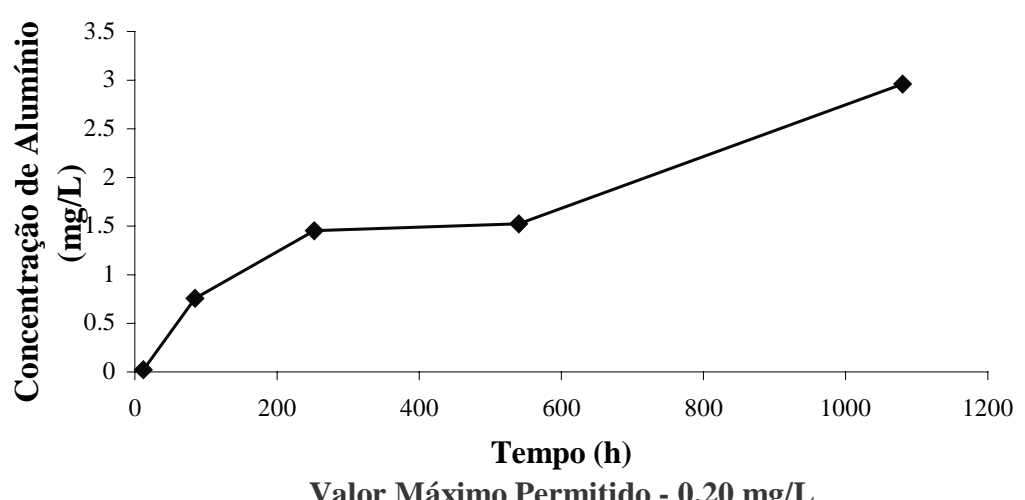

Método - absorção atômica com forno de grafite

\section{Comportamento da Prata}

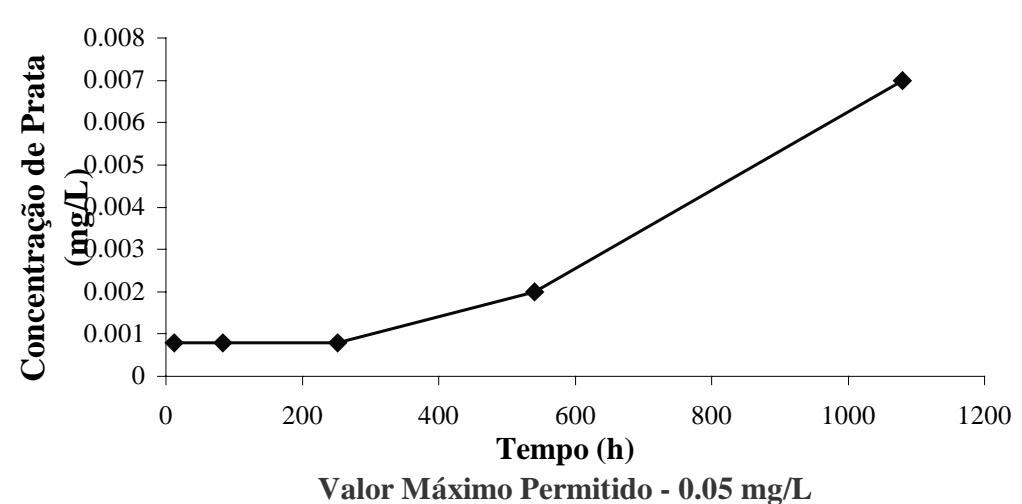

Método - absorção atômica

\section{Comportamento dos Cloretos}

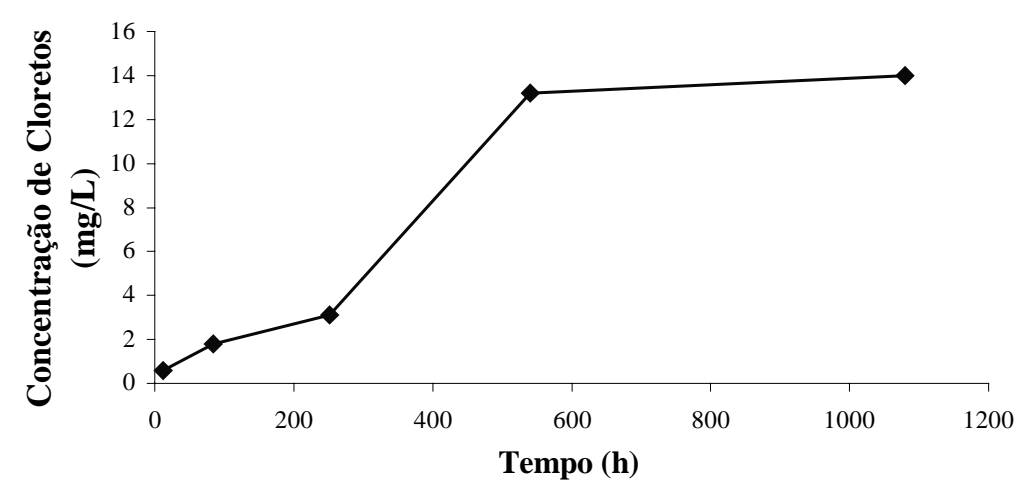

Valor Máximo Permitido - 250.0 mg/L Método - Titrimetria

Figura C.03. Comportamento de parâmetros químicos ao longo do tempo (lixiviação com extrator soxhlet) - Situação I 


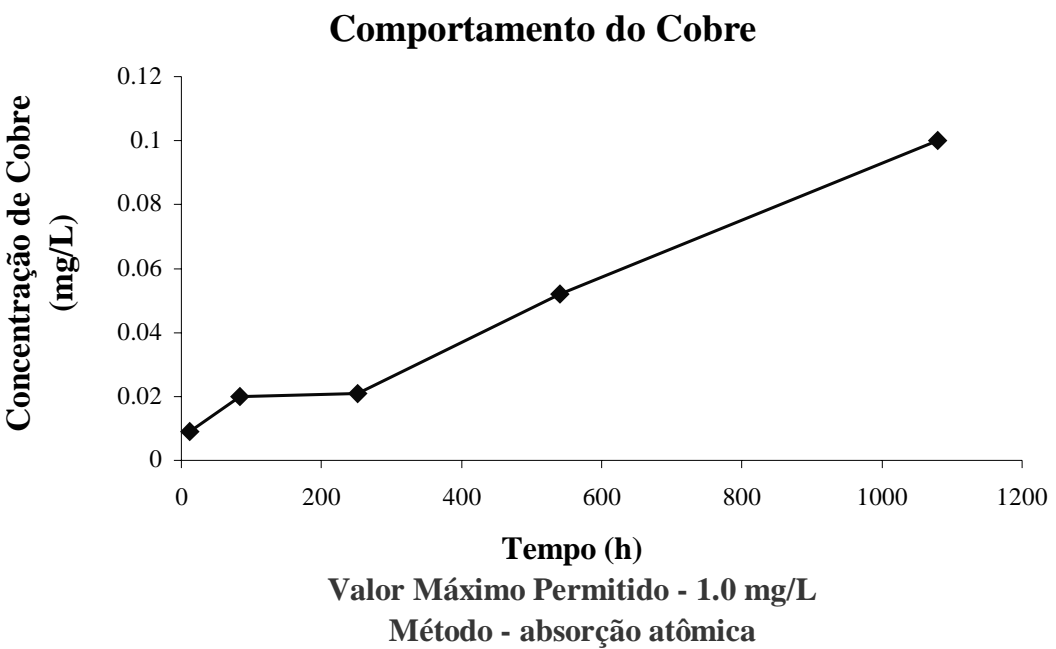

Comportamento do Ferro

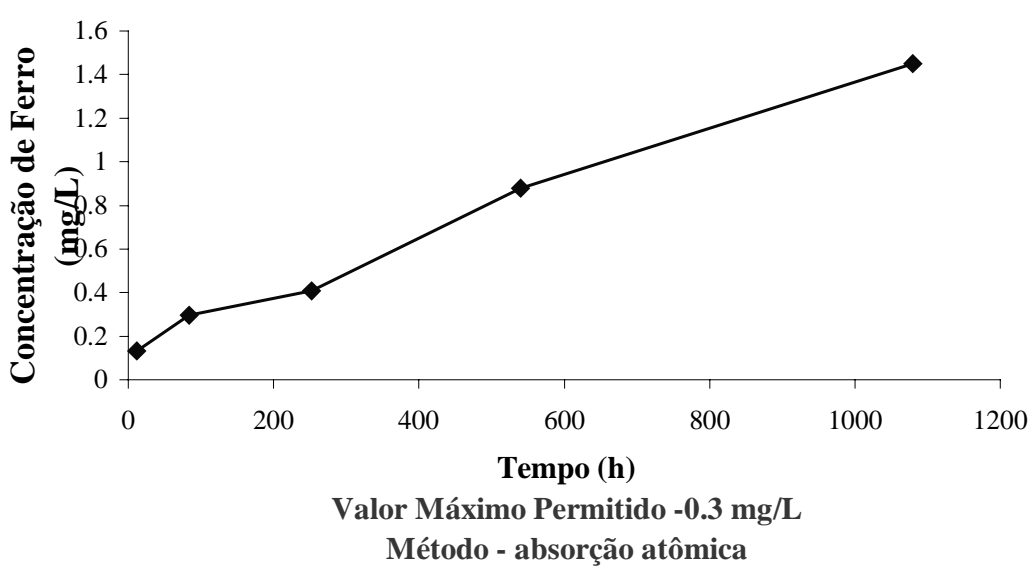

Comportamento da Dureza Total

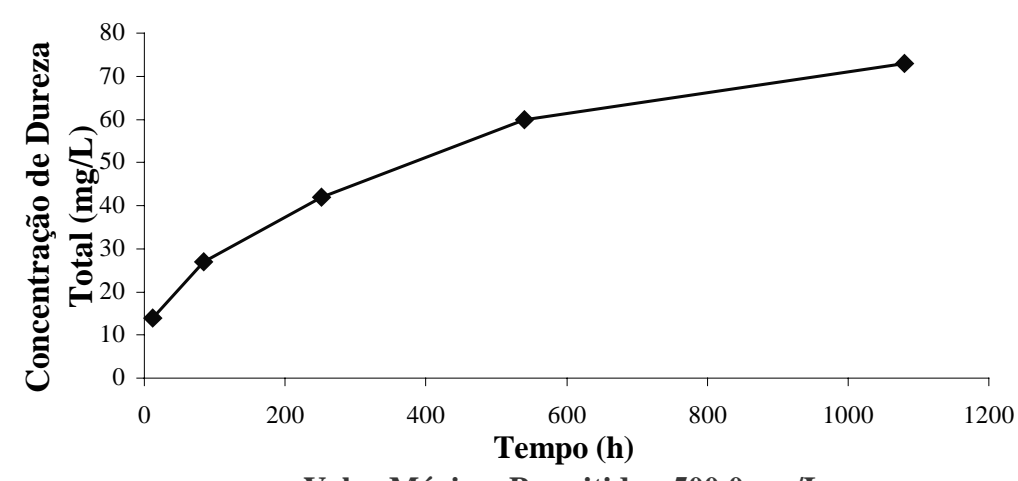

Valor Máximo Permitido - 500.0 mg/L

Método - titrimetria

\section{Comportamento do Manganês}

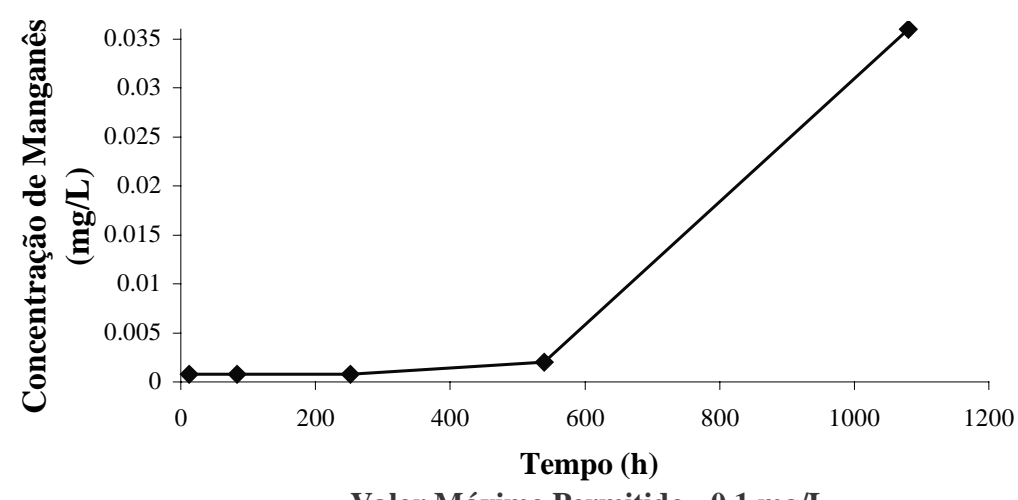

Valor Máximo Permitido - $0.1 \mathrm{mg} / \mathrm{L}$ Método - absorção atômica

Figura C.04. Comportamento de parâmetros químicos ao longo do tempo (lixiviação com extrator soxhlet) - Situação I 


\section{Comportamento do Sódio}

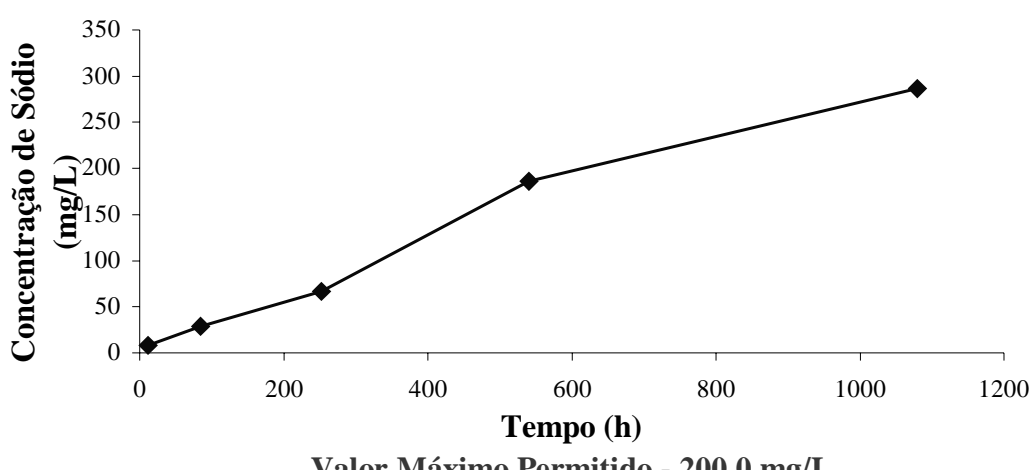

Valor Máximo Permitido - 200.0 mg/L Método - fotometria de chama

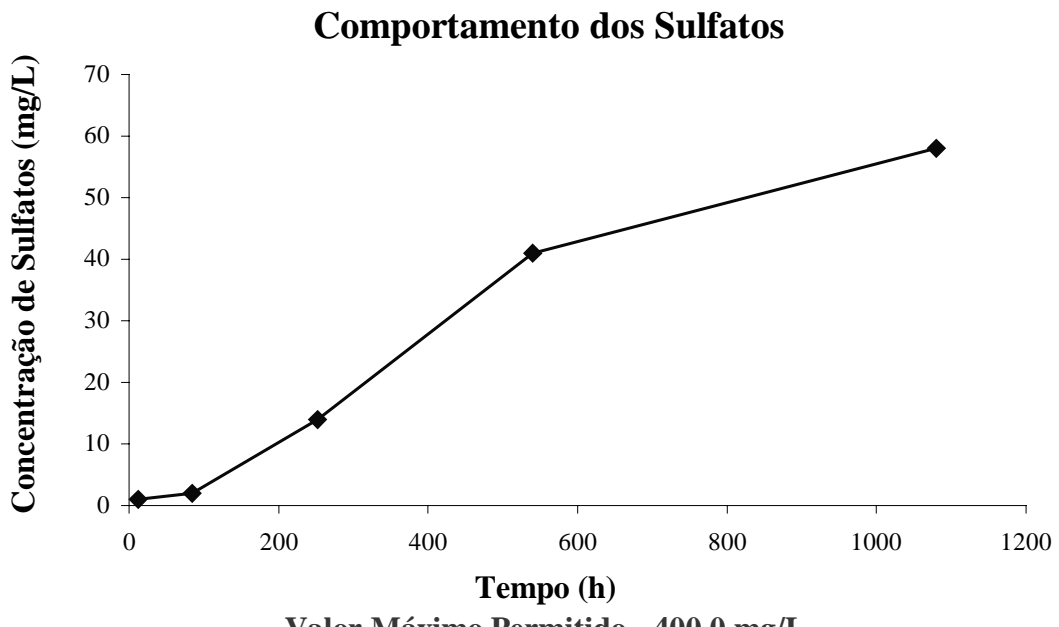

Valor Máximo Permitido - 400.0 mg/L

Método - colorimetria espectrofotometria visível

\section{Comportamento dos Surfactantes}

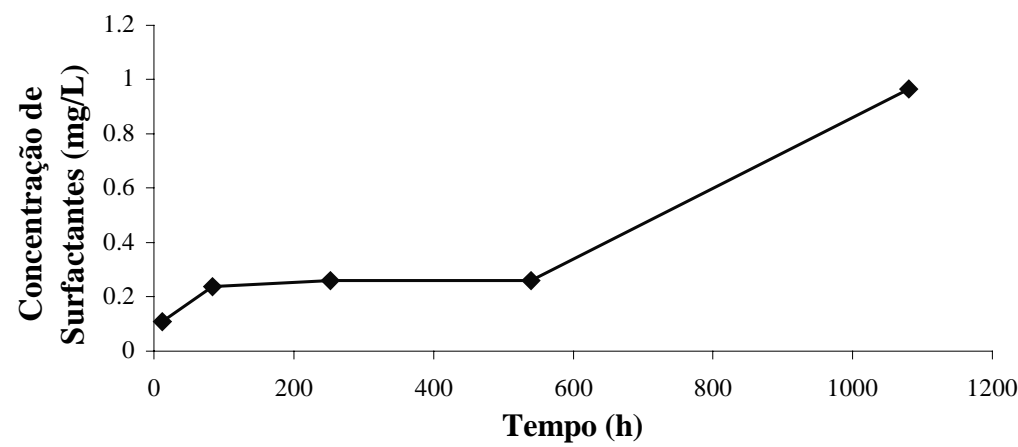

Valor Máximo Permitido - 0.2 mg/L Método - colorimetria

Comportamento do Zinco

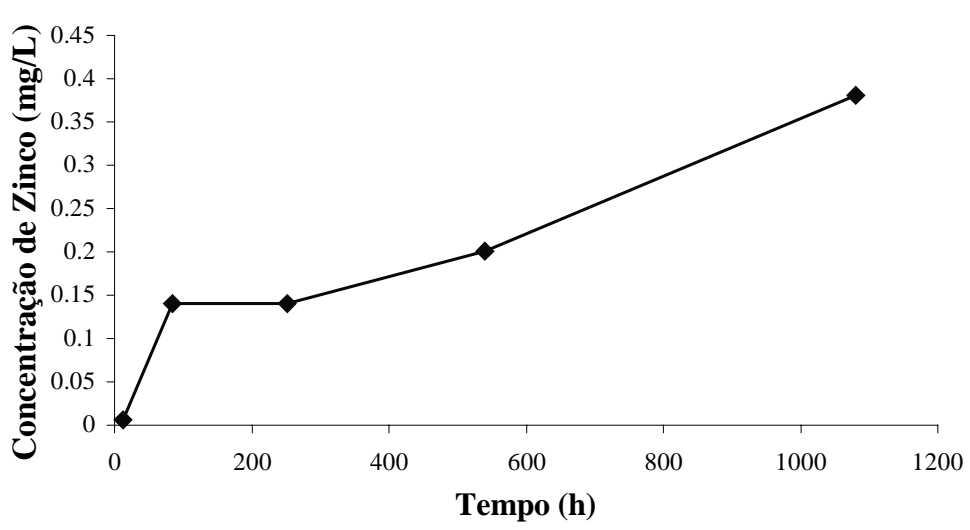

Valor Máximo Permitido - 5.0 mg/L Método - absorção atômica

Figura C.05. Comportamento de parâmetros químicos ao longo do tempo (lixiviação com extrator soxhlet) - Situação I 


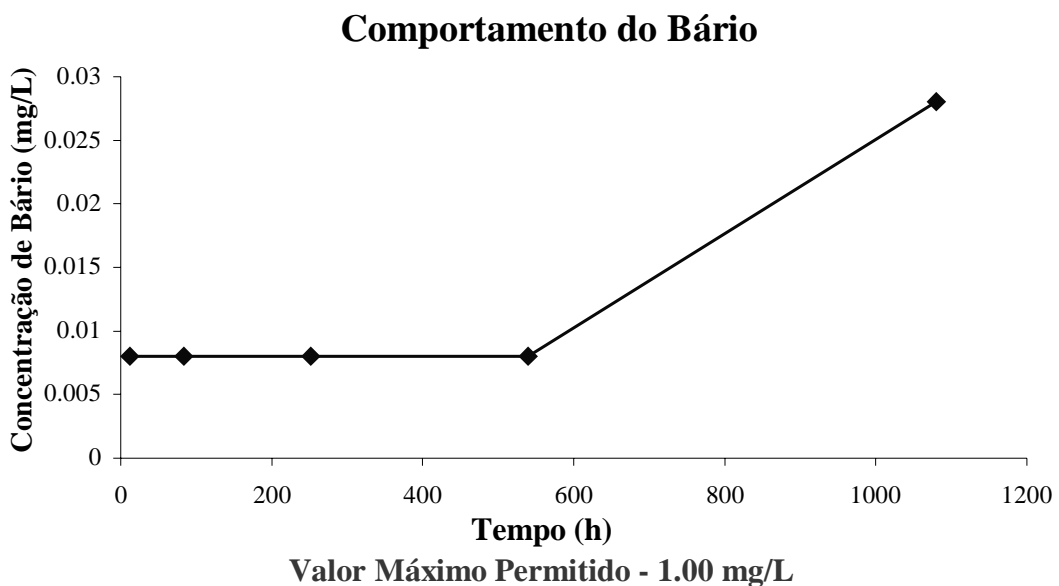

Valor Máximo Permitido - 1.00 mg/L

Método - absorção atômica

Comportamento do Chumbo

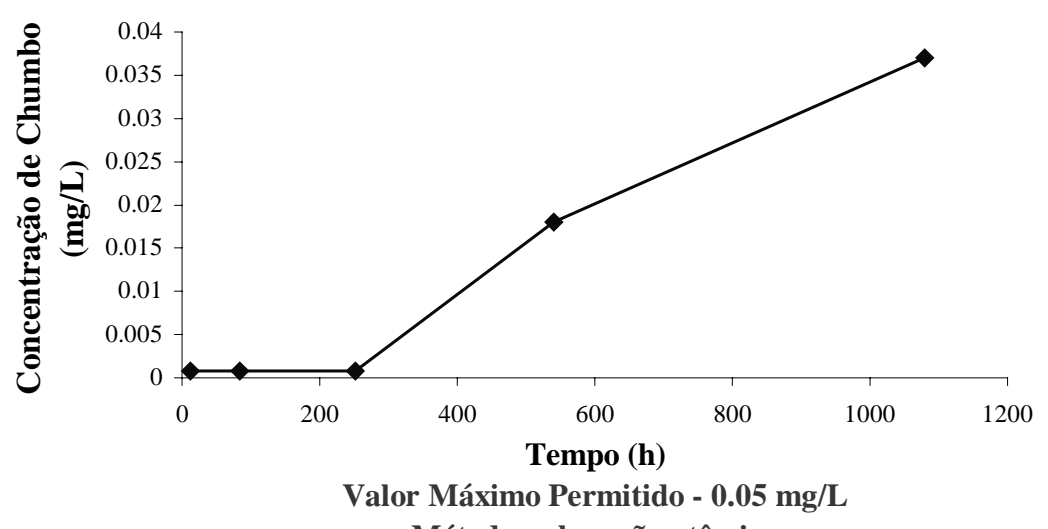

Método - absorção atômica

\section{Comportamento do Cádmio}

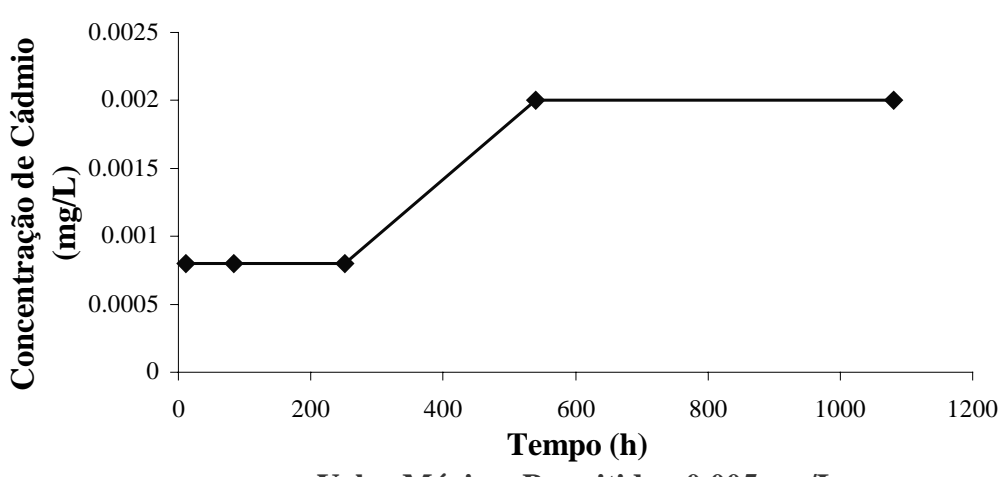

Valor Máximo Permitido - 0.005 mg/L

Método - absorção atômica

\section{Comportamento dos Cianetos}

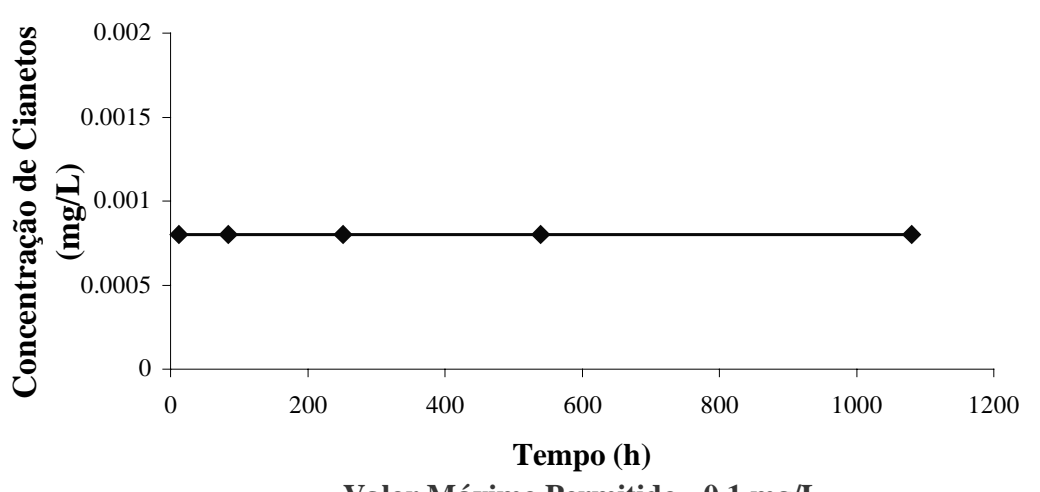

Valor Máximo Permitido - 0.1 mg/L

Método - colorimetria espectrofotometria visível

Figura C.06. Comportamento de parâmetros químicos ao longo do tempo (lixiviação com extrator soxhlet) - Situação II 


\section{Comportamento do Cromo Total}

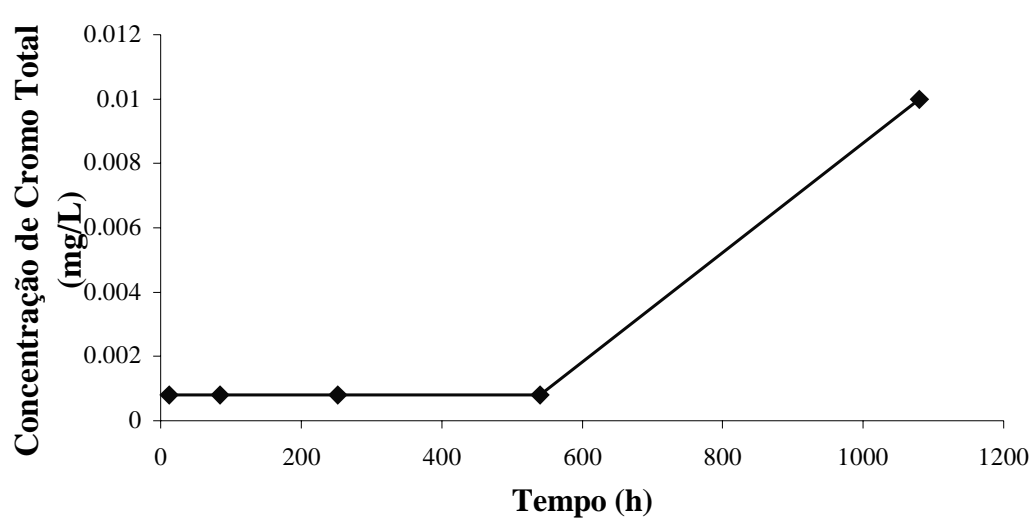

Valor Máximo Permitido - $0.05 \mathrm{mg} / \mathrm{L}$ Método - absorção atômica

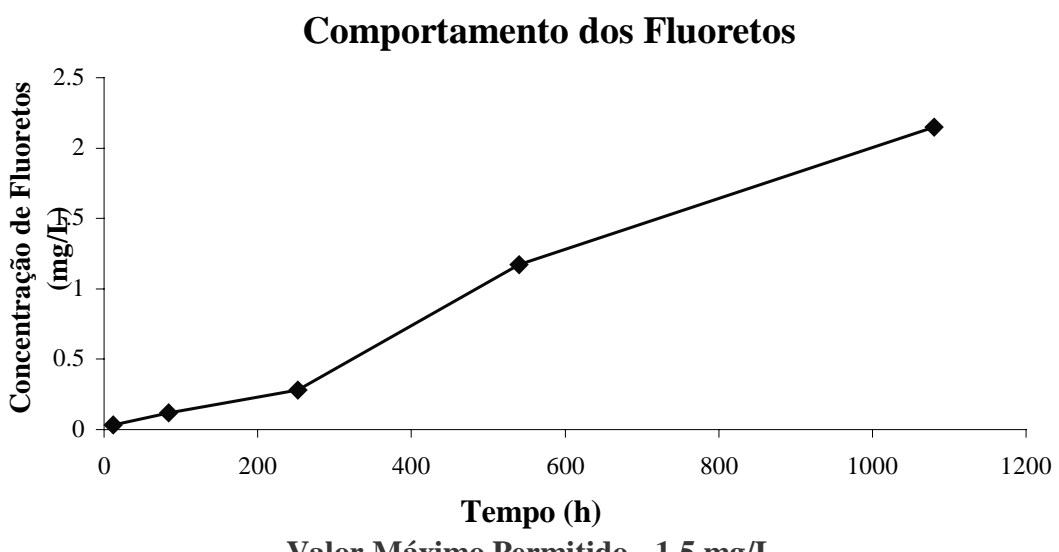

Valor Máximo Permitido - 1.5 mg/L

Método - colorimetria espectrofotometria visível
Comportamento do Índice de Fenóis

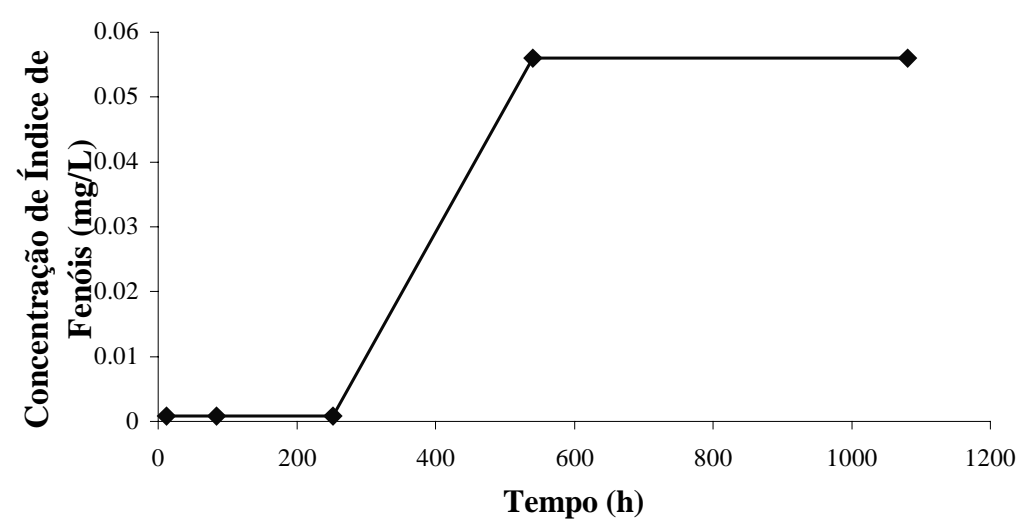

Valor Máximo Permitido - 0.001 mg/L

Método - colorimetria espectrofotometria visível

Comportamento do Mercúrio

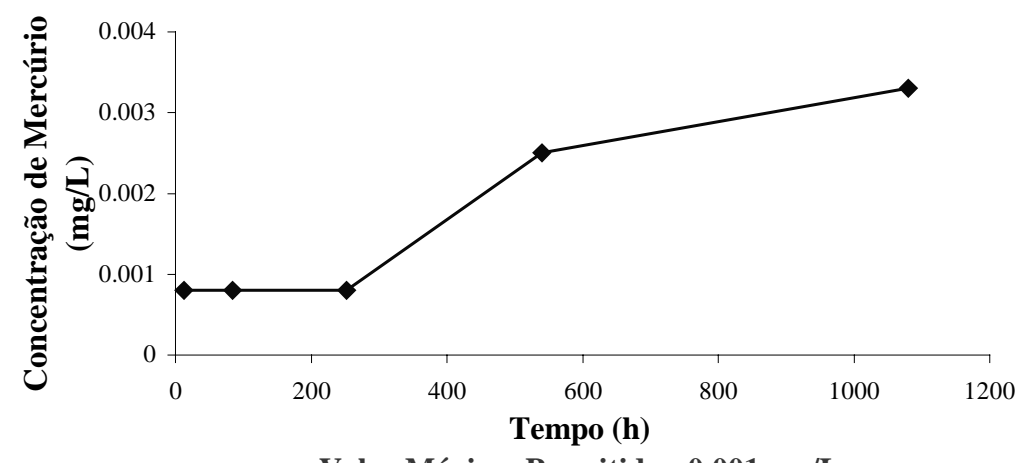

Valor Máximo Permitido - $0.001 \mathrm{mg} / \mathrm{L}$

Método - absorção atômica com gerador de hidreto

Figura C.07. Comportamento de parâmetros químicos ao longo do tempo (lixiviação com extrator soxhlet) - Situação II 
Comportamento dos Nitratos

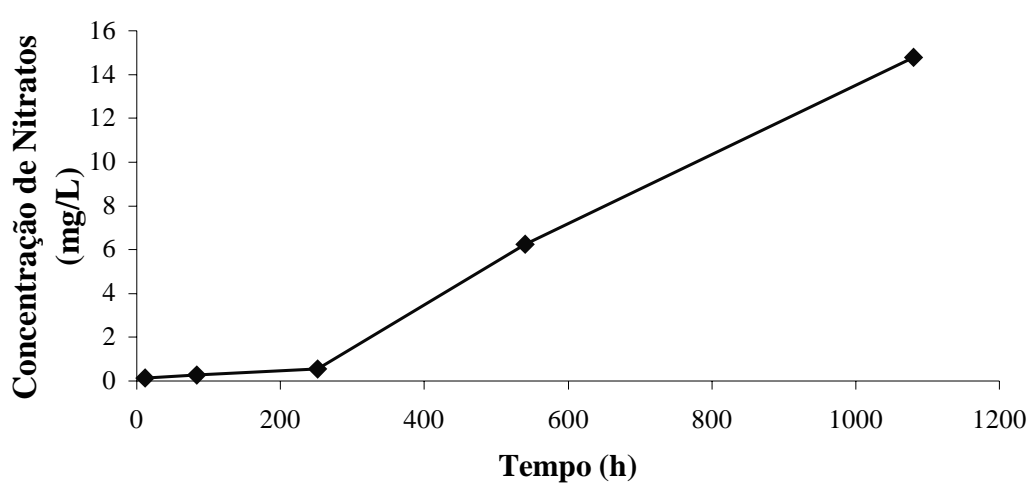

Valor Máximo Permitido -10.0 mg/L

Método - colorimetria espectrofotometria ultravioleta

\section{Comportamento do Alumínio}

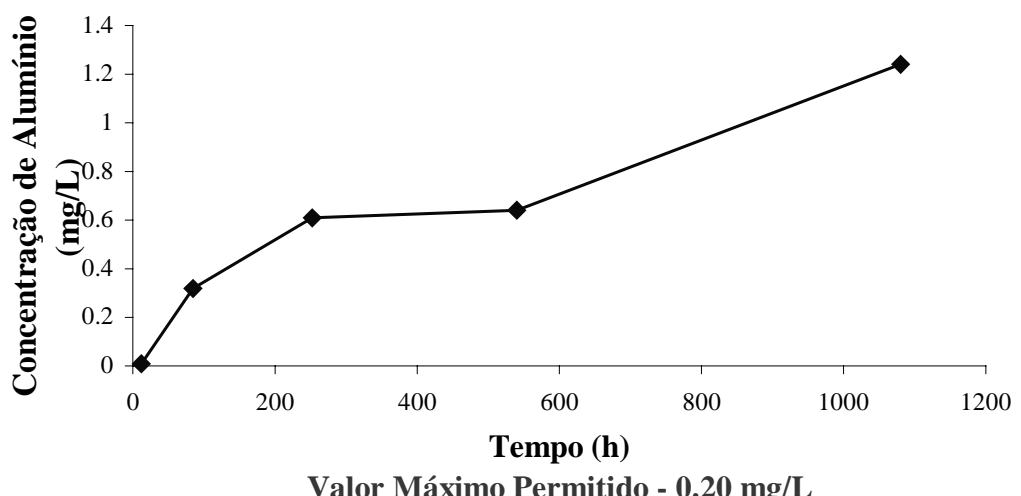

Método - absorção atômica com forno de grafite

\section{Comportamento da Prata}

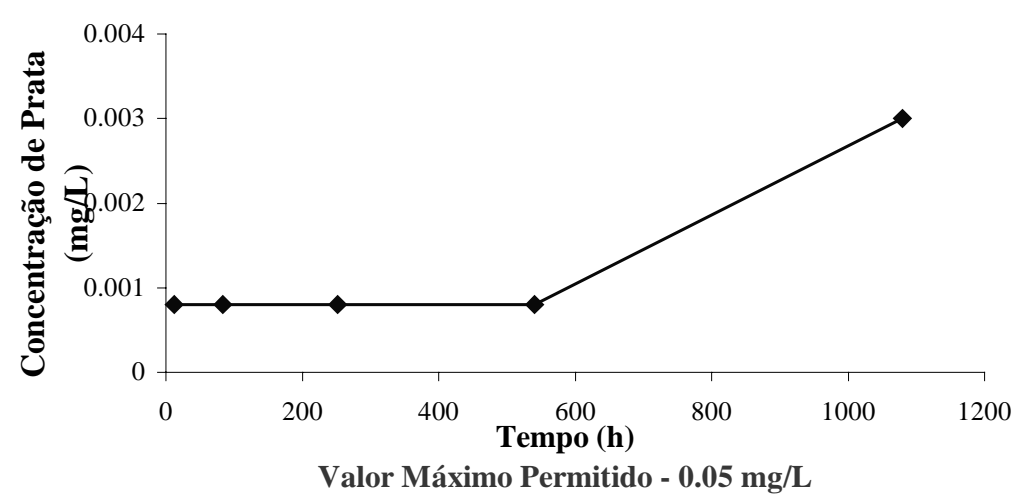

Método - absorção atômica

\section{Comportamento dos Cloretos}

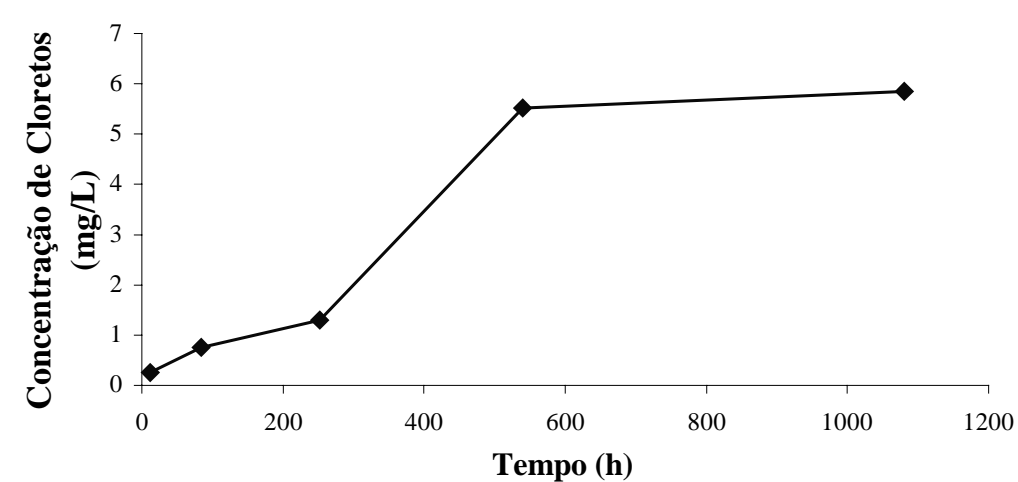

Valor Máximo Permitido - 250.0 mg/L Método - titrimetria

Figura C.08. Comportamento de parâmetros químicos ao longo do tempo (lixiviação com extrator soxhlet) - Situação II 

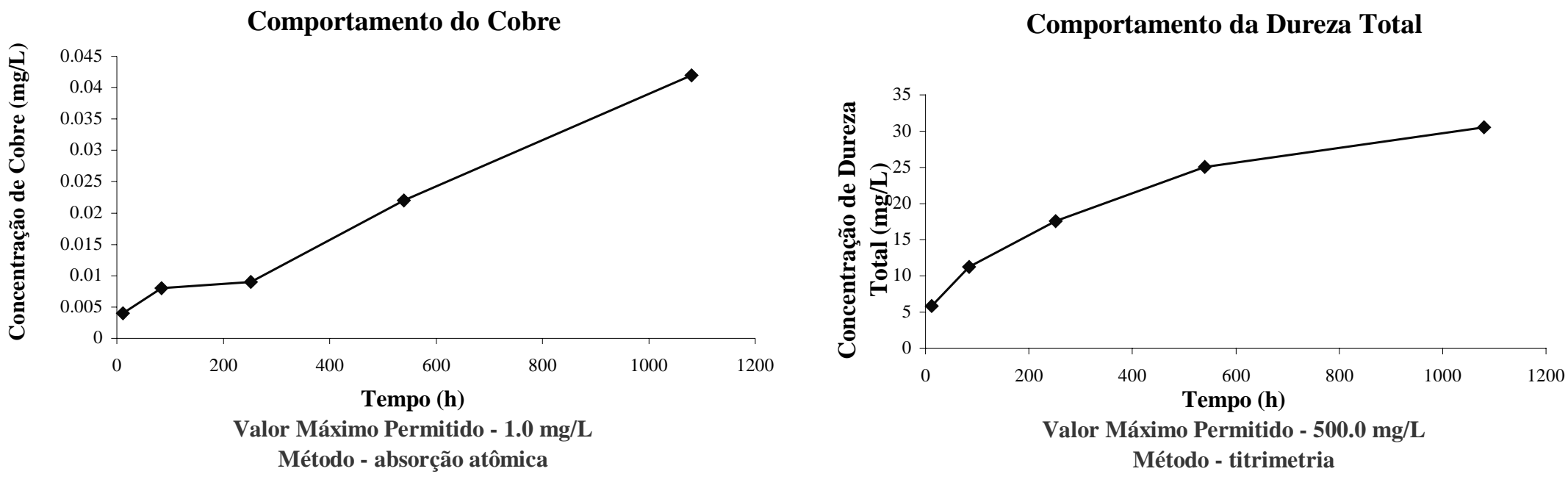

Comportamento do Ferro

Método - titrimetria
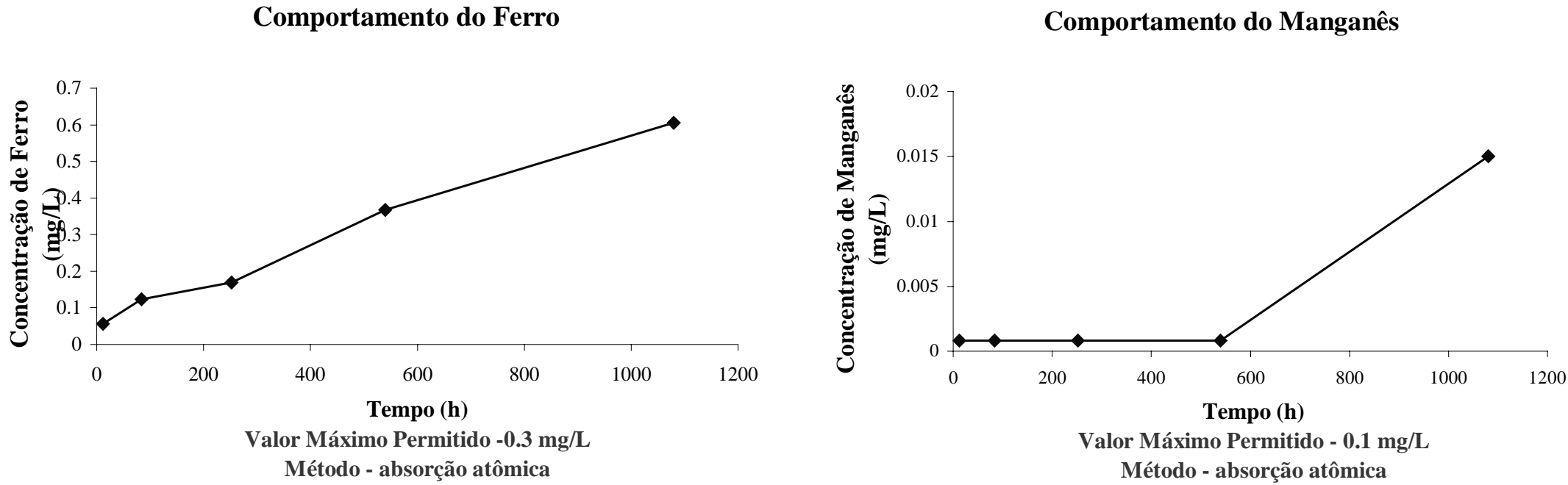

Figura C.09. Comportamento de parâmetros químicos ao longo do tempo (lixiviação com extrator soxhlet) - Situação II 


\section{Comportamento do Sódio}

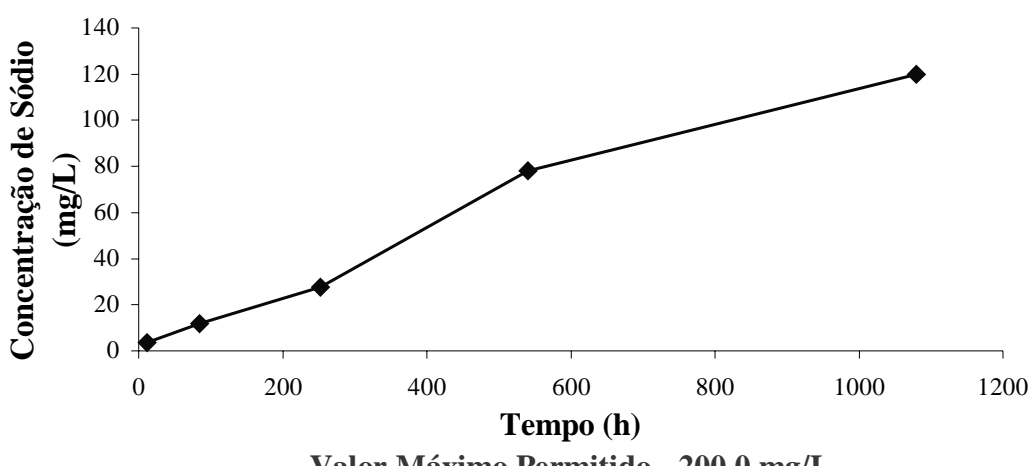

Valor Máximo Permitido - 200.0 mg/L Método - fotometria de chama

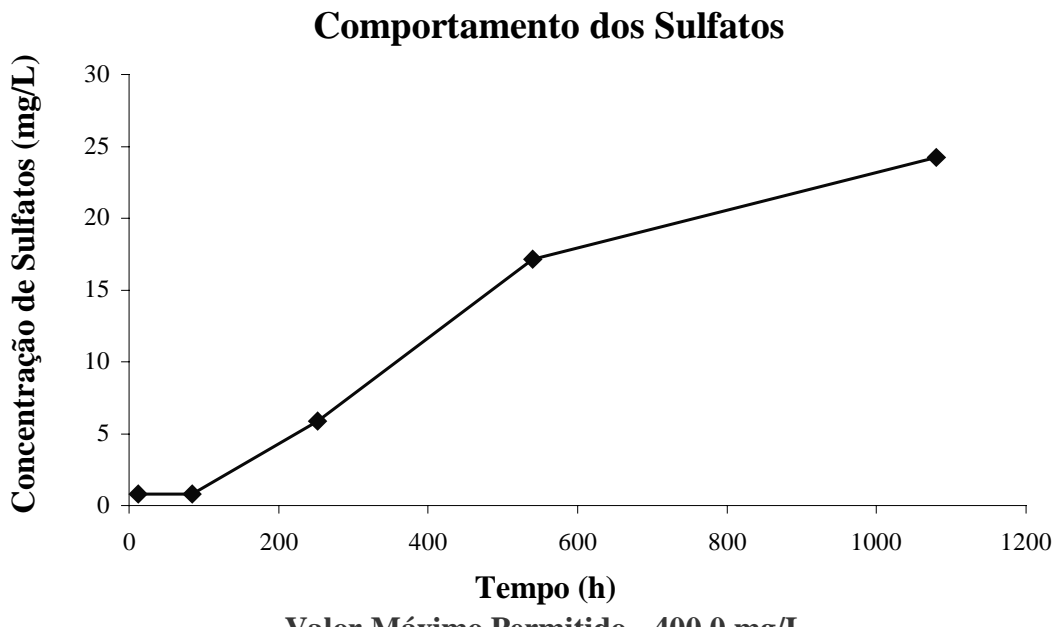

Valor Máximo Permitido - 400.0 mg/L

Método - colorimetria espectrofotometria visível

\section{Comportamento dos Surfactantes}

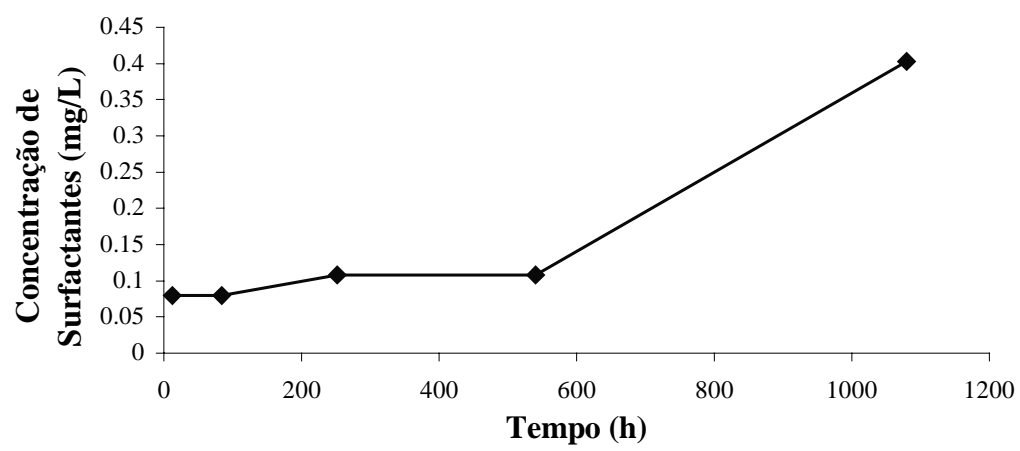

Valor Máximo Permitido - $0.2 \mathrm{mg} / \mathrm{L}$ Método - colorimetria

Comportamento do Zinco

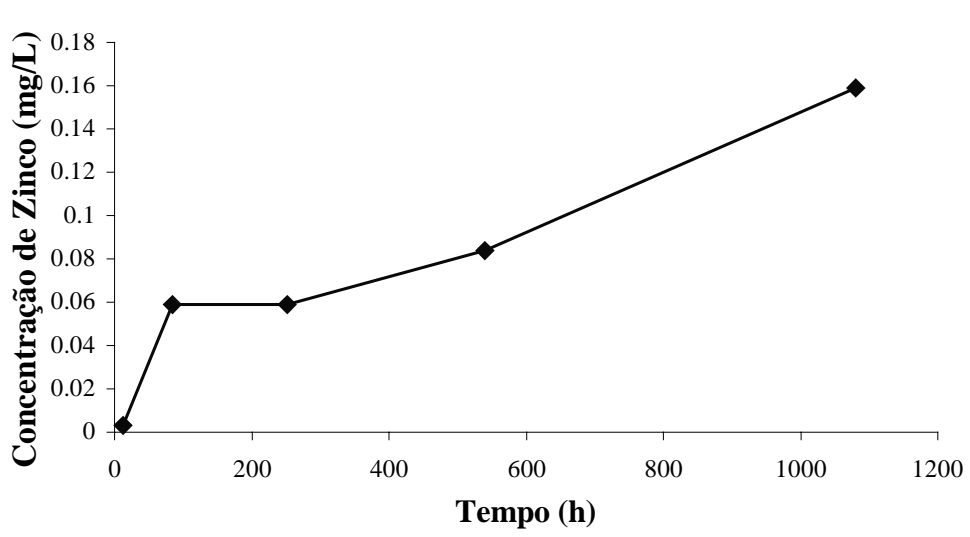

Valor Máximo Permitido - $5.0 \mathrm{mg} / \mathrm{L}$ Método - absorção atômica

Figura C.10. Comportamento de parâmetros químicos ao longo do tempo (lixiviação com extrator soxhlet) - Situação II 


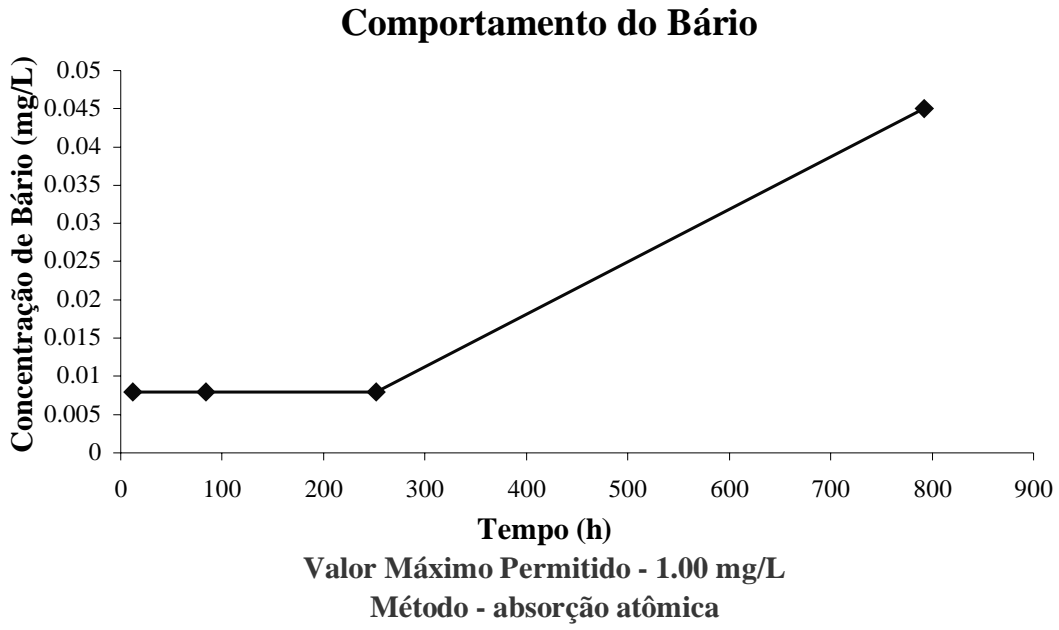

Comportamento do Chumbo

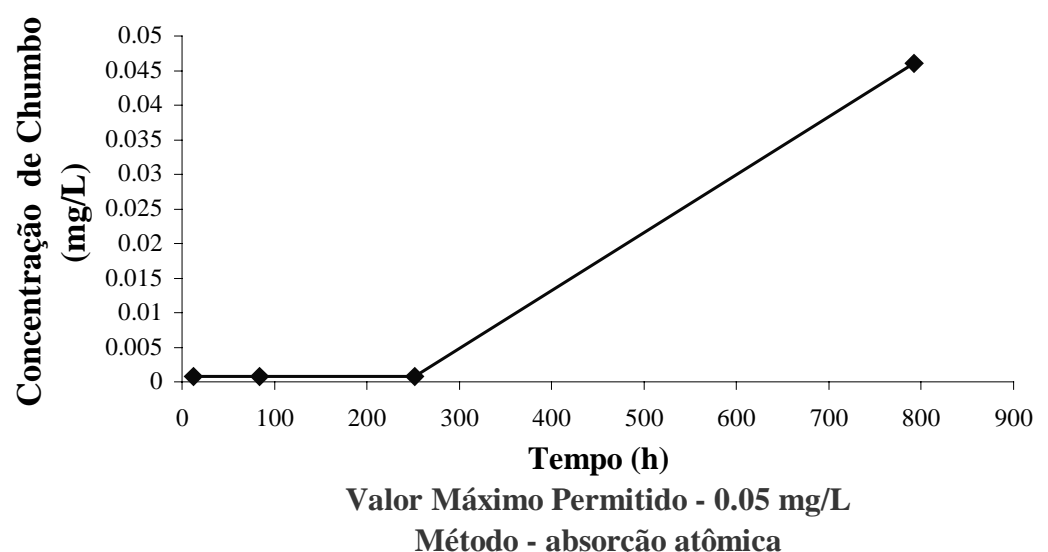

Comportamento do Cádmio

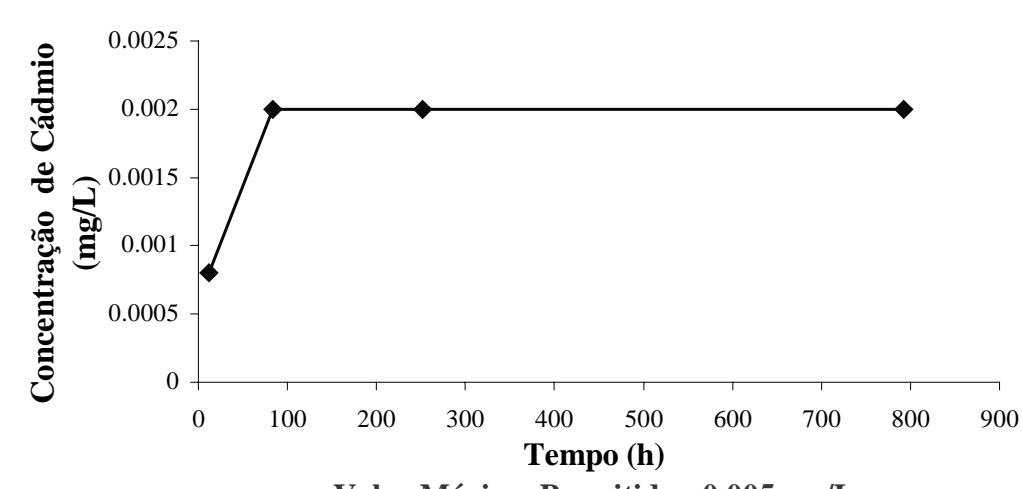

Valor Máximo Permitido - 0.005 mg/L

Método - absorção atômica

\section{Comportamento dos Cianetos}

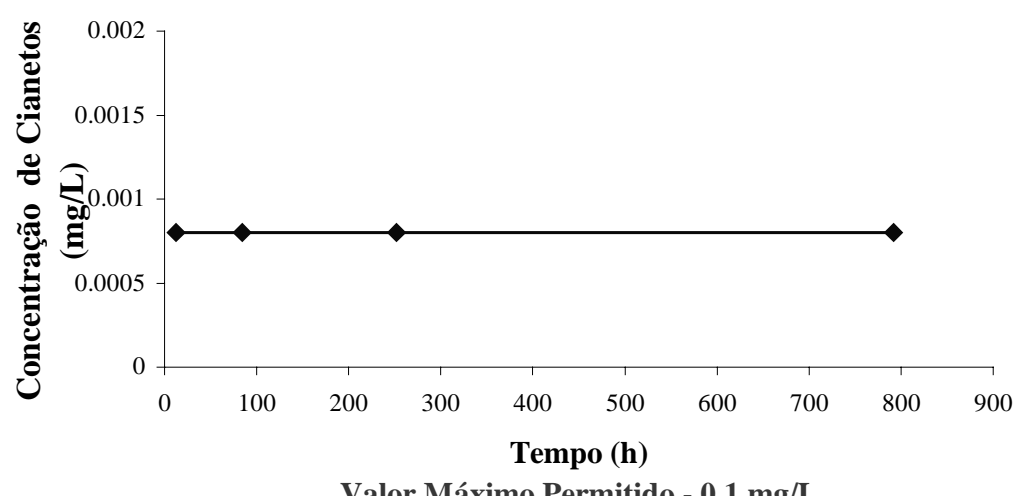

Método - colorimetria espectrofotometria visível

Figura C.11. Comportamento de parâmetros químicos ao longo do tempo (lixiviação com extrator soxhlet) - Situação III 
Comportamento do Cromo Total

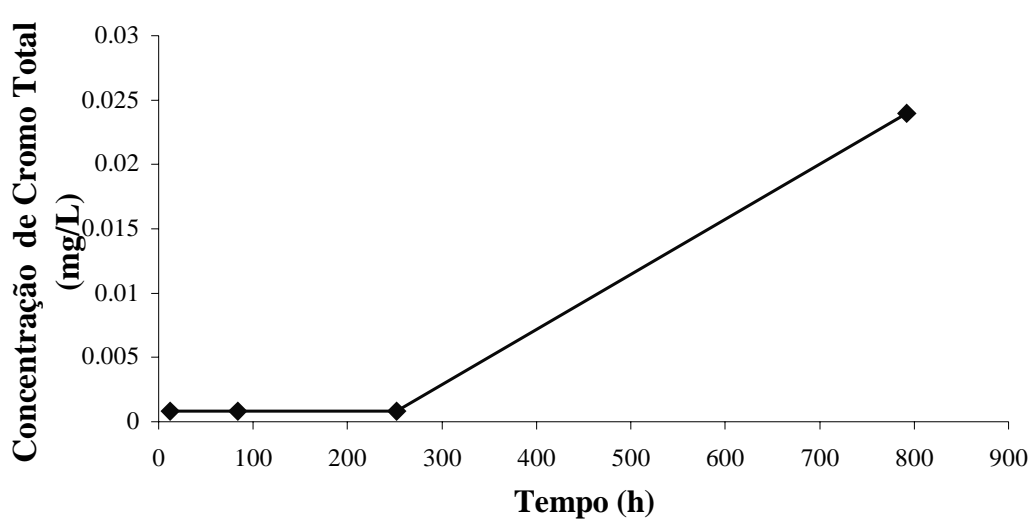

Valor Máximo Permitido - $0.05 \mathrm{mg} / \mathrm{L}$ Método - absorção atômica

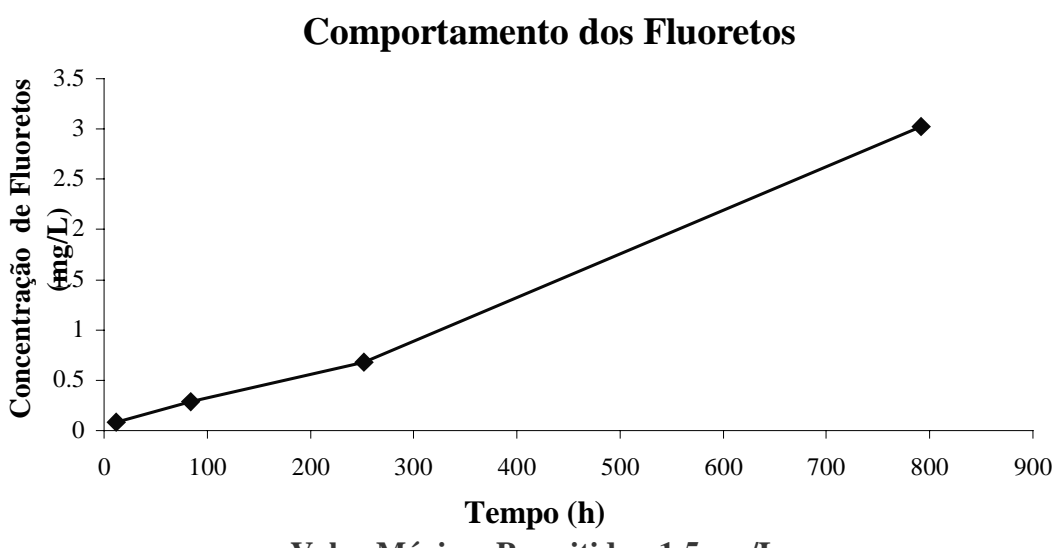

Valor Máximo Permitido - $1.5 \mathrm{mg} / \mathrm{L}$

Método - colorimetria espectrofotometria visível
Comportamento do Índice de Fenóis

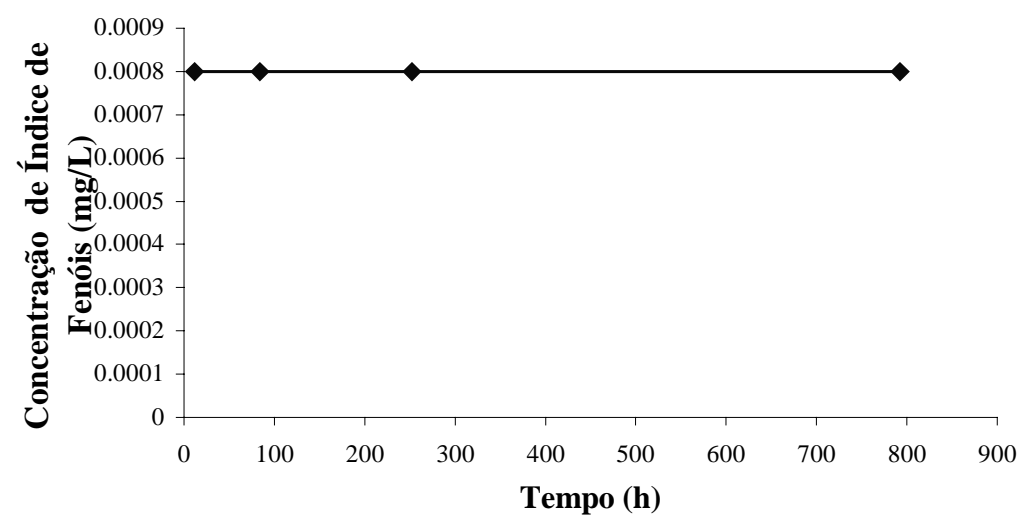

Valor Máximo Permitido - 0.001 mg/L

Método - colorimetria espectrofotometria visível

Comportamento do Mercúrio

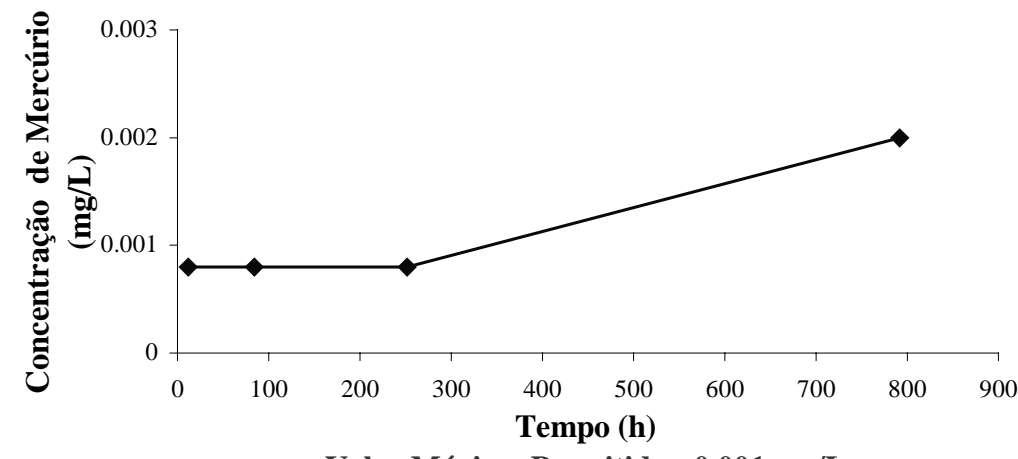

Valor Máximo Permitido - $0.001 \mathrm{mg} / \mathrm{L}$

Método - absorção atômica com gerador de hidreto

Figura C.12. Comportamento de parâmetros químicos ao longo do tempo (lixiviação com extrator soxhlet) - Situação III 
Comportamento dos Nitratos

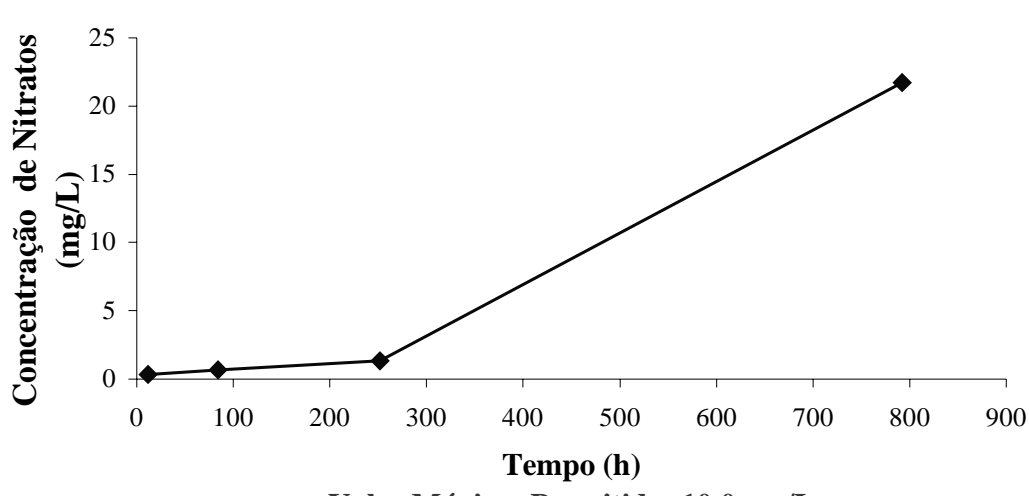

Valor Máximo Permitido -10.0 mg/L

Método - colorimetria espectrofotometria ultravioleta

\section{Comportamento do Alumínio}

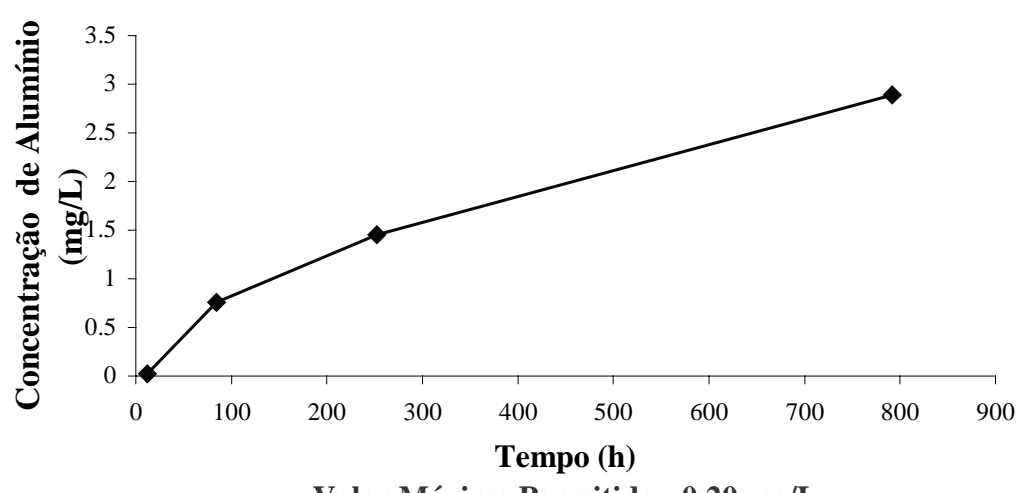

Valor Máximo Permitido - 0.20 mg/L

Método - absorção atômica com forno de grafite
Comportamento da Prata

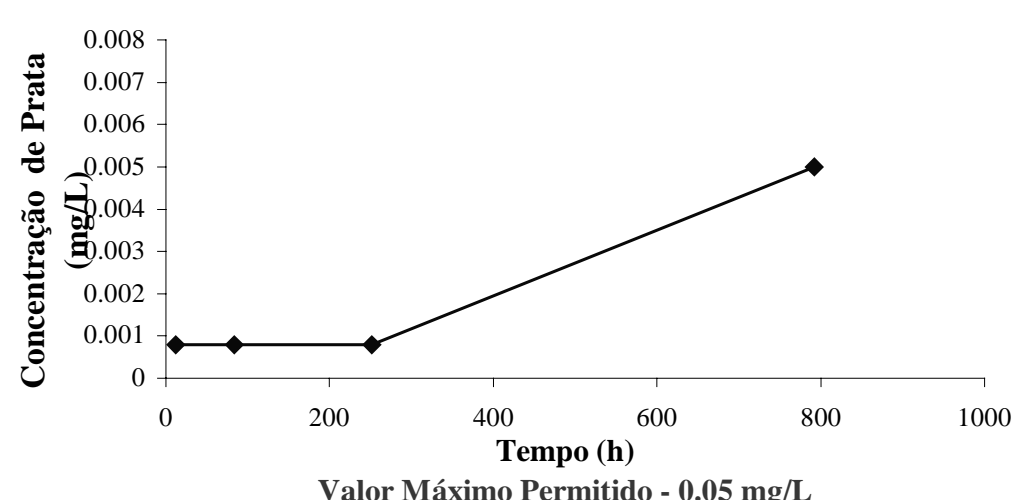

$$
\text { Método - absorção atômica }
$$

\section{Comportamento dos Cloretos}

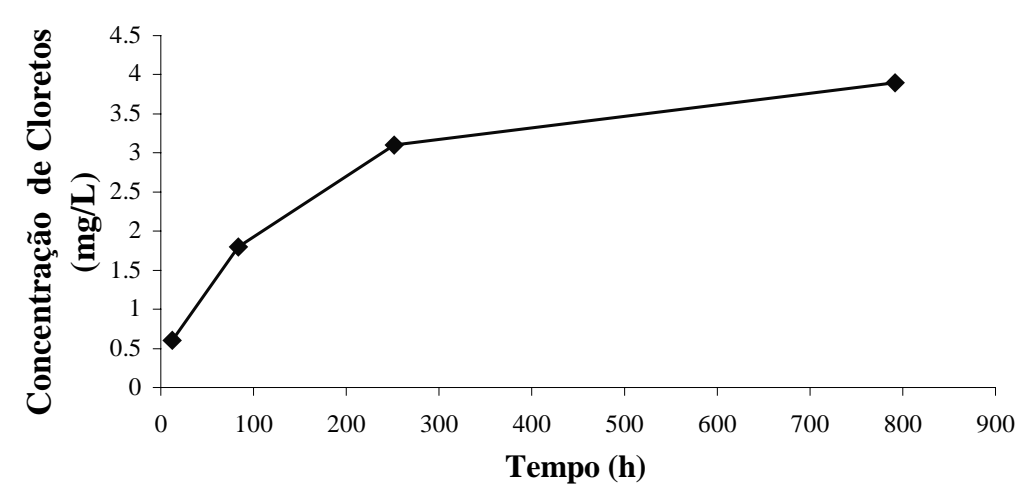

Valor Máximo Permitido - $250.0 \mathrm{mg} / \mathrm{L}$ Método - titrimetria

Figura C.13. Comportamento de parâmetros químicos ao longo do tempo (lixiviação com extrator soxhlet) - Situação III 


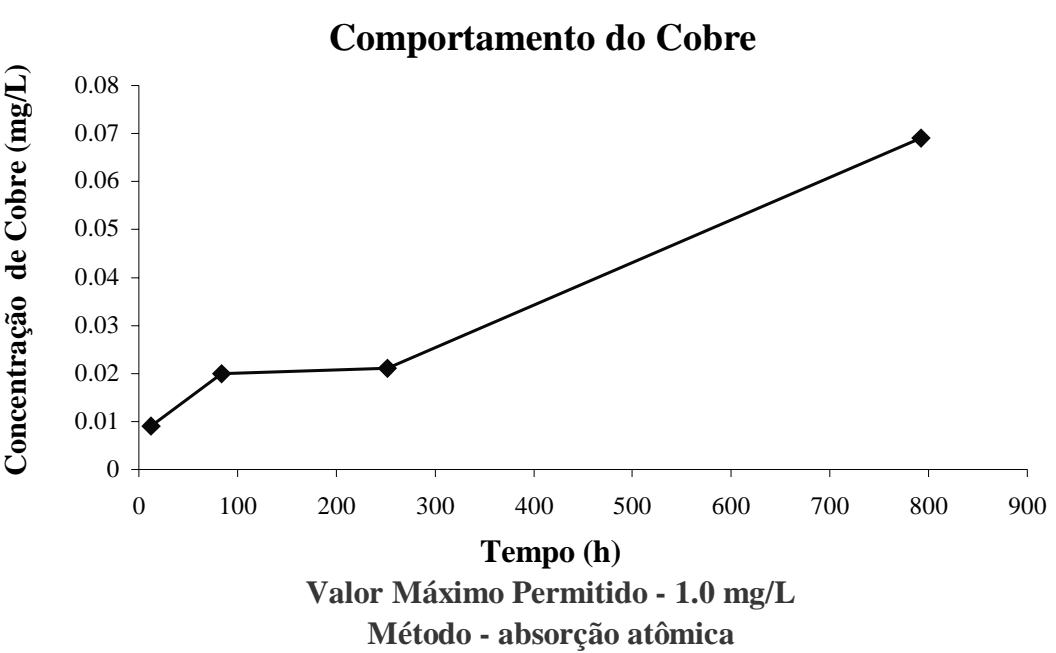

\section{Comportamento do Ferro}

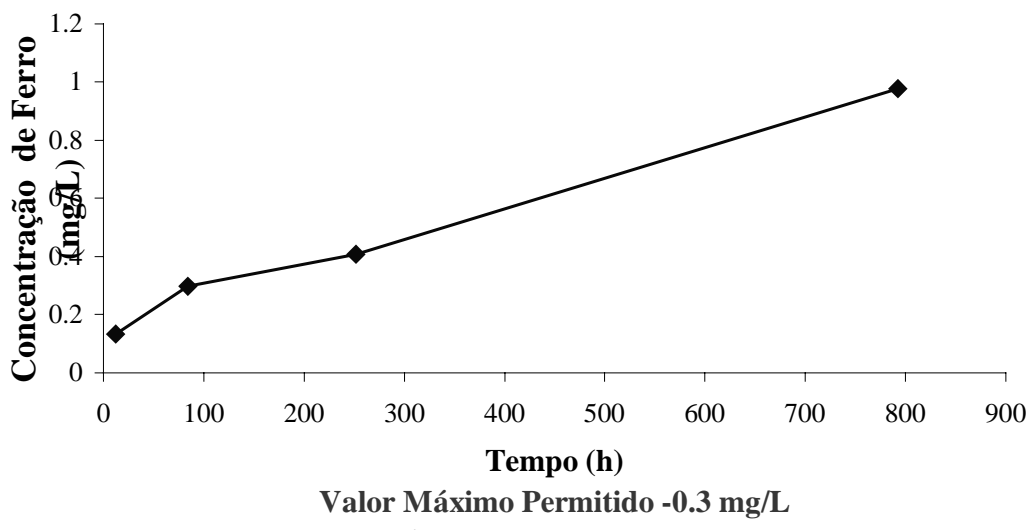

Método - absorção atômica
Comportamento da Dureza Total

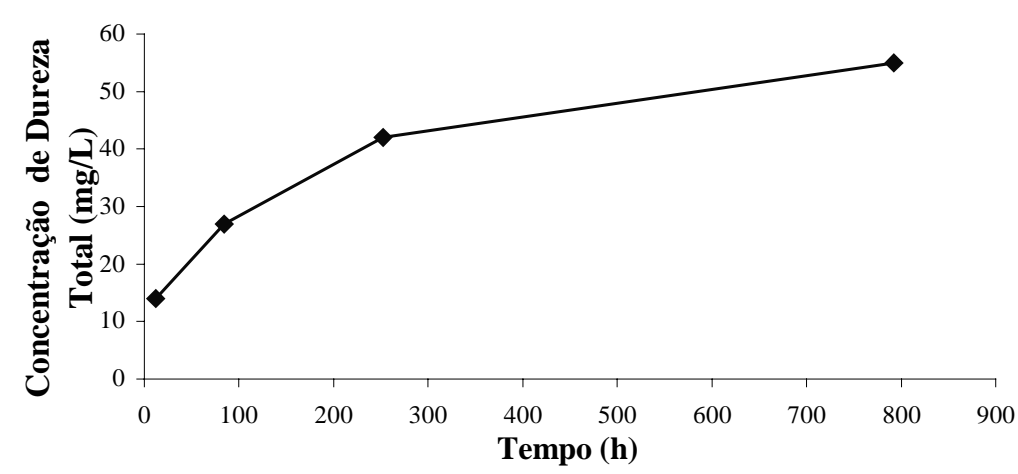

Valor Máximo Permitido - 500.0 mg/L Método - titrimetria

\section{Comportamento do Manganês}

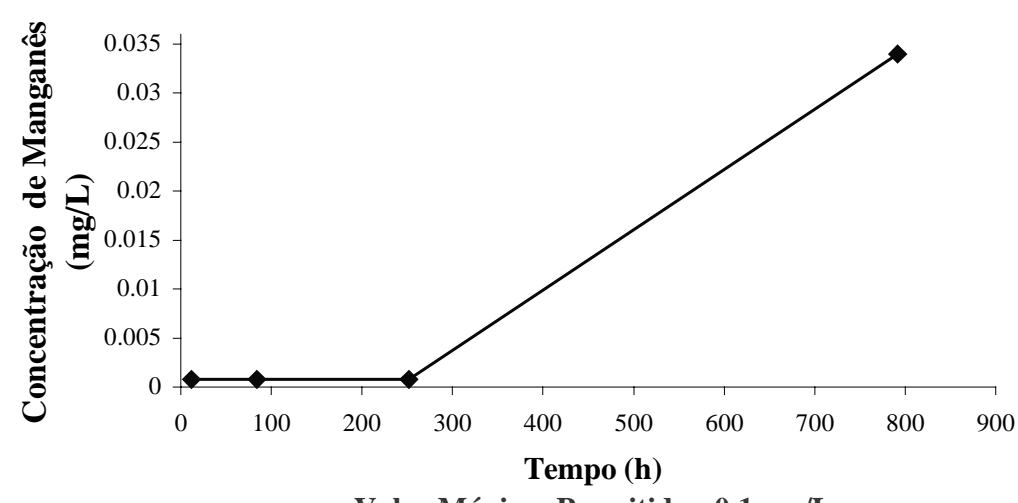

Valor Máximo Permitido - $0.1 \mathrm{mg} / \mathrm{L}$ Método - absorção atômica 


\section{Comportamento do Sódio}
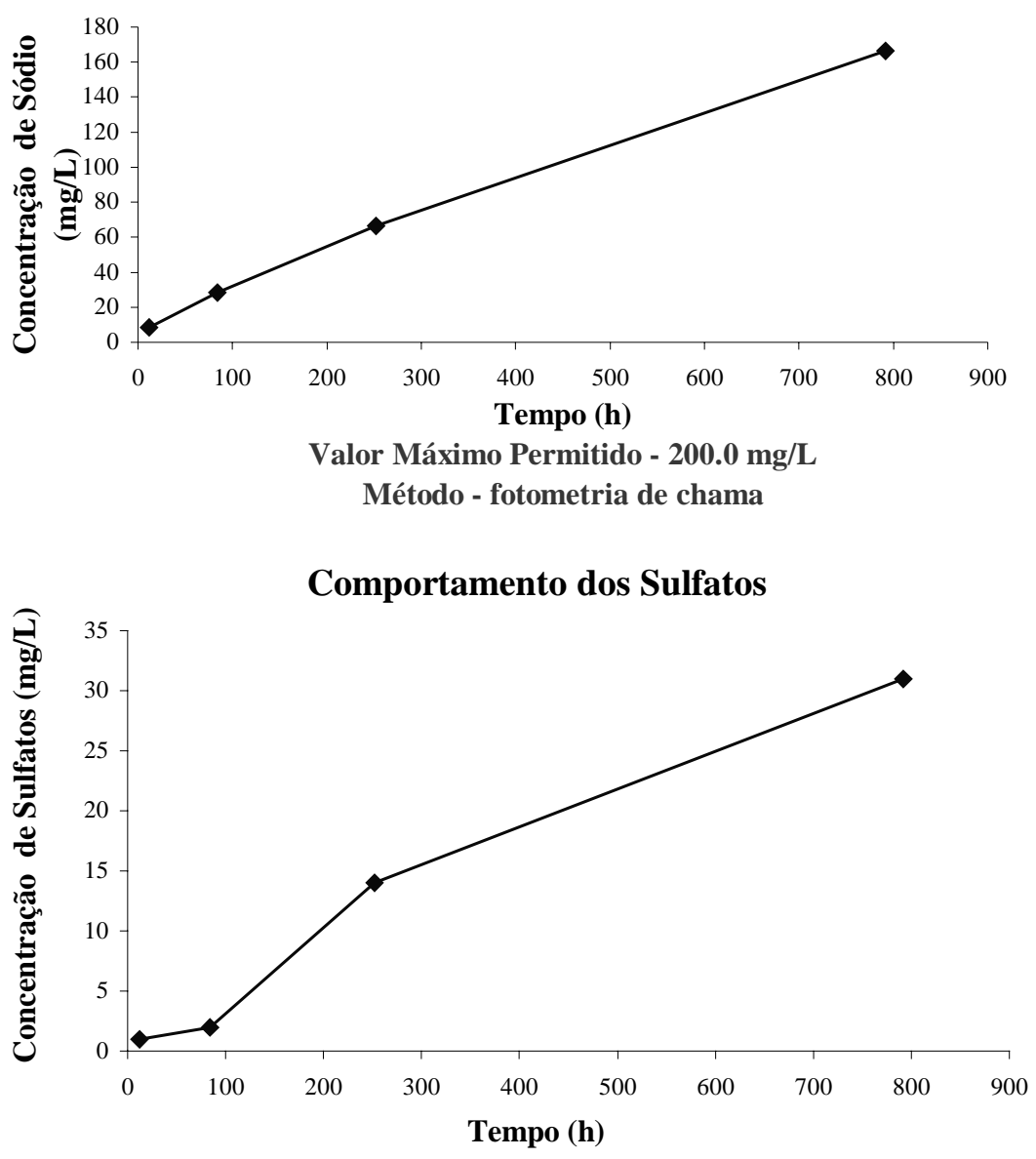

Valor Máximo Permitido - $400.0 \mathrm{mg} / \mathrm{L}$ Método - colorimetria espectrofotometria visível
Comportamento dos Surfactantes

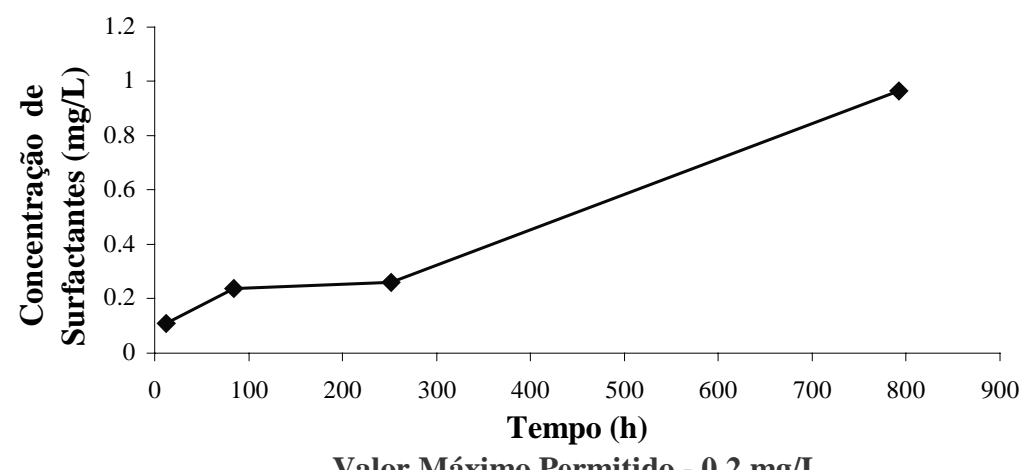

Valor Máximo Permitido - $0.2 \mathrm{mg} / \mathrm{L}$

Método - colorimetria

\section{Comportamento do Zinco}

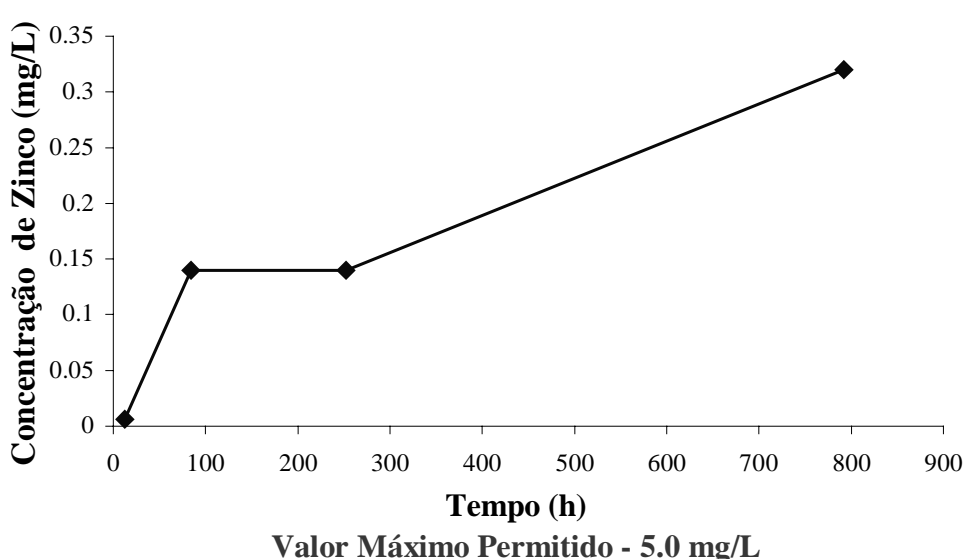

Método - absorção atômica

Figura C.15. Comportamento de parâmetros químicos ao longo do tempo (lixiviação com extrator soxhlet) - Situação III 